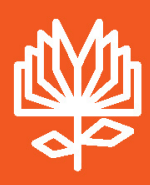

OBJEM

\title{
Urednica: Dragica Haramija
}

\section{GRADNIKI BRALNE PISMENOSTI Teoretična izhodišča}
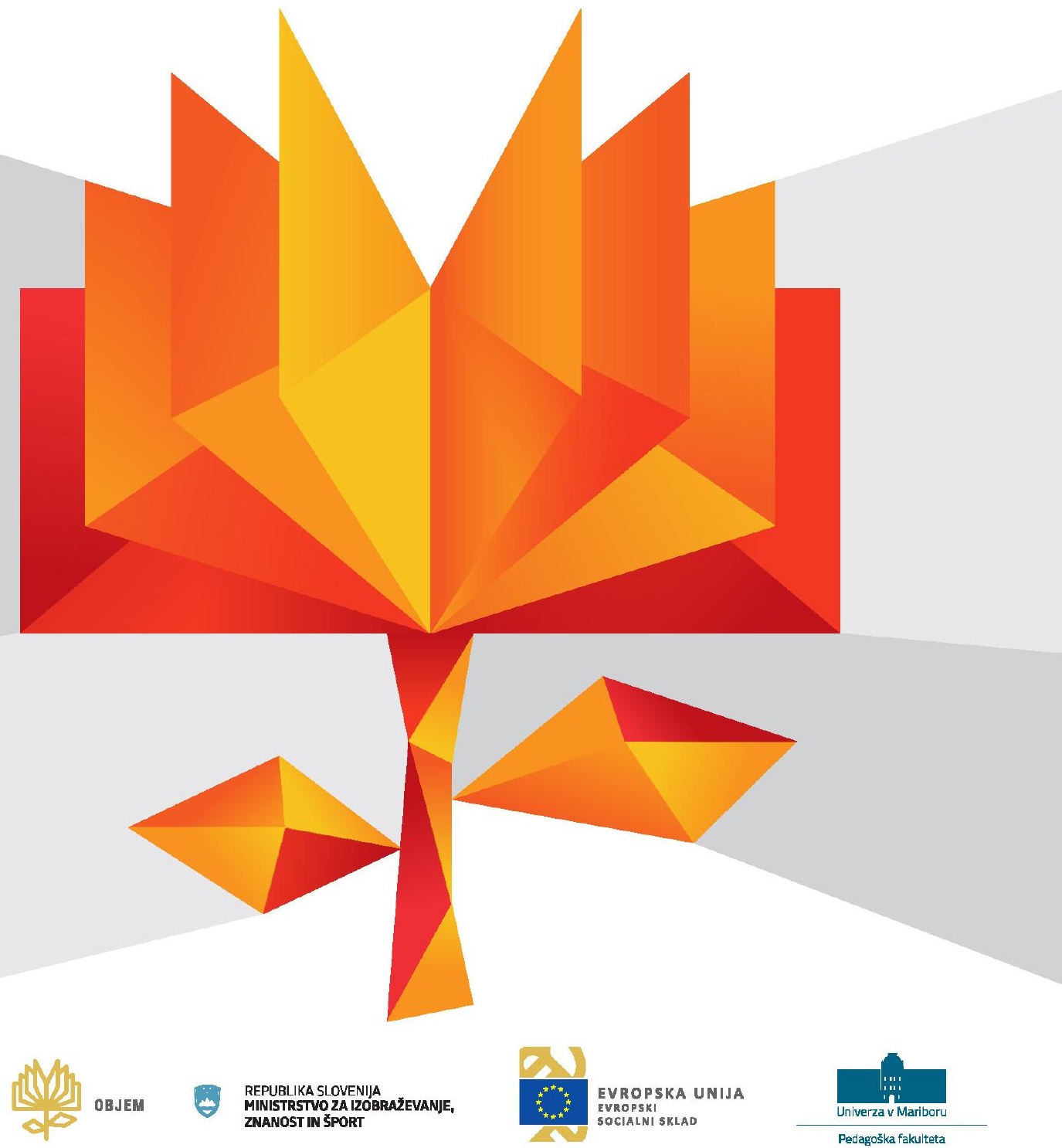

Univerza v Mariboru

Pedagoška fakulteta

\section{Gradniki bralne pismenosti}

Teoretična izhodišča

Urednica

Dragica Haramija

November 2020 


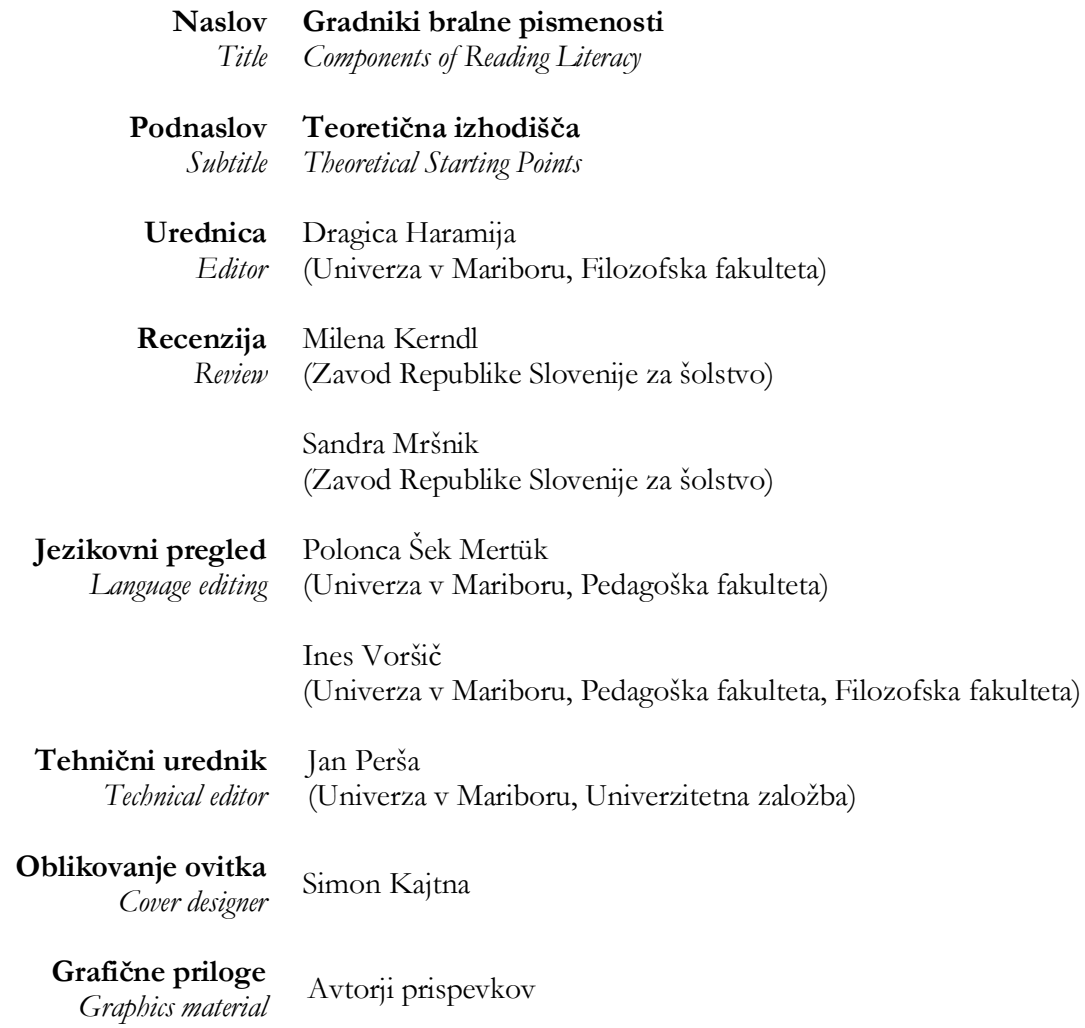

Založnik / Publibed by

Univerza v Mariboru

Univerzitetna založba

Slomškov trg 15, 2000 Maribor, Slovenija

https://press.um.si, zalozba@um.si
Izdajatelj / Co-published by

Univerza v Mariboru

Pedagoška fakulteta

Koroška cesta 160, 2000 Maribor, Slovenija https://www.pef.um.si, dekanat.pef@um.si

Soizdajatelj / Co-published by

Zavod Republike Slovenije za šolstvo

Poljanska 28, 1000 Ljubljana

https://www.zrss.si,info@zrss.si

\section{Izdaja \\ Edition \\ Vrsta publikacije}

Publication type

Dostopno na

Available at

Izdano

Published
Prva izdaja

E-knjiga

https://press.um.si/index.php/ump/catalog/book/515

https://pef.um.si/raziskovanje-in-umetnost/projekti-izevropskih-skladov/objem/

www.zrss.si/pdf/gradniki_bralne_pismenosti_PefMB.pdf

Maribor, november 2020 
To delo je objavljeno pod licenco Creative Commons Priznanje avtorstva-Nekomercialno 4.0 Mednarodna. / This work is licensed under the Creative Commons Attribution-NonCommercial 4.0 International License.

https://creativecommons.org/licenses/by-nd/4.0/

Gradivo je nastalo v okviru projekta Bralna pismenost in razvoj slovenščine - OBJEM: Ozaveščanje, Branje, Jezik, Evalvacija, Modeli (2017-2022), šifra projekta OP20.01462. Projekt v okviru Zavoda RS za šolstvo vodi dr. Sandra Mršnik.

Naložbo sofinancirata Republika Slovenija in Evropska unija iz Evropskega socialnega sklada

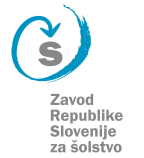

REPUBLIKA SLOVENIJA MINISTRSTVO ZA IZOBRAŽEVANJE ZNANOST IN ŠPORT
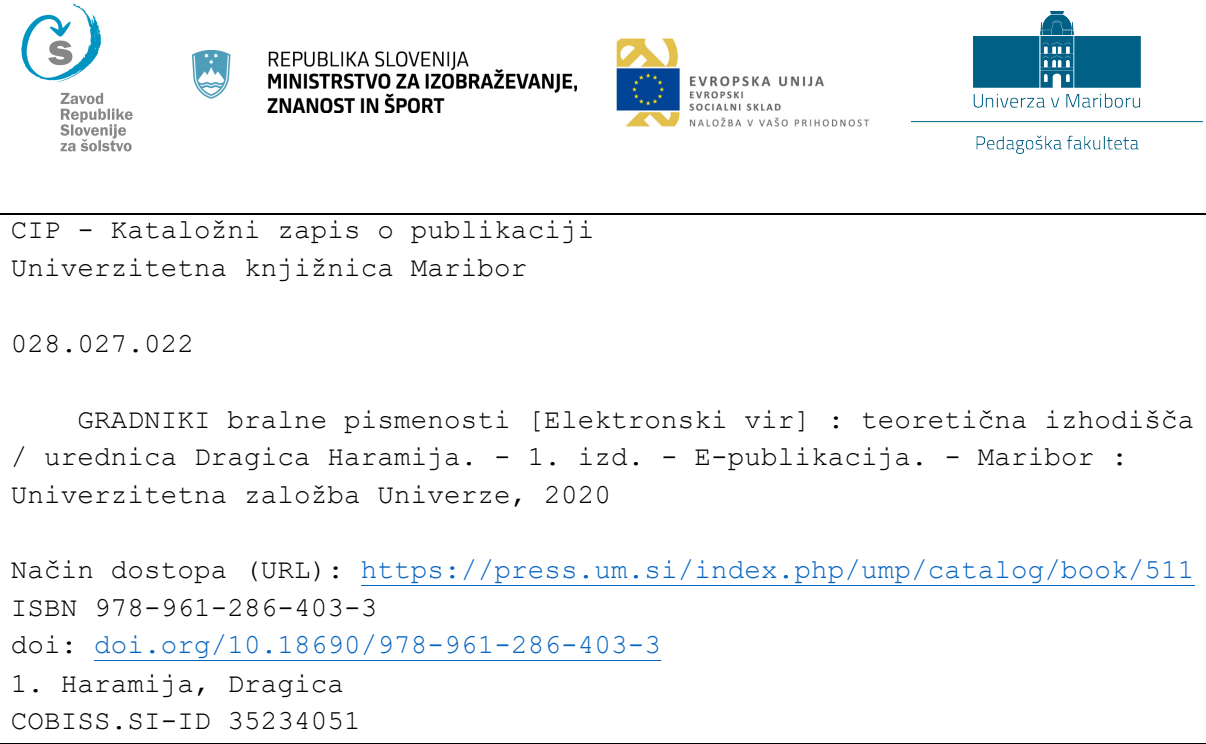

ISBN 978-961-286-403-3 (pdf)

DOI https://doi.org/10.18690/978-961-286-403-3

Cena
Price

Odgovorna oseba založnika prof. dr. Zdravko Kačič, For publisher rektor Univerze v Mariboru 



\section{Kazalo}

Predgovor

Dragica Haramija

Gradniki bralne pismenosti

Dragica Haramija in Milena Ivanuš Grmek

1. gradnik: Govor

Polonca Šek Mertük in Zlatka Cugmas

2. gradnik: Motiviranost za branje

Blanka Bošnjak in Katja Košir

3. gradnik: Razumevanje koncepta bralnega gradiva

Dragica Haramija in Janja Batič

4. gradnik: Glasovno zavedanje

Melita Zemljak Jontes in Barbara Bednjički Rošer

5. gradnik: Besedišče

Ines Voršič in Marija Ropič Kop

6. gradnik: Tekoče branje

Marija Ropič Kop in Nika Vizjak Puškar

7. gradnik: Razumevanje besedil

Mira Krajnc Ivič

8. gradnik: Odziv na besedilo in tvorjenje besedil

Simona Pulko in Eva Kranjec

9. gradnik: Kritično branje

Kritično branje - razvijajoča se veščina bralne pismenosti v vrtcu, osnovni in srednji šoli

Marta Licardo in Mira Krajnc Ivič

9. gradnik: Kritično branje

Dialoški preskoki književnosti: interpretacija in doživetje, kontekstualizacija ter medmedialni prehodi

Miran Stuhec 
Vloga šolske knjižnice pri razvoju gradnikov bralne pismenosti Polona Vilar in Vlasta Zabukovec

Preglednice 


\section{Predgovor}

DRAGICA HARAMIJA

Znanstvena monografija o gradnikih bralne pismenosti vsebuje 11 poglavij, v katerih je poglobljeno zajeto izhodišče posameznega gradnika. Razvijanje gradnikov je sistematično, saj so namenjeni vsem stopnjam izobraževanja od vrtca do konca srednješolskega obdobja, hkrati pa je njihov temeljni namen, da se pozornost za razvoj bralne pismenosti usmerja na vsa področja dejavnosti v vrtcu in na vse predmete $\mathrm{v}$ osnovni in srednji šoli. Posamezni gradnik se razvija kot del celote, vsi gradniki so povezani s cilji vseh predmetov/področij, razvijajo se procesno. Pomembno je, da se gradniki razvijajo integrirano in v skladu z zmožnostjo otrok, učencev in dijakov glede na njihov razvoj, predznanje, potrebe in posebnosti. 


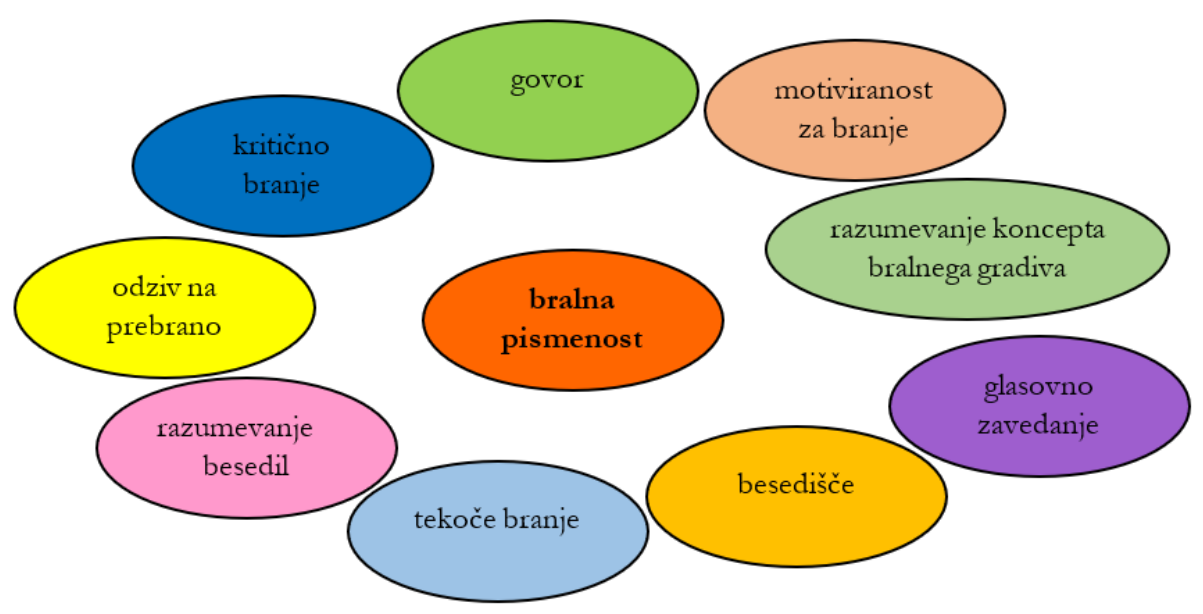

Slika: Bralna pismenost

V izobraževalnem procesu razvijamo elemente posameznega gradnika skupaj s preostalimi gradniki bralne pismenosti $\mathrm{v}$ povezavi s cilji in vsebinami pri vseh predmetih oz. predmetnih področjih. 1. gradnik: govor predstavlja zmožnosti nebesednega in besednega sporazumevanja ter otrokov razvoj jezikovnih zmožnosti. 2. gradnik: motiviranost za branje predstavlja interes za branje, pozitiven odnos do branja različnih vrst besedil in bralno samoučinkovitost mladih bralcev. 3. gradnik: razumevanje koncepta bralnega gradiva osvetljuje pomen multimodalne pismenosti, poseben poudarek je na razumevanju in sestavljanju različnih kodov sporočanja za celostno branje raznolikih besedil. 4. gradnik: glasovno zavedanje predstavlja analize teoretičnih podstav glasovnih značilnosti slovenskega knjižnega jezika glede na različne pristope. 5. gradnik: besedišče vsebuje razvoj razumevanja pomena besed in njihove uporabe pri sprejemanju in tvorjenju besedil; širjenje in usvajanje besedišča za uspešno branje $z$ razumevanjem, učenje in sporazumevanje. 6. gradnik: tekoče branje osvetljuje tehnike branja (natančnost, hitrost, izraznost, ritem), zlasti glede na možnost preverjanja otrokovega napredka. 7. gradnik: razumevanje besedila predstavlja sistematično razvijanje branja $z$ razumevanjem (uzaveščanje procesa branja ob uporabi različnih bralnih strategij), pri čemer je poudarek na neumetnostnih besedilih, povezanih z vsemi predmetnimi področji. 8 . gradnik: odziv na besedilo in tvorjenje besedil predstavlja tvorjenje ustreznih in smiselnih govorjenih in pisnih besedil o prebranem, o uporabi prebranega $\mathrm{v}$ novih situacijah in o razvijanju veščine pisanja ustreznih besedil. 9. gradnik: kritično branje opozarja na prepoznavanje, presojanje, vrednotenje sporočilnosti, dejstev in 
stališč $\mathrm{v}$ besedilu ter avtorjevega načina pisanja; oblikovanje lastnega mnenja $\mathrm{z}$ utemeljevanjem. V nadaljevanju je predstavljen 9. gradnik s stališča kritičnega vrednotenja leposlovja. Postavljanje kriterijev za kritično vrednotenje besedil je zajeto $\mathrm{v}$ vseh poglavjih, saj je to temelj kakovostnega bralnega razvoja otrok in mladostnikov. Prav tako je osvetljena vloga šolske knjižnice, podane so smernice za razvoj knjižnic in za njihovo vlogo v izobraževalnem procesu.

\section{Components of Reading Literacy: Theoretical Bases}

The academic monograph on the components of reading literacy includes eleven chapters that take an in-depth look at the basis for each individual block. Developing components of reading literacy is systematic as they are intended for all levels of education, from kndergarten to secondary education, and at the same time their essential purpose is to direct the attention on the development of reading literacy into all areas of activities in kindergarten and into all subjects in primary and secondary education. Each individual component of reading literacy develops as part of a whole, all components are linked to the goals and objectives of all subjects/areas, and they develop procedurally. It is important that the components of reading literacy develop in an integrated way, in line with the abilities of children and students, depending on their development, prior knowledge, needs and particularities.

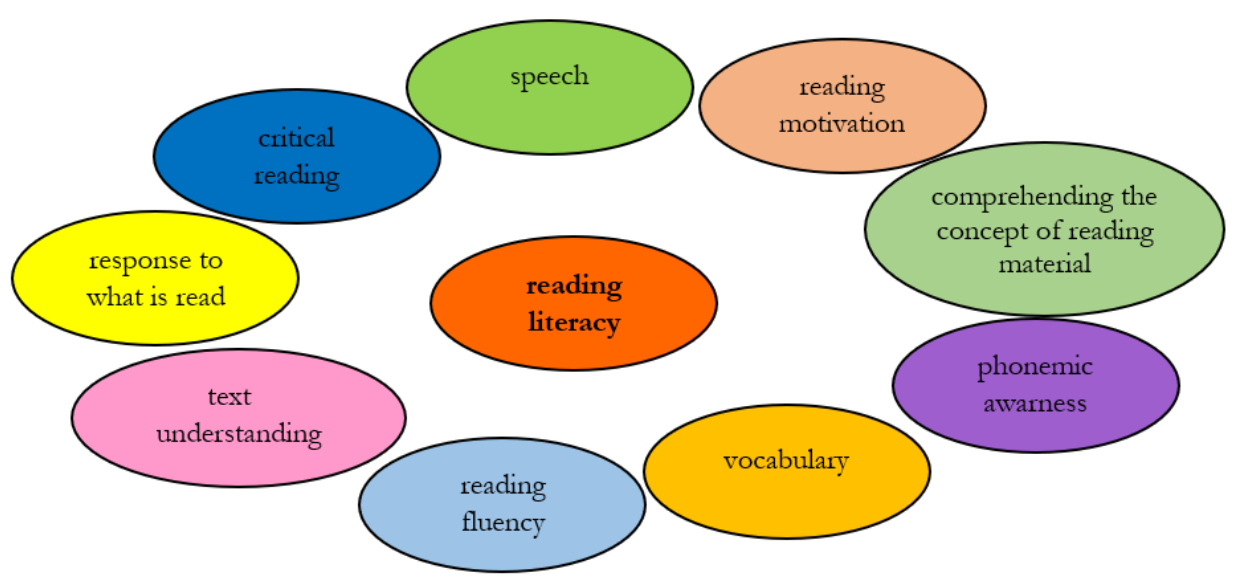

Figure: Reading literacy 
In the education process elements of each individual component are developed in conjunction with all the components of reading literacy (synonym building blocks) and connected with the goals and contents of all subjects or subject areas. The following components of reading literacy are examined: 1 . speech represents the abilities of nonverbal and verbal communication and the child's development of linguistic abilities; 2. reading motivation represents the interest in reading, the positive attitude to reading various kinds of texts, and the self-efficacy of young readers; 3. comprehending the concept of reading material enlightens the meaning of multimodal literacy, special emphasis is on understanding and constructing various codes of communication for comprehensive reading of diverse texts; 4. phonemic awareness represents the analysis of theoretical basis of the sound characteristics of Standard Slovene according to various approaches; 5. vocabulary contains the development of understanding the meaning of words and their use in receiving and forming texts; broadening and assimilation of vocabulary for successful reading with comprehension, learning and communication; 6. reading fluency highlights the techniques of reading (accuracy, speed, expressiveness, rhythm), especially regarding the possibility of assessing the child's progress; 7 . text understanding represents a systematic development of reading with understanding (becoming aware of the process of reading through using various reading strategies), with an emphasis on non-literary texts related to all subject areas; 8 . response to the text and creating texts represents the creation of appropriate and coherent spoken and written texts about what is read, about using what is read in new situations, and about developing the skill of writing appropriate texts; 9. critical reading alerts to the recognition, assessment, evaluating the communicativeness, facts and standpoint in the text, the author's way of writing; forming a personal substantiated opinion. The ninth components is further looked at in terms of critical evaluation of literature. Setting the criteria for critical evaluation of texts is covered by all chapters as it is the foundation of quality literacy development in children and adolescents. Also highlighted is the role of the school library with guidelines given for the development of libraries and their role in the educational process. 
IZHODIŠČA ZA RAZVIJANJE IN VREDNOTENJE POSAMEZNIH GRADNIKOV BRALNE PISMENOSTI PRI VSEH PREDMETIH 
1. Vsi gradniki se razvijajo v povezavi s cilji in vsebinami pri vseh predmetih/področjih.

2. Vsak gradnik se razvija kot del celote.

3. Izhodišče za razvijanje vseh gradnikov so besedila (pisna, govorjena, avdio, video ...) pri vseh predmetih/področjih. Vrsta in zahtevnost besedil se po vertikali stopnjujeta $z$ obsegom vsebine, njeno abstraktnostjo (tudi v povezavi s terminologijo) in poglobljenostjo ter jezikovno zahtevnostjo.

4. Integriranost - pomeni, da se gradnik, ki je usvojen v nekem obdobju, razvija tudi naprej, čeprav ni izrecno zapisano.

5. Gradnike razvijamo sistematično: načrtno in premišljeno v celotnem izvedbenem kurikulu in pri pouku vseh predmetov.

6. Pri razvijanju gradnikov se upošteva razvoj, predznanje, potrebe in posebnosti vsakega otroka/učenca/dijaka.

7. Gradniki se razvijajo procesno, skozi daljše obdobje, zato je opis pričakovanega dosežka zapisan za konec obdobja. 


\title{
GRADNIKI BRALNE PISMENOSTI
}

\author{
DRAGICA HARAMIJA ${ }^{1,2}$ IN MILENA IVANUŠ GRMEK ${ }^{2}$ \\ ${ }^{1}$ Univerza v Mariboru, Filozofska fakulteta, Maribor, Slovenija. \\ E-pošta: dragica.haramija@um.si \\ ${ }^{2}$ Univerza v Mariboru, Pedagoška fakulteta, Maribor, Slovenija. \\ E-pošta: dragica.haramija@um.si,milena.grmek@um.si
}

Povzetek Za celostno obravnavo Gradnikov bralne pismenosti (2018, delovno gradivo ZRSŠ) smo se v izhodišču naslonili na tri ključne dokumente, in sicer na Belo knjigo o vaggoji in izobraževanju v RS (2011), na Nacionalno strategijo za razvoj bralne pismenosti za obdobje 2019-2030 (2019) in na Osem ključnih kompetenc za vsę̌iviljenjsko üénje (2018). V okviru dela pri projektu OBJEM smo $\mathrm{v}$ raziskavah bralno pismenost opazovali z več vidikov, med katerimi je treba izpostaviti zlasti tri: (1) z vidika oblikovanja gradnikov bralne pismenosti, (2) z vidika didaktičnih pristopov, ki prispevajo $\mathrm{k}$ bralni pismenosti, še zlasti pri presoji učbeniških gradiv, in (3) z vidika izbora kakovostnih bralnih gradiv za vsa področja dejavnosti $\mathrm{v}$ vrtcih in vse predmete $\mathrm{v}$ osnovnošolskem in srednješolskem izobraževanju.

Ključne besede:
bralna
pismenost,
razvijanje
pismenosti,
gradniki
bralne
pismenosti,
didaktični
pristopi,
kakovostna
bralna
gradiva.




\title{
COMPONENTS OF READING
} LITERACY

\author{
Dragica HARAMIJA ${ }^{1,2} \&$ MILENA IVANUŠ GRMEK ${ }^{2}$ \\ ${ }^{1}$ University of Maribor, Faculty of Arts, Maribor, Slovenija. \\ E-mail: dragica.haramija@um.si \\ ${ }^{2}$ University of Maribor, Faculty of Education, Maribor, Slovenija. \\ E-mail: dragica.haramija@um.si,milena.grmek@um.si
}

Keywords: reading literacy, literacy development, components of reading literacy, didactic approaches, quality reading material.

\begin{abstract}
Three key documents were used as the basis of the comprehensive discussion of The Components of Reading Literacy (2018, research material of the National Educational Institute Slovenia), namely, the White Paper on Education in the Republic of Slovenia (2011), the National Strategy for the Development of Reading Literacy for 2019-2030 (2019), and Eight Key Competences for Lifelong Learning (2018). Within the framework of working on the project 'OBJEM: Reading Literacy and Development of Slovene Language', we observed reading literacy from a number of aspects among which attention should be drawn particularly to the following three: 1 . the aspect of forming the components of reading literacy, 2. the aspect of didactic approaches that contribute to reading literacy, especially in evaluating textbook material, and 3. the aspect of selecting quality reading material for all areas of activities in nursery schools and all subjects in primary and secondary school education.
\end{abstract}




\section{$1 \quad$ Uvod}

Gradniki bralne pismenosti (2018, delovno gradivo ZRSŠ) se navezujejo na celotno vertikalo izobraževanja v Sloveniji od vrtcev, osnovnošolskega in srednješolskega izobraževanja, vsekakor pa so pomembni tudi pri izobraževanju bodočih pedagoških delavcev, zlasti vzgojiteljev, učiteljev razrednega pouka in učiteljev vseh predmetov na predmetni stopnji osnovne šole in $\mathrm{v}$ srednješolskem izobraževanju. Temelj gradnikov je torej zavedanje, da se vsi gradniki razvijajo $\mathrm{v}$ povezavi s cilji in vsebinami na vseh področjih dejavnosti v vrtcu in pri vseh predmetih v OŠ in SŠ. Pismenost se prenaša medgeneracijsko, to pomeni, da smo vsi odrasli odgovorni za pismenost otrok, učencev in dijakov.

V knjigi Zgodovina branja je Manguel (2007: 33) zapisal, da »je branje postopek, ki se sešteva in geometrično napreduje: vsako novo branje gradi na tem, kar je bralec že prebrak.

\section{Pomembni dokumenti za razvoj bralne pismenosti}

Za celostno obravnavo Gradnikov bralne pismenosti (2018) smo se v izhodišču naslonili na tri ključne dokumente, in sicer na Belo knjigo o vagoji in iz̧obraževanju v Republiki Sloveniji (2011, v nadaljevanju Bela knjiga), na Nacionalno strategijo za razvoj bralne pismenosti (predlog 2017, potrjena 2019) in na ključne kompetence za 21. stoletje, ki izhajajo iz osmih ključnih kompetenc za vseživljenjsko učenje (2018).

V uvodu Bele knjige (2011: 13) je zapisano: »Temeljne vrednote vzgoje in izobraževanja v Republiki Sloveniji izhajajo iz skupne evropske dediščine kulturnih, političnih in moralnih vrednot, ki jih združujejo človekove pravice in njim pripadajoče dolžnosti ter načela pluralne demokracije, strpnosti, solidarnosti in pravne države.« Gre torej za usmeritev izobraževalnega sistema, ki vključuje človekove pravice, avtonomijo strokovnih delavcev, pravičnost (enake možnosti za vse) in kakovost izobraževalnega sistema za vse vključene učence. Poudarjeno je pridobivanje kompetenc otrok, učencev in dijakov, ki pomenijo njihove veščine in zmožnosti (Bela knjiga 2011: 23): »Koncept kompetence je tako opozoril na kompleksnost znanja, na njegovo prepletenost z dispozicijami posameznika in na nujnost poučevanja uporabe znanja.« Bela knjiga (2011: 33-35) vsebuje načela, cilje in strateške usmeritve vzgoje in izobraževanja, najprej splošne, v nadaljevanju po stopnjah šolanja (vrtec, OŠ, SŠ). 
Posebej pomembna je ozaveščenost o rabi jezikov v vzgoji in izobraževanju: slovenščina kot prvi in drugi jezik, materinščina in tuji jeziki. S stališča razvoja bralne pismenosti je v Beli knjigi (2011: 35) posebej pomembno sporočilo:

Jezik je hkrati cilj in sredstvo; pri jezikovnem pouku to dosegamo $\mathrm{z}$ učenjem jezika, usmerjenim $\mathrm{v}$ vsebino, pri nejezikovnih predmetih pa z jezikovno ozaveščenim učenjem vsebin. Razvijanje splošne sporazumevalne zmožnosti tako nadgradimo $\mathrm{z}$ razvojem strokovne pismenosti učencev na posameznih predmetih oz. disciplinarnih področjih.

Vsi pedagoški delavci, ne glede na matično stroko, bi torej morali ozaveščenost o rabi jezika prenašati na otroke, učence in dijake. Učenje jezika torej ni le stvar slovenščine kot predmeta, temveč mora zavzemati pomembno mesto pri vseh dejavnostih v vrtcu in pri vseh predmetih v osnovni in srednji šoli. Cilj na vseh stopnjah izobraževanja je torej usvajati knjižni jezik kot učni jezik, ki je uradni jezik države šolanja, in to pri vseh predmetih; na narodnostno mešanih območjih sta uradna jezika tudi madžarščina in italijanščina. Otroci, učenci in dijaki usvajajo kompetence sporazumevalne zmožnosti, ki je ključna za kakršno koli učenje na kateri koli stopnji izobraževanja.

Ključne kompetence za vseživljenjsko učenje: evropski referenčni okvir (v nadaljevanju ključne kompetence) spodbujajo formalne, neformalne in priložnostne oblike izobraževanja, pri čemer gre za podporo ljudem "pri izboljšanju njihovih kompetenc od zgodnjega otroštva skozi vse življenje« (UL EU 2018/C 189/01: 4). V nadaljevanju je poudarjeno, da ključne kompetence med drugim podpirajo "pobude za nadaljnji razvoj in spodbujanje izobraževanja za trajnostni razvoj $v$ skladu s 4. ciljem trajnostnega razvoja $\mathrm{ZN}$ : vsem enakopravno zagotoviti kakovostno izobrazbo ter spodbujati možnosti vseživljenjskega učenja za vsakogar« (UL EU 2018/C 189/01: 5). Referenčni okvir določa osem ključnih kompetenc (te so opredeljene kot kombinacija znanja, spretnosti in odnosov): pismenost; večjezičnost; matematična, naravoslovna, tehniška in inženirska kompetenca; digitalna kompetenca; osebnostna, družbena in učna kompetenca; državljanska kompetenca; podjetnostna kompetenca; kulturna zavest in izražanje. Prav vse kompetence so zajete, seveda glede na starostno stopnjo in kognitivni razvoj otrok in mladostnikov, $v$ različnih 
predmetnih področjih v vrtcu in pri predmetih v OŠ in SŠ. Prva ključna kompetenca se navezuje na pismenost:

Pismenost je sposobnost prepoznati, razumeti, izraziti, ustvariti in razlagati koncepte, čustva, dejstva in mnenja v ustni in pisni obliki z uporabo vizualnega, zvočnega in digitalnega gradiva na vseh področjih in $\mathrm{v}$ vseh okoliščinah. Pomeni sposobnost uspešnega sporazumevanja in povezovanja $z$ drugimi na ustrezen in ustvarjalen način. Razvoj pismenosti je temelj za nadaljnje učenje in nadaljnjo jezikovno interakcijo. Odvisno od okoliščin se lahko pismenost razvije v maternem jeziku, jeziku šolanja in/ali uradnem jeziku države ali regije. (UL EU 2018/C 189/01: 8)

Nacionalna strategija za razvoj bralne pismenosti za obdobje 2019-2030 (2019: 3)1 bralno pismenost opredeljuje:

Bralna pismenost je stalno razvijajoča se zmožnost posameznika in posameznice za razumevanje, kritično vrednotenje in uporabo pisnih informacij. Ta zmožnost vključuje razvite bralne veščine, (kritično) razumevanje prebranega in bralno kulturo (pojmovanje branja kot vrednote in motiviranost za branje). Zato je temelj vseh drugih pismenosti ${ }^{2}$ in je ključna za razvijanje posameznikovih in posamezničinih sposobnosti ter njuno uspešno sodelovanje v družbi.

V Nacionalni strategiji za razvoj bralne pismenosti za obdobje 2019-2030 (2019) so upoštevana vsa načela ključnih kompetenc, predvsem pa je poudarjeno, da se pismenost razvija vse življenje in na vseh področjih. Prvič so na Slovenskem predstavljeni cilji in ravni bralne pismenosti po posameznih stopnjah izobraževanja

\footnotetext{
1 Nacionalna strategija za razvoj bralne pismenosti za obdobje 2019-2030 je bila maja 2017 poslana v javno obravnavo; potrjeni dokument iz leta 2019 ni bistveno spremenjen. Na dolgo pot do potrditve opozarjamo zato, da ne bi prihajalo do nesporazumov, saj delovno gradivo Gradniki bralne pismenosti (2018), ki jih v monografiji uporabljamo kot izhodišče, upoštevajo Nacionalno strategijo za rąvoj bralne pismenosti, ta pa je bila uradno sprejeta več kakor eno leto za gradniki.

2 Kot npr. matematične, naravoslovne ali digitalne pismenosti, ki označuje zmožnost/kompetenco posameznika ali posameznice za razumevanje in reševanje problemov v pisnih informacijah z določenega področja (matematike, naravoslovja, e-gradiva); funkcionalne pismenosti, ki poudarja, da branje ni samo sebi namen, ampak je namenjeno učinkovitemu delovanju posameznika v okolju, v katerem živi; informacijske in medijske pismenosti, pri katerih je pomembna zmožnost pridobivanja in (kritične) predelave informacij.
} 
od predšolske vzgoje, osnovne šole (po treh vzgojno-izobraževalnih obdobjih), srednje šole, univerzitetnega izobraževanja in (predvsem neformalnega) izobraževanja odraslih. Posebej je opozorjeno, da je treba v vseh obdobjih ravnati podporno do ranljivih skupin prebivalstva. Za vse mladostnike pa je zlasti pomembno obdobje ob koncu osnovnošolskega izobraževanja, za katerega so standardi ravni bralne pismenosti povzeti po raziskavi PISA: »Raven ob končanju programa osnovne šole: najmanj temeljno raven bralne pismenosti doseže vsaj $90 \%$ učencev in učenk; najvišje ravni bralne pismenosti (kompetence) pa naj bi doseglo vsaj $10 \%$ učencev in učenk. (Nacionalna strategija za razvoj bralne pismenosti za obdobje 2019-2030, 2019: 11) V preglednici Nacionalne strategije za razvoj bralne pismenosti za obdobje 2019-2030 (2019) so zastavljeni tudi specifični cilji za študente in odrasle, ti cilji pa v primeru projekta OBJEM pomenijo ozaveščanje pedagoških delavcev o pomenu branja. Strategija posebej izpostavlja branje, čeprav so v njej vsaj deloma omenjene tudi druge tri dejavnosti, povezane s pismenostjo (poslušanje, govorjenje in pisanje).

Tabela 1: Cilji in ravni pismenosti po posameznih stopnjah izobraževanja

\begin{tabular}{|l|l|}
\hline SPECIFIČNI CILJI & RAVNI PISMENOSTI \\
\hline $\begin{array}{l}\text { PREDŠOLSKO OBDOBJE } \\
(0-6 \text { let })\end{array}$ & RAVNI OB KONCU \\
& PREDŠOLSKEGA \\
OBDOBJA
\end{tabular}

- Ozaveščanje vseh staršev in bodočih staršev o pomenu družinskega branja, razvoja zgodnje pismenosti in bralne kulture $z$ organiziranimi oblikami vzgoje in izobraževanja.

- Ozaveščeni starši so prek različnih organiziranih oblik vzgoje in izobraževanja seznanjeni s pomenom družinskega branja, zgodnje pismenosti in bralne kulture.

- $\quad$ Vsem otrokom v vrtcih in drugih oblikah organiziranega varstva zagotoviti spodbudne predbralne in predpisalne dejavnosti za razvoj pojmovanja tiska, fonološkega zavedanja, grafomotorike, vidnega zaznavanja, in to v skladu z njihovimi razvojnimi značilnostmi ob upoštevanju individualnih potreb, interesov in okolja, iz katerega izhajajo.

- Z Z didaktično igro otrokom omogočiti spoznavanje jezika, razvoj govora, širjenje besedišča,

- Otroci so motivirani za poslušanje in branje besedil. 


\begin{tabular}{|c|c|}
\hline $\begin{array}{l}\text { razvoj razumevanja prebranega ter razvoj pozitivnega } \\
\text { odnosa do branja. }\end{array}$ & $\begin{array}{l}\text { - Otroci se pogovarjajo } \\
\text { o prebranem. }\end{array}$ \\
\hline $\begin{array}{l}\text { - } \quad \text { Navajanje otrok na uporabo knjižnega in } \\
\text { neknjižnega gradiva ter različnih medijev. }\end{array}$ & $\begin{array}{l}\text { Otroci skupaj z } \\
\text { odraslimi uporabljajo } \\
\text { knjižno in neknjižno } \\
\text { gradivo ter različne } \\
\text { medije in obiskujejo } \\
\text { knjižnico. }\end{array}$ \\
\hline $\begin{array}{l}\text { Zagotavljanje brezplačne ponudbe } \\
\text { kakovostnih prostočasnih dejavnosti v lokalnih } \\
\text { skupnostih za spodbujanje razvoja porajajoče se } \\
\text { pismenosti. }\end{array}$ & $\begin{array}{l}\text { - Otroci so vključeni v } \\
\text { različne brezplačne } \\
\text { prostočasne dejavnosti } \\
\text { za spodbujanje razvoja } \\
\text { porajajoče se } \\
\text { pismenosti. }\end{array}$ \\
\hline $\begin{array}{l}\text { OSNOVNOŠOLSKO OBDOBJE - } 1 . \text { VIO } \\
(6-9 \text { let })\end{array}$ & $\begin{array}{l}\text { RAVNI OB KONCU } \\
\text { 1. VIO }\end{array}$ \\
\hline $\begin{array}{l}\text { Z Z individualiziranim pristopom razvijati: } \\
\text { bralno kulturo in motivacijo učenk in učencev } \\
\text { za branje, } \\
\text { - tekoče branje in razumevanje prebranega, } \\
\text { - tehniko pisanja in tvorjenje besedil. }\end{array}$ & $\begin{array}{ll}\text { - } & \text { Učenke in učenci so } \\
\text { motivirani za branje. } \\
\text { - } & \text { Tekoče in z } \\
& \text { razumevanjem berejo } \\
\text { besedila v obsegu } & \text { najmanj } 500 \text { besed. } \\
& \text { O prebranem jasno in } \\
& \text { razumljivo govorijo. } \\
-\quad & \text { Pišejo jasna, } \\
& \text { raznovrstna in } \\
& \text { razumljiva besedila o } \\
\text { prebranem v obsegu } \\
\text { od } 100 \text { do } 150 \text { besed. }\end{array}$ \\
\hline - $\quad$ Intenzivno širiti besedišča učencev in učenk. & $\begin{array}{l}\text { - } \quad \text { Učenke in učenci } \\
\text { usvojijo besedišče, ki } \\
\text { jim omogoča uspešno } \\
\text { branje, učenje in } \\
\text { sporazumevanje. }\end{array}$ \\
\hline $\begin{array}{l}\text { - Z organiziranimi oblikami vzgoje in } \\
\text { izobraževanja ozaveščati starše o pomenu } \\
\text { družinskega branja in razvoja bralne kulture. }\end{array}$ & $\begin{array}{l}\text { - Učenke in učenci v } \\
\text { prostem času berejo } \\
\text { raznovrstna bralna } \\
\text { gradiva (spodbude } \mathrm{v} \\
\text { družini). }\end{array}$ \\
\hline $\begin{array}{l}\text { - Spoznavati lokacije in uporaba bralnih in } \\
\text { drugih informacijskih virov (npr. knjižnice, } \\
\text { medmrěje ipd.). }\end{array}$ & $\begin{array}{l}\text { - Učenke in učenci } \\
\text { poznajo in smiselno } \\
\text { uporabljajo lokacije } \\
\text { bralnih virov } \\
\text { (knjižnice, medmrežje } \\
\text { ipd.). }\end{array}$ \\
\hline
\end{tabular}




\begin{tabular}{|c|c|}
\hline $\begin{array}{l}\text { OSNOVNOŠOLSKO OBDOBJE - 2. VIO } \\
\text { (9-12 let) }\end{array}$ & $\begin{array}{l}\text { RAVNI OB KONCU } \\
\text { 2. VIO }\end{array}$ \\
\hline $\begin{array}{l}\text { - Razvijati bralno kulturo in motivacijo učenk in } \\
\text { učencev za branje različnih vrst besedil v šoli in v } \\
\text { prostem času. }\end{array}$ & $\begin{array}{l}\text { - Učenke in učenci so } \\
\text { motivirani za branje v } \\
\text { šoli in zunaj nje. }\end{array}$ \\
\hline $\begin{array}{l}\text { - } \quad \text { Razvijanje avtomatizirane tehnike branja in } \\
\text { branja z razumevanjem. }\end{array}$ & $\begin{array}{l}\text { - Učenke in učenci } \\
\text { glasno in tiho tekoče }\end{array}$ \\
\hline $\begin{array}{l}\text { - Sistematično razvijati besedišče, potrebno za } \\
\text { tekoče branje z razumevanjem. }\end{array}$ & $\begin{array}{l}\text { berejo besedila in } \\
\text { prebrano razumejo. }\end{array}$ \\
\hline $\begin{array}{l}\text { - Učence in učenke naučiti uporabe bralnih } \\
\text { učnih strategij za razumevanje prebranega, npr. } \\
\text { strategije iskanja bistva, razumevanja odnosov med } \\
\text { deli besedila, povzemanja, primerjanja delov besedila. } \\
\text { - Uzaveščanje lastnega procesa branja in učenja } \\
\text { z branjem. }\end{array}$ & $\begin{array}{l}\text { - Učenke in učenci } \\
\text { poznajo in znajo } \\
\text { uporabljati osnovne, } \\
\text { nekateri pa tudi } \\
\text { kompleksne bralne } \\
\text { strategije za iskanje }\end{array}$ \\
\hline $\begin{array}{l}\text { - Učenke in učence naučiti uporabe } \\
\text { kompleksnih strategij za doseganje višjih ravni } \\
\text { pismenosti v daljših besedilih (iskanja in organiziranja } \\
\text { več delov besedila, uporabe pomembnih informacij } \\
\text { pri reševanju novih problemov, strategij za kritično } \\
\text { vrednotenje besedila). }\end{array}$ & $\begin{array}{l}\text { bistva, povzemanja, } \\
\text { urejanja in kritičnega } \\
\text { vrednotenja } \\
\text { informacij. }\end{array}$ \\
\hline $\begin{array}{l}\text { - Učence in učenke naučiti odzvati se na } \\
\text { prebrano s samostojnim pisnim tvorjenjem besedila } \\
\text { in utemeljevanjem odgovorov. }\end{array}$ & $\begin{array}{l}\text { - Učenke in učenci } \\
\text { vodeno in samostojno } \\
\text { pisno tvorijo in } \\
\text { utemeljujejo svoje } \\
\text { odzive na prebrano. }\end{array}$ \\
\hline $\begin{array}{l}\text { - Urjenje učenk in učencev za uporabo tiskanih } \\
\text { in digitalnih (spletnih) virov za branje. }\end{array}$ & $\begin{array}{l}\text { - Učenke in učenci } \\
\text { večinoma samostojno }\end{array}$ \\
\hline $\begin{array}{l}\text { - } \quad \text { Razvijati kritičnost pri izbiri in uporabi } \\
\text { različnih virov za branje. }\end{array}$ & $\begin{array}{l}\text { in kritično uporabljajo } \\
\text { različne bralne vire. }\end{array}$ \\
\hline $\begin{array}{l}\text { - Učiti in spodbujati učence in učenke za } \\
\text { samostojno uporabo šolske in splošnih knjižnic. }\end{array}$ & $\begin{array}{l}\text { - Učenke in učenci } \\
\text { večinoma samostojno } \\
\text { uporabljajo šolske in } \\
\text { splošne knjižnice. }\end{array}$ \\
\hline $\begin{array}{l}\text { OSNOVNOŠOLSKO OBDOBJE - } 3 \text {. VIO } \\
\text { (12-15 let) }\end{array}$ & $\begin{array}{l}\text { RAVNI OB KONCU } \\
\text { 3. VIO }\end{array}$ \\
\hline $\begin{array}{l}\text { - Spodbujanje bralne kulture in motivacije za } \\
\text { branje daljših in zahtevnejših besedil pri vseh } \\
\text { predmetih in tudi zunaj šole. }\end{array}$ & $\begin{array}{l}\text { - Učenke in učenci so } \\
\text { motivirani za branje } \\
\text { v šoli in zunaj nje. }\end{array}$ \\
\hline $\begin{array}{l}\text { - Razvijanje razumevanja prebranega s tekočim } \\
\text { fleksibilnim branjem različnih besedil. }\end{array}$ & $\begin{array}{l}\text { - Učenke in učenci } \\
\text { tekoče berejo daljša }\end{array}$ \\
\hline $\begin{array}{l}\text { - Sistematično razvijanje besedišča, ki omogoča } \\
\text { bralno razumevanje. }\end{array}$ & $\begin{array}{l}\text { in zahtevnejša } \\
\text { besedila ter } \\
\text { prilagajajo hitrost } \\
\text { branja zahtevam } \\
\text { besedila. }\end{array}$ \\
\hline
\end{tabular}




\begin{tabular}{|c|c|}
\hline $\begin{array}{l}\text { - Urjenje učencev in učenk v izbiri in uporabi } \\
\text { osnovnih in kompleksnih bralnih učnih strategij za } \\
\text { doseganje temeljne in višjih ravni bralne pismenosti. }\end{array}$ & $\begin{array}{l}\text { - Učenke in učenci } \\
\text { glede na namen } \\
\text { samostojno izbirajo } \\
\text { tiskane in druge } \\
\text { informacijske vire } \\
\text { ter uporabijo } \\
\text { primerne bralne } \\
\text { strategije. }\end{array}$ \\
\hline $\begin{array}{l}\text { - Razvijati sposobnosti kritičnega sprejemanja } \\
\text { in razumevanja vsebine pri branju: oblikovanje } \\
\text { hipotez in iskanje argumentov zanje v besedilu, } \\
\text { uporabiti informacije pri reševanju novih problemov, } \\
\text { primerjati več besedil med seboj, vrednotiti besedilo } \\
\text { z različnimi kriteriji. }\end{array}$ & $\begin{array}{ll}- & \text { Učenke in učenci } \\
\text { primerjajo več } \\
\text { besedil med seboj in } \\
\text { jih ovrednotijo z } \\
\text { različnimi kriteriji; } \\
\text { - } \\
\text { samostojno } \\
\text { oblikujejo domneve } \\
\text { na podlagi podatkov } \\
\text { iz besedila in jih } \\
\text { utemeljujejo. }\end{array}$ \\
\hline $\begin{array}{l}\text { - Razvijanje sposobnosti samostojnega pisnega } \\
\text { tvorjenja in utemeljevanja odgovorov na vprašanja o } \\
\text { prebranem. }\end{array}$ & $\begin{array}{l}\text { - Učenke in učenci } \\
\text { samostojno pisno tvorijo } \\
\text { besedila in utemeljujejo } \\
\text { svoje odzive na prebrano. }\end{array}$ \\
\hline $\begin{array}{l}\text { - Učenje samostojne, namenske, kritične in } \\
\text { odgovorne izbire in uporabe tiskanih in drugih } \\
\text { informacijskih virov. }\end{array}$ & $\begin{array}{l}\text { - Učenke in učenci } \\
\text { samostojno, namensko, } \\
\text { kritično in odgovorno } \\
\text { izbirajo in uporabljajo } \\
\text { tiskane in druge } \\
\text { informacijske vire. }\end{array}$ \\
\hline $\begin{array}{l}\text { - Naučiti se samostojne uporabe šolske in } \\
\text { splošnih knjižnic. }\end{array}$ & $\begin{array}{l}\text { - Učenke in učenci } \\
\text { samostojno uporabljajo } \\
\text { šolske in splošne knjižnice; } \\
\text { - prebrano } \\
\text { uporabljajo pri reševanju } \\
\text { problemov v različnih } \\
\text { položajih - učnih in v } \\
\text { osebnem življenju. }\end{array}$ \\
\hline $\begin{array}{l}\text { SREDNJEŠOLSKO OBDOBJE } \\
\text { (15-19 let) }\end{array}$ & $\begin{array}{l}\text { RAVNI OB KONCU } \\
\text { SREDNJEŠOLSKEGA } \\
\text { OBDOBJA }\end{array}$ \\
\hline $\begin{array}{l}\text { - Spodbujanje in razvijanje gradnikov bralne } \\
\text { pismenosti za samostojno delo z besedili, in sicer } \\
\text { zavzetosti, vztrajnosti in znanja o procesih branja, ki } \\
\text { omogočajo dobro bralno razumevanje. }\end{array}$ & $\begin{array}{l}\text { - Dijakinje in dijaki so } \\
\text { motivirani za branje } \\
\text { različnih vrst besedil in } \\
\text { vztrajajo pri zahtevnejših } \\
\text { bralnih nalogah. }\end{array}$ \\
\hline
\end{tabular}




\begin{tabular}{|c|c|}
\hline $\begin{array}{l}\text { - Omogočanje spodbudnega okolja za razvoj } \\
\text { bralne kulture. }\end{array}$ & $\begin{array}{l}\text { - Dijakinje in dijaki } \\
\text { znajo utemeljiti pomen } \\
\text { pismenosti za delovanje v } \\
\text { družbi in oblikovanje } \\
\text { identitete. }\end{array}$ \\
\hline $\begin{array}{l}\text { - Razvijanje zmožnosti povezovanja, razlaganja } \\
\text { in kritičnega vrednotenja informacij v besedilih } \\
\text { različnih vrst ter zmožnosti utemeljevanja mnenja o } \\
\text { prebranem. }\end{array}$ & $\begin{array}{l}\text { - Dijakinje in dijaki } \\
\text { samostojno preberejo ter } \\
\text { govorno ali pisno } \\
\text { povzamejo besedilo v } \\
\text { skladu z zahtevnostjo } \\
\text { programa; } \\
\text { - povezujejo in } \\
\text { kritično vrednotijo } \\
\text { informacije v različnih } \\
\text { vrstah besedil. }\end{array}$ \\
\hline $\begin{array}{ll}- & \text { Poglobljeno spoznavanje jezikovne in } \\
\text { družbenokulturne značilnosti pisnih sporočil. }\end{array}$ & $\begin{array}{l}\text { - Dijakinje in dijaki } \\
\text { bralno-pisno zmožnost } \\
\text { dokažejo s smiselnim, } \\
\text { slogovno dodelanim in } \\
\text { jezikovno pravilnim } \\
\text { besedilom; } \\
\text { - poznajo in pri } \\
\text { govornih ali pisnih odzivih } \\
\text { na prebrano upoštevajo } \\
\text { značilnosti besedilnih vrst } \\
\text { in jezikovnih pravil. }\end{array}$ \\
\hline $\begin{array}{l}\text { - Spodbujanje rabe bralnih učnih strategij v } \\
\text { vseh programih in pri vseh predmetih oziroma } \\
\text { programskih enotah srednješolskega izobraževanja za } \\
\text { uporabo v različnih kontekstih (branje za osebni } \\
\text { razvoj, nadaljnje izobraževanje in delovanje v poklicu } \\
\text { in družbi). }\end{array}$ & $\begin{array}{l}\text { - Dijakinje in dijaki pri } \\
\text { branju in tvorjenju pisnih } \\
\text { besedil izberejo učinkovite } \\
\text { strategije, jih pojasnijo ter } \\
\text { besedila glede na namen in } \\
\text { vsebino utemeljeno } \\
\text { povežejo s svojim } \\
\text { predstavnim svetom, } \\
\text { učenjem in prihodnjim } \\
\text { poklicem; } \\
\text { - razumejo in tvorijo } \\
\text { strokovna besedila in } \\
\text { uporabljajo strokovno } \\
\text { izrazje. }\end{array}$ \\
\hline $\begin{array}{l}\text { - Nadaljnje učenje smiselne uporabe virov v } \\
\text { šolski in splošni knjižnici. }\end{array}$ & $\begin{array}{l}\text { - Dijakinje in dijaki } \\
\text { poznajo in smiselno } \\
\text { uporabijo vire v knjižnicah. }\end{array}$ \\
\hline
\end{tabular}


- $\quad$ Spodbujanje rabe in kritične presoje tradicionalnih in novih bralno-pisnih tehnologij in virov.
- $\quad$ Dijakinje in dijaki preberejo, obnovijo in uredijo informacije iz elektronskih in tiskanih besedil; rokopisno in $\mathrm{v}$ elektronski obliki oblikujejo lastna besedila.

Vir: Nacionalna strategija za razvoj bralne pismenosti 2019-2030 (2019: 9-12)

Nacionalna strategija je kot strateški dokument države pomembna pridobitev za spodbujanje razvoja bralne pismenosti prebivalstva tudi po koncu formalnega izobraževanja. $\mathrm{Na}$ tem mestu sicer ne posegamo na področje razvoja bralne pismenosti študentov in odraslih, vseeno pa je treba opozoriti, da morajo biti zlasti študentje, ki bodo izobraževalci, in pedagoški delavci vseh strok posebej občutljivi za jezikovni razvoj otrok, ki jih izobražujejo.

\section{Gradniki bralne pismenosti}

Pod terminom bralna pismenost razumemo vse štiri dejavnosti, povezane $\mathrm{z}$ branjem, torej poslušanje, branje ter govorjenje in pisanje (Pečjak in Gradišar 2015: 59), prvi dve kot receptivni in drugi dve kot produktivni dejavnosti. Manguel (2007: 85) pravi: »Metode, s katerimi se učimo brati, namreč niso samo zgolj utelešenje konvencij naše družbe glede pismenosti - usmerjanja informacij, hierarhij znanja in moči, ampak tudi določajo in omejujejo načine, kako svojo bralno zmožnost uporabljamo.« Iz zgoraj navedenih dokumentov (Bela knjiga o vagoji in iz̧obraževanju v Republiki Sloveniji, Nacionalna strategija za razvoj bralne pismenosti 2019-2030 in Kljucne kompetence za vseživljenjsko ǘenje: evropski referenčni okvir) jasno izhaja, da je razvoj pismenosti vseživljenjska dejavnost, pri kateri pridobivamo kompetence v vseh položajih učenja (formalnem, neformalnem in priložnostnem), v izobraževalnem procesu pa se razvija na vseh področjih dejavnosti $\mathrm{v}$ vrtcu in pri vseh predmetih $\mathrm{v}$ osnovni in srednji šoli.

V okviru dela pri projektu OBJEM - Bralna pismenost in razvoj slovenščine (Ozaveščanje, Branje, Jezik, Evalvacija, Modeli) smo v raziskavah bralno pismenost opazovali z več vidikov, med katerimi je treba izpostaviti zlasti tri:

- z vidika oblikovanja gradnikov bralne pismenosti;

- $\quad \mathrm{z}$ vidika didaktičnih pristopov, ki prispevajo $\mathrm{k}$ bralni pismenosti; 
- $\mathrm{z}$ vidika izbora kakovostnih bralnih gradiv za vsa področja dejavnosti $\mathrm{v}$ vrtcih in vse predmete $\mathrm{v}$ osnovnošolskem in srednješolskem izobraževanju.

Pri kulturnih dejavnikih bralne pismenosti velja, kakor ugotavlja IFLA, spodbujati: otrokovo/učenčevo/dijakovo obkroženost $z$ bralnim gradivom ( $v$ vrtcu oz. šoli in v domačem okolju), vlogo knjižnice (ne samo kot prostora izposoje gradiva, temveč tudi dejavnosti za mlade bralce), glasno branje (kar velja zlasti za predšolsko in zgodnje šolsko izobraževanje, kaže pa se tudi kot pozitiven vpliv odraslih na branje starejših učencev in dijakov) in odraslega, ki je bralni zgled. Otrok mora nujno imeti stik $\mathrm{z}$ raznolikim bralnim gradivom (leposlovjem in informativno literaturo), da bi razvil zavedanje o pomenu branja na vseh predmetnih področjih, pri čemer ni zanemarljiva dimenzija multimodalne pismenosti, ta pa vključuje pri bralnem gradivu jezikovni in vizualni kod izražanja (in s tem interakcijo ob sestavljanju pomenov obeh sporazumevalnih kodov). Ne nazadnje je pomemben faktor branja tudi pozitivna družbena klima, ki branje spoštuje in ga neguje (Haramija 2018).

Iz primerjalne študije sistemskih dejavnikov pismenosti, ki so se pokazali v organizaciji predšolskega in osnovnošolskega izobraževanja $\mathrm{V}$ povezavi $\mathrm{z}$ opismenjevanjem, $\mathrm{v}$ ciljnem raziskovalnem projektu Kulturni in sistemski dejavniki bralne pismenosti ${ }^{3}$ navajamo natančno razdelan sistem za spodbujanje branja $\mathrm{v}$ Šanghaju, saj se učenci teh šol v vseh raziskavah o bralni pismenosti uvrščajo na lestvicah v sam vrh; posledično smemo trditi, da sistem učinkovito deluje. V šanghajskem kurikulumu za izobraževanje (razdeljen je po stopnjah za vrtce in osnovnošolsko izobraževanje $)^{4}$ so v poglavju $3 \mathrm{~B}$, naslovljenem Reading to Learn, med drugim natančno opredeljene vloge odraslih pri razvoju bralne pismenosti otrok (za kitajski in angleški jezik), in sicer vloga ravnateljev in oblikovalcev učnega načrta, naloge učiteljev - knjižničarjev, naloge učiteljev vseh predmetov in tudi naloge staršev. V Zaključnem poročilu CRP Kulturni in sistemski dejavniki bralne pismenosti sta Haramija in Batič (2016: 73-74) izpostavili naslednje ugotovitve, povezane $z$ vlogo odraslih pri bralni pismenosti otrok v Šanghaju:

\footnotetext{
${ }^{3} \mathrm{~V}$ navedenem ciljnem raziskovalnem projektu (CRP), vodila ga je Polona Vilar; za primerjavo izobraževalnih sistemov sta bili zadolženi Dragica Haramija in Janja Batič, so bile primerjane države, določene z razpisom CRP: Estonija, Finska, Poljska, Japonska, Kitajska, Singapur in Slovenija; gre za države, ki se uvrščajo v mednarodnih raziskavah pismenosti v države z najvišjimi dosežki. Projekt je potekal v letih 2015-2016.

${ }^{4}$ Učni načrt za osnovnošolsko izobraževanje je najprej predstavljen po predmetih, nato sledi delitev na štiri področja: Moralna in državljanska vzgoja (3A); Branje za učenje (3B), Projektno učenje (3C) in Informacijska tehnologija za interaktivno učenje (3D); vsako področje ima svoj zvezek, na portalu so na enem mestu zbrani vsi učni načrti, razporeditev ur in druga organizacijska navodila: https://cd1.edb.hkedcity.net/cd/EN/Content_2909/html/index.html.
} 
Ravnatelji in oblikovalci učnih načrtov naj bi kot prednostno nalogo šole postavili branje, namenili sredstva za promocijo branja (vključno z določanjem časa za branje $\mathrm{v}$ urniku). Izhajali naj bi iz obstoječih močnih področij (učne ure branja ipd.) in jih uporabili kot izhodišča za promocijo učinkovitejših bralnih veščin v šolah. Sprejeli naj bi najnovejše koncepte učinkovitih knjižničnih storitev in spodbujali sodelovanje med zaposlenimi pri pripravi bralnih projektov. Nadzorovali naj bi nakup materialov za branje. Promovirali naj bi uporabo učinkovitih bralnih strategij in aktivnosti. Gojili naj bi bralno kulturo med učitelji.

Opredeljene so tudi naloge učiteljev - knjižničarjev, ki naj bi učencem pomagali uporabljati knjižnico na tak način, ki spodbuja učenje učenja. Primeri:

- Omogočanje preprostega dostopa do informacij različnih formatov in tehnologij.

- Razvijanje programov za krepitev veščin samostojnega učenja učencev.

- Razvijanje strategij, ki negujejo interes za branje in redne bralne navade učencev.

- Sodelovanje z učitelji pri načrtovanju, poučevanju in promociji uporabe različnih virov informacij pri učenju in poučevanju za učitelje in učence.

- Zagotavljanje dostopnosti kakovostnih knjižničnih virov in učnih pripomočkov.

- Izboljšanje knjižničnih storitev v šolah, npr. podaljšanje odpiralnega časa, namenjenega branju in učenju.

- Pospeševanje razvoja informacijske pismenosti znotraj šole, slednje najnovejšim smernicam v kurikulumu in tehnologiji.

Opredeljene so naloge učiteljev. Učitelji pomagajo učencem $k$ boljšemu učenju skozi učinkovito branje $\mathrm{z}$ refleksijo in spodbujanjem branja, ki presega zgolj branje učbenikov v razredih. Promocija branja se nanaša na vse učitelje (ne zgolj pri poučevanju jezika). Učitelji učencem pomagajo uporabljati branje kot pripomoček za izgradnjo znanja pri svojem predmetu. To lahko naredijo tako, da:

- načrtujejo učne ure, v katerih ima branje pomembno vlogo;

- seznanjajo učence $z$ zahtevnejšimi ali nepoznanimi koncepti in besediščem pred branjem;

- spodbudijo učence, da si oblikujejo slovarček; 
- postavijo učencem vprašanja pred branjem, ki spodbudijo interes za branje;

- postavljajo vprašanja, ki se navezujejo na prebrano besedilo;

- omogočajo učencem, da uporabljajo različne bralne strategije;

- učence spodbudijo, da si delajo zapiske o prebranem;

- spodbujajo že najmlajše učence, da preidejo od branja učbenikov na branje knjig na določeno strokovno temo ali za določen namen.

Učitelji pridobijo ustrezne kompetence in strategije (npr. za motiviranje nebralcev) skozi samostojno ali organizirano učenje. Sodelujejo z drugimi učitelji pri organizaciji časa in prostora za pomoč učencem.

Učni načrt opredeljuje tudi naloge staršev, ki naj bi bili vzor z rednim lastnim branjem doma. Starši naj bi doma določili čas za skupno branje $z$ otroki (pol ure vsak dan). Omogočili naj bi prijetno bralno okolje (ugasnjena televizija), stanovanje naj bi opremili s kakovostnim bralnim gradivom, se udeleževali organiziranih dogodkov, povezanih z branjem itd.

Učitelji in starši naj bi skupaj skrbeli za čas, namenjen branju. Šole naj bi skrbele za razvijanje interesa za samostojno branje, in sicer naj bi:

- zagotovile, da je branje vključeno $\mathrm{v}$ učenje in poučevanje pri učnih urah kitajščine in angleščine;

- spodbudile vse učitelje, da prevzamejo branje za učenje kot primarno učno strategijo za učence;

- omogočile primeren urnik šolskih knjižnic.

Ugotovimo lahko, da bralne učne strategije, kakor so opredeljene v knjigi Reading to Learn (2002), izpostavljajo zelo podobne poudarke kot gradniki bralne pismenosti, le da ima hongkonški model tudi jasno začrtane vloge odraslih in njihovo odgovornost pri razvoju pismenosti otrok. Menimo, da bi bilo tudi v gradnikih nujno upoštevati ta organizacijsko-sistemski vidik razvoja bralne pismenosti, in sicer v izobraževalnem sistemu, splošnih knjižnicah, celotni družbi. Na to nas navajajo tudi rezultati najnovejše raziskave Knjiga in bralci VI (Rupar, Blatnik, Kovač in Rugelj 2019), kjer je na podlagi empiričnih rezultatov predstavljeno, da $v$ zadnjih letih narašča število nebralcev, število bralcev pa, glede na pretekle raziskave, pada. 


\subsection{Utemeljitev gradnikov bralne pismenosti}

Gradniki bralne pismenosti imajo skupna izhodišča (Gradniki bralne pismenosti 2018: 1):

1. Vsi gradniki se razvijajo v povezavi s cilji in vsebinami pri vseh predmetih/področjih.

2. Vsak gradnik se razvija kot del celote.

3. Izhodišče za razvijanje vseh gradnikov so besedila (pisna, govorjena, avdio, video ...) pri vseh predmetih/področjih. Vrsta in zahtevnost besedil se po vertikali stopnjujeta $\mathrm{z}$ obsegom vsebine, njeno abstraktnostjo (tudi v povezavi s terminologijo) in poglobljenostjo ter jezikovno zahtevnostjo.

4. Integriranost - pomeni, da se gradnik, ki je usvojen v nekem obdobju, razvija tudi naprej, čeprav ni izrecno zapisano.

5. Gradnike razvijamo sistematično: načrtno in premišljeno v celotnem izvedbenem kurikulu in pri pouku vseh predmetov.

6. Pri razvijanju gradnikov se upoštevajo razvoj, predznanje, potrebe in posebnosti vsakega otroka/učenca/dijaka.

7. Gradniki se razvijajo procesno, skozi daljše obdobje, zato je opis pričakovanega dosežka zapisan za konec obdobja.

Pri zapisanih gradnikih bralne pismenosti, ki jih razvijajo tako učitelji kot vzgojitelji, igrajo pomembno vlogo didaktična načela: načelo strukturnosti in sistematičnosti, načelo učne aktivnosti, nazornosti, diferenciacije in individualizacije, problemskosti in življenjskosti pouka in šole (Ivanuš Grmek in Javornik Krečič 2011). Didaktična načela, ki so teorija pouka $\mathrm{v}$ malem, vplivajo na učiteljeva pojmovanja učenja, poučevanja, vlogo učenca in dijaka pri pouku. Vse omenjeno pa vpliva na učiteljevo ravnanje pri pouku, ki se kaže $\mathrm{v}$ rabi učnih metod in učnih oblik. Na razvoj gradnikov bralne pismenosti vpliva učna vsebina, ki je izjemno širok in kompleksen pojem, saj predstavlja vsa raznovrstna sredstva, s katerimi vzgajamo in izobražujemo (Blažič, Ivanuš Grmek, Kramar in Strmčnik 2003). Zato je pri razvoju gradnikov bralne pismenosti treba izbirati kakovostna besedila, ki omogočajo tako koncentrični kot spiralni pristop k oblikovanju učne vsebine v učnih načrtih (prim. Ivanuš Grmek in Javornik Krečič 2011). 


\subsection{Didaktična izhodišča za razvoj bralne pismenosti na vseh področjih dejavnosti $v$ vrtcu in pri vseh predmetih $v$ osnovni in srednji šoli}

Pomemben dejavnik razvoja bralne pismenosti za otroke $\mathrm{v}$ vrtcu na formalni ravni predstavlja Kurikulum za vrtce (1999), za učence in dijake, ki obiskujejo osnovno in srednjo šolo, pa učni načrti posameznih predmetov. Tako kurikulum za vrtce kot učni načrti so šolsko upravni dokumenti. V Kurikulumu za vrtce (1999) je dobro poudarjeno, da je vrtec prostor, kjer se otroci ob poslušanju vsakdanjih pogovorov, branju različnih besedil in izražanju lastnih misli učijo jezika. Prav tako v vrtcu spoznavajo knjigo in se nanjo navajajo. Pogovor in navajanje na branje, kar opravljajo vzgojitelji, pa seveda tudi starši, predstavlja osnovo razvoja bralne pismenosti pri otrocih. Ta proces se nadaljuje $\mathrm{v}$ osnovni in nato $\mathrm{v}$ srednji šoli. Učni načrti s svojo naravnanostjo in strukturo opravljajo pri razvoju bralne pismenosti pomembno vlogo, ki se kaže v smiselnem izboru ter strukturi učne vsebine, $\mathrm{v}$ zapisu ciljev in standardov znanja, pa tudi $\mathrm{v}$ zapisu didaktičnih priporočil, ki so namenjena delu učiteljev. Za razvoj bralne pismenosti ni pomemben le učni načrt za slovenščino (UN 2018), temveč učni načrti vseh učnih predmetov. Nadaljnji dejavnik, ki odigrava pomembno vlogo pri razvoju bralne pismenosti pri otrocih, učencih in dijakih, je smiselna uporaba učnih metod. Vzgojitelji in učitelji se glede na značilnosti učne vsebine, zahtevnost učnih ciljev, ki jih morajo doseči, razpoložljiv čas pri pouku, pedagoško znanje in izkušnje, zainteresiranost učencev in dijakov pri pouku odločajo za rabo različnih učnih metod (Ivanuš Grmek in Javornik Krečič 2011). Učitelji pri pouku izbirajo različne oblike metode razlage, različne oblike učnega pogovora, delo z besedilom, prikazovanje, reševanje problemov. Vse naštete učne metode prispevajo $\mathrm{k}$ razvoju bralne pismenosti. Ker je učni pogovor poleg razlage najpogosteje uporabljena učna metoda tako $\mathrm{v}$ vrtcih kot $\mathrm{v}$ šolah, vendar pogosto ne dovolj premišljeno načrtovan, se je treba zavedati, da je kakovostni učni pogovor sestavljen iz petih korakov, ki jih učitelj izvaja z namenom, da spodbuja mišljenje učencev (Walsh in Sattes 2011):

- oblikovanje kakovostnih vprašanj z vidika učne vsebine, njene strukture in zahtevnosti;

- krepitev mišljenja učencev: čas za razmislek, stopnjevanje zahtevnosti vprašanj, vzpodbujanje samoregulacijskih in metakognitivnih sposobnosti in spretnosti; 
- dajanje sprotne povratne informacije, kar služi nadaljnjemu učenju in razvoju mišljenja;

- spodbujanje odgovornosti pri učencih: spodbujanje učencev k zastavljanju vprašanj, kar pripomore k usmerjanju učenja;

- razvijanje kulture mišljenja, kar pomeni, da je mišljenje pri pouku pričakovano in cenjeno, saj so učitelji in učenci partnerji pri vzpostavljanju klime v razredu.

Tako strukturiran učni pogovor bo s smiselno kombinacijo drugih metod zagotovo prispeval k razvoju bralne pismenosti.

\subsection{Izbor kakovostnih bralnih gradiv za vsa področja dejavnosti v vrtcih in pri vseh predmetih $\mathbf{v}$ osnovni in srednji šoli}

Izbor besedil mora biti skladen s Kurikulumom za vrtce (1999) in učnimi načrti za OŠ in SŠ za vsa predmetna področja (ne samo za slovenščino kot učni predmet). Uporaba različnih metod pri delu z besedili je seveda odvisna od starosti otroka, učenca ali dijaka in od ciljev, ki si jih ob delu z nekim besedilom pedagoški delavec zastavi. Metode dela so podrobneje predstavljene pri posameznih gradnikih.

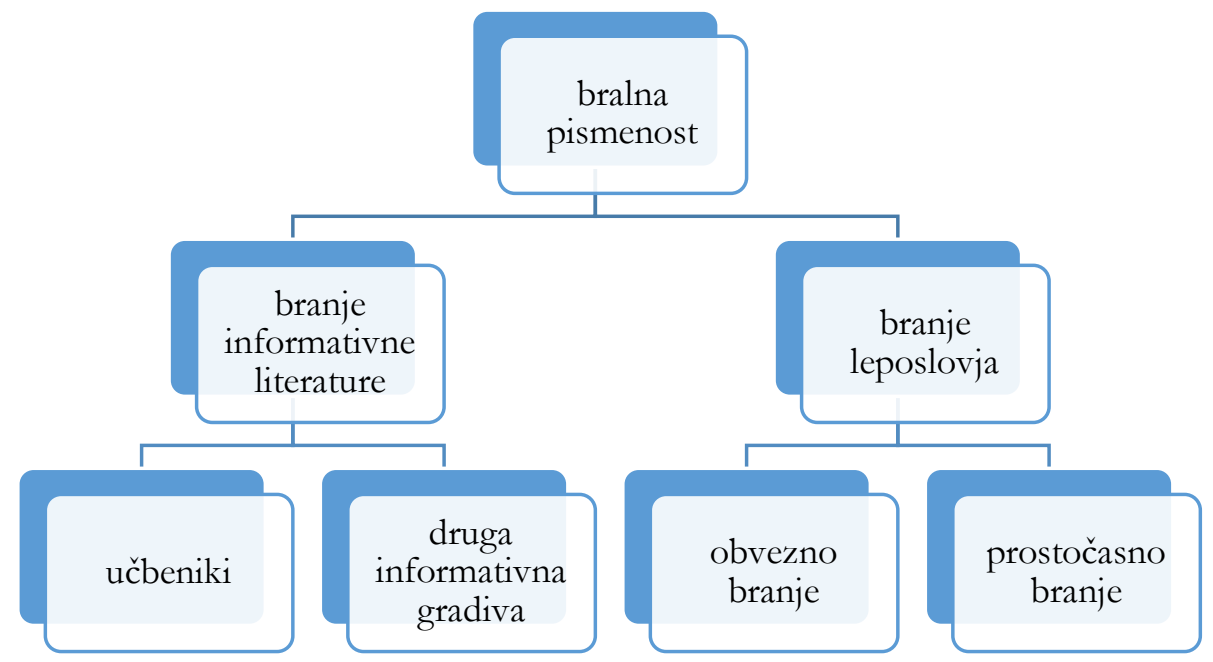

Slika 1: Razvrstitev tiskanih in elektronskih bralnih gradiv 
Učbenik je temeljna šolska knjiga, ki jo učenci uporabljajo vsak dan (Ivanuš Grmek 2003; Mullis, Martin, Foy in Arora 2012). Pravilnik o potrjevanju uchenikov (2015) v 2. členu opredeljuje učbenik kot »osnovno učno gradivo za doseganje vzgojnoizobraževalnih ciljev in standardov znanja, opredeljenih $\mathrm{v}$ učnem načrtu oziroma katalogu znanja«. Učbenik torej pomembno prispeva $\mathrm{k}$ uresničevanju ciljev, zapisanih v učnem načrtu (Hadar 2017). Pri oblikovanju učbenika odigravata pomembno vlogo didaktično-metodična predstavitev učne vsebine ter likovna in grafična podoba učbenika. Učbenik je torej tisto učno gradivo, ki omogoča pridobivanje znanja in samostojno učenje. Prav zaradi tega je izjemnega pomena, da je učbenik tako po vsebinski kot po oblikovni plati pripravljen čim bolj kakovostno. Za učbenike so pomembne vsebinsko-didaktične karakteristike ter organizacijskotehnični vidik. $Z$ vsebinsko-didaktičnim vidikom mislimo na ustreznost vsebine glede na razvojno stopnjo učenca, na njeno znanstveno ustreznost in na stopnjevanje zahtevnosti učne vsebine. Prav tako je pomembno, da učbenik pri učencih spodbuja kritično in ustvarjalno mišljenje, da spodbuja učence $\mathrm{k}$ bogatenju besedišča ter $\mathrm{k}$ spoznavanju novih pojmov s pomočjo primerov. Pomembno je, da učbenik navaja učence na spoznavanje in uporabo primerov iz vsakdanjega življenja (Jurman 1999; Ivanuš Grmek 2003; Mithans in Ivanuš Grmek 2020).

Rezultati raziskave, opravljene $\mathrm{v}$ okviru projekta Za kakovost slovenskih uchenikov (Ivanuš Grmek 2018), kažejo, da se učitelji v glavnem odločajo za izbiro učbenika zaradi vsebine. Ostali dejavniki, kot je videz učbenika ter vpliv sodelavcev, so se pri izboru učbenika pokazali kot manj pomembni. Naslednje pomembno vprašanje je, v katerih artikulacijskih stopnjah pouka učitelji učbenik uporabljajo pri pouku. Med učitelji razrednega pouka, predmetnega pouka in srednješolskimi učitelji prihaja do nekaterih razlik glede na artikulacijsko stopnjo. Učitelji razrednega pouka in učitelji predmetnega pouka učbenik večinoma uporabljajo $\mathrm{v}$ fazi ponavljanja in utrjevanja učne vsebine, najredkeje se na učbenik opirajo $v$ fazi uvodne motivacije. Pri srednješolskih učiteljih je praksa uporabe učbenikov nekoliko drugačna, saj prevladuje uporaba učbenika $\mathrm{v}$ fazi razlage učne vsebine. Prav tako kot osnovnošolski učitelji pa učbenik najredkeje uporabljajo za uvodno motivacijo. Ker je pomemben namen učbenika usmeriti učenca in dijaka k samostojnemu učenju, nas presenečajo rezultati raziskave, saj so tako učenci kot dijaki povedali, da učbenik pogosteje uporabljajo pri pouku kot doma. Ko se pripravljajo na preverjanje in ocenjevanje znanja, učbenik sicer uporabljajo skupaj s šolskim zvezkom (Ivanuš Grmek 2018: 35). 
Z vidika spodbujanja bralne pismenosti je smiselno učence in dijake usmerjati $\mathrm{k}$ rabi učbenika zato, da poglobijo znanje, o njem samostojno razmišljajo ter si zastavljajo vprašanja, ki jih vodijo do razumevanja. Poleg učbenika učitelji uporabljajo pri pouku tudi druga učna gradiva: e-učbenik, delovni zvezek, dostopna učna gradiva na spletu, spletne strani založb in fotokopije. Vendar je njihova uporaba relativno skromna (Ivanuš Grmek 2018: 33-46).

$\mathrm{Z}$ vidika bralne pismenosti bi bilo treba učence in dijake usmerjati $\mathrm{k}$ rabi različnih gradiv. S tem bi prispevali k temu, da bi učenci in dijaki več brali, prebrano razumeli, znanje povezovali in ga postavljali $\mathrm{v}$ nov kontekst.

Vse zgoraj navedeno velja tudi za leposlovna gradiva, pri katerih pa je treba upoštevati še naslednje kriterije za izbiro (prim. Haramija 2017: 24-25):

- kakovost dela, kakor ga utemeljuje že Janko Kos (2001: 35-41): spoznavna, etična, estetska vrednost besedila (in ilustracije);

- razmerje med branjem domačega in prevedenega leposlovja, ki mora biti vedno malce v prid izvirni slovenski (otroški in mladinski) književnosti;

- razmerje med branjem kanonskega (klasičnega) in sodobnega leposlovja;

- raznolikost literarnih besedil glede na književne zvrsti, vrste in žanrsko pripadnost.

V zadnjih letih se pojavljajo dileme o smiselnosti branja klasične literature oziroma kanonskih besedil, še posebej v okviru domačega branja učencev in dijakov, kar je treba nujno zavrniti. Otrok, učenec ali dijak mora namreč poznati temeljna besedila, ki sestavljajo kulturno dediščino naroda in sveta. Marko Juvan je pri utemeljitvi termina medbesedilnost navedel, da »je opozorila stroko na pomembno razsežnost književnosti: da je v literarna dela, njihovo ustvarjanje in sprejemanje vselej - čeprav $\mathrm{v}$ različnem obsegu in $\mathrm{z}$ neenako očitnostjo - vgrajeno tuje gradivo, takšno, ki ni zajeto iz avtorjeve domišljije, življenja ali iz družbenih in zgodovinskih dogodkov, temveč je izposojeno iz narejenih besedil, bodisi iz zakladnice tradicije bodisi iz sodobnega sporočevalnega obtoka« (Juvan 1999: 395). Torej nekdo, ki ne pozna kanonskih besedil iz slovenske ali svetovne književnosti, ne more prepoznavati medbesedilnih elementov ali s pomočjo teh drugače in bolj poglobljeno interpretirati besedila, ki ga bere. Ali povedano drugače: npr. Igor Saksida navaja tri zahtevnostne ravni zastavljanja vprašanj ob prebranem besedilu, in sicer priklic, sklepanje in 
vrednotenje (Saksida 2017: 53); če mladi bralec ne pozna določenega korpusa besedil (seveda v skladu z njegovo starostjo in bralnimi izkušnjami), lahko tvori odgovore s priklicem informacij iz besedila, pa tudi sklepa in vrednoti lahko le na podlagi besedila, ne pa tudi na podlagi morebitnih medbesedilnih navezav, ker jih ne pozna. Seveda pa je treba otrokom, učencem in dijakom nuditi izbiro, zlasti sodobne otroške in mladinske književnosti.

\section{$4 \quad$ Sklep}

Bralna pismenost je ena od ključnih kompetenc sodobnega človeka, saj funkcioniranje $\mathrm{v}$ družbi brez branja ni mogoče. Njen razvoj je vseživljenjska dejavnost, saj naj bi se posameznik nenehno izpopolnjeval v poslušanju, govorjenju, branju in pisanju, torej $\mathrm{v}$ vseh štirih dejavnostih, ki tvorijo bralno pismenost.

Kriteriji za izbiro kakovostnih besedil (prim. Haramija 2017: 24-25) so v splošnem odvisni od starosti mladega bralca in od namena ali zastavljenega cilja, kadar gre za kurikularno branje:

- kakovost izbranega informativnega ali leposlovnega besedila, pri čemer je zelo pomembna tudi kakovost drugih kodov sporočanja (primeri so natančneje predstavljeni v poglavju o tretjem gradniku bralne pismenosti);

- skladnost s Kurikulumom za vrtce (1999) in učnimi načrti za vse predmete za osnovnošolsko in srednješolsko izobraževanje;

- razvijanje različnih metod dela ob spoznavanju leposlovja in informativne literature;

- spoznavanje različnih oblik knjig (slikanica brez besedila, strip, slikanica, ilustrirana knjiga, knjiga brez ilustracij);

- primerna dolžina besedila (kar je pomembno predvsem za mlajše otroke);

- upoštevanje drugih dejavnikov in interesa otrok, učencev in dijakov.

Odgovornost za pozitiven razvoj kompetence bralne pismenosti nosimo vsi odrasli, še posebej pa vsi, ki smo kakor koli povezani z izobraževanjem otrok in mladostnikov, kajti pismenost se prenaša medgeneracijsko. 


\section{Literatura}

Basic Education Curriculum Guide, 2002. Curriculum Development Council Secretariat, Hong Kong: Curriculum Development Council Correspondence.

https://cd1.edb.hkedcity.net/cd/EN/Content_2909/html/index.html

Bela knjiga o vagoji in izobraževanju v Republiki Sloveniji, 2011. Janez KREK (ur.) in Mira METLJAK (ur.). Ljubljana: Zavod RS za šolstvo. http://pefprints.pef.uni-lj.si/1195/

Marjan BLAŽIČ, Milena IVANUŠ GRMEK, Martin KRAMAR in France STRMČNIK, 2003: Didaktika - visokošolski učbenik. Novo mesto: Visokošolsko središče, Inštitut za raziskovalno in razvojno delo.

Gradniki bralne pismenosti: delovno gradivo, 2018. Ljubljana: Zavod RS za šolstvo.

Linor L. HADAR, 2017: Opportunities to learn: Mathematics textbooks and students' achievements. Studies in Educational Evaluation 55. 153-166. https://www.sciencedirect.com/science/article/abs/pii/S0191491X17300949

Dragica HARAMIJA, 2017: Književnost v predšolskem obdobju. V objemu besed. Dragica Haramija (ur.). Univerza v Mariboru: Univerzitetna založba, Pedagoška fakulteta. 23-29.

Dragica HARAMIJA, 2018: Dejavniki bralne pismenosti in družinskega branja $\mathrm{v}$ otrokovem predšolskem obdobju. Jezile in slovstvo 63(4). 3-15.

Dragica HARAMIJA in Janja BATIČ, 2016: Primerjava izbranih držav glede na organiziranost predšolske vzgoje in opismenjevanja ter branje v prostem času. Zaključno poročilo Ciljnega raziskovalnega projekta V5-1506 - Kulturni in sistemski dejavniki bralne pismenosti v Sloveniji. Ur. Polona Vilar. 39-100.

Milena IVANUŠ GRMEK, 2003: Učbeniški kompleti v prvem triletju devetletne osnovne šole. Sodobna pedagogika 54(5). 74-89.

Milena IVANUŠ GRMEK, 2018: Raziskava med učitelii in učenci o uporabi in zaznavnih značilnostih učbenikov. https://kauc.splet.arnes.si/files/2020/01/Predstavitev_KAUC_Grmek_Koper_2018.pdf

Milena IVANUŠ GRMEK in Marija JAVORNIK KREČIČ, 2011: Osnove didaktike. Maribor: Pedagoška fakulteta.

Benjamin JURMAN, 1999: Kako narediti dober učbenik: na podlagi antropološke vagoje. Ljubljana: Jutro.

Marko JUVAN, 1999: Medbesedilnost - figure in vrste. Slavisticna revija 47(4). 393-416.

Ključne kompetence za vsę̌ivljenjsko ǚenje: evropski referenčni okvir. Uradni list EU, 2018/C 189/01. https://eur-lex.europa.eu/legalcontent/SL/TXT/PDF/?uri=OJ:C:2018:189:FULL\&f\%20rom=SL

Janko KOS, 2001: Literarna teorija. Ljubljana: DZS.

Kurikulum za vrtce, 1999.

https://www.gov.si/assets/Ministrstva/MIZS/Dokumenti/Storitve/Predsolskavzgoja/6634c981ba/ Kurikul_za_vrtce.pdf

Alberto MANGUEL, 2007: Zgodovina branja. Ljubljana: Cankarjeva založba (Zbirka Bralna znamenja).

Monika MITHANS in Milena IVANUŠ GRMEK, 2020: The use of textbooks in the teaching-learning process. New horizons in subject-specific education: research aspects of subjects specific didactics. Maribor: University Press: Faculty of Education. Alenka LIPOVEC (ur.), Janja BATIČ (ur.), Eva KRANJEC (ur.). 201-227. https://press.um.si/index.php/ump/catalog/view/481/590/9871

Ina V. MULLIS, Michael O. MARTIN, Pierre FOY, Pierre in Alka ARORA, 2012: TIMSS 2011 International results in mathematics. Chestnut Hill, MA, Amsterdam: TIMMS International Association for the Evaluation of Educational Achievement (IEA). https:/ / eric.ed.gov/?id=ED544554

Nacionalna strategija za razvoj bralne pismenosti za obdobje 2019-2030. Vlada Republike Slovenije, 2019. https://www.gov.si/novice/2020-01-15-nacionalna-strategija-za-razvoj-bralne-pismenostiza-obdobje-2019-2030/

Sonja PEČJAK in Ana GRADIŠAR, 2015: Bralne učne strategije. Ljubljana: Zavod Republike Slovenije za šolstvo.

Pravilnik o potrjevanju übenikov, 2015: Uradni list RS, (34/2015, 27/2017). http://www.pisrs.si/Pis.web/pregledPredpisa?id=PRAV12484 
Učni načrt. Program osnovna šola. Slovenščina, 2018. Ljubljana: Ministrstvo za izobraževanje, znanost in šport, Zavod RS za šolstvo.

https://www.gov.si/assets/ministrstva/MIZS/Dokumenti/Osnovna-sola/Ucninacrti/obvezni/UN_slovenscina

Reading to Learn (3B), 2002. Four Key Tasks - Achieving Learning to Learn. Basic Education Curriculum Guide. Curriculum Development Council Secretariat. Hong Kong: Curriculum Development Council Correspondence. http://cd1.edb.hkedcity.net/cd/EN/Content_2909/html/index.html.

Patricia RUPAR, Andrej BLATNIK, Miha KOVAČ in Samo RUGELJ, 2019: Knjiga in bralci VI: bralna kultura in nakupovanje knjig v letu 2019. Ljubljana: UMco.

Igor SAKSIDA, 2017: Bralni dogodek v vrtcu. $V$ objemu besed. Dragica Haramija (ur.). Univerza v Mariboru: Univerzitetna založba, Pedagoška fakulteta. 47-54.

Jackie Acree WALSH in Beth Dankert SATTES, 2011: Thinking Through Quality Questioning: Deepening Student Engagement. Thousand Oaks: Corwin, A Sage Companx. https://books.google.si/books?id=F7QpxicmA18C\&pg=PA17\&hl=sl\&source=gbs_selecte d_pages\&cad $=2 \#$ 


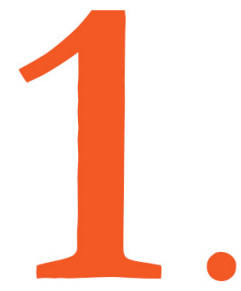

GRA DN I K

GOVOR

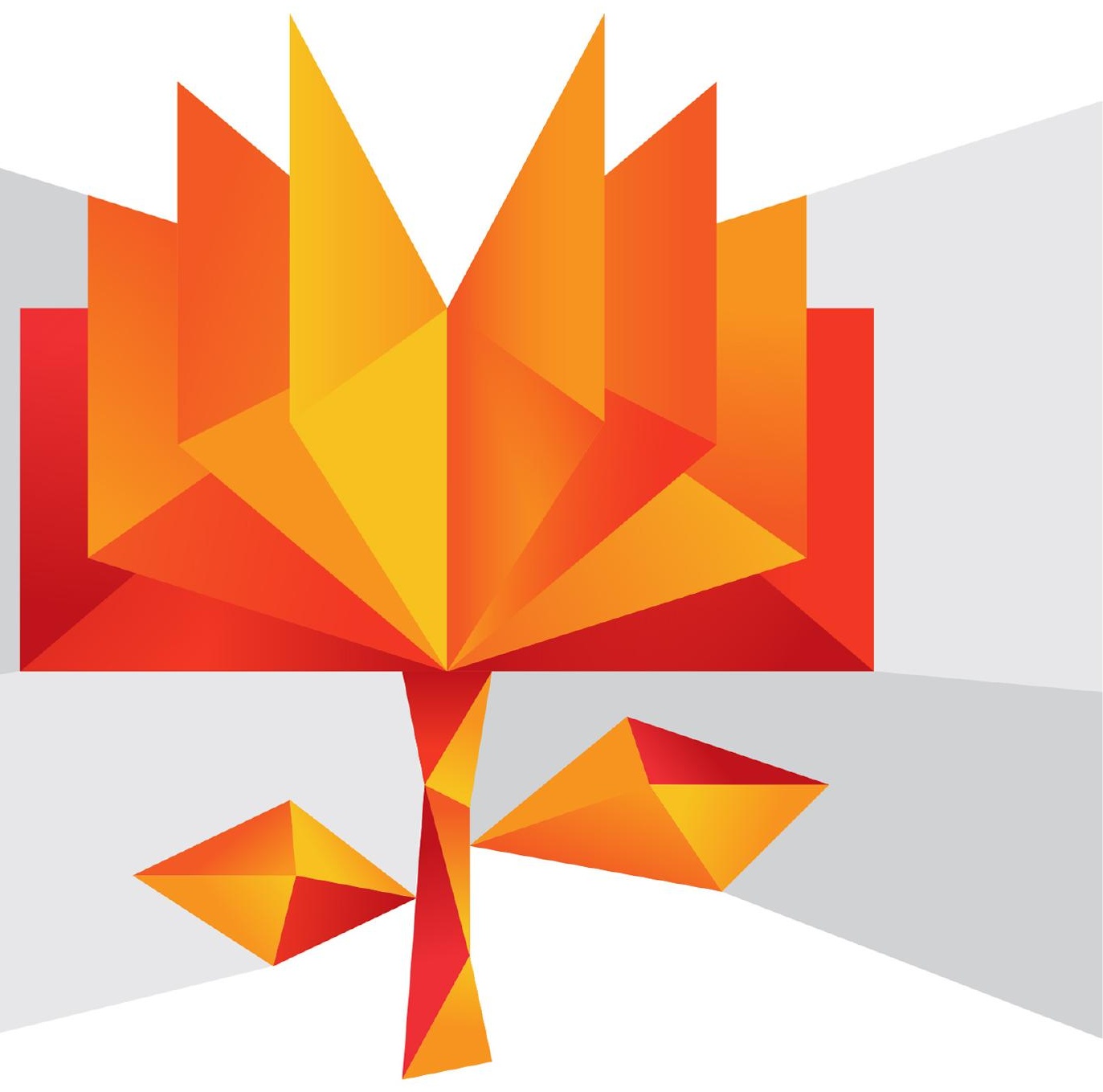




\section{Elementi gradnika:}

- zmožnost nebesednega sporazumevanja

- jezikovna zmožnost (besedna zmožnost; skladenjska/slovnična zmožnost: opisovanje, pripovedovanje, razlaganje, utemeljevanje; pravorečna zmožnost)

- uporaba govora v različnih govornih položajih, za različne namene in $\mathrm{v}$ različnih situacijah

- uporaba izrazov za čustvena/mentalna stanja 


\section{GRADNIK:}

\section{GOVOR}

\section{POLONCA ŠEK MERTÜK IN ZLATKA CUGMAS}

Univerza v Mariboru, Pedagoška fakulteta, Maribor, Slovenija.

E-pošta: polonca.sek@um.si, zlatka.cugmas@um.si

Povzetek Razvoj govora najintenzivneje poteka $\mathrm{v}$ obdobju malčka in zgodnjega otroštva ter $\mathrm{v}$ različnih fazah. Za predjezikovno fazo so značilni gruljenje, raba in ponavljanje različnih glasov ter bebljanje. $V$ jezikovni fazi malček začne tvoriti prve besede, ki najpogosteje označujejo znane predmete, preproste prošnje in vsakodnevne dejavnosti. S skladenjskega vidika malček svoje misli najprej izraža s po dvema, nato z vedno več besedami, povezanimi v stavek. Postopoma usvaja slovnična pravila, skokovito bogati besedni zaklad, v zgodnjem otroštvu pa tvori že večstavčne povedi. Ena od pomembnejših nalog vrtca in šole je skrb za govorni razvoj otrok in učencev. Pomembno vlogo v razvoju govora imata vzgojitelj in učitelj. Jasno bi se morala zavedati svoje vloge $\mathrm{v}$ spodbujanju otrokovega govornega razvoja, saj $\mathrm{z}$ njim hkrati vplivata na otrokov spoznavni, socialni in čustveni razvoj. S stopnjami formalnega izobraževanja se krepi in spreminja razvoj govora, s koncem izobraževanja pa nikakor ne konča, ampak se nadaljuje vse življenje. V prispevku so predstavljeni tudi psihodiagnostični pripomočki za ocenjevanje in spremljanje otrokovega razvoja govora, ki se osredotočajo na različna govorna področja, in sicer na govorno razumevanje, rabo govora, skladnjo in pravopis ter pripovedovanje zgodbe.

Ključne besede:

bralna

pismenost,

govor,

razvoj

govora,

zgodnje

otroštvo,

izobraževanje. 


\title{
THE First COMPONENT OF READING LITERACY: SPEECH
}

\author{
POLONCA ŠEK MERTÜK \& ZLATKA CUGMAS ${ }^{2}$ \\ University of Maribor, Faculty of Education, Maribor, Slovenija. \\ E-mail:polonca.sek@um.si, zlatka.cugmas@um.si
}

\begin{abstract}
Speech development is most intense in the toddler and early childhood stages and takes place in different stages, depending on the child's age. The prelinguistic stage is characterised by cooing, the use and repetition of various sounds, and babbling. The linguistic stage marks the formation of first words-these most often denote familiar objects, simple requests, and everyday activities. From a syntactic point of view, the toddler first expresses their thoughts with two, then more words forming a clause. The child gradually learns grammatical rules, rapidly enriches their vocabulary, and in early childhood, begins forming multi-clause sentences. One of the more important tasks of kindergarten and school is taking care of children's speech development, where educators play an important role and should be aware of their role in promoting children's speech development; the educators simultaneously influence the child's cognitive, social and emotional development. The development of speech strengthens and changes with the levels of formal education. However, it does not stop with the end of education, but continues throughout life. The paper also presents psychodiagnostic tools for assessing and monitoring a child's speech development, focusing on different areas of speech: speech comprehension, speech use, syntax and spelling, and storytelling.
\end{abstract}

Keywords: components of reading literacy, speech, speech development, early childhood, education. 


\section{Uvod}

Govor je prvi izmed devetih gradnikov bralne pismenosti (Gradniki bralne pismenosti 2018, delovno gradivo ZRSŠ), oblikovanih v okviru projekta OBJEM. Poleg govora gradnike bralne pismenosti sestavljajo še motiviranost za branje, razumevanje koncepta bralnega gradiva, glasovno zavedanje, besedišče, tekoče branje, razumevanje besedil, odziv na besedilo in tvorjenje besedil ter kritično branje. Posamezni gradniki so med seboj povezani, vsak se razvija kot del celote. Govora si ne moremo zamišljati na primer brez razvitega besedišča in glasovnega zavedanja, poleg tega pa je povezan tudi z razumevanjem in tvorjenjem besedil. Gradnikom je skupno tudi to, da se njihov razvoj ne konča $v$ nekem obdobju oziroma na neki stopnji, ampak se razvijajo konstantno in skozi daljše obdobje ter celo življenje (nikakor samo v času izobraževanja).

Tudi po Nacionalni strategiji za razvoj bralne pismenosti za obdobje 2019-2030 (2019) govor oz. govorjenje spada v okvir bralne pismenosti, ki vključuje še branje, poslušanje in pisanje. Duffy in Roehler (1993: 30, v Pečjak in Gradišar 2012: 59) med osnovne komunikacijske sposobnosti uvrščata govorjenje, pisanje, poslušanje in branje. Pečjak in Gradišar (2012: 59) opozarjata, da gre za "psihološki model, ker izhaja iz vloge, ki jo ima človek/učenec v komunikacijskem procesu«. Govorjenje in pisanje sta produktivni komunikacijski dejavnosti, saj gre za tvorjenje sporočil, poslušanje in branje pa receptivni, saj gre za sprejemanje sporočil. Razlika med obojima je v primarni funkciji, ki je pri govorjenju in pisanju oblikovanje razumljivih sporočil, pri poslušanju in branju pa recepcija/sprejemanje sporočil, ter v izhodišču dražljaja: pri prvih dveh dražljaj prihaja iz človeka (posreduje ga naprej v govorni (govorjenje) ali pisni obliki (pisanje), pri drugih dveh pa od zunaj (učenec/receptor sprejme sporočilo, ki ga je drugi posredoval po slušni (poslušanje) ali vidni (branje) obliki). »Kadar je učenec sposoben razumeti poslušana/brana umetnostna in neumetnostna besedila in kadar je sposoben sam tvoriti razumljiva umetnostna in neumetnostna besedila v govorni ali pisni obliki, lahko rečemo, da je pismen. (Pečjak in Gradišar 2012: 59)

Pismenost pa je tudi ena od osmih ključnih kompetenc, ki so v dokumentu Ključne kompetence za useživljenjsko ucenje: europski referenčni okvir (UL EU 2018/C 189: 7) opredeljene kot kombinacija znanja, spretnosti in odnosov ter »so tiste, ki jih vsi posamezniki potrebujejo za osebnostno izpolnitev in razvoj, zaposljivost, socialno vključenost, uspešno življenje $\mathrm{v}$ mirnih družbah, trajnosten in zdrav način življenja 
ter aktivno državljanstvo«. Pismenost vključuje »ozaveščenost o glavnih vrstah verbalne interakcije, različnih literarnih in neliterarnih besedilih ter glavnih značilnostih različnih slogov in registrov jezika» (Ključne kompetence za vseživiljenjsko učenje 2018: 8). Tako bralna pismenost kot kompetence se razvijajo vse življenje, od rojstva skozi zgodnje otroštvo, nadalje skozi izobraževanje $\mathrm{v}$ osnovni in srednji šoli pa tudi kasneje in v odrasli dobi, ter v najrazličnejših okoljih (doma, $v$ vrtcu, $v$ šoli, $\mathrm{v}$ službi in $\mathrm{v}$ drugih skupnostih). Predvsem pa je treba poudariti, da se $\mathrm{v}$ izobraževanju ne razvijajo samo pri predmetu slovenščina, ampak na vseh predmetnih področjih in pri vseh predmetih. Zato so za govorni razvoj otrok/učencev/dijakov/študentov odgovorni vsi, ki sodelujejo v izobraževalnem procesu.

\section{Razvoj govora v različnih obdobjih}

\subsection{Govor v predšolskem obdobju}

Bloom in Lahey (1978, v Marjanovič Umek in Fekonja 2019) v govoru dojenčka in otroka v predšolskem obdobju razlikujeta tri komponente govora: obliko, vsebino in uporabo. Oblika vključuje npr. oblike besed, strukture stavkov, izgovorjavo glasov in izgled zapisanih jezikovnih znakov; vsebina označuje pomen besed in stavkov; pri rabi pa gre za različne cilje, namene in situacije, v katerih posameznik govor rabi, npr. za informiranje, reševanje problemov, organiziranje dogodkov ali opisovanje svojega počutja in počutja drugih. Raba govora se ne glede na isti namen razlikuje glede na to, komu in kje posameznik kaj sporoča, ali je sporočilo javno ali zasebno, formalno ali neformalno. Tako se npr. namen dobiti nekaj za pitiv različnih govornih položajih lahko izraža kot »Žejen sem«, »Rabim nekaj za piti«, »Bi labko, prosim, dobil kozarec vode» (Marjanovič Umek in Fekonja 2019: 108).

Razvoj govora poteka v dveh fazah: predjezikovni in jezikovni. Za otrokov razvoj nebesednega in besednega sporazumevanja imajo ključno vlogo kompetentnejši sogovorci, ki niso le starši, sorojenci, drugi sorodniki, ampak tudi ljudje izven družine, kot je npr. vzgojitelj.

Interakcije, ki spodbujajo otrokov razvoj govora, se začnejo z rojstvom in potekajo med otrokom in starši (Brodin 2018, Sommer 2012, v Brodin in Renblad 2019). Za razvoj govora je ključnih prvih pet let življenja (Brodin in Renblad 2019). Že takoj po rojstvu se začne razvoj zgodnjega zaznavanja in razumevanja govora, kar se kaže 
tudi $\mathrm{v}$ tem, da so novorojenčki usmerjeni $\mathrm{k}$ poslušanju človeških glasov (pred ostalimi glasovi) in maternega jezika (pred tujimi jeziki) (Marjanovič Umek in Fekonja 2020). Ljudje imamo prirojene zmožnosti nebesednega sporazumevanja. Dojenček se z drugimi sporazumeva s pogledi, sledenjem s pogledom, vokalizacijo, odpiranjem in zapiranjem ust, nasmehi in smehanjem, kriljenjem $z$ rokami, brcanjem z nogami ipd. Zato je Vigotski (1983) trdil, da je prvi govor nebesedni in socializirani, da se šele nato razvije egocentrični govor, ki se pretvori v notranjega, le-ta pa je povezan z mislijo. Dojenček še pred pojavom prvih besed uporablja geste in kretnje. $S$ protoimperativnimi gestami usmeri pozornost na predmete in dejanja, $\mathrm{s}$ protodeklarativnimi gestami pa želi spodbuditi pozornost druge osebe (Karmiloff in Karmiloff Smith 2001, v Marjanovič Umek in Fekonja 2020). Npr. ko zagleda kužka, začne vriskati od navdušenja, proti njemu steguje roke, poskakuje s telesom, kar pomeni, da z gestami in kretnjami (protoimperativnimi) jasno kaže svojo osredotočenost na kužka. Mimo pride mama, dojenček jo vleče za krilo in kaže kužka, da bi tudi mamino pozornost usmeril na kužka (protodeklarativne geste) (Marjanovič Umek in Fekonja Peklaj 2008). Za predjezikovno obdobje je značilno zgodnje zaznavanje in razumevanje govora, vključuje pa tudi jok, vokalizacijo, bebljanje in naključno posnemanje glasov, a brez razumevanja njihovega pomena. Otrok svoj govorni aparat preizkuša s pomočjo joka, prvih glasov in bebljanja, tako tudi sporoča svoje potrebe in čustva. $\mathrm{V}$ namene komunikacije dojenček $\mathrm{v}$ predjezikovnem obdobju uporablja geste in kretnje, ki jih pogosto spremlja tudi neposreden očesni stik z osebo, s katero komunicira. Po prvem letu starosti malček uporablja geste tudi »za simboliziranje predmetov in dejavnosti, npr. razširi roke in s tem sporoča, da je ptič ali letalo« (Marjanovič Umek, Kranjc in Fekonja 2006: 17).

S tem ko se odrasli odzivajo na otrokovo oglašanje, otrok dobi občutek za komunikacijo. Posnemanje glasov iz govora odraslih se začne približno pri desetem mesecu. Otrok jih posnema, a še ne pozna njihovega pomena (Kranjc 1999). Posnema pa jih lahko le s poslušanjem.

Jezikovno obdobje se začne pri približno 13. mesecih, ko malček začne uporabljati prve besede. Te najpogosteje posnemajo oglašanje živali ( $\mathrm{ga}$ ga) ali predmetov (brrrr) (Marjanovič Umek, Kranjc in Fekonja 2006). 
Od prvega do tretjega leta je obdobje intenzivnega učenja jezika, ko gre otrok skozi tri glavne stopnje. $» \mathrm{Na}$ prvi stopnji je njegova sposobnost produkcije omejena na enobesedne enote, imenovane holofraze, na drugi se zmožnost tvorjenja poveča na več enot znotraj enega stavka, na tretji stopnji pa doseže zmožnost tvorjenja zapletenejših večstavčnih besedilnih enot« (Kranjc 2006: 51-52).

»Pragmatična raven jezika se enako kot pomenska in skladenjska razvija $\mathrm{v}$ vseh razvojnih obdobjih« (Marjanovič Umek in Fekonja Peklaj 2008: 62). Pomembno je otroka vključiti v komunikacijo, ki jo lahko opredelimo kot »družbeno dejavnost, ki temelji na interakciji in pomeni deliti izkušnje, občutja in dejavnosti« (Brodin in Renblad 2019: 2). Otroci v zgodnjem otroštvu prilagajajo komunikacijo situacijam in razvijejo zmožnost socialno referenčne komunikacije, kar pomeni, da znajo opisati osebo ali predmet na način, da si jo poslušalec lahko predstavlja, čeprav je ne vidi (Marjanovič Umek in Fekonja Peklaj 2008). Razvija se tudi metajezikovno zavedanje, ki vključuje razumevanje enote jezikovnega sistema, odnosa med besedo in njenim pomenom in poznavanje skladnje jezika (Bialystok 1986, v Marjanovič Umek in Fekonja Peklaj 2008). Metajezik je tesno povezan z otrokovim razvojem teorije uma, ki pomeni »zmožnost predstavljanja, konceptualizacije in razmišljanja o mentalnih stanjih sebe in drugih « (Malle 2002; Wellman 1996, v Marjanovič Umek in Fekonja 2019: 119-123). Tako dveletni malčki zmorejo predvidevati obnašanja drugih na podlagi poznavanja njihovih želja; triletni malčki pa poleg želja upoštevajo tudi prepričanja drugih. Imajo težave tudi pri prepoznavanju razlik med lastnimi prepričanji in stvarnostjo. Večina štiriletnikov se zaveda, da so prepričanja lahko napačna; da se razlikujejo od njihovega lastnega prepričanja ali od dejanskega stanja. Višje ravni teorije uma pa se pojavijo šele pri šestletnikih. Ti lahko razmišljajo v smislu naslednje povedi: »Jaka misli, da je Meta mislila, da si bo lahko kupila sladoled v parku.« Kot navajata Marjanovič Umek in Fekonja (2019), je otrokov razvoj teorije uma mogoče preučevati tudi s spremljanjem njegove uporabe besed, ki označujejo čustvena oz. mentalna stanja, $\mathrm{v}$ prostem govoru ali med skupnim branjem ali z ocenjevanjem, koliko otrok razlikuje besede, ki označujejo mentalna stanja, od drugih besed ipd. Avtorici Baumgartner in Devescovi (2001, v Baloh 2019) menita, da so čustva in mentalna stanja ter sposobnost njihovega pravilnega prepoznavanja in razumevanja $\mathrm{v}$ otrokovih socialnih odnosih izrednega pomena, kajti šele $\mathrm{z}$ natančnim opisom svojih čustev dajemo sogovorcu možnost, da se nanje odzove. Tudi z vidika didaktike jezika je pomembno, da se z otrokom po prebrani zgodbi pogovarjamo, ne le o poteku dogodkov, pač pa tudi o značaju, čustvih, mišljenju in ravnanju oseb iz zgodbe, ter malčku na tak način omogočimo, da si gradi lastno 
pripovedovalno shemo (Baloh 2019). Baumgartner in Devescovi (2001, v Baloh 2019) sta izražanje čustvenih in mentalnih stanj $\mathrm{v}$ otrokovem pripovedovanju povezovali z: 1 . besednimi izrazi, ki se nanašajo na čustva in mentalna stanja, to so izrazi za zaznavanje, dojemanje (npr. vidi, gleda, čuti, se rani, spi), izrazi za čustva, vznemirjenost, naklonjenost (npr. dobro/slabo se počuti, je osamljen, boji se, kriči, se imajo radi), izrazi za metaspoznavnost, kognicijo (npr. razmišlja, ve, misli, odloci se), izrazi za želje, namere (npr. želi, hoče, labko, mu uspe), izrazi za moralne sodbe in dolžnosti/obveznosti (npr. je dober, je priden, je uspešen, je nagajiv); 2. z različnimi eksplicitnimi ali implicitnimi izreki, ki se nanašajo na čustva in mentalna stanja.

»Otroci se komuniciranja učijo ob raznovrstnih jezikovnih dejavnostih, ki jih zgolj spremljajo ali $\mathrm{v}$ njih tudi aktivno sodelujejo, npr. ob poslušanju vsakdanjih pogovorov in glasnega branja odraslih, z opisovanjem, s pripovedovanjem, ob domišljijskih igrah, igrah vlog, izmišljanju zgodb, pesmi, ob izštevankah, ugankah ipd., tudi z učenjem od drugih otrok.« (Krajnc Ivič, Pulko, Ropič in Zemljak Jontes 2017: 62).

»Govorni razvoj otroka v predšolski dobi pomembno vpliva na celostni govorni razvoj otroka tudi $\mathrm{v}$ šolskem obdobju in se kaže $\mathrm{v}$ samem usvajanju ter razvijanju jezikovne sporazumevalne zmožnosti posameznika_ce.« (Krajnc Ivič, Pulko, Ropič in Zemljak Jontes 2017: 58)

Govomi razvoj se začne že ob rojstvu. Prvo sredstvo komunikacije sta jok in neverbalno sporazumevanje, nadaljuje se $z$ oblikovanjem in povezovanjem prvih glasov, nato besed in širjenjem besednjaka do povezovanja besed $v$ enostavne in zapletenejše povedi, usvajanja slovničnih pravil, razumevanja različnih besedil ter rabe govora $\mathrm{v}$ različnih govornih položajih. Od telesnega ustroja se postopoma razvija $z$ duševnim in spoznavnim razvojem (Kranjc 1999).

$\mathrm{Na}$ govorni razvoj vplivajo notranji (psihološki) dejavniki, kot so motivacija, čustveno stanje in prirojene predispozicije, ter zunanji (socialni in sociološki) dejavniki, kot so ekonomski status družine, stopnja izobrazbe staršev ter širše družbeno okolje (Kranjc 1999). Toda sindividualne razlike v razvoju in učenju dojenčkov, malčkov in otrok v zgodnjem otroštvu, zlasti tiste, ki so povezane z različnimi dejavniki okolja, kot so socialnoekonomski in kulturni status staršev otrok, jezikovni kodi, ki jih rabijo starši, je moč v veliki meri preseči s kakovostnimi predšolskimi (tudi kompenzatornimi) programi« (Bela knjiga o vagoji in ižobraževanju 
2011: 72). Za malčke in otroke, ki prihajajo iz manj spodbudnega družinskega okolja, je še posebej pomembno, »da se čim mlajši vključijo v vrtec, ki je visokokakovosten in zanje lahko deluje kot varovalni dejavnik npr. v otrokovem govornem razvoju, pripravljenosti za šolo in kasnejši akademski uspešnosti« (Bela knjiga o vaggoji in ižbraževanju 2011: 72).

V Beli knjigi o vagoji in izobraževanju (2011: 71) je poudarjeno, da » otrokovem zgodnjem razvoju igra pomembno vlogo govor in drugi znakovni sistemi, ki so kulturno posredovani: pomembno je torej bogato simbolno okolje in kakovostne socialne interakcije«. Iz načel predšolske vzgoje v vrtcih je izpeljan cilj »spodbujati razvoj in učenje govora za učinkovito sporazumevanje, ustvarjalno rabo govora in fleksibilno mišljenje« (Bela knjiga o vagoji in izobraževanju 2011: 76). Tudi Kurikulum za vrtce (1999) posebej poudarja vlogo rabe govora pri vseh dejavnostih v vrtcu, po Beli knjigi o vaggoi in izobraževanju (2011: 88) pa naj bi še posebej okrepil »dejavnosti spodbujanja razvoja in učenja govora otrok in dejavnosti predopismenjevanja oziroma porajajoče se pismenosti (npr. širjenje besednjaka, sporazumevalne zmožnosti, pripovedovanje, simbolno izražanje, branje knjig, socialne interakcije, drobnogibalne spretnosti)«. Posebej je poudarjena skrb za dodatno učenje govora za govorno šibke otroke iz socialno in kulturno manj ugodnega okolja.

Raziskava Erženičnik Pačnik (2009) je pokazala, da so vzgojitelji, ki so otrokom večkrat omogočili, da so pripovedovali, in za to pripravili spodbudno okolje, otrokom omogočili napredovanje na govornem področju. Otroci so namreč preko načrtovanih dejavnosti razvijali govorno izražanje, bogatili besedni zaklad, se urili v logičnem sklepanju in samostojnem mišljenju ter imeli možnost opisovanja in poimenovanja predmetov ali pojavov.

Teoretske temelje preučevanja in razumevanja govornega razvoja sta postavila Piaget in Vigotski, pri čemer se je Piaget osredotočil na pomen izkušenj in razvoj mentalnih struktur, Vigotski pa je izpostavil učenje in cono proksimalnega razvoja ter pomen družbeno-kulturnega konteksta in opozoril na pomembno vlogo odraslih pri spodbujanju socialne interakcije (Brodin in Renblad 2019).

Neodvisno od jezika, ki ga govorijo otroci, je za njihov govorni in spoznavni razvoj pomembno, da so v vrtcih izpostavljeni bogatemu in kompleksnemu besednjaku. Ta ne spodbuja samo njihovega govornega razvoja, ampak je dobra podlaga za učenje branja in pisanja (Stavely 2019). Posebno skrb je treba posvetiti otrokom z motnjami 
v govornem razvoju in z manj kakovostnimi komunikacijskimi spretnostmi. Prav na področju govornega razvoja imajo vrtci tudi vlogo kompenzacije pri otrocih, ki ne dobijo dovolj spodbud za razvoj govora v družini (Brodin in Renblad 2019).

Razvoj govora se najbolj intenzivno odvija v obdobju zgodnjega otroštva, in sicer med drugim in šestim letom starosti. V tem obdobju učenje poteka posredno, preko govora, ki ga otrok sliši od drugih oseb, ki komunicirajo z njim (Kranjc 1999).

Skrb za govorni razvoj otrok, ki obiskujejo vrtec, mora biti ena izmed glavnih nalog vrtca. Metode in didaktične strategije temeljijo na različnih teoretskih perspektivah (Aronsson 2019). V Kurikulumu za vrtce (1999) je poudarjeno, da mora biti v vrtcu dovolj časa za pogovor, pripovedovanje, razlago, opisovanje, dramatizacijo, igro vlog, predvsem pa razvijanje jezikovne zmožnosti. $V$ predšolskem obdobju se otroci "učijo izražati izkušnje, čustva, misli in razumeti sporočila drugih. Jezikovne dejavnosti so povezane z vsemi jezikovnimi ravninami: s fonološko, morfološko, skladenjsko-pomensko (in pragmatično), razvoj jezika pa je naravno vpleten v vsa področja dejavnosti« (Kurikulum za vrtce 1999: 19).

Značilnosti govora $\mathrm{v}$ predšolskem obdobju so povezane $\mathrm{z}$ obvladovanjem besed oziroma besedišča, z obvladovanjem različnih vrst besed, z usvajanjem določenega števila besed $\mathrm{v}$ posameznem obdobju ipd., zato so pomembnejši mejniki in značilnosti govornega razvoja $\mathrm{s}$ tega vidika predstavljeni $\mathrm{v}$ petem gradniku (Besedišče).

Govorni razvoj se kaže tudi z razvojem pripovedovanja zgodb. »Pripovedovanje zgodbe je vidik otrokove govorne kompetentnosti, ki se tesno povezuje z njegovim spoznavnim in socialnospoznavnim razvojem, še posebej razvojem teorije uma« (Baldock 2006; Paul, Hernandez, Taylor in Johnson 1996, v Marjanovič Umek in Fekonja 2019: 19).

Že nekateri dveletni otroci povedo zgodbo, ki vključuje vsaj eno izmed njenih pomembnih lastnosti, to so začetek, konec in uporaba preteklika. Nato postajajo zgodbe vedno bolj strukturirane, povečuje se njihova koherentnost in kohezivnost. Otroci v zgodnjem otroštvu že ustrezno vrednotijo dejanja junakov zgodb (Marjanovič Umek in Fekonja Peklaj 2008). 
Koherentnost zgodbe se kaže v smiselni celoti, časovni in vzročni povezanosti. Zgodbo je pomembno postaviti $\mathrm{v}$ čas in kraj, nato pa jo graditi na časovno povezanih dogodkih. Kohezivnost pa se kaže v uporabi jezikovnih sredstev, s katerimi otrok povezuje posamezne dele zgodbe med seboj (Marjanovič Umek in Fekonja 2019).

»Obdobje malčka in zgodnjega otroštva je najpomembnejše obdobje za razvoj porajajoče se pismenosti oz. razvoj spretnosti, znanja in vedenja, ki predhodijo formalnemu branju in pisanju« (Hall 1987; Pullen in Justice 2003, v Marjanovič Umek in Fekonja Peklaj 2008: 63).

Za razvoj pismenosti so pomembne predvsem naslednje komponente govora: besednjak, metajezikovno zavedanje, metakomunikacija in pripovedovanje zgodbe (Marjanovič Umek in Fekonja Peklaj 2008).

Pri preučevanju bralne pismenosti pri otrocih $\mathrm{v}$ predšolskem in zgodnjem šolskem obdobju je pomembno zavedanje o tem, kako poteka razvoj bralnih sposobnosti. Sonja Pečjak v monografiji Psibološki vidiki bralne pismenosti (2010: 45-62) po različnih avtorjih predstavlja dva modela razvoja zgodnje pismenosti ter štiri modele razvoja bralne pismenosti. Po Barone, Mallette in Xu (2005) deli zgodnjo pismenost v tri obdobja: porajajoča se pismenost, začetna pismenost in prehodna pismenost.

V monografiji Labko je brati se Dragica Haramija in Tatjana Knapp (2019) naslanjata na opredelitev dveh faz opismenjevanja po Sonji Pečjak in Ani Gradišar, ki sta jih opisali v delu Bralne učne strategije (2015: 66-67). Haramija in Knapp povzemata (2019: 75-76):

- Faza opismenjevanja v ožjem pomenu besede vsebuje porajajočo se pismenost (ta je poimenovana tudi predopismenjevanje) in začetno pismenost (opismenjevanje). V predšolskem obdobju gre za razvijanje otrokove komunikacijske spretnosti, prepoznavanje socialnih in funkcijskih zvrsti jezika ter razvijanje jezika na vseh jezikovnih ravninah (glasoslovna, oblikoslovna, skladenjska in pomenoslovna), pomembno je razvijanje zavedanja o tisku (torej vsega, kar otrok ve o tiskanih medijih: listanje, smer branja ipd.). $\mathrm{V}$ začetnem opismenjevanju je poudarek na usvajanju tehnike branja in avtomatizaciji branja in pisanja. Začetno opismenjevanje vsebuje tri faze: logografsko ali slikovno fazo (branje besed globalno: bralec 
vsako besedo zazna kot sliko); alfabetsko ali abecedno fazo (vzpostavljanje razmerja med črko in glasom); ortografsko ali pravopisno fazo (tekočnost branja, razumevanje prebranega).

- Faza opismenjevanja $\mathrm{v}$ širšem pomenu, ki ga avtorici razumeta $\mathrm{v}$ funkciji pridobivanja novega znanja, torej branje za učenje.

V obeh fazah opismenjevanja je gradivo za otroke in mladostnike prilagojeno njihovi starosti in zmožnosti razumevanja prebranega. Informativno gradivo (načeloma) sledi učnim načrtom za posamezne predmete, leposlovno gradivo se izbira za otroke zlasti glede na zvrstno-vrstno in žanrsko delitev besedil, ter glede na vsebino besedila, njegovo dolžino, število literarnih likov, količino ilustracij ipd. (Haramija in Knapp 2019: 76).

Otrokov kognitivni razvoj pri branju in pisanju pogojuje njegovo zmožnost vidnega razločevanja (pri čemer mislimo na razločevanje črk in njihovo povezovanje $\mathrm{v}$ besede), razumevanje jezikovnih struktur (na vseh jezikovnih ravninah) in besedni zaklad. Sonja Pečjak (1995: 11, v Haramija in Knapp 2019: 76) navaja, da »pojem besedni zaklad pri branju označuje število besed v pisni obliki, ki jih posameznik prepozna. Bralno besedišče predstavlja pasivno (receptivno) besedišče, ki se razlikuje od besedišča v govoru in pri pisanju, ki je aktivno besedišče. / .../ Vsako leto naj bi učenci pridobili od 2700 do 3000 novih besed. / ... / Razmerje med aktivnim in pasivnim besediščem je v povprečju 1 : 3- do 4-kratno, kar pomeni, da je besedišče pri branju 3- do 4-krat večje kot besedišče v govoru ali pri pisanju.«

V starostni skupini do treh let otroci poslušajo besedila, s pomočjo ilustracij razumejo zgodbo, jo pripovedujejo in bogatijo besedišče. Pri otroku spodbujamo senzorične izkušnje, ki vključujejo čute: vid, zvok, dotik, vonj, gibanje. Do vstopa v šolo otroka pripravljamo na branje tako, da posluša, ločuje simbole (črke) po videzu, loči črke od glasov, dva glasova med seboj ipd. Besedam otrok že pripisuje pomen, določi prvi glas (slušno zavedanje), s podporno tehniko (npr. s fonomimično metodo) pridobiva glasove, se orientira na ploskvi, loči ilustrativni in tekstovni del besedila, prepoznava dele besedila, pridobi občutek za smer branja od leve proti desni (vaje za orientacijo oz. smer branja), z vsemi čutili pridobiva predbralne spretnosti in lista po knjigi. Otrok v starosti od 6 do 8 let spoznava in usvoji glasove, loči prvi-zadnji-vmesni glas, pretvori glas v črko (simbol) in obratno. Pozna črke in glasove, poveže glasove v zlog, zloge v besedo. Otrok poveže besedilo in ilustracijo, pripoveduje o prebranem (prav tam: 77). 


\subsection{Govor v osnovnošolski dobi}

Jezikovna sporazumevalna zmožnost je ob sociolingvistični in pragmatični zmožnosti delna sporazumevalna zmožnost. $\mathrm{V}$ jezikovno zmožnost vključujemo sposobnost uporabe jezikovnega sistema: leksikalno, slovnično, pravopisno, fonološko pravorečno in semantično zmožnost. Sociolingvistična zmožnost pomeni posedovanje znanja in veščin za pravilno rabo jezika. Pragmatična zmožnost pa je sestavljena iz diskurzne in funkcijske zmožnosti ter zmožnosti načrtovanja (Bagarić in Mihaljević Djigunović 2007).

V Sloveniji je pojem sporazumevalna zmožnost vpeljala Olga Kunst Gnamuš (1983) $\mathrm{v}$ svojem komunikacijskem modelu jezikovne vzgoje. Zapisala je, da je za sporazumevanje potrebno več kot le poznavanje pravil slovničnega oblikovanja. Pomembna so jezikovna sredstva ter razumevanje družbenih razmerij med sporočevalcem in naslovnikom. Le tako lahko dosežemo nek sporočilni namen. Njena delitev sporazumevalne zmožnosti je poimenovalno sicer nekoliko drugačna, saj loči med jezikovno in sporazumevalno zmožnostjo. Jezikovno zmožnost sestavljajo pravila povezovanja, ki usmerjajo oblikovanje povedi ter njihovo povezovanje v nadpovedne sestave. Sporazumevalna zmožnost pa je sestavljena iz določenih pravil, ki usmerjajo sporočilni namen in govorni položaj ter ustrezno izbiro funkcijske, socialne, prenosniške zvrsti, besedja, skladnje, sporazumevalnih vzorcev glede na vsebino (Kunst Gnamuš 1983).

Razvijanje jezikovne sporazumevalne zmožnosti je eden izmed temeljnih ciljev na vseh stopnjah obveznega izobraževanja, ustrezne temelje za doseganje tega cilja pa je nujno postaviti že v predšolskem obdobju (Bešter Turk 2011).

Z vstopom v formalno izobraževanje se nadaljuje načrtno razvijanje govora oz. govornega sporazumevanja pri učencih, toda ne le pri predmetu slovenščina, ampak pri vseh predmetih in vseh področjih. Poudarke, povezane z govorom in govorno zmožnostjo, podajamo iz učnega načrta za slovenščino za osnovno šolo (UN 2018). Pri predmetu slovenščina (UN 2018: 6), ki je temeljni splošnoizobraževalni predmet v slovenski osnovni šoli, se učenci in učenke »usposabljajo za učinkovito govorno in pisno sporazumevanje v slovenskem jeziku, še posebej v njegovi knjižni zvrsti, razvijajo zavest o pomenu materinščine in slovenščine, o slovenščini kot državnem in uradnem jeziku, o njenem položaju v Evropski uniji ter o njeni izrazni razvitosti na vseh področjih zasebnega in javnega življenja. Cilji predmeta se uresničujejo z 
jezikovnim in književnim poukom v okviru vseh sporazumevalnih dejavnosti: pogovarjanja, dopisovanja, poslušanja, branja, govorjenja in pisanja. Namen jezikovnega pouka je razviti sporazumevalno zmožnost v slovenskem (knjižnem) jeziku, tj. praktično in ustvarjalno obvladovanje vseh sporazumevalnih dejavnosti pa tudi jezikovnosistemskih osnov.«

Od splošnih ciljev se na govor v okviru jezikovne zmožnosti nanašajo trije cilji (UN 2018: 7-8):

- Učenci in učenke razvijajo zmožnost sprejemanja, razumevanja, doživljanja in vrednotenja ter tvorjenja besedil $\mathrm{v}$ slovenskem knjižnem jeziku. Hkrati si oblikujejo jezikovno in književno kulturo.

- Učenci in učenke ob sprejemanju, razumevanju, doživljanju in vrednotenju ter tvorjenju besedil razvijajo svojo jezikovno (tj. poimenovalno, skladenjsko, pravorečno, pravopisno) in slogovno zmožnost, in sicer zato da bi samozavestno uporabljali slovenski knjižni jezik za svoje osebne, učne, interesne ipd. potrebe.

- Učenci in učenke ob sprejemanju, razumevanju, doživljanju in vrednotenju neumetnostnih besedil razvijajo tudi svojo metajezikovno zmožnost - pridobivajo znanje o vlogah jezika ter o značilnostih slovenskega knjižnega jezika, to pa dopolnjujejo z uporabo raznih priročnikov ter osmišljajo $z$ opazovanjem in prepoznavanjem vloge dane jezikovne prvine $\mathrm{v}$ neumetnostnih in umetnostnih besedilih.

Z govorom so povezani domala vsi operativni cilji, tako na področju jezik kot na področju književnost. S področja jezik izpostavljamo nekatere ključne poudarke, vezane na govor.

1. VIO (UN 2018: 9-19): razvijanje jezikoune, narodne in dř̌avljanske zavesti (poimenujejo oz. opisujejo), razvijanje żmožnosti pogovarjanja (se pogovarjajo, igra vlog), razuijanje zmožnosti poslušanja (pred poslušanjem in po njem se pogovarjajo), razvijanje zmožnosti govornega nastopanja (govorni nastop, pogovor), razvijanje zmožnosti branja in pisanja (slušno razločevanje, tehnika branja), razvijanje jerikoovne in slogovne zmožnosti (poimenujejo, razlagajo, tvorijo besede, vrednotijo), rasvijanje metajez̧ikoune ₹mo:̌nosti 
(učenci in učenke $\mathrm{v}$ svojem okolju in $\mathrm{v}$ besedilih opazujejo jezikovne pojave, navedene $\mathrm{v}$ razdelku vsebine (spoznavajo strokovne izraze, jih uporabljajo).

2. VIO (UN 2018: 19-32): razvijanje jezikovne, narodne in dry̌avljanske zavesti (primerjajo, poimenujejo oz. opisujejo), razvijanje zmožnosti dvosmernega sporazumevanja (se pogovarjajo, povzamejo, poročajo, vrednotijo), razvijanje zmožnosti enosmernega sporazumevanja (se pogovarjajo, govorno nastopajo), razvijanje jeaikovne in slogovne zmo:̌nosti (razlagajo, so pozorni na knjižno izreko besed in povedi, govorni nastopi), razvijanje metajer̨ikoune zmo:̌nosti (v pogovorih spoznavajo strategije pogovarjanja, govornega nastopanja, načela uspešnega pogovarjanja, govornega nastopanja).

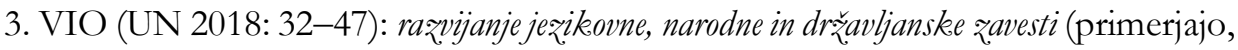
poimenujejo oz. predstavljajo), razvijanje żmožnosti dvosmernega sporazumevanja (se pogovarjajo o načelih ustreznega pogovarjanja, o značilni zgradbi pogovora, o vplivu okoliščin na zgradbo pogovora in o merilih za vrednotenje dialoških besedil; tvorijo dialoško besedilo (pogovor), se pogovarjajo o strategijah in načelih ustreznega pogovarjanja), razvijanje zmožnosti enosmernega sporazumevanja (se pogovarjajo, govorno nastopajo), razvijanje jezilkoune in slogovne ₹možnosti (med govornimi nastopi govorijo knjižno in razločno, prepoznajo svojo in tujo neknjižno izreko ter besede izgovorijo knjižno), razvijanje metajezilkovne zmožnosti (spoznavajo strokovne izraze in jih uporabijo, $\mathrm{v}$ pogovorih pred sprejemanjem in tvorjenjem besedil spoznavajo strategije pogovarjanja, govornega nastopanja, načela uspešnega pogovarjanja).

S področja književnost izpostavljamo cilje, vezane na govorno nastopanje.

1. VIO (UN 2018: 18): Učenci in učenke $\mathrm{v}$ 3. razredu predstavijo svojo bralno izkušnjo: obnovijo umetnostno besedilo in povedo, zakaj so si izbrali to besedilo; vživljajo se v književno osebo, ubesedujejo svojo domišlijijko predstavo te osebe, predstavijo njeno razpoloženje in vrednotijo njeno ravnanje; izrazijo svoje mnenje o prebranem; deklamirajo/recitirajo pesem in predstavijo ustvarjalca/pesniško zbirko ipd.; predstavijo svoje (po)ustvarjalno besedilo: predstavijo narobe pravljico, nadaljevanje zgodbe ipd.; preberejo svojo pesem, povedo, zakaj so jo napisali oz. katero književno delo jih je spodbudilo k pisanju te pesmi. 
2. VIO (UN 2018: 31): Učenci in učenke razvijajo zmožnost doživljanja, razumevanja in vrednotenja umetnostnih besedil tako, da se »strokovno« in/ali (po)ustvarjalno govorno odzivajo na umetnostna besedila. V vsakem razredu pripravijo en govorni nastop - izbirajo med ponujenimi možnostmi, se odločijo za povezavo $\mathrm{z}$ domačim branjem ali temo izberejo samostojno. Med govornim nastopom govorijo prosto, čim bolj zborno in naravno ter upoštevajo jezikovno ustreznost in pravilnost; pazijo tudi na ustrezno rabo zvočnih in vidnih spremljevalcev govorjenja. Na koncu pojasnijo svojo izbiro teme govornega nastopa. Učenec/učenka: v »književnostrokovnem« govornem nastopu predstavi svoje razumevanje deloma že obravnavanega umetnostnega besedila, npr.: predstavi celo besedilo (na podlagi $\mathrm{v}$ šoli obravnavanega odlomka): umesti odlomek v kontekst, poda zvrstno/vrstno oznako dela, predstavi književne osebe in dogajanje, vrednoti prepričljivost in medbesedilnost (npr. Moja najljubša knjiga) ipd.; predstavi avtorja in našteje njegova dela, eno njegovo delo predstavi podrobneje; v poustvarjalnem govornem nastopu predstavi svoje razumevanje $\mathrm{v}$ šoli še neobravnavanega umetnostnega besedila, npr.: recitira/deklamira pesem, navede nekaj pesmi na isto temo, predstavi najbolj opazne pesniške izrazne prvine in njihovo vlogo v pesmi; predstavi svojo pravljico/svojo predzgodbo/svoje nadaljevanje pravljice/svojo narobe pravljico; primerja pravljici (temo, književne osebe, dogajanje, kraj in čas dogajanja, značilnosti); predstavi prozno besedilo, v katerem je dogajanje razpeto med realni in domišlijijki svet; predstavi realistično zgodbo/nesmiselno zgodbo; uprizori odlomek iz dramskega dela/krajše dramsko delo/dramatizirano prozo (individualno ali skupinsko).

3. VIO (UN 2018: 45): Učenci in učenke razvijajo zmožnost doživljanja, razumevanja in vrednotenja umetnostnih besedil tudi tako, da se strokovno in (po)ustvarjalno odzivajo na umetnostna besedila. V vsakem razredu pripravijo en govorni nastop - izberejo temo (npr. eno od ponujenih možnosti, lahko tudi v povezavi z domačim branjem oz. $v$ dogovoru $z$ učiteljem izberejo temo, ki je ni na seznamu). Med govornim nastopom govorijo prosto, čim bolj zborno in naravno ter upoštevajo jezikovno ustreznost in pravilnost; pazijo tudi na ustrezno rabo zvočnih in vidnih nebesednih spremljevalcev govorjenja. $\mathrm{Na}$ koncu pojasnijo svojo izbiro teme govornega nastopa. Učenec/učenka v književnostrokovnem govornem nastopu: predstavi $\mathrm{v}$ šoli še neobravnavano književno besedilo (npr. avtorja, vsebinske in slogovne značilnosti, zvrst/vrsto besedila), ga ovrednoti, svoje trditve pa utemelji s sklicevanjem na njegove značilnosti oz. jih ponazarja s primeri iz besedila; primerja književni besedili (njuno temo, književne osebe, dogajanje, kraj in 
čas dogajanja, zvrst/vrsto, slogovne značilnosti, literarnozgodovinsko obdobje ...); predstavi avtorja/avtorje in njegova/njihova dela - bio- in bibliografske podatke o avtorju/avtorjih, slikovno gradivo, odlomke iz njegovih/njihovih književnih del, citate o njih iz strokovne literature ...; predstavi intervju s književnim ustvarjalcem (lahko tudi fiktivni intervju, npr. s Francetom Prešernom) - o njegovem življenju in delu, o bistvenih značilnostih njegovega dela: o literarnozgodovinskem obdobju, o zvrstni/vrstni umestitvi, o prevladujoči temi/ideji ipd.; predstavi anketo o bralnem interesu sošolcev in sošolk o najbolj priljubljenih književnih delih in svoje ugotovitve ter jih interpretira; v (po)ustvarjalnem govornem nastopu: recitira/deklamira svojo pesem oz. svojo (po)ustvarjalno predelavo izbrane pesmi, navaja pesmi raznih avtorjev $\mathrm{z}$ isto temo/tematiko, predstavi temeljne podobnosti in razlike med temi pesmimi ter pove, zakaj se je odločil/odločila predstaviti svojo pesem; predstavi svojo parodijo/travestijo znanega književnega besedila, pove, zakaj je izbral/izbrala to besedilo za predelavo, in poroča o svojem poustvarjalnem postopku; nastopi z dramskim monologom in subjektivno predstavi celotno književno besedilo; pove, zakaj je izbral/izbrala to besedilo, in poroča o svojih pripravah na govorni nastop; nastopi v skupinskem dramskem prizoru ter predstavi in ovrednoti svojo vlogo pri pripravi in izvedbi govornega nastopa.

Poudarjeno je, naj učenci med govornim nastopanjem skušajo govoriti čim bolj knjižno in razločno.

\section{$2.3 \quad$ Govor v srednješolski dobi}

Opredelitev predmeta slovenščina v učnem načrtu za slovenščino $v$ gimnaziji (UN 2008): „Slovenščina kot materni/prvi jezik za večino dijakov/dijakinj in kot drugi jezik/jezik okolja za manjšino je ključni splošnoizobraževalni predmet v gimnaziji, podlaga za samorazumevanje, za vsakršno učenje s slovenskim jezikom izraženih vsebin, za razumevanje, doživljanje in vrednotenje pojavov okrog nas. Dijaki/dijakinje se pri njem usposabljajo za učinkovito govorno in pisno sporazumevanje v slovenskem jeziku, razvijajo zavest o pomenu materinščine sploh, o slovenščini kot državnem in uradnem jeziku, o njenem položaju v Evropski uniji in o njeni izrazni razvitosti na vseh področjih javnega in zasebnega življenja.» 
V srednji šoli se govor preusmeri na pogovor, zato je eden izmed ciljev razvijanje zmožnosti (uradnega) pogovarjanja (UN 2008: 11). Pred kritičnim sprejemanjem enogovornih neumetnostnih besedil dijaki sodelujejo v vodenem pogovoru. Tudi sami tvorijo enogovorna neumetnostna besedila, pred tvorjenjem pa sodelujejo $\mathrm{v}$ vodenem pogovoru (UN 2008: 12). Ostajajo tudi govorni nastopi, med katerimi skušajo govoriti čim bolj knjižno (UN 2008: 13). Za razvijanje pravorečne zmožnosti sistematično spoznavajo, vadijo in utrjujejo knjižni izgovor posameznih besed in povedi ter prepoznavajo pravorečne napake $\mathrm{v}$ svojih in tujih besedilih ter jih odpravljajo (UN 2008: 13). Slogovno zmožnost razvijajo tako, da izrekajo isto govorno dejanje na različne načine in vsakemu izreku določijo ustrezne okoliščine (UN 2008: 14). Učni načrt za srednjo šolo poudari tudi nebesedne spremljevalce govorjenja, ki jih morajo dijaki med pogovarjanjem zavestno uporabljati, hkrati pa opazovati sogovorčeve nebesedne spremljevalce govorjenja, prepoznavati njihovo vlogo in se nanje odzvati, nato $\mathrm{v}$ pogovoru vrednotijo učinkovitost in ustreznost sogovorčevih in svojih nebesednih spremljevalcev govorjenja, med sprejemanjem besedil opazujejo njihove nebesedne dele in nebesedne spremljevalce pisanja oz. govorjenja, prepoznavajo njihovo vlogo ter vrednotijo njihovo učinkovitost in ustreznost, si pred govornim nastopanjem oz. pred pisanjem besedila pripravijo vidna nebesedna ponazorila, nato jih smiselno uporabljajo med govornim nastopanjem oz. jih smiselno vključujejo $\mathrm{v}$ zapisano besedilo, med govornim nastopanjem zavestno uporabljajo nebesedne spremljevalce govorjenja, med pisanjem pa nebesedne spremljevalce pisanja; nato sodelujejo $\mathrm{v}$ pogovoru o njihovi ustreznosti in učinkovitosti (UN 2008: 14). Razvijanje metajezikovne zmožnosti se kaže v tvorjenju enogovornih neumetnostnih besedil (UN 2008: 15). Dijaki v 1. letniku usvajajo načela uspešnega dvogovornega in enogovornega sporazumevanja, ki jih v vseh letnikih upoštevajo pri tvorjenju in sprejemanju besedil ter presojajo njihovo uresničevanje $\mathrm{v}$ tujih besedilih; usvajajo tudi strategije sprejemanja in tvorjenja besedil, ki jih v vseh letnikih upoštevajo pri tvorjenju in sprejemanju besedil ter presojajo njihovo uresničevanje v tujih besedilih (UN 2008: 15). Podobno kot učenci tudi dijaki izvajajo govorne nastope (UN 2008: 16).

Seveda je treba tudi za srednješolsko izobraževanje poudariti, da se govor ne razvija in uresničuje le pri predmetu slovenščina, ampak pri vseh predmetih in na vseh predmetnih področjih. Še posebej se v tem obdobju zgodi preskok k usvajanju strokovnega izrazja na različnih področjih. Srednja šola od dijaka tudi pričakuje, da upošteva načela dobrega sloga (živost, jedrnatost, jasnost ...) in da zna usvojen besedni zaklad glede na vrsto in namen pri vseh predmetih uporabiti pri tvorjenju 
novih sporočil (besedil). Za razvoj govora mladostnikov so torej odgovorni ne samo učitelji slavisti, ampak prav vsi učitelji, ki sodelujejo v vzgojno-izobraževalnem procesu.

\section{$2.4 \quad$ Govor v odrasli dobi}

Z zaključkom srednješolskega izobraževanja se razvoj nikakor ne zaključi, ampak se nadaljuje tudi kasneje v življenju. Študenti ga razvijajo in bogatijo ne samo na svojem študijskem področju, ampak na vseh področjih in $\mathrm{v}$ najrazličnejših govornih situacijah. Tudi v študijskem procesu so ena od oblik uresničevanja govora oziroma govorne kompetence govorni nastopi, ki potekajo na različne načine. Pri tem je treba poudariti, da bi na tej stopnji izobraževanja že vsi študenti pri govoru morali obvladati pravilno knjižno zborno izreko, kar pa se žal po izkušnjah redko uresničuje. Študent poleg tega mora obvladati ne samo jezikovna pravila in pravila tvorjenja govorjenih besedil, pač pa mora tudi upoštevati načela dobrega sloga in znati presoditi glede ustrezne izbire besedila glede na namen in okoliščne.

Z zaključkom študija se razvoj govora ne zaključi, ampak se bogati, pili in izpopolnjuje še naprej v poklicni poti na najrazličnejših področjih. Še posebej za vzgojitelje in učitelje velja, da $\mathrm{v}$ največji meri vplivajo na govor otrok/učencev/dijakov in da so jim vsakodnevno v zgled.

\section{$3 \quad$ Vseživljenjski razvoj govora}

Razvoj govora poteka in se dopolnjuje vse življenje. Podobno kot razvoj risanja, ki je prav tako kot govor simbolno delovanje, se tudi razvoj govora razvija po fazah. Zaključi se $\mathrm{v}$ lingvistični fazi (razvoj risbe pa $\mathrm{z}$ realističnim risanjem). Kot risar, ki lahko še nadalje usvaja tehnike risanja in izpopolnjuje svojo risbo, tudi govorec izpopolnjuje svoj govor in spoznava jezik, ki ga govori. Jezik je »živ«, se nenehno razvija, oblikujejo se nova pravila, ustvarjajo se nove besede, stavčne zveze ipd. Zato je pomembno, da otrok že v predšolskem obdobju vzljubi jezik, ki ga govori, da mu pravica do njegove rabe pomeni posebno vrednoto, da razvije motivacijo ter da spremlja in sprejema njegove spremembe. 
Otrok se najprej sporazumeva nebesedno, z usvajanjem besed pa se začne govorno sporazumevanje. Pozna, razume in uporablja vedno več besed, najprej osnovne, vezane na najožji svet okrog njega, potem pa se širi na različna področja. Od usvajanja in poznavanja besed preide na tvorbo različnih govorjenih sporočil, pri tem pa usvaja vedno več novih in novih besed, jih zna sčasoma tudi razložiti in uporabiti v različnih situacijah in $z$ različnimi nameni. Od usvajanja tako prehaja na pragmatično raven. $Z$ višino stopnje izobraževanja se razvija in pričakuje tudi upoštevanje dobrega sloga, hkrati pa posameznik vedno bolj razvija svoj slog govorjenja.

\section{$4 \quad$ Razvoj govora na različnih področjih delovanja in bivanja}

Govorni razvoj je le eno izmed področij razvoja. Povezan je z razvojem drugih področij, kot je spoznavni, čustveni in socialni razvoj (Marjanovič Umek in Fekonja 2019). Napredek na področju razvoja mišljenja se odrazi v otrokovem govornem razvoju, in obratno. Ko otrok usvaja nove besede, s tem razvija nove pojme, kar sodi $v$ področje spoznavnega. Podobno obstaja interakcija s čustvenim in socialnim razvojem. Kot smo že omenili, je povezan z razvojem risbe. »Otrok v zgodnjem otroštvu vse bolj razume, da lahko posamezne znake, ki se jih nauči v družbenem in kulturnem prostoru, uporabi za sporazumevanje in sporočanje« (Marjanovič Umek in Fekonja Peklaj 2008: 59). To je povezano ne le z govorom, ampak tudi z začetki usvajanja črk in številk. Kot so razvoj mišljenja, socialni in čustveni razvoj vpleteni $\mathrm{v}$ vse sfere delovanja in pojavljanja, tako tudi spodbujanje razvoja otrokovega govora ne more biti omejeno le na »minute za jezik« ali šolski predmet »Slovenščina« ipd. Otrok razvija svoj govor in usvaja jezik tudi takrat, ko dejavnosti niso temu posebej posvečene.

Učinkoviti programi spodbujanja otrokovega govornega razvoja vsebujejo tako zaznavne kot izrazne dejavnosti. Med prve prištevamo poslušanje in branje, med druge pa govorjenje in pisanje (Saracho in Spodek 2007). Mlajši otroci morajo biti dejavno vpleteni v razvijanje besedišča, da si bodo zapomnili nove besede in začeli dojemati večpomenskost besed. Smiselno je, da besede večkrat slišijo ali celo izgovorijo, pri učenju besedišča je smiselno kombinirati enaktivne, ikonične in simbolne modele (Jalongo in Sobolak 2011). To pomeni, da prepoznavajo pomen besed preko dejavnosti, zaznav in simbolov. Svoje besedišče širijo na različnih področjih delovanja. Ko z lopatico premetavajo pesek v peskovniku, spoznavajo, da lahko z lopatico zajamejo pesek, lahko ga odrinejo, si ga približajo ipd. (enaktivno 
ali dejavnostno dojemanje besede lopatica). Prepoznavajo značilnosti lopatice. Njihova lopatica ima npr. lesen ročaj in plastično travnato zeleno "posodico«, lopatica prijatelja Jureta pa ima plastičen tako ročaj kot "posodico« in je rdeča, po obliki pa je enaka njihovi lopatici (slikovno ali ikonično dojemanje besede lopatica). $\mathrm{V}$ peskovniku pa ne uporabljajo samo lopatice, ampak tudi grabljice in metle. Vse te pripomočke lahko imenujejo orodje (simbolno dojemanje besede lopatica).

Na govorno-jezikovni razvoj lahko vplivamo npr. z uporabo pripovedovalnih kock. »Kocke se praviloma uporabljajo tako, da je pri predšolskih otrocih prisoten odrasli, ki igro usmerja. Slike na kockah so simboli, ki sprožajo različne asociacije. Vsak simbol lahko igralci razumejo po svoje in ga povežejo $\mathrm{z}$ naslednjim simbolom $\mathrm{v}$ smiselno zgodbo. Pravilnih in napačnih interpretacij simbolov na kockah ni, saj je namen igranja s kockami dosežen s tem, da otrok skozi igro spozna (razume) čim več različnih predstav in interpretacij posameznih simbolov, ki jih ubesedimo in povežemo v zgodbo (npr. noga, ki brca, lahko predstavlja nogomet, udarec, poskok, tek, tekmovanje).« (Licardo in Haramija 2017: 64)

》Glede na funkcijske zvrsti jezika lahko skozi igro s kockami utrjujemo tudi razlike med umetnostnim jezikom (otrok pripoveduje zgodbo, ki ima npr. lastnosti pravljice, realistične ali fantastične zgodbe) in jezikom vsakdanjega sporazumevanja. Pri razvijanju jezika vsakdanjega sporazumevanja lahko podamo otroku iztočnico za pripovedovanje o vsakdanji življenjski situaciji, npr.: Popoldan gremo kot družina v trgovino. Otrok naj glede na simbole pripoveduje, kaj bodo kupili. Pri simbolih, ki se jih ne da kupiti, naj poskuša smiselno povezati simbol z nekim izdelkom (npr. sonce - krema za sončenje; žalost - nečesa v trgovini ni bilo). Gremo k babici na počitnice. Kaj nesemo s seboj? Otrok naj utemelji vse simbole in ob tem razloži, zakaj jih bo potreboval. Ob igranju s kockami se razvijajo predvsem govornojezikovne sposobnosti, in sicer od enobesednih izjav do besedila, kar pa pomeni logičen prehod k zapisanim besedilom. Igri s kockami so najbolj podobni slikopisi, ki določen del vsebine prav tako izražajo s piktogrami. Slikopisi so dober uvod v celostno branje slikanic in razumevanje obeh kodov sporočanja (jezikovnega in ilustrativni/likovni kod) ter interakcije med njima.« (Licardo in Haramija 2017: 67)

Ob hitrem razvoju digitalne družbe se je toliko pomembneje zavedati pomena otrokovega jezikovnega razvoja in ustrezne komunikacije, $\mathrm{k}$ čemur lahko veliko prispeva vrtec (Brodin in Renblad 2019). V današnjem času se otroci zelo zgodaj, nekateri že pred prvim rojstnim dnevom, srečajo z digitalnimi napravami. Odrasli so 
vedno bolj vpleteni v dejavnosti s sodobno elektronsko tehnologijo. Ta jim ne koristi le za opravljanje vsakodnevnih službenih in privatnih dejavnosti, ampak jim nudi tudi zabavo in sprostitev, zato ni presenetljivo, da jo približajo tudi otrokom, saj so prepričani, da lahko $\mathrm{z}$ vpletenostjo $\mathrm{v}$ digitalni svet razvijajo svoje mišljenje, zaznavanje, spomin, gibalne sposobnosti ipd. in se pri tem zabavajo. Jezik $\mathrm{v}$ digitalnem svetu pa je pogosto tuj in/ali osiromašen. Nekatere virtualne vsebine so kakovostne in prav bi bilo, da bi bile kot take tudi označene, podobno kot so kakovostne igrače označene z znakom »dobra igrača«. Oznake kakovosti virtualnih vsebin za otroke bi staršem (in vzgojiteljem) olajšale izbiro vsebin za otroke in jih poučile o tem, za koliko stare otroke so določene vsebine primerne. Negativne posledice tega, da otrok nenadzorovano spremlja digitalne vsebine, se lahko odrazijo tudi v njegovem govomem razvoju in rabi jezika. Te vsebine redko spodbujajo otrokovo natančnost, osredotočenost na podrobnosti in poglobljenost. To pa so lastnosti, ki so potrebne pri kakovostni rabi jezika.

Za vsakega posameznika je velikega pomena, da razvije sposobnost izraziti občutja, misli in preference, za kar sta potrebni kakovostna komunikacija in bogato besedišče (Brodin in Renblad 2019). Otroci razvijajo govor v družbeno-kulturnem kontekstu, pri interaktivni igri z vrstniki s poslušanjem drugih in izražanjem sebe (Brodin 2018, v Brodin in Renblad 2019). Razvijajo ga na vseh področjih delovanja v vrtcu in izven njega (Kranjc in Saksida 2001, v Marjanovič Umek, Kranjc in Fekonja 2006). Razvoj komunikacijskih spretnosti je v kurikulumu za vrtce podobno kot moralni in socialni razvoj umeščen v medpodročne vsebine (Marjanovič Umek in Fekonja Peklaj 2008). Izsledki slovenske raziskave z otroki, starimi od štirih do petih let (glej Fekonja 2002a; Fekonja idr. 2005a, v Marjanovič Umek in Fekonja Peklaj 2008), so pokazali, da so otroci v prosti igri uporabljali z vidika strukture in govornih položajev višje razvojne ravni govora kot pri vodeni in rutinski dejavnosti, kot je npr. zajtrk.

\section{$5 \quad$ Vloga vzgojitelja/učitelja v govornem razvoju}

K otrokovemu govornemu razvoju pomembno prispevajo številni dejavniki, med katerimi so v najzgodnejši dobi vrtec kot institucija in otrokovi stiki z vrstniki v okviru vrtca. Domače in tuje raziskave (pregled v: Marjanovič Umek, Kranjc in Fekonja 2006) kažejo, da ima visoko kakovosten vrtec (tako glede procesnih kot strukturnih kazalcev) pomemben pozitiven učinek na govorni razvoj tako pri otrocih, katerih starši imajo nižjo izobrazbo (in običajno tudi nižjo raven govorne kompetentnosti), kot pri otrocih, katerih starši imajo višjo izobrazbo, vendar je 
predvsem pri prvih učinek večji, kar pomeni, da lahko ima visoko kakovostni vrtec kompenzacijski učinek na govorni razvoj otrok staršev z nižjo izobrazbo.

Vzgojitelj »/.../ naj bi otroku nudil idealno jezikovno obliko, tj. drugačen govorni vzorec, kot so ga doma deležni otroci iz družin z nižjim socialnoekonomskim položajem«. Pomembno je, da vzgojitelj v sporazumevanju z otrokom uporablja razširjen jezikovni kod. Takšnega uporabljajo starši srednjega sloja, za katerega »so značilni slovnično zapleteni stavki, raznoliko besedišče, podredni vezniki, izjave, s katerimi logično ohranjajo in nadaljujejo temo pogovora, izvirnost $\mathrm{v}$ rabi jezika, opisovanje abstraktnih idej in raba argumentov« (Marjanovič Umek, Fekonja Peklaj in Pečjak 2011: 10).

Vzgojitelj na različne načine spodbuja otrokov govor, tudi pri dejavnostih, kot so oblačenje, hranjenje, sprehod ipd. (Marjanovič Umek, Kranjc in Fekonja 2006). Spodbuja ga z lastnim govorom; predlogi za pogovor, v katerega so vpleteni otroci; s knjigami, revijami, časopisi, slikanicami, katalogi, priročniki, enciklopedijami, slovarji, zemljevidi ipd., ki so otrokom na voljo; s tem, da jih pelje v gledališče, kino, na razstave ipd.; z jezikovnimi igrami ipd.; hkrati pa z različnimi igrami spodbuja tudi razvoj otrokove nebesedne komunikacije (Kranjc in Saksida 2001, v Marjanovič Umek, Kranjc in Fekonja 2006). Otroci, ki imajo veliko izkušenj branja iz različnih medijev in v okolju, kjer so njihovi starši vpleteni v bralne dejavnosti, imajo višje fonološko zavedanje, širše poznavanje črk in obsežnejši besedni zaklad v primerjavi z otroki, ki niso deležni tovrstnih spodbud (Brodin in Renblad 2019). Slovenska raziskava (Marjanovič Umek, Lešnik Musek, Kranjc in Fekonja 2001, v Marjanovič Umek, Kranjc in Fekonja 2006) je pokazala, da namensko, redno in pogosto branje otrokom $v$ vrtcu pomembno prispeva $\mathrm{k}$ razvoju višjih ravni govora, pri čemer je pomemben tudi vzgojiteljičin način branja (Marjanovič Umek in Fekonja 2004b, v Marjanovič Umek, Kranjc in Fekonja 2006). Branje knjig je zelo koristno, ker se ob njem otroci seznanijo $\mathrm{z}$ besedami, ki jih ne slišijo $\mathrm{v}$ vsakodnevnem življenju (Greenberg, Bowles, Peterson in Altidor-Brooks 2019).

Ob vzgojiteljevem spodbujanju otrokovega govora imajo otroci možnost, da uporabljajo govor $\mathrm{v}$ različnih govornih položajih, uporabljajo ga za različne namene in v različnih situacijah (Marjanovič Umek, Kranjc in Fekonja 2006). 
Tudi vzgojitelj »rabi govor za sporazumevanje, informiranje, pojasnjevanje, opisovanje, dajanje navodil pri vseh dejavnostih z otroki« (Browne 1996, v Marjanovič Umek, Kranjc in Fekonja Peklaj in Pečjak 2011: 26). Tuje in slovenske raziskave (pregled v: Marjanovič Umek in Fekonja 2020) kažejo, da je spodbudno za razvoj otrokovega govora, če vzgojitelj otroke vključuje $\mathrm{v}$ interaktivno skupno branje, jih spodbuja $\mathrm{k}$ simbolni igri, $\mathrm{k}$ samostojnemu pripovedovanju in razlagi in se z njimi kakovostno pogovarja o vsakodnevnih temah.

Marjanovič Umek in Fekonja (2000) povzemata po številnih avtorijh ugotovitev, da odrasli (velikokrat povsem spontano) spremenijo svoj govor, ko komunicirajo z dojenčkom ali malčkom. Govorijo krajše stavke, kot če govorijo npr. z odraslimi, z več odmori in počasneje; njihov besednjak je prilagojen otrokovim neposrednim izkušnjam, kar pomeni, da redko uporabljajo pridevnike, prislove, nadredne pojme, veznike ipd., večinoma uporabljajo glagole v sedanjiku; veliko ponavljajo; uporabljajo besede kot hov-hov, ku-ku ipd., ki jih v stiku z odraslimi ne uporabljajo ipd.

Vzgojitelj bi se moral jasno zavedati svoje vloge $\mathrm{v}$ spodbujanju otrokovega govornega razvoja. Mora dobro poznati značilnosti posameznih faz razvoja govora. Njegova komunikacija z otrokom je pomembna že ob prvih stikih z njim, četudi je ta še v predjezikovni fazi govora. Občutljivo se mora odzivati na dojenčkovo nebesedno komunikacijo, na njegov jok, vokalizacijo, čebljanje oz. bebljanje. Pozoren mora biti na to, da že $\mathrm{v}$ tem otrokovem obdobju vzpostavi dvosmerno komunikacijo, pri kateri bo otrok poslušal in se glasovno izražal. V otrokovi jezikovni fazi govora je pomembno, da razširja otrokov govor, in kadar je le mogoče, naredi odmik od konkretnosti. Če otrok izgovori besedo »banana«, razširi njegov govor $\mathrm{z}$ »と̌elel bi jesti banano« ali »banano bi rad vžel izposode« ipd. Odmik od konkretnosti naredi s pojasnilom »rad bi pojedel banano, saj si že lačen«. Otroci prej razvijejo razumevanje govora kot izražanje, zato je opisana komunikacija z otrokom izrednega pomena ne le za njegov razvoj govora, ampak tudi za njegov spoznavni, socialni in čustveni razvoj.

$\mathrm{K}$ otrokovemu govornemu razvoju in $\mathrm{h}$ komunikaciji pomembno prispevajo vzgojiteljevo glasno branje in pripovedovanje zgodb (Brodin in Renblad 2019). Pomembna je usposobljenost vzgojitelja, ki prispeva $\mathrm{k}$ ustrezni izbiri knjig in kakovostni interakciji z otroki ob branju. Način, kako vzgojitelj bere knjigo, pomembno prispeva $\mathrm{k}$ možnostim pogovora o knjigi in $\mathrm{k}$ učenju (Lennox 2013). 
Brodin in Renblad (2019) sta v svoji študiji ugotovili, da vzgojiteljevo glasno branje ne pomeni nujno, da spodbuja komunikacijo otrok v vrtčevski skupini. Nujni so branje, spremljanje, razgovor in razmislek o vsebini prebranega in o slikah v knjigi. Težava je, če branju ne sledi razgovor o vsebini prebranega. $V$ tem primeru je možnost, da bo otrok razvijal besedišče in usvojil nove pojme, manjša, še posebno, če se otrokov materin jezik razlikuje od tistega, ki je v uporabi v vrtcu.

Pomembno je, da se vzgojitelj z otroki pogovarja o različnih vsebinah; jih spodbuja, da pojasnjujejo svoja mnenja; kaže zanimanje za to, kaj mu pripovedujejo; jim daje možnosti, da govorijo $\mathrm{v}$ različnih situacijah pred različnim občinstvom; organizira vsakodnevne dejavnosti, ki otrokom omogočajo rabo govora in poslušanje in ne nazadnje s svojim govorom vpliva na govor otrok v skupini (Browne 1996, v Marjanovič Umek, Kranjc in Fekonja 2006).

Vzgojitelj mora veliko pozornosti posvetiti tudi lastni rabi jezika, s katerim komunicira z otroki. Do jezika mora imeti pozitiven odnos. Spoštovanje jezika ga lahko spodbuja k rabi slovnično pravilnega jezika in kakovostnih povedi. Seveda $\mathrm{v}$ pogovoru z otrokom način govora pogosto prilagodi tako, da oblikuje krajše in preprostejše izjave. Po Marjanovič Umek, Kranjc in Fekonja (2006) sta pomembni tudi ustrezna intonacija in višina glasu, ki morata biti prilagojeni otroku, to je namreč dojenčku oz. malčku znak, da je govor namenjen njemu. Pomembna mesta v izjavi malčku pomagamo prepoznati tudi s poudarjanjem ključnih besed. Posnemanje malčkovega govora (t. i. pootročeni govor) ima negativne lastnosti, če ga uporabljamo na vseh jezikovnih ravninah. Ustrezno razporeditev rabe otroku zamegli tudi pretirana uporaba pomanjševalnic, saj ga s tem osiromaši za zavedanje o rabi pomanjševalnic za oznako čustveno. Pogosta napaka, ki jo delajo odrasli v pogovoru $\mathrm{z}$ otrokom, je tudi govorjenje zase $\mathrm{v}$ tretji osebi, saj $\mathrm{s}$ tem otroku povzročajo velike težave pri izražanju svoje identitete, ter naslavljanje otroka, ki sodeluje v pogovoru in je naslovnik, s tretjo osebo (npr. »No, kaj je izvlekla Špela? « namesto »No, Špela, kaj si izvlekla?«).

\section{Psihodiagnostični pripomočki za ocenjevanje in spremljanje govora}

Psihodiagnostični pripomočki za ocenjevanje in spremljanje otrokovega razvoja govora se osredotočajo na različna govorna področja, in sicer na govorno razumevanje, rabo govora, skladnjo in pravopis ter pripovedovanje zgodbe (Marjanovič Umek, Fekonja Peklaj in Pečjak 2011). Obstajajo tudi metode in tehnike 
za preučevanje govornega razvoja fetusa in dojenčka, ki so osredotočene predvsem na preučevanje govornega zaznavanja (Marjanovič Umek in Fekonja 2020). Te metode in tehnike temeljijo na procesu habituacije in dishabituacije. Po predvajanju določenih glasov se fetus ali dojenček habituirata na te dražljaje. Pri fetusu (npr. v zadnjih treh mesecih) je možno (dis)habituacijo meriti s spremljanjem njegovega gibanja ali bitja srca, pri dojenčku pa s hitrostjo brcanja ali sesanja dude. »Habituacija je vrsta učenja, pri kateri se ponavljajoče izpostavljenje istim dražljajem kaže v upadu posameznikovega odziva na te dražljaje /.../ « (Zupančič 2000: 207). Ob spremembi glasov ali njihovega ritma se lahko fetus ali dojenček odzoveta z dishabituacijo oz. obnovitvijo pozornosti in s tem tudi odzivov. Podobno so že nekaj dni stari dojenčki sposobni s svojim gibanjem vplivati na predvajanje tistih dražljajev, ki so jim ljubši (Marjanovič Umek in Fekonja 2000). Metode in tehnike za preučevanje otrokovega govornega razumevanja zahtevajo otrokov nebesedni odziv na besedne dražljaje, pri otrokovem izražanju pa je zahtevan besedni odziv na nebesedne ali besedne dražljaje (Marjanovič Umek in Fekonja 2019). Lestvica splošnega govornega razvoja - Lj (LSGR LJ) je mersko ustrezen pripomoček za merjenje govornega razvoja slovenskih malčkov in otrok, starih od dve do sedem let, ki meri govorno razumevanje, izražanje in metajezikovno zavedanje. Oblikovale so ga Marjanovič Umek, Fekonja, Podlesek, Kranjc in Bajc (2008). Posebna vrednost pripomočka je dodatek Lista za analizo otrokove rabe govora, s katero je mogoče oceniti malčkov oziroma otrokov prosti govor, ko vstopa $\mathrm{v}$ interakcijo $\mathrm{z}$ vrstniki in odraslimi. Slovenski avtorici in avtorja (Marjanovič Umek, Fekonja Peklaj, Sočan in Komidar 2011) so oblikovali tudi Preizkus pripovedovanja zgodbe. Vsebuje dve različici, prva je namenjena slovenskim otrokom, starim od tri do šest let, druga pa slovenskim otrokom, starim od šest do devet let. S tem pripomočkom je mogoče podati splošno oceno otrokovega pripovedovanja zgodbe, kot tudi ocene besednjaka ter slovnične in vsebinske strukture zgodbe. Slovenske avtorice so razvile tudi listi razvoja sporazumevalnih zmožnosti, s pomočjo katerih starši ocenijo govorni razvoj svojega otroka. Tudi ta pripomoček ima dve različici. S prvo (Lista razuoja sporazumevalnih zmo:̌nosti: Besede in geste; Marjanovič Umek in Fekonja Peklaj 2011) lahko merimo razumevanje in rabo besed, razumevanje izjav ter uporabo sporazumevalnih in simbolnih gest pri dojenčkih in malčkih, starih od 8 do 16 mesecev. Z drugo različico pripomočka (Lista rąvoja sporazumevalnih zmožnosti: Besede in stavki; Marjanovič Umek, Fekonja Peklaj, Kranjc in Bajc 2010) pa lahko merimo besednjak in usvajanje slovnice jezika pri malčkih, starih od 16 do 30 mesecev. 


\section{$7 \quad$ Sklep}

Govor je kot eden izmed gradnikov bralne pismenosti kompleksna sposobnost in zahteva usklajeno sodelovanje različnih človekovih sposobnosti. Govorni razvoj je le eno izmed področij človekovega razvoja. Najbolj intenzivno se razvija v obdobju malčka in zgodnjega otroštva, takrat $\mathrm{v}$ obliki usvajanja in bogatenja besednega zaklada ter razumevanja prvih besed in povezovanja njih $\mathrm{v}$ povedi, nadaljuje pa se $\mathrm{v}$ vseh oblikah formalnega izobraževanja ter tudi po zaključku le-tega. Poteka vse življenje. Razvoj govora nikakor ni vezan samo na (materni) jezik, ampak se razvija na vseh predmetnih področjih, v času formalnega izobraževanja pri vseh predmetih. Zato so prav vsi, ki so vključeni v vzgojno-izobraževalni proces otrok, učencev, dijakov in študentov ter tudi starejših v izobraževanju, odgovorni za razvoj govora. Razvoj govora pa ne pomeni le usvajanja besed in bogatenja besednega zaklada, pač pa tudi obvladovanje pragmatične rabe in oblikovanje stila posameznikovega govora ter je pomemben gradnik bralne pismenosti posameznika, ki se izpopolnjuje vse življenje.

\section{Literatura}

Lena ARONSSON, 2019: The concept of language in the Swedish preschool curriculum: A theoretical and empirical examination of its productions. Journal of Early Childhood Literacy 10(3): 271-293.

Barbara BALOH, 2019: Umetnost pripovedovanja otrok v zgodnjem otroštvu. Koper: Založba Univerze na Primorskem.

Bela knjiga o vagoji in izobraževanju v Republiki Sloveniji, 2011. Janez KREK (ur.) in Mira METLJAK (ur.). Ljubljana: Zavod RS za šolstvo. http://pefprints.pef.uni-lj.si/1195/

Vesna BAGARIĆ in Jelena MIHALJEVIĆ DJIGUNOVIĆ, 2007: Defining communicative competence. Metodika 8(1). 94-103.

Kurikulum za vrtce, 1999. https://www.gov.si/assets/ministrstva/MIZS/Dokumenti/Sektor-zapredsolsko-vzgojo/Programi/Kurikulum-za-vrtce.pdf.

Marja BEŠTER TURK, 2011: Sporazumevalna zmožnost - eden izmed temeljnih ciljev pouka slovenščine. Jeritk in slovstvo 56(4). 122-127.

Jane BRODIN in Karin RENBLAD, 2019: Improvement of preschool children's speech and language skills. Early Child Development and Care. Dostop https://doi.org/10.1080/03004430.2018.1564917

Marjana ERŽENIČNIK PAČNIK, 2009: Spodbujanje otrokovega govora. Pedagoška obzorja 24(1). 1635.

Gradniki bralne pismenosti: delovno gradivo, 2018. Ljubljana: Zavod RS za šolstvo.

Janice GREENBERG, Pam BOWLES, Shelly Stagg PETERSON in Alison ALTIDOR-BROOKS, 2019: Supporting children's vocabulary and thinking in a magic potion laboratory: A reflective conversation between educators, a speech-language pathologist and a linguist. Early Childhood Education 46(1). 3-9.

Dragica HARAMIJA in Tatjana KNAPP, 2019: Labko branje za strokounjake. http://www.lahkojebrati.si/Portals/1/Knjige/Lahko\%20branje \%20za\%20strokovnjake.pdf 
Mary Renck JALONGO in Michelle J. SOBOLAK, 2011: Supporting young children's vocabulary growth: The challenges, the benefits, and evidence-based strategies. Early Cbildhood Education Journal 38(5). 421-429.

Ključne kompetence za vsę̌ivljenjsko učenje: evropski referenčni okvir. Uradni list EU, 2018/C 189/01. https:/ / eur-lex.europa.eu/legalcontent/SL/TXT/PDF/?uri=OJ:C:2018:189:FULL\&f\%20rom=SL

Mira KRAJNC IVIČ, Simona PULKO, Marija ROPIČ in Melita ZEMLJAKJONTES, 2017: Spodbujanje jezikovne sporazumevalne zmožnosti predšolskih otrok ob neumetnostnih besedilih. $V$ objemu besed. Ur. Dragica Haramija. Maribor: Univerzitetna založba Univerze v Mariboru. 55-68. https://press.um.si/index.php/ump/catalog/book/268

Simona KRANJC, 1999: Ražvoj govora predšlskih otrok. Ljubljana: Znanstvenoraziskovalni inštitut Filozofske fakultete.

Simona KRANJC, 2006: Poglavja iz skladnje otroškega govora. Ljubljana: Izolit.

Olga KUNST GNAMUŠ, 1983: Govorno dejanje dru乏̌beno dejanje. Komunikacijski model jerikovne vagoje. Ljubljana: Pedagoški inštitut pri Univerzi Edvarda Kardelja Ljubljana.

Kurikulum za vrtce, 1999. Ljubljana: Ministrstvo za izobraževanje, znanost in šport: ZRSŠ.

Sandra P. LENNOX, 2013: Intective read-alouds - An avenue for enhancing children's language for thinking and understanding: A review of recent research. Early Childhood Education Journal 41(5). 381-389.

Marta LICARDO in Dragica HARAMIJA, 2017: Kako uporabljati pripovedovalne kocke - navodila za pedagoške delavce in starše. Kako rąvijati druそ̌insko pismenost v predšlskem obdobju. Marta Licardo (ur.) in Dragica Haramija (ur.) Maribor: Univerzitetna založba Univerze v Mariboru. 63-67. https://press.um.si/index.php/ump/catalog/book/268

Ljubica MARJANOVIČ UMEK, 1990: Mišljenje in govor predšlskega otroka. Ljubljana: Državna založba Slovenije.

Ljubica MARJANOVIČ UMEK in Urška FEKONJA, 2019: Ocenjevanje govora otrok in teorije uma. V: Ljubica Marjanovič Umek (ur.) in Maja Zupančič (ur). Ražvojna psibologija. Ižbrane teme. Ljubljana: Znanstvena založba Filozofske fakultete. 108-126.

Ljubica MARJANOVIČ UMEK in Urška FEKONJA, 2020: Govorni razvoj dojenčka in malčka. Ljubica Marjanovič Umek (ur.) in Maja Zupančič (ur). Razvojna psibologija. Ljubljana: Znanstvena založba Filozofske fakultete. 237-256.

Ljubica MARJANOVIČ UMEK in Urška FEKONJA, 2019: Zgodbe otrok: Razvoj in spodbujanje pripovedovanja. Ljubljana: Znanstvena založba Filozofske fakultete.

Ljubica MARJANOVIČ UMEK in Urška FEKONJA PEKLAJ, 2011: Lista razvoja sporazumevalnih żmožnosti: Besede in geste. Ljubljana: Center za psihodiagnostična sredstva.

Ljubica MARJANOVIČ UMEK in Urška FEKONJA PEKLAJ, 2008: Sodobni vrtec: možnosti za otrokov raquoj in zgodnje učenje. Ljubljana: Znanstvenoraziskovalni inštitut Filozofske fakultete.

Ljubica Marjanovič Umek, Urška FEKONJA PEKLAJ, Simona KRANJC in Katja BAJC, 2010: Lista razuoja sporazumevalnih zmožnosti: Besede in stavki. Ljubljana: Center za psihodiagnostična sredstva.

Ljubica MARJANOVIČ UMEK, Urška FEKONJA PEKLAJ in Sonja PEČJAK, 2011: Govor in branje otrok: ocenjevanje in spodbujanje. Ljubljana: Center za psihodiagnostična sredstva.

Ljubica MARJANOVIČ UMEK, Urška FEKONJA, Anja PODLESEK, Simona KRANJC in Katja BAJC, 2008: Lestvica splošnega govornega rąvoja - Lj (LSGR - LJ). Priročnik. Ljubljana: Center za psihodiagnostična sredstva.

Ljubica MARJANOVIČ UMEK, Urška FEKONJA PEKLAJ, Gregor SOČAN in Luka KOMIDAR, 2011: Pripovedovanje zgodbe. Preizkus pripovedovanja zgodbe: Rokavickea in Preizkeus pripovedovanja zgodbe: Žabji kralj. Ljubljana: Center za psihodiagnostična sredstva.

Ljubica MARJANOVIČ UMEK, Simona KRANJC in Urška FEKONJA, 2006: Otroški govor: razvoj in učenje. Domžale: Izolit.

Nacionalno strategijo za razvoj bralne pismenosti za obdobje 2019-2030. Vlada Republike Slovenije, 2019. https://www.gov.si/novice/2020-01-15-nacionalna-strategija-za-razvoj-bralne-pismenostiza-obdobje-2019-2030/

Sonja PEČJAK, 2010: Psibološki vidiki bralne pismenosti: od teorije k praksi. Ljubljana: Znanstvena založba Filozofske fakultete. 
Sonja PEČJAK in Ana GRADIŠAR, 2012: Bralne ǔ̌ne strategije. Ljubljana: Zavod Republike Slovenije za šolstvo.

Olivia N. SARACHO in Bernard SPODEK, 2007: Oracy: Social facets of language learning. Early Child Development and Care 177(6-7). 695-705.

Zaidee STAVELY, 2019: New training for California preschool teachers to help bilingual children prepare for kindergarten. http://edsource.org/2019/ new-training-for-california-preschool-teachers-tohelp-bilingual-children-prepare-for-kindergarten/610058

Ǔ́ni načrt. Slovenščna: gimnazija: splošna, klasična, strokovna gimnarija, 2008. Ljubljana: Ministrstvo za šolstvo in šport, Zavod RS za šolstvo.

http://eportal.mss.edus.si/msswww/programi2019/programi/media/pdf/un_gimnazija/un _slovenscina_gimn.pdf

Ǔ̌ni nă̌rt. Program osnovna šla. Slovenščna, 2018. Ljubljana: Ministrstvo za izobraževanje, znanost in šport, Zavod RS za šolstvo.

https://www.gov.si/assets/ministrstva/MIZS/Dokumenti/Osnovna-sola/Ucni-

nacrti/obvezni/UN_slovenscina.pdf

Lev VIGOTSKI, 1983: Mišljenje i govor. Beograd: Nolit.

Maja ZUPANČIČ, 2020: Zaznavni in spoznavni razvoj dojenčka in malčka. Ljubica Marjanovič Umek (ur.) in Maja Zupančič (ur). Razvojna psibologija. Ljubljana: Znanstvena založba Filozofske fakultete. 203-236. 


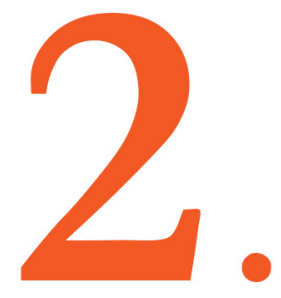

GRA DN I K

\section{MOTIVIRANOST ZA BRANJE}

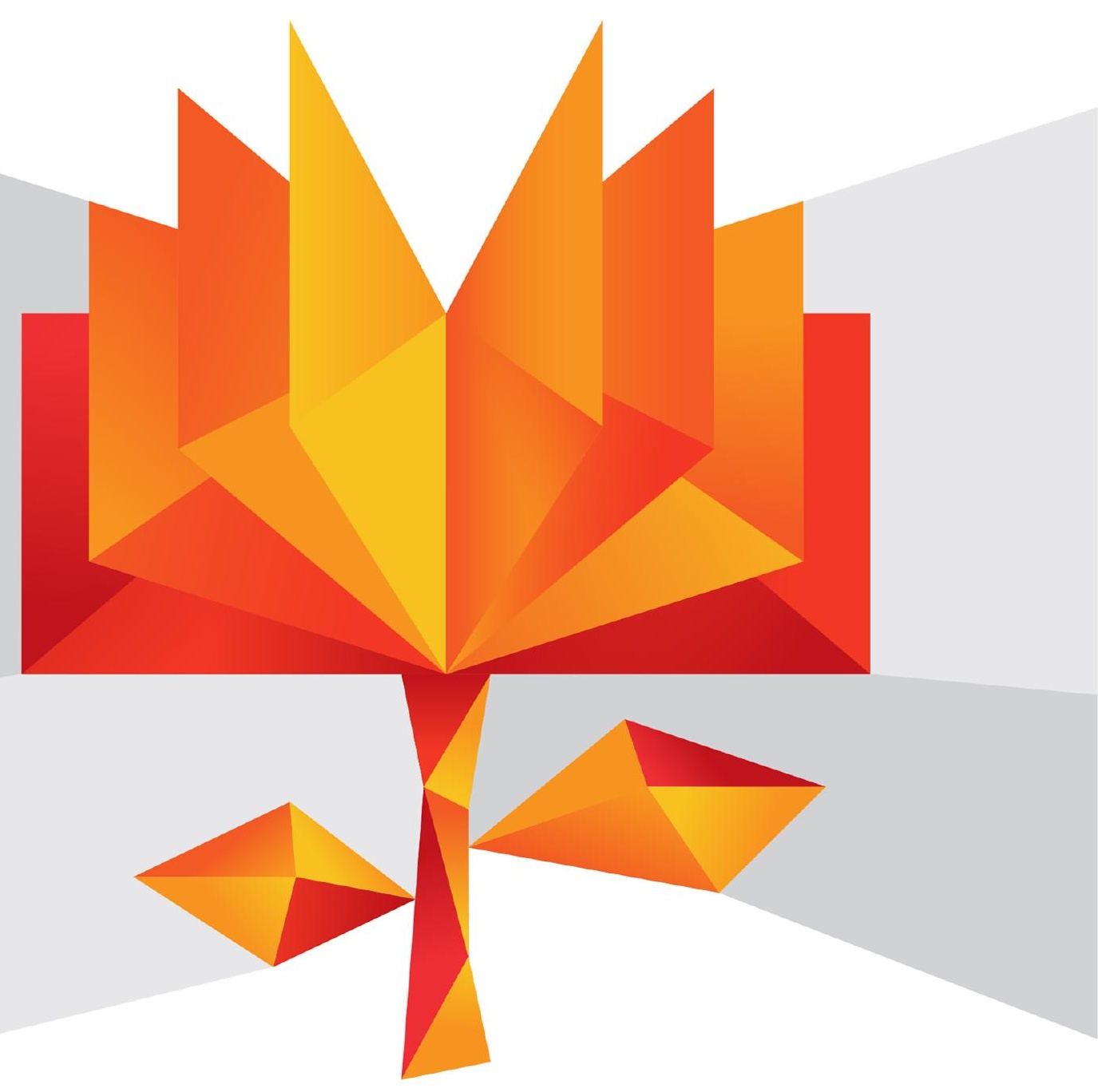


${ }^{1}$ Pozitiven odnos do branja različnih vist besedil za različne namene: branje za znanje, branje leposlovja (razvijanje bralne kulture).

${ }^{2}$ Različne viste besedil: pripovedovalna, opisovalna in poustvarjalna besedila.

\section{Elementi gradnika:}

- interes za branje

- pozitiven odnos do branja ${ }^{1}$ različnih vrst besedil ${ }^{2}$

- bralna samoučinkovitost

- izbira tiskanih in drugih informacijskih virov glede na namen branja

- uporaba različnih lokacij bralnih virov 


\title{
2. GRADNIK:
}

\section{MOTIVIRANOST ZA BRANJE}

\author{
BLANKA BOŠNJAK IN KATJA KOŠIR
}

Univerza v Mariboru, Filozofska fakulteta, Maribor, Slovenija.

E-pošta: blanka.bosnjak@um.si, katja.kosir@um.si

Povzetek Bralna motivacija je večdimenzionalen konstrukt, pri čemer je v literaturi razdeljena na različne dimenzije oz. vidike, kot so: interes za branje, zaznan nadzor nad branjem, bralna samoučinkovitost, zatopljenost $\mathrm{v}$ branje ter sodelovanje in socialna interakcija. Preučevanje in razumevanje bralne motivacije je predvsem pomembno zaradi vzajemnega odnosa med njo in bralnim razumevanjem, saj so bolj kakovostne oblike bralne motivacije tiste, ki vodijo $\mathrm{v}$ bolj poglobljene bralne dejavnosti in $\mathrm{s}$ tem vodijo prav tako $\mathrm{v}$ boljše bralno razumevanje in bralno pismenost. $\mathrm{V}$ kontekstu uresničevanja motiviranja za branje smo se izmed metodičnih postopkov, primernih glede na širok starostni razpon otrok in mladostnikov, osredinili predvsem na motivacijske strategije, ki so vzete iz šolske interpretacije književnosti, s prilagoditvijo pa so primerne tudi za različna druga predmetna področja, in sicer: doživljajskoizkušenjska uvodna motivacija, ki ji sledijo najava besedila in njegova umestitev $\mathrm{v}$ kontekst, interpretativno branje, premor po branju in izražanje doživetij ob prebranem $\mathrm{v}$ obliki pogovora, metoda diskusije pa je primernejša za starejše učenke in učence višjih VIO. Branje kot motivacijo lahko uporabljamo v okviru različnih učnih predmetov in medpredmetno, pri čemer je $\mathrm{v}$ prispevku podan predlog izbora umetnostnih besedil, ki lahko na začetnih stopnjah pridobivanja bralne pismenosti predstavljajo most do branja neumetnostnih besedil.

Ključne besede: bralna pismenost, motiviranost za branje, oblike (bralne) motivacije, teorija samoodločanja, ekstrinzična in intrinzična motivacija. 


\title{
THE SECOND COMPONENT OF READING LITERACY: READING MotiVATION
}

\author{
BLANKA BOŠNJAK \& KATJA KOŠIR \\ University of Maribor, Faculty of Arts, Maribor, Slovenija. \\ E-mail: blanka.bosnjak@um.si,katja.kosir@um.si
}

\begin{abstract}
Reading motivation is a multidimensional construct with various aspects, commonly defined as interest in reading, perceived control over reading, reading self-efficacy, reading involvement, and cooperation/social interaction. Investigating and understanding reading motivation is especially important because of the reciprocal relationship between reading motivation and reading comprehension; more quality forms of reading motivation lead to more profound reading activities and thus enhance reading comprehension and reading literacy. In the context of the enhancement of reading motivation, among the methodological procedures appropriate to the broad age range of children and adolescents, we focused mainly on motivational strategies taken from the school interpretation of literature. However, with adaptation, they are also suitable for various other subject areas such as introductory experiential motivation, followed by the announcement of the text and its placement in context, interpretive reading, pause after reading, and conversation about reading experiences. The discussion method seems more appropriate for older students in higher grades of elementary school. Reading as motivation can be used in various subjects and interdisciplinary, and the paper presents a proposal for the selection of literary texts, which can be a bridge to reading non-fiction texts in the initial stages of acquiring reading literacy.
\end{abstract}

Keywords: reading literacy, reading motivation, forms of (reading) motivation, self-determination theory, extrinsic and intrinsic motivation. 


\section{Uvod}

Najrazličnejše metode/strategije bralne motivacije in bralne učne strategije lahko pri vzgojnem in pedagoškem procesu na posameznih izobraževalnih nivojih od vrtca, osnovne in srednje šole na različnih predmetnih področjih razvijajo veliko zmožnosti otrok ter mladostnikov, spretnosti oziroma kompetenc, ki so tudi zapisane $\mathrm{v}$ splošnih ali operativnih ciljih učnih načrtov za posamezne stopnje vzgojno-izobraževalnega dela. Vzgojni in pedagoški kader pa se pri različnih predmetnih področjih lahko avtonomno odloča, katere strategije bodo uporabili (izmed metod različnih strok, npr. laboratorijskih, eksperimentalnih, metod izkustvenega učenja). Primer: učni načrt pri matematiki za osnovno šolo sistematično (skozi vsa tri VIO) navaja cilje in dejavnosti za razvoj bralne pismenosti. $\mathrm{Na}$ ravni ciljev, vsebin in didaktičnih priporočil je predlagana vrsta dejavnosti, pri katerih učenci razvijajo natančno in pravilno izražanje, predlagane so bralne strategije, upoštevajo se bralne sposobnosti za razumevanje prebranega, izpostavljeni so odnos do branja, interes za branje ipd. (Žakelj 2016: 174). Podobno je $\mathrm{z}$ učnim načrtom pri matematiki za gimnazijo, kjer pri pouku matematike $\mathrm{v}$ kontekstu matematičnih vsebin dijaki razvijajo slušno razumevanje, govorno sporočanje, bralno razumevanje in pisno sporočanje. Vzpostavljena je povezava s slovenščino ob branju matematičnega besedila, razvijajo se bralne strategije (prelet, postavitev vprašanja, branje, ponovni pregled, poročanje), bralne sposobnosti, odnos do branja, interes za branje ipd. (Žakelj 2016: 174-175).

$\mathrm{V}$ kontekstu uresničevanja bralne motivacije se tako priporoča medpredmetno sodelovanje in njihovo povezano načrtovanje, pri čemer pa je treba upoštevati predvsem psihološke vidike motiviranosti za branje in učenje. Slednje najbolj celostno pojasnjuje teorija samodoločanja, ki utemeljuje pomen avtonomnega oz. samodoločenega vedenja. $\mathrm{V}$ tem prispevku se bomo $\mathrm{v}$ tej povezavi osredinili predvsem na prve tri elemente motiviranosti za branje: interes za branje, pozitiven odnos do branja različnih vrst besedil in bralna samoučinkovitost (Mršnik 2018: 3).

\section{Opredelitev in elementi bralne motivacije}

Motivacija se nanaša na procese, ki spodbujajo, usmerjajo in vzdržujejo neko vedenje. Ko govorimo o bralni motivaciji, imamo torej v mislih dejavnike, zaradi katerih se bralci lotijo in vztrajajo v bralnih dejavnostih. Pri tem motivi, ki so v ozadju branja, ter njihova intenzivnost, pomembno določajo tudi poglobljenost in kakovost 
branja. Preučevanje in razumevanje bralne motivacije je pomembno tako samo po sebi kot tudi zaradi vzajemnega odnosa med bralno motivacijo in bralnim razumevanjem (Guthrie, Hoa, Wigfield, Tonks, Humenick in Littles 2007: 286): bolj kakovostne oblike bralne motivacije so tiste, ki vodijo v bolj poglobljene bralne dejavnosti in vodijo $\mathrm{v}$ boljše bralno razumevanje in bralno pismenost, kar povratno deluje na bralno motivacijo na način, da jo še okrepi. Pečjak in Gradišar (2002: 51) opredeljujeta bralno motivacijo kot krovni pojem za različne motivacijske dejavnike, ki posameznika spodbujajo $\mathrm{k}$ branju, mu osmišljajo bralni proces in tako posameznika podprejo, da vztraja do cilja in si želi bralno izkušnjo ponoviti oziroma ponovno doživeti.

(Bralna) motivacija je torej večdimenzionalen konstrukt, pri čemer lahko v literaturi zasledimo delitev na različne dimenzije. Ena izmed najbolj uveljavljenih je delitev avtorjev Guthria idr. (2007: 284-285) na naslednjih pet vidikov bralne motivacije:

1. Interes za branje kot pomemben vidik bolj ponotranjenih oblik bralne motivacije; bralci z visoko stopnjo interesa za branje so v branje bolj vpleteni, pri njem bolj uživajo ter imajo običajno višjo stopnjo znanja na področju njihovega interesa.

2. Zaznan nadzor nad branjem se nanaša na otrokovo oziroma mladostnikovo zaznavo, da lahko izbira oziroma soodloča o svojem branju. Raziskave kažejo, da sta zaznan nadzor in izbira pri branju pri učencih povezana $z$ višjo stopnjo bralnih dosežkov (Sweet, Guthrie in Ng 1998). Načine za spodbujanje visoke stopnje nadzora nad branjem bomo podrobneje nagovorili v poglavju, kjer opredeljujemo pogoje za razvoj bolj ponotranjenih oblik motivacije (avtonomija).

3. Bralna samoučinkovitost se nanaša na posameznikova prepričanja o lastnih bralnih zmožnostih. Za razvoj in ohranjanje visoke stopnje bralne samoučinkovitosti je ključno, da omogočanje priložnosti za samovrednotenje ter omogočanje napredka v usvajanju bralnih spretnosti. Načine za spodbujanje bralne samoučinkovitosti bomo podrobneje predstavili v poglavju, kjer opredeljujemo pogoje za razvoj bolj ponotranjenih oblik motivacije (zadovoljevanje potrebe po kompetentnosti).

4. Zatopljenost $\mathrm{v}$ branje je proces, ki je opredeljen kot občutek zlivanja $\mathrm{z}$ bralno aktivnostjo. Združuje tako kognitivne kot čustvene procese in se kaže kot popolna pozornost na bralno nalogo. Gre za proces, ki je pogosto opisan z izrazom zanos (angl. flow; Czikszentmihalyi 1997). Zanos predstavlja stanje skrajno intrinzične 
motivacije, za katerega je značilno, da posameznika (bralna) dejavnost tako pritegne, da izgubi občutek za čas in utrujenost ter ustvarja spontano, brez težav. To spremljajo zelo pozitivna občutja močne vpletenosti in navdušenja. Avtor koncepta Csikszentmihalyi (1997) opredeljuje zanos kot posebno stanje zavesti, ki se pojavi, ko so naše sposobnosti in izzivi okolja uravnoteženi. Z vidika spodbujanja zanosa pri branju to pomeni tudi omogočanje bralnega gradiva, ki je prilagojeno tako posameznikovim bralnim zmožnostim kot njegovim bralnim interesom. Pokazatelj zatopljenosti v branje je tako globina bralne izkušnje kakor tudi količina prebranega. 5. Sodelovanje in socialna interakcija sta vidika bralne motivacije, ki se nanašata na vzorce medosebnega vedenja. Kažeta se kot sodelovanje $\mathrm{v}$ skupinskih bralnih aktivnostih, učinkovitem sodelovanju $\mathrm{z}$ drugimi pri nalogah branja in pisanja ter $\mathrm{v}$ veselju ob pripovedovanju o prebranem.

V pričujoči monografiji uporabljamo nekoliko prilagojeno pojmovanje elementov gradnika bralne motivacije; bralna motivacija se tako kaže kot:

- interes za branje,

- pozitiven odnos do branja različnih vrst besedil,

- bralna samoučinkovitost,

- izbira tiskanih in drugih informacijskih virov glede na namen branja,

- uporaba različnih lokacij bralnih virov.

\section{Kaj vse lahko posameznika motivira za branje: oblike (bralne) motivacije}

Kadar govorimo o motivaciji, pogosto uporabljamo delitev na zunanjo in notranjo motivacijo. Pri tem je pomembno vedeti, da zunanja in notranja motivacija nista dihotomni kategoriji: to pomeni, da motivov ni mogoče umeščati le $\mathrm{v}$ eno ali le $\mathrm{v}$ drugo kategorijo, saj gre za motivacijski kontinuum, kjer sta povsem zunanja in povsem notranja motivacija le skrajna pola, na dimenziji med skrajno zunanjo in skrajno notranjo motivacijo pa so različni motivi, ki se razlikujejo $\mathrm{v}$ stopnji ponotranjenosti motiva. Delitev na zunanjo in notranjo motivacijo je torej preveč toga in ne opiše ustrezno vseh oblik motivacije. 
Motivi za branje predstavljajo odgovor na vprašanje, zakaj posameznik bere (oziroma ne bere). Najpogostejši razlog, ki ga otroci in mladostniki navajajo za prostočasno branje, je užitek ob branju - berejo torej zgolj zaradi dejavnosti same in ne zaradi posledic, ki jih ima zanje ta dejavnost, kar predstavlja povsem intrinzično motivacijo.

Učenci, ki berejo iz lastnega interesa, so običajno dobri bralci z visokimi bralnimi dosežki. Tako Wigfield in Guthrie (1997) poročata, da učenci z intrinzično bralno motivacijo branju namenijo $300 \%$ več svojega časa kot učenci z nizko intrinzično motivacijo za branje.

Vendar pa zlasti branje za šolo nikakor ni vedno intrinzično motivirano. Pogost razlog za bralne aktivnosti, povezane s šolo, je zunanji pritisk (npr. učiteljica nam je naročila; če tega ne bom prebral, bom v težavah). Gre torej za zunanje motive, ki so lahko povsem ekstrinzični (npr. prisila, obljubljena nagrada), lahko pa so do neke mere ponotranjeni. Raziskave kažejo, da se $\mathrm{v}$ začetnem obdobju šolanja zunanji motivi za branje ne povezujejo negativno z bralnimi zmožnostmi, $\mathrm{v}$ kasnejših letih šolanja pa je odnos med zunanjimi motivi za branje in bralnimi zmožnostmi negativen. To pomeni, da imajo v višjih razredih osnovne šole in $v$ srednji šoli učenci, ki berejo izključno z namenom izogibanja negativnim posledicam, če bralnih dejavnosti ne bi opravili, nižje bralne dosežke (Otis, Frederick in Pelletier 2005). Ugotovitev je pomembna, ker nakazuje, da je v obdobju urjenja bralnih zmožnosti določena stopnja zunanjega motiviranja še lahko konstruktivna, v kasnejšem obdobju pa so zunanji pritiski za spodbujanje kakovostnih bralnih dosežkov neučinkoviti oziroma imajo lahko celo negativen učinek.

Za ovrednotenje posameznikove bralne motivacije in njegove bralne pismenosti torej ne zadostuje odgovor na vprašanje, ali posameznik bere, temveč je pomembno, zakaj bere. Raznolike motive za branje v obliki motivacijskega kontinuuma od odsotnosti motivacije do skrajno ponotranjenih oblik motivacije odlično opisuje ena izmed najvplivnejših in najpomembnejših sodobnejših teorij motivacije, teorija samodoločanja (angl. self-determination theory; Ryan in Deci 2002, 2020), ki jo predstavljamo $\mathrm{v}$ nadaljevanju. Teorija ponuja tudi veliko iztočnic za spodbujanje kakovostnih oblik bralne motivacije, saj izhajajoč iz predpostavke, da kakovostna motivacija nastopi, ko ima posameznik zadovoljene temeljne psihološke potrebe po kompetentnosti, avtonomiji in povezanosti, opisuje značilnosti socialnega učnega okolja, ki podpirajo razvoj in ohranjanje kakovostne (bralne) motivacije. 
Prispevek teorije samodoločanja $\mathrm{k}$ razumevanju bralne motivacije: kakšno je učno okolje, ki podpira kakovostno bralno motivacijo?

Teorija samodoločanja je ena izmed najbolj celostnih in empirično podprtih teorij motivacije. Ključna predpostavka te teorije je, da smo ljudje aktivni organizmi z notranjo težnjo $\mathrm{k}$ psihični rasti in razvoju in da težimo $\mathrm{k}$ obvladovanju izzivov iz okolja ter integraciji lastnih izkušenj v koherenten občutek sebstva (Ryan in Deci 2002, 2020). Vendar pa ta naravna težnja ne deluje avtomatično; za učinkovito delovanje zahteva podporo socialnega okolja. Socialni kontekst lahko tako podpira kot ogroža posameznikovo naravno težnjo k aktivnemu delovanju in psihološki rasti. To težnjo avtorji v okviru tega pristopa imenujejo samodoločanje. Samodoločeno vedenje je spodbujeno in uravnavano na podlagi posameznikove izbire. Temu nasprotno je kontrolirano vedenje, ki ga spodbujajo intrapsihični (torej taki, ki izhajajo iz posameznika) in okoljski pritiski in ne predstavlja resnične izbire.

Intrinzična bralna motivacija se po tej teoriji nanaša na tiste bralne dejavnosti, ki so nagrajujoče same po sebi - motivacija za opravljanje teh dejavnosti torej ni odvisna od zunanjih vzpodbud. Gre za željo po branju zaradi dejavnosti same po sebi, torej zaradi zadovoljstva, ki ga posameznik občuti ob branju. Ekstrinzična motivacija za branje pa za razliko od intrinzične izhaja iz pogojev v okolju. Nanaša se na vse situacije, ko posameznik bere zaradi zunanjih vzrokov (ki pa so lahko tudi ponotranjeni, kar podrobneje pojasnjujemo $\mathrm{v}$ nadaljevanju). Ekstrinzično motivirano branje je instrumentalno, izvedeno zaradi zunanjih nagrad ali posledic, ki jih ima branje za posameznika.

Koncepta intrinzične motivacije ni upravičeno enačiti $\mathrm{z}$ notranjo kontrolo. Posameznik je intrinzično motiviran, kadar občuti zanimanje za (bralno) dejavnost in obenem zaznava možnost izbire dejavnosti. Notranje kontrolirana vedenja pa so vedenja, ki jih posameznik izvaja, ker občuti notranji pritisk po doseganju določenih standardov ali izidov. Takšna vedenja redko spremlja zanimanje in zaznana možnost izbire. Prav tako tudi ekstrinzično motivirano ni enako kontrolirano; ekstrinzično motivirana vedenja so lahko bolj ali manj avtonomna oz. samodoločena. Samodoločeno vedenje je mogoče tako $\mathrm{v}$ primeru intrinzične kot ekstrinzične motivacije. Teorija samodoločenosti predpostavlja štiri tipe ekstrinzične regulacije, ki se razlikujejo glede na stopnjo samodoločenosti. Ti štirje tipi so skupaj s konceptoma amotivacije in intrinzične motivacije predstavljeni na spodnjem kontinuumu: 
Tabela 1: Motivacijski kontinuum glede na stopnje samodoločenosti

(Ryan in Deci 2000)

\begin{tabular}{|c|c|c|c|c|c|}
\hline \multirow[t]{2}{*}{ Amotivacija } & \multicolumn{4}{|c|}{$\begin{array}{l}\text { Ekstrinzična motivacija: dejavnost je sredstvo za doseganje } \\
\text { nekega cilja }\end{array}$} & \multirow{2}{*}{$\begin{array}{c}\text { Intrinzična } \\
\text { motivacija: } \\
\text { dejavnost je cilj } \\
\text { sama po sebi }\end{array}$} \\
\hline & $\begin{array}{l}\text { Zunanja } \\
\text { regulacija }\end{array}$ & $\begin{array}{l}\text { Ponotranjena } \\
\text { regulacija }\end{array}$ & $\begin{array}{l}\text { Identificirana } \\
\text { regulacija }\end{array}$ & $\begin{array}{l}\text { Integrirana } \\
\text { regulacija }\end{array}$ & \\
\hline $\begin{array}{l}\text { odsotnost } \\
\text { vedenja }\end{array}$ & $\begin{array}{l}\text { vedenja, ki so } \\
\text { uravnavana s } \\
\text { pogoji, ki so } \\
\text { očitno } \\
\text { zunanji v } \\
\text { odnosu do } \\
\text { posameznika } \\
\text { (npr. obljuba, } \\
\text { nagrada, } \\
\text { grožnja } \\
\text { kazni) }\end{array}$ & $\begin{array}{l}\text { vedenja, ki so } \\
\text { motivirana s } \\
\text { strani } \\
\text { notranjih } \\
\text { pritiskov; } \\
\text { posameznik } \\
\text { se vede na } \\
\text { določen } \\
\text { način, ker je } \\
\text { prepričan, da } \\
\text { je tako prav - } \\
\text { drugačno } \\
\text { vedenje } \\
\text { spremljajo } \\
\text { občutja } \\
\text { krivde }\end{array}$ & $\begin{array}{l}\text { vedenje je za } \\
\text { posameznika } \\
\text { osebno } \\
\text { pomembno; } \\
\text { gre za } \\
\text { identifikacijo } \\
\text { z določeno } \\
\text { vrednoto ali } \\
\text { dejavnostjo }\end{array}$ & $\begin{array}{l}\text { integracija } \\
\text { posameznih } \\
\text { identifikacij } \\
z \\
\text { določenim } \\
\text { vedenjem v } \\
\text { koherenten } \\
\text { občutek } \\
\text { sebstva }\end{array}$ & $\begin{array}{l}\text { veselje ob } \\
\text { opravljanju } \\
\text { dejavnosti; } \\
\text { stanje zanosa }\end{array}$ \\
\hline $\begin{array}{l}\text { Primer: Luka } \\
\text { ne bere. }\end{array}$ & $\begin{array}{l}\text { Primer: Ula } \\
\text { bere gradivo za } \\
\text { domače branje, } \\
\text { ker se želi } \\
\text { izogniti } \\
\text { negativni oceni } \\
\text { in } \\
\text { nezadovoljstvu } \\
\text { staršev ter } \\
\text { učiteljev. }\end{array}$ & $\begin{array}{l}\text { Primer: } \\
\text { Lina sodeluje } \\
\text { pri Bralni } \\
\text { znački, da se ne } \\
\text { bi počutila kot } \\
\text { "zguba«, ker } \\
\text { sodelujejo vsi } \\
\text { dobri učenci. }\end{array}$ & $\begin{array}{l}\text { Primer: Lenka } \\
\text { poglobljeno } \\
\text { prebira } \\
\text { leposlovna dela } \\
\text { za maturo, saj } \\
\text { se želi pri } \\
\text { maturi iz } \\
\text { slovenšcine } \\
\text { iqkazati. }\end{array}$ & $\begin{array}{l}\text { Primer: } \\
\text { Ajda z } \\
\text { veseljem } \\
\text { prebira } \\
\text { gradivo za } \\
\text { Cankarjevo } \\
\text { tekmovanje, } \\
\text { saj ji branje } \\
\text { predstavlja } \\
\text { pomembno } \\
\text { vrednoto. }\end{array}$ & $\begin{array}{l}\text { Primer: } \\
\text { Milos pri branju } \\
\text { Harryja Potterja } \\
\text { tako ǔ̌iva, da } \\
\text { pozabi na čas. }\end{array}$ \\
\hline
\end{tabular}

Nadalje teorija samodoločanja pojasnjuje, kako lahko učno okolje podpre kakovostne bolj ponotranjene oblike motivacije. Samoregulacija učencev je po tej teoriji optimalna, kadar socialni kontekst zadovoljuje njihove osnovne potrebe; te so naslednje (Niemiec in Ryan 2009; Reeve, Bolt in Cai 1999):

- potreba po občutju kompetentnosti, 
- potreba po avtonomiji,

- potreba po povezanosti $z$ drugimi.

V nadaljevanju opisujemo značilnosti socialnega učnega okolja, ki učencem omogoča zadovoljevanje temeljnih psiholoških potreb po kompetentnosti, avtonomiji in povezanosti ter torej podpira razvoj in ohranjanje kakovostne (bralne) motivacije. Pri tem se bomo osredotočili pretežno na tiste vidike socialnega okolja, ki bodisi neposredno izhajajo iz učiteljevega dela v razredu bodisi ima učitelj nanje vpliv.

\subsection{Socialni kontekst, ki omogoča doživljanje kompetentnosti ob branju}

Potreba po kompetentnosti je opredeljena kot potreba po doživljanju sebe kot sposobnega doseči določene izide in izogniti se negativnim izidom. Občutja kompetentnosti učencev pri branju učitelj najučinkoviteje spodbuja $\mathrm{z}$ vzpostavljanjem optimalne strukture, kar pomeni, da daje jasne informacije o tem, kako učinkovito doseči želene izide. Učitelj lahko zagotavlja strukturo na naslednje načine: z jasnim izražanjem svojih pričakovanj, konsistentnim, predvidljivim in skladnim odzivanjem, zagotavljanjem potrebne podpore ter prilagajanjem poučevanja tako razvojni stopnji kot individualnim trenutnim zmožnostim učencev. S takšnim vedenjem učitelj vpliva na zaznano kontrolo pri učencih, tj. na njihovo prepričanje, da lahko z lastnim vedenjem vplivajo na želene izide. Izkušnja, da je učenec pri branju lahko uspešen, če se potrudi, je ključna za razvoj bralne samoučinkovitosti. Omogočanje te izkušnje vsem učencem pa od učitelja seveda zahteva prilagajanje bralnih nalog trenutnim zmožnostim učenca. Če učitelj bralnih izzivov ne individualizira, so nekateri učenci s tem prisiljeni v kronično doživljanje neuspeha, ker določenim izzivom pač (še!) niso kos. Izkušnja neuspeha kljub vladanju truda pa vodi $\mathrm{v}$ naučeno nemoč - na preteklih izkušnjah osnovano prepričanje posameznika, da kljub prizadevanju ne more biti uspešen. Naučena nemoč je lahko razlog za izogibanje branju. (Nima smisla, da se trudim, nikoli mi ne bo uspelo.)

Odsotnost prilagajanja bralnih izzivov bralnim zmožnostim učencev pa ima negativne posledice tudi za učence, ki so dobri bralci. Tudi vztrajanje pri tem, da otrok enako kot vsi drugi učenci sodeluje v bralnih aktivnostih, ki so zanj premalo zahtevne (npr. žetoniranje vsakodnevnega branja v obliki bralne hišice za prvošolko, 
ki že dlje časa tekoče bere za užitek in ji ni več potrebno uriti bralne tehnike), ima lahko negativen učinek na ohranjanje bralne motivacije.

\subsection{Socialni kontekst, ki omogoča doživljanje avtonomije ob branju}

Potreba po avtonomiji je opredeljena kot potreba po doživljanju izbire pri začetku, vzdrževanju in regulaciji dejavnosti ter doživljanju povezanosti med svojim vedenjem in osebnimi cilji ter vrednotami. Potrebo učencev po avtonomiji pri bralnih dejavnostih lahko učitelj zadovoljuje tako, da jim zagotavlja določeno stopnjo izbire. To je mogoče $\mathrm{z}$ dovoljevanjem izbire med različnimi bralnimi dejavnostmi ali med načinom oziroma vrstnim redom opravljanja dejavnosti, z zagotavljanjem povezanosti med bralnimi dejavnostmi in interesi učencev, še zlasti pa s čim manjšo prisotnostjo zunanjih nagrad, nadzora in pritiskov. Raziskave kažejo, da so učenci učiteljev, ki spodbujajo avtonomijo učencev, bolj intrinzično motivirani kot učenci učiteljev, ki uporabljajo visoko stopnjo nadzora. Prav tako je z vidika podpiranja avtonomije učencev pomemben način nagrajevanja: načeloma je z vidika spodbujanja intrinzične motivacije za branje smiselno čim manj izpostavljati nadzorno funkcijo nagrade (npr. Če boš prebral tri knjige, si boš prislužil priznanje.) in nagrado čim bolj uporabljati kot povratno informacijo (npr. Vesela sem, da si se potrudil in vztrajal pri branju, tudi ko ti ni šlo najbolje. Tvoj trud bom nagradila $\mathrm{z}$ dobro oceno.). S takšnim vedenjem prispevamo $\mathrm{k}$ razvoju in ohranjanju zaznanega nadzora nad lastnim branjem pri učencih - torej vidika, ki smo ga uvodoma opredelili kot enega elementov bralne motivacije.

\subsection{Socialni kontekst, ki spodbuja povezanost učencev $\mathrm{z}$ drugimi}

Potreba po povezanosti je opredeljena kot potreba po občutju varne povezanosti s socialnim okoljem ter po doživljanju sebe kot vrednega ter ljubljenega in spoštovanega. Za zadovoljevanje potrebe učencev po povezanosti $z$ drugimi je ključna visoka stopnja učiteljeve opore pri branju, ki se nanaša na kvaliteto medosebnih odnosov $\mathrm{z}$ učenci in se kaže $\mathrm{v}$ obsegu, $\mathrm{v}$ katerem si učitelj vzame čas za učence, izraža pozitivna čustva do njih, se je pripravljen prilagajati učencem, izraža prepričanje $\mathrm{v}$ njihove zmožnosti napredovanja in izboljšanja branja ipd. Prav tako lahko učitelj $\mathrm{k}$ zadovoljevanju te potrebe pri učencih prispeva s sooblikovanjem spoštljivih in podpornih vrstniških odnosov $\mathrm{v}$ razredu ter $\mathrm{z}$ uvajanjem bralnih dejavnosti, ki učencem omogočajo smiselno sodelovanje in socialno interakcijo (npr. 
pogovori o prebranem, skupinske bralne dejavnosti, ki ne temelijo na tekmovanju in ne spodbujajo socialnega primerjanja).

Učno okolje, ki učencem omogoča zadovoljevanje navedenih temeljnih psiholoških potreb, je optimalno z vidika razvoja in ohranjanja kakovostne bralne motivacije.

\section{Bralna motivacija in bralna pismenost}

Opisana bralna motivacija je tudi ključna sestavina bralne pismenosti, z vidika kognitivne psihologije je tako neločljiv del bralne učinkovitosti in je povezana $s$ celotno učno motivacijo ter $\mathrm{z}$ razvojem pismenosti. Ob tem se pojavlja še pojem bralna zavzetost (angl. reading engagement), ki povezuje motivacijske in kognitivne vidike branja. Bralno zavzet bralec, bralka sta notranje motivirana, svoje znanje pa gradita $\mathrm{z}$ uporabo kognitivnih strategij in $\mathrm{v}$ sodelovanju $\mathrm{z}$ drugimi, kar je bilo $\mathrm{v}$ prvem delu prispevka že podano (Pečjak, Bucik, Gradišar in Peklaj 2006: 7). K bralni motivaciji $\mathrm{v}$ vzgojno-izobraževalnem sistemu tako dodatno pripomore socialni kontekst (kar je bilo prav tako s psihološkega vidika $\mathrm{v}$ predhodnih razdelkih pojasnjeno), ki pa naj temelji na osnovi interakcijsko-komunikacijskega pristopa - ta izvira predvsem iz soodvisne povezanosti pedagoško-vzgojnega kadra z otroki ali mladostniki. Takšen pristop poudarja ustrezne in kvalitetne medosebne odnose na vseh stopnjah izobraževanja, na katerih temelji uspešna vzgojna dejavnost, in sicer med drugim tako, da je prisotno ustvarjalno sodelovanje, da se upoštevajo razvojne zakonitosti otrok in mladostnikov, pri čemer je konstruktiven ter spodbuden dialog osnova tovrstni interakciji in komunikaciji (Bratanić 1993; Marentič Požarnik 1987; Sahr in Schlund 1992). Glede bralne pismenosti pa je v Nacionalni strategiji za razvoj bralne pismenosti za obdobje 2019-2030 (2019) sprejeta definicija, na podlagi katere je pripravljena tudi strategija pismenosti v okviru projekta OBJEM; bralna pismenost kot taka je tako temelj vseh drugih pismenosti (Nacionalna strategija 2019: 3).

V monografiji V objemu besed: razvijanje drǔ̌inske pismenosti iz 2017 pa je glede bralne pismenosti, ki je imenovana tudi kot bralna zmožnost, podano, da je »predpogoj« za razvoj bralne kulture. Razvija se vse življenje $\mathrm{v}$ različnih okoliščinah in na različnih področjih ter "prežema vse človekove dejavnosti. Poudariti je treba, da se tudi razumevanje termina bralna pismenost $\mathrm{z}$ razvojem družbe in tehnologije spreminja« (Haramija 2017: 1). V že navedeni Nacionalni strategïi za razuoj bralne pismenosti je nadalje med drugim zapisano, da je bralna pismenost temeljna za razvitje jezikovne zmožnosti, ki pripomore k boljšemu obvladovanju maternega in drugih jezikov, tudi 
k večji jezikovni samozavesti, predvsem pa k pripravljenosti posameznika za sprejemanje jezikovne in kulturne različnosti ter učinkovitemu vključevanju $\mathrm{v}$ digitalizirano družbo. Pomembno pripomore $\mathrm{k}$ hitrejšemu pridobivanju ali izpopolnjevanju poklicnih kompetenc ter različnih kvalifikacij na vseh ravneh vzgoje in izobraževanja. Pomemben del pismenosti je prav tako bralna kultura, ki je opredeljena kot odnos (splet pojmovanj in vrednot) posameznika in posameznice ter družbe do knjig in branja. Nastanek in posodobitev te strategije utemeljujejo z izsledki mednarodnih raziskav (PIRLS, PISA, PIAAC), kot jih navaja Nacionalna strategija, ki so pokazale, da so se dosežki slovenskih učencev in učenk na področju bralne pismenosti pomembno izboljšali, a vendarle delež višjih ravni bralne pismenosti slovenskih osnovnošolcev, osnovnošolk, srednješolcev in srednješolk ni zadosten. Četudi mnogi obvladajo manj zahtevne (temeljne) bralne procese, jim višje ravni bralnih odzivov (npr. kritično vrednotenje prebranega) povzročajo težave (Nacionalna strategija 2019: 4.).

$\mathrm{V}$ navedeni strategiji so podani tudi specifični cilji in ravni pismenosti po posameznih stopnjah izobraževanja (Nacionalna strategija 2019: 9-13), pri čemer je prav bralna motivacija temeljnega pomena za njihovo doseganje.

Iz predhodnega razdelka 4 bi lahko s pomočjo razlage t. i. teorije samodoločanja $\mathrm{v}$ povezavi z bralno motivacijo in učnim okoljem, ki naj podpira kakovostno bralno motivacijo, postavili domnevno povezavo med visokim nivojem bralne pismenosti, zadnjo stopnjo ekstrinzične motivacije (ki je integrirana regulacija v smislu integracije posameznih identifikacij $z$ določenim vedenjem $\mathrm{v}$ koherenten občutek sebstva) ter intrinzično motivacijo v tem smislu, da je prav približevanje slednji, kjer je dejavnost, torej branje, cilj sam po sebi, najboljše izhodišče za razvoj višjih ravni bralne pismenosti oz. bralnih odzivov.

\section{Bralna motivacija $\mathrm{v}$ povezavi $\mathrm{z}$ metodami literarnega branja}

\subsection{Branje kot temelj bralne pismenosti}

Branje kot dejavnost pelje $\mathrm{k}$ bralni pismenosti in je $\mathrm{v}$ pedagoški psihologiji pojmovano kot »visoko organizirana vsestranska interakcija različnih psihičnih procesov« (Pečjak 1993: 9) oziroma predstavlja interakcijo med bralcem in besedilom, pri čemer bralec tvori pomen besedila. Pri tovrstni dejavnosti sodelujejo psihični procesi na različnih ravneh bralčeve duševnosti: kognitivni, čustveno- 
motivacijski in razvojni, ki vplivajo na bralno učinkovitost. Tem se pridružujejo še socialni dejavniki ter sama struktura besedila, in sicer (Krakar Vogel 2020: 27-29):

- Kognitivni dejavniki - mdr. bralčevo predznanje in pričakovanja, inteligentnost in tehnika branja, ki tvorijo mreže pojmov, v katere bralec vnaša nove informacije iz besedila.

- Čustveno-motivacijski dejavniki - mdr. pozitiven ali negativen odnos do branja, kar je odvisno od predhodnih bralčevih izkušenj z branjem, interes za branje določene vsebine (za motivacijo branja je potrebno za otroke in mladostnike bralno gradivo ustrezno izbirati).

- Vpliv besedila samega, njegovo besedišče, skladenjsko-pomenska sestava, število in zgradba informacij.

- Vpliv socialnih dejavnikov (npr. odnos do branja v družini in širšem socialnem okolju) in stopnja bralnega razvoja.

Za razvijanje bralnih sposobnosti so v okviru vzgoje in izobraževanja odgovorni pri vseh učnih predmetih, ne le pri književnem pouku, pri čemer je lahko v metodološko pomoč t. i. Kolbov krog (Kolb 1984). To metodo bi z ustrezno adaptacijo lahko uporabili kot motivacijo za branje pri različnih učnih predmetih. Pri tej obliki izkušenjskega učenja gre za štiri učne dejavnosti, preko katerih poteka dejavno spoznavanje določenega predmeta ( $v$ oklepaju $z$ navezavo na branje) in kjer izhajamo: 1. iz konkretne izkušnje (motivirano branje besedila, njegovo zaznavanje, doživljanje oz. subjektivna konkretizacija, aktualizacija), 2. razmišljujočega opazovanja (postopki razčlenjevanja in razumevanja besedila), 3. abstraktne konceptualizacije (sintetiziranje, formaliziranje spoznanj, razvrščanje, presojanje) in 4. aktivnega eksperimentiranja (novo branje) (Krakar Vogel 2004: 42, 57-58, 2020 : 26).

\subsection{Literarno branje ali branje literarnih besedil}

Podane stopnje spoznavanja Kolbovega kroga se ujemajo tudi z načini sprejemanja/branja literarnih del oz. s stopnjami branja, kot jih opredeljujeta teorija bralčevega odziva in psihologija branja, in sicer: spoznavno-sprejemna stopnja kot doživljanje, zatem razumevanje ter vrednotenje. Branje literarnih besedil poteka torej od začetnega (doživljajskega) sprejemanja, pri katerem so lahko bralni učinki okrnjeni, saj so odvisni od bralčevega obzorja pričakovanj - do globljega 
razumevanja in vrednotenja ob ponovnih branjih istega besedila (lahko opazimo prej prezrte sestavine, globlje razumemo besedilo, razvijamo argumentacijo za utemeljevanje svojih vidikov, krepimo sprejemanje novih, presenetljivih rešitev) (Krakar Vogel 2004: 42, 57-58, 2020: 26, 30; Kerndl 2016: 146-147).

Pri razumevanju pojma bralna motivacija imamo torej v mislih tudi branje literarnih besedil, pri čemer ne razumemo motiviranega branja literature le $\mathrm{v}$ funkciji - ampak predvsem kot pogoj za dosego zmožnosti boljšega, bolj poglobljenega in bolj motiviranega branja tudi pri drugih predmetnih področjih (npr. fizike, geografije, zgodovine), pri čemer še posebej motivirano in usmerjeno branje literarnih tekstov zlasti pripomore $\mathrm{k}$ načrtnemu, sistematičnemu in temeljitemu usvajanju bralne tehnike ter vadenju tekočnosti branja (zlasti na začetku opismenjevanja $\mathrm{s}$ pripovednimi oz. narativno oblikovanimi besedili), saj se na tem temelju lahko gradi motivirano branje na vseh drugih predmetnih področjih (Bošnjak 2020: 7). V tem kontekstu je treba izpostaviti specifiko literarne zmožnosti (ali književne sposobnosti (Krakar Vogel 2004: 40)), ki prav tako vpliva na bralno motivacijo, in je predvsem zmožnost za literarno branje, raziskovanje in ustvarjanje ter je ena od temeljnih kompetenc, ki se razvija pri pouku književnosti. Pomembno pa je, da jo razvijamo skupaj še z drugimi specifičnimi kompetencami oz. zmožnostmi znotraj medpredmetnega povezovanja, npr. ob kulturni, medkulturni, digitalni zmožnosti kot tudi v obliki literarnega raziskovanja in ustvarjanja (Krakar Vogel 2004: 40-45; Žbogar 2019: 73).

Literarno branje oziroma branje literature se od neliterarnega razlikuje po bralčevi recepciji in naravi literarnih besedil, kar pomeni, da pri prvem razločevalnem dejavniku sodelujejo bralčeva čustva, subjektivna prepričanja in domišljija, kar pomeni doživljanje, razumevanje in vrednotenje besedil. Branje literarnih besedil poteka torej od prvega subjektivnega (doživljajskega) sprejemanja, pri čemer so bralni učinki odvisni od subjektivnega bralčevega obzorja pričakovanj, do globljega razumevanja in vrednotenja ob ponovnih branjih. Glede narave literarnih besedil pa je tako, da mora bralec ali bralka za njihovo razumevanje poleg splošnih dejavnikov (jezik, družbenokulturne okoliščine nastanka in recepcije) poznati tudi specifične lastnosti besedila, ki ga opredeljujejo kot literarno, npr. večpomenskost, posebna oblikovanost, odprtost za različne interpretacije (Krakar Vogel 2020: 30-31). 


\subsubsection{Metoda (literarne/književne) šolske interpretacije}

Doživljanje, razumevanje in vrednotenje (primerjanje, razvrščanje) in vzporedno izražanje mnenj poteka $v$ sedmih fazah, ki sledijo spoznavno-sprejemnim stopnjam v komunikaciji z literarnim besedilom. Prve štiri faze predvsem spodbujajo doživljajsko in celostno (izkušenjsko) sprejemanje besedila pred prvim branjem, med njim in po njem, naslednje tri pa služijo analitičnemu in kritičnemu odzivanju ob nadaljnjih branjih besedila kot tudi novemu samostojnemu branju istega ali drugega teksta (Krakar Vogel 2020: 116-117):

1. Uvodna motivacija.

2. Najava besedila in njegova umestitev $\mathrm{v}$ kontekst.

3. Interpretativno branje.

4. Premor po branju in izražanje doživetij.

5. Razčlenjevanje besedila.

6. Sinteza in vrednotenje.

7. Nove naloge.

Glede na to, da se v uvodni motivaciji spodbuja priklic že znanih spoznavnih oz. čustveno-doživljajskih izkušenj, lahko se tudi nagovarja domišljijske predstave ali rešujejo novi problemi, jo delimo v tri tipe (Krakar Vogel 2020: 119-123): ponovitev književnega ali drugega znanja, doživljajsko-izkušenjska motivacija, problemskoustvarjalna motivacija.

Najprimernejša za različne starostne stopnje otrok in mladostnikov (predšolskih in šolskih) in njeno vključevanje za motiviranje branja tudi pri drugih predmetih, je prav druga - doživljajsko-izkušenjska uvodna motivacija, pri kateri navezujemo obliko in vsebino novega besedila na že znane literarne in zunajliterarne izkušnje, znanja, doživetja sodelujočih. Pomembno je, da se pri tej motivaciji poleg informacij priklicujejo predvsem občutja, zaznave, predstave, asociacije, socialne ali moralne izkušnje, npr.: »Kaj občutimo, ko zaslišimo šumenje vode, gledamo v sonce ...? Vas zvok in svetloba na kaj spominjata?« (Krakar Vogel 2020: 120). Tej uvodni motivaciji sledi najava besedila in njegova umestitev $\mathrm{v}$ kontekst, (interpretativno) branje, premor po branju in izražanje doživetij ob prebranem, kar vse spodbuja doživljajsko in celostno (izkušenjsko) sprejemanje besedila, hkrati pa se lahko uporabi tudi za branje različnih besedil na drugih predmetnih področjih (s prilagoditvami). Razčlenjevanje besedila, sintezo in vrednotenje ter nove naloge pa naj v okviru 
branja literarnih tekstov izvajajo kompetentni učitelji in učiteljice razrednega pouka in/ali slovenščne oz. slovenisti, slovenistke, ki edini lahko zagotovijo potrebno poznavanje literarnega sistema, da razpravljanje o literarnih besedilih (vključujoč tudi kritično presojanje) ne bi ostalo samo na nivoju doživljajskega odzivanja učenk in učencev. V tem smislu bi bili elementi predlagane književne interpretacije izpeljani strokovno avtonomno in bi še dodatno spodbujali nadaljnjo motivacijo za branje strokovnih in informativnih besedil pri različnih drugih predmetih.

\subsubsection{Metoda diskusije}

V kontekstu motiviranja za branje $\mathrm{v}$ okviru šolske interpretacije, katere elemente lahko vključimo prav tako pri drugih predmetih, ne le književnosti, je nujno upoštevati še metodo diskusije (ali diskusijski pogovor, razgovor, razpravo, polemiko, debato ipd., ki je integralni del uresničevanja šolske interpretacije), vendar je ta primernejša za starejše učence in učenke, v tretjem VIO in srednji šoli (temelje metode diskusije pa vzpostavljamo že bistveno prej). Poteka naj med njimi samimi ali med njimi in učiteljem, učiteljico. S to metodo mislimo odprto razpravo o vsebini besedila, temi in sporočilnosti, pri čemer učenci in učenke pojasnjujejo, utemeljujejo, dokazujejo, primerjajo svoja razumevanja besedila, tudi odnos do branja oz. izražajo osebni odnos do prebranega besedila. Predmet pogovora naj bo predvsem lastno doživetje besedila, postavljajo naj se odprta vprašanja (vprašanja na višjih taksonomskih ravneh), ki spodbujajo interakcijo v razredu. Tovrstna vprašanja naj bi spodbujala izmenjavo mnenj, ugotovitev, spoznanj (oz. zahtevnejše miselne procese: analizo, sintezo, primerjanje, vrednotenje, kritično mišljenje in razmišljanje o lastnem branju); pri takšni diskusiji se bo odkrival t. i. horizont pričakovanj (npr. izkušnje, stališča do branja, medbesedilne izkušnje), pri čemer bodo učenci in učenke ugotavljali, da raznoliko doživljajo književno besedilo, da imajo o njem različne predstave, pri čemer je pomembno zlasti razvijanje zmožnosti argumentiranja in poleg tega $-\mathrm{z}$ diskusijo razvijamo tudi zmožnosti kritičnega branja. Najbolj so za mladostnike zanimivi tisti deli besedila, ki so blizu njhovim lastnim izkušnjam (ali pa so jim nasprotni), prav zato je priporočljivo, da za diskusijo najprej izberemo tovrstna besedila; treba je slediti interesom in pojasniti nerazumljivo, pri čemer moramo vedeti, kateri cilj želimo z metodo diskusije doseči, zato se je nanjo treba sistematično pripraviti. Problem, o katerem se diskutira, naj bo čim bolj zanimiv, tudi po izbiri mladostnikov (Grosman 2004: 217-226), saj velja, kot je zapisano v 3. razdelku tega poglavja (Kaj vse lahko posameznika motivira za branje: oblike (bralne) motivacije), da je v obdobju urjenja bralnih zmožnosti ( $\mathrm{v}$ vrtcu in še $\mathrm{v}$ prvem VIO) 
določena stopnja zunanjega motiviranja lahko konstruktivna, v kasnejšem obdobju ( $v$ drugem, tretjem VIO in srednji šoli) pa so zunanji pritiski spodbujanja bralnih dosežkov neučinkoviti ali imajo lahko celo negativen učinek.

\section{$7 \quad$ Sklep}

Učno okolje naj bi za spodbujanje ter uresničevanje kakovostnih oblik bralne motivacije otrokom in mladostnikom omogočalo zadovoljevanje temeljnih psiholoških potreb. K samoregulaciji učenk in učencev pripomore socialni kontekst, ki zadovoljuje njihove osnovne potrebe, kot so: potreba po občutju kompetentnosti, avtonomiji in povezanosti $z$ drugimi. Upoštevanje naštetih psiholoških dejavnikov je $z$ vidika razvoja in ohranjanja kakovostne bralne motivacije optimalno.

Iztočnice za uresničevanje predstavljenih motivacijskih strategij na predšolski, osnovnošolski in srednješolski ravni ob upoštevanju medpredmetnih povezav so naslednje: uporaba doživljajsko izkušenjske uvodne motivacije na začetku, zatem naj se s pomočjo pedagoške interakcije spodbudi, da izbrano besedilo nekdo izmed otrok ali mladostnikov (lahko jih je tudi več) prebere na glas (v predšolskem obdobju ustrezno besedilo prebere vzgojiteljica ali vzgojitelj), nadalje sledi pogovor, ki je pri različnih predmetnih področjih prav tako fokusiran predvsem na lastno doživetje prebranega besedila (če gre za starejše učenke in učence, se lahko vodi zahtevnejša diskusija). Takšen pogovor naj poteka najprej v manjših skupinah, zatem vodeno v obliki skupne refleksije, ki naj se snovno-tematsko naveže tudi na določeno drugo predmetno področje, ne le književnost, in sicer na izbrani predmet (npr. geografijo, zgodovino, matematiko), pri katerem se takšno branje izvaja. Umestitev besedila $\mathrm{v}$ literarni sistem, če gre za branje literarnega teksta, pa naj poteka obvezno medpredmetno v povezavi s književnostjo.

\section{Opomba}

Avtorica Blanka Bošnjak je prispevek napisala v okviru projekta OBJEM - Bralna pismenost in razvoj slovenščine (Ozaveščanje, Branje, Jezik, Evalvacija, Modeli), šifra projekta OP20.01462, vodja dr. Sandra Mršnik, ki ga vodi Zavod RS za šolstvo. Naložbo sofinancirata Republika Slovenija in Evropska unija iz Evropskega socialnega sklada.

\section{Literatura}

Blanka BOŠNJAK, 2020: Motivacija za branje s kratko prozo. Jezile in slovstvo 65(1). 3-15.

Marija BRATANIĆ, 1993: Mikropedagogija: interakcijsko-komunikacijski aspekt odgoja. 3. izd.

Zagreb: Školska knjiga, 1993. 
Mihaly CSIKSZENTMIHALYI, 1997: Finding flow: The psychology of engagement with everyday life. New York: Basic Books.

Gradniki bralne pismenosti: delovno gradivo, 2018. Ljubljana: Zavod RS za šolstvo.

Meta GROSMAN, 2004: Zagovor branja. Bralec in književevnost v 21. stoletju. Ljubljana: Založba Sophia.

John T. GUTHRIE, A. Laurel W. HOA, Allan WIGFIELD, Stephen M. TONKS, Nicole M. HUMENICK in Erin LITTLES, 2007: Reading motivation and reading comprehension growth in the later elementary years. Contemporary Educational Psychology 32. 282-313.

Dragica HARAMIJA, 2017: Uvod. Haramija, Dragica (ur.): V objemu besed: razvijanje družinske pismenosti. Maribor: Univerzitetna založba Univerze. 1-5.

Mojca JURIŠEVIČ, 2012: Motiviranje učencev v sooli. Ljubljana: Pedagoška fakulteta.

Milena KERNDL, 2016: Sodoben pouk (književnosti) in rą̧like med učenci. Murska Sobota: BoMa.

Boža KRAKAR VOGEL, 2004: Poglavja į didaktike književnosti. Ljubljana: DZS.

Boža KRAKAR VOGEL, 2020: Didaktika književernosti pri pouku slovenščne. Ljubljana: Rokus.

David A. KOLB, 1984: Experiential Learning. Experience as the Source of Learning and Development. Prentice Hall, Inc. New Jersey.

Barica MARENTIČ POŽARNIK, 1987: Nova pota v izobraževanju učiteljev: [priročnik za učitelje].

Ljubljana: Državna založba Slovenije.

Christopher P. NIEMIEC in Richard M. RYAN, 2009: Autonomy, competence, and relatedness in the classroom. Applying self-determination theory to educational practice. Theory and Research in Education 7, 133-144.

Nancy OTIS, Frederick M. E. GROUZET in Luc G. PELLETIER, 2005: Latent motivational change in an academic setting: A 3-year longitudinal study. Journal of Educational Psychology 97. 170-183.

Sonja PEČJAK, 1993: Kako do boljšga branja: tehnike in metode za ižboljsanje bralne učinkovitosti. Ljubljana: Zavod republike Slovenije za šolstvo in šport.

Sonja PEČJAK in Ana GRADIŚAR, 2002: Bralne ǔ̃ne strategije. Ljubljana: Zavod Republike Slovenije za šolstvo.

Sonja PEČJAK, Nataša BUCIK, Ana GRADIŠAR in Cirila PEKLAJ, 2006: Bralna motivacija v šoli: merjenje in razvijanje. Ljubljana: Zavod Republike Slovenije za šolstvo.

Nacionalna strategija za razvoj bralne pismenosti 2019-2030, 2019. http://www.ff.uni-

lj.si/sites/default/files/Dokumenti/OHK/Obvestila/nacionalna_strategija_za_razvoj_braln e_pismenosti_2019-2030.pdf.

Johnmarshall REEVE, Elizabeth BOLT in Yi CAI, 1999: Autonomy-supportive teachers: how they teach and motivate students. Journal of Educational Psychology 91. 537-548.

Richard M. RYAN in Edward L. DECI, 2000: Intrinsic and extrinsic motivations: Classic definitions and new directions. Contemporary Educational Psychology 25. 54-67.

Richard M. RYAN in Edward L. DECI, 2020: Intrinsic and extrinsic motivation from a selfdetermination theory perspective: Definitions, theory, practices, and future directions. Contemporary Educational Psychology 61.

Michael SAHR in Angela SCHLUND, 1992: Das Bilderbuch in der Grundscbule. 1. Aufl. Regensburg: Wolf. Monteserrat SARTO, 2015: Strategije motiviranja za branje: z. įkušnjami slovenskih motivatork in motivatorjev. Medvode: Malinc.

Paula J. SCHWANENFLUGEL in Phillip D. TOMPOROWSKI (ur.), 2018: Physical Activity and Learning After School: The PAL Program. New York, London: The Guilford Press.

Anne P. SWEET, John T. GUTHRIE in Mary M. NG, 1998: Teacher perceptions and student reading motivation. Journal of Educational Psychology 90. 210-224.

Allan WIGFIELD in John T. GUTHRIE, 1997: Motivation for reading: individual, home, textual, and classroom perspective. Educational Psychologist 32. 57-135.

Allan WIGFIELD, 1997: Children's motivations for reading and reading engagement. Guthrie, John T.; Wigfield, Allan (ur.): Reading engagement: motivating readers through integrated instruction. Newark: International Reading Association.

Maja ZUPANČIČ in Janez JUSTIN, 1991: Otrok, pravila, vrednote: otrokov moralni in socialni razvoj. Radovljica: Didakta. 
Amalija ŽAKELJ, 2016: Jezikovna dimenzija matematike in pouk matematike. Devjak, Tatjana; Saksida, Igor (ur.): Bralna pismenost kot i₹ziv in odgovornost. Ljubljana: Pedagoška fakulteta. 163175.

Alenka ŽBOGAR, 2019: Razvijanje literarne zmožnosti pri pouku književnosti. Jez̧ik in slovstvo 64(1). 73-83. 


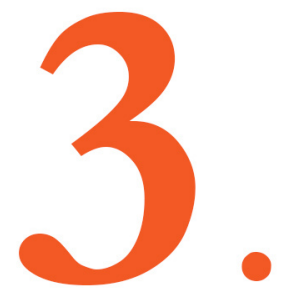

G R A D N I K

RAZUMEVANJE

KONCEPTA BRALNEGA GRADIVA 
${ }^{1}$ Celostno branje multimodalnih besedil: sestavljanje pomenov iz besedila in ilustracij, upoštevanje odnosa ali interakcije (zavedanje o pomenu multimodalnosti).

${ }^{2}$ Multimodalna besedila: vsebujejo besedilo in ilustracije, slike, fotografije, grafe, miselne vzorce, tabele, zemljevide, notne zapise ipd.

\section{Elementi gradnika:}

- orientacija $\mathbf{v}$ bralnem gradivu

- povezovanje besednega in slikovnega dela $\mathrm{v}$ besedilu

- poznavanje in obvladovanje smeri branja

- celostno branje ${ }^{1}$ multimodalnih besedil ${ }^{2}$

- poznavanje tiskanih in digitalnih gradiv 


\title{
3. GRADNIK:
}

\section{RAZUMEVANJE KONCEPTA BRALNEGA GRADIVA}

\author{
DragiCA HARAMIJA ${ }^{1,2}$ IN JANJA BATIČ ${ }^{2}$ \\ ${ }^{1}$ Univerza v Mariboru, Filozofska fakulteta, Maribor, Slovenija. \\ E-pošta: dragica.haramija@um.si \\ 2 Univerza v Mariboru, Pedagoška fakulteta, Maribor, Slovenija. \\ E-pošta: dragica.haramija@um.si,janja.batic@um.si
}

Povzetek V poglavju o 3. gradniku, razumevanju koncepta bralnega gradiva, sta predstavljeni monomodalna pismenost in njen prehod $\mathrm{v}$ multimodalno pismenost, slednja od bralca zahteva sestavljanje več kodov sporočanja, da bi njihov sumativni pomen razkril celotno delo. Linearno branje poteka od leve proti desni, od zgoraj navzdol, in sicer ne glede na to, ali gre za informativno ali leposlovno bralno gradivo. Izbirno branje načeloma ni linearno, temveč bralec sestavlja parcialne pomene, šele na koncu lahko sestavi celoto. Razumevanje koncepta bralnega gradiva je pomembno za vsa področja $\mathrm{v}$ vrtcu in za vse predmete $\mathrm{v}$ osnovni in srednji šoli. Predstavljena je analiza izbrane slikanice Manice K. Musil, ki je z dvema različnima izdajama (klasična, postmoderna) dober primer za razumevanje koncepta multimodalnosti. V vseh multimodalnih analizah leposlovja se kaže, da ilustracije vplivajo na razumevanje zgodbe in (vsaj delno) spreminjajo ali natančneje predstavljajo temeljne morfološke lastnosti besedil.

Ključne besede: gradniki bralne pismenosti, bralna pismenost, vizualna pismenost, multimodalna sporočila, vsebinskooblikovni odnos med besedilom in ilustracijo. 


\title{
THE THIRD COMPONENT OF
} READING LITERACY:

COMPREHENDING THE CONCEPT OF READING MATERIAL

\author{
DragiCA HARAMIJA ${ }^{1,2} \&$ JANJA BATIČ́ \\ ${ }^{1}$ University of Maribor, Faculty of Arts, Maribor, Slovenija. \\ E-mail: dragica.haramija@um.si \\ ${ }^{2}$ University of Maribor, Faculty of Education, Maribor, Slovenija. \\ E-mail: dragica.haramija@um.si,janja.batic@um.si
}

Keywords: components of reading literacy, reading literacy, visual literacy, multimodal messages, content and formative relationship between text and illustration.
Abstract The chapter on the third components of reading literacy, comprehending the concept of reading material, looks at monomodal literacy and its transition to multimodal literacy. The latter demands of the reader the combination of numerous codes of communication in order for their combined meaning to reveal the complete work. Linear reading proceeds from left to right, from top to bottom, regardless of whether the reading material is informative or literary. For the most part, selective reading is not linear, instead the reader combines partial meanings to ultimately construct a whole. Understanding the concept of reading material is important in all areas at nursery school and in all subjects at primary and secondary school. Also presented is an analysis of a selected picture book by Manica K. Musil, which, with two different editions (classical and postmodern), is a good example for understanding the concept of multimodality. Multimodal analysis of literature indicates that illustrations influence the comprehension of the story and (at least partially) change or, more precisely, present the basic morphological attributes of a text. 


\section{$1 \quad$ Uvod}

V izobraževalnem prostoru tradicionalno učno gradivo, ki je izraženo zgolj z enim, to je jezikovnim kodom sporočanja, vedno bolj nadomeščajo multimodalna bralna gradiva. Tovrstna gradiva zahtevajo nove, drugačne (učne) bralne strategije. Že po osnovnem konceptu se gradiva delijo na literarna besedila in informativna gradiva, ki zajemajo vsa predmetna področja (učbeniki, delovni zvezki, poljudne in strokovne enciklopedije in priročniki, druga poljudna in strokovna gradiva, ki so označena kot poučne knjige).

$\mathrm{V}$ procesu izobraževanja izhajamo iz štirih temeljnih veščin, ki tvorijo bralno pismenost: poslušanje, govorjenje, branje in pisanje (prim. Pečjak in Gradišar 2015), pri čemer sta poslušanje in branje pasivni, govorjenje in pisanje pa aktivni dejavnosti.

Pri konceptu multimodalne pismenosti je treba poudariti dvoje:

- tovrstno branje večinoma ni več (le) linearno, temveč gre za izbirni način branja in sestavljanja pomenov;

- ob zgoraj navedenih veščinah je treba uzavestiti opazovanje drugih kodov sporočanja ter uriti sestavljanje pomenov multimodalnih sporočil.

\section{Od monomodalnosti k multimodalnosti}

Morebiti najlažje razložimo, kako delujejo različni kodi sporočanja $\mathrm{v}$ skupnem, novem sporočilu, če izhajamo iz strukturalizma. Ferdinand de Saussure je že v začetku 20. st. izpostavil, da so znaki jezika sestavljeni iz označevalcev (fonemov) in označencev (pojmovne plati znakov); jezik je torej eden od kodov sporočanja, ki ima svojo strukturo in sistem. Roland Barthes je povezal strukturalizem s semiotiko, vedo, ki se ukvarja z jezikovnimi znaki (simboli). Njen začetnik je Charles Sanders Peirce.

Semiotični trikotnik (slika 1), ki je bil sicer razvit v okviru jezikoslovja, nazorno predstavlja konstrukcijo konceptov oziroma pojmov. Semiotika je nujno povezana s semantiko (ki se ukvarja s pomeni besed/besedil). 


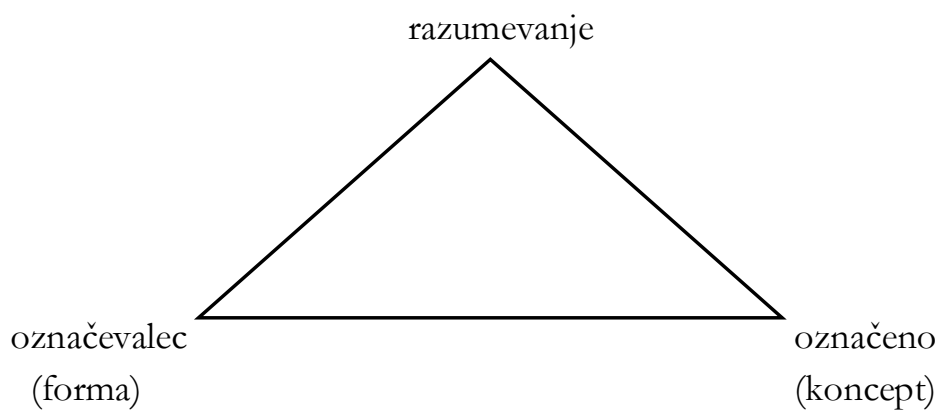

Slika 1: Semiotični trikotnik

V okviru sistemske in empirične obravnave literature Marijan Dović (2004: 30) poudarja: »Konstrukcija pojmov vedno poteka v okviru jezika, zato je semantična analiza ključni element vsake teorije znanja.« $\mathrm{V}$ nadaljevanju avtor predstavi semantiko na podlagi razvoja otrokovega govora (Dović 2004: 32):

Jezika se namreč nismo naučili iz slovarja, temveč postopoma, s poskusi, z eksperimenti. Kako otroka naučimo, kaj je »skodelica«? Pokažemo nanjo, da se otrok v morju vidnih signalov osredotoči nanjo. Nato jo izoliramo, jo premikamo, da si jo lahko predstavlja kot ločeno stvar, zraven ponavljamo besedo, označevalec, da otrok lahko asociira predmet in slušno podobo. Otrok se torej uči izključno iz elementov, ki jih abstrahira iz lastne izkušnje - toda njegova predstava o skodelici še dolgo ni taka kot naša. Skodelico povezuje še z dejavnostjo pitja, pogosto celo z mlekom, ki je v njej. Šele po napornih jezikovnih vajah se izoblikuje taka skodelica, ki obstaja tudi, ne da bi kdo iz nje pil in ne glede na to, kaj je/ni v njej - kot bi odrasli rekli, da je "pravi« pomen besede. Učenje besed pa ni omejeno na otroštvo, temveč poteka vse življenje. Pogosti konflikti so tako plod različnih koncepcij, in če ne priznamo konstruiranosti lastnih konceptov in vztrajamo pri reprezentacionizmu, se zdi včasih sprava nemogoča.

Koncept konstrukcije pojmov lahko v izobraževalnem sistemu apliciramo na vsa področja dejavnosti v vrtcu in na vse predmete v OŠ in SŠ; nujno je torej zavedanje, da se otrok, učenka in učenec, dijakinja in dijak uči novih besed in njihovih pomenov v celotni izobraževalni vertikali na vseh predmetnih področjih. Enako kot za 
jezikovni kod pa velja tudi za vse druge kode sporočanja, pri čemer je treba jasno premisliti, kateri kod bo otroku pripomogel k razumevanju katere koli obravnavane teme. Raznolikost predmetnih področij v vrtcu in predmetov v OŠ in SŠ namreč že sama po sebi ne dopušča uniformiranosti konceptov multimodalnih besedil, še zlasti je to opazno pri predmetih, ki se navezujejo na umetnost.

Gibbons in Whiteley (2018: 250) sta razvrstili kode sporočanja glede na čutilo, s katerim sprejemamo informacije, $v$ tri senzorične sisteme in jim dopisali primere kodov: vid (slikovni znaki, grafološki poudarki, barva, postavitev in sestava besedila, pisni znaki, numerični znaki, geste); zvok (govorni znaki, zvoki (kot so zvočni učinki), glasba (vključno z zvočnimi posnetki)); tip (tekstura, kinestetično gibanje). $\mathrm{Na}$ podlagi njunih ugotovitev smo prilagodili in razširili shemo na štiri čutila, izjema je okus (ki ga pri branju uporabljamo le kot preneseni pomen, ne pa tudi dejansko), in jih povezali z različnimi kodi sporočanja, posebej smo izpostavili umetniška področja in njihovo navezavo na sprejemanje skozi posamezno čutilo.

Tabela 1: Primeri kodov sporočanja v posameznih umetnostih skozi različna čutila

\begin{tabular}{|c|c|c|}
\hline Čutilo & Področje umetnosti & Primeri kodov \\
\hline Vid & $\begin{array}{l}\text { književnost, likovna umetnost, } \\
\text { gledališka umetnost (dramsko } \\
\text { gledališče, lutkovno gledališče, } \\
\text { balet in druga plesna } \\
\text { ustvarjalnost), film, arhitektura }\end{array}$ & $\begin{array}{l}\text { slikovni znaki, grafološki poudarki, } \\
\text { barva, postavitev in sestava besedila, } \\
\text { pisni znaki, numerični znaki, geste, } \\
\text { svetloba/senca, note }\end{array}$ \\
\hline Sluh & $\begin{array}{l}\text { zvočna knjiga, glasno branje } \\
\text { knjige, gledališka umetnost } \\
\text { (dramsko gledališče, lutkovno } \\
\text { gledališče; tudi operna predstava), } \\
\text { glasba (vse zvrsti), radijska igra, } \\
\text { film }\end{array}$ & $\begin{array}{l}\text { govorni znaki (glasovi, besede), glasba } \\
\text { (vključno z zvočnimi posnetki), šumi, } \\
\text { tišina }\end{array}$ \\
\hline Tip & $\begin{array}{l}\text { knjige, napisane v brajici, } \\
\text { tridimenzionalne ilustracije (tudi } \\
\text { knjige } \mathrm{z} \text { dodanimi elementi, ki } \\
\text { ponazarjajo teksturo) }\end{array}$ & tekstura, kinestetično gibanje, dotik \\
\hline Voh & $\begin{array}{l}\text { v knjige dodane vonjave, ki se } \\
\text { sprožijo npr. ob drgnjenju, } \\
\text { gledališke ali filmske predstave z } \\
\text { dodanimi vonjavami }\end{array}$ & vonji \\
\hline
\end{tabular}


$\mathrm{V}$ umetnosti imata multimodalni sestav sporočil kot svoje osnovno izhodišče gledališka umetnost in igrani film: govor, petje, glasba, gibanje, ples; ne nazadnje pa tudi prikaz prostora (arhitektura), raba rekvizitov, zvočno in vizualno slikanje atmosfere, kostumografija (zlasti za predstavitev časa) ipd.

Navedena čutila uporabljamo tudi na drugih predmetnih področjih, ne le na polju umetnosti. Npr. gledamo in tipamo tridimenzionalne makete pokrajin, makete različnih objektov, modele matematičnih teles, pri biologiji rastline in živali, vonjamo pri kemijskih poskusih ipd. V izobraževalnem prostoru so zlasti uporabni dokumentarni in dokumentarno-igrani filmi, zlasti za področja, ki si jih ni mogoče ogledati v živo ali jih izkusiti.

Graham in Benson (2010) sta s študenti (bodočimi učitelji materinščine) izvedli multimodalno analizo televizijskih nadaljevank. Študentje so v okviru projekta analizirali nekaj popularnih televizijskih nanizank z vidika različnih kodov: jezikovni kod (kakšen je govor, kakšna je vsebina in struktura besedila, ali je besedilo organizirano in povezano), zvočni kod (glasba in zvočni efekti), prostorski kod (vpliv prostora na izkušnjo gledalca, postavitev igralcev $\mathrm{v}$ prostor, kaj postavitev pove $\mathrm{o}$ odnosu med posameznimi liki), gestualni kod (telesna govorica igralca, čustva ...), vizualni kod (kako je nekaj videti, pri filmu ali televiziji, se nanaša tudi na zorni kot, ki spreminja izkušnjo gledalca). Temu je sledil multimodalni del analize, ki »proučuje, kako vsi kodi skupaj ustvarjajo skupni sumativni pomen« (Graham in Benson 2010: 95).

\section{$3 \quad$ Multimodalna bralna gradiva}

Ob jezikovnem kodu sporočanja je tudi v tradicionalnem bralnem gradivu prisoten slikovni material, ki pa nima vedno enakega značaja. K nekemu besedilu je lahko dodano slikovno gradivo (fotografija, ilustracija), ki lahko bistveno spremeni pomen besedila ali pa z besedilom pomensko ni povezano in ima zgolj estetsko funkcijo. Ko je k tiskanemu besedilu dodano vizualno gradivo, ki nosi sporočilo, se odmikamo od tradicionalnega besedila in od ustaljenih načinov linearnega branja besedila oziroma bralnega gradiva. Ob prisotnosti vizualnega gradiva $\mathrm{v}$ besedilu se pojavi vprašanje razumevanja koncepta bralnega gradiva in načinov branja, ki so povezani s prisotnostjo novega koda sporočanja, posledično z multimodalnostjo. 
Sipe (1998) na primeru slikanice pojasni, kako se spremeni način branja, kadar je napisanemu besedilu dodano vizualno gradivo (ilustracija). Sipe (1998) ugotavlja, da branje teksta poudarja linearno smer (beremo od začetka do konca), medtem ko slike zahtevajo, da se ustavljamo. Branje večkodnih (multimodalnih) gradiv ni samo linearno, ampak se premikamo naprej in nazaj, da lahko povežemo ilustracije med seboj, povežemo besedilo z ilustracijo na prejšnji strani itd. Slikanice in tudi druga besedila, ki vključujejo vizualno gradivo, zahtevajo večkratno branje, saj, kakor ugotavlja Sipe (1998), ne moremo nikoli v celoti dojeti vseh možnih pomenov besedila, slik ali pomenov, ki izhajajo iz medsebojnega odnosa med slikami in besedilom. Sipe (1998: 101-103) posebej poudari teorijo transmediacije. Izhaja iz koncepta Charlesa Suhorja, ki pravi, da gre za prevajanje vsebine enega znakovnega sistema v drugega (Suhor 1984, v Sipe 1998). Pri slikanicah gre za nihanje od znakovnega sistema besedila do znakovnega sistema ilustracij: kadar koli se premikamo od enega do drugega sistema, ustvarjamo nove pomene, saj si razlagamo besedilo glede na ilustracije in ilustracije glede na besedilo $\mathrm{v}$ potencialno nikoli končanem zaporedju. Pri tem Sipe (1998) navaja Marjorie Siegel, ki pri pojasnjevanju transmediacije izhaja iz semiotične teorije. M. Siegel pojasnjuje, kaj se zgodi pri transmediaciji, in sicer pravi, da kadar se premikamo od enega do drugega znakovnega sistema, celoten semiotični trikotnik služi kot objekt (to, kar je označeno) novemu trikotniku (Siegel 1995, v Sipe 1998: 102). Sipe (1998: 102) za ponazoritev uporabi dva semiotična trikotnika (slika 2).
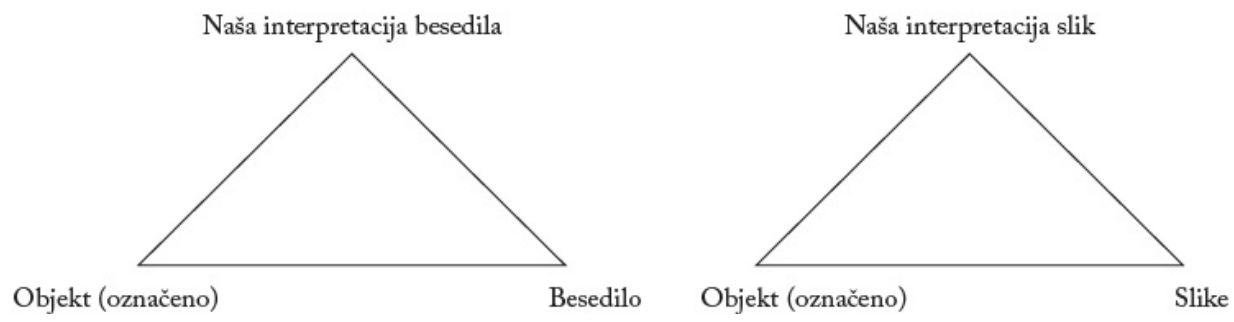

Slika 2: Dva znakovna sistema zahtevata dva semiotična trikotnika (Sipe 1998: 102)

Prehajanje od enega znakovnega sistema k drugemu ponazori s spodnjo shemo (slika 3). Sipe (1998: 103) ugotavlja, da pride, ko prilagajamo interpretacijo slike glede na besedilo ter interpretacijo besedila glede na sliko, do neke vrste nihanja, ki se nikoli ne konča, saj se pomen znakov ves čas premika. 

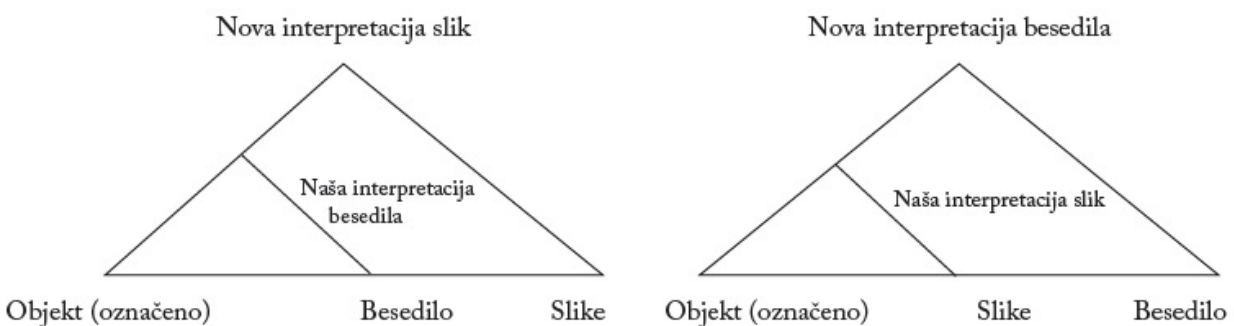

Slika 3: Prehajanje med znakovnima sistemoma

(Sipe 1998: 103)

Iz opisanega primera je razvidno, kako kompleksno postane razbiranje pomena iz bralnega gradiva, ki vključuje dva koda sporočanja. Sodobna bralna gradiva (npr. iučbeniki) vključujejo še več različnih kodov, zato težko govorimo samo o bralnem gradivu, ampak se kot ustreznejši kaže termin multimodalno besedilo ali multimodalni sestav. V procesu oblikovanja pomena $\mathrm{v}$ multimodalnem besedilu Jewitt (2008: 246) izpostavi šest elementov, in sicer »jezikovni pomen, vizualni pomen, zvočni pomen, gestualni pomen, prostorski pomen in multimodalne vzorce pomena, ki povezujejo pomene prvih petih kodov sporočanja med seboj«. Določanje sumativnega pomena, ki ga skupaj ustvarjajo kodi sporočanja, se imenuje multimodalna analiza. Multimodalna analiza poteka pri obravnavi različnih multimodalnih del, pri čemer niso mišljene samo knjige, ampak tudi radijska igra, gledališče (dramska predstava, lutkovna predstava, opera, balet), film.

Pri tem je treba opozoriti na izhodiščni problem branja multimodalnih besedil, in sicer na vizualno (ne)pismenost. V multimodalnem besedilu slika ni le dodatek besedilu, ampak enakovreden nosilec informacij. To pomeni, da je za razumevanje multimodalnega besedila potrebno razumevanje informacij iz besedila, razumevanje informacij iz slike ter oblikovanje pomena, ki izhaja iz interakcije med obema kodoma sporočanja. Kljub množici vizualnih sporočil, ki zaznamujejo sodobni svet, težko govorimo o visoki stopnji vizualne pismenosti. Vizualna pismenost je neke vrste predhodnica bralne pismenosti (Debes 1974: 3): »Pred razvojem govora so se ljudje sporazumevali s telesno govorico, branje telesne govorice je bilo bistvenega pomena za preživetje.« Vizualna pismenost je sposobnost branja in interpretiranja vizualnih podob ter tudi podajanja informacij z vizualnimi sredstvi (npr. z risanjem). Vizualna edukacija sledi štirim ciljem (Messaris 1994, v Newfield 2011): (1) razumevanje vizualnega medija $\mathrm{v}$ različnih oblikah (diagrami, grafi, spreminjanje podob z računalniškimi programi), (2) izboljšanje kognitivnih sposobnost (npr. 
prostorski odnosi), (3) ozaveščanje o manipuliranju s podobami (popačenje in dezinformacije $\mathrm{v}$ svetu oglaševanja in politične propagande), (4) estetsko vrednotenje likovne umetnosti in vizualnega izražanja v različnih oblikah vizualnega komuniciranja.

Vidimo lahko, da vizualna pismenost daleč presega okvirje pouka likovne umetnosti, kamor je največkrat umeščena. Vizualna gradiva, ki nosijo sporočilo, so npr. grafi, tabele, diagrami, miselni vzorci, sheme, načrti, zemljevidi, simboli, ikone, oznake, fotografije, ilustracije, videoposnetki. Vizualna gradiva lahko predstavljajo osrednji vir informacij, lahko so uporabljena za poudarjanje določene podrobnosti posamezne informacije, kot sredstvo za razvijanje otrokovih kognitivnih učnih sposobnosti, kot pomoč otrokom pri interpretiranju informacij, podanih v različnih oblikah, in/ali kot pomoč pri razumevanju zahtevnejših pojavov (konceptov) (Eilam 2012). Osnova za interpretacijo vizualnih podob je natančno zaznavanje in opisovanje. Običajno pa učenci slike sprejemajo le pasivno (Pauwels 2008, v Gillenwater 2014). To pomeni, da preberejo besedilo, poskušajo razbrati pomen besedila, sliko pa samo na hitro pogledajo. $V$ tem primeru je težko govoriti o kakšni posebni multimodalni analizi (spraševanje o tem, kaj pove besedilo, kaj pove slika in kakšen pomen podajata skupaj). Hkrati pa je treba razumeti tudi odnos med besedilom in sliko. V multimodalnem besedilu so vsi kodi sporočanja samo delni. Običajno ne gre za preprosto ponavljanje, npr. slika predmeta in beseda za ta predmet, ampak za bolj kompleksno celoto. Kot primer lahko navedemo knjige z obogateno resničnostjo (augmented reality ${ }^{1}$ ). Ob besedilu in sliki se namreč pojavijo še drugi kodi sporočanja (npr. gibanje in zvok), ki ponujajo vsak svoj del informacije o nekem pojavu.

Primeri multimodalnega besedila $\mathrm{v}$ šolskem prostoru so tudi: besedilna naloga s pripadajočo ilustracijo $\mathrm{v}$ delovnem zvezku; spletna stran, ki vključuje besedilo, fotografijo in videoposnetek; strip; plakat ipd. Tudi na tem področju se kaže problem vizualne (ne)pismenosti in neobčutljivosti. Za primerjavo navajamo učbenik Slovenšcina, i-uchenik za 8. razred osnovne sole (2015) in berilo Drevo iz zemlje rase, berilo za 4. razred osnovne sole (1976). I-učbenik je zasnovan zelo interaktivno, veliko je shem, fotografij, različnih nalog. $\mathrm{Na}$ eni od strani (slika 4) sta v nalogo, pri kateri morajo

\footnotetext{
${ }^{1}$ Obogatena resničnost se od virtualne razlikuje po tem, da združuje realni svet z virtualnim. Uporabnik doživi virtualne objekte v realnem svetu. Gre za tehnologijo, ki bo močno vplivala na način poučevanja (oziroma ponekod že vpliva). Več v: Raymond Hughes (ur.), 2014: Augmented Reality: Developments, Technologies and Applications. New York: Nova Publishers.
} 
učenci s premetavanjem črk dobiti besedo, kot primer vključeni dve likovni deli (prepoznamo Groharjevega Sejalca in Zeleni pajčolan Riharda Jakopiča). Obe sliki sta postavljeni ena ob drugo, brez razmika. Ko pravilno premečemo črke in pridemo do naslova obeh del, je to vse, kar o delu izvemo. Glede na to, da imajo i-učbeniki številne možnosti gradnje multimodalnega besedila (npr. odpiranje novih podoken), se ponuja priložnost, da osmošolcem ponudimo osnovne informacije o obeh delih.

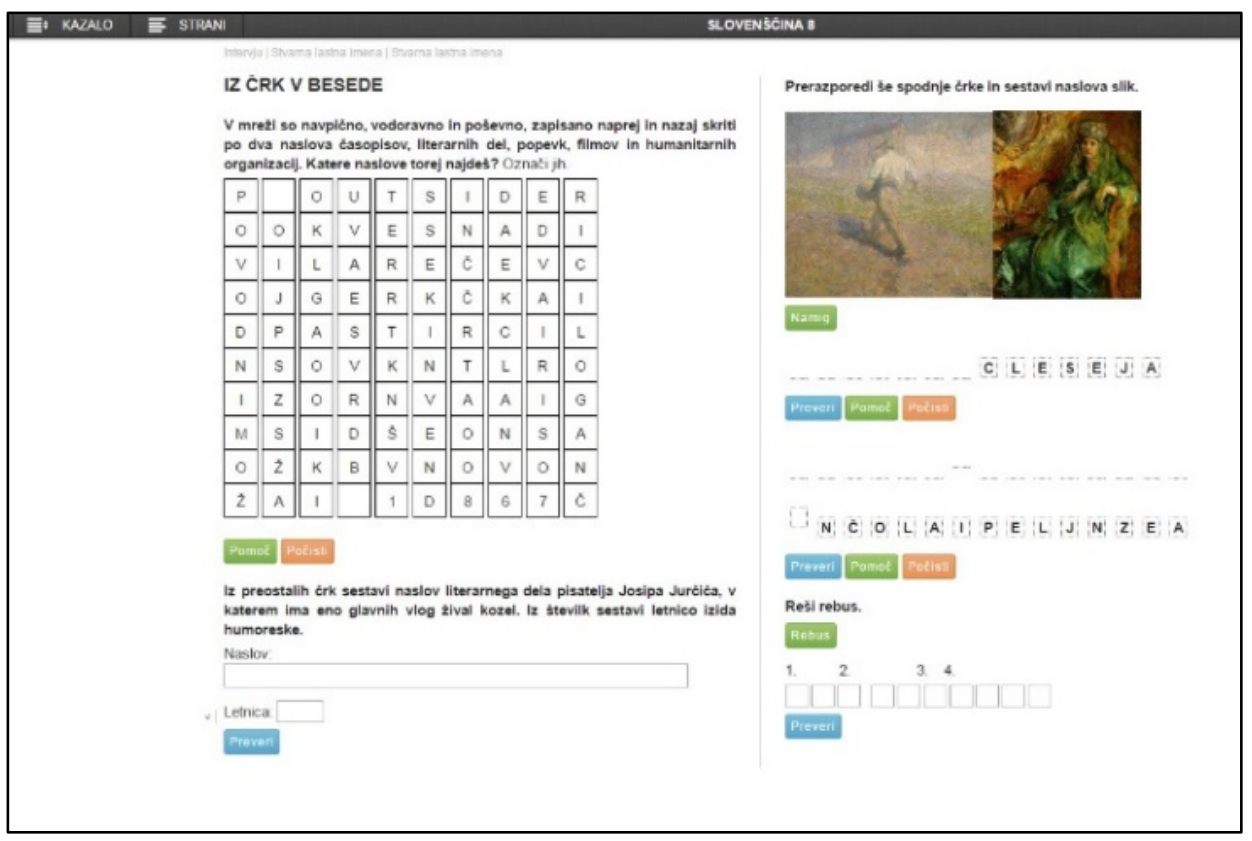

Slika 4: Stran iz i-učbenika

(vir: https://eucbeniki.sio.si/slo8/2297/index.html, str. 50)

Berilo iz leta 1976 je oblikovano kot zbirka besedil, ki so jim dodana umetniška dela (reprodukcije likovnih del umetnikov, tudi Grohar in Jakopič). Vsa dela so predstavljena z osnovnimi podatki in kratko analizo (slika 5, slika 6). Ob koncu berila je celo zapisano, kdo je avtor izbora del (Marijan Tršar, akademski slikar, in dr. Helena Berce Golob). 


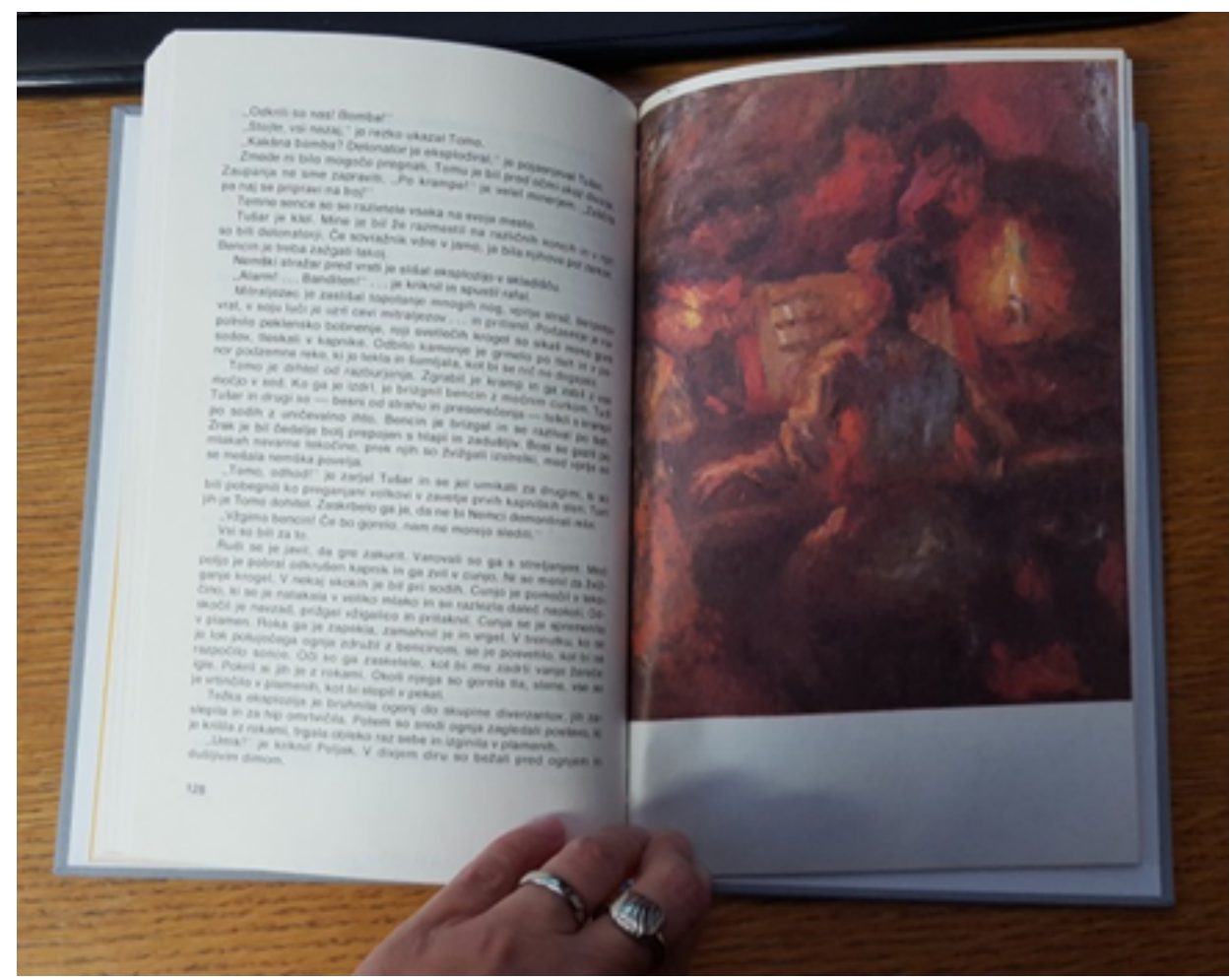

Slika 5: Drevo iz zemlje rase $(1976: 128,129)$

Rihard Jakopič (1869-1943): „Pri klavirju« (olje, 1907, Mestni muzej v Ljubljani)

$V$ tej zgodnji impresionistični dobi svojega slikarstva se je Jakopič posvečal slikanju krajin in študiju različnih svetlob, ki osvetljujejo predmete in figure $v$ notranjščinah. Oblike teles še ni do kraja razkrojil, kot si je to drznil v svojem kasnejšem slikarstvu, je pa že zmehčal njihove obrise do take mere, da se skoraj neopazno zgubljajo $v$ barvni polmrak. Slika „Pri klavirju« je ena od študij takih wfigur $v$ notranjščini«. Slikar je dostikrat $v$ enakem ali podobnem prizoru poskušal različne barvne sestave, raziskoval učinke svetlob, dnevne ali umetne luči petrolejk. Zavoljo bogastva in izrazne moči barvnih odtekov uvrščamo Jakopiča med mojstre barve - ali kakor pravimo $s$ tujo besedo - med izrazite koloriste.

Slika 6: Drevo iz zemlje rase (1976: 130) 
Oba primera sta podana za ilustracijo spremembe v odnosu do podajanja vizualnih informacij, $v$ tem primeru še posebej do likovne umetnosti pri snovanju učnih gradiv.

Multimodalnost lahko v sodobnem času zasledimo tudi znotraj polja literature, predvsem tiste, ki je izdana $\mathrm{v}$ digitalni obliki. Opazimo lahko naslednje elemente: nenavadne postavitve besedila in oblikovanje strani; besedilo je oblikovano tako, da prikazuje neko podobo; raznolika tipografija; vizualno gradivo, kot so risbe in fotografije; uporaba barve, elementi premičnih knjig, posebni vizualni učinki (npr. izrezek iz časopisa) (Gibbons 2012, v Gibbons in Whiteley 2018).

Posebej zanimive so razlike med monomodalnim in multimodalnim romanom, ki, kot pravi Hallet (2009, v Gibbons in Whiteley 2018), temeljijo na konceptualnih premikih:

- pisatelj se od pisanja obrača k oblikovanju, saj v besedila vključuje različne semiotične vire (besede, slike, barve, postavitve);

- od ustvarjanja monomodalnega besedila se premika na polje ustvarjanja multimodalnega besedila; od pripovedovalca do pripovedovalca predstavitelja, saj zgodbe ne podaja več samo z besedami;

- od branja $\mathrm{k}$ transmodalni konstrukciji pomena, saj mora bralec pomen razbrati iz različnih kodov sporočanja;

- od bralca do uporabnika, saj običajno branje besedila ne zadošča, ampak branje vključuje določene druge dejavnosti bralca (npr. premikanj po vsebini).

Glede na zgoraj navedeno se zastavlja vprašanje, kako v šolskem prostoru razvijati sposobnost učencev za razbiranje pomenov iz multimodalnih besedil oziroma kako razvijati multimodalno pismenost. Najpogosteje gre $\mathrm{v}$ šolskem prostoru za tiskana multimodalna besedila, ki jih, kot ugotavlja Serafini (2014), sestavljajo trije osnovni elementi tiskanih multimodalnih celot: besedilo, vizualne podobe (fotografije, risbe, slike, grafi, tabele) in oblikovanje (robovi, tipografija, drugi grafični elementi). 
Serafini (2014) je zasnoval ogrodje, s pomočjo katerega učitelji v treh fazah pomagajo učencem pri delu z multimodalnim besedilom, in sicer: faza izpostavljanja, faza raziskovanja in faza oblikovanja multimodalnega besedila. Zasnova ogrodja omogoča postopno prenašanje odgovornosti z učitelja na učenca, ki skozi učni proces pridobiva izkušnje za delo z različnimi multimodalnimi celotami oziroma multimodalnimi besedili (Serafini 2014).

Potek posameznih faz pridobivanja izkušenj z branjem multimodalnih besedil (Serafini 2014):

- Prva faza je namenjena temu, da si učenci ogledajo veliko različnih multimodalnih besedil oziroma celot. Ta faza predstavlja pomembno osnovo za naslednjo fazo.

- Druga faza je namenjena raziskovanju posameznih elementov. Prvi del te faze se nanaša na spoznavanje osnovnih pojmov in terminologije. Npr. usvajanje besedišča za analizo slikanice se nanaša na pojme, kot so naslovnica, vezni listi, notranja naslovnica, besedilo, elementi likovnega jezika, kompozicija, fokus, zorni kot itd.

- Zadnja faza je namenjena temu, da učenci s pomočjo učitelja (pomoč se nanaša predvsem na uporabo manj znanih orodij) oblikujejo svoje multimodalno besedilo z upoštevanjem elementov, ki so jih spoznali. Učenci sprejemajo odločitve glede vsebine, dizajna, razmišljajo tudi o naslovniku (publiki, ki ji je to multimodalno besedilo namenjeno) in o namenu svojega multimodalnega besedila.

Najpogostejša oblika multimodalnega besedila, $\mathrm{v}$ katerem se tesno prepletata jezikovni in vizualni kod sporočanja, so slikanice. Slikanice so multimodalne knjige, za katere sta značilna najmanj dva koda sporočanja, to sta besedni in vizualni kod. Slikanice imajo tri glavne sestavine, in sicer »besedilo, ilustracije in vsebinskooblikovni odnos med besedilom in ilustracijo« (Haramija in Batič 2013: 23). Vsebinski odnos med besedilom in ilustracijo imenujemo interakcija. Nikolajeva (2003) govori o treh glavnih vrstah interakcije med besedilom in ilustracijami, in sicer o simetrični (informacije $\mathrm{v}$ ilustraciji in besedilu se ponovijo), komplementarni (informacije se dopolnjujejo) in stopnjevalni (slike presegajo besedilo ali obratno) interakciji. Zato so še posebej primerne za razvijanje multimodalne pismenosti v vrtcih in nižjih razredih osnovne šole. Hkrati pa lahko iz modela, ki ga je zasnovala Jane Doonan (1993) in prilagodila starejšim učencem (dvanajst in štirinajst let), 
razberemo, da so slikanice primeren pripomoček za razvijanje multimodalne pismenosti tudi pri starejših učencih.

Model branja slikanic pri starejših učencih (Doonan 1993):

- Prva faza se nanaša na seznanjanje. Učence seznanimo s tem, da bodo v naslednjih tednih spoznavali slikanice. Namen bo raziskovanje, kako slike in besede ustvarjajo zgodbo. Učencem ponudimo škatlo slikanic (število slikanic je večje od števila učencev) in jim damo možnost, da si samostojno ogledujejo slikanice.

- Druga faza se nanaša na pogovor o različnih kodih sporočanja. Učenci se učijo spoštovanja obeh kodov sporočanja, verbalnega in vizualnega. Učenci razumejo, da se gledanje slik razlikuje od govorjenja o slikah, da se pri pogovoru o slikah nekatere informacije izgubijo. Spoznajo tudi, da opazovanje slik spodbuja čustvene odzive, ki vplivajo na miselne procese. V tej fazi si učenci izmenjujejo slikanice.

- Tretja faza je namenjena seznanjanju z besednjakom (platnica, vezni listi, naslovna stran, velikost, format) ob ogledovanju slikanic.

- Četrta faza je vizualno raziskovanje. V tej fazi učenci spoznavajo značilnosti likovnih materialov (npr. tuš, akvarel, svinčnik, kolaž) in likovnih elementov (npr. črta, barva). Vsak učenec ima pred seboj svojo izbrano slikanico, ki jo raziskuje do sedme faze.

- Peta faza je nadaljevanje vizualnega raziskovanja. Raziskovanje se nanaša na kompozicijo in odnose med likovnimi elementi, na zorni kot in fokus.

- Šesta faza pomeni raziskovanje odnosa med besedami in slikami, in sicer učenci raziskujejo, kako jih besede usmerjajo pri interpretaciji slike in obratno.

- Sedma faza je branje slikanice, pri čemer je treba uzavestiti razliko med hitrostjo branja besedila in branja slik. Zgodbo, ki jo ponuja besedilo, lahko preberemo v nekaj minutah, zgodbe, ki jih skrivajo ilustracije, pa se razkrivajo opazovalcu dlje časa in $\mathrm{z}$ vsakim ponovnim ogledovanjem ilustracij.

- V osmi fazi učenci pišejo o slikanici (lahko o slikanici, ki so jo spoznavali, ali kakšni novi). Učenci preberejo slikanico, najprej besedilo, nato pa zelo natančno še ilustracije (barva, ponavljanje oblik, postavitev besedila in 
ilustracij itd.). V tej fazi učenci raziskujejo odnos med besedilom in ilustracijo.

Na osnovi modelov, ki jih podajata Serafini (2014) in Doonan (1993), smo za analizo leposlovnih del pripravili tabelo (tabela 2), v kateri je razvidno, kateri podatki so pomembni, da bi v izobraževalnem prostoru lahko celostno analizirali slikaniška gradiva; način analize je uporaben tudi za ilustrirane knjige (čeprav v njih ilustracija ne razvije svoje zgodbe, temveč le dopolnjuje ali osvetljuje ključne dogodke). Pozornost velja nameniti zlasti ilustracijam, saj analiza besedila ostaja v okviru istega koda sporočanja, analiza ilustracij pa iz likovnega koda prehaja v jezikovni kod. Multimodalna analiza slikanic ima interdisciplinarno naravo, saj gre za tesno povezavo književnosti in likovne umetnosti oziroma $\mathrm{v}$ izobraževalnem prostoru medpredmetno povezavo slovenščine (oziroma jezika) in likovne umetnosti.

Tabela 2: Osnovni podatki o slikanici, analiza parabesedila (naslovnica, vezni listi, notranja naslovnica) in oblikovnega odnosa med besedilom in ilustracijami

\begin{tabular}{|l|}
\hline Naslov slikanice, leto izdaje, založba: \\
\hline Avtor besedila: \\
\hline Avtor ilustracij: \\
\hline Naslovnica: \\
\hline Vezni listi: \\
\hline Notranja naslovnica: \\
\hline Oblikovni odnos med besedilom in ilustracijami: \\
\hline
\end{tabular}

Po oblikovni analizi sledi še vsebinska analiza slikanice (tabela 3), ki poda razmerje med tem, kaj je napisano $\mathrm{v}$ besedilu in kaj $\mathrm{v}$ ilustracijah. Kadar ima slikanica ilustracijo na posamezni strani, je to enota analize, če pa je ilustracija dvostranska, jemljemo to kot enoto.

Tabela 3: Besedilo in ilustracije v izbrani slikanici

\begin{tabular}{|l|l|l|}
\hline & Besedilo & Ilustracije \\
\hline 1 & $\begin{array}{l}\text { Kratka vsebina. Pozorni smo zlasti na } \\
\text { elemente, ki niso ilustrirani. }\end{array}$ & $\begin{array}{l}\text { Kaj je upodobljeno in kako. Pozorni } \\
\text { smo zlasti na elemente, ki v besedilu } \\
\text { niso omenjeni. }\end{array}$ \\
\hline
\end{tabular}


Temu sledi sumativna analiza, in sicer kako besedilo in ilustracija skupaj podata informacije o književnem času, prostoru, literarnih likih itd. (tabela 4).

Tabela 4: Vsebinski odnos med besedilom in ilustracijami (pomen, ki ga ustvarita besedilo in ilustracija skupaj)

\begin{tabular}{|l|l|}
\hline Književni čas & \\
\hline Književni prostor & \\
\hline Literarni liki & \\
\hline Razpoloženje & \\
\hline Intraikonično besedilo & \\
\hline$\ldots$ & \\
\hline$\ldots$ & \\
\hline
\end{tabular}

V tabeli dodajamo tiste sestavine, ki so za posamezno slikanico pomembne.

\section{$4 \quad$ Analiza primerov $\mathrm{z}$ vidika razumevanja koncepta bralnega gradiva}

V predhodnih študijah, ki sva jih opravili Haramija in Batič, se je pokazalo, da se princip multimodalnosti zlahka pokaže v primerjalni analizi pri tistih slikanicah, ki imajo is to besedilo in so ga ilustrirali različni ilustratorji, npr. v Poetiki slikanice (2013):

- slikanice Juri Muri v Afriki Toneta Pavčka z ilustracijami Melite Vovk (1958), Marjance Jemec Božič (1988), Damijana Stepančiča (2012),

- slikanice Pekarna Mišmaš Svetlane Makarovič z ilustracijami Marije Lucije Stupica (1974), Gorazda Vahna (1997) in Kostje Gatnika (2011) (Haramija in Batič 2013: 124-138).

V prispevku Životinje u Ogledalcu (2020, v tisku) gre za analizo klasične živalske pravljice Grigora Viteza z ilustracijami Danice Rusjan (1965), Marjana Mančka (1990) in Tomislava Torjanca (2016).

V vseh multimodalnih analizah se kaže, da ilustracije vplivajo na razumevanje zgodbe in (vsaj delno) spreminjajo ali natančneje predstavljajo temeljne morfološke lastnosti besedil: književni čas, književni prostor, literarne like ipd. Najbolj transparentno je vplivanje različnih kodov sporočanja pri zgoraj navedenih primerih (isto besedilo, različni ilustratorji), ko vsaka slikanica isti literarni lik, predmet, prostor itd. prikaže drugače. 
Druga varianta, ki pa se pojavlja še bolj redko, je možnost, da avtor sam prezentira isto temo (ne istega besedila!) na dva načina. Kot primer analize predstavljamo avtorski slikanici Trije mucki in zmaj (2011) in Tri muce in żmaj (2020) Manice K. Musil (slika 7). Avtorica je živalsko pravljico z isto temo predstavila na način klasične in postmoderne slikanice.
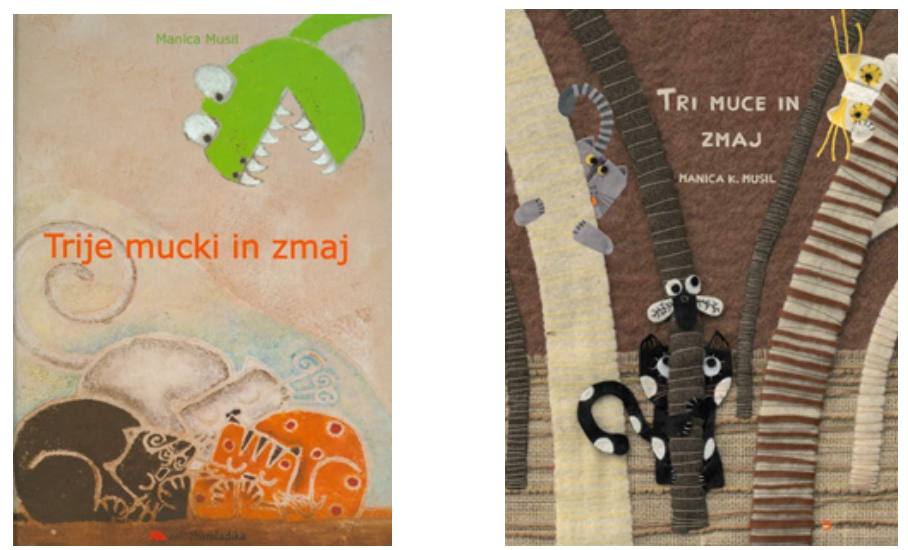

Slika 7: Naslovnici Trije mucki in zmaj (Manica K. Musil 2011) ter Tri muce in zmaj (Manica K. Musil 2020) (objavljeno z dovoljenjem avtorice)

Trije mucki in zmaj (2011) je klasična živalska pravljica, v kateri so naslovni liki hkrati tudi glavni literarni liki. Dogajalni prostor je Zeleno Polje, prebivališče različnih živali (omenjeni so mravlja, krt, žolna, pajek), ki so predstavljene antropomorfno, njihova bivališča so opisana kot hiše ljudi, izjema so podzemni rovi, ki ta prebivališča povezujejo, da se lahko skrijejo v rove pred zmajem. Mačji mladiči Sivko, Belka in Pikec nastopajo v zgodbi kot kolektivni literarni lik, vzrok njihovega odhoda iz varnega doma je iskanje mame, ki naj bi jo odnesel zmaj. Mladiči so edini prebivalci Zelenega Polja, ki se soočijo z zmajem, za katerega velja, da je hudoben in prebivalcem nenehno škoduje, še več: ti ves čas pred zmajem trepetajo za svoja življenja. Čarobni element je podzemna dvorana 'zdaj zunaj, zdaj notri', ki mačje mladiče prestavi s podzemnih rovov na travnik. Tako Sivko, Belka in Pikec najdejo zmaja oziroma on njih, nato se zgodi nepričakovan obrat - zmaj se zjoče in jim pravi: »Osamljen sem, mucki! Grd sem, strašen, zato se me vsi bojijo! Nobenega prijatelja nimam!« (Musil 2011: 20) Mački zmaju najprej ne verjamejo, naučeni so na nezaupanje, ko pa ugotovijo, da zmaj ni krivec za izginjanje sovaščanov, povedo vsem prebivalcem, naj se zmaja ne bojijo. Zmaj pomaga $v$ neštetih rovih poiskati prebivalce Zelenega Polja, vsi prebivalci pa si obljubijo, da se bodo o čemer koli 
najprej prepričali in nikoli več ne bodo nikogar takoj obsojali in s tem povzročali krivice. Klasična slikanica ima besedilo postavljeno na velike enobarvne ploskve, posamezna ilustracija sega čez dve strani. Literarni liki in književni prostor so upodobljeni shematizirano, interakcija med besedilom in ilustracijo je šibka.

V slikanici Tri muce in $\boldsymbol{z} m \boldsymbol{m a j}$ (2020) je Manica K. Musil ohranila temeljno idejo, ki pa je izpeljana drugače. V ilustracijah je predstavljenih več likov kot $\mathrm{v}$ izhodiščnem besedilu, prostori na ilustracijah so natančno definirani.

Slikanici (tabela 5) se razlikujeta po likovnem izrazu in oblikovanju, saj gre za razliko v likovni tehniki, ki jo je uporabila ilustratorka, načinu in veščini oblikovanja likov, postavitve prostora, količini domiselnih podrobnosti ter odnosa med besedilom in ilustracijami. Tri muce in zmaj (2020) so oblikovane iz blaga in s šivanjem. Barvne ploskve ustvarjajo kosi blaga različnih tekstur, ki jih dopolnjujejo črte (šivi, nizi šivov, prepletene niti itd.). Prisotna je skladnost med in vsebino in likovno podobo.

Tabela 5: Analiza slikanic Trije mucki in zmaj(2011) ter Tri muce in zmaj(2020)

\begin{tabular}{|c|c|c|}
\hline & Trije mucki in zmaj (2011) & Tri muce in zmaj (2020) \\
\hline \multicolumn{3}{|c|}{$\begin{array}{l}\text { Analiza parabesedila (naslovmica, verni listi, notranja nasloomica) in oblikornega odnosa med besedilom } \\
\text { in ilustracijami }\end{array}$} \\
\hline $\begin{array}{l}\text { Parabesedilo - } \\
\text { naslovnica }\end{array}$ & $\begin{array}{l}\text { Naslovnica je postavljena tako, da } \\
\text { prikaže tri speče mucke in zmajevo } \\
\text { glavo (predvsem je to ponovitev } \\
\text { informacije, ki jo podaja naslov). }\end{array}$ & $\begin{array}{l}\text { Dinamično zasnovana } \\
\text { kompozicija, upodobljene so tri } \\
\text { muce, ki se skrivajo za drevesi, } \\
\text { dodan je nov lik (muha). }\end{array}$ \\
\hline $\begin{array}{l}\text { Parabesedilo - } \\
\text { vezni listi }\end{array}$ & Vezni listi niso ilustrirani. & $\begin{array}{l}\text { Na prvih in zadnjih veznih listih } \\
\text { je upodobljena muha, ki v } \\
\text { slikanici ustvarja zgodbo v } \\
\text { zgodbi (rešiti se želi pred } \\
\text { pajkom, zato ponudi pomoč pri } \\
\text { lovu na zmaja, ujame zmaja, se } \\
\text { reši pajka). }\end{array}$ \\
\hline $\begin{array}{l}\text { Parabesedilo - } \\
\text { notranja } \\
\text { naslovnica }\end{array}$ & $\begin{array}{l}\text { Na belem ozadju je v spodnjem } \\
\text { delu dodana manjša poenostavljena } \\
\text { ilustracija treh mačk, upodobljenih } \\
\text { z zadnje strani. }\end{array}$ & $\begin{array}{l}\text { Notranja naslovnica je } \\
\text { oblikovana kot dvostranska } \\
\text { ilustracija. Upodobljene so tri } \\
\text { muce s številnimi podrobnostmi, } \\
\text { ki ležijo skupaj (ena ima zaprte } \\
\text { oči, druga ima odprto samo eno } \\
\text { oko, tretja pa s široko odprtimi } \\
\text { očmi pogleduje navzgor). V } \\
\text { zgornjem desnem delu je } \\
\text { upodobljena muha. }\end{array}$ \\
\hline
\end{tabular}




\begin{tabular}{|c|c|c|}
\hline $\begin{array}{l}\text { Oblikovni } \\
\text { vidik }\end{array}$ & $\begin{array}{l}\text { Klasična zasnova slikanice } \\
\text { (obsežno besedilo je vstavljeno na } \\
\text { barvno enovite dele ilustracije). } \\
\text { Tipografija je enotna, spreminja se } \\
\text { barva pisave (npr. temno besedilo } \\
\text { na svetli podlagi in obratno). } \\
\text { Oblikovna zasnova spodbuja } \\
\text { linearno branje. }\end{array}$ & $\begin{array}{l}\text { Postmoderna zasnova slikanice } \\
\text { (besedilo je razporejeno tako, da } \\
\text { je dosežen preplet med } \\
\text { ilustracijo in besedilom). } \\
\text { Tipografija se spreminja glede na } \\
\text { vsebino. S spreminjanjem } \\
\text { velikosti pisave avtorica doseže } \\
\text { razgibanost v oblikovnem in } \\
\text { vsebinskem smislu. }\end{array}$ \\
\hline Besedilo & $\begin{array}{l}\text { Besedilo je strnjeno, nima } \\
\text { preskokov. Časovno zaporedna } \\
\text { zgodba je podana skozi pot treh } \\
\text { muckov, ki iščejo mamo. }\end{array}$ & $\begin{array}{l}\text { V slikanici so različni tipi } \\
\text { besedila: } \\
\text { - Temeljna zgodba, ki je } \\
\text { umeščena na zgornje četrtine } \\
\text { strani. } \\
\text { - Intraikonično besedilo: } \\
\text { a) Notranji monologi živali: npr. } \\
\text { Sivko si misli, da bo ulovil } \\
\text { metulja; krt se sprašuje, ali bo } \\
\text { kdaj v življenju nehal kopati. } \\
\text { b) Dialog med mucki: Belka } \\
\text { vpraša Pikca, ali je dobro spal, ta } \\
\text { pa ji odgovori, da je sanjal o } \\
\text { zmaju. } \\
\text { c) Poimenovanje: ob vsakem } \\
\text { prostoru je navedeno, čemu } \\
\text { služi (npr. otroška soba, } \\
\text { igralnica, bazen, šola, pot). }\end{array}$ \\
\hline \multicolumn{3}{|c|}{ V sebinski odnos med besedilom in ilustracijami (pomen, ki ga ustvarita besedilo in ilustracija skupaj) } \\
\hline $\begin{array}{l}\text { Literarni liki - } \\
\text { tri muce }\end{array}$ & $\begin{array}{l}\text { Trije mucki: v besedilu so } \\
\text { poimenovani Sivko, Belka in Pikec. } \\
\text { V ilustracijah so upodobljeni črna } \\
\text { mačka, bela mačka in oranžna } \\
\text { mačka z rdečimi pikami. }\end{array}$ & $\begin{array}{l}\text { Tri muce: Sivko, Belka in Pikec. } \\
\text { Sivko je siv mucek s progastim } \\
\text { repom, Belka je bela muca z } \\
\text { rumenimi »laski«, Pikec je črn } \\
\text { muc z belimi pikami. Liki so } \\
\text { poimenovani skladno s svojimi } \\
\text { upodobitvami, hkrati pa je ob } \\
\text { ilustracijo dodano intraikonično } \\
\text { besedilo, ki natančno sporoča, } \\
\text { katera muca je upodobljena (npr. } \\
\text { Toje Belka.). }\end{array}$ \\
\hline $\begin{array}{l}\text { Literarni liki - } \\
\text { zmaj }\end{array}$ & $\begin{array}{l}\text { Poenostavljena podoba zmaja, ki se } \\
\text { pojavi enkrat celopostavno, drugič } \\
\text { pa samo zmajeva glava, ki toči } \\
\text { solze. }\end{array}$ & $\begin{array}{l}\text { Zmaj se pojavi v petih } \\
\text { dvostranskih ilustracijah. Prvič je } \\
\text { prikazan v drugi dvostranski } \\
\text { ilustraciji, in sicer tako, kot si ga } \\
\text { vsak muca sama predstavlja (nad } \\
\text { vsako muco je upodobljen v } \\
\text { stripovskem oblačku - zelen } \\
\text { zmaj z rumenimi pikami in } \\
\text { oranžnimi izrastki, dvoglavi }\end{array}$ \\
\hline
\end{tabular}




\begin{tabular}{|c|c|c|}
\hline & & $\begin{array}{l}\text { zmaj, ukročen zmaj z rdečim } \\
\text { jezikom in rumenimi progami). } \\
\text { V dvanajsti dvostranski ilustraciji } \\
\text { vidimo samo zmajeve kremplje, } \\
\text { ki pograbijo tri muce. V trinajsti } \\
\text { dvostranski ilustraciji je } \\
\text { upodobljen čez obe strani, toči } \\
\text { solze, muha ga ima na vajetih. } \\
\text { Nato se pojavi še v dveh } \\
\text { ilustracijah (približan pogled na } \\
\text { zmajevo glavo in celopostavni } \\
\text { prikaz zmaja, ki pleše v krogu z } \\
\text { vsemi novimi prijatelji). }\end{array}$ \\
\hline $\begin{array}{l}\text { Literarni liki - } \\
\text { ostali liki }\end{array}$ & $\begin{array}{l}\text { Krt, pajek in trije majhni pajki, } \\
\text { žolna, pajek, kamenčki. Liki so } \\
\text { oblikovani brez prepoznavnih } \\
\text { podrobnosti, večinoma so } \\
\text { postavljeni na isto ravnino. Njihova } \\
\text { prisotnost ne spreminja besedila. }\end{array}$ & $\begin{array}{l}\text { Muha, krt, metulj, mravlja z } \\
\text { dvema mravljicama, žolna, } \\
\text { kamenčki, pajek in trije majhni } \\
\text { pajki, mama muca. Liki so } \\
\text { oblikovani s številnimi } \\
\text { podrobnostmi, individualnimi } \\
\text { značilnostmi, ki kažejo tudi na } \\
\text { njihov značaj. Postavitev likov je } \\
\text { zelo dinamična, kar potencira } \\
\text { dogajanje in ustvarja napetost. }\end{array}$ \\
\hline $\begin{array}{l}\text { Književni } \\
\text { prostor }\end{array}$ & $\begin{array}{l}\text { Književni prostor je podrobno } \\
\text { opisan v besedilu. V ilustracijah je } \\
\text { prostor nakazan s tremi hišami, } \\
\text { poenostavljenim rovom. O } \\
\text { prostoru iz ilustracij ne dobimo } \\
\text { veliko informacij. }\end{array}$ & $\begin{array}{l}\text { V besedilu je prostor } \\
\text { poimenovan (Na Zelenem Polju } \\
\text { pod visoko goro ...) (slika 8). } \\
\text { Glavno informacijo o prostoru } \\
\text { pa nosijo ilustracije - oštevilčene } \\
\text { hiše različnih oblik in velikosti, } \\
\text { podzemni svet, z različnimi } \\
\text { prostori (otroška soba, igralnica, } \\
\text { bazen ...), zunanji prostor, } \\
\text { gozd, žolnino drevo, notranjost } \\
\text { žolninega drevesa, pajkova } \\
\text { mreža, travnik ... }\end{array}$ \\
\hline Književni čas & $\begin{array}{l}\text { V besedilu je omenjeno jutro, ko } \\
\text { mucki ugotovijo, da ni mame. Nato } \\
\text { lahko predvidevamo, da hodijo ves } \\
\text { dan, zaspijo in naslednji dan se } \\
\text { soočijo z zmajem. Na ilustraciji je } \\
\text { upodobljena luna (noč). }\end{array}$ & $\begin{array}{l}\text { O času sklepamo iz } \\
\text { intraikoničnega besedila, in sicer } \\
\text { iz dialoga med mucki (»Si se } \\
\text { naspal? Sanjal sem o zmaju?«) }\end{array}$ \\
\hline Razpoloženje & $\begin{array}{l}\text { Razpoloženje je v besedilu podano } \\
\text { s podrobnimi opisi razpoloženja } \\
\text { likov (zlasti strahu pred zmajem), } \\
\text { česar pa ilustracije ne podpirajo. }\end{array}$ & $\begin{array}{l}\text { Razpoloženje je podano skozi } \\
\text { preplet besedila in bogatih } \\
\text { ilustracij, ki prikažejo čustveno } \\
\text { stanje likov (solze, začuden } \\
\text { pogled, igrivost, strah ...). }\end{array}$ \\
\hline
\end{tabular}


Obe slikanici se razlikujeta predvsem po načinu sporočanja. V prvem primeru gre, čeprav gre za slikanico, za bolj monomodalna. Osrednji vir informacij je besedilo, ki je zgoščeno in spodbuja linearno branje. Ilustracije so likovno šibkejše in delujejo kot dodatek, ki ga lahko sprejemamo povsem pasivno.

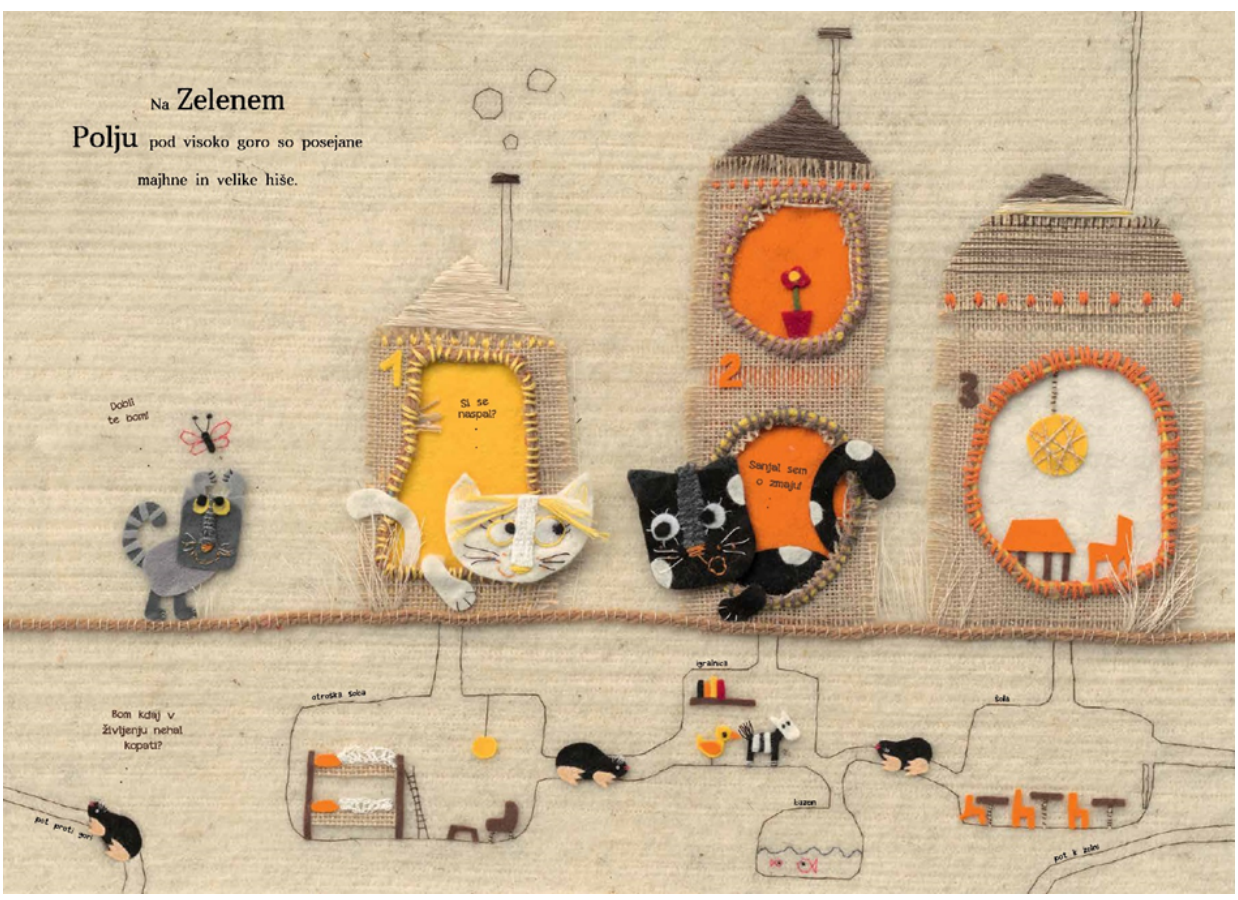

Slika 8: Tri muce in zmaj

(Manica K. Musil 2020) (objavljeno z dovoljenjem avtorice)

Druga slikanica (slika 8) je izrazito multimodalna, saj sporočilo podajata literarni in likovni kod, in sicer tako, da drug drugega dopolnjujeta in sta primerljiva tudi po kakovosti izraza. Slikanica Tri muce in zmaj (2020) podpira:

- Nelinearno, torej izbirno branje. Bralec se mora ves čas odločati, kaj bo prebral in $\mathrm{v}$ kakšnem zaporedju.

- Aktivno opazovanje ilustracij, ki je doseženo s postavitvijo likov, upodobitvijo prostora, številnimi podrobnostmi in tesno pomensko povezavo z vsemi ravnmi besedila.

- Prepoznavanje različnih kodov sporočanja kot enakovrednih virov informacij, ki imajo svoje zakonitosti. Kakovostna likovna podoba slikanice 
torej ni povezana samo s kakovostjo ilustracij, ampak s kakovostjo multimodalnega besedila kot celote. Kakovost ilustracij je namreč odvisna od tega, kako je ilustracija oblikovana (likovna govorica ilustratorja) in kakšne informacije prinaša (kaj je upodobljeno).

V izbranem primeru besedilo ni več le eno besedilo, temveč gre za različne ravni besedil (temeljno besedilo, ki razvija zgodbo + notranji monologi + komentarji ali dialogi likov, ki v temeljnem besedilu sploh niso omenjeni + intraikonično besedilo), ki niso nujno neposredno povezane. Šele vsa besedila skupaj tvorijo besedilno celoto, ta pa vstopa $\mathrm{v}$ odnos z ilustracijo, ki prav tako ni ena sama. Zanimiv je tudi material, ki ga Manica K. Musil uporablja, gre namreč za šivane slikanice iz različnih materialov (avtorica ilustracije šiva!).

\section{$5 \quad$ Sklep}

Pismenost se razvija postopoma, v sodobnem času pa ni dovolj, da otrok razume smer branja, ki je običajna za monomodalna besedila (od leve proti desni, od zgoraj navzdol), saj je večina besedil - literarnih in informativnih - opremljena tudi z ilustrativnim gradivom, kar pa od bralca zahteva izbirni način branja in orientacijo $\mathrm{v}$ bralnem gradivu. Nujno je torej smiselno povezovanje besednega in slikovnega dela $\mathrm{v}$ besedilu, ki smo ga poimenovali celostno branje multimodalnih besedil. Tak princip branja je zelo pogost $\mathrm{v}$ elektronskih medijih (npr. ko iščemo neko temo, odpiramo različne povezave in jih sestavljamo v smiselno celoto). Multimodalna besedila so prisotna pri vseh predmetnih področjih, zato si danes težko predstavljamo katero koli izobraževalno gradivo (učbeniki, delovni zvezki, spletne strani, i-učbeniki), ki bi bilo zasnovano monomodalno. Besedilo je opremljeno s tabelami, grafi, shemami, fotografijami. Dodatne razlage so od glavnega besedila ločene tudi oblikovno (npr. v okvirčkih, odebeljeno ali s spremembo fonta). Za pridobivanje znanja pri katerem koli predmetnem področju je potrebno obvladovanje bralnega gradiva tistega področja. Npr. razumevanje kroženja vode je tesno povezano s sposobnostjo združevanja informacij, ki jih ponuja besedilo $\mathrm{v}$ učbeniku, in informacij, ki jih prinaša pripadajoča shema; razumevanje nekega matematičnega problema besedilne naloge, ki so ji dodani podatki v preglednici, je prav tako povezano s sposobnostjo razbiranja pomena iz najmanj dveh kodov sporočanja. Problem, na katerega želimo opozoriti, pa je potreba po sistematičnem in zavestnem razvijanju multimodalne pismenosti $\mathrm{v}$ izobraževalnem procesu kot 
celote in ne kot spontane dejavnosti, ki je razdrobljena na posamezna predmetna področja.

\section{Opombi}

Avtorica Dragica Haramija je prispevek napisala v okviru projekta OBJEM - Bralna pismenost in razvoj slovenščine (Ozaveščanje, Branje, Jezik, Evalvacija, Modeli), šifra projekta OP20.01462, vodja dr. Sandra Mršnik, ki ga vodi Zavod RS za šolstvo. Naložbo sofinancirata Republika Slovenija in Evropska unija iz Evropskega socialnega sklada.

Avtorica Janja Batič je prispevek napisala v okviru projekta OBJEM - Bralna pismenost in razvoj slovenščine (Ozaveščanje, Branje, Jezik, Evalvacija, Modeli), šifra projekta OP20.01462, vodja dr. Sandra Mršnik, ki ga vodi Zavod RS za šolstvo. Naložbo sofinancirata Republika Slovenija in Evropska unija iz Evropskega socialnega sklada.

\section{Vira}

Manica K. MUSIL, 2011: Trije mucki in ₹maj. Maribor: Založba Pivec.

Manica K. MUSIL, 2020: Tri muce in zmaj. Maribor: Založba Pivec.

\section{Literatura}

John L. DEBES, 1974: Mind, languages, and Literacy. Paper presented at Anual Conventiron of the National Council of techers of English (New Orleans, Lousiana, November 29, 1974).

Jane DOONAN, 1993: Looking at pictures in picture books. Stroud: Thimble Press.

Marijan DOVIĆ, 2004: Sistemske in empirične obravnave literature. Ljubljana: ZRC SAZU (Studia Litteraria).

Drevo iz zemlje rase: berilo za čtrti razred osnovne šle, 1976. Ur. Vladimir Cvetko [et al.]; slikovne priloge sta izbrala Marijan Tršar, Helena Berce - Golobova. Ljubljana: Državna založba Slovenije.

Billie EILAM, 2012: Teaching, Learning, and Visual Literacy: The Dual Role of Visual Representation. New York: Cambridge University Press.

Alison GIBBONS in Sara WHITELEY, 2018: Contemporary Stylistics: Language, Cognition, Interpretation. Edinburgh: Edinburgh University Press. https://www.jstor.org/stable/10.3366/j.ctt1tqx9wz.25

Cary GILLENWATER, 2014: Reading images: The Phenomenon of Intertextuality and How it May Contribute to developing Visual Literacy with Asvanced Placement English/Language Arts Students. Journal of Ethnographic \& Qualitative Research 8(4). 251-263.

Meadow Sherrill GRAHAM in Sheila BENSON, 2010: A Springboard Rather Than a Bridge: Diving into Multimodal Literacy. The English Journal 100(2). 93-97.

Dragica HARAMIJA in Janja BATIČ, 2013: Poetika slikanice. Murska Sobota: Franc-Franc.

Dragica HARAMIJA in Janja BATIČ, 2020: Životinje u Ogledalcu. Kulturna animalistika: interdisciplinarna polazista i tradicijskee prakse. Zagreb: Institut za etnologiju (v tisku).

Denise NEWFIELD, 2011: From visual literacy to critical visual literacy: An analysis of educational materials. English teaching: Practice and Critique 10(1). 81-94.

Sonja PEČJAK in Ana GRADIŠAR, 2015: Bralne ǔne strategije. Ljubljana: Zavod Republike Slovenije za šolstvo.

Frank SERAFINI, 2014: Reading the visual: An introduction to teaching multimodal literacy. New York in London: Teachers college press.

Lawrence R. SIPE, 1998: How Picture Books Work: A Semiotically Framed Theory of text-Picture Relationships. Children's Literature in Education 29(2). 97-108. 


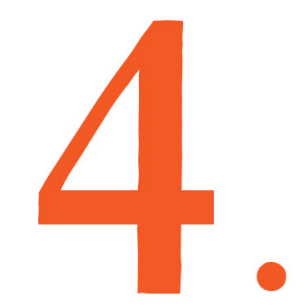

G R A D N I K

\section{GLASOVNO ZAVEDANJE}


${ }^{1}$ Glasovno razločevanje: razločevanje dolžine besed in razločevanje glasov med seboj.

${ }^{2}$ Glasovno razčlenjevanje: členitve povedi na posamezne besede, na posamezne zloge, na posamezne glasove.

\section{Elementi gradnika:}

- glasovno razločevanje ${ }^{1}$

- glasovno razčlenjevanje ${ }^{2}$

- poznavanje in uporaba knjižnega naglasa/knjižne izreke 


\section{GRADNIK:}

\section{GLASOVNO ZAVEDANJE}

\author{
MELITA ZEMLJAK JONTES ${ }^{1}$ IN \\ BARBARA BEDNJIČKI ROŠER ${ }^{2}$ \\ ${ }^{1}$ Univerza v Mariboru, Filozofska fakulteta, Maribor, Slovenija. \\ E-pošta: melita.zemljak@um.si \\ ${ }^{2}$ Vrtec Ivana Glinška Maribor, Maribor, Slovenija. \\ E-pošta: barbara.bednjicki@guest.um.si
}

Povzetek Prispevek predstavlja četrti gradnik bralne pismenosti, tj. glasovno zavedanje, njegovo razvijanje glede na temeljne elemente gradnika (glasovno razločevanje, glasovno razčlenjevanje, poznavanje in uporaba knjižnega naglasa/knjižne izreke) po posameznih stopnjah formalnega izobraževanja in po ravneh, ki napovedujejo uspešnost začetnega opismenjevanja in pozneje boljše bralne zmožnosti otrok in mladostnikov.
Ključne besede: gradniki bralne pismenosti, glasovno zavedanje, izobraževanje, učitelji, medpodročno in medpredmetno povezovanje. 


\title{
THE FOURTH COMPONENT OF READING LITERACY: PHONOLOGICAL AWARENESS
}

\begin{abstract}
Keywords: components of reading literacy, phonological awareness, education, teachers, interdisciplinary and crosscurricular integration.
\end{abstract}

\author{
Melita ZemLjaK JONTES ${ }^{1}$ \& \\ BARBARA BEDNJIČKI ROŠER ${ }^{2}$
}

${ }^{1}$ University of Maribor, Faculty of Arts, Maribor, Slovenija. E-mail: melita.zemljak@um.si

${ }^{2}$ Kindergarten Ivan Glinšek Maribor, Maribor, Slovenija. E-mail: barbara.bednjicki@guest.um.si

Abstract The chapter represents the fourth component of reading literacy, i.e. phonological awareness, its development according to the basic elements of the component (sound recognition, sound division, knowledge and use of literary accent/literary expression) by individual levels of formal education and by levels that predict the success of initial literacy and later on better reading skills of children and youth.

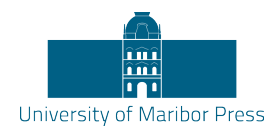




\section{$1 \quad$ Glasovno zavedanje}

Fonološko oziroma glasovno zavedanje (angl. phonological awareness) ${ }^{1}$ je ena od ravni jezikovnega zavedanja in ima $\mathrm{v}$ abecednem sistemu pisave osrednjo vlogo pri učenju branja in pisanja. V strokovni literaturi je opredeljeno kot zavedanje odnosa med tiskano besedo in njeno reprezentacijo (Jelenc 1997: 293) ter zajema splošno zavest o našem govorjenem jeziku. Barrus Smith, Simmons in Kameenui (1995, v Zorman 2013: 38) ga opredeljujejo kot občutljivost za glasovno strukturo jezika in zavestno sposobnost razločevanja, združevanja in upravljanja glasovnih enot različnih velikosti. Pečjak (2004: 10) k sposobnostim glasovnega zaznavanja prišteva sposobnost glasovnega razločevanja, sposobnost glasovnega razčlenjevanja in sposobnost rimanja. Ključni element glasovnega zavedanja pa poleg glasovnega razločevanja (razločevanja dolžine besed in razločevanja glasov med seboj), glasovnega razčlenjevanja (členitve povedi na posamezne besede, posamezne zloge in na posamezne glasove) predstavljata tudi poznavanje in uporaba knjižnega naglasa ter knjižne izreke. Raziskovalcem glasovnega zavedanja je vendarle skupno razmišljanje, da je glasovno zavedanje - metajezikovna sposobnost glasovnega procesiranja jezika - enovita delna spretnost branja in pisanja, ki se kaže in jo je treba razvijati na vseh strokovnih področjih, ne zgolj na področju (slovenskega) jezika, in na vseh ravneh izobraževanja. Sestavljena je iz različnih ravni, ki so hierarhično razporejene glede na zahtevnost miselne operacije, potrebne za njihovo izvedbo. Posamezne ravni se kronološko razvijajo in so pogojene z miselnim razvojem otrok.

\section{$2 \quad$ Ravni glasovnega zavedanja}

Govorni razvoj otroka v predšolski dobi pomembno vpliva na celostni govorni razvoj otroka tudi $\mathrm{v}$ šolskem obdobju in se kaže $\mathrm{v}$ samem usvajanju ter razvijanju sporazumevalne zmožnosti posameznika. Gre za t. i. komunikacijski pristop k usvajanju jezika (Vogel 2015: 177, po Skela 2005; Skela 2010) z besedilom kot izhodiščem in s sporazumevalno dejavnostjo kot osnovno, ključno metodo dela s temeljnim ciljem vzgojiti čim bolj učinkovitega uporabnika jezika.

${ }^{1}$ Zorman (2013: 38). 
O pomenu sporazumevalne zmožnosti v slovenskem izobraževalnem sistemu pišejo didaktiki slovenskega jezika in/ali književnosti že v osemdesetih letih 20. stoletja in kasneje. Tako razmišljajo npr. Kunst Gnamuš (npr. 1984, 1991, 1992), Lipnik (npr. 1994a, 1994b), Lipnik in Matić (npr. 1993), Krakar Vogel (npr. 2004), Križaj Ortar (npr. 2010), Zadravec Pešec (npr. 1994), Pulko (npr. 2007: 36-37).

Komunikacijska didaktika raziskuje (Kunst Gnamuš 1992: 7) »oblike govorne dejavnosti pri pouku, njihovo spoznavno zgradbo in družbene predpostavke ter na tej podlagi sklepa o vzgojno-izobraževalnih učinkih, ki jih ima sporazumevanje na mišljenje, hotenje, čustvovanje in ravnanje udeležencev sporazumevanja«. Temelj komunikacijske didaktike predstavlja dialoška oziroma interakcijska teorija pomena (Kunst Gnamuš 1992: 8), iz česar izhaja predstavitev drugačnega pogleda na pouk (slovenščine) (Križaj Ortar, Bešter in Kržišnik 1994). Načine razvijanja sporazumevalne zmožnosti $\mathrm{v}$ šolskem sistemu in pomen te $\mathrm{pa} \mathrm{v}$ več delih izpostavi in natančno predstavi tudi Pulko (npr. 2007: 36-37).

Bešter Turk (2011: 127) postavlja razvijanje sporazumevalne zmožnosti v slovenskem jeziku kot enega izmed temeljnih ciljev predmeta slovenščina na vseh stopnjah obveznega izobraževanja. Avtorica poudarja, da je $v$ šoli slovenščina predvsem tudi učni jezik in ne zgolj učni predmet, da (Bešter Turk 2011: 127) »učenci $\mathrm{v}$ šoli ne razvijajo sporazumevalne zmožnosti samo pri predmetu slovenščina, temveč tudi (oz. bi jo morali) pri vseh drugih predmetih /.../, zato se lahko vprašamo, ali se načrtovalci pouka drugih predmetov, učitelji teh predmetov in avtorji učnih gradiv zanje sploh zavedajo vloge, ki jo imajo pri razvijanju sporazumevalne zmožnosti učencev«.

Skleniti je mogoče, da je razvijanje sporazumevalne zmožnosti v slovenskem jeziku pomembno na vseh ravneh izobraževanja (od vrtca do univerzitetne stopnje) in ne glede na njegovo predmetno področje.

V predšolskem obdobju in še v 1 . VIO sta ključna elementa razvijanja glasovnega zavedanja glasovno razločevanje in glasovno razčlenjevanje, medtem ko se $\mathrm{v}$ nadaljnjem izobraževanju poudarja predvsem razlikovanje med knjižno in neknjižno izreko: v 2. VIO je izpostavljeno spoznavanje razlik med knjižnimi in neknjižnimi naglasi, v 3. VIO ter v srednješolskem izobraževanju pa ločevanje in razumevanje razlik med knjižnimi in neknjižnimi naglasi ter zmožnost uporabe knjižnega naglasa oziroma knjižne izreke. 
Za razvoj sposobnosti glasovnega zavedanja je pomemben razvoj slušnega zavedanja, predvsem razločujoče poslušanje, ki predstavlja temelj vsem drugim vrstam poslušanja in je osnova pri pridobivanju jezikovnih sposobnosti (Brumen 2012). Poslušanje (Pečjak 2009: 15) je prva komunikacijska dejavnost, s katero se otroci srečajo, spoznavajo svet okoli sebe, se učijo maternega jezika. V predšolskem obdobju pedagoški delavci v vrtcih razločujoče poslušanje spodbujajo z enostavnimi vajami zaznavanja in prepoznavanja različnih zvokov ${ }^{2} \mathrm{v}$ obliki iger. $\mathrm{Na}$ voljo so številni didaktični materiali in igre, ki jih lahko izdelamo tudi sami po priporočilih strokovnjakov (Bucik 2009; Grginič 2008, 2009; Pečjak 2003 idr.) in z njimi otrokom omogočamo igriv, sproščen in zabaven razvoj spretnosti oziroma sposobnosti glasovnega zavedanja oziroma načrtno in sistematično uzaveščamo različne načine členjenja vezane govorice na manjše dele ter manipulacije $\mathrm{z}$ njimi pri učencih $\mathrm{v} 1$. VIO. Chard in Dickson (1999, v Zorman 2013: 40-42) sta opredelila pet ravni glasovnega zavedanja: (1) rime, (2) členjenje povedi, (3) členjenje in spajanje zlogov, (4) členjenje in spajanje začetkov in koncev, (5) členjenje in spajanje posamičnih fonemov. Čok in Brčaninović (2015) ravni fonološkega zavedanja dopolnita, od najenostavnejše - (1) zavedanje o dolžini besed; (2) zaznavanje in tvorjenje rim ter aliteracij; 3 (3) členjenje povedi na besede; (4) zlogovno zavedanje (zlogovanje in združevanje zlogov v besedo); (5) zavedanje o začetkih in koncih besed (deljenje besed na začetke in konce, združevanje začetkov in koncev v besedo, tvorjenje besed s podanimi začetki in/ali konci); do najvišje, najzahtevnejše - (6) fonemično zavedanje, ki vključuje prepoznavanje (identifikacijo glasov) v glasovni verigi; manipuliranje glasov (npr. opuščanje/redukcija, dodajanje/adicija ali nadomeščanje/substitucija glasov); členjenje/segmentacija glasovne verige na glasove in spajanje glasov $\mathrm{v}$ besede.

\footnotetext{
${ }^{2}$ Za zaznavanje in prepoznavanje različnih zvokov so na voljo številna didaktična gradiva, didaktične igre - namizni zvončki, zvoki čustev, živali na kmetiji, zvočne cevi, lesene zvočne prizme in valjčki idr. Dostop http://sccompas.si/files/2017/11/Seznam-pripomo\%C4\%8Dkov.pdf.

${ }^{3}$ Rima (polni stik) je glasovna figura, kjer se ujemajo končni samoglasniki in soglasniki v besedah (pravljica - mravljica; knjiga - figa; zvonec - lonec); aliteracija (soglasniški stik) je glasovna figura ujemanja začetnih črk besed (krokodil Karel korajžno koraka; riba reže raci rep ...) (Povzeto po Kos (2001); lastni primeri.).
} 


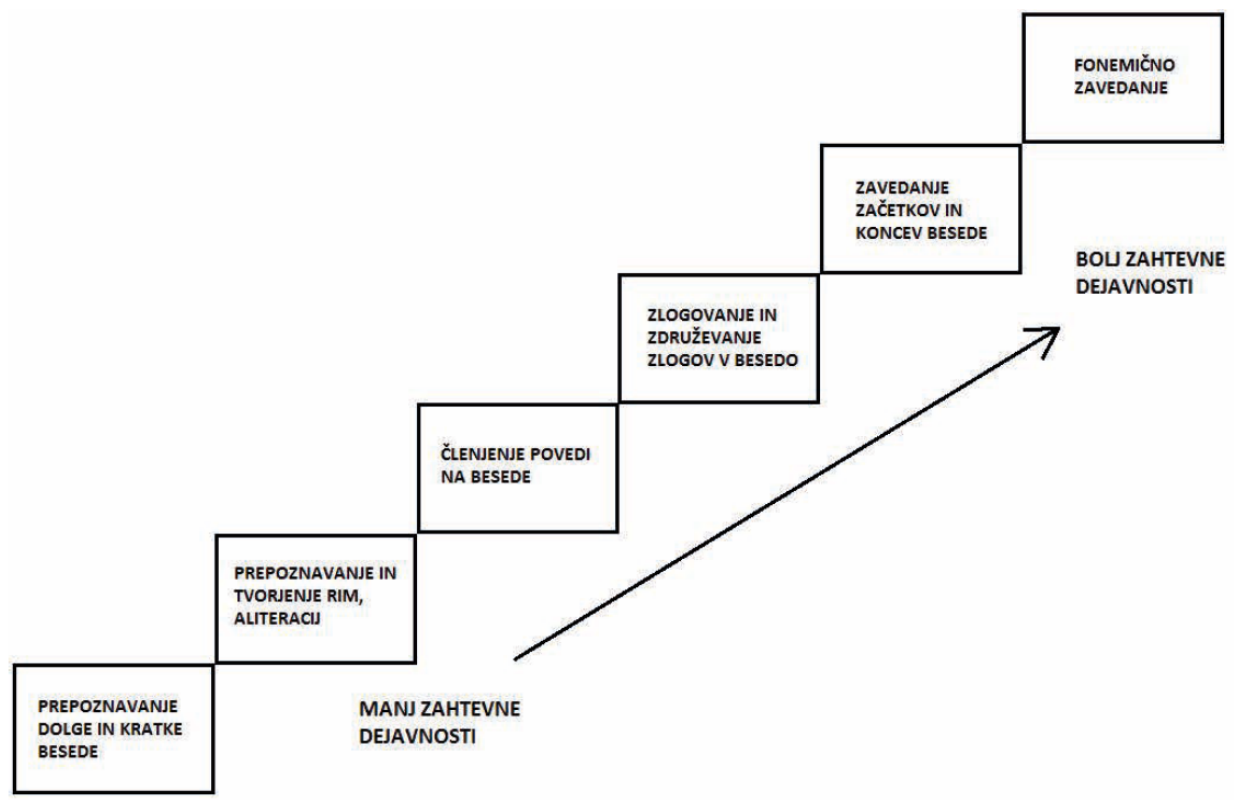

Slika 1: Razvijanje sposobnosti glasovnega zavedanja

(Čok in Brčaninović 2015: 153)

Sposobnosti fonološkega zavedanja se razvijajo postopoma v zaporedju od največjih glasovnih enot (besede, zlogi) do najmanjših, zahtevnejših (glasovi). Pečjak (2004: 10-11) navaja, da sistematično urjenje glasovnega zavedanja vpliva na boljše bralne spretnosti učencev $\mathrm{v} 2$. in 3. VIO, če treninge urjenja pričnemo dovolj zgodaj. ${ }^{4}$ Sposobnosti glasovnega zaznavanja pomembno napovedujejo tudi uspešnost pričetka opismenjevanja oziroma so celo pogoj zanj. Pečjak $(2004,2009) \mathrm{k}$ sposobnostim glasovnega razločevanja oziroma fonemske diskriminacije prišteva (1) razločevanje dolžine besed, kjer otroci primerjajo pare različno dolgih besed ${ }^{5}$ in povedo, katera je daljša, ter (2) razločevanje glasov med seboj, kar se pri otrocih intenzivno razvija od tretjega leta. Razločevanje posameznih glasov lahko urimo v dvojicah in/ali posamezni glas razločujemo $\mathrm{v}$ nizu glasov, kjer smo posebej pozorni na razločevanje glasov, ki so si akustično podobni $(b-p, d-t, g-k \ldots)$. Sposobnosti glasovnega razčlenjevanja ali fonemske segmentacije (Pečjak 2004: 11) zajemajo sposobnosti otrok za razčlenitev (1) povedi na posamezne besede, (2) besede na posamezne zloge - zlogovanje in (3) besede na posamezne glasove - glaskovanje. $\mathrm{H}$

\footnotetext{
${ }^{4} \mathrm{~V}$ obdobju porajajoče se pismenosti, torej v predšolskem obdobju.

${ }^{5} \mathrm{Npr}$. sok-telovadnica, nit-nabrbtnik.
} 
glasovnemu zaznavanju Pečjak (2004: 10-11) prišteva tudi sposobnost rimanja, saj sposobnosti otrok, da slišani besedi poiščejo rimo, napovedujejo uspešnejši razvoj slušnega razločevanja in razčlenjevanja besed ter pozneje boljše bralne zmožnosti otrok, kar je Liberman (Zrimšek 2003: 79) v svoji raziskavi potrdila že leta 1973. Glasovno zavedanje je med sedem najpomembnejših elementov porajajoče se pismenosti ${ }^{6}$ uvrstila tudi Jurišič, zato pedagoški delavci v vrtcu pripravljajo raznolike dejavnosti in didaktične igre (Bednjički Rošer 2017), ki pomenijo dobro pripravo otroka na sistematično opismenjevanje.

K razvijanju glasovnega zavedanja zelo pripomorejo tudi informativne in leposlovne slikanice, ki so posebne oblike knjig, multimodalna dela (Haramija in Batič 2013: 9, 23), ki v enovito celoto združujejo besedilo in ilustracijo. Slikanice spodbujajo ustvarjalnost in jezik, otrokom predstavijo osnovno strukturo zgodbe ter interakcijo med besedo in podobo. Zeece (2006) piše, da ima glasovno zavedanje ključni pomen za razvijanje bralnih spretnosti in navaja primere petnajstih tujih kakovostnih slikanic, $\mathrm{s}$ katerimi otrokom na sproščen in interaktiven način omogočamo vstop $\mathrm{v}$ svet branja in s participacijo krepimo njihove glasovne sposobnosti ob in po branju. V slovenskem prostoru imajo pedagoški delavci na voljo številne kakovostne slikanice, ki so v predšolskem in zgodnjem šolskem obdobju najprimernejša oblika knjige. Odličen pripomoček za slušno razlikovanje glasov in govorno-jezikovni razvoj je tudi serija dvanajstih zvočnih logopedskih pravljic, ${ }^{7}$ ki jih je v sodelovanju z logopedinjo Moniko Rataj napisala slovenska mladinska pisateljica Nina Mav Hrovat.

\section{Glasovno zavedanje v učnih načrtih}

Glasovno zavedanje je sistematično zajeto $\mathrm{v}$ učne načrte formalnega izobraževalnega sistema, in sicer kot splošni cilji pri vseh dejavnostih na vseh kurikularnih področjih ter kot specifični cilji na področju jezika v predšolskem izobraževanju, v osnovnoin srednješolskem izobraževanju pa $\mathrm{v}$ okviru učnih načrtov različnih predmetnih področij, še posebej izpostavljeno pa je za področje slovenščine.

\footnotetext{
${ }^{6}$ Elementi porajajoče se pismenosti pri slovenskih predšolskih otrocih so zaznavanje in prepoznavanje tiska iz okolja, spoznavanje s črkami, razgovorno branje, razumevanje vloge tiska, razumevanje navodil, glasovno zavedanje in računalniško opismenjevanje.

${ }^{7}$ Logopedske pravljice. https:/ /www.lahkonocnice.si/na-obisku/logopedske pravljice?gclid=EAIaIQobChMIg8H47YT_6QIVuIBQBh0HKAbIEAAYASAAEgLs8vD_BwE.
} 


\subsection{Kurikulum za vrtce}

Glasovno zavedanje v predšolskem obdobju pedagoški delavci posredno razvijajo z načrtovanimi dejavnostmi na vseh kurikularnih področjih, ${ }^{8}$ saj je razvoj jezika naravno vpleten $\mathrm{v}$ vsa področja dejavnosti. Neposredno pa je glasovno zavedanje $\mathrm{v}$ Kurikulumu za vrtce (2017: 32) zajeto v področju jezika kot del jezikovnih dejavnosti, ki jih opredeljujejo globalni cilji: jezik kot objekt igre; poslušanje, razumevanje in doživljanje jezika; spodbujanje jezikovne zmožnosti (artikulacija, besednjak, besedila, komunikacija idr.) in spoznavanje simbolov pisnega jezika. V Kurikulumи za vrtce (2011: 33-37) so navedeni cilji in primeri dejavnosti za 1. in 2. starostno obdobje, s katerimi spodbujamo predbralne in predpisalne dejavnosti, tudi slušno razločevanje in razčlenjevanje $\mathrm{v}$ vsakdanji komunikaciji, $\mathrm{z}$ jezikovnimi igrami, ugankami, rimami; z uporabo simbolov; s poimenovanjem stvari; spoznavanjem glasov in črk; sodelovanjem $\mathrm{v}$ različnih družabnih in didaktičnih igrah, ki spodbujajo bogatenje besednega zaklada (npr. čarobne karte, pripovedovalne kocke); pripovedovanjem; branjem idr. Vse jezikovne dejavnosti, vključno s književno vzgojo, spodbujajo glasovno zavedanje in so $\mathrm{v}$ otrokovem vsakdanjiku tesno povezane.

\subsection{Učni načrti za osnovno šolo}

Učni načrt za slovenščino (UN 2018) že v sami opredelitvi predmeta, v splošnih ciljih, še posebej pa $\mathrm{v}$ operativnih ciljih in vsebinah, razdeljenih po posameznih vzgojno-izobraževalnih obdobjih, znotraj tega pa tudi po področjih jezik in književnost, $\mathrm{v}$ standardih znanja in didaktičnih priporočilih kot ključni splošnoizobraževalni predmet (ob vseh drugih ciljih) učence in učenke usposablja za učinkovito govorno in pisno sporazumevanje $\mathrm{v}$ slovenskem jeziku (predvsem $\mathrm{v}$ njegovi knjižni zvrsti), kar pomembno vpliva tudi na njihovo uspešnost pri drugih predmetih (UN 2018: 4). Temelj sporazumevanja je zagotovo razvito otrokovo glasovno zavedanje. Cilji predmeta slovenščina se v skladu s tem uresničujejo z jezikovnim in književnim poukom $\mathrm{v}$ okviru vseh sporazumevalnih dejavnosti (pogovarjanje, dopisovanje, poslušanje, branje, govorjenje, pisanje). Glavni (UN 2018: 4) »namen jezikovnega pouka je razviti sporazumevalno zmožnost v slovenskem (knjižnem) jeziku, tj. praktično in ustvarjalno obvladovanje vseh sporazumevalnih dejavnosti pa tudi jezikovnosistemskih osnov. Pri književnem

\footnotetext{
${ }^{8}$ Kurikularna področja dejavnosti v vrtcu so: jezik, družba, umetnost, narava, gibanje in matematika.
} 
pouku pa se učenci in učenke srečujejo z umetnostnimi oz. književnimi besedili ter ob njih poleg sporazumevalne zmožnosti razvijajo tudi doživljajsko, domišljijsko, ustvarjalno, vrednotenjsko in intelektualno zmožnost.« Izpostavljeno je, da se (UN 2018: 6) »[v] vseh vzgojno-izobraževalnih obdobjih /.../ predmet s cilji, z vsebinami in dejavnostmi učencev in učenk tesno povezuje $z$ drugimi predmeti in pri njih kot učni jezik poleg pridobivanja stvarnega znanja pomembno prispeva $\mathrm{k}$ razvijanju sporazumevalne zmožnosti učencev in učenk«.

To velja tudi za t. i. začetno opismenjevanje, ki traja celotno prvo vzgojno-izobraževalno obdobje ter poteka individualizirano, postopoma in sistematično; učenci in učenke $\mathrm{v}$ tem obdobju poleg vstopanja $\mathrm{v}$ svet branja in pisanja opravljajo tudi druge sporazumevalne dejavnosti, npr. se pogovarjajo, kritično sprejemajo oz. interpretirajo govorjena in zapisana besedila, se (po)ustvarjalno odzivajo nanje, govorno nastopajo, pišejo krajša besedila ter razvijajo svojo jezikovno (poimenovalno, skladenjsko, pravorečno, pravopisno), slogovno in metajezikovno zmožnost. V 2. in 3. vzgojno-izobraževalnem obdobju pa sprejemajo, interpretirajo, vrednotijo in razčlenjujejo svoji starosti, sporazumevalni, spoznavni in domišljijjki zmožnosti, izkušnjam in interesom ustrezna neumetnostna in umetnostna besedila, tvorijo govorjena in zapisana monološka besedila, se pogovarjajo in pišejo dopise raznih vrst; tako dejavno razvijajo svojo sporazumevalno, spoznavno in ustvarjalno zmožnost ter uzaveščajo temeljne podobnosti in razlike na ravni sprejemanja, razumevanja, doživljanja in vrednotenja neumetnostnih in umetnostnih besedil, na ravni tvorjenja neumetnostnih in poustvarjalnih besedil, na ravni enosmernega in dvosmernega sporazumevanja, na ravni tvorjenja tiskanih in elektronskih sporočil, na ravni sprejemanja, razumevanja, doživljanja in vrednotenja prikazovalnih in oglasnih besedil ipd. $\mathrm{Ob}$ tem sistematično razvijajo vse sestavine sporazumevalne zmožnosti, torej tudi metajezikovno zmožnost, hkrati pa uzaveščajo znanje za uspešno tvorjenje, sprejemanje, razumevanje, doživljanje in vrednotenje besedil $\mathrm{v}$ novih, 
dolgoročno nepredvidljivih medijih in oblikah, ki jih prinaša elektronska doba. (UN 2018: 6) ${ }^{9}$

V Ǔ́nem načrtu za slovenšcino kot drugi tuji jerike (dvojęična osnouna šla) (Poznanovič Jezeršek idr. 2011a) je slovenščina opredeljena kot splošnoizobraževalni predmet $\mathrm{v}$ osnovni šoli kot materni/prvi jezik za večino učencev in učenk ter kot drugi/jezik okolja za pripadnike manjšin (z madžarščino kot materinščino; slovenščina kot drugi jezik je v predmetniku dvojezične slovensko-madžarske osnovne šole le v 1 . VIO, v 2. in 3. VIO poteka pouk slovenščine po učnem načrtu za slovenščino v enojezičnih osnovnih šolah s slovenskim učnim jezikom). V Uinnem načrtu za slovenšcino kot drugi tuji jezilk (osnouna šola zitalijanskim ǔnim jezilkom) (Poznanovič Jezeršek idr. 2011b) pa je slovenščina opredeljena kot splošnoizobraževalni predmet $v$ osnovni šoli za nekatere učence na narodno mešanem območju Slovenske Istre kot drugi jezik/jezik okolja.

Cilji predmeta se uresničujejo $z$ jezikovnim in književnim poukom v sklopu štirih sporazumevalnih dejavnosti - poslušanja, branja, govorjenja in pisanja. Namen jezikovnega pouka je razviti sporazumevalno zmožnost, to je praktično in ustvarjalno obvladovanje vseh štirih sporazumevalnih dejavnosti pa tudi jezikovnosistemskih temeljev. /.../ V prvem vzgojnoizobraževalnem obdobju se predmet s cilji, vsebinami in dejavnostmi učencev tesno povezuje $z$ drugimi predmeti, ${ }^{10}$ to velja tudi za tako imenovano začetno opismenjevanje, ki traja celotno prvo vzgojno-izobraževalno obdobje (in sicer v 1 . in 2. razredu kot sistematično usvajanje tehnike branja in pisanja, $v$ 3. razredu pa kot njeno utrjevanje in izboljševanje); ${ }^{11}$ učenci $\mathrm{v}$ tem obdobju poleg vstopanja $\mathrm{v}$ svet branja in pisanja opravljajo tudi druge dejavnosti, na primer sodelujejo $\mathrm{v}$ pogovorih, kritično sprejemajo oziroma interpretirajo govorjena in zapisana besedila, se (po)ustvarjalno odzivajo nanje, govorno nastopajo, pišejo krajša besedila ter sistematično razvijajo svojo poimenovalno, skladenjsko,

\footnotetext{
${ }^{9}$ Natančen pregled razvoja govora v povezavi s sporazumevalno zmožnostjo v osnovno- in srednješolskem sistemu po učnih načrtih za slovenščino predstavlja S. Pulko (2019: 85-92).

${ }^{10} \mathrm{~V}$ Ǔ̌nem nắrtu za slovenšcino kot drugi tuji jezik (osnovna šola z italijanskim učnim jęikom) (Poznanovič Jezeršek idr. 2011b: 4) so predmeti zapisani: italijanščina, glasba in spoznavanje okolja.

${ }^{11} \mathrm{~V}$ Uínem nă̌rtu za slovenšcino kot drugi tuji jęik (osnovna šola z italijanskim učnim jez̧ikom) (Poznanovič Jezeršek idr. 2011b: 4) je dodano še, da začetno opismenjevanje sledi opismenjevanju v italijanščini.
} 
pravorečno, pravopisno, slogovno, metajezikovno zmožnost in zmožnost nebesednega sporazumevanja. ${ }^{12}$ (Poznanovič Jezeršek idr. 2011a: 4-5; Poznanovič Jezeršek idr. 2011b: 4-5)

Oba učna načrta med splošnimi cilji izpostavljata (1) razvijanje sporazumevalne zmožnosti v slovenskem jeziku, tj. možnosti sprejemanja in tvorjenja raznih vrst besedil, med katerimi še posebej pripravljenost za pogovarjanje in dopisovanje ter govorno nastopanje in pisanje, ter (2) razvijanje t. i. sestavin ${ }^{13}$ sporazumevalne zmožnosti, med drugimi tudi jezikovne zmožnosti (poimenovalne, skladenjske, pravorečne in pravopisne) (Poznanovič Jezeršek idr. 2011a: 7; Poznanovič Jezeršek idr. 2011b: 7).

\subsection{Učni načrti za srednješolsko izobraževanje}

Učni načrt za slovenšcino za splošno, klasično in strokovno gimnazijo (UN 2008) opredeljuje slovenščino (kot materni/prvi jezik za večino dijakov in dijakinj in kot drugi jezik/jezik okolja za manjšino) kot ključni splošnoizobraževalni predmet v gimnaziji, natančneje pa predstavlja v splošnih ciljih/kompetencah, še posebej pa v ciljih in vsebinah ter znotraj njih glede na jezikovni in književni pouk s procesnorazvojnimi in vsebinskimi sklopi (Poznanovič Jezeršek idr. 2008: 5). Učni načrt (UN 2008: 5) je "podlaga za samorazumevanje, za vsakršno učenje s slovenskim jezikom izraženih vsebin, za razumevanje, doživljanje in vrednotenje pojavov okrog nas. Dijaki/dijakinje se pri njem usposabljajo za učinkovito govorno in pisno sporazumevanje v slovenskem jeziku, razvijajo zavest o pomenu materinščine sploh, o slovenščini kot državnem in uradnem jeziku, o njenem položaju v Evropski uniji in o njeni izrazni razvitosti na vseh področjih javnega in zasebnega življenja.« Dijaki in dijakinje se s slovenskim jezikom srečujejo še zlasti ob umetnostnih besedilih, ki jih berejo, osebno doživljajo in odprto razumevajo obvezna ter prostoizbirna umetnostna besedila slovenske in prevodne književnosti. Dijaki in dijakinje s tem (UN 2008: 5) »razvijajo doživljajske, domišljijsko ustvarjalne, vrednotenjske in intelektualne zmožnosti, ki bogatijo posameznikovo osebnost in so sestavina

\footnotetext{
${ }^{12} \mathrm{~V}$ Učnem načrtu za slovenšcino kot drugi tuji jeqik (osnovna šola z italijanskim učnim jeqikeom) (Poznanovič Jezeršek idr. 2011b: 4-5) poimenovalne slovnične zmožnosti niso posebej opredeljene: »/.../ dejavno razvijajo svojo sporazumevalno, spoznavno in ustvarjalno zmožnost ter si uzaveščajo temeljne razlike na ravni sprejemanja neumetnostnih in umetnostnih besedil ter na ravni tvorjenja besedil«.

${ }^{13} \mathrm{~V}$ Učnem načrtu za slovenščno kot drugi tuji ję̧ike (osnovna šola z italijanskim ǔnim ję̧ikom) (Poznanovič Jezeršek idr. 2011b: 7) so sestavine sporazumevalne zmožnosti opredeljene kot gradniki sporazumevalne zmožnosti.
} 
estetske zmožnosti, ter poglabljajo splošno sporazumevalno zmožnost za sprejemanje in izražanje raznovrstnih besedil«.

S splošnimi cilji predmet slovenščina (UN 2008: 6) »omogoča razvijanje osebne, narodne in državljanske identitete ter ključnih zmožnosti vseživljenjskega učenja predvsem sporazumevanje v slovenščini /.../«. Izmed osmih splošnih ciljev velja izpostaviti predvsem drugega, pri katerem dijaki in dijakinje razvijajo zmožnost pogovarjanja, poslušanja (gledanja), branja, pisanja in govorjenja raznih besedil, in tretjega, pri katerem dijaki in dijakinje razvijajo jezikovno, slogovno in metajezikovno zmožnost $\mathrm{v}$ slovenskem knjižnem jeziku, in sicer s sistematičnim opazovanjem, razčlenjevanjem ter utrjevanjem in nadgrajevanjem med drugim svoje jezikovne zmožnosti, s spoznavanjem sistemskih zakonitosti slovenskega knjižnega jezika in z zavedanjem njihovega pomena s ciljem njihovega zavestnega vključevanja $\mathrm{v}$ lastna besedila, z zmožnostjo presojanja ustreznosti izbire posamezne jezikovne zvrsti v danih sporazumevalnih okoliščinah (UN 2008: 6-7).

$\mathrm{V}$ Katalogu znanja - slovenšcina (SSI) ${ }^{14}$ in Katalogu znanja - slovenšcina (PTI) 15 je v predstavitvi (filozofiji) predmeta zapisano, da se dijaki in dijakinje pri predmetu usposabljajo za učinkovito govorno in pisno sporazumevanje v slovenskem jeziku in pridobivajo za to potrebno znanje. Razvijajo (KZ (SSI): 2; (KZ (PTI): 1) »doživljajske, domišljijsko ustvarjalne, vrednotenjske in intelektualne dejavnosti, ki bogatijo posameznikovo osebnost, so sestavina estetske zmožnosti in poglabljajo splošno sporazumevalno zmožnost za sprejemanje in izražanje raznovrstnih jezikovnih sporočil. Pri udejanjanju kompetenc oba kataloga znanja v zvezi z glasovnim zavedanjem izpostavljata razvoj dveh ključnih zmožnosti oziroma kompetenc posameznika, in sicer (1) razvijanje sporazumevalne zmožnosti v slovenščini (»Sporazumevalna zmožnost je zmožnost kritičnega sprejemanja besedil raznih vrst ter zmožnost tvorjenja ustreznih, razumljivih, pravilnih in učinkovitih besedil raznih vrst; je torej zmožnost izvajanja štirih sporazumevalnih dejavnosti, in sicer dveh sprejemalnih (poslušanje in branje) in dveh tvorbnih (govorjenje in pisanje).«) ter (2) razvijanje socialne zmožnosti (»Prek razumevanja izrazne in ustvarjalne enakovrednosti $\mathrm{v}$ družbi evropskih jezikov in družbene vloge slovenskega jezika $\mathrm{v}$ Sloveniji dijaki razvijajo pomembne sestavine socialne zmožnosti.«) (KZ (SSI): 2; KZ (PTI): 2). Med ključne usmerjevalne oziroma splošne

\footnotetext{
${ }^{14}$ SSI - srednje strokovno izobraževanje.

${ }^{15} \mathrm{PTI}$ - poklicno-tehniško izobraževanje.
} 
cilje predmeta pa oba kataloga znanj med drugim vključujeta (1) razvijanje sporazumevalne zmožnosti v slovenskem knjižnem jeziku (»Obvladajo slovenski knjižni jezik in ga zavestno uporabljajo v svojih besedilih. Znajo presoditi, ali je v danih sporazumevalnih okoliščinah ustrezna raba knjižnega ali neknjižnega jezika.«) in (2) razvijanje zmožnosti pogovarjanja, poslušanja (gledanja) in branja raznih besedil ter zmožnost ustnega in pisnega sporočanja (»[p]ogovarjajo se vljudno in strpno; spoštujejo mnenje drugih, izražajo svoje mnenje oz. svoje strinjanje/nestrinjanje $\mathrm{z}$ mnenjem drugih ter to tudi utemeljiio; [z]najo se sporazumevati o strokovnih in poslovnih zadevah s sodelavci, strankami in poslovnimi partnerji; [b]esedila poslušajo oz. berejo razmišljujoče in kritično, vrednotijo jih z raznih vidikov ter prepoznajo morebitno sporočevalčevo prevaro, pretvarjanje/preračunljivost/skriti namen oz. manipulativnost; [o]b pomoči učitelja sistematično opazujejo in razčlenjujejo besedila $z$ raznih vidikov ter utrjujejo in nadgrajujejo svoje znanje o pragmatičnih, funkcijskih, pomenskih, oblikovnih, jezikovnih ipd. značilnostih besedilnih vrst, povedi in besed; [ $\mathrm{t}$ ]vorijo učinkovita, ustrezna, razumljiva in jezikovno pravilna govorjena in zapisana besedila.«) (KZ (SSI): 3; KZ (PTI): 2-3).

\section{$4 \quad$ Raziskovanje in merjenje glasovnega zavedanja}

Izraz glasovno zavedanje (Zorman 2013: 42) se je uveljavil v sedemdesetih letih prejšnjega stoletja $\mathrm{v}$ okviru raziskav, ki so preučevale povezave med delnimi spretnostmi branja in pisanja ter učenjem branja in pisanja. Korelacijske študije so bile prve na področju preučevanja glasovnega zavedanja. Njihovi rezultati so pospešili raziskovanje sposobnosti metaglasovnega procesiranja jezika, številni raziskovalci so mnenja, da je odkritje soodvisnosti med glasovnim zavedanjem in napredkom pri učenju branja in pisanja eden največjih uspehov sodobne psihologije (Zorman 2013: 42). Korelacijske študije (Malaguti 1994; Chard in Dickson 1999; Hempenstall 1999; Vellutino 2003, v Zorman 2013: 43-44) kažejo, da je osnovna pismenost najtesneje povezana z glasovnimi spretnostmi otrok in njihovim besednim zakladom. Sledile so prediktivne studije (Wolf 1991; Tressoldi 1993; Torgesen 1998; Iozzino 1998; Kail 1999, v Zorman 2007: 48-52), namenjene zgodnjemu odkrivanju učencev s specifičnimi težavami pri začetnem opismenjevanju, ki so potrdile pomembno vlogo razvijanja in merjenja glasovnega zavedanja otrok v vrtcu, kjer so najučinkovitejši instrumenti testi hitrega poimenovanja barv, predmetov, številk in črk, saj naj bi te naloge merile otrokove sposobnosti avtomatičnega izvajanja procesov, ki so specifični za branje. Sodobne prediktivne študije se ukvarjajo z izpopolnjevanjem 
instrumentov za merjenje glasovnega zavedanja, ki bi zagotavljali natančno odkrivanje otrok s potencialnimi težavami pri branju že zgodaj v razvoju (Zorman 2013: 45-48). Slednje so eksperimentalne študije, ki spremljajo napredek učencev, ki so deležni programa razvijanja glasovnega zavedanja. Rezultati tovrstnih programov (Scanlon in Vellutino 1987; Aleksander 1999; Donelson in Graney 2000, v Zorman 2013: 48-50) so pogojeni $z$ vsebino programa samega in potrjujejo, da je razvoj bralne pismenosti pri otrocih $z$ boljšim glasovnim zavedanjem tesno povezan $z$ dejavnostmi skupnega (razgovornega) branja (Bednjički Rošer 2020; Grginič 2005), ko pedagoški delavci kot profesionalni posredniki berejo in obenem usmerjajo otrokovo/učenčevo pozornost $\mathrm{v}$ brano besedilo (sledenje branju). Razvijanje glasovnega zavedanja se pri otrocih običajno zelo zgodaj začne s prepoznavanjem in tvorjenjem rim, k čemur pomembno prispeva branje poezije - »Eno je brada, drugo je Breda, / eno je torek, drugo je sreda. "16 usvajanje izštevank, prepevanje pesmi, poslušanje pravljic, opazovanje in opisovanje ilustracij, slik ... Pri delu z otroki/učenci je ključno didaktično načelo postopnosti. Začenja se s preprostejšimi nalogami, ki se jih postopoma nadgrajuje z vedno zahtevnejšimi.

${ }^{16}$ Miroslav Košuta: Eno in drugo. 
Tabela 1: Didaktična načela razvijanja fonološkega zavedanja

(Zorman 2005: 13-14, 2018: 19-20)

\begin{tabular}{|c|c|c|}
\hline preprosto & & zapleteno \\
\hline & dejavnik & \\
\hline $\begin{array}{l}\text { Znane besede. Otrok ni } \\
\text { obremenjen s pomenom } \\
\text { besede, pozoren je le na } \\
\text { njeno glasovno sestavo. }\end{array}$ & pomen besede & $\begin{array}{r}\text { Neznane ali redkeje } \\
\text { uporabljene besede. Otrok } \\
\text { se ukvarja s pomenom } \\
\text { besede, manjšo pozornost } \\
\text { posveča glasovni sestavi } \\
\text { besede. }\end{array}$ \\
\hline $\begin{array}{l}\text { Krajše besede. Dolžina } \\
\text { besede ne obremenjuje } \\
\text { spomina. }\end{array}$ & dolžina besede & $\begin{array}{r}\text { Daljše besede. } \\
\text { Obremenitev spomina je } \\
\text { večja. }\end{array}$ \\
\hline $\begin{array}{l}\text { Besede, ki ne vsebujejo } \\
\text { soglasniških sklopov. V } \\
\text { slovenščini in italijanščini } \\
\text { so sestavljene iz KVKV, v } \\
\text { angleščini pa KVK. }\end{array}$ & glasovna zgradba besede & $\begin{array}{l}\text { Besede, ki vsebujejo } \\
\text { soglasniške sklope, in druge } \\
\text { »težje« besede glede na } \\
\text { jezikovni substrat. }\end{array}$ \\
\hline $\begin{array}{l}\text { Rime. } \\
\text { Členjenje na zloge. } \\
\text { Členjenje na začetke, konce } \\
\text { in poljubne enote. }\end{array}$ & $\begin{array}{c}\text { velikost glasovne enote } \\
\text { in raven glasovnega } \\
\text { zavedanja }\end{array}$ & $\begin{array}{r}\text { Členjenje na posamezne } \\
\text { glasove v besedi. }\end{array}$ \\
\hline $\begin{array}{l}\text { Začetni glasovi. } \\
\text { Končni glasovi. }\end{array}$ & $\begin{array}{c}\text { mesto glasu v besedi ali } \\
\text { glasovni verigi }\end{array}$ & Sredinski glasovi. \\
\hline $\begin{array}{l}\text { Podaljšani glasovi oziroma } \\
\text { glasovi, ki jih je mogoče } \\
\text { izgovoriti podaljšano. }\end{array}$ & $\begin{array}{l}\text { razvoj govornega aparata } \\
\text { in glasovne značilnosti } \\
\text { procesiranih glasovnih } \\
\text { enot }\end{array}$ & $\begin{array}{r}\text { Zaporniki. } \\
\text { Soglasniški sklopi. } \\
\text { Glasovi, ki so jih skladno z } \\
\text { razvojem govornega } \\
\text { aparata otroci zmožni } \\
\text { izgovarjati v kasnejšem } \\
\text { obdobju razvoja: } / \mathrm{r} /, / 1 / .\end{array}$ \\
\hline
\end{tabular}

Pričakovati je bilo, da se največ raziskav glasovnega zavedanja nanaša na predšolsko in začetno osnovnošolsko obdobje (1. VIO), manj pa na glasovno zavedanje v 2. in 3. VIO, v srednješolskem in nadaljnjem izobraževanju. Pregled raziskav glasovnega zavedanja pa vendarle kaže, da je predvsem $\mathrm{v}$ zadnjem desetletju tovrstnih raziskav čedalje več, s čimer tako učitelji različnih stopenj izobraževanja kot tudi sami študenti pedagoških študijskih programov, torej bodoči učitelji, jasno izražajo vse večjo potrebo po spremembah dojemanja pomena obravnavane problematike in njenega drugačnega, konkretnejšega ter strokovno sodobnejšemu času ustreznejšega normiranja. 
Eno prvih sodobnejših monografskih del za delo s predšolskimi otroki v zvezi z glasovnim zavedanjem (čeprav glasovnega zavedanja kot termin še ne uvaja), je prevod in priredba Lipnika, ki vsebuje nekaj poglavij dela Metodika govorne vagoje (1993) avtorja Matića (s podnaslovom Priročnik za delo vagojiteljic in stař̌ev). Teoretične postavke so večinoma prevod Matićevega izvirnika, praktični primeri pa stvaritve slovenskih ustvarjalcev, ki jih je Lipnik preoblikoval in priredil slovenskim potrebam. Teoretično zasnovanemu poglavju o jeziku in govoru sledijo štiri teoretičnopraktično zasnovana poglavja, nanašajoča se na glasovno zavedanje: o različnih vrstah govornih iger in njihovih funkcijah (pregovori in njim podobni izrazi, uganke, glasovne govorne igre, zagovori, izštevanke, naštevanke, hitro govorjenje, lažnjivke, gibalne govorne igre, leksikalne (besedne) govorne igre, posmehljivke, sintaktične igre pripovedovanja, nekatere gibalne govorne igre za otroke do treh let); o igri kot načelu in metodi dela, o pogovoru kot dvosmemi komunikaciji in drugih načelih ter metodah dela; o spoznanjih o govornih vajah (poslušanje in diskriminacija kot dvosmerna komunikacija, razvoj glasovne strani govora in artikulacije, razvoj besednega zaklada in pomen besed, razvoj stavka pri otrocih); o govorni ustvarjalnosti $\mathrm{z}$ mislijo na govor $\mathrm{v}$ igri predšolskega otroka in na samogovor, na ustvarjalno otroško pripovedovanje ter na rimanje besed in tvorbo stihov.

Avtorja vseskozi poudarjata, da je za otroka v predšolskem obdobju in tudi še vsaj v prvem VIO šolskega obdobja igra izrednega pomena, saj mu predstavlja dojemanje in način življenja, skozi igro spoznava okolico in se uči. Zato je še kako pomembno, da se izhaja iz načela igre (ne glede na to, da se uporabljajo tudi druga načela) in iz vodilne vloge vzgojitelja kot soigralca ali kvečjemu kot vodje skupin, hkrati pa je treba biti dovolj 'nevzgojiteljski' oz. 'neučiteljski', da se dosežeta namen naravnosti in spontanosti v izražanju (Lipnik 1993: 21). Pri metodi igre gre torej za vrsto postopkov, s katerimi se vadijo poslušanje in razločevanje, oblikovanje glasov, uporaba besedišča, tvorba stavka ipd., s čimer se razvija in neguje osnovne komponente in lastnosti (dobrega) govorjenja (Lipnik 1993: 22). Temeljna je zagotovo vsebina, saj je ta tista, za katero želimo, da jo otrok usvoji, se pa določena tema lahko uporabi za razne elemente znotraj enega področja (npr. za govorno vzgojo), smiselno pa jo je uporabiti tudi za različna področja, za medpodročno povezovanje $\mathrm{v}$ vrtcu (za matematične pojme, spoznavanje okolja, za glasbeno in likovno vzgojo ipd.) (Lipnik 1993: 23). 
Leto dni kasneje je k priročniku Metodika govorne vagoje izšla še zbirka besedil Mali čeek avtorja Lipnika (1994) z besedili, ki so delno ali v celoti vključena v Metodiko, besedila, ki jih v Metodiki ni, so pa omenjena in priporočena, in tem sorodna besedila. Zbirka je zastavljena $z$ namenom podati po več primerov besedil za posamezno vrsto govornih dejavnosti. Avtor poudarja, da je za usvajanje pomembnega dela sporazumevalne kompetence, tj. jezikovne kompetence otrok, $v$ predšolskem obdobju še posebej pomembna pravilna izgovarjava glasov, saj je ustrezno slušno razumevanje pogoj za ustrezno rabo jezika ne le $\mathrm{v}$ govoru, ampak $\mathrm{v}$ sledečem šolskem obdobju tudi za uvajanje znakov (črk) za zapis glasov. V dveh poglavjih, Hitrogovorjenke in Razne jezilkovne govorne igre, so zbrana besedila za razvijanje jezikovne kompetence predšolskega otroka.

Poglavje Hitrogovorjenke prinaša nabor besedil, hitrogovorjenk, ki so posebne igre za urjenje izgovarjave glasov. Krajša tovrstna besedila se izgovarjajo večkrat, daljša običajno enkrat. Avtor jih zastavlja z vodilnim igralcem (vzgojitelj, starši, tudi otrok), ki besedila govori najprej, drugi (otroci) pa za njim besedilo ponavljajo. Poglavje vsebuje 18 kratkih hitrogovorjenk in štiri daljše hitrogovorjenke (trije primeri so prevodni, eden avtorski), ki jih je mogoče po potrebi tudi krajšati. Hitro govorjenje kot govorna igra je natančno predstavljena v Metodiki (Lipnik in Matić 1993: 104 107). Kot priljubljena otroška igra je odlično motivacijsko sredstvo, saj ob napakah pri izgovarjavi vzbuja smeh, hkrati pa pozitivno tekmovalnost za čim pravilnejšo izgovarjavo. Lipnik in Matić pišeta (1993: 104), da so za mlajše predšolske otroke primerne predvsem norčevanke, za predšolske otroke srednje starosti predvsem čistogovorjenke, za starejše pa hitrogovorjenke. Norčevanke temeljijo na poudarjanju izgovarjave posameznih glasov ( $v$ veliki meri samoglasnikov, pa tudi problematičnih soglasnikov, kot sta npr. jezičnika $r$ in $l$, še razlikovanje med sičniki in šumevci ipd.), čistogovorjenke so podobne hitrogovorjenkam in spodbujajo glasovno ustrezno izgovarjavo (npr. na samoglasnik $a$, iskanje rim, ki se začnejo na soglasnik $r$ ipd.), hitrogovorjenke pa se uporabljajo za vaje $\mathrm{v}$ artikulaciji, diskriminaciji, intonaciji in jasnosti (Lipnik in Matić 1993: 106).

Poglavje Razne jezileovne govorne igre se osredinja na igre z glasovi, z zlogi, deli besed, besedami in besednimi zvezami, s povedmi in z daljšimi sporočili. Gre za besedila, $\mathrm{v}$ katerih se posnema naravne šume in zvoke, ponavlja posamezne glasove, tvori nove besede, pripoveduje, si izmišljuje (Lipnik 1994: 101). Zbranih je 19 različnih besedil različnih slovenskih avtorjev in avtoric. Otroci se ob konkretnih besedilih učijo ne zgolj ustrezne izgovarjave, temveč tudi pridobivajo znanja morfemov besed, 
predvsem korena besed in z njim povezane besedne družine, naglaševanja, besedne medmetne rabe in glagolske raznolikosti (npr. ob vrstah oglašanja ptic) ter povezave obojega (npr. kikiriki - kikirikanje), števnikov ob štetju ipd.

Nekatere raziskave načinov in količine spodbujanja govorno-jezikovnega razvoja otrok v vrtcu (npr. Višček 2019: 25-37) kažejo različne, tudi inovativne pristope (npr. Korošec 2019: 39-46) in načrtovanje raznolikih dejavnosti, v prvem starostnem obdobju predvsem bibarij (gibalnih iger z dotikom ob izrekanju ritmičnih besedil, izštevank ipd.), poslušanja starosti primernih zgodb ob slikanicah ali aplikatih, otroških rajalnih iger in učenja deklamacij z gibom/brez giba, v drugem starostnem obdobju pa naj so najpogostejše dejavnosti poslušanje zgodb, pripovedovanje oziroma obnavljanje zgodb, vaje za govorni aparat in razne govorno-jezikovne igre (Višček 2019: 27).

Z metaanalitično študijo National Reading Panel (2000, v Pečjak 2010: 108) je bilo dokazano, da urjenje otrok/učencev $v$ fonološkem zavedanju izboljšuje sposobnost glasovnega zavedanja in sposobnost branja. $\mathrm{V}$ našem prostoru je prvi test glasovnega zavedanja v treh oblikah za učence 1. VIO (od 6 do 9 let starosti) leta 1995 zasnovala Lidija Magajna. Kot pomemben element je glasovno zavedanje zajeto tudi $\mathrm{v}$ testu zgodnjih bralnih zmožnosti Branke D. Jurišić. Oblikovala ga je leta 2001 in je namenjen otrokom pred vstopom $\mathrm{v}$ šolo (od 4. leta). Z njim prepoznavamo otroke, ki sodijo v skupino s tveganjem za motnje branja. 


\begin{tabular}{|c|c|c|c|}
\hline $\begin{array}{l}\text { Zap. št. } \\
\text { preizk. }\end{array}$ & Navodilo otroku & Pravilni odgovor & Gradivo \\
\hline 1 & Kaj je to? & Lego kocke & $\begin{array}{l}\text { Slika1: originalen zapis } \\
\text { LEGO }\end{array}$ \\
\hline 5 & Povej, katere črke so to? & $\begin{array}{l}\text { Pokaže in } \\
\text { poimenuje vse črke. }\end{array}$ & Velike črke: A, I, E \\
\hline 8 & $\begin{array}{l}\text { Predstavljaj si, da je to } \\
\text { knjiga. Natančno pokaži, } \\
\text { kje začnemo brati. Kje je } \\
\text { začetek? Kje je konec? }\end{array}$ & $\begin{array}{l}\text { Pokaže na začetek } \\
\text { in konec besedila. } \\
\text { Oboje za } 1 \text { točko. }\end{array}$ & $\begin{array}{l}\text { Slika besedila, kjer je jasno } \\
\text { viden začetek in konec } \\
\text { besedila. }\end{array}$ \\
\hline 9 & $\begin{array}{l}\text { Pokaži, kje piše: } \\
\text { - banana } \\
\text { - avto } \\
\text { - hiša }\end{array}$ & $\begin{array}{l}\text { Poveže sliko in } \\
\text { besedo. Vse tri za } \\
1 \text { točko. }\end{array}$ & $\begin{array}{l}\text { Slika } 8 \text { - narisani predmeti } \\
\text { banana, avto, hiša. Besede } \\
\text { za predmete, napisane } \\
\text { pomešano spodaj. }\end{array}$ \\
\hline 15 & Kje piše telefon? & $\begin{array}{l}\text { Pokaže besedo } \\
\text { TELEFON. }\end{array}$ & $\begin{array}{l}\text { Poleg slike telefona } \\
\text { so napisane tri besede. } \\
\text { TELEVIZIJA, TELEFON, } \\
\text { BELEŽKA. }\end{array}$ \\
\hline 16 & Poimenuj črke. & $\begin{array}{l}\text { Pravilno poimenuje } \\
\text { vse črke za } 1 \text { točko. }\end{array}$ & $\begin{array}{l}\text { Velike tiskane črke } \mathrm{v} \\
\text { neabecednem zaporedju. }\end{array}$ \\
\hline 19 & $\begin{array}{l}\text { Preberi prvo poved in } \\
\text { naredi, kar piše. } \\
\text { Zdaj preberi še drugo } \\
\text { poved in naredi, kar piše. } \\
\text { Zdaj preberi še tretjo } \\
\text { poved in naredi, kar piše. }\end{array}$ & $\begin{array}{l}\text { Prebere in naredi } \\
\text { (lahko prebere tudi } \\
\text { tiho in preverjamo le } \\
\text { izvedbo). }\end{array}$ & $\begin{array}{l}\text { Napisane tri povedi z } \\
\text { velikimi tiskanimi črkami: } \\
\text { DVIGNI ROKO. } \\
\text { POKAŽI JEZIK. } \\
\text { ZAPRI OČI. }\end{array}$ \\
\hline 20 & $\begin{array}{l}\text { Čim hitreje beri. Preberi } \\
\text { te besede, kolikor hitro } \\
\text { zmoreš. }\end{array}$ & $\begin{array}{l}\text { Število točk je enako } \\
\text { številu prebranih } \\
\text { besed v } 10 \text { sekundah. } \\
\text { Če je besed več kot } \\
4 \text {, dobi } 4 \text { točke. }\end{array}$ & $\begin{array}{l}\text { ZELENA DVE RDEČA TRI } \\
\text { RUMENA ORANŽNA ŠEST } \\
\text { ENA MODRA PET ČRNA } \\
\text { RUMENA DVE ZELENA } \\
\text { RDEČA BELA }\end{array}$ \\
\hline
\end{tabular}

Slika 2: Struktura Testa zgodnjih bralnih zmožnosti Branke D. Jurišić (Pečjak 2010: 110)

Za 5-6-letne otroke in učence prvega razreda OŠ je preizkus predopismenjevalnih spretnosti oblikovala tudi Marija Grginič leta 2005. Izdelala je vprašalnik s štiriindvajsetimi različnimi nalogami, ki vključuje tudi vsebinski sklop o glasovnem zavedanju, kjer se naloge nanašajo na iskanje rim ob sličicah, poimenovanje prvih glasov, poimenovanje zadnjih glasov in glaskovanje. Raziskava Pečjak s sodelavci 
(1999, v Pečjak 2010: 113-115) je z eksperimentalno in kontrolno skupino 291 učencev pokazala statistično visoko pomembne razlike šestmesečnega sistematičnega razvijanja posameznih sposobnosti glasovnega zavedanja.

V več razpravah različnih avtorjev je izpostavljeno, da je učitelj tisti, ki je izjemno pomemben modelni govorec, po katerem se zgledujejo predvsem otroci v vrtcih in učenci v osnovni šoli (Tivadar 2015: 162), seveda pa tudi v 2. in 3. VIO in v srednješolskem izobraževanju ter na fakultetah.

Učiteljevo glavno orodje je govor, ki je nedvomno povezan tudi z njegovo avtoriteto $\mathrm{v}$ razredu, a govor ni zgolj pravorečna norma, temveč tudi nebesedna komunikacija, izražena z različnimi zvočnimi sredstvi (Kejžar 2019: 65); pomensko je učitelj torej soustvarjalec opolnomočenja učencev (Čačinovič Vogrinčič 2008: 79, v Kejžar 2019: 65). Na podlagi raziskav so nastala tudi že posamezna nadvse dobrodošla priporočila oziroma smernice učiteljem glede glasovnega zavedanja (npr. Rot Vrhovec 2019: 6263; Ozbič idr. 2014: 500-506), tudi v monografskih publikacijah (npr. Dolar 2003; Marc in Torkar Papež 2006; Štih 2016; Petek 2019). Slovenski jezik potrebuje normativni pravorečni priročnik, ki bi omogočil lažjo umestitev glasovnega zavedanja $\mathrm{v}$ vse formalne in predpisovalne dokumente tako pedagoških kot tudi nepedagoških strokovnjakov vseh področij. Temeljna naloga fakultetnega izobraževanja pa je vsekakor aktualizacija jezikovnega opisa glasoslovja slovenskega knjižnega jezika z ustreznim učnim gradivom s temeljem na realni podobi knjižnega jezika, podprtega z zvočnimi posnetki (Horjak in Tivadar 2019: 157).

Izpostaviti velja, da je tovrstna strokovna usposobljenost učitelja za govorno nastopanje (torej kompetentnost na tem področju) eden izmed pogojev za njegovo osebno in poklicno ter akademsko uspešnost, česar se mora naučiti (Petek 2019: 142), hkrati pa, da morajo tovrstne kompetence obvladati učitelji vseh predmetnih področij (npr. Žmavc 2019: 81-82; Pulko 2019: 91; Zemljak Jontes 2019: 124). Na premalo pozornosti, ki jo učitelji posvečajo glasovnemu zavedanju, opozarja tudi nekaj raziskav mnenja dijakov (npr. Jožef Beg 2019: 98-101) z večinskim mnenjem, da bi posledično zmanjkalo časa za druge stvari. Tudi zato na nekaterih osnovnih in srednjih šolah primanjkljaj nadomeščajo z izbirnimi in/ali obveznimi izbimimi vsebinami (npr. Marc in Torkar Papež 2019: 103-111), kar je sicer nadvse dobrodošla praksa, a vendarle ne zajame vseh učečih se. 
Predmeti, ki bi samostojno ali kot deli študijskih predmetov vključevali vsebine glasovnega zavedanja na fakultetah, bi vsekakor morali biti $\mathrm{z}$ nadgrajevanjem osnovno- in srednješolskega znanja tudi del vseh študijskih programov (Valh Lopert 2019: 138, po Zemljak Jontes in Valh Lopert 2016: 106), saj sicer morebitnih napak $\mathrm{v}$ glasovnem razločevanju, razčlenjevanju in poznavanju ter uporabi knjižnega naglasa in knjižne izreke študenti v svojem govoru ne morejo popraviti, posledično pa s tem vplivajo na glasovno zavedanje bodočih generacij, ne glede na to, ali gre za bodoče pedagoške ali nepedagoške ciljne poklice. Spodbudno je, da čedalje več študentov sicer večinoma pedagoških študijskih programov $v$ zaključnih delih raziskuje glasovno zavedanje, na vseh stopnjah izobraževanja. Dejstvo pa je, da le nadgrajevanje pisne in govorjene slovenščne lahko vodi $\mathrm{v}$ suverenost tvorbe (strokovnih) besedil (Valh Lopert 2019: 131).

\section{Pomen razvijanja sposobnosti fonološkega zavedanja pri učenju tujega jezika}

V sodobni družbi je vse bolj prisotno zgodnje uzaveščanje o jezikovni in kulturni raznolikosti, ki s sprejemanjem jezikov spodbuja medkulturni dialog (Bednjički Rošer 2019) in s procesi primerjanja ter razlikovanja jezikov krepi razvoj metajezikovne sposobnosti procesiranja tujih jezikov. Približevanje procesa usvajanja tujega jezika procesu usvajanja prvega jezika je v veliki meri odvisno od didaktičnega modela pridobivanja tujega jezika (Čok in Brčaninović 2015). Urjenje glasov, razvijanje fonološkega zavedanja in natančnost izgovora moramo $\mathrm{v}$ predšolskem in 1. VIO prepletati $\mathrm{z}$ igro, $\mathrm{s}$ petjem, $\mathrm{z}$ risanjem, lutkami, gibanjem in $\mathrm{s}$ plesom, da se izognemo napornemu in dolgočasnemu urjenju in ponavljanju, ki lahko otrokovo/učenčevo zanimanje za tuji jezik odvrne. Sposobnosti glasovnega zavedanja so prenosljive iz maternega jezika $\mathrm{v}$ drugi/tuji jezik kot iz drugega/tujega jezika $\mathrm{v}$ materni, zato otroci, ki imajo vsaj deloma razvito glasovno zavedanje $\mathrm{v}$ prvem jeziku, dosegajo pomembne rezultate $\mathrm{v}$ drugem jeziku, kljub slabo razviti sporazumevalni zmožnosti v tujem jeziku (Čok in Brčaninović 2015). Pedagoški delavci si morajo oblikovati načrt, zastaviti cilje, določiti oblike in metode dela ter sredstva in pripomočke, ki jih bodo uporabljali, hkrati pa upoštevati potrebe otrok v skupini in vsebine, primerne njihovi razvojni stopnji, da bodo lahko učinkovito razvijali sposobnosti glasovnega zavedanja $\mathrm{v}$ tujem jeziku. 
Sistematično in načrtno razvijanje sposobnosti glasovnega zavedanja je kompleksno in zahteva veliko znanja o glasovnih sistemih ter pisavah obeh jezikov, o samem razvoju glasovnega zavedanja in dejavnikih, ki vplivajo na zahtevnost fonološkega procesiranja jezika. Izvedba dejavnosti mora potekati na konkretni ravni po zahtevnosti od lažje k težji, naloge naj bodo podprte s slikovnim gradivom, otrokom je treba omogočiti tudi možnost izbire. Zaradi pravočasnega prepoznavanja težav in prilagoditev oblik dela je vrednotenje razvoja glasovnega zavedanja zelo pomembno. Otrokom omogočimo, da različne vrste izdelkov hranijo v svojih mapah (portfolio), s čimer jih spodbujamo k vrednotenju lastnega dela in navajamo na kritičnost.

\begin{tabular}{|c|c|}
\hline RAVEN FZ & Primer \\
\hline $\begin{array}{l}\text { Zavedanje dolžine } \\
\text { besede (dolga - } \\
\text { kratka) }\end{array}$ & $\begin{array}{l}\text { Otrok slušno primerja pare različno dolgih besed in pove, katera je daljša, npr. } \\
\text { AVTO - PIKAPOLONICA / CAR - ELEPHANT. }\end{array}$ \\
\hline $\begin{array}{l}\text { Prepoznavanje in } \\
\text { tvorjenje rim }\end{array}$ & $\begin{array}{l}\text { Otrok poišče besedo na sliki, ki se rima na besedo žoga - noga / mouse - } \\
\text { house. Otrok tvori rimo na izgovorjeno besedo, npr. mačka - tačka / cat - rat. }\end{array}$ \\
\hline $\begin{array}{l}\text { Členjenje povedi } \\
\text { na besede }\end{array}$ & $\begin{array}{l}\text { Otrok s pomočjo žetonov členi poved na besede. Za vsako besedo položi } \\
\text { predse en žeton (npr. Mama kuha kosilo. / Babies are sleeping.). }\end{array}$ \\
\hline $\begin{array}{l}\text { Zlogovno } \\
\text { zavedanje }\end{array}$ & Otrok zloguje besedo s pomočjo ploskanja (npr. ko-ša-ra / e-le-phant). \\
\hline $\begin{array}{l}\text { Zavedanje } \\
\text { začetkov in koncev }\end{array}$ & $\begin{array}{l}\text { Otrok prepozna besedo, ki jo izgovorimo s podaljšanim začetkom (npr. } \\
\text { mmmmmiš - otrok pove, da je to beseda miš). } \\
\text { Otrok tvori besede, ki se začnejo na mi-. Primeri za angleščino: fffffoox, } \\
\text { mmmmouse, rrrrrat. }\end{array}$ \\
\hline $\begin{array}{l}\text { Razločevanje } \\
\text { enakih prvih/ } \\
\text { zadnjih glasov }\end{array}$ & $\begin{array}{l}\text { Otroka vprašamo, ali se besedi začneta na enak prvi/zadnji glas (npr. kača, } \\
\text { kitara; gos, gora). Primeri za angleščino: dad, this; love, cow; thanks, fine; } \\
\text { down, doll. } \\
\text { Otrok med podanimi sličicami poišče tiste, katerih besede se začnejo/končajo } \\
\text { na določen glas. }\end{array}$ \\
\hline $\begin{array}{l}\text { Prepoznavanje in } \\
\text { tvorjenje aliteracij }\end{array}$ & $\begin{array}{l}\text { Otroku povemo tri besede zaporedoma in ga vprašamo, ali se začnejo na isti } \\
\text { glas } \\
\text { (npr. Katja kupuje korenje. / Lucy likes Iollypops.). } \\
\text { Otrok prepoznava aliteracije ob branju, npr. pesmi. } \\
\text { Otrok sam tvori podobne povedi ali poljubno tri besede. }\end{array}$ \\
\hline $\begin{array}{l}\text { Prepoznavanje } \\
\text { prvega/zadnjega } \\
\text { glasu v besedah }\end{array}$ & $\begin{array}{c}\text { Otrok nam pove, na kateri glas se začne/konča določena beseda. Pomaga si s } \\
\text { sličicami. } \\
\text { Otrok tvori besedo na podan glas. }\end{array}$ \\
\hline $\begin{array}{l}\text { Razločevanje } \\
\text { glasov v besedah }\end{array}$ & $\begin{array}{c}\text { Otrok poišče sličico, katere beseda vsebuje npr. glas /s/ (lahko ga vsebuje na } \\
\text { začetku, na koncu ali v sredini). }\end{array}$ \\
\hline
\end{tabular}

Slika 3: Primeri nalog za razvijanje sposobnosti fonološkega zavedanja v slovenščini in angleščini

(Čok in Brčaninović 2015: 158) 
V Skupnem evropskem jezikovnem okviru: ǔ́enje, poučevanje, ocenjevanje (SEJO) (2011) sam termin glasovno zavedanje ni zapisan, je pa poleg splošnih zmožnosti predstavljena sporazumevalna zmožnost, ki vključuje jezikovne, sociolingvistične in pragmatične zmožnosti (SEJO 2011: 132). Med jezikovnimi zmožnostmi se na glasovno zavedanje nanašata fonološka (SEJO 2011: 140-141) in pravorečna zmožnost (SEJO 2011: 141-142), ki sta glede na (želeno) stopnjo obvladovanja jezika od stopnje A1 do C2 tudi natančno opredeljeni (SEJO 2011: 141, 142). Fonološka zmožnost je opredeljena kot zmožnost, ki vključuje poznavanje in spretnosti zaznavanja ter tvorjenja, kamor sodijo (SEJO 2011: 140-141): »glasovne enote (fonemi) jezika in njihove uresničitve $\mathrm{v}$ posameznih kontekstih (alofonı); fonetične značilnosti, po katerih se fonemi med seboj razločujejo (razločevalne značilnosti, na primer zvenečnost/nezvenečnost, razločevanje glede na vrsto, mesto ovire); fonetične sestave besed (struktura zlogov, na primer zaporedje fonemov, jakostno in tonemsko naglaševanje); stavčna fonetika (prozodija): stavčni poudarek in ritem, intonacija; fonetična redukcija: samoglasniška redukcija, krepke in šibke oblike, prilikovanje, izpad končnega glasu (elizija)«. Pravorečna zmožnost pa opredeljuje zmožnost uporabnikov, da pri glasnem branju besedil ali v govoru uporabijo besede, ki jih vidijo prvič, pri tem pa so jih zmožni pravilno izgovoriti (če gre za zapisano besedo, le na podlagi pisne predloge, za kar so potrebni (SEJO 2011: 142): "poznavanje pravopisnih pravil; sposobnost uporabe slovarja in poznavanje dogovorjenih načinov zapisovanja izgovorjave; poznavanje učinkov pisnih oblik, predvsem ločil, na označevanje ritma in intonacije; sposobnost razreševanja dvoumnosti (homonimov, skladenjskih dvoumnosti itn.) s pomočjo sobesedila«.

\section{$7 \quad$ Povezanost glasovnega zavedanja in glasbenih sposobnosti}

Glasba s svojo integrativno razsežnostjo predstavlja učinkovito sredstvo celostnega spodbujanja razvoja otrokovih sposobnosti (Sicherl - Kafol 2001). Vpliv glasbe na različne funkcije človeškega delovanja je prvi dokazal Tomatis (1950, v Campbell 2004) in v raziskavi potrdil, da poslušanje Mozartove glasbe in materinega glasu pri otrocih izboljša slušne in govorne sposobnosti, njihovo čustveno stabilnost in miselno prožnost. Povezanost glasovnega zavedanja in glasbenih sposobnosti so v svojih empiričnih raziskavah potrdili tudi Božič, Habe in Jerman (2007) ter Zrimšek (2003: 147), ki navaja, da ima s splošnim glasovnim zavedanjem in glaskovanjem največjo povezavo melodični posluh, z zaznavanjem zadnjega zloga ritmični posluh. Pevska tehnika se v največji meri povezuje z zaznavanjem dolžine besed, zadnjega zloga in rimami. Otrok pridobi s petjem tudi občutek za stavčno melodijo, besedne 
in stavčne poudarke. Ritmična ustvarjalnost korelira $z$ zaznavanjem prvega in zadnjega zloga, spretnost igranja na otroška glasbila ima povezavo z glaskovanjem. Z glasbenimi sposobnostmi se najpogosteje povezuje glaskovanje, sledi mu zaznavanje zadnjega zloga, vse glasbene sposobnosti pa pomembno korelirajo s slušnim razločevanjem in razčlenjevajem. Lever (2001, v Zrimšek 2003: 91) meni, da k razvoju glasovnega zavedanja najučinkoviteje pripomorejo otroške igre (igranje z glasovi, petje pesmi, ritmično izgovarjanje izštevank, igranje na inštrumente ...), povezane $z$ glasbo, saj sta jezik in glasba $v$ dinamičnem odnosu, ki omogoča pomnjenje sestavljenih jezikovnih struktur in težko izgovorljivih glasovnih sklopov. Božič, Habe in Jerman (2007: 49) ugotavljajo, da ima zvok besede ali melodije do otroka podobne zahteve, zato se lahko s pomočjo enega približa tudi drugemu. Pomembno vlogo pri razvijanju fonološkega zavedanja in glasbenih sposobnosti ima okolje, ki lahko otroku nudi veliko možnosti, zato opozarjajo na pomen načrtovanja pedagoškega procesa, ki z glasbenimi dejavnostmi prepoznavanja melodičnih in ritmičnih vzorcev pomembno vpliva na otrokovo uspešnost pri branju in s tem tudi na ostale šolske dejavnosti, ne glede na starostno obdobje učečega se (npr. Tivadar 2018: 5, 14-15).

\section{8}

\section{Sklep}

Osrednjo vlogo pri učenju branja in pisanja $\mathrm{v}$ abecednem sistemu pisave ima fonološko oziroma glasovno zavedanje, ki omogoča razločevanje, združevanje in upravljanje glasovnih enot različnih velikosti. Sestavljeno je iz različnih ravni, posamezne ravni se kronološko razvijajo in so pogojene $z$ miselnim razvojem otrok. $\mathrm{V}$ prispevku je podrobneje predstavljeno glasovno zavedanje, razvijanje po posameznih ravneh, ki napovedujejo uspešnost pričetka opismenjevanja in pozneje boljše bralne zmožnosti otrok in mladostnikov. Sodobne raziskave potrjujejo, da sistematično in načrtno razvijanje sposobnosti glasovnega zavedanja izboljšuje bralno zmožnost otrok in mladostnikov, a je hkrati kompleksno in zahteva veliko znanja o glasovnem sistemu ter pisavi jezika, o samem razvoju glasovnega zavedanja in dejavnikih, ki vplivajo na zahtevnost fonološkega procesiranja jezika. Spodbujanje fonološkega zavedanja omogoča, ne glede na stopnjo izobraževanja, tudi medpredmetno povezovanje, ki $\mathrm{k}$ razvoju, sploh $\mathrm{v}$ prvih obdobjih formalnega izobraževanja, najučinkoviteje pripomore $\mathrm{z}$ didaktičnimi igrami, povezanimi $\mathrm{z}$ glasbo, saj sta jezik in glasba $v$ dinamičnem odnosu, ki omogoča pomnjenje sestavljenih jezikovnih struktur in težko izgovorljivih glasovnih sklopov. Vsekakor pa je sistematično nadgrajevanje vseh elementov gradnika glasovno zavedanje na 
vseh stopnjah izobraževanja in na vseh predmetnih področjih, ne zgolj na področju (slovenskega) jezika, nujno potrebno, za kar je ključnega pomena ustrezna kompetentnost učitelja ne glede na njegovo temeljno predmetno področje.

\section{Opomba}

Avtorica Melita Zemljak Jontes je prispevek napisala v okviru projekta OBJEM - Bralna pismenost in razvoj slovenščine (Ozaveščanje, Branje, Jezik, Evalvacija, Modeli), šifra projekta OP20.01462, vodja dr. Sandra Mršnik, ki ga vodi Zavod RS za šolstvo. Naložbo sofinancirata Republika Slovenija in Evropska unija iz Evropskega socialnega sklada.

\section{Literatura}

Barbara BEDNJIČKI ROŠER, 2017: Slikanice in branje za zgodnje opismenjevanje. Kako razvijati družinsko pismenost v predšlskem obdobju. Ur. Marta Licardo in Dragica Haramija. Maribor: Univerzitetna založba Univerze. 53-62.

Barbara BEDNJIČKI ROŠER, 2019: Medkulturna vzgoja v vrtcu. Migracije v slovanskem prostoru v 20. in 21. stoletju. Ur. Rok Mrvič, Lidija Rezoničnik, Branislava Vičar in Nina Zavašnik. Ljubljana: Zveza društev Slavistično društvo Slovenije. 145-159.

Barbara BEDNJIČKI ROŠER, 2020: Sožitje različnosti bogati. V agojno izobraževalne potrebe predšolskega otroka. Ur. Maruška Željeznov Seničar. Ljubljana: MIB. 119-122.

Marja BEŠTER TURK, 2011: Sporazumevalna zmožnost - eden izmed temeljnih ciljev pouka slovenščine. Jerik in slovstvo 56(3-4). 122-127.

Anja BOŽIČ, Katarina HABE in Janez JERMAN, 2007: Povezanost glasbenih sposobnosti in fonološkega zavedanja pri predšolskih otrocih. Psibološka obrorja, 16(1). 39-52.

Nataša BUCIK, 2009: Didaktične igre za spodbujanje porajajoče se pismenosti. Branje za znanje in branje za zabavo. Ur. Livija Knaflič in Nataša Bucik. Ljubljana: Andragoški center Slovenije.

Dušanka BRUMEN, 2012: Glasovno zavedanje v prvem razredu. Revija za elementarno izobraževevanje, 5(4). 73-86.

Don G. CAMPBELL, 2004: Mozart za otroke: prebujanje otrokove ustvarjalnosti in mišljenja s pomočjo glasbe. Ljubljana: Tangram.

Igor CVETKO in Eva D. BAHOVEC, 2011: Kurikulum za vrtce. Ljubljana: Zavod Republike Slovenije za šolstvo.

Gabi ČAČINOVIČ VOGRINČIČ, 2008: Soustvarjanje v šoli. Ljubljana: Zavod RS za šolstvo.

Lucija ČOK in Anita BRČANINOVIĆ, 2015: Z igro glasov v angleškem jeziku do razvijanja fonološkega zavedanja. Revija za elementarno iz̧obraževanje 8(1-2). 147-166.

Mladen DOLAR, 2003: O glasu. Ljubljana: Društvo za teoretsko psihoanalizo (Zbirka Analecta).

Marija GRGINIČ, 2005: Porajajoča se pismenost. Domžale: Izolit.

Marija GRGINIČ, 2008: Vsak po svoji poti do pismenosti. Priročnik za vagojitelje in starše predšolskih otrok. Mengeš: Založba Izolit.

Marija GRGINIČ, 2009: ABC karte. Mengeš: Izolit.

Dragica HARAMIJA in Janja BATIČ, 2013: Poetika slikeanice. Murska Sobota: Podjetje za promocijo kulture Franc-Franc.

Luka HORJAK in Hotimir TIVADAR, 2019: Odprta vprašanja kodifikacije in smiselno univerzitetno poučevanje slovenskega govorjenega jezika. Govor v pedagoški praksi. Ur. Katarina Podbevšek, Nina Žavbi. Ljubljana: Znanstvena založba Filozofske fakultete Univerze v Ljubljani (Akademija za gledališče, radio, film in televizijo Univerze v Ljubljani). 151-158. https://eknjige.ff.uni-li.si/znanstvena-zalozba/catalog/view/185/283/4874-1

Dora JELENC, 1997: Pomen fonološkega zavedanja za začetno branje in pisanje otrok s posebnimi potrebami. Uresničevanje integracije v praksi. Ur. Karl Destovnik. Ljubljana: Društvo defektologov Slovenije. 288-296. 
Jožica JOŽEF BEG, 2019: Govorna interpretacija literarnega besedila v gimnaziji. Govor v pedagoški praksi. Ur. Katarina Podbevšek, Nina Žavbi. Ljubljana: Znanstvena založba Filozofske fakultete Univerze v Ljubljani (Akademija za gledališče, radio, film in televizijo Univerze $\mathrm{v}$ Ljubljani). $95-102$. https://e-knjige.ff.uni-lj.si/znanstvenazalozba/catalog/view/185/283/4868-1

Katalog znanja za slovenšcino (SSI), 2010.

http://portal.mss.edus.si/msswww/programi2015/programi/SSI/KZ-IK/katalog.htm

Katalog znanja za slovenšcino (PTI).

http://portal.mss.edus.si/msswww/programi2015/programi/SSI/KZ-IK/katalog.htm

Katarina KEJŽAR, 2019: Učim - torej govorim. Govor v pedagoški praksi. Ur. Katarina Podbevšek, Nina Žavbi. Ljubljana: Znanstvena založba Filozofske fakultete Univerze v Ljubljani (Akademija za gledališče, radio, film in televizijo Univerze $\mathrm{v}$ Ljubljani). 65-73. https://e-knjige.ff.unilj.si/znanstvena-zalozba/catalog/view/185/283/4865-1

Helena KOROŠEC, 2019: Komunikacijski potenciali lutke kot spodbuda za učenje govora. Govor v pedagoški praksi. Ur. Katarina Podbevšek, Nina Žavbi. Ljubljana: Znanstvena založba Filozofske fakultete Univerze v Ljubljani (Akademija za gledališče, radio, film in televizijo Univerze v Ljubljani). 39-46. https://e-knjige.ff.uni-lj.si/znanstvenazalozba/catalog/view/185/283/4862-1

Janko KOS, 2001: Literarna teorija. Ljubljana: DZS, Založništvo in trgovina, d. d.

Boža KRAKAR VOGEL, 2004: Poglavja iz didaktike književnosti. DZS.

Martina KRIŽAJ ORTAR, Marja BEŠTER in Erika KRŽIŠNIK, 1994: Pouk slovenščine malo drugače. Trzin: Založba Different.

Olga KUNST GNAMUŠ, 1984: Govorno dejanje - dru乏̌beno dejanje. Ljubljana: Pedagoški inštitut pri Univerzi Edvarda Kardelja Ljubljana.

Olga KUNST GNAMUŠ, 1991: Sporazumevanje med そ̌eljo, resnico in učnkom. Ljubljana: Slovensko društvo raziskovalcev šolskega polja.

Olga KUNST GNAMUŠ, 1992: Sporazumevanje in spoznavanje jez̨ika. Ljubljana: Državna založba Slovenije.

Jože LIPNIK, 1994a: Mali čvek. Zbirka besedil h knjigi Metodika govorne vaggje. Maribor: Založba Obzorja Maribor.

Jože LIPNIK, 1994b: Govorne igre in jezikovna ustvarjalnost otrok. Pedagoška obzorja 9(1). 24-35.

Jože LIPNIK in Radomir MATIĆ, 1993: Metodika govorne vagoje. Priročnik za delo vagojiteljic in staršev. Maribor: Založba Obzorja Maribor.

Lidija MAGAJNA, 2000: Razvoj glasovnega zavedanja in začetno branje. Slovenščna v 1. triletju devetletne osnovne sole. Ur. Martina Križaj Ortar. Trzin: Izolit.

Darinka MARC in Katarina TORKAR PAPEŽ, 2006: Kultura govorjene in zapisane besede ali Retorika za današnjo rabo. Ljubljana: DZS, Založništvo in trgovina, d. d.

Darinka MARC in Katarina TORKAR PAPEŽ, 2019: Kultura govorjene besede. Govor v pedagoški praksi. Ur. Katarina Podbevšek, Nina Žavbi. Ljubljana: Znanstvena založba Filozofske fakultete Univerze v Ljubljani (Akademija za gledališče, radio, film in televizijo Univerze v Ljubljani). 103-111.

https://e-knjige.ff.uni-lj.si/znanstvena-zalozba/catalog/view/185/283/4869-1

Martina OZBIČ idr., 2014: Transkripcija govora kot osnovna veščina za natančen zapis in analizo govora: primer poučevanja študentov logopedije in surdopedagogike na Pedagoški fakulteti v Ljubljani. EDUvision 2014 »Sodobni pristopi poučevanja pribajajoč́h generacij«. Ur. Mojca Orel. Ljubljana (Polhov Gradec): EDUvision, Stanislav Jurjevčič, s. p. 500-506. http://eduvision.si/Content/Docs/Zbornik\%20EDUvision\%202014.pdf

Sonja PEČJAK, 2010: Psibološki vidiki bralne pismenosti: od teorije k praksi. Ljubljana: Znanstvena založba Filozofske fakultete.

Sonja PEČJAK, 2009: Z igro razvijamo komunikacijske sposobnosti ucencev. Ljubljana: Zavod Republike Slovenije za šolstvo.

Sonja PEČJAK, 2004: Dejavniki začetnega učenja branja in pisanja. ABC igralnica: priročnik za učitelje. Ur. Marija Grginič, Maja Zupančič. Domžale: Izolit. 
Sonja PEČJAK, 2003: Porajajoča se pismenost. Beremo skupaj. Priročnik za spodbujanje branja. Ur. Marina Blatnik Mohar. Ljubljana: Mladinska knjiga. 119-123.

Tomaž PETEK, 2019a: Govorno nastopanje v pedagoškem procesu. Ljubljana: Pedagoška fakulteta.Tomaž PETEK, 2019b: Kako izboljšati govorno nastopanje učiteljev. Govor v pedagoški praksi. Ur. Katarina Podbevšek, Nina Žavbi. Ljubljana: Znanstvena založba Filozofske fakultete Univerze v Ljubljani (Akademija za gledališ̌ce, radio, film in televizijo Univerze v Ljubljani). 141-158. https://e-knjige.ff.uni-lj.si/znanstvena-zalozba/catalog/view/185/283/4873-1

Uíni načrt. Slovenšcina: gimnazija: splošna, klasična, strokovna gimnarija, 2008. Ljubljana: Ministrstvo za šolstvo in šport, Zavod RS za šolstvo.

http://eportal.mss.edus.si/msswww/programi2020/programi/media/pdf/un_gimnazija/un_slovens cina_gimn.pdf

Mojca POZNANOVIČ JEZERŠEK, Mojca CESTNIK, Milena ČUDEN, Vida GOMIVNIK THUMA, Mojca HONZAK, Martina KRIŽAJ ORTAR, Darinka ROSC LESKOVEC in Marija ŽVEGLIČ 2011a: Učni načrt za slovenščno kot drugi tuji jezile (dvojezična osnovna šola). Ljubljana: Ministrstvo za šolstvo in šport, Zavod RS za šolstvo.

https://www.gov.si/assets/ministrstva/MIZS/Dokumenti/Osnovna-sola/Ucninacrti/obvezni/UN_slovenscina_DOS.pdf

Mojca POZNANOVIČ JEZERŠEK, Mojca CESTNIK, Milena ČUDEN, Vida GOMIVNIK THUMA, Mojca HONZAK, Martina KRIŽAJ ORTAR, Darinka ROSC LESKOVEC in

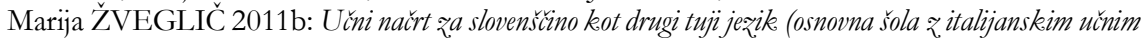
načrtom). Ljubljana: Ministrstvo za šolstvo in šport, Zavod RS za šolstvo. https://www.gov.si/assets/ministrstva/MIZS/Dokumenti/Osnovna-sola/Ucninacrti/obvezni/UN_slovenscina_OSIJ.pdf

Ǔ́ni naŭrt. Program osnovna šola. Slovenščna, 2018. Ljubljana: Ministrstvo za šolstvo in šport, Zavod RS za šolstvo.

http://www.mizs.gov.si/fileadmin/mizs.gov.si/pageuploads/podrocje/os/prenovljeni_UN/ UN_slovenscina.pdf

Simona PULKO, 2007: Sporočanje v osnovni šoli. Maribor: Dravska tiskarna. 36-37.

Simona PULKO, 2019: Poučevanje govora v učnih načrtih za osnovno šolo, srednje šole in gimnazije. Govor v pedagoški praksi. Ur. Katarina Podbevšek, Nina Žavbi. Ljubljana: Znanstvena založba Filozofske fakultete Univerze v Ljubljani (Akademija za gledališče, radio, film in televizijo Univerze v Ljubljani). 85-92. https://e-knjige.ff.uni-lj.si/znanstvenazalozba/catalog/view/185/283/4867-1

Alenka ROT VRHOVEC, 2019: Možnosti za razvijanje govorjenja učencev v 1. in 2. triletju osnovne šole. Govor v pedagoški praksi. Ur. Katarina Podbevšek, Nina Žavbi. Ljubljana: Znanstvena založba Filozofske fakultete Univerze v Ljubljani (Akademija za gledališče, radio, film in televizijo Univerze v Ljubljani). 57-64. https://e-knjige.ff.uni-lj.si/znanstvenazalozba/catalog/view/185/283/4864-1

Barbara SICHERL - KAFOL, 2001: Celostna glasbena vagoja. Ljubljana: Debora.

Janez SKELA, 2005: The Communicative Approach to Foreign Language Teaching: Naturally Rational or Rationally Natural? Vestnik Drustva za tuje jezike in književnosti Slovenije 39(1-2). 93-112.

Janez SKELA, 2010: Tuji jeziki in materinščina: vljudni gostje v našem domu ali vsiljivci? Pot kejerikovni politiki v izobraževanju. Ljubljana: Zavod RS za šolstvo. 136-164.

SEJO. Skupni evropski jerikeovni okvir: ǔenje, poučevanje, ocenjevanje. 2011. Ljubljana: Ministrstvo RS za šolstvo in šport, Urad za razvoj šolstva. https://centerslo.si/wp-content/uploads/2015/10/SEJO-komplet-za-splet.pdf

Stephanie SCHMITZ, 2011: The Development of Phonological Awareness in Young Children: Examining the Effectiveness of a Phonological Awareness Program. https: / / digitalcommons.unl.edu/cgi/viewcontent.cgi? referer $=\&$ httpsredir $=1 \&$ article $=1113 \&$ context $=$ cehsdiss

Aleksandra ŠTIH, 2016: Pravorě̌na żmožnost dijakov med govornim nastopanjem pri pouku slovenščne v splošni gimnaziji. Magistrsko delo. Maribor: Filozofska fakulteta Univerze v Mariboru. https://dk.um.si/Dokument.php?id=107367 
Hotimir TIVADAR, 2015: Vloga pravorečja in njegovo poučevanje v slovenskem osnovno- in srednješolskem izobraževanju. Jerik in slovstvo 60(3-4). 161-172.

Hotimir TIVADAR, 2018: Različni pristopi poučevanja govora. Ljubljana: Filozofska fakulteta, Junijsko izobraževanje Centra za SDT.

https://centerslo.si/wpcontent/uploads/2015/12/Tivadar_izrocek_2018_Center.pdf

Alenka VALH LOPERT, 2019: Kultura govora za študente Medijskih komunikacij (UM FERI). Govor $v$ pedagoški praksi. Ur. Katarina Podbevšek, Nina Žavbi. Ljubljana: Znanstvena založba Filozofske fakultete Univerze v Ljubljani (Akademija za gledališče, radio, film in televizijo Univerze v Ljubljani). 131-139.

https://e-knjige.ff.uni-lj.si/znanstvena-zalozba/catalog/view/185/283/4872-1

Maja VIŠČEK, 2019: Skrb za govor v vrtcu. Govor v pedagoški praksi. Ur. Katarina Podbevšek, Nina Žavbi. Ljubljana: Znanstvena založba Filozofske fakultete Univerze v Ljubljani (Akademija za gledališce, radio, film in televizijo Univerze $\mathrm{v}$ Ljubljani). 25-37. https://e-knjige.ff.unilj.si/znanstvena-zalozba/catalog/view/185/283/4861-1

Jerca VOGEL, 2015: Modeli jezikovnega pouka pri predmetu slovenščina od leta 1990 do danes. Jezile in slovstvo 60 (3-4). 173-183.

Renata ZADRAVEC PEŠEC, 1994: Pragmatično jerikeslovje. Temeljni pojmi. Ljubljana: Pedagoški inštitut, Center za diskurzivne študije.

Davey ZEECE, 2006: Sound Reading and Reading Sounds: The Case for Phonemic Awareness. https://faculty.sfcc.spokane.edu/InetShare/AutoWebs/kimt/Sound $\% 20$ reading\%20and $\% 20$ reading $\% 20$ sounds.pdf

Melita ZEMLJAK JONTES, 2017: Čebljavčki, brbljavčki, čvekavčki in Mali čvek Jožeta Lipnika. Med didaktiko slovenskega jerikea in poerijo: ob 80-letnici Jožeta Lipnika $=$ When Slovene language didactics meets poetry: Jože Lipnik's 80th anniversary. Ur. Marko Jesenšek. Maribor: Univerzitetna založba Univerze (Mednarodna knjižna zbirka Zora, 119). 42-53.

Melita ZEMLJAK JONTES, 2019: Kultura govora v študijskem programu Slovenski jezik in književnost (UM FF). Govor v pedagoški praksi. Ur. Katarina Podbevšek, Nina Žavbi. Ljubljana: Znanstvena založba Filozofske fakultete Univerze v Ljubljani (Akademija za gledališče, radio, film in televizijo Univerze v Ljubljani). 123-130. https://e-knjige.ff.uni-lj.si/znanstvenazalozba/catalog/view/185/283/4872-1

Melita ZEMLJAK JONTES in Alenka VALH LOPERT, 2016: Pismenost v teoriji in praksi - temelini cilj slovenskega institucionalnega izobraževalnega sistema. Annales: analiza istrske in mediteranske studije, Series historia et sociologia 26(1). 95-106. ŽĐ https://zdjp.si/wp-content/uploads/2016/06/ASHS_26-2016-1_ZEMLJAK.pdf

Anja ZORMAN, 2018: Pismenost. https://studentski.net/gradivo/upr_pfk_rp1_pis_sno_skripta_01

Anja ZORMAN, 2013: Razvoj osnovne pismenosti enojezičnih in večjezičnih otrok. Koper: Univerza na primorskem, Znanstveno-raziskovalno središče, Univerzitetna založba Annales.

Anja ZORMAN, 2007: Prepoznavanje glasov in spoznavanje njihovih pisnib ustreznic v maternem in drugem oz: tujem jerikeu. Doktorska disertacija. Univerza v Ljubljani: Pedagoška fakulteta.

Anja ZORMAN, 2005: Glasovno zavedanje in razvoj osnovne pismenosti v prvem, druge/tujem jeziku. Sodobna pedagogika 56 (posebna izd.). 24-45.

Nataša ZRIMŠEK, 2003: Začetno opismenjevanje. Ljubljana: Pedagoška fakulteta.

Janja ŽMAVC, 2019: Nekoč k retorju in gledališkemu igralcu - kam pa danes? (Poskus kritičnega pogleda na kurikularne umestitve govornega nastopa v okviru osnovnošolskega izobraževanja). Govor v pedagoški praksi. Ur. Katarina Podbevšek, Nina Žavbi. Ljubljana: Znanstvena založba Filozofske fakultete Univerze $\mathrm{v}$ Ljubljani (Akademija za gledališče, radio, film in televizijo Univerze v Ljubljani). 75-84.

https://e-knjige.ff.uni-lj.si/znanstvena-zalozba/catalog/view/185/283/4866-1. 


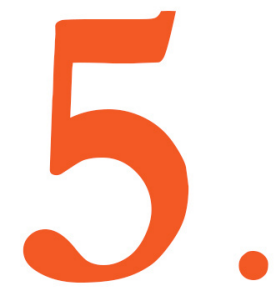

G R A D N I K

BESEDIŠČE

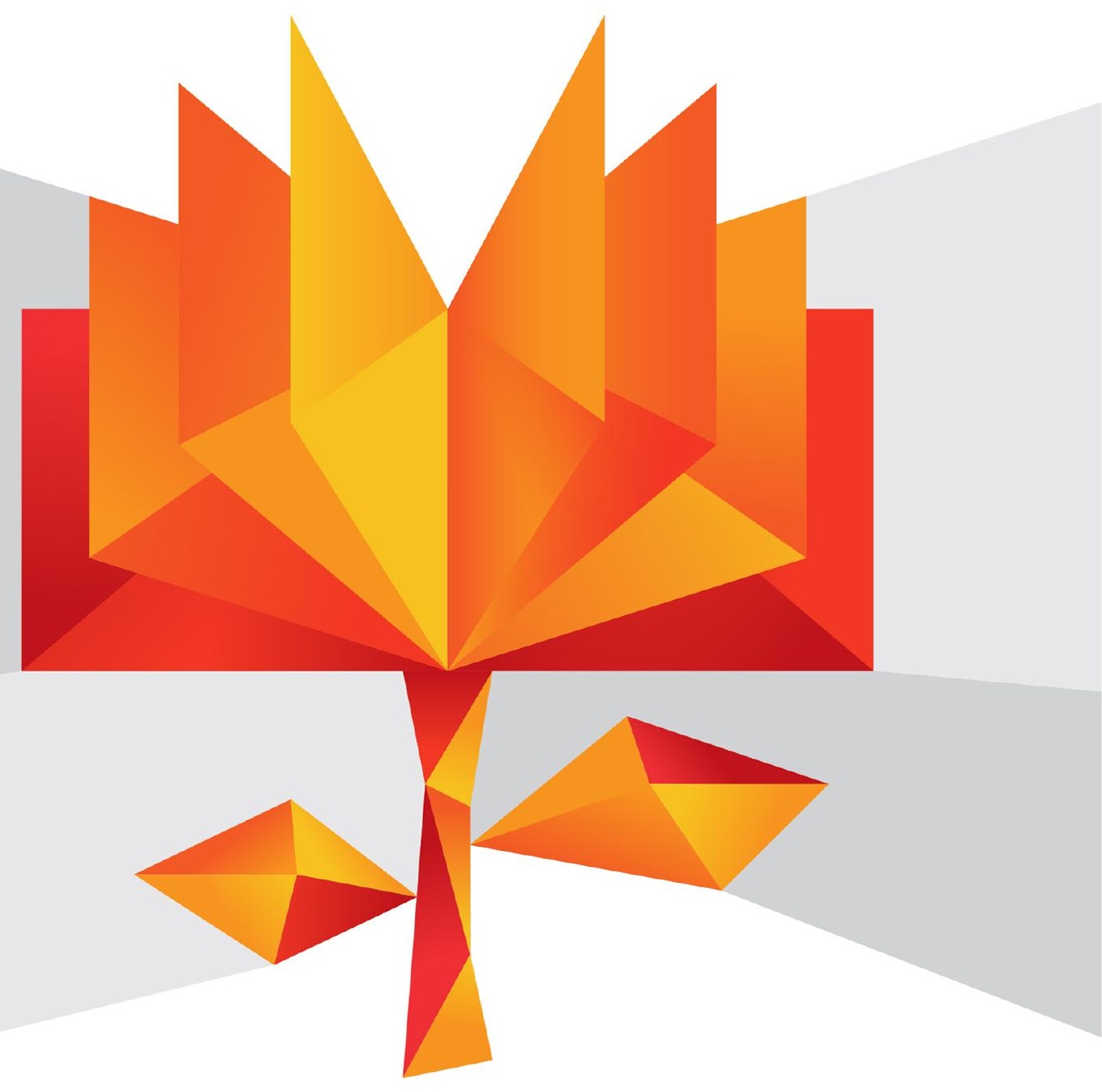


Elementi gradnika:

- razumevanje pomena besed in njihova uporaba pri sprejemanju in tvorjenju besedil

- širjenje in usvajanje besedišča za uspešno branje $z$ razumevanjem, učenje in sporazumevanje

- uporaba jezikovnih virov in priročnikov 


\section{GRADNIK: BESEDIŠČE}

\author{
INES VORŠIČ ${ }^{1,2}$ IN MARIJA ROPIČ KOP ${ }^{1}$ \\ ${ }^{1}$ Univerza v Mariboru, Pedagoška fakulteta, Maribor, Slovenija. \\ E-pošta: ines.vorsic@um.si,marija.ropic@um.si \\ 2 Univerza v Mariboru, Filozofska fakulteta, Maribor, Slovenija. \\ E-pošta: ines.vorsic@um.si
}

Povzetek Človek je edino bitje, ki se sporazumeva s pomočjo besednega jezika. Da razvije to sposobnost, potrebuje bogato besedišče, saj mora najprej ustrezno poimenovati prvine predmetnega in duhovnega sveta. Za uspešno sodelovanje $\mathrm{v}$ komunikacijskem procesu pa mora obvladati tudi slovnična, pravopisna in pravorečna pravila ter pragmatična načela. Osnovo celovitemu razvoju sporazumevalne zmožnosti tako predstavlja obvladovanje besedišča, ki ga je treba intenzivno razvijati že v predšolskem obdobju - obseg besedišča otrok se namreč nenehno potrjuje kot temeljni napovedovalec bralne pismenosti. $\mathrm{V}$ zgodnjem otroštvu otrok usvaja temeljne poimenovalne in slovnične prvine besednega jezika, proces razvijanja in širjenja besedišča pa se nato skladno z didaktičnimi priporočili iz učnih načrtov poglablja do zaključka srednje šole. Prispevek predstavlja besedišče kot ključen element bralne pismenosti, ki zajema usvajanje in širjenje besedišča, razumevanje pomena besed in njihovo rabo pri sprejemanju in tvorjenju različnih besedil ter uporabo jezikovnih virov in priročnikov. Ker se jezik nenehno razvija, na področju besedišča še posebej dinamično, ga nihče nikoli ne more do popolnosti obvladovati. Zato je širjenje besednega zaklada vseživljenjska dejavnost slehernega človeka.
Ključne besede: gradniki bralne pismenosti, besedišče, usvajanje besedišča, širjenje besedišča, jezikovni viri in priročniki. 


\title{
THE FIFTH COMPONENT OF READING LITERACY: VOCABULARY
}

\author{
INES VORŠIČ $\check{1}^{1,2} \&$ MARIJA ROPIČ KOP ${ }^{1}$ \\ ${ }^{1}$ University of Maribor, Faculty of Education, Maribor, Slovenija. \\ E-mail: ines.vorsic@um.si,marija.ropic@um.si \\ ${ }^{2}$ University of Maribor, Faculty of Arts, Maribor, Slovenija. \\ E-mail: ines.vorsic@um.si
}

\begin{abstract}
Man is the only being who communicates through verbal language. To develop this ability, he needs a rich vocabulary, as he must first appropriately name the elements of the material and spiritual world. In order to successfully participate in the communication process, he must also master grammatical, orthographic and orthoepic rules and pragmatic principles. The basis for the comprehensive development of communicative ability is thus mastery of vocabulary, which must be intensively developed in the preschool period - the extent of children's vocabulary is constantly confirmed as a fundamental predictor of reading literacy. In early childhood, the child learns basic naming and grammatical elements. The process of developing and expanding vocabulary is then deepened in accordance with the didactic recommendations until the end of high school. The paper presents vocabulary as a key element of reading literacy, which includes the acquisition and expansion of vocabulary, understanding the meaning of words and their use in the reception and creation of various texts, and the use of language resources and manuals. Because language is constantly evolving, especially dynamically in the field of vocabulary, no one can ever master it to perfection. Therefore, expanding vocabulary is a lifelong activity of every human being.
\end{abstract}

Keywords: components of reading literacy, vocabulary, vocabulary acquisition, vocabulary expansion, language resources and manuals. 


\section{Uvod}

Človek je edino bitje, ki mu je dano, da svoje želje, potrebe in čustva ubesedi in se z drugimi sporazumeva s pomočjo besednega jezika. Da razvije sposobnost izraziti svoja občutja in misli, pa potrebuje bogato besedišče, saj mora najprej ustrezno poimenovati prvine predmetnega in duhovnega sveta. Vendar za uspešno sodelovanje $\mathrm{v}$ komunikacijskem procesu ne zadošča le poznavanje pomena, temveč je treba obvladati slovnična pravila za pregibanje in tvorbo besed ter sestavljanje povedi; hkrati pa mora udeleženec govornega dejanja poznati tudi pragmatična načela, kdaj, s kom, kako, o čem govoriti (Kranjc 1996). Sporazumevanje v maternem jeziku je pogoj za razvoj vseh drugih bistvenih zmožnosti (Bešter Turk 2011: 112), ki jih človek potrebuje za celosten razvoj, socialno vključenost in delovanje $v$ družbi nasploh ter ne nazadnje za oblikovanje osebne in narodne identitete, ustvarjalnost, kritičnost, gospodarnost ipd. Zato je za vsakega posameznika oziroma posameznico zelo pomembno pridobivanje oziroma sistematično razvijanje sporazumevalne zmožnosti, ki vznika iz leksikalne zmožnosti, tj. iz poznavanja besed in njihove rabe. Obenem so vse pogostejše raziskave, ki obvladovanje besedišča izpostavljajo kot temeljni element razvoja bralne pismenosti. Besedišče sodi med ključne kognitivne dejavnike, ki neposredno napovedujejo razumevanje prebranega (Pečjak, Bucik, Peštaj, Podlesek in Pirc 2010). $\mathrm{V}$ prispevku zato natančneje predstavljamo gradnik besedišče kot element bralne pismenosti, ki zajema usvajanje in širjenje besedišča za uspešno branje $\mathrm{z}$ razumevanjem, učenje in sporazumevanje, razumevanje pomena besed in njihovo uporabo pri sprejemanju in tvorjenju besedil ter uporabo jezikovnih virov in priročnikov.

\section{Besedišče in razvoj besedišča kot osnova za razvoj sporazumevalne (jezikovne) zmožnosti}

Besede so najmanjše pomensko samostojne enote stavčne povedi oziroma najmanjše enote najmanjšega možnega sporočila; navadno jih pojmujemo kot nerazdružne pomenonosne enote iz glasov (Toporišič 2000: 103). Z besedami človek izraža svoja občutja, želje, potrebe, misli, stališča, vrednote, prepričanja. Zato so tudi z vidika slovnice (Toporišič 2000: 116) besede kot nosilci stvarnih (npr. hrast, plesati, rjav) in slovničnih pomenov (npr. $p a, i \vartheta$ najvažnejši del jezikovne zgradbe, ki ga imenujemo besedje, tudi besedišče, besednjak in besedni zaklad ter redkeje slovar (v 2. pomenu SSKJ 2). 
Zmožnost sporazumevanja z drugimi je ena od bistvenih človekovih preferenc. Sporazumevalne dejavnosti namreč človeku omogočajo zmožnost ubesedovanja vsega predmetnega in pojmovnega in s tem zadovoljevanje čustvenih in družbenih potreb. Z razvijanjem komunikacijske kompetence se razvija človekova sposobnost delovanja $\mathrm{v}$ družbi ter olajša spoznavanje sveta in življenjskih danosti. Besedišče kot vitalen element sporazumevalne zmožnosti pa je eden najmočnejših kazalcev bralnega razumevanja. Številne raziskave (npr. Muter, Hulme, Snowling in Stevenson 2004; Share in Leikin 2004, v Kolić-Vehovec, Pečjak, Ajdišek in Rončević 2008: 93) obseg besednjaka potrjujejo kot najmočnejšo prediktorsko spremenljivko bralnega razumevanja otrok ${ }^{1}$ in relevanten napovedovalec poznejše akademske pismenosti $\mathrm{v}$ vseh pogledih. Zato je temelje za razvoj otrokovega besedišča treba vzpostaviti že zelo zgodaj, jih intenzivno širiti v predšolskem obdobju in nato poglabljati na vseh izobraževalnih stopnjah, in sicer na vseh predmetnih področjih. V nadaljevanju podrobneje predstavljamo razvijanje in usvajanje besedišča $\mathrm{v}$ različnih (izobraževalnih) obdobjih.

\subsection{Besedišče v predšolskem obdobju}

Razvoj besedišča se prične že ob rojstvu otroka. Novorojenčki imajo namreč sposobnost razlikovanja glasov v vseh jezikih, približno do 6. meseca pa pozornost že usmerijo na specifične glasove maternega jezika (Marjanovič Umek in Fekonja 2019: 2). Tako otrok veliko besed prepozna in razume, še preden spregovori prvo besedo. Ko izgovori prvo besedo, pa se začne njegov govor silovito razvijati.

Prva beseda je skupina glasov s pomenom. Opredeliti jo je mogoče s pomočjo treh meril (Whitehead 1999, v Marjanovič Umek in Fekonja 2019: 2): (1) otrok govori besedo spontano; (2) otrok uporablja besedo za označevanje iste osebe, predmeta ali dejavnosti; (3) otrokovo besedo prepozna odrasla oseba v različnih situacijah. Pri uporabi prvih besed obstaja med otroki velika podobnost; govorijo o osebah, ki so jim blizu in so v njihovem neposrednem okolju (npr. mama, oče), o vozilih, hrani, obleki, predmetih, ki jih zanimajo, igračah, živalih, okolju, v katerem živijo. Med prvimi besedami so tudi takšne, ki se nanašajo na socialne interakcije (Marjanovič Umek in Fekonja 2019: 10). Prevladujejo torej besede, ki jih odrasli v okolju uporabljajo pri dnevnih rutinskih opravilih in dejavnostih, otroci pa prve izgovorjene

\footnotetext{
${ }^{1}$ Kot ugotavljajo strokovnjaki (npr. Nagy in Scott 2000, v Pečjak, Bucik, Peštaj, Podlesek, Pirc 2010) je za ustrezno razumevanje besedila potrebno, da oseba razume od 90 do 95 odstotkov besed.
} 
besede navadno pospremijo z gestami (Krajnc Ivič, Pulko, Ropič in Zemljak Jontes 2017: 62).

Večina otrok prve besede spregovori med 12. in 20. mesecem starosti. V tem obdobju poteka razvoj besedišča izjemno hitro, tako v količinskem kot kakovostnem smislu. Bates, Marchman, Thal, Fenson, Dale, Reily idr. (1994, v Marjanovič Umek in Fekonja 2019: 2) so v raziskavi, $\mathrm{v}$ kateri so besedišče s posebno standardizirano listo ocenjevale mame, dognali, da dojenčki, stari 12 mesecev, govorijo od 0 do 52 besed, otroci, stari 16 mesecev, od 0 do 347 besed, otroci, stari 30 mesecev, pa od 208 do 675 besed. Ko otrokov besednjak obsega približno 150 besed, se njegov govor praviloma začne razvijati zelo hitro, kar pomeni, da v povprečju usvoji 3 nove besede na teden, $v$ času hitrega razvoja oziroma $v$ času t. i. skokov $v$ razvoju besednjaka pa od 8 do 10 besed dnevno (Karmiloff in Karmiloff-Smith 2001, v Marjanovič Umek in Fekonja 2019: 2). V razvoju besedišča se največkrat izpostavljata dva t. i. skoka, in sicer se prvi pojavi med 16. in 20. mesecem, drugi pa med 24. in 30. mesecem starosti (Marjanovič Umek in Fekonja 2019: 2).

S starostjo otrok se spreminja tudi raba posameznih besednih vrst. Med 11. in 14 . mesecem otrok uporablja medmete in samostalnike (Marjanovič Umek, Božin, Čermak Hauko, Štiglic Hribernik, Bajc in Fekonja Peklaj 2016). Kot pojasnjuje Simona Kranjc (1996: 319), raba medmetov ni presenetljiva, saj gre za prvo obdobje jezikovne faze $v$ razvoju govora, ki je nekakšen prehod iz t. i. predjezikovnega obdobja; raba samostalnikov pa dokazuje, da je otrokov govor v tem obdobju še zelo konkreten. Nove besedne vrste, in sicer glagoli, pridevniki, zaimki, prislovi in členki, se pojavijo med 19. in 22. mesecem, na vse besedne vrste pa se otrokovo besedišče razširi okrog 30. meseca starosti (Marjanovič Umek, Božin, Čermak Hauko, Štiglic Hribernik, Bajc in Fekonja Peklaj 2016), ko začne otrok uporabljati še funkcijske besede, kot so vezniki in predlogi. Otrok torej sprva tvori enobesedne izjave (npr. muca v pomenu vidim muco), nato sledijo dvobesedne izjave (npr. Vidim muco.); to pomeni, da otrok uporablja polnopomenske besede oziroma besede, ki po njegovi presoji najnatančneje odražajo to, kar je želel sporočiti (Krajnc Ivičc, Pulko, Ropič in Zemljak Jontes 2017: 62). Napredek malčka v skladenjskem razvoju se kaže $\mathrm{v}$ dodajanju pridevniških besed (npr. bela muca) in mesta nahajanja predmetov (npr. muca postelja); med 24. in 27. mesecem starosti pa otroci že oblikujejo stavke iz treh ali štirih besed in vedno bolj pravilno rabijo skladnjo in oblikoslovje (npr. Na stolu sedi muca.) (Marjanovič Umek in Fekonja 2019: 3). 
Kakovost otrokovega besedišča ločimo na (1) količinski vidik, pri čemer fluentnost besed pomeni skupno število vseh besed, fleksibilnost besed pa vsebinsko različne besede; in (2) kakovostni vidik, ki se odraža ob pripovedovanju zgodbe in zajema število (asociativnih) dogodkov, nenavadnost naslova in zaključka, originalnost oziroma izvirnost (Kramarič, Ropič in Urbančič Jelovšek 2000; Hadley, Dickinson, Hirsh-Pasek, Golinkoff in Nesbitt 2016). Poglobljeno razumevanje otrokovega besedišča se odraža zlasti v fleksibilnosti besed. To pomeni, da otrok besedo izgovori oziroma pravilno poimenuje, prepozna pomen besede, izkaže zmožnost uporabe besede v povedi ipd. Fleksibilnost besedišča vpliva na jezikovne spretnosti otroka, ki so pogoj za razvoj pismenosti $\mathrm{v}$ zgodnjem obdobju, in je napovednik bralnega razumevanja $\mathrm{v}$ povezavi s slovnico in slušnim razumevanjem (Roth, Speece in Cooper 2002).

Zgodnje obdobje odraščanja, ko je otrok še dojenček in malček, je tako izredno občutljivo obdobje za razvoj govora, saj tedaj prihaja do velikih kvantitativnih in kvalitativnih razvojnih sprememb $\mathrm{v}$ govoru. To potrjuje tudi raziskava Ljubice Marjanovič Umek in Urške Fekonja (2019), ki jasno izpostavljata dejstvo, da so za zgodnji razvoj govora značilne velike individualne razlike med otroki, in sicer tako $\mathrm{v}$ obsegu kot $\mathrm{v}$ hitrosti naraščanja besedišča. Avtorici spoznavata, da so področja govora dojenčkov in malčkov tesno povezana, kar pomeni, da dojenčki, ki uporabljajo več sporazumevalnih gest, razumejo in govorijo več besed, malčki, ki govorijo več besed, pa strukturirajo daljše in zapletenejše povedi. Omenjena raziskava izpostavlja tudi pomen nekaterih dejavnikov družinskega okolja, in sicer izobrazbe staršev in pogostosti skupnega branja za razvoj govora. Da so starši neprecenljivi posredniki med otrokom in knjigo in da so prav učinki zgodnjih bralnih izkušenj ter razvoj porajajoče se bralne pismenosti $\mathrm{v}$ domačem okolju ključnega pomena za razvoj branja in pismenosti otroka $v$ poznejšem šolskem obdobju, poudarja tudi Robertina Jug (2013), ki svetuje, naj bo otrokovo doživljanje družinskega branja prijetno in zabavno doživetje, starši naj sledijo otrokovemu interesu, saj se tako njegovo udejstvovanje še poveča, pozitivne bralne izkušnje pa pripomorejo k notranji motivaciji za razvoj bralnih navad. Bralna pismenost, piše Dragica Haramija (2017: 1), se kot zmožnost in družbena praksa razvija vse življenje ter prežema vse človekove dejavnosti. 
Jasno je torej, da se prve interakcije, ki spodbujajo otrokov razvoj govora, začnejo že ob rojstvu in potekajo med otrokom in starši (Brodin 2018; Sommer 2012, v Brodin in Renblad 2019), ki imajo kot otrokov primarni zgled pomembno vlogo pri razvoju in širjenju njegovega besednega zaklada. Družinsko okolje na razvoj govora učinkuje zlasti prek značilnosti govora staršev (jezikovni kod) ob opravljanju vsakodnevnih dejavnosti, pogostosti in kakovosti literarnih dejavnosti (npr. skupno branje, gledanje televizije, obiskovanje knjižnice, lutkovnega gledališča ipd.) ter zagotavljanja simbolno bogatega okolja (npr. število knjig, revij, material za risanje in pisanje) (Marjanovič Umek in Fekonja 2019: 3). Da ima velik učinek na razvoj besedišča materino branje, v svoji raziskavi potrjujejo Phillips, Norris, Hayward in Lovell (2017), vse bolj pa se kaže, da ima pomemben vpliv na bogatost besedišča predšolskih otrok intenzivno glasno branje (Pollard-Durodela, Gonzalez, Simmons, Kwok, Taylor, Davis, Kim in Simmons 2011). Kot podpora interakciji med otroki in starši pa na bogatenje otroškega besedišča vpliva tudi t. i. tehnološko izboljšano pripovedovanje zgodb, so dognali Teepe, Molenaar in Verhoeven (2017). Uporaba izobraževalne tehnologije omogoča izvedbo skupnega besednega pripovedovanja s pomočjo tabličnega računalnika. Ob strukturi zgodbe se sprožajo takojšnji vidni, slušni in besedilni učinki, kar aktivira otroke in spodbudi interakcijo s starši, slednje pa spodbudno vpliva na bogatenje besednjaka. Podobno so ugotovili že Dennis, Whalon, Kraut in Herron (2016) in izpostavili, da ima izobraževalna tehnologija na področju besedišča pozitiven učinek na pridobivanje aktivnega in pasivnega besedišča.

Varovalni dejavnik za otrokov razvoj govora ob kakovostnem družinskem okolju predstavlja tudi kakovosten vrtec, tako na ravni strukturne kot procesne kakovosti (Marjanovič Umek in Fekonja 2019: 4), zato je pri razvijanju govora $v$ ranem otroštvu ključno tudi sodelovanje profesionalnih odraslih bralcev, tj. pedagoških delavcev oziroma delavk, knjižničarjev oziroma knjižničark, ki otroka usmerjajo k ustreznim jezikovnim dejavnostim (Krajnc Ivič, Pulko, Ropič in Zemljak Jontes 2017: 55-56). Še zlasti je to pomembno, ko gre za otroke iz družin z nizkimi dohodki in nižjo izobrazbo. Izobrazba staršev je namreč spremenljivka, ki (zlasti v luči kakovosti in pogostosti skupnega branja) pomembno vpliva tako na obseg besednjaka kot slovnično strukturo govora malčkov (Marjanovič Umek in Fekonja 2019: 10). 
Otroci se komuniciranja učijo ob raznovrstnih jezikovnih dejavnostih, ki jih spremljajo in $\mathrm{v}$ njih tudi aktivno sodelujejo, tj. ob poslušanju vsakdanjih pogovorov in glasnega branja odraslih, $\mathrm{z}$ opisovanjem, s pripovedovanjem, ob domišljijskih igrah, igrah vlog, izmišljanju zgodb, pesmi, ob izštevankah, ugankah ipd., tudi z učenjem od drugih otrok (Krajnc Ivič, Pulko, Ropič in Zemljak Jontes 2017: 59). Tako otrok pomembno razvija in širi tudi svoj besedni zaklad, besede pa se uči pravilno in ustrezno uporabljati.

Pri besedi ločimo njen pomen (pojmovna stran) in izrazno glasovno podobo (tvarna stran), zato je takrat, ko govorimo o razvoju besedišča, neizogibno spregovoriti o glasovnem zavedanju, tj. zmožnosti prepoznavanja, razlikovanja in rabe glasov (fonemov) govorjene besede. Besede lahko v osnovi členimo na zloge, začetne ali končne zloge in glasove. Ravni glasovnega zavedanja se razvijejo postopoma, in sicer sprva ob manj zahtevnih in nato ob zahtevnejših dejavnostih. Raziskave kažejo, da otroci najprej zaznajo začetni glas $\mathrm{v}$ besedi, nato končni glas in nazadnje vmesne glasove, hkrati pa se izpostavlja dejstvo, da na uspešnost zaznavanja vpliva dolžina besede. Otroci so uspešnejši v zaznavanju začetnih oziroma končnih glasov v nezložnih ali enozložnih besedah in v podajanju začetnih soglasnikov v primerjavi s končnimi samoglasniki (Ropič 2016: 48-49). V zmožnostih glasovnega zavedanja obstajajo med otroki velike razlike, zato je pomembno, da vaje za spodbujanje začetnih/končnih glasov skladno $\mathrm{z}$ diferenciacijo in individualizacijo sledijo ustreznemu zaporedju oziroma težavnostni stopnji (Ropič 2016: 50). Krajnc Ivič, Pulko, Ropič in Zemljak Jontes (2017) poudarjajo, da je že v prvem starostnem obdobju priporočljivo izvajati dejavnosti, kot so glasovno zavedanje, zavedanje izgovorjenih besed, začetni glas besede, končni glas besede, glas znotraj besede, glaskovanje besed ipd.

Kot že poudarjeno, se obseg besedišča dosledno kaže kot najboljši indikator bralnega razumevanja (Cain, Oakhill in Lemmon 2004; Kolić-Vehovec 1994; Pečjak 1989, v Pečjak, Bucik, Peštaj, Podlesek in Pirc 2010). Širina besednjaka je najpomembnejši dejavnik bralne učinkovitosti, saj vpliva na hitrost branja, še bolj pa na razumevanje pri branju. Če želimo hitreje brati in prebrano dobro in ustrezno razumeti, je smiselno povečati besedišče. Po mnenju M. N. Young in C. V. Young (1975, v Pečjak 1993: 65-66) je s primerno kombinacijo ugank in besednih iger mogoče vplivati na različne dejavnike, kot so prepoznavanje besed, zgradba besed, struktura stavka, dopolnjevanje stavkov in identifikacija oseb. 
Spodbujanje razvoja besedišča otrok je torej zelo pomembno, poteka pa lahko na različne načine - Kramarič, Ropič in Urbančič Jelovšek (2000) navajajo naslednje možnosti: (1) z neposrednim poučevanjem (kurikularni pristop); (2) s pomočjo igre (prosta igra, vodena igra, usmerjena igra); (3) z eksplicitnimi navodili (pogosto ob branju, tj. pred branjem, med branjem in po branju, včasih pa tudi pozneje, ko se dejavnost branja že zaključi); (4) s kognitivnim pristopom (jasna opredelitev, razlaga in primer, ponovitev nove besede, uporaba nove besede); (5) koncept tiska; (6) pripovedovanje ob slikah (pogosto so na voljo tri okoliščne pripovedovanja zgodbe: ob zaporednih ilustracijah, ob nepovezanih slikah, ena slika z več ali manj elementi); (7) naštevanje besed na določen glas (fleksibilnost besed); (8) besedam določajo asociacije; (9) dokončajo/nadaljujejo zgodbo; (10) ustvarijo domišljijski binom; (11) ustvarijo delni domišljijski binom.

Ugodno pa na razvoj besedišča pri predšolskih otrocih vplivajo tudi fine motorične spretnosti, kar je dokazala zlasti raziskava, v kateri sta Suggate in Stoeger (2014) spremljala starost in opazovala delež samostalnikov v primerjavi z glagoli. Rezultati raziskave so potrdili močno povezavo med finimi motoričnimi spretnostmi in splošnim besediščem, zato je smiselno pozornost usmerjati tudi na finomotorične sposobnosti otrok.

Velja izpostaviti, da obseg otrokovega besedišča v predšolskem obdobju pomembno vpliva tudi na vsa druga predmetna področja, na razvoj mišljenja, socialnega razumevanja, čustvenega doživljanja in izražanja ipd. V Kurikulumu za vrtce (1999) je zapisano, da spodbujanje razvoja govora in njegovo načrtovanje ni samo stvar t. i. jezikovne vzgoje $v$ vrtcu, ampak vseh predmetnih področij. To pa velja tudi za šolsko obdobje, saj slovenščina ni le učni predmet, temveč tudi učni jezik, zato je treba ohranjati zavedanje, da se sporazumevalna (jezikovna) zmožnost ne razvija samo pri slovenščni, ampak še pri vseh drugih predmetih, kar posebej poudarja tudi Marja Bešter Turk (2011: 127). Učenci in učenke ter dijaki in dijakinje besedje usvajajo pri vseh predmetih, saj v okviru vsakega predmeta spoznavajo tudi specifično strokovno izrazje in obravnavajo terminologijo različnih področij (npr. matematična, računalniška, družboslovna in naravoslovna terminologija, likovno, glasbeno izrazje, termini s področja športa itd.). Tako se gradnik besedišče kot vsi gradniki bralne pismenosti nanaša na vsa predmetna področja, ker pa bi pregled usvajanja besedišča pri vseh predmetih zajetno presegel obseg prispevka, se v nadaljevanju posvečamo razvoju jezikovne zmožnosti v okviru predmeta slovenščina. 


\subsection{Besedišče v osnovnošolskem obdobju}

V vseh treh vzgojno-izobraževalnih obdobjih osnovne šole ima jezikovni pouk dva temeljna cilja, in sicer: 1) razvijanje jezikovne, narodne in državljanske zavesti ter 2) razvijanje sporazumevalne zmožnosti. Ker je slovenščina ne samo materni, temveč tudi učni jezik, sta oba cilja tesno povezana.

Sodobne teorije sporazumevalno zmožnost dokaj enotno pojmujejo, a jo različno poimenujejo in razmejujejo, zato je najprej smiselno na kratko predstaviti pojmovanje sporazumevalne zmožnosti, kot mu sledimo $\mathrm{v}$ prispevku. Najaktualnejše pojmovanje sporazumevalne zmožnosti v slovenskem prostoru prinaša Skupni europski jezilkouni okvir: ǔ́enje, poučevanje, ocenjevanje (SEJO 2011), ki je podlaga za poučevanje jezikov v Evropi. Sporazumevalno zmožnost opredeljuje kot sporazumevalno jezikovno zmožnost, ki se $\mathrm{v}$ ožjem pomenu lahko deli na troje: jezikovne zmožnosti, sociolingvistične zmožnosti in pragmatične zmožnosti. Za sporazumevalno zmožnost je $\mathrm{v}$ prvi vrsti torej nujna jezikovna zmožnost, ki vključuje leksikalno, slovnično, semantično, fonološko, pravopisno in pravorečno zmožnost. Vse (pod)zmožnosti jezikovne kompetence so tesno prepletene, na poznavanje besedišča in sposobnost njegove uporabe pa se prvenstveno nanaša leksikalna zmožnost, ki je sestavljena iz leksikalnih in slovničnih pravil. Med leksikalne prvine (SEJO 2011: 134-135) se štejejo: (1) stalne besedne zveze, ki so strukturirane iz več besed, učijo in uporabljajo pa se kot celota (npr. pregovori, idiomatski izrazi, frazni glagoli ipd.); (2) enobesedne oblike, ki so polnopomenske besede (samostalnik, glagol, pridevnik, prislov). Med slovnične prvine (SEJO 2011: 135) se upoštevajo nepolnopomenske besede (pomožni glagoli, zaimki, predlogi, členki, vezniki). Sociolingvistična zmožnost se navezuje na družbene in kulturne okoliščine rabe jezika, pragmatična zmožnost pa na funkcionalno rabo razpoložljivih jezikovnih virov (tvorjenja jezikovnih funkcij, govornih dejanj) z naslanjanjem na scenarije interakcijskih izmenjav.

Pojmovanje sporazumevalne zmožnosti $\mathrm{v}$ učnem načrtu za slovenščino pojasnjuje Bešter Turk (2011: 121), in sicer kot kompleksno zmožnost, ki jo sestavlja več gradnikov: a) motiviranost za sprejemanje in sporočanje, b) stvarno/enciklopedično znanje prejemnika in sporočevalca, c) jezikovne zmožnost prejemnika in sporočevalca, č) pragmatična/slogovna/empatična zmožnost prejemnika in sporočevalca, d) zmožnost nebesednega sporazumevanja prejemnika in sporočevalca, e) metajezikovna zmožnost prejemnika in sporočevalca. Razvijanje 
sporazumevalne zmožnosti neposredno oziroma eksplicitno, kot v nadaljevanju izpostavlja Bešter Turk (2011: 126), vključuje razvijanje jezikovne, tj. poimenovalne, upovedovalne, pravorečne, pravopisne, pragmatične in metajezikovne zmožnosti ter zmožnosti nebesednega sporazumevanja, posredno oziroma implicitno pa tudi motiviranosti in stvarnega znanja. $\mathrm{V}$ nadaljevanju se posvečamo jezikovni zmožnosti, kot jo predstavlja učni načrt za slovenščino v osnovni šoli (UN 2018) in se uporablja v pedagoški praksi.

Jezik sestoji iz besed. Vsaka beseda ima pomen, navadno celo več pomenov. A za obvladovanje besednega jezika, kot že poudarjeno, ni dovolj zgolj poznavanje pomena, pomembno je tudi poznavanje pravil za povezovanje besed v razširjene enote, tj. stavke oziroma povedi in besedila, ter pravil za njihovo slušno oziroma vidno oblikovanje. Zato je za razvoj jezikovne zmožnosti ključnega pomena poimenovalna/besedna/slovarska zmožnost, a hkrati tudi upovedovalna/skladenjska/slovnična ter pravorečna in pravopisna zmožnost, kot jezikovne zmožnosti navaja Bešter Turk (2011: 122). Razvoj jezikovne sporazumevalne zmožnosti torej poteka na različnih jezikovnih ravneh, ki se med seboj tesno prepletajo, $\mathrm{v}$ pričujočem prispevku, usmerjenem $\mathrm{v}$ besedišče, pa se osredotočamo na poimenovalno zmožnost.

Poimenovalno (tudi besedno ali slovarsko) zmožnost Bešter Turk (2011: 122) pojasnjuje kot zmožnost, ki

/.../ odraža sporočevalčevo zmožnost poimenovanja prvin predmetnosti (bitij, stvari), njihovih lastnosti, njihove vrste, njihove količine, njihovega dejanja/stanja, sporočevalčevih miselnih procesov (vrednotenja, hotenja, prepričanja, doživljanja ...) itd. $z$ besedami in stalnimi besednimi zvezami. Za prejemnika pa pomeni zmožnost razumevanja besed in stalnih besednih zvez, tj. da besede in stalne besedne zveze $v$ njem vzbudijo pravilno predstavo določene prvine predmetnosti. ${ }^{2}$

\footnotetext{
${ }^{2}$ Upovedovalna/skladenjska/slovnična zmožnost pomeni zmožnost tvorjenja besednih zvez, povedi, zvez povedi (v enogovornih večpovednih besedilih) in zvez replik (v dvogovornih besedilih), za prejemnika pa zmožnost razumevanja naštetega. Pravorečna zmožnost pomeni obvladanje prvin in pravil zborne izreke, pravopisna pa obvladanje pisanja besed/povedi/besedil (Bešter Turk 2011: 122-123).
} 
Predstavljamo razvijanje poimenovalne zmožnosti $\mathrm{v}$ vseh treh vzgojnoizobraževalnih obdobjih, kot izhaja iz didaktičnih priporočil za uresničevanje ciljev, zavedenih v učnem načrtu za slovenščino v osnovni šoli (UN 2018).

\subsubsection{Razvijanje poimenovalne zmožnosti v 1 . VIO}

Upoštevajoč učni načrt za slovenščino v osnovni šoli (2018: 11), učenci in učenke v 1. VIO poimenovalno zmožnost razvijajo tako, da: (1) poimenujejo bitja, predmete, dejanja ipd. v svoji okolici ali na sliki s knjižnimi besedami in besednimi zvezami; (2) razlagajo dane besede oziroma besedne zveze iz besedila in jih smiselno uporabljajo $\mathrm{v}$ svojem besedilu; (3) navajajo knjižne besede iz istega tematskega polja, $\mathrm{z}$ nasprotnim, enakim, ožjim ali širšim pomenom; (4) tvorijo manjšalnice, ljubkovalnice, ženski par moškemu (feminative) in obratno (maskulinative), samostalniške izpeljanke iz glagolov (za živega in neživega vršilca dejanja, za dejanje in prostor dejanja) ter izsamostalniške pridevniške izpeljanke (za svojino in snovnost) ipd.

Če strnemo, se obvladovanje besedišča kot gradnika bralne pismenosti v 1 . VIO izkazuje s poznavanjem, razumevanjem in uporabo besedišča različnih predmetnih področij, pri čemer otrok poišče razlago neznanih besed v sobesedilu ali z zunanjo pomočjo in uporabi preprost slovar (npr. slikovni, tematski). Otrok zna uporabiti novo besedo $\mathrm{v}$ novi povedi, $\mathrm{z}$ usvojenim besediščem pa tvori različna govorjena in zapisana besedila (Gradniki bralne pismenosti 2018).

Skladno s priporočili posodobljenega učnega načrta za slovenščino (UN 2018: 68) učenci in učenke $\mathrm{v} 1$. VIO vstopajo $\mathrm{v}$ svet branja in pisanja individualizirano, postopno in sistematično. Glede na svoje predznanje branja in pisanja ter razvite veščine, spretnosti in zmožnosti prehajajo skozi faze oziroma dejavnosti začetnega opismenjevanja, zato je pomembno, da učitelj oziroma učiteljica na začetku obdobja in sproti pri vsakem učencu in učenki preverja razvitost veščin, spretnosti in zmožnosti, potrebnih za branje in pisanje, nato pa za vsakega učenca in učenko izdela individualni načrt razvijanja zmožnosti branja in pisanja. 


\subsubsection{Razvijanje poimenovalne zmožnosti v 2. VIO}

V 2. VIO učenci in učenke poimenovalno zmožnost po učnem načrtu (UN 2018: 21) razvijajo tako, da: (1) razlagajo dane besede oziroma besedne zveze iz besedila in jih smiselno uporabljajo $\mathrm{v}$ svojem besedilu; (2) navajajo knjižne besede $\mathrm{z}$ nasprotnim, enakim, ožjim in širšim pomenom in besede iz iste besedne družine; (3) ob danem korenu navajajo knjižne besede iz iste besedne družine; (4) tvorijo pridevniške izpeljanke iz samostalnikov (za izvor in namembnost) ter samostalniške izpeljanke iz pridevnikov (za nosilca lastnosti, napravo in abstraktno lastnost); (5) razlagajo dane večpomenske besede in njihove pomene ponazarjajo v povedih; $(6) \mathrm{v}$ besedilu prepoznajo besede oziroma besedne zveze s prenesenim pomenom in jih tudi razložijo; (7) izogibajo se nepotrebnemu ponavljanju iste besede v besedilu; (8) $\mathrm{v}$ svojih besedilih in $\mathrm{v}$ besedilih drugih prepoznajo poimenovalne napake in neustreznosti ter jih odpravijo; pri tem si po potrebi pomagajo s slovarji v knjižni in elektronski obliki ter z raznimi jezikovnimi svetovalnicami; (9) uporabljajo slovarje v knjižni in elektronski obliki.

V 2. VIO otrok tako pozna, razume in uporablja besedišče različnih predmetnih področij, sklepa o pomenu besed in besednih zvez iz sobesedila, poišče razlago neznanih besed v kontekstu in jezikovnih priročnikih, z usvojenim besediščem tvori različna govorjena in zapisana besedila (Gradniki bralne pismenosti 2018).

\subsubsection{Razvijanje poimenovalne zmožnosti v 3. VIO}

V 3. VIO učenci in učenke skladno z učnim načrtom za slovenščino (UN 2018: 34 35) razvijajo poimenovalno zmožnost tako, da: (1) razlagajo dane besede in frazeme iz besedila ter jih smiselno uporabljajo v svojem besedilu; (2) k besedam iz besedila dodajajo knjižne besede $z$ nasprotnim, enakim, ožjim in širšim pomenom ter besede iz iste besedne družine; (3) delajo tvorjenke iz danih skladenjskih podstav, npr. samostalniške izpeljanke iz glagolov (za vršilca dejanja in dejanje), samostalniške izpeljanke iz predložne zveze, samostalniške in pridevniške zloženke, ter razložijo dane tvorjenke; (4) $\mathrm{v}$ svojih besedilih se izogibajo nepotrebnim besednim ponovitvam; (5) v svojih in $\mathrm{v}$ besedilih drugih prepoznajo poimenovalne napake in neustreznosti ter jih odpravijo, pri tem pa si, če je potrebno, pomagajo z jezikovnimi svetovalnicami in slovarji v knjižni ter elektronski obliki; (6) uporabljajo slovarje v knjižni in elektronski obliki. 
Za gradnik besedišče kot element bralne pismenosti je tako pomembno, da v 3. VIO otrok pozna, razume in uporablja besedišče različnih predmetnih področij, razume nove besede na podlagi konteksta oziroma zna poiskati njihovo razlago v tiskanih in spletnih jezikovnih priročnikih, razume (stalne) besedne zveze oziroma fraze in preneseno rabo besed, primerno svoji starosti, uporablja jezikovne priročnike in jezikovne vire, pozna in uporablja učne strategije za določanje pomena neznanih besed, usvojeno besedišče glede na vrsto, namen in okoliščine uporablja pri tvorjenju novih besedil (Gradniki bralne pismenosti 2018).

Z ozirom na priporočilo učnega načrta za slovenščino (UN 2018: 66-67) naj bi učitelji oziroma učiteljice pri razvijanju poimenovalne jezikovne (in slogovne) zmožnosti upoštevali, da je težišče na bogatenju knjižnega besedišča, razlaganju danih besed oziroma besednih zvez iz besedila, poimenovanju s tvorjenkami (namesto $\mathrm{z}$ opisnim poimenovanjem) in razlaganju tvorjenk, na iskanju poimenovalnih različic, s katerimi odpravimo nepotrebno ponavljanje besed $\mathrm{v}$ besedilu, ter postopoma na uporabi slovarjev $\mathrm{v}$ knjižni in elektronski obliki ter prepoznavanju in odpravljanju poimenovalnih napak in neustreznosti $\mathrm{v}$ svojih besedilih in $\mathrm{v}$ besedilih drugih ipd. Po priporočilih snovalcev učnega načrta za slovenščino v osnovni šoli (UN 2018: 69) naj bi v 2. in še zlasti v 3. VIO učitelj oziroma učiteljica po potrebi občasno usmerjala učence in učenke k povezovanju jezikovnosistemskega znanja - povežejo naj usvojeno jezikovno vsebino v smiselno zaokroženo celoto in ta naj do 9. razreda postopoma dobi dokončno strnjeno podobo. Pri tem učitelj oziroma učiteljica skrbi za smiselno razmejitev temeljnega od manj pomembnega. Učenci in učenke si tako krepijo jezikovno samozavest $\mathrm{v}$ slovenščini, ker so sposobni umestiti vsakdanje jezikovne zagate v enoten okvir, hkrati pa pridobivajo splošno jezikoslovno teoretično osnovo, ki jim lahko pomaga tudi pri učenju tujih jezikov. Učenci in učenke obvladovanje jezikovnosistemskega znanja izkažejo tako, da: utemelijo svoje jezikovne popravke z umestitvijo v zaokrožen jezikovnosistemski okvir; določijo oblikovne, skladenjske ter pravopisne in druge značilnosti (izbranih) besed, besednih zvez ali stavkov v izbranem besedilu ali povedi; razložijo oblikovne in/ali besedotvorne posebnosti s pomočjo jezikovnosistemskih zakonitosti; povzamejo osnovne značilnosti določenega jezikoslovnega pojma (npr. lastnosti samostalnika ipd.); primerjajo oblikovne, skladenjske in pravopisne značilnosti domačih besed oziroma besednih zvez in njihovih ustreznic v tujem jeziku, ki se ga učijo. 
Ob vsem navedenem pa je pomembno, da $\mathrm{v}$ osnovni šoli $\mathrm{v}$ vseh treh vzgojnoizobraževalnih obdobjih besedno sporazumevanje, bodisi na slušni bodisi na vidni ravni, stalno povezujemo tudi $\mathrm{z}$ nebesednim sporazumevanjem, tj. likovnim, gibalnim, glasbenim, pozneje tudi z računalniškim opismenjevanjem itd.

\subsection{Razvijanje poimenovalne zmožnosti v srednješolskem izobraževanju}

Ker je širjenje besednega zaklada proces, ki traja vse življenje, se razvijanje poimenovalne zmožnosti poudarja tudi na srednješolski stopnji izobraževanja, in sicer zlasti $\mathrm{v}$ okviru predmeta slovenščina, ki po učnem načrtu za gimnazije (UN 2008: 6) omogoča razvijanje osebne, narodne in državljanske identitete ter ključnih zmožnosti vseživljenjskega učenja - predvsem sporazumevanje $\mathrm{v}$ slovenščini, socialno, estetsko, kulturno in medkulturno zmožnost, digitalno pismenost ipd.

V gimnazijah in srednjih šolah se poimenovalna zmožnost usvaja in utrjuje vzajemno s skladenjsko, pravorečno, pravopisno in slogovno zmožnostjo ter zmožnostjo nebesednega sporazumevanja. Kot predpisuje učni načrt za slovenščino v splošnih, klasičnih in strokovnih gimnazijah (UN 2008: 13-15), dijaki in dijakinje poimenovalno zmožnost razvijajo tako, da: (1) pred sprejemanjem besedil ali po njem predstavljajo pomen danih besed in frazemov iz besedila, med tvorjenjem besedil poimenujejo prvine stvarnosti, ob tem pa pazijo, da ne ponavljajo istih besed; (2) prepoznavajo poimenovalne napake v svojih in tujih besedilih ter jih odpravljajo. Posebna pozornost je razvijanju poimenovalne zmožnosti posvečena $\mathrm{v} 2$. letniku, ko dijaki in dijakinje sistematično usvajajo temeljne pomenske, slogovne, izvorne, tvorbne, oblikovne in tvarne značilnosti besede, in sicer tako, da predstavljajo pomene večpomenskih besed, smiselno uporabljajo večpomenske besede, ločujejo blizuzvočnice, predstavljajo njihov pomen in jih smiselno uporabljajo, spoznavajo odnose med besedami - iščejo sopomenke, protipomenke, nadpomenke in podpomenke, besede iz iste besedne družine in besede iz istega tematskega polja, opisne besedne zveze nadomeščajo $s$ tvorjenkami in obratno, proste besedne zveze nadomeščajo s frazemi in nasprotno, prevzete besede zamenjujejo z domačimi ustreznicami in domače besede s prevzetimi ustreznicami. Ob tem dijaki in dijakinje vrednotijo učinek pridobljenega vsebinskega in procesnega znanja na rabo in razumevanje besede ter na svoje poznavanje značilnosti besed; izdelajo načrt za odpravljanje težav pri rabi in razumevanju besed. 
Če nekoliko strnemo, v srednješolskem obdobju dijak oziroma dijakinja pridobljeno besedišče različnih predmetnih področij smiselno uporablja ter z njim izraža razumevanje in koncepte različnih strokovnih predmetov oziroma področij, z usvojenim besediščem pa tvori ustrezna besedila za različne namene in pri tem upošteva načela dobrega sloga, kot so živost, jedrnatost, jasnost ipd. (Gradniki bralne pismenosti 2018).

\subsection{Razvijanje besedišča in uporaba jezikovnih virov}

Pri vprašanjih, povezanih z jezikom, in iskanju ustreznih leksikalnih možnosti so koristen pripomoček priročniki in enojezični slovarji, ki slehernemu uporabniku ponujajo vpogled v obsežen nabor besedja kakega jezika, saj mu podajajo bistvene informacije o posamezni besedi. Kakor je razvidno iz ciljev učnega načrta in priporočil didaktikov $\mathrm{v}$ njem tako $\mathrm{v}$ osnovni kot srednji šoli, je spoznavanje in usvajanje besedišča v izobraževalnem procesu tesno povezano $\mathrm{z}$ jezikovnimi viri in (slovarskimi) priročniki, saj je poznavanje rabe jezikovnih virov učinkovito za sporazumevalno zmožnost vsakega posameznika. Že v 1 . VIO se učenci in učenke poslužujejo preprostejših slovarjev, kot so slikovni in tematski slovarji. V 2. in še intenzivneje v 3 . VIO ter nato $\mathrm{v}$ srednji šoli pa se učenci in učenke oziroma dijaki in dijakinje navajajo na redno uporabo knjižnih in elektronskih slovarjev in priročnikov. Z razvojem informacijske tehnologije je prišlo tudi do nekaterih premikov v samem procesu pouka, saj so v sodobnem času pomembnejši jezikovni viri in priročniki dostopni na spletu, tako da imajo učitelji oziroma profesorji in učenci oziroma dijaki vse večjo možnost uporabe elektronskih besedilnih zbirk in portalov ter jezikovnih orodij. Kot poudarjajo Stabej in sodelavci (2008), pomenijo sodobne jezikovne tehnologije velik tehnološki preskok pri spoznavanju, usvajanju, raziskovanju besedišča tako $\mathrm{v}$ šoli kot doma, obenem pa omogočajo nove oblike in metode dela za vse, vključene v izobraževalni proces. Učitelju oziroma učiteljici omogočajo pripravo in prilagoditev besedil, nalog in drugega gradiva za doseganje raznih ciljev, zapisanih $\mathrm{v}$ učnem načrtu, učence in učenke pa učenje s pomočjo sodobne tehnologije motivira (UN 2018: 76-77).

Razvijanje sporazumevalne zmožnosti $\mathrm{v}$ slovenskem jeziku se tesno povezuje $z$ razvijanjem digitalne zmožnosti, zato ni presenetljivo, da učni načrti in katalogi znanja za slovenščino omenjajo digitalno zmožnost kot del sporazumevalne zmožnosti in priporočajo izvedbo učne ure slovenščine $\mathrm{v}$ računalniški učilnici, vse pogostejše pa je tudi seznanjanje z elektronskimi (jezikovnimi) viri s pomočjo tablic 
in pametnih telefonov. V sodobnem času je digitalizacija jezika oziroma tehnološko podprto učno gradivo nujno in učinkovito sredstvo pri opismenjevanju in razvijanju sporazumevalne zmožnosti, saj omogoča hitrejše, a kakovostno doseganje ciljev.

Zaradi vsega navedenega je priporočljivo učence in učenke spodbujati $\mathrm{k}$ iskanju odgovorov na pravopisna, oblikovna, tvorbna in druga jezikovna vprašanja $\mathrm{v}$ raznovrstnih jezikovnih virih, kot so Slovar slovenskega knjižnega jezika 2, Slovenski pravopis, Slovar slovenskih frazemov, Sinonimni slovar slovenskega jezika ipd., ter jezikovnih svetovalnicah. Dobrodošlo jih je tudi poučiti, da podatke o rabi besed prav tako ponujajo korpusi oziroma besedilne zbirke (npr. Gigafida).

\section{$3 \quad$ Zaključek}

$\mathrm{Na}$ hitre spremembe sodobnega načina življenja ter na gospodarsko-politične in družbene procese aktualnega vsakdana se tudi jezik dinamično odziva z ubesedovanjem in upomenjanjem. Leksikalni fond jezika se izpopolnjuje z novimi besedami, bodisi s prevzemanjem bodisi tvorjenjem novih besed, že znane besede dobivajo nove pomene, besede, ki so zašle $\mathrm{v}$ pozabo, se vračajo $\mathrm{v}$ aktualno rabo. Ravno zato, ker je jezik izredno kompleksna živa tvorba, ki se kot posledica napredka ter močnih domačih in svetovnih družbenih, kulturnih ter političnih dogajanj nenehno razvija in prilagaja zahtevam sporazumevanja (SEJO 2011: 132), nihče nikoli ne more do popolnosti obvladovati jezika. In zato je razvijanje sporazumevalne zmožnosti vseživljenjska dejavnost slehernega človeka. Pogoj za uspešen razvoj sporazumevalne zmožnosti pa je v prvi vrsti zmožnost ustreznega poimenovanja prvin stvarnega in abstraktnega sveta - osnovo celovitemu razvoju sporazumevalne zmožnosti tako predstavlja obvladovanje besedišča, ki sodi v okvir sporazumevalne jezikovne zmožnosti. Razvijanje te je eden temeljnih ciljev sodobnega pouka pri slovenščini na vseh stopnjah obveznega izobraževanja in tudi v srednji šoli, ustrezne temelje za doseganje tega cilja pa je nujno treba postaviti že v predšolskem obdobju (Bešter Turk 2011: 127), saj se obseg besedišča otrok nenehno potrjuje kot temeljni napovedovalec bralne pismenosti. Takrat je proces usvajanja in razvijanja besedišča tudi najintenzivnejši, saj otrok razvija temeljne poimenovalne in slovnične prvine besednega jezika. V tem obdobju so pomemben steber v uspešnosti otrok na področju besedišča starši, ključno pa je tudi sodelovanje s pedagoško stroko. Čeprav je usvajanje besedišča najaktivnejše v zgodnjem otroštvu, poglablja pa se $\mathrm{v}$ obdobju šolanja, in to na vseh predmetnih področjih, moramo ohranjati 
zavedanje, da je širjenje besednega zaklada vrednota, ki jo je treba negovati vse življenje. Če jo negujemo, ne bogatimo le svojega besedišča, temveč tudi sebe.

\section{Literatura}

Marja BEŠTER TURK, 2011: Sporazumevalna zmožnost - eden izmed temeljnih ciljev pouka slovenščine. Jerike in slovstvo 56(4). 122-127.

Jane BRODIN in Karin RENBLAD, 2019: Improvement of preschool children's speech and language skills. Early Child Development and Care. https://www.tandfonline.com/doi/full/10.1080/03004430.2018.1564917

Lindsay R. DENNIS, Kelly WHALON, Lisa KRAUT in Deborah HERRON, 2016: Effects of a Teacher versus iPad-Facilitated Intervention on the Vocabulary of At-Risk Preschool Children. Journal of Early Intervention 38(3). 170-186.

Gradniki bralne pismenosti: delovno gradivo, 2018. Ljubljana: Zavod RS za šolstvo.

Elizabeth B. HADLEY, David K. DICKINSON, Kathy HIRSH-PASEK, Roberta MICHNICK GOLINKOFF in Kimberly T. NESBITT, 2016: Examining the acquisition of vocabulary knowledge depth among preschool students. Reading Research Quarterly 51(2). 181-198.

Dragica HARAMIJA (ur.), 2017: V objemu besed: razvijanje družinske pismenosti. Maribor: Univerzitetna založba Univerze v Mariboru. https://press.um.si/index.php/ump/catalog/book/268

Robertina JUG, 2013: Bralne navade, širjenje besedišča in družinsko branje. Bralna pismenost v vrtcu in soli. Didaktični primeri. Ur. Fani Nolimal in Tanja Novaković. Ljubljana: Zavod Republike Slovenije za šolstvo. 141-147.

Svjetlana KOLIĆ-VEHOVEC, Sonja PEČJAK, Neža AJDIŠEK in Barbara RONČEVIĆ, 2008. Razlike med spoloma v (meta)kognitivnih in motivacijsko emocionalnih dejavnikih bralnega razumevanja. Psibološka obzorja 17(4). 89-116.

Mira KRAJNC IVIČ, Simona PULKO, Marija ROPIČ in Melita ZEMLJAK JONTES, 2017: Spodbujanje jezikovne sporazumevalne zmožnosti predšolskih otrok ob neumetnostnih besedilih. $V$ objemu besed. Ur. Dragica Haramija. Maribor: Univerzitetna založba Univerze v Mariboru. 55-68. https://press.um.si/index.php/ump/catalog/book/268

Mira KRAMARIČ, Marija ROPIČ in Mateja URBANČIČ JELOVŠEK, 2000: Na vrtiljaku řrk 2. Priročnik za učitelje (pri pouku slovenšcine v 2. rasredu devetletne osnovne sole). Ljubljana: Rokus.

Simona KRANJC, 1996: Slovnična zmožnost otrok na besedotvorni ravni. Jerik in slovstvo 41/6, 309326.

Kurikulum za vrtce, 1999. Ljubljana: Ministrstvo za izobraževanje, znanost in šport: ZRSŠ.

Ljubica MARJANOVIČ UMEK, Nera BOŽIN, Nika ČERMAK HAUKO, Neža ŠTIGLIC HRIBERNIK, Saša BAJC in Urška FEKONJA PEKLAJ, 2016: Zgodnji govorni razvoj: primerjava besednjaka slovenskih malčkov in malčic. Sodobna pedagogika 67(1). 12-37.

Ljubica MARJANOVIČ UMEK in Urška FEKONJA, 2019: Zgodnji govorni razvoj: Varovalni in dejavniki tveganja v družinskem okolju. Javno zdravje 2,1-13.

https://www.nijz.si/sites/www.nijz.si/files/uploaded/marjanovic_umek_et_al._jz_2019_02. pdf

Nacionalna strategija za razvoj bralne pismenosti 2019-2030, 2019. https://www.gov.si/novice/2020-01-15nacionalna-strategija-za-razvoj-bralne-pismenosti-za-obdobje-2019-2030/

Skupni evropski jez̧ikovni okvir: üenje, poǚvvanje, ocenjevanje, 2011. Ljubljana: Ministrstvo RS za šolstvo in šport, Urad za razvoj šolstva. https://centerslo.si/wp-content/uploads/2015/10/SEJOkomplet-za-splet.pdf

Sebastian P. SUGGATE in Heidrun STOEGER, 2014: Do Nimble Hands Make for Nimble Lexicons? Fine Motor Skills Predict Knowledge of Embodied Vocabulary Items. First Language 34(3). 244-261.

Sonja PEČJAK, 1993: Kako do boljšega branja: tehnike in metode za iə̧boljšanje bralne učinkovitosti. Ljubljana: Zavod Republike Slovenije za šolstvo in šport. 
Sonja PEČJAK, Nataša BUCIK, Martina PEŠTAJ, Anja PODLESEK in Tina PIRC, 2010: Bralna pismenost ob koncu osnovne šole - ali fantje berejo drugače kot dekleta? Sodobna pedagogika 61(1). 86-102. http://www.dlib.si/details/URN:NBN:SI:doc-RK7BVPHJ

Linda M. PHILLIPS, Stephen P. NORRIS, Denyse V. HAYWARD in Meridith A. LOVELL, 2017: Unique Contributions of Maternal Reading Proficiency to Predicting Children's Preschool Receptive Vocabulary and Reading Proficiency. Early Childhood Education Journal 45(1). 111119.

Sharolyn D. POLLARD-DURODOLA, Jorge E. GONZALEZ, Deborah C. SIMMONS, Oiman KWOK, Aaron B. TAYLOR, Matthew J. DAVIS, Minjung KIM in Leslie SIMMONS, 2011: The Effects of an Intensive Shared Book-Reading Intervention for Preschool Children at Risk for Vocabulary Delay. Exceptional Children 77(2) 161-183.

Marija ROPIČ, 2016: Zmožnost zaznavanja začetnih in končnih glasov v nezložnih in večzložnih besedah. Sodobna pedagogika 31(1) 44-55.

Froma P. ROTH, Deborah L. SPEECE in David H. COOPER, 2002: A longitudinal analysis of the connection betweeen oral language and early reading. Journal of Educational Research 95(5). 259272.

Sebastian P. SUGGATE in Heidrun STOEGER, 2014: Do Nimble Hands Make for Nimble Lexicons? Fine Motor Skills Predict Knowledge of Embodied Vocabulary Items. First Language 34(3). 244-261.

Marko STABEJ, Tadeja ROZMAN, Nataša PIRIH SVETINA, Nina MODRIJAN in Boštjan BAJEC, 2008: Jezikouni viri pri jezilkovnem pouku v osnovni in srednji šoli: končno poročilo z requltati dela. http://www.trojina.si/wp-content/uploads/2019/08/StabejRozman.pdf

Rosa Catharina TEEPE, Inge MOLENAAR inLudo VERHOEVEN, 2017: Technology-Enhanced Storytelling Stimulating Parent-Child Interaction and Preschool Children's Vocabulary. Knowledge Journal of Computer Assisted Learning 33(2). 123-136.

Jože TOPORIŠIĆ, 2000: Slovenska slovnica. Maribor: Založba Obzorja.

Ǔ́ni načrt. Slovenščna: gimnazija: splošna, klasična, strokovna gimnarija, 2008. Ljubljana: Ministrstvo za šolstvo in šport, Zavod RS za šolstvo.

http://eportal.mss.edus.si/msswww/programi2019/programi/media/pdf/un_gimnazija/un _slovenscina_gimn.pdf

Učni načrt. Program osnovna šola. Slovenščina, 2018. Ljubljana: Ministrstvo za izobraževanje, znanost in šport, Zavod RS za šolstvo.

https://www.gov.si/assets/ministrstva/MIZS/Dokumenti/Osnovna-sola/Ucninacrti/obvezni/UN_slovenscina.pdf 


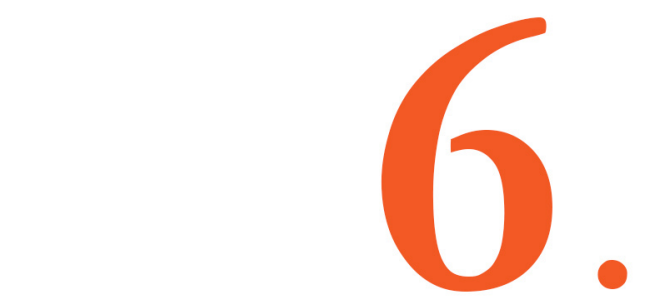

GRA D N I K

\section{TEKOČE BRANJE}

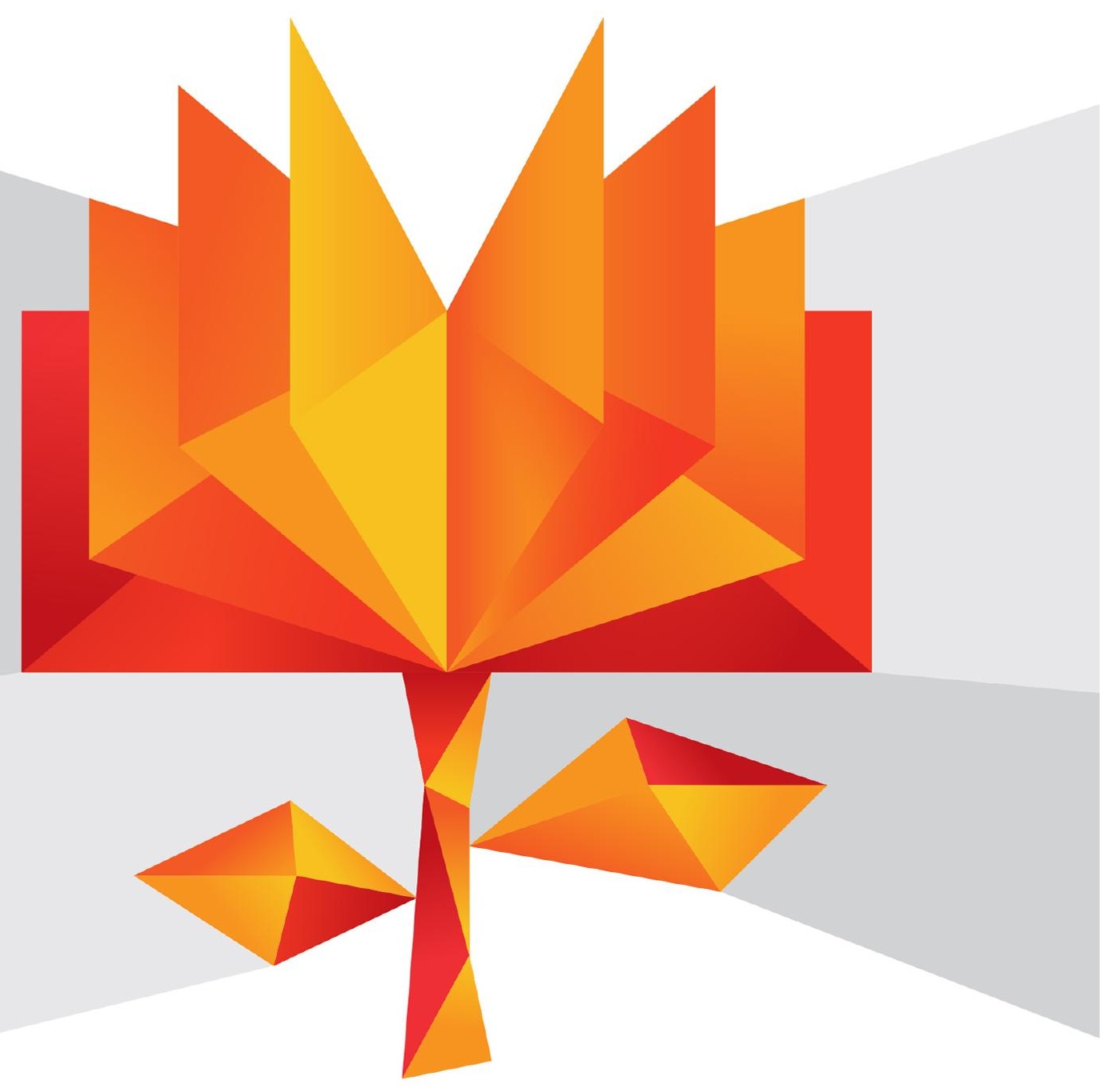




\section{Elementi gradnika:}

- tehnika branja

- natančnost

- hitrost

- izraznost

- ritem 


\title{
6. GRADNIK: TEKOČE BRANJE
}

\author{
MARIJA ROPIČ KOP ${ }^{1}$ IN NIKA VIZJAK PUŠKAR ${ }^{2}$ \\ ${ }^{1}$ Univerza v Mariboru, Pedagoška fakulteta, Maribor, Slovenija. \\ E-pošta: marija.ropic@um.si \\ ${ }^{2}$ Center za sluh in govor Maribor, Maribor, Slovenija. \\ E-pošta: nika.vizjak-puskar@csgm.si
}

Povzetek V prispevku je predstavljeno tekoče branje kot eden od gradnikov bralne pismenosti. Tekoče branje določajo naslednji elementi: tehnika branja, natančnost, hitrost, izraznost in ritem. $\mathrm{Na}$ tekočnost branja vplivajo različni dejavniki: vrsta besedila in tema, osebnostne lastnosti posameznika, morebitne jezikovne motnje oziroma fiziološke okvare ter zunanji pogoji. Glasno branje se precej razlikuje od prostega govora, zato je zelo pomembno, da učitelj poleg načrtovanih ciljev v pouk vključuje tudi glasno branje besedil, ki so lahko leposlovne, praktičnosporazumevalne ali celo znanstvene narave. Pomembno je, da besedila berejo tako učenci kot tudi učitelj. Pri pouku učitelj, glede na predmetno področje in tip besedila, uporablja dva tipa glasnega branja, nevtralno branje in interpretativno branje. Učitelj tako predstavlja učencem zgled ustreznega tekočega branja različnih vrst besedil. Pomembno je, da se ta gradnik razvija skozi celoten vzgojno-izobraževalni proces, od predšolskega obdobja do srednje šole, in da ga razvijajo učitelji pri vseh predmetih.

Ključne besede: tekoče branje, tehnika branja, glasno branje, hitrost branja, izraznost. 


\title{
THE SIXTH COMPONENT OF READING LITERACY: READING FLUENCY
}

\author{
MARIJA ROPIČ KOP ${ }^{1} \&$ NIKA VIZJAK PUŠKAR ${ }^{2}$ \\ ${ }^{1}$ University of Maribor, Faculty of Education, Maribor, Slovenija. \\ E-mail:marija.ropic@um.si \\ ${ }^{2}$ Hearing and Speech Center Maribor, Maribor, Slovenija. \\ E-mail: nika.vizjak-puskar@csgm.si
}

\begin{abstract}
The paper presents fluent reading as one of the components of reading literacy. Fluent reading is determined by the following elements, namely reading technique, accuracy, speed, expressiveness, and rhythm. The fluency of reading is influenced by various factors: the type of text and the topic, the personality traits of the individual, possible language disorders or physiological impairments, and external conditions. Reading aloud is quite different from free speech, so it is very important that the teacher, in addition to the daily explanation of the subject matter, includes reading aloud of texts in the lesson, which can be literary, practical or even scientific. It is important that the texts are read by both the students and the teacher. In the lesson, the teacher, depending on the subject area and the type of text, uses two types of reading aloud, neutral reading and interpretive reading. The teacher should present to the students an example of proper fluent reading of different types of texts. It is important that this component of reading literacy is developed throughout the educational process, from preschool to secondary school, and that it is developed by teachers in all subjects.
\end{abstract}

Keywords: reading fluency, reading technique, reading aloud, reading speed, expressiveness. 


\section{Branje}

Branje je ena izmed štirih komunikacijskih dejavnosti t. i. komunikacijskega modela učenja jezika. Sodobni bralni pouk si prizadeva pripeljati učence ob zaključku obveznega šolanja do stopnje bralne pismenosti (Pečjak in Gradišar 2002).

Bralni razvoj poteka po določenih zakonitostih. Z vidika časovnega zaporedja ločimo dve osnovni fazi bralnega razvoja. Prvo fazo predstavlja učenje branja. Ta faza je za bralce zahtevna in časovno obsežna. Najprej ima pomembno vlogo dekodiranje, na katerega vplivata dva procesa. Prvi proces je vidno zaznavanje, ki vključuje zaznavanje oziroma prepoznavanje grafičnih simbolov. Drugi proces je slušno zaznavanje. Sem sodi fonemska segmentacija oziroma glasovno razčlenjevanje in fonemska diskriminacija oziroma glasovno razločevanje. V branju se kmalu ob dekodiranju pojavi potreba po uporabi jezikovnih sposobnosti. Učenci se $\mathrm{v}$ bralnih spretnostih razlikujejo in med njimi obstajajo velike individualne razlike. $\mathrm{V}$ bralni tehniki se te odražajo $\mathrm{v}$ natančnosti, hitrosti, izraznosti in ritmu branja. Fazi učenja branja sledi faza učenja s pomočjo branja. Čeprav ni mogoče govoriti o tem, da $\mathrm{v}$ prvi fazi ne posvečamo pozornosti razumevanju prebranega, $\mathrm{v}$ drugi fazi spodbujamo sposobnost razumevanja. Bralno razumevanje predstavlja proces, $\mathrm{v}$ katerem skuša bralec interpretirati, kar je prebral, v skladu s svojim predznanjem in besediščem (Pečjak 1995; Kramarič, Ropič in Urbančič Jelovšek 2002). Eden izmed ciljev sodobnega bralnega pouka je, da bralci preidejo od razumevanja prebranega $\mathrm{k}$ uporabi branja za učenje oziroma razvijanju učnih strategij (Pečjak in Gradišar 2002).

\section{Tekočnost branja}

Tekočnost branja se ugotavlja ob glasnem branju učenca. Opredeljena je kot število pravilno prebranih besed $\mathrm{v}$ minuti. Bralec, ki tekoče bere, bere hitro, natančno, z ustreznim ritmom, intonacijo in izraznostjo. »Tekočnost branja je zmožnost natančnega in hitrega branja $\mathrm{z}$ ustrezno izraznostjo (tonom, poudarki, glasnostjo, naglasom), kar vse omogoča bralno razumevanje.« (Jurišič 2016: 11)

Tekočnost branja je po mnenju številnih raziskovalcev izjemno pomembna, saj bralci, ki tekoče berejo, bolje razumejo prebrano. To sicer ni nujno, vendar raziskave kažejo, da učenec, ki tekoče bere, manj časa in miselne energije porabi za dekodiranje zapisanih besed in tako lahko več energije nameni razumevanju prebranega (po Pečjak 2012: 71). 
Drugi segment, ki ga prinaša tekoče branje, je, da branje bralcu ne predstavlja napora, pač pa sprostitev, zato je velika verjetnost, da bo dober bralec branje izbral tudi kot prostočasno dejavnost, medtem ko se slabši bralci, ki berejo počasi in zatikajoče, samoiniciativno redko odločijo za branje. Če je branje tekoče, je za učenca manj naporno in manj stresno. Tekoče branje zelo pogosto vodi v užitek ob branju in povečuje verjetnost, da se bo bralec $\mathrm{k}$ njemu vračal. Medtem ko bo bralec, ki vlaga ogromno truda v dekodiranje zapisanega, težko občutil zadovoljstvo, ki ga sicer tekoče branje prinaša (Pečjak 2012). Dokaz, kako močno tekočnost branja vpliva na bralno motivacijo, je gotovo dejstvo, da otroci, pri katerih so evidentirane različne jezikovne motnje, zaradi katerih nikoli ne morejo zadovoljivo izuriti svoje bralne tehnike, zelo neradi berejo. Branje jim predstavlja tako velik napor, da jih vsebina, ki bi jim bila sicer zanimiva, sploh ne pritegne. Velikokrat sploh ne spoznajo užitka, ki ga lahko njihovi vrstniki brez evidentiranih motenj doživljajo ob branju (Vizjak 2016).

$\mathrm{Na}$ tekočnost branja vplivajo številni dejavniki. Glede na to, da se tekočnost branja ocenjuje na osnovi glasnega branja, je v prvi vrsti pomemben brezhibno delujoč govorni aparat. Velik vpliv na tekočnost branja imajo tudi morebitne artikulacijske in govorno-jezikovne motnje, ki zaradi fizioloških, nevroloških ali kognitivnih posebnosti posameznika le-temu onemogočajo tekoče (glasno in/ali tiho) branje. Pri ugotavljanju tekočnosti glasnega branja je nujno upoštevati tudi osebnostne lastnosti posameznika, saj glasno branje lahko za marsikaterega otroka/posameznika predstavlja stisko zaradi izpostavljenosti ali tremo, ki močno vpliva na tekočnost njegovega branja. Kadar torej govorimo o tekočem branju kot gradniku bralne pismenosti posameznika, moramo imeti v mislih tudi ta segment, ki učitelju lahko onemogoči realen vpogled $\mathrm{v}$ tekočnost otrokovega glasnega branja. Prav tako je pomembno, da so izpolnjeni vsi zunanji pogoji za tekoče branje oziroma da niso prisotni moteči dražljaji iz okolice, ki bi bralcu onemogočali nemoteno tekoče branje. Upoštevati je treba tudi vrsto besedila. Bralec bo besedila, katerih vsebina, struktura in besedišče so mu (vsaj delno) poznani, gotovo prebral bolj tekoče, kakor besedila z nepoznanim besediščem in njemu popolnoma tujo vsebino. Prav to je dokaz, da je tekočnost branja zelo pomembno razvijati skozi celoten proces šolanja in to pri vseh predmetih. 


\subsection{Kriteriji tekočnosti branja}

Tekoče branje določajo različni kriteriji, ki so prikazani v spodnji preglednici.

\section{Preglednica 1: Kriteriji tekočnosti branja}

\begin{tabular}{|c|c|c|c|}
\hline & NI TEKOČE & $\begin{array}{l}\text { DELNO } \\
\text { TEKOČE }\end{array}$ & TEKOČE \\
\hline NATANČNOST & pod $90 \%$ & $90-95 \%$ & nad $95 \%$ \\
\hline RITEM & $\begin{array}{ll}- & \text { pogosto } \\
- & \text { omahovanje } \\
- & \text { številni premori } \\
- & \text { pogoste } \\
& \text { ponovitve } \\
-\quad & \text { menjajoč } \\
& \text { razburkan ritem } \\
\end{array}$ & $\begin{array}{ll}- & \text { manj } \\
- & \text { omahovanja } \\
- & \text { nekaj premorov } \\
- & \text { nekaj ponovitev } \\
- & \text { razmeroma } \\
& \text { enakomeren } \\
& \text { ritem } \\
\end{array}$ & $\begin{array}{ll}- & \text { redka } \\
& \text { omahovanja } \\
- & \text { redki premori } \\
- & \text { enakomeren } \\
& \text { ritem }\end{array}$ \\
\hline TEHNIKA & $\begin{array}{ll}- & \text { bere besedo za } \\
& \text { besedo } \\
- & \text { ne upošteva } \\
& \text { ločil }\end{array}$ & $\begin{array}{l}\text { - } \text { bere skupine } \\
\text { besed in le } \\
\text { izjemoma } \\
\text { besedo za } \\
\text { besedo }\end{array}$ & $\begin{array}{ll}\text { - } & \text { bere smiselne } \\
& \text { skupine besed } \\
- & \text { upošteva ločila }\end{array}$ \\
\hline IZRAZNOST & $\begin{array}{l}-\quad \begin{array}{l}\text { monotono } \\
\text { branje }\end{array} \\
\end{array}$ & $\begin{array}{ll}- & \text { branje } z \text { nekaj } \\
\text { izraznosti }\end{array}$ & $\begin{array}{ll}- & \text { ustrezna } \\
& \text { izraznost } \\
\end{array}$ \\
\hline
\end{tabular}

Vir: Barone idr. 2005, v Pečjak 2012: 73

Prvi kriterij tekočnosti branja je natančnost. To pomeni, da učenec natančno prebere vse besede, jih pravilno artikulira in naglasi. Že v zgodnji fazi otrokovega razvoja je izjemno pomembno, da je otrok izpostavljen pozitivnim govornim vplivom, ki imajo pomembno vlogo pri pravilni artikulaciji in naglaševanju.

Drugi kriterij je ritem. Ritmično tekoče branje je branje brez omahovanj, z ustreznim govornim ritmom, tempom in smiselnimi premori glede na ločila in vsebino prebranega.

Otroci se z branjem srečujejo že $\mathrm{v}$ predšolskem obdobju, s samo tehniko branja pa se začnejo seznanjati ob vstopu $\mathrm{v}$ osnovno šolo ob začetkih opismenjevanja. Tehniko branja usvajajo pri pouku slovenščine in jo urijo pri vseh ostalih predmetih. Zelo pomembno je, da se ta način urjenja branja ohranja skozi celoten proces šolanja, tudi v 3 . VIO in v srednješolskem izobraževanju. Tehniko branja je treba uriti skozi branje raznovrstnih besedil, ne le leposlovja. Pogosto so prav informativna besedila tista, pri katerih je ustrezna bralna tehnika izjemnega pomena, saj učenci prav skozi 
tovrstna besedila spoznavajo učno vsebino. Večina učnih gradiv je pisnih, zato je še posebej pomembno, da učenci v prvi vrsti usvojijo samo tehniko.

Tekoče branje mora biti tudi ustrezno izrazno. To pomeni, da je branje prilagojeno vrsti besedila in temu primerno vključuje tudi obrazno mimiko in gestikulacijo ter da bralec ustrezno navezuje stik z občinstvom.

Kadar govorimo o hitrosti branja, moramo nujno opredeliti, ali gre za tiho ali glasno branje. Medtem ko je bistvo tihega branja predvsem dekodiranje in razumevanje besedila, gre pri glasnem branju za prekodiranje zapisanega grafičnega koda $\mathrm{v}$ glasovni kod, pri čemer pa mora priti tudi do razumevanja (Pečjak 2012). Hitrost glasnega branja je torej odvisna od hitrosti dekodiranja informacij iz enega koda $\mathrm{v}$ drugega in hkratnega razumevanja besedila, torej prenosa iz abstrakcije $\mathrm{v}$ konkretizacijo. Hitrost branja strokovnjaki opredeljujejo s številom prebranih besed na minuto. Pri tem je nujno upoštevati tudi stopnjo razumevanja prebranega. $\mathrm{Na}$ hitrost branja posameznika seveda močno vpliva mnogo dejavnikov. Razlike v hitrosti branja so med posameznimi bralci že zaradi njihovih osebnostnih lastnosti, saj ljudje tudi sicer govorimo različno hitro. Prav tako lahko isti bralec določeno besedilo bere hitreje od drugega. To je odvisno od zahtevnosti in vrste gradiva, cilja branja, pogosto pa tudi od splošnega psihofizičnega stanja posameznika in zunanjih okoliščin (Pečjak 2012).

\subsection{Strategije za razvoj tekočnosti branja}

Pri razvijanju tekočnosti branja učencev ne smemo pozabiti, kako pomembno je glasno branje učitelja. Učitelji pogosto $v$ pouk vključujejo glasno branje učencev, vse prevečkrat pa pozabljajo, da morajo biti prav oni zgled bralca, ki obvlada vse prvine tekočega branja - natančnost, hitrost, izraznost in ritem. Glasno branje se precej razlikuje od prostega govora, zato je zelo pomembno, da učitelj učencem večkrat glasno prebere kakšno besedilo, ki je lahko leposlovne, praktičnosporazumevalne ali celo znanstvene narave. Tako se učenci skozi zgled učijo predvsem izraznosti branja različnih vrst besedil. Prav zato je izjemno pomembno, da učitelj bere tekoče in upošteva vse prvine tega gradnika. $S$ tem učitelj učencem tudi $v$ višjih razredih neposredno pokaže pomembnost tekočega glasnega branja. Pri pouku so za razvijanje tekočnosti branja $\mathrm{v}$ razredu nujne tri dejavnosti, in sicer učiteljevo branje učencem, učiteljevo branje z učenci ter branje učencev (Mooney 1990, v Pečjak 2012). 
Pečjak (2012: 75) strategije za razvoj tekočnosti branja povzema po več avtorjih in kot najpomembnejše navaja naslednje:

\section{- Ponavljajoče branje ali večkratno branje istega besedila}

Ta tehnika je primerna predvsem za povečevanje hitrosti branja.

- Zborno branje

Manjša skupina učencev izmenično bere z učiteljem. Učiteljevo branje učencem služi kot model, ki ga le-ti skušajo posnemati.

- Eho branje

Gre za glasno branje učencev z rahlim zamikom za učiteljem (kot odmev).

- Poslušanje posnetega branja

Učenci najprej poslušajo posnetek, nato pa sami preberejo isto besedilo.

Pri pouku učitelj, glede na predmetno področje in tip besedila, uporablja dva tipa glasnega branja. Prvo je nevtralno, logično, neinterpretativno branje in drugo je interpretativno, čustveno obarvano branje. V obeh primerih gre za prekodiranje pisanega besedila v govorjenega. Zelo pomembno je, da bralec poleg pisnega pozna tudi govorni kod, to pomeni, da mora iz jezikovne organiziranosti besedila znati razbirati tudi njegovo govorno urejenost (ločila, naglase, posebno glasovje, besedni red, vrivke, elipse itd.) (Podbevšek 1995: 105).

Nevtralno branje pomeni branje brez izrazitejših stavčnih poudarkov, z majhnimi intonacijskimi razponi, z zgolj logičnimi pavzami, ki sledijo členjenju napisanih misli, brez posebnega zvočnega barvanja besedila, ves čas v približno enaki govorni hitrosti. Tudi vizualni elementi govora niso izpostavljeni. Takšno vrsto branja učitelj uporablja, kadar pred razredom bere neumetnostno besedilo (publicistično besedilo, strokovno besedilo ...). Namen takšnega branja je zgolj informiranje o nečem v avtentični obliki brez bralčevega odnosa do besedila oziroma brez bralčeve čustvene zavzetosti (Podbevšek 1995: 106).

Kadar pa učitelj glasno bere umetnostno besedilo, naj bi bilo njegovo branje interpretativno. Tako branje je napolnjeno s čustvenim odnosom. Pri takem branju ne gre zgolj za prekodiranje podatkov, ampak gre tudi za čustveno doživetje tako bralca kot poslušalca. Takšno branje želi pri učencih/poslušalcih spodbuditi umetniško doživljanje (Podbevšek 1995: 106). 
Interpretativno branje zahteva natančno pripravo. Poleg tega, da se bralec z besedilom literarnoteoretsko in literarnozgodovinsko seznani v širšem smislu, se mora na branje pripraviti in se seznaniti z besedilom tudi v ožjem smislu. Ta priprava zahteva večkratno tiho in kasneje glasno branje besedila, pri čemer je treba posebno pozornost nameniti ločilom in intonaciji, naglasom, glasovnim premenam ter pravorečni izreki. Prav tako je treba smiselno spreminjati tempo in jakost branja, da $s$ tem povečujemo dramatičnost. Vsebini besedila je treba prilagajati in menjavati glasovno barvo ter register in vključiti tudi vidne prvine govora, obrazno mimiko in kretnje (Podbevšek 1995: 107).

Učenci se morajo seznaniti z obema vrstama branja. Medtem ko je interpretativno branje stvar jezikovnega pouka oziroma pouka književnosti, nevtralno branje razvijamo in gradimo pri vseh predmetih. Kadar od učenca pričakujemo interpretativno branje literarnega besedila, ne smemo pozabiti, da je za tako branje potrebna natančna priprava, ki jo moramo učencu predstaviti, mu jo omogočiti in ga z zgledom naučiti vseh elementov takega branja.

V spodnji tabeli so predstavljene dejavnosti za razvoj tekočnosti branja v razredu, kot jih je povzela Sonja Pečjak (2012).

Preglednica 2: Pregled možnih bralnih dejavnosti v razredih

\begin{tabular}{|c|c|c|c|c|}
\hline $\begin{array}{l}\text { Vrsta } \\
\text { branja }\end{array}$ & Namen & Vloga učitelja & Vloga učenca & Oblika dela \\
\hline $\begin{array}{l}\text { Glasno } \\
\text { branje } \\
\text { učitelja }\end{array}$ & $\begin{array}{ll}- & \text { spodbujati } \\
& \text { tekočnost } \\
- & \text { seznanjati } \\
& \text { učence z } \\
& \text { novimi } \\
& \text { zvrstmi in } \\
& \text { avtorji } \\
- & \text { spodbujati } \\
& \text { razumevanje } \\
- & \text { izvabljati } \\
& \text { odgovore } \\
\text { učencev } \\
- & \text { širiti } \\
\text { besedišče } \\
- & \text { razvijati } \\
\text { interes za } \\
\text { branje }\end{array}$ & $\begin{array}{ll}- & \text { pokaže } \\
\text { model } \\
\text { tekočega } \\
\text { branja } \\
-\quad & \text { vodi } \\
& \text { pogovor o } \\
& \text { besedilu } \\
- & \text { uvaja } \mathrm{v} \\
& \text { besedišče }\end{array}$ & $\begin{array}{ll}- & \text { aktivno } \\
& \text { poslušanje } \\
- & \text { sodelovanje } \mathrm{v} \\
& \text { pogovoru o } \\
& \text { besedilu } \\
- & \text { pisanje } \\
& \text { odgovorov } \\
- & \text { branje skupaj } \\
& \text { z učiteljem }\end{array}$ & $\begin{array}{ll}- & \text { cel razred } \\
- & \text { v manjših } \\
& \text { skupinah }\end{array}$ \\
\hline
\end{tabular}




\begin{tabular}{|c|c|c|c|c|}
\hline $\begin{array}{l}\text { Glasno } \\
\text { branje } \\
\text { učencev }\end{array}$ & $\begin{array}{ll}- & \text { razvijati } \\
& \text { tehniko } \\
& \text { branja } \\
- & \text { razvijati } \\
\text { tekočnost } \\
\text { branja }\end{array}$ & $\begin{array}{ll}\text { - } & \text { pokazati } \\
& \text { kriterije } \\
\text { tekočnosti } & \text { branja } \\
- & \text { ugotoviti } \\
\text { branje } \\
\text { posameznika } \\
\text { ali skupine }\end{array}$ & $\begin{array}{ll}- & \begin{array}{l}\text { ponavljanje } \\
\text { glasnega }\end{array} \\
\text { branja } & \\
- & \text { uporaba } \\
\text { kriterijev } & \text { tekočega } \\
\text { branja pri } \\
\text { sebi in drugih } \\
\text { - } & \text { pomoč } \\
\text { sošolcu ali } \\
\text { skupini }\end{array}$ & $\begin{array}{ll}- & \text { individualno } \\
- & \mathrm{v} \text { dvojicah } \\
- & \mathrm{v} \text { manjših } \\
& \text { skupinah }\end{array}$ \\
\hline $\begin{array}{l}\text { Vodeno } \\
\text { branje }\end{array}$ & $\begin{array}{ll}- & \text { učiti se in } \\
\text { uporabljati } \\
\text { strategije } \\
\text { branja } \\
-\quad \text { pridobiti } \\
\text { besedišče } \\
-\quad & \text { razumeti } \\
\text { zanimiva } \\
\text { besedila }\end{array}$ & $\begin{array}{ll}\text { - } & \begin{array}{l}\text { modelirati } \\
\text { strategije }\end{array} \\
\text { branja } \\
-\quad & \text { aktivirati ali } \\
& \text { ustvarjati } \\
& \text { predznanje } \\
- & \text { uvajati novo } \\
& \text { besedišče } \\
- & \text { postavljati } \\
& \text { vprašanja }\end{array}$ & $\begin{array}{ll}- & \text { tiho branje } \\
\text { določenega } \\
\text { besedila } \\
-\quad \text { pogovor } \\
\text { celega } \\
\text { razreda ali } \\
\text { manjših } \\
\text { skupin o } \\
\text { prebranem } \\
-\quad \text { uporaba } \\
\text { delovnih } \\
\text { listov z } \\
\text { navodili } \\
\text { pisanje } \\
\text { spremenjenih } \\
\text { besedil } \\
\end{array}$ & $\begin{array}{cl}- & \text { cel razred } \\
- & \text { v manjših } \\
& \text { skupinah }\end{array}$ \\
\hline $\begin{array}{l}\text { Bralne } \\
\text { delavnice }\end{array}$ & $\begin{array}{ll}\text { - } & \text { pridobivati } \\
\text { izkušnje in } \\
\text { samostojnost } \\
\text { pri delu z } \\
\text { različnim } \\
\text { bralnim } \\
\text { gradivom } \\
\text { - } \\
\text { pridobivati } \\
\text { besedišče, } \\
\text { strukturo } \\
\text { jezika } \\
\text { razvijati } \\
\text { pozitivna } \\
\text { stališča do } \\
\text { branja }\end{array}$ & $\begin{array}{ll}\text { - } & \text { spoznavati } \\
& \text { različne vrste } \\
& \text { branja } \\
- & \text { spremljati } \\
& \text { napredek } \\
\text { učenca na } & \text { okroglih } \\
\text { mizah in pri } \\
\text { pisnih } \\
\text { odgovorih } \\
\text { ocenjevati in } \\
\text { spodbujati } \\
\text { uporabo } \\
\text { bralnih } \\
\text { strategij }\end{array}$ & $\begin{array}{ll}- & \text { izbirati } \\
& \text { besedila } \\
& \text { različnih } \\
& \text { žanrov } \\
- & \text { samostojno } \\
\text { brati } & \\
-\quad & \text { s pisanjem se } \\
\text { odzivati na } & \text { prebrano } \\
\text { opisovati in } \\
\text { pogovarjati } \\
\text { se o } \\
\text { prebranem } \\
\text { na okroglih } \\
\text { mizah } \\
\text { zapomniti si } \\
\text { prebrano, } \\
\text { izbirati } \\
\text { bralne cilje in } \\
\text { vrednotiti } \\
\text { prebrano } \\
\end{array}$ & $\begin{array}{ll}- & \text { individualno } \\
- & \mathrm{v} \text { dvojicah } \\
- & \mathrm{v} \text { manjših } \\
& \text { skupinah } \\
- & \text { cel razred }\end{array}$ \\
\hline
\end{tabular}

Vir: Rycik in Irvin 2005, v Pečjak 2012 


\subsubsection{Predšolsko obdobje}

O tekočem branju lahko govorimo šele, ko je tehnika branja usvojena oziroma ko je otrok opismenjen. Priprave na opismenjevanje se začnejo že v predšolskem obdobju skozi slikopise in skozi spremljanje ilustracij ter vzorcev v knjigah. V tem obdobju se otrok navaja predvsem na smer branja od leve proti desni ter od zgoraj navzdol. Zelo pomemben je zgled staršev in vzgojiteljev. Otrok mora nujno že $\mathrm{v}$ zelo zgodnjem obdobju imeti stik s tekočim in pravorečno pravilnim ter izraznim glasnim branjem. Poslušanje branja se precej loči od poslušanja prostega govora.

$\mathrm{Na}$ uspešnost opismenjevanja $\mathrm{v}$ 1. razredu osnovne šole pomembno vpliva tudi otrokova zmožnost glasovnega zavedanja. Otrok razvije zmožnost zaznavanja rim že v 1. starostnem obdobju. Pozneje postopoma razvije zmožnost členiti povedi na besede, zaznati daljše oz. krajše besede, členiti besede na zloge, zaznati začetni glas $\mathrm{v}$ besedi, zaznati končni glas $\mathrm{v}$ besedi, zaznati glasove znotraj besede in na koncu še zmožnost zaznati posamezne glasove v besedi oz. zaporedje glasov v besedi (Ropič 2017).

V longitudinalni študiji, ki je opazovala otroke v predšolskem obdobju in pozneje $\mathrm{v}$ 1. in 2. razredu, so v času vrtca ovrednotili glasovno zavedanje, avtomatizirano poimenovanje, glasovni kratkoročni spomin, slušno procesiranje, motorične sposobnosti in govor. V 1. in 2. razredu je bila ocenjena uspešnost branja. Rezultati so pokazali, da v 1. razredu napovedujejo rezultati vrtca in glasovnega spomina ne le splošno bralno uspešnost, ampak tudi natančnost in tekočnost branja. Govor ima najpomembnejšo vlogo pri napovedovanju razumevanja branja. V 2. razredu napovedujejo splošno bralno uspešnost in tekoče branje naslednji trije dejavniki: rezultati vrtca, glasovno zavedanje in glasovni spomin. Raziskovalci ocenjujejo, da so za natančnost branja pomembni glasovno zavedanje, glasovni spomin in »kopije« potez oziroma oblik črk. Rezultati raziskave kažejo na smiselno upoštevanje tega $\mathrm{v}$ izvedbi programa $\mathrm{v}$ predšolski dobi, saj lahko to prispeva $\mathrm{k}$ preprečevanju morebitnih težav pri branju učencev v prvih šolskih letih (Papadimitriou in Vlachos 2014).

Izraznost branja vpliva na poslušanje razumevanja predšolskih otrok v vrtcu. To je potrdila tudi študija, ki je bila izvedena v vrtcu z otroki, starimi med štiri in pet leti. Njen namen je bil ugotoviti učinek izraznosti glasnega branja zgodb odrasle osebe na razumevanje pri otrocih. Otroci so poslušali posnetke glasnega branja dveh 
podobnih zgodb. $\mathrm{V}$ enem primeru je bila $\mathrm{v}$ glasnem branju prisotna izraznost, $\mathrm{v}$ drugem nasprotno (brez izraznosti). Pomembno je, da je otroke statistično značilno bolj pritegnilo izrazno branje. Branje, ki je bilo zelo izrazno, je omogočilo boljše razumevanje zgodb otrokom v vrtcu (Mira in Schwanenenflugel 2013).

Ob tem naj dodamo, da aktualna književna didaktika v slovenskem prostoru posveča pomembno skrb za izrazno branje oziroma pripovedovanje umetnostnih besedil $\mathrm{v}$ vrtcu ter v 1. in 2. VIO OŠ (Kordigel in Saksida 2000).

Nekatere študije povezujejo uspešnost opismenjevanja otrok z domačim okoljem. Raziskali so povezave med zakonskim zadovoljstvom, družinsko čustveno izraznostjo, domačim učnim okoljem in spretnostmi pismenosti predšolskih otrok. $\mathrm{V}$ študiji je sodelovalo skoraj štiristo mater in njihovih otrok. Raziskovalci so ugotovili, da je bilo večje zadovoljstvo mater povezano z višjo stopnjo pozitivne in nižjo stopnjo negativne družinske čustvene izraznosti. Tako domače okolje je boljše za učenje doma in je posledično povezano z uspešnejšim opismenjevanjem otrok. Prav tako ugotovitve študije poudarjajo pomen zakonskih in družinskih procesov pri pridobivanju znanj majhnih otrok (Froyen, Skibbe, Bowles, Blow in Gerde 2013).

Predšolski otroci naj v vrtcu sledijo branju in pisanju po načelu od leve proti desni in zgoraj navzdol. S tem se naj soočajo pri različnih aktivnostih in ne glede na predmetno področje.

\subsubsection{Prvo vzgojno-izobraževalno obdobje}

1. VIO je namenjeno opismenjevanju. Otroci se v tem obdobju naučijo branja ter zapisovanja besedil. Naučijo se pisanja in branja tiskanih ter pisanih črk. Cilj 1. VIO je, da se otrok nauči tekoče glasno ali polglasno brati. Pri tem je zaželeno, da je v njegovem branju čim manj premorov in omahovanj ter ponovitev. Ritem branja mora biti enakomeren. Branje mora biti natančno s pravilno artikulacijo glasov in upoštevanjem stavčne intonacije. V 2. VIO je branje že avtomatizirano. Otrok v tem obdobju izpopolni tehniko glasnega in tihega branja tudi nepoznanih besedil. Dosledno upošteva vsa ločila in stavčno intonacijo (UN 2018). 
Pri učencih 1. razreda so osnove branja $\mathrm{v}$ različni fazi. $\mathrm{Na}$ razvoj tehnike branja vplivajo različni dejavniki. Pri spodbujanju učencev za razvoj bralne tehnike je zelo pomemben dejavnik učitelj. Pri pouku naj bi iskal poti, ki omogočajo večjo motiviranost učencev za branje.

Primerjalna študija $\mathrm{v}$ pridobivanju in izpopolnjevanju bralne tehnike učencev 2. in 3 . razreda, ki naj bi pokazala razlike med dvema pristopoma, kjer je eden nekoliko bolj tradicionalen (branje, delovni listi, pogovor o prebranem) in drugi nekoliko bolj razgiban (branje navodil za izvajanje didaktične igre, branje in razvrščanja besednih in slikovnih kartic), ni pokazala bistvene razlike v uspešnosti učencev. Anketa pa je opozorila na to, da je večina učencev izrazila pozitiven odnos do branja $\mathrm{v}$ didaktičnih igrah (Webb, Rule, Cavanaugh in Munson 2014). Pomembno je, da je učitelj pri opismenjevanju primerno ustvarjalen. Motiviranost učencev za branje bo imelo dolgoročne posledice.

Pomemben dejavnik v razvoju bralne tehnike je glasno branje učencev drugim navzočim. Pri tem kaže opozoriti na branje besedil pri pouku, in sicer na ustrezno diskusijo učiteljev $z$ učenci med branjem besedila oziroma po branju besedila. Ocene raziskav kažejo na večji učinek v primeru, ko poteka pogovor med branjem na glas na ravni makrostrukture in mikrostrukture ter kritičnim pristopom do besedila. Učenci se po večkratnih obravnavah besedil lažje osredotočajo na pomembne podatke v besedilu, iščejo povezave med besedili in ob tem izboljšujejo razumevanje prebranega (Heisey 2009; Heisey in Kucan 2010).

Raziskave kažejo, da $57 \%$ učencev 3. razreda, ki imajo težave pri branju, grozi, da bodo imeli težave $z$ branjem tudi $\mathrm{v}$ naslednjih letih. $\mathrm{S}$ tem bodo imeli tudi manj možnosti, da zaključijo srednjo šolo. Nerazumevanje prebranega lahko predstavlja tako težavo razumevanja prebranega tistim učencem, ki berejo brez večjega napora, kot tistim, ki se bojijo dekodiranja besedila. Učitelji naj poiščejo v branju ravnovesje med tekočim branjem in razumevanjem prebranega. Ena izmed rešitev izboljšanja tehnike branja je večkratno branje. Ta tehnika branja učence vključuje v raznolike skupine, ki zagotavljajo motivacijo, socializacijo in sodelovanje. Glasno ponovljeno branje je učencem zanimivo, motivirajoče in bi lahko koristilo tudi pri pridobivanju znanja (Marshall 2009; Kramarič, Ropič in Urbančič Jelovšek 2002). 
Ključnega pomena je zgodnja identifikacija morebitnih učencev, ki bi lahko imeli težave pri branju. $\mathrm{V}$ ta namen so preverili z ustreznim instrumentarijem skoraj tisoč učencev 2. in 3. razreda osnovne šole, diagnosticirali natančnost tekočega glasnega branja in identificirali učence, za katere obstaja tveganje za težave v branju. Za prakso je pomembno, da so ti pregledovalniki ključni sestavni del uspešne zgodnje identifikacije in nadaljnje obravnave (Parker, Zaslofsky, Burns, Kanive, Hodgson, Scholin in Klingbeil 2015). V slovenskem prostoru nimamo standardiziranega preizkusa branja, s pomočjo katerega bi usposobljeni strokovni delavci izvedli preverjanje branja, ob katerem bi dovolj zgodaj identificirali učence s težavami $\mathrm{v}$ branju in jih napotili $\mathrm{v}$ nadaljnjo obravnavo. Učitelji pogosto prepoznajo učence $\mathrm{s}$ težavami pri branju v vsakodnevni praksi in nato ustrezno ukrepajo.

Glasno branje je za učence, še zlasti 1. razreda, stresno. Pogosto so obremenjeni s hitrostjo branja (čas branja). Prozodična občutljivost branja ni neposredno povezana z branjem besed. Njena zveza se odraža s fonološkim in morfološkim zavedanjem. Ko so preverili povezave $z$ branjem besed, $z$ razumevanjem poslušanja in delovnega spomina, ni bila prozodična občutljivost povezana $z$ razumevanjem branja. Zato se zdi, da prozodična občutljivost prispeva $\mathrm{k}$ branju besed predvsem $\mathrm{s}$ pomočjo fonološkega in morfološkega zavedanja. Iz rezultatov raziskave je razvidno, da s posvečanjem pozornosti prozodični občutljivosti pri branju koristno vplivamo na razvoj fonološkega in morfološkega zavedanja, kar pa izboljša bralne spretnosti (Kim in Petscher 2016).

Raziskave kažejo, da angleški otroci razvijejo svoje bralne prozodije (t. i. pavze, trajanje različnih segmentov, variacije naklona) med 1. in 2. razredom. Ker v Španiji ni bilo izvedenih podobnih raziskav, so izvedli longitudinalno študijo, v kateri so spremljali učence od 1. do 3. razreda. Raziskovalci so bili mnenja, da se lahko pri španskih otrocih razvije branje že prej, saj je španččina pregleden jezik, kar omogoča doseganje visoke natančnosti $\mathrm{v}$ prvem letu učenja branja. Učenci so $\mathrm{v}$ raziskavi glasno brali. Rezultati so pokazali, da so mlajši učenci delali več pavz, ki so bile daljše, ter so brali manj natančno. Na natančnost branja v vseh razredih so vplivale pogoste besede. Med 1. in 2. razredom se je izboljšal čas branja. Na branje v vseh omenjenih razredih so vplivale pogoste besede in končna intonacija. Prav tako so opazili, da so se učenci v 1. razredu pri glasnem branju manj posluževali intonacije, učenci v 2. razredu pa so jo pri glasnem branju pretirano spreminjali. Rezultati španske raziskave so potrdili, da se tekočnost branja med 1. in 2. razredom močno poveča (ÁlvarezCañizo, Martínez-García, Cuetos in Suárez-Coalla 2020). 
V iskanju različnih poti do uspešnega učenja branja je bila izvedena longitudinalna raziskava. Analizirali so tri dimenzije branja (natančnost in hitrost branja ter razumevanje prebranega). Ta študija je ovrednotila vlogo vizualne analize in miselnih slik pri bralnih predstavah učencev na različnih stopnjah bralnega pridobivanja. Pomen te raziskave je $\mathrm{v}$ uporabi strategij posredovanja, ki so osredotočene na vizualne posnetke. Ti bi lahko povečali bralne predstave pri učencih in tudi tistih učencih, ki jim grozijo težave pri učenju (Commodari, Guarnera Di Stefano in Di Nuovo 2020). Didaktična gradiva za učence v devetletni osnovni šoli v Sloveniji vsebujejo vizualne posnetke. Gradiva so pripravljena v obliki, ki zahteva sodelovanje vseh učencev v razredu. Prav tako je vizualna dejavnost integrirana s poslušanjem, govorjenjem, branjem in pisanjem (Kramarič, Ropič in Urbančič Jelovšek 2000).

V usmerjanju uspešnosti branja učencev so dobrodošli učiteljevi napotki. To potrjuje tudi raziskava, ki je bila izvedena v 3. razredu. Učenci so sprejeli mnenje in napotke, s katerimi bodo osredotočeni na natančnost na tekočnost branja. Učenci so na tak način v naslednji fazi dosegli večjo natančnost pri branju in pozneje izboljšali tudi tekočnost branja. Vse to je privedlo do tega, da so učenci pravilno prebrali vsaj 93 \% besed (Parker in Burns 2014). Načela formativnega spremljanja branja učencev učitelje spodbuja $\mathrm{k}$ prepoznavanju zmožnosti posameznih učencev $\mathrm{v}$ glasnem branju, spremljanju in nujnosti usmerjanja k doseganju višjih ciljev (Breznik 2019).

Slabi bralci so sorazmerno počasnejši od dobrih bralcev. Hitrost branja je pokazala, da je povezana $z$ besediščem in glasovnim zavedanjem. Raziskovalci ugotavljajo, da učenci, ki so brali počasi oziroma so imeli težave pri branju, imajo tudi nižjo zmožnost glasovnega zavedanja (Manis, Doi in Bhadha 2000).

Ovira pri uspehu pri branju številnih učencev v 3. razredu je raba abecednega načela oziroma črkovanja, zato je obstajala potreba po vplivu na to težavo. Odločili so se, da bodo razširili vaje za izboljšanje črkovanja v celotnem razredu. Raziskovalec je $\mathrm{v}$ ta namen pripravil vzročno-primerjalni načrt, ki je ocenil njegovo učinkovitost. Načrt je vseboval tudi šestdeset vaj za učence. Podatki podpirajo učinkovitost izvedenega učenja $\mathrm{v}$ celotnem razredu na povečanje sposobnosti dekodiranja, na povečanje avtomatiziranega dekodiranja in na povečano uporabo abecednega načela pri branju besedila. Učenci so s tem izboljšali tudi hitrost branja (Donnell 2007). 
Pomembno razmerje med hitrostjo glasnega branja in razumevanjem prebranega pri učencih drugega in tretjega razreda, pri katerih je bilo prepoznano tveganje pri branju, ugotavlja pomembno povezavo med številom napak, glasnim branjem in uspešnostjo razumevanja prebranega. Zmanjšanje napak napoveduje uspešnost razumevanja (Abbott, Wills, Miller in Kaufman 2012).

Pomembno je, da učitelji v praksi čim hitreje prepoznajo učence, ki imajo določene težave $\mathrm{v}$ branju oziroma jih nakazujejo. Nekatere študije so želele ugotoviti značilnosti otrok oziroma učencev, ki napovedujejo odzivnost in neodzivnost na splošno učinkovite usmeritve v zgodnji pismenosti. Otroci so bili testirani v vrtcu in v prvem razredu. Status odziven/neodziven je bil določen po dveh letih, ko je otrok sodeloval $\mathrm{v}$ najboljši praksi: $\mathrm{v}$ vrtcu in prvem razredu, samo $\mathrm{v}$ vrtcu, samo $\mathrm{v}$ prvem razredu, $v$ nobenem letu. To je olajšalo raziskovanje $\mathrm{v}$ treh skupinah, in sicer »vedno odzivni« (učenci so izpolnjevali merila odzivnosti v obeh letih), "včasih odzivni« (učenci so kriterije izpolnjevali v enem letu) in »neodzivni učenci« (v nobenem letu niso izpolnjevali meril). Multivariantna analiza variance in analiza diskriminatornih funkcij je pokazala, da so se omenjene skupine zanesljivo razlikovale med seboj v določenih meritvah (problematično vedenje, besedni spomin, posnemanje povedi, skladenjsko zavedanje, besedišče, hitrost poimenovanja in členjenje). Pri tem je pomembno, da je t. i. kombinacija hitrosti poimenovanja, besedišča, posnemanja povedi, problematičnega vedenja in količine nudenih usmerjanj učencev pravilno napovedala $82,1 \%$ neodzivnih učencev, 30,0 \% včasih odzivnih in 84,1\% vedno odzivnih učencev (Al Otaib in Fuchs 2006).

Od vrtca do konca prvega razreda se razvijajo avtomatizirane komponente poimenovanja, tudi čas artikulacije in čas premora. Raziskava pravi, da je bil čas pavze od vrtca do konca prvega razreda zelo stabilen in se je močno razvil ter bil povezan $z$ natančnostjo branja in tekočim branjem. Čas artikulacije je bil manj stabilen in je bil šibko izboljšan po bralnih ukrepih (Georgiou, Parrila in Kirby 2006).

Izvedene so bile tudi raziskave, ki naj bi preučile hitrost branja velikih in malih tiskanih črk. Na tem področju so preverili 732 učencev različnih razredov osnovne šole v Turčiji. Zabeležili so število besed, ki jih je posameznik prebral v eni minuti. Hitrost branja besedila, ki je bilo napisano z malimi tiskanimi črkami, je uspešnejša od hitrosti branja z veliki tiskanimi črkami. Med branjem besedila z malimi in veliki tiskanimi črkami se je pokazala statistično značilna razlika v hitrosti branja. Prav tako 
je raziskava pokazala, da je hitrost branja besedila z malimi tiskanimi črkami $13 \%$ večja od hitrosti branja besedila velikih tiskanih črk (Babayigit 2019).

Raziskovalci so oblikovali številne lestvice za ocenjevanje spretnosti branja ter jih preizkušali in utemeljevali. Ena izmed njih je preverjala izraznost, hitrost in natančnost. Raziskovalci so ocenjevali glasno branje učencev v drugem razredu (prva faza) in nato ponovno $v$ tretjem razredu (druga faza). Trije strokovnjaki, ki so neodvisno ocenili glasno branje učencev $v$ drugem razredu $s$ t. i. »celovito lestvico tekočnosti branja«, so prepoznali močno korelacijo med bralno izraznostjo, hitrostjo in natančnostjo branja. Prav tako so preverili v glasnem branju dveh novih besedil učence $v$ tretjem razredu (druga faza). $S$ pomočjo končne različice lestvice sta dva strokovnjaka neodvisno ocenila branje in ugotovila primerljive rezultate s prvo fazo raziskave (Benjamin, Schwanenflugel, Meisinger, Groff, Kuhn in Steiner 2013).

Včasih se pojavi vprašanje glede natančnosti učiteljeve presoje oz. ocene v branju učencev. $\mathrm{V}$ ta namen so izvedli študijo, $\mathrm{v}$ kateri so želeli odkriti učiteljevo natančnost $\mathrm{v}$ bralni sposobnosti pri učencih 2. in 3. razreda. $\mathrm{V}$ njej je sodelovalo 1.468 učencev in 86 učiteljev. Na splošno so učitelji presodili bralne zmožnosti natančneje kot dekodirne sposobnosti. Kljub temu so bile sposobnosti učencev z nizkimi dosežki ocenjene manj natančno. Natančnost pri presojanju dekodiranja je bila večja $\mathrm{v}$ majhnih razredih in pri učencih s posebnimi izobraževalnimi potrebami. Natančnost pri presojanju bralnega razumevanja je $z$ leti rasla in je bila $\mathrm{v} 3$. razredu in na koncu šolskega leta natančnejša (Paleczek, Seifert in Gasteiger-Klicpera 2017). Formativno spremljanje učencev predstavlja mnogim slovenskim učiteljem velik izziv - tudi v presojanju bralnih sposobnosti učencev v prvem, drugem in tretjem razredu (Breznik, 2019).

\subsubsection{Drugo vzgojno-izobraževalno obdobje}

$\mathrm{Na}$ uspešnost branja je smiselno vplivati z načrtnim bogatenjem besedišča učencev tudi še v 2. VIO. Izvedene so bile primerjalne študije besedišča in branja, ki so preverjale iste učence jeseni in spomladi $v$ 4. razredu ter 5. razredu in opozorile na znatno zvišanje rezultatov na preverjanju (Jones, Kim, LaRusso, Kim in Snow 2015). 
Avtorji raziskave menijo, da je natančno in avtomatizirano glasno branje pomembno povezano z razumevanjem branja. $V$ tej raziskavi so $\mathrm{v}$ glasnem branju učencev 4. razreda opazovali natančnost, hitrost in prozodijo branja besed. Raziskava kaže, da so kazalniki tekočega branja še naprej pojasnjevali razlike v razumevanju prebranega, in sicer tudi takrat, ko so imeli učenci možnost seznanitve $z$ besedilom pred glasnim branjem. Prav tako rezultati raziskave pravijo, da natančno branje besed in hitrost branja pojasnjujeta rezultate razumevanja branja. Skoraj vsem učencem z nizko stopnjo branja je skupno to, da so imeli težave s prepoznavanjem besed, kar potrjuje razmeroma večje število napak pri branju besed in nizke ocene prozodiranja (Sabatini, Wang in O'Reilly 2019).

Zanimiva je raziskava, ki je primerjala natančnost, hitrost in t. i. prozodije (izraznost pri glasnem branju: pavze, trajanje, višina, intenziteta) v glasnem branju učencev tretjega in petega razreda ter odraslih. Namen študije je bil raziskati, kako se razvoj bralne prozodije pri španskih učencih razlikuje glede na vrsto in dolžino povedi. Glasno branje učencev tretjega in petega razreda so primerjali z glasnim branjem odraslih. Ugotovili so, da učenci tretjega razreda $\mathrm{v}$ glasnem branju še niso razvili prozodije, podobne odraslim. Naredili so več premora, imeli revnejši melodični pristop in težko so predvideli stavčno zgradbo. Učenci 5. razreda so pokazali v glasnem branju že nekatere značilnosti prozodije odraslih. Na izraznost branja je v vseh treh skupinah vplivala dolžina povedi. Raziskovalci so mnenja, da je bralna izraznost povezana $z$ bralno izkušnjo in se razvija na podoben način kot dekodiranje in hitrost branja (Álvarez-Cañizo, Suárez-Coalla in Cuetos 2018).

Študija primera si zastavlja vprašanje, ali je možno razumevanje prebranega izboljšati z razvojem izraznega branja. Poleg hitrosti in natančnosti so v vajo branja vključili še izraznost. $Z$ učencem četrtega razreda so opravili sedemnajst individualnih srečanj, na katerih je učenec ob večkratnem branju besedila dal poudarek izraznemu branju. V primerjavi z izhodiščnimi rezultati je učenec izboljšal bralno tekočnost in razumevanje prebranega. Kljub temu ni mogoče pripisati napredka glasnemu branju z vajo izraznosti branja (Calet, Pérez-Morenilla in De los Santos-Roig 2019).

V branju tradicionalno pričakujemo, da dosežemo že v nižjih razredih osnovne šole takšen cilj v branju, ki bo omogočal obvladovanje branja in učenje z branjem. Raziskali so vlogo tekočnosti branja na pridobitev znanja iz branja in morebitnih bralnih težav učencev. Ocenili so tekočnost branja pri velikem številu učencev tretjega, petega in sedmega razreda. Ob tem so kot merilo za tekoče branje uporabili 
prozodijo (izraznost pri glasnem branju) in ne hitrost branja (avtomatizacija prepoznave besed). Zaznali so zmerno močno korelacijo med tekočim branjem in razumevanjem. Njihove ugotovitve kažejo, da je tekoče branje pomembno pri učencih tretjega in petega razreda ter da je prozodija pomemben del popolnega branja. Obe komponenti tekočega branja, avtomatiziranost prepoznavanja besed in prozodičnost $\mathrm{v}$ glasnem branju, je treba upoštevati pri meritvah tekočnosti branja. Raziskovalci opozarjajo, da bi to morali upoštevati tudi pri pouku v vajah za izboljšanje tekočega branja. Predlagajo, da bi raziskali vlogo tekočega branja med mladostniki, še zlasti pri tistih, ki imajo težave pri doseganju visoke ravni pismenosti (Rasinski, Rikli in Johnston 2009).

Učence, stare od osem do deset let, so ocenili trikrat v tekočnosti in izraznosti branja. Ocenjevalci branja so v 57 od 67 primerov dodelili enako oceno v tekočnosti. V oceni izraznosti so se strinjali v 34 primerih. Ker je bilo nestrinjanje v ocenjevanju izraznosti razmeroma pogosto, so v poznejši analizi za izraznost branja določili novo lestvico ocenjevanja izraznosti, in sicer visoko, srednjo in nizko. Splošna porazdelitev rezultatov kaže na korelacijo med ocenami izraznosti in tekočnosti. Prisotna je bila velika asimetrija. Visoka izraznost pri glasnem branju je bila močno povezana $z$ visoko tekočnostjo branja. Bralci $z$ nizko izraznostjo pri branju so razmeroma enakomerno razdeljeni na nivo tekočnosti (Cowie, Douglas in Wichmann 2002).

V longitudinalni študiji so preverili pomen ritma kot napovedovalca bralne sposobnosti pri istih učencih od prvega do petega razreda. Ritem je napovedoval pomembno razliko $\mathrm{v}$ sposobnosti branja $\mathrm{v}$ vseh razredih. Raziskava potrjuje pomembno povezavo ritma $\mathrm{s}$ fonološkim zavedanjem in hitrostjo dekodiranja. Učenci petega razreda so $\mathrm{v}$ primerjavi s prejšnjimi leti (razredi) imeli fonološko zavedanje uspešno razvito, zato je pri njih ritem pomemben napovedovalec bralne sposobnosti. Ko so učenci izboljšali hitrost dekodiranja, je ritem napovedal edinstvene razlike v bralni sposobnosti v 2., 3. in 5. razredu (David, Wade-Woolley, Kirby in Smithrim 2007). 


\subsubsection{Tretje vzgojno-izobraževalno obdobje}

Skozi 1. in 2. VIO naj bi učenci že dodobra usvojili tehniko branja. V 3. VIO pa je učenec že sposoben samostojnega branja zahtevnejših leposlovnih in informativnih besedil. Pogosto je mnenje, da so otroci, ko pridejo do 7. razreda, že popolnoma opremljeni z bralnimi strategijami in tehnikami ter da na tem področju z njimi ni več treba delati. To mišljenje je zmotno. Res je, da je za razvoj bralne pismenosti in tekočnosti branja ključnega pomena dober in pravilen pristop $\mathrm{v}$ zgodnejših obdobjih, vendar zgolj z usvojeno tehniko branja učenec še ne doseže končne stopnje bralne pismenosti. V 1. in še tudi 2. VIO se tekočnost branja razvija neposredno tako skozi cilje in vsebine jezikovnega pouka (slovenščine) kot tudi skozi cilje in vsebine ostalih predmetnih področij, medtem ko se v 3 . VIO ta gradnik razvija in nadgrajuje posredno ob obravnavi posameznih učnih vsebin. Pri tem ne smemo pozabiti, da se razvija tudi skozi cilje vseh ostalih predmetov, ne le slovenščine.

3. VIO je glede tega bolj problematično tudi zato, ker so vsebine posameznih predmetov priporočene $z$ učnimi načrti, zato je medpredmetne povezave treba zelo premišljeno in skrbno načrtovati že pri načrtovanju letne priprave. Tekočnost branja namreč ni navedena med neposrednimi cilji učnih načrtov, je pa to vsekakor posredni cilj vseh predmetov. V 1. in 2. VIO učitelj brez težav cilje in vsebine različnih predmetov med seboj povezuje ter sproti gradi in krepi tudi tekočnost branja svojih učencev, posebej pa je treba opozoriti na skrb za tekočnost branja tudi v 3. VIO. Razvijanje tekočnosti branja v 3. VIO nikakor ni le v domeni učiteljev slovenščine oziroma jezikovnega pouka. Treba jo je uriti in graditi na vseh predmetnih področjih. Vsako predmetno področje ima svoje besedilne posebnosti in strokovne izraze, ki morajo biti pravilno brani in pravilno razumljeni. Prav zato je izjemnega pomena zavedanje predmetnih učiteljev o pomembnosti tekočega branja in krepitve tega gradnika skozi celoten proces šolanja.

Kot že rečeno, je izjemo pomembno, da se na tekočnosti branja gradi pri vseh predmetih. Najbolj neposredno se sicer ta gradnik razvija pri pouku slovenščine. Pomembno je, da učitelj uporablja različne tehnike in izvaja različne bralne dejavnosti (predstavljene $\mathrm{v}$ preglednici 2) za razvoj tekočega branja pri učencih. Posebej pri slovenščini ima učitelj veliko možnosti, saj je učni načrt zasnovan kot delo z različnimi besedili. Pri branju leposlovnih (umetnostnih) besedil je zelo pomembno, da besedila kot model najprej interpretativno prebere učitelj. Pri tem 
mora dosledno upoštevati vse elemente tekočega branja. Posebej mora biti pozoren na zborno izreko, izraznost, natančnost in ritem. Upoštevati mora tudi vse nejezikovne (vidne) prvine govora oziroma branja. Kadar leposlovna besedila glasno berejo učenci, morajo imeti možnost besedilo najprej slišati in tudi samostojno tiho prebrati. Še posebej, če gre za branje poezije, kjer so zvočne prvine govora/branja na prvem mestu. Učenec mora imeti tudi možnost, da besedilo prebere večkrat, saj se le tako lahko izuri v branju, ki bo tekoče po vseh kriterijih.

V nadaljevanju podajamo nekaj praktičnih primerov, kako lahko učitelji tudi pri drugih predmetih gradijo tekočnost branja svojih učencev. Besedila so primeri iz naključno izbranih učbenikov za različne predmete v 3 . VIO. Podčrtane so besede in besedne zveze, ki so specifične za določeno predmetno področje in s katerimi se učenci v 3 . VIO praviloma na novo srečujejo, zato je zelo pomembno, da jih učitelj pripravi na njihovo branje.

Pri družboslovnih predmetih, kot so geografija (prim. slika 1), zgodovina, državljanska vzgoja in etika, učitelj uvaja novo besedišče, pri čemer je zelo pomembno, da učence nauči pravilne izreke in posledično tudi pravilnega branja tega besedišča. Pri teh predmetih se v 3. VIO pojavljajo številni strokovni izrazi, tuja osebna lastna imena, zemljepisna lastna imena, prevzete besede, različne kratice in krajšave, s katerimi se učenci običajno prvič srečajo.

Jugovzhodna Azija je veliko območje, ki ima zelo različne naravne in družbene razmere. Velike pokrajinske enote so: Arabski polotok na jugu, nižina Mezopotamija, po kateri tečeta reki Evfrat in Tigris, gorovja, ki se vlečejo od Tavrusa na zahodu in polotoka Mala Azija ... (Baloh idr. 2015: 93) ${ }^{1}$

Ob prihodu španskih zavojevalcev (imenujemo jih konkvistadorji) $\mathrm{v}$ Ameriko sta tam obstajala azteški in inkovski imperii, ki sta bila $\mathrm{v}$ začetku 16. st. 22 na vrhuncu svojih moči. Leta 1519 se je na mehiški obali izkrcal španski konkvistador Hernando Cortes. (Mirjanič idr. $2014)^{3}$

\footnotetext{
${ }^{1}$ Besedilo iz učbenika Geografija 7 založbe Mladinska knjiga.

${ }^{2}$ Pomembno je, da učenec pravilno prebere vrstilni števnik, pozna krajšavo in jo pravilno prebere.

${ }^{3}$ Besedilo iz učbenika Raz̧iskujem preteklost, Učbenik za 8. rą̧red osnovne šole založbe Rokus.
} 


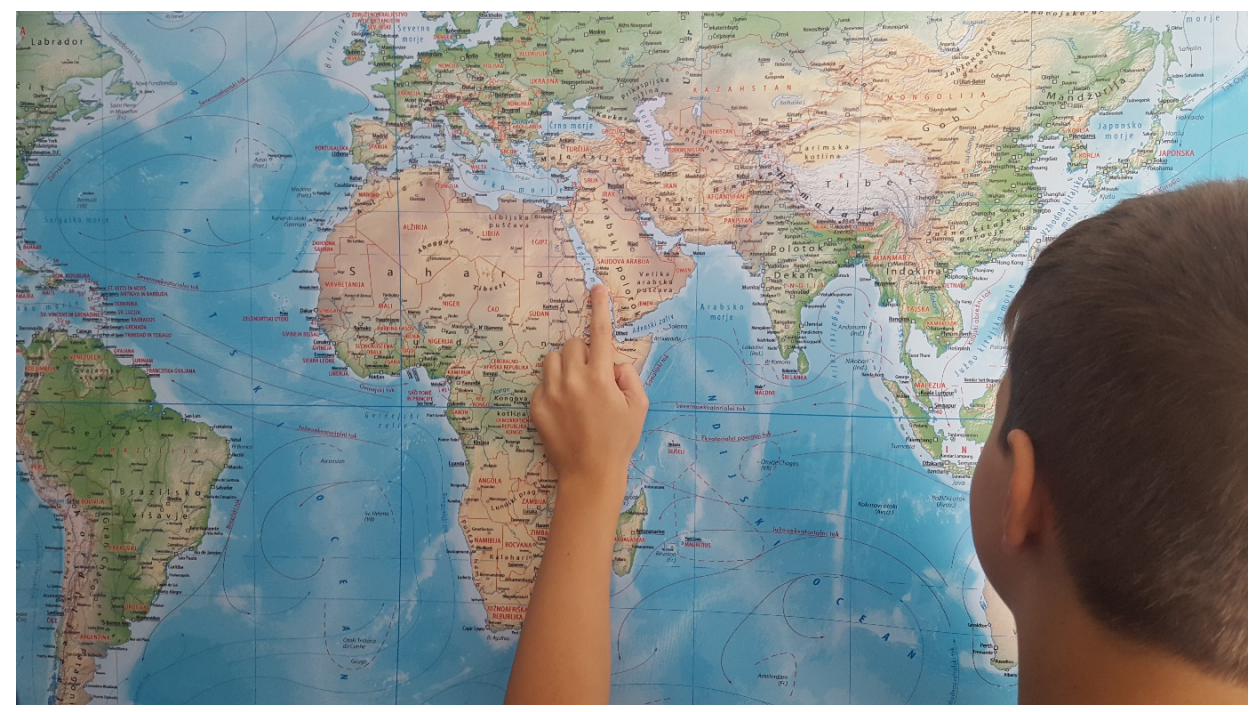

Slika 1: Branje zemljevida

(osebni arhiv Vizjak Puškar)

Pri naravoslovnih predmetih, kot so biologija, kemija, fizika in tudi matematika, se učenci prav tako srečujejo z besedili, ki imajo določene posebnosti, za katere je pomembno, da se jih naučijo pravilno brati. Pri teh predmetih se srečujejo predvsem $s$ števili, pri čemer je zelo pomembno, da jih znajo pravilno prebrati oziroma pretvoriti v besedo, če so zapisana s številko, in obratno. Predvsem so problematična zelo velika in decimalna števila, potence in podobno. Pri naravoslovnih predmetih se učenci v 3 . VIO srečajo tudi s kemijskimi elementi, formulami, merskimi enotami, simboli in drugim zelo specifičnim strokovnim besediščem, za katerega je pomembno, da jim ga učitelj pravorečno pravilno predstavi in tudi učence navaja na njihovo pravilno uporabo in branje. Prav tako se pri naravoslovnih predmetih učenci srečujejo s tujimi lastnimi imeni avtorjev določenih teorij, za katere je pomembno, da jih znajo pravilno prebrati.

Atomi so premajhni, da bi jih lahko posamično šteli ali tehtali. Tudi

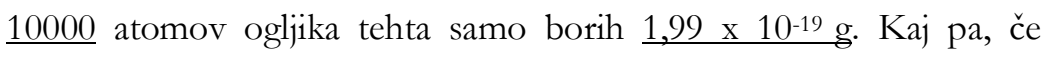
namesto posameznih stehtamo kakšno zelo veliko število atomov? Prav zato smo kemiki uvedli posebno enoto za množino snovi $z$ imenom mol. Množino snovi označimo s črko $\mathrm{n}$.

Znanstveniki so se dogovorili, da je $1 \mathrm{~mol}$ katerekoli snovi sestavljen iz $\underline{6,02 \times 10^{23}}$ delcev. Ti delci so lahko atomi, molekule, ioni ali drugo. 


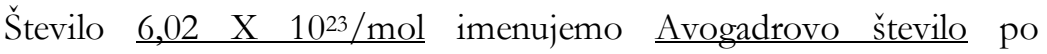
italijanskem kemiku iz 19. stoletja Amadeu Avogadru. Označimo ga s simbolom $\underline{N}_{A}$, enota pa je 1/mol. (Vrtačnik idr. 2016: 206) ${ }^{4}$

\subsubsection{Srednja šola}

$\mathrm{V}$ srednji šoli se znanje, spretnosti in veščine, pridobljene $\mathrm{v}$ osnovni šoli, nadgrajujejo. Širi se splošno besedišče in razvija tudi ozko strokovno besedišče, odvisno od posameznega programa srednješolskega izobraževanja. Besedila so kompleksnejša in zahtevnejša, zato je še toliko bolj pomembno, da se še dalje pri vseh predmetih razvija in spodbuja tekočnost branja. Tudi srednješolski učitelji ne smejo pozabljati na vključevanje glasnega branja v svoje poučevanje. Enako kot v osnovni šoli je tudi v srednji šoli pomembno, da vključujejo tako branje učitelja, ki služi kot vzor tekočega branja, kot glasno branje dijakov. Po končani srednji šoli naj bi bila tekočnost branja že $\mathrm{v}$ celoti dosežena. Dijaki jo izkažejo s smiselnim, razločnim in tekočim ter pravorečno pravilnim branjem vseh vrst besedil. Pri tem upoštevajo vse zvočne prvine govora (intonacija, hitrost, register, premori ...) in tudi vidne prvine govora/branja (mimika, gestikulacija). Po učnem načrtu za slovenščino naj bi dijaki po končani gimnaziji imeli razvito bralno zmožnost na stopnji kultiviranega bralca in bili sposobni glasno ali tiho brati raznovrstna besedila (UN 2008).

Pri slovenščini dijaki berejo vse vrste besedil. Pravilno berejo tudi slogovno zaznamovane, arhaične, narečne, prevzete besede, tuja lastna imena. Poznajo razliko med interpretativnim in nevtralnim branjem ter znajo glede na vrsto besedila in priložnost presoditi, na kak način prebrati določeno besedilo. Zavedajo se, da lahko tudi literarno besedilo služi kot vir podatkov in da v določenem kontekstu ne zahteva interpretativnega branja (Grosman 2006).

Pri ostalih predmetih se $\mathrm{v}$ srednji šoli, odvisno od programa srednješolskega izobraževanja, pojavljajo že zelo specifični strokovni termini. Besedila so zelo ozko strokovno usmerjena. Dijaki se navajajo na strokovno besedišče določene stroke, pri čemer je zelo pomembna pravilna izreka, s katero jih mora seznaniti učitelj posameznega predmeta. Pomembno je, da dijak pozna simbole, kratice in krajšave določene stroke ter da jih tudi pravilno prebere.

\footnotetext{
${ }^{4}$ Besedilo je iz učbenika Moja prva kemija, Učbenik za 8. in 9. rąred osnovne šle založbe Modrijan.
} 
V nadaljevanju podajamo nekaj praktičnih primerov, kako lahko učitelji pri različnih, tudi ozko strokovnih predmetih, gradijo tekočnost branja svojih učencev. Besedila so primeri iz naključno izbranih učbenikov za različne srednješolske predmete. Podčrtane so besede in besedne zveze, ki so specifične za določeno predmetno področje in s katerimi se učenci v srednji šoli srečujejo, zato je zelo pomembno, da jih učitelj pripravi na njihovo branje.

Le Chatelierovo načelo: Če se v sistemu, ki je v ravnotežju, spremeni temperatura, tlak ali koncentracija reaktantov oz. produktov, se položaj ravnotežja spremeni $\mathrm{v}$ smer, ki minimizira to spremembo. /.../ $\mathrm{S}$ spremembo celotnega tlaka lahko vplivamo le na ravnotežne reakcije, pri katerih vsota koeficientov plinastih reaktantov ni enaka vsoti koeficientov plinastih produktov. / . . / Pri reakciji med vodikom $\mathrm{H}_{2}$ in jodom $\mathrm{I}_{2}$ nastane vodikov jodid $\mathrm{HI}$. V tej enačbi je vsota koeficientov plinastih reaktantov enaka koeficientu plinastega produkta, zato $\mathrm{s}$ tlakom ne moremo vplivati na to ravnotežje. ${ }^{5}$ (Smrdu 2008: 42)

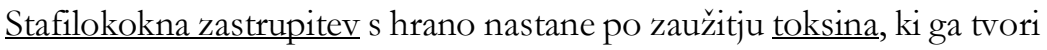
Staphylococcus aureus. Hrano okuži človek kliconosec, ki jo pripravlja in nosi stafilokoke v nosno-žrelnem prostoru. Lahko ima tudi kožno okužbo. Kontaminirana so lahko različna živila ...6 (Šumak 2006: 92)

Perzijci so častili Ahurmazdo, boga svetlobe, ki se nenehno bojuje z bogom zlih duhov in teme Arimanom. Pravični ljudje morajo pomagati Ahrumazdi. Religija se imenuje mazdaizem, njeni nauki so zapisani v sveti knjigi Avesti. Najbolj znan verski učitelj je bil Zoroaster s konca 6. st. pr. Kr. ${ }^{7}$ (Brodnik idr. 2017)

Vodja badenske smeri novokantovske filozofske šole je bil Heinrich Rickert (1863-1936), učenec zgodovinarja filozofije Wilhelma Windelbanda (1848-1915). Windelband je spoznavno teorijo zastavil kot problem veljavnosti, torej (s tujko) kot aksiološki problem. ${ }^{8}$ (Jerman 1992)

\footnotetext{
${ }^{5}$ Besedilo je iz učbenika Kemija, Snov in spremembe 2 za 2. letnik gimnazije.

${ }^{6}$ Besedilo je iz učbenika Zdravstvena nega infekecijskega bolnika za 4. letnik srednje zdravstvene šole za program tehnik zdravstvene nege.

${ }^{7}$ Besedilo je iz učbenika za zgodovino v prvem letniku gimnazije.

${ }^{8}$ Besedilo je iz srednješolskega učbenika Filozofija.
} 


\section{$3 \quad$ Sklep}

Otrok se z branjem (npr. smer branja, tehnika branja) srečuje že v predšolskem obdobju. Bralni razvoj poteka po določenih zakonitostih. $\mathrm{V}$ začetnem obdobju učenja branja je najprej pomembno dekodiranje, ki vključuje vidno zaznavanje in prepoznavanje grafičnih simbolov ter slušno prepoznavanje oziroma glasovno zavedanje. Zelo pomembno je, da je otrok od samega začetka izpostavljen pozitivnim bralnim vplivom, na osnovi katerih gradi svojo tehniko branja, natančnost, hitrost, izraznost in ritem. Razvoj tekočnosti branja se ne zaključi z opismenjevanjem, pač pa traja skozi celoten vzgojno-izobraževalni proces. Zato je nujno, ne glede na predmetno področje, v pouk vključevati različne strategije za razvoj tekočnosti branja tudi v višjih razredih osnovne šole ter nadaljnjem šolanju. Tekočnost branja posameznika se razvija pravzaprav vse življenje.

\section{Literatura}

Mary ABBOTT, Howard WILLS, Angela MILLER in Journ KAUFMAN, 2012: The Relationship of Error Rate and Comprehension in Second and Third Grade Oral Reading Fluency. Reading Psychology 33(1-2). 104-132.

Stephanie AL OTAIBA in Douglas FUCHS, 2006: Who Are the Young Children for Whom Best Practices in Reading Are Ineffective? An Experimental and Longitudinal Study. Journal of Learning Disabilities 39(5). 414-431.

Marta ÁLVAREZ-CAÑIZO, Paz SUÁREZ-COALLA in Fernando CUETOS, 2018: Reading Prosody Development in Spanish Children. Reading and Writing: An Interdisciplinary Journal 31(1). 35-52.

Marta ÁLVAREZ-CAÑIZO, Cristina MARTÍNEZ-GARCÍA, Fernando CUETOS, Paz SUÁREZCOALLA in Fernando CUETOS, 2020: Development of Reading Prosody in School-Age Spannish Children: A Longitudinal Study. Journal of Research in Reading 43(1). 1-18.

Özgür BABAYIGIT, 2019: The Reading Speed of Elementary School Students on the All Text Written with Capital and Lowercase Letters. Universal Journal of Educational Research 7(2). 371-380.

Eneja BALOH, 2015: Geografija 7. Ljubljana: Mladinska knjiga.

Rebekah George BENJAMIN, Paula J. SCHWANENFLUGEL, Elizabeth B. MEISINGER, Carolyn GROFF, Melanie R. KUHN in Lilly Steiner, 2013: A

Spectrographically Grounded Scale for Evaluating Reading Expressiveness. Reading Research Quartel 48(2). 105-133.

Inge BREZNIK, 2019: Formativno spremljanje ₹nanja: Inovativna učna okolja, podprta ₹.IKT. Maribor: Zavod Antona Martina Slomška.

Vilma BRODNIK idr., 2017: Zgodovina. Učbenik za 1. letnik gimnazije. 6. izdaja. Ljubljana: DZS.

Amy BURKE, 2017: An Analysis of a Teacher's Use of Revoicing during a Third Grade Literature Discussion. Literacy Research and Instruction 56(1). 1-20.

Nuria CALET, M. Carmen PÉREZ-MORENILLA in Macarena DE LOS SANTOS-ROIG, 2019: Overcoming Reading Comprehension Difficulties through a Prosodic Reading Intervention: A Single-Case Study. Child Language Teaching and Therapy 35(1). 75-88.

Elena COMMODARI, Maria GUARNERA, Andrea DI STEFANO in Santo DI NUOVO, 2020: Children Learn to Read: How Visual Analysis and Mental Imagery Contribute to the Reading Performances at Different Stages of Reading. Journal of psycholinguistic Research 49(1). 59-72. 
Roddy COWIE, E. DOUGLAS-COWIE in A. WICHMANN, 2002: Prosodic Characteristics of Skilled Reading: fluency and Expressiveness in 8-10-Year-Old Readers. Language and Speech 45(1). 47-82.

Dana DAVID, Lesly WADE-WOOLLEY, John R. KIRBY in Katharine SMITHRIM, 2007: Rhythm and Development in School-Age Children: A Logitudinal Stady. Journal of Research in Reading 30(2). 169-183.

Wendy Johnson DONNELL, 2007: The Effects of Multisensory Vowel Instruction during Word Study for Third-Grade Students. Reading Research Quarterly 42(4). 468-471.

Laura C. FROYEN, Lori E. SKIBBE, Ryan P, BOWLES, Adrian J. BLOW in Hope K. GERDE, 2013: Marital Satisfaction, Family Emotional Expressiveness, Home Learning Environments, and Childre Emergent Literacy. Journal of Marriage and Family 75(1). 42-55.

George K. GEORGIOU, Rauno PARRILA, in Jon KIRBY, 2006: Rapid Naming Speed Components and Early Reading Acquisition. Scientifis Studies of Reading 10(2). 199-220.

Meta GROSMAN, 2006: Ražsežnosti branja. Ljubljana: Karantanija.

Natalie Denise HEISEY, 2009: Reading Aloud Expository Text to First- and Second-Graders: A Comparison of the Effects on Comprehension of During- and After.reading Questioning. University of Pittsburgh, doktorska disertacija. http:/ /www.proquest.com.ezproxy.lib.ukm.si/en

Natalie HEISEY in Linda KUCAN, 2010: Introducing Science Concepts to Primary Students through Read-Alouds: Interactions and Muultiple Texts Make the Difference. Reading Teacher 63(8). 666-676.

Frane JERMAN, 1992: Filozofija. Ljubljana: DZS.

Stephanie M. JONES, James KIM, Maria LARUSSO, Ha Yeon KIM in Catherine SNOW, 2015: Experimental Effects of Word Generation on Reading Performance in High Poverty Middle Schools. Harvard Library: DASH. https://eric.ed.gov/contentdelivery/servlet/ERICServlet?accno=ED562156

Branka D. JURIŠIĆ, 2016: Tekočnost branja. Merjenje in spremljanje. Ljubljana: Izobraževalni center Pika.

Young-Suk Grace KIM in Yaacov PETSCHER, 2016: Prosodic Sensitivity and Reading: An Investigation of Pathways of Relations Using a Latent Variable Approach. Journal of Educational Psychology 108(5). 630-645.

Metka KORDIGEL in Igor SAKSIDA, 2000: Jaz pa berem. Priročnik za učitelje. Ljubljana: Rokus.

Mira KRAMARIČ, Marija ROPIČ in Mateja URBANČIČ JELOVŠEK, 2000: Na vrtiljaku črk 2. Priročnik za učitelje pri pouku slovenšine v 2. rąredu devetletne osnovne sole. Ljubljana: Rokus.

Franklin R. MANIS, Lisa Michelle DOI in Bhaktawahr BHADHA, 2000: Namig Speed, Phonological Awareness, and Orthographic Knowledge in Second Graders. Journal of Learning Disabilities 33(4). 325-333.

Holly B. MARSHALL, 2009: The Effectivenessof readers' Theatre on Fluency, Comprehension, and Motivation on Primary Students. Middle Tennessee State University, doktorska disertacija. http://www.proquest.com.ezproxy.lib.ukm.si/en

William A. MIRA in Paula J. SCHWANENFLUGEL, 2013: The Impact of Reading Expressiveness on the Listening Comprehension of Storybooks by Prekindergarten Children. Language, Speech, and Hearing Services in Schools 44(2). 183-194.

Artemis M. PAPADIMITRIOU in Filippos M. VLACHOS, 2014: Which Specific Skills Developing during Preschool Years Predict the Reading Performance in the First and Second Grade of Primary School? Early Child Development and Care 184(11). 1706-1722.

David C. PARKER in Matthew K. BURNS, 2014: Using the Instructional Level as a Criterion to Target Reading Interventions. Reading \& Writing Quarterly 30(1). 79-94.

David C. PARKER, Anne F. ZASLOFSKY, Matthew K. BURNS, Rebecca KANIVE, Jennifer HODGSON, Sarah E. SCHOLIN in David A. KLINGBEIL, 2015: A brief Report of the Diagnostic Accuracy of oral Reading Fluency and Reading Inventory Levels for Reading Failure Risk among Second- and Third- Grade Students. Reading \& Writing Quarterly 31(1). 5667.

Sonja PEČJAK, 1995: Ravni razumevanja in strategije branja. Trzin: Založba Different, d. o. o.

Sonja PEČJAK in Ana GRADIŠAR, 2002: Bralne vǐne strategije. Ljubljana: Zavod Republike Slovenije za šolstvo.

Sonja PEČJAK, 2012: Psibološki vidiki bralne pismenosti. Ljubljana: Filozofska fakulteta. 
Katja PODBEVŠEK, 1995: Interpretativno branje kot del učiteljevega govornega nastopa. Ježik in sloustvo 40(3-4). 103-110.

Timothy RASINSKI, Andrew RIKLI in Susan JOHNSTON, 2009: Reading Fluency: More than Automaticity? More than a Concern for the Primary Grades? Literacy Research and Instruction 48(4). 350-361.

Marija ROPIČ, 2017: Razvoj določenih ravni glasovnega zavedanja v predšolskem obdobju. Bralna pismenost v predšolski vągoji in izobraževanju. Dragica Haramija (ur). Maribor: Univerzitetna založba Univerze. 57-66.

John SABATINI, Zuowei WANG in Tenaha O'REILLY, 2019: Relating Reading Comprehension to Oral Reading Performance in the NAEP Fourth-Grade Special Study of Oral Reading. Reading Research Quarterly 54(2). 253-271.

Andrej SMRDU, 2010: Kemija. Snov in spremembe 2. Ljubljana: Založništvo Jutro.

Irena SUMAK, 2006: Zdravstvena nega infekcijskega bolnika. Maribor: Založba Pivec.

Učni načrt. Slovenščna: gimnazija: splošna, klasična, strokovna gimnarija, 2008. Ljubljana: Ministrstvo za šolstvo in šport, Zavod RS za šolstvo.

http://eportal.mss.edus.si/msswww/programi2019/programi/media/pdf/un_gimnazija/un _slovenscina_gimn.pdf

Ǔ̌ni nă̌rt. Program osnovna šola. Slovenščna, 2018. Ljubljana: Ministrstvo za izobraževanje, znanost in šport, Zavod RS za šolstvo.

https://www.gov.si/assets/ministrstva/MIZS/Dokumenti/Osnovna-sola/Ucninacrti/obvezni/UN_slovenscina.pdf

Nika VIZJAK, 2016: Priredbe leposlovja za otroke z motnjami sluba in govorno-jezilkovnimi motnjami (magistrsko delo). Maribor: Filozofska fakulteta.

Margarita VRTAČNIK idr., 2016: Moja prva kemija. Ljubljana: Modrijan.

Angela Naomi WEBB, Andrey C. RULE, Adrianna D. CAVANAUGH in Angel MUNSON, 2014: Primary Grade Students Engage in Creative Word Play through Traditional and Hands-On Methods. Education 3-13 International Journal of Primary, Elementary and Early Years 42(5). 528541.

Mary ABBOTT, Howard WILLS, Angela MILLER in Journ KAUFMAN, 2012: the Relationship of Error Rate and Comprehension in Second and Third Grade Oral Reading Fluency. Reading Psychology 33(1-2). 104-132.

Stephanie AL OTAIBA in Douglas FUCHS, 2006: Who Are the Young Children for Whom Best Practices in Reading AreIneffective? An Experimental and Longitudinal Study. Journal of Learning Disabilities 39(5). 414-431. 


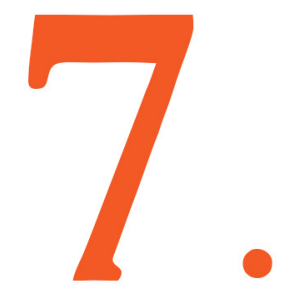

G R A D N I K

\section{RAZUMEVANJE BESEDIL}

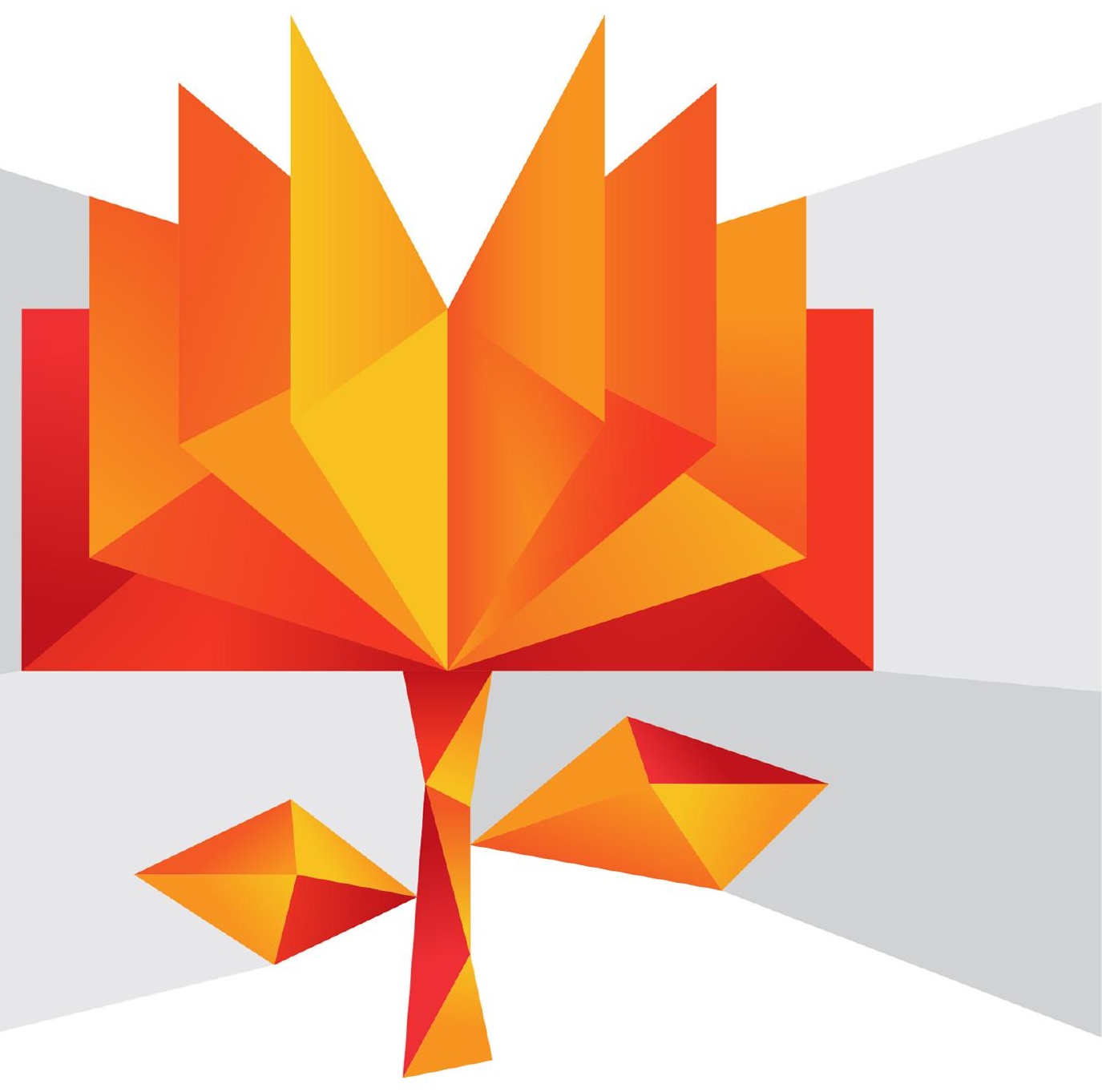


Elementi gradnika:

- sistematično razvijanje branja $\mathrm{z}$ razumevanjem

- iskanje, primerjanje, urejanje, organiziranje podatkov iz besedil

- sklepanje, razbiranje bistva

- povzemanje in vrednotenje besedil

- uporaba bralnih učnih strategij

- uzaveščanje procesa branja 


\title{
7. GRADNIK:
}

\section{RAZUMEVANJE BESEDIL}

\author{
MIRA KRAJNC IVIČ
}

Univerza v Mariboru, Filozofska fakulteta, Maribor, Slovenija.

E-pošta: mira.krajnc@um.si

Povzetek Jezikovnokomunikacijska interakcija je v večji ali manjši meri prvina večine človekovih delovanj v skupnosti ali različnih skupinah, npr. pri igri šaha, nogometa, obisku frizerskega salona, pripravi jedi, sodni obravnavi, javnem govornem nastopanju. Osnova za sodelovanje v jezikovnokomunikacijski interakciji je razumevanje besedil, tako pisanih kot govorjenih ali tako klasičnih tiskanih kot elektronskih in digitalnih. Razumevanje besedila je proces prepoznavanja prvin nejezikovnega konteksta, npr. kraja, časa nastanka besedila, udeležencev, razmerij med udeleženci, in prepoznavanja prvin jezikovnega konteksta, npr. prenosnika, besedilne vrste, teme, tvorčeve namere in drugih leksikalnih ter oblikoslovnoskladenjskih značilnosti besedila. Obe obliki prepoznavanja prvin sta posledici naslovnikovega ločevanja bistvenega od nebistvenega, da najde smisel besedilnega sporočila, saj se ta nanaša na konkretni posamezni diskurz oziroma besedilo. Razumevanje besedila je posledica prepoznavanja dela dejanskosti, na katerega se ubesediljeno nanaša, ter razmerja med znanimi in novimi informacijami $\mathrm{v}$ besedilu.

Ključne besede: gradniki bralne pismenosti, razumevanje besedil, besedilo, informativnost, prepoznavanje nanosnika. 


\title{
The SEVEnTH Component of READING LITERACY: TEXT UNDERSTANDING
}

\author{
MIRA KRAJNC IVIČ \\ University of Maribor, Faculty of Arts, Maribor, Slovenija. \\ E-mail: mira.krajnc@um.si
}

Keywords: components of reading literacy, text understanding, text, informativity, identifying of referent.

\begin{abstract}
Language communicative interaction is more or less an element of most human activities in a group or in different kinds of groups, for example at chess playing, football playing, in a hairdressing salon, at preparing a meal, in a court trial, at public speeches. The bases for cooperation in language communicative interaction is the understanding of classical or digital written or spoken text. Text understanding is a process of identifying nonlinguistics elements of context, such as the place or time of text forming, participants, relationships between participants, and a process of identifying linguistics elements of context, such as media, genre, theme, author's intention and other lexical, morphological and syntactical characteristics of a text. Both types of identifying the contextual element are consequences of addressee's ability to differ essential from un-essential to understand the meaning of (text) message since the meaning of (text) message refers to actual discourse or text. Text understanding is consequence of identifying a part of reality, which is textualized, and relationship between given and new information in a text.
\end{abstract}




\section{Uvod}

Gradnik razumevanje besedil se neposredno povezuje z gradnikoma a) odziv na besedilo in tvorjenje besedil ter b) kritično branje, posredno pa še z gradniki c) motiviranost za branje, č) tekoče branje in d) besedišče. Namen gradnika razumevanje besedil je sistematično razvijanje branja, a tudi poslušanja $\mathrm{z}$ razumevanjem. To pa je odvisno ne le od posameznikovih psihofizičnih zmožnosti in danosti, ampak tudi od konkretnega komunikacijskega stika/dogodka, pridobljenih in privzgojenih komunikacijskih vzorcev ter ozaveščenosti samega procesa razumevanja besedila. Ta proces je $\mathrm{v}$ veliki meri posledica predvidevanj in pričakovanj obeh udeležencev, skupnega védenja, statusa informacije $v$ besedilu in prepoznavanja dela dejanskosti, na katerega se ubesediljeno nanaša. Ti vplivi so v prispevku na kratko predstavljani, in sicer z odlomki različnih besedil iz različnih predmetnih področij (matematike, fizike, biologije, geografije). Tako je še dodatno izpostavljen namen gradnika razumevanje besedila kot gradnika, ki se kot vsi gradniki bralne pismenosti nanaša na vsa predmetna področja.

\section{Jezikovnokomunikacijska interakcija}

Človek se s svojim notranjim in zunanjim svetom povezuje z jezikom, in sicer z njegovo rabo $\mathrm{v}$ komunikacijskih procesih. To so procesi posredovanja informacij $\mathrm{z}$ dogovorjenimi znaki, ki so skladni z značilnostmi izbranega (jezikovnega) koda, posredovane informacije pa so vezane na kontekst in $\mathrm{v}$ smiselna (besedilna) sporočila. Jezikovnokomunikacijska interakcija človeku omogoča fleksibilno (so)delovanje v skupini, ne da bi za to moral poznati vsakega od sodelujočih. V nasprotju z drugimi bitji, ki komunicirajo, da bi opisale realnost, ima človek sposobnost ustvarjanja zgodb in tudi verjetja tem zgodbam. Človek tako z jezikom ne le poustvarja svet, temveč ga tudi ustvarja.

Jezikovno komuniciranje je tako bistveni ali vsaj spremljevalni del vsake človekove dejavnosti (Levinson 1995: 70). Je posledica želje po vzpostavljanju skupnega, odpravljanju vrzeli, a tudi izpostavljanju razlik in individualnosti. Značilne aktivnosti udeležencev so izbiranje, tvorjenje oziroma ukodiranje (šifriranje), prenos sporočila, interpretacija, razumevanje oziroma razkodiranje (dešifriranje) ${ }^{1}$ in izvabljanje

\footnotetext{
1 Naslovnik pri poslušanju ali branju nikakor ni pasiven, zato te njegove aktivnosti ne predstavljajo pasivne sporazumevalne zmožnosti.
} 
povratne informacije. Ločujemo med obvestilnimi in delovalnimi prispevki udeleženca $\mathrm{k}$ jezikovnokomunikacijski interakciji (Fairclough 2004: 106). Pri obvestilnih prispevkih je žarišče na jezikovnem prenosu informacij, pridobivanju in dajanju informacij, oblikovanju in izrekanju trditev, npr. Koliko si star? - Petnajst. Pri delovalnih je žarišče dejavnost oziroma nebesedilna aktivnost, torej delati stvari ali druge pripraviti do tega, da kaj naredijo, npr. Mi daš, prosim, še malo medu? - Seveda, izvoli. Pogosto ni ostrih meja med obvestilnimi in delovalnimi prispevki, npr. Odgovori na uprašanje! je prvi del delovalnega prispevka, kot drugi del se pričakuje besedilni odziv, to je odgovarjanje. Žarišče tega prispevka je na odgovarjanju kot dejavnosti in ne na odgovoru kot informaciji.

Komuniciranje je umeščeno $\mathrm{v}$ določene družbeno, civilizacijsko in kulturno spreminjajoče se dejanskosti, zato je ubesedeno posledica individualnega dejanja, pomembnega predvsem znotraj družbene interakcije (Vezovnik 2009: 40). Najpomembnejša oblika interakcije je dvogovor. To pomeni, da sta za jezikovnokomunikacijsko interakcijo praviloma potrebna vsaj dva udeleženca: tvorec in naslovnik.

Udeleženci s sodelovanjem $v$ različnih oblikah interakcije razvijajo sporazumevalno jezikovno zmožnost. To je zmožnost (kritičnega) razumevanja in tvorjenja ubesediljenega. Vključuje teoretično znanje, spretnosti in praktično/operativno znanje ter tudi poznavanje tematike in splošno razgledanost (povz. po Bešter 2011; Vogel 2014 in SEJO 2011). K razvoju sporazumevalne jezikovne zmožnosti prispeva celotno posameznikovo znanje in vse njegove izkušnje z jeziki ter kulturami.

Vsaka jezikovnokomunikacijska interakcija je mikrokozmos temeljnih družbenih in osebnih razmerij: izbor jezikovnih sredstev izraža, kdo govori s kom in kaj je smisel ubesediljenega (Stubbs 1983). Npr. učitelj z načinom, s katerim govori z učenci, neizbežno sporoča učencem svoje videnje položaja in obliko razmerja učitelj učenec, za katero meni, da je primerna.

\subsection{Vloga konteksta jezikovnokomunikacijske interakcije}

Jezikovno komuniciranje je kot kognitivno, družbeno in kulturno določena oblika človekovega simbolnega vedenja postavljeno v kontekst, ki ga lahko opišemo z nejezikovnimi in jezikovnimi prvinami, npr. kraj in čas, družbena vloga udeleženca, medsebojno razmerje med udeleženci, tvorčeva namera; tema, jezikovne značilnosti 
besedila (leksika, pozaimljanje in druge oblike vzpostavljanja nanašanjskih razmerij med besedilnimi enotami). Te prvine izhajajo iz udeleženca oziroma se glede na udeleženca določajo. Informacija o kontekstu je informacija, ki je prepoznana v razmerju do trenutnega tvorca (govorca ali pisca besedila). Kontekst ne obstaja, ne da bi ga udeleženec zaznal, dojel in interpretiral ter tako ločil pomembno ob nepomembnega. Nejezikovne prvine konteksta, kot sta kraj in čas, tvorijo neposredno komunikacijsko situacijo. Predstavljajo jo prvine, zaradi katerih nek smisel besedila prevlada nad drugimi, prav tako možnimi pomeni. Za aktiviranje pomena neke besede, lahko je večpomenska, namreč naslovnik potrebuje le 100 350 milisekund (Attardo 2001: 16), da izloči vse kontekstno neustrezne pomene. Kontekstno neustrezni pomeni tako niti ne prestopijo praga zavesti. Besedilo šele v konkretnem kontekstu postane relevantno za neko komunikacijsko interakcijo.

Nejezikovni kontekst pa ne vpliva le na potek komunikacijskega stika, ampak ima tudi obvestilno vrednost. Kontekst ustvarja besedilo, ki je glede na kontekst ustvarjeno. Besedilo je del kulture, ki je ozadje za dejanja, prepričanja in razumevanja ter ozadje, $\mathrm{v}$ katerem jezikovno komuniciranje postaja smiselno. Tvorec in naslovnik drug drugemu pripisujeta pripravljenost za sodelovanje, kar je osnova vljudnosti. Ta predpostavka skupaj $\mathrm{z}$ besedilnimi in $\mathrm{s}$ kontekstnimi informacijami omogoča prirazumljenja o tvorčevi nameri. Ker ubesediljeno lahko prispeva $\mathrm{k}$ razumevanju smisla drugega ubesediljenja, je besedilo veriga prirazumljenih razmerij. Ta razmerja izhajajo iz maksim sodelovalnega in vljudnostnega načela. Prirazumljenja o jezikovnih pojavih, tvorčevih namerah, o razmerjih med izreki itd. so lahko osnovana le na posameznikovih jezikovnih oziroma nejezikovnih delovanjih.

Kontekst omogoča prirazumljanje smisla ubesediljenega in ustvarja okvir za pričakovanja, ki se jim jezikovnokomunikacijska interakcija nato prilagodi. Vsak prispevek k interakciji je le »trenutek v neprenehnem komuniciranju« (Vezovnik 2009: 40). Iz konteksta otrok ali učečih se sklepa na smisel ubesediljenega. 


\section{Smisel vs. pomen ubesediljenega/besedila}

$\mathrm{V}$ nasprotju $\mathrm{s}$ tvorjenjem besedila je pri njegovem interpretiranju oziroma razumevanju ${ }^{2}$ naslovnik vedno soustvarjalec besedilnega smisla. Pri razlikovanju med pomenom in smislom ugotovimo, da se le smisel nanaša na dejanskost, medtem ko je pomen le orodje, ki nima ustreznika $\mathrm{v}$ dejanskost. To potrjujejo vsakdanja opozorila (Pozor, stopnica, Poslovni prostori, Ni vstopa), nagovori, tudi živalim (Priden, Daj tačko) in leposlovje, še zlasti poezija (Drevo. Podrtija. Hiša ob cesti) (Žele 2010: 119).

Razlikovanje med pomenom in smislom ponazarja primer: ustavi delo na cesti (de Beaugrande, Dressler 1992: 17). Če se naslovnik na cesti približuje odseku, kjer potekajo dela, bo ubesedeno razumel kot poziv, naj vozilo ustavi ali upočasni, saj na cesti poteka delo. Če je naslovnik nadzomik pri izvajanju sanacijskih del na cesti, ubesedeno dobi drugi smisel: ustaviti je treba delo, ki poteka na cesti. Potencialne dvoumnosti glede na kontekst naslovnik pogosto niti ne ozavesti, kar je posledica pridobljenih izkušenj v različnih vrstah jezikovne interakcije. Po drugi strani pa otrok ali učeči se, ki se jezika šele uči, najprej razume le dobesedni pomen, npr. na mamin poziv, naj triletna deklica reče da ali ne, se deklica odzove: $\gg D a$ ali ne. «To pomeni, da je mamin ukaz razumela dobesedno. Šele kasneje s pridobivanjem izkušenj jezikovni uporabnik tovrstne primere začenja razumevati skladno s smislom. Npr. ubesediljeno $V$ sak dan berem tvoja sporočila lahko naslovnik glede na kontekst in izkušnje, ki jih ima, razume kot ljubezensko izpoved o aktualni ali nekdanji ljubezni, ugotovitve dejstva ali očitek. Verjetno je, da večina pomisli na prvo navedeno možnost, redkeje na zadnjo, kar pomeni, da imamo več izkušenj s prvim smislom ubesediljenega.

Celotni smisel besedila je oblikovan v interakciji med jezikovnimi oblikami in pomeni, družbenimi in kulturnimi pomeni ter interpretativnimi danostmi. Smisel besedila kot celote ali le njegovega dela pomensko pogojuje kontekst, predhodni in/ali sledeči del besedila: prvi del pomensko pogojuje drugega oziroma interpretacija drugega je odvisna od prvega.

\footnotetext{
${ }^{2}$ Razumevanje besedila je vedno interpretacija, saj naslovnik besedilo razume le skladno s svojim mentalnim svetom, tj. glede na svoje misli, vrednote, hotenja, želje, izkušnje, čustvovanja ipd.
} 


\subsection{Oblikovanje smisla}

Uresničitev jezika v dani jezikovnokomunikacijski interakciji je besedilo. Neposredni kontekst in družbeno razmerje med udeleženci (lahko določeno z družbenimi institucijami, v katerih interakcija poteka) lahko določajo temo interakcije, zahtevajo različne stopnje objektivnosti pri ubesediljenju ter možne in sprejemljive tvorčeve namere. Vse to naslovnik prepoznava in presoja pri razumevanju besedila. Namere, ki jih imata udeleženca interakcije, in sprejemljivost interakcije za oba udeleženca zagotavljata smiselnost in trajanje interakcije, torej tudi ohranjata interes za branje besedila. Vsak udeleženec interakcije ima svoje cilje, ki jih z interakcijo skuša doseči. Cilji se kažejo v nameri, ki je večplastna posledica udeleženčevih hotenj, potreb in želja. Tvorčeva namera glede na jezikovni in nejezikovni kontekst ter skladno z naslovnikovo namero določi vplivanjsko besedilno funkcijo, pogovorna sklepanja pa omogočajo naslovniku, da razbere smisel besedila. Izbrana namera vpliva na obliko in smisel ubesediljenega.

Svojo izbrano namero lahko tvorec izrazi eksplicitno/neposredno ali implicitno/posredno. Pri neposrednih govornih dejanjih je oblika ${ }^{3}$ ubesedenega skladna s smislom. Posredna govorna dejanja pa so dejanja, pri katerih izrazimo ilokucijsko moč s sredstvi drugega govornega dejanja. Smisel besedilnega sporočila se zato razlikuje od stavčnopovednega pomena. Tako lahko $\mathrm{z}$ različnimi propozicijami ubesedimo isto namero (slika 1): levi stolpec predstavlja možnosti izražanja zahteve, da naslovnik zapre vrata, desni stolpec pa možnosti, kako se lahko kot tvorec poskušam opravičiti.

3 Oblika so različne oblikoslovno-skladenjske izrazne zmožnosti jezika. Govorno dejanje je osnovna jezikovnokomunikacijska enota. Kot sopomenski termin se uporabljata še izraza izrek ali izreka. Izrek je poved v nekem kontekstu in skupaj s tem kontekstom. 


\begin{tabular}{|ll|}
\hline Vrata! & Opravičujem se, da ... \\
Zapri vrata. & Oprosti, da \\
Zahtevam, da zapreš vrata. & Zelo mi je žal, ker \\
Hočem/Želim, da zapreš vrata. & Sorry \\
Lahko zapreš vrata? & Pardon \\
Prosim, ali bi lahko zaprl vrata? & Oprostite \\
Prosim, ali bi lahko zaprli vrata? & Oprostite, prosim. \\
Kako piha./Zebe me./Dovolj je že prezračeno. & Nisem namerno. \\
Spet je imel nekdo dolg rep. & Bila je pomota. \\
A imaš rep? & Oprosti, da diham. \\
& No, lahko bi bilo slabše. \\
& Saj se samo delaš. \\
& Saj ni nič hudega, a ne. \\
& Pa saj to vsi počnejo. \\
&
\end{tabular}

Slika 1: Možne propozicije za ubesediljenje iste namere

Z eno propozicijo pa lahko ubesedimo dve ali več različnih namer - predstavitveno vlogo: V sak dan berem tvoja pisma; Nevaren cestni odsek; Tukaj postaja vroče; Voda je topla ali pozivno vlogo v pomenu: Ne pošiljaj mi toliko sporočil; Vo žnjo prilagodite rąumeram na cesti; Umakni se; Pojdi se kopat.

Pri tem ubesediljeno ni stvar motivacije, temveč diskurzne strategije, kako udeleženca postopoma uresničujeta svoje namere. Že na videz minimalne razlike lahko ubesediljeno precej spremenijo, npr. Jutri pridem in Obljubim, da jutri pridem. Izvajalniški glagol obljubiti tu jasno streže "posebnemu smotru narediti, da je eksplicitno /.../, katero delo izvajamo, ko formuliramo izrek« (Kunst Gnamuš 1994: 191). Ker je »govorec avtentični razlagalec ilokucijske namere, naslovnik pa le perlokucijskega učinka« (p. t.), sta navedena izreka lahko interpretirana enako. To isto interpretacijo bi lahko potrdili že s kontekstualnimi namigi. Ti namigi spodbujajo zaželene interpretacije ubesedenega in izključujejo druge. 
Zgleda Jutri pridem in Obljubim, da jutri pridem prikazujeta tudi, da so pri rabi jezika številna govorna dejanja pravzaprav hibridna oziroma večfunkcijska. ${ }^{4}$ To pomeni, da z enim dejanjem lahko zaradi okoliščin in zaradi znanja, ki ga imamo o pogojih in pravilih tvorjenja določenega govornega dejanja, opravimo več kot eno dejanje hkrati. To dejstvo naslovniku omogoča različne odzivne možnosti, npr. A: Ali greva na kavo? - B1: Z veseljem; B2: Nimaš predavanj čez pet minut?; B3: Samo, č ti častis; B4: Telefon mi zvoni.

Med eksplicitnim in implicitnim ne obstaja ostra meja, ampak so le prehodi v smislu, da je nek smisel ubesedenega glede na aktualni kontekst za naslovnika običajnejši ali zanesljivejši. Običajnejši smisel temelji na ustaljeni in razširjeni rabi, medtem ko je smisel zanesljivejši takrat, ko je njegovo razumevanje verjetnejše ali ga imamo za verjetnejšega. Tipična primera mehkih prehodov med implicitnim in eksplicitnim sta npr. vprašanji Kako si? in Imaš uro/telefon? Prvo najpogosteje razumemo kot vljudnostno vprašanje po naslovnikovem počutju, drugega kot poziv, da naj naslovnik tvorcu pove, katero uro kažeta kazalca na uri oziroma telefonu. Ustaljenost je tako velika, da naslovnik smisel razume prej kot pomen.

Razliko med pomenom in smislom po P. Griceu (1989, 1989a) premeščamo s pogovornimi sklepanji. ${ }^{5}$ To je prirazumljeno védenje, s katerim po predvidevanjih tvorca razpolaga tudi naslovnik. Prek pogovornih sklepanj naslovnik prepoznava tvorčeve namere in ugotavlja, kako tvorec sledi komunikacijskim načelom, npr. načelu sodelovanja ali načelu vljudnosti.

Ali je prisotno sklepanje, naslovnik ugotovi tako, da si pomaga $z$ a) ustaljenim pomenom rabljenih besed, skupaj z identiteto možnih vključenih nanašalnic, ${ }^{6}$ b) s sodelovalnim načelom in njegovimi maksimami (kakovosti, količine, načina, relevantnosti), c) z jezikovnim in nejezikovnim kontekstom izreka, č) z drugimi posameznostmi o skupnem védenju in d) s predpostavko, da vsak izrek predpostavlja optimalno relevantnost. S sklepanji lahko naslovnik npr. ubesedeno Pse je treba nositi in Ko vozim, ne pijem interpretira kot Č na podzemno železnico vstopim s psom, ga moram imeti v narǒ́ju in Čre sem kot voznica udeležena v prometu, ne smem piti alkoholnih pijar.

\footnotetext{
${ }^{4}$ Razlike med izrekama Jutri pridem in Obljubim, da jutri pridem lahko pojasnimo z Griceovo maksimo količine. Tvorec brez razloga ne uporablja dodatnih besed.

5 Griceova teorija pogovornih sklepanj je ključna za razumevanje humornih procesov. Humorno namreč ni ubesedeno izrecno, ampak naj bi ga naslovnik kot takega prepoznal.

${ }^{6}$ Nanašalnica je jezikovni izraz, ki se nanaša na del besedilne ali zunajbesedilne dejanskosti.
} 
Pogovorna sklepanja temeljijo zlasti na sodelovalnem načelu, saj so neupoštevanja nekaterih maksim lahko posledice pomenskih problemov, npr. Ti si smetana na moji kavi. Naslovnik tu ne išče prirazumljenega, ampak metaforo (naslovnik je smetana) interpretira kot nekaj pozitivnega, kot tisto, kar zadovolji njegovo potrebo po trenutno ustrezni interpretaciji.

Uspeh komuniciranja je odvisen od poti, $\mathrm{v}$ katerih uspevata tvorec in naslovnik manipulirati z možnostmi, ki jih ponujata jezikovni in nejezikovni kontekst, ${ }^{7}$ in zahtevami konteksta. Besedilo je treba razumeti znotraj vsakokratnega komunikacijskega dogodka, saj ta določa smisel. Smisel pa določi besedilno funkcijo in tvori besedilno sporočilo. Smisel besedila torej ni razviden le iz strukture in pomenov, ampak se oblikuje skupaj z družbenimi in kulturnimi pomeni ter interpretativnimi pričakovanji. Smisel je dosežen interaktivno, to pomeni, da je razumevanje besedila posledica interakcije med tvorcem in naslovnikom. Razumevanje besedila torej ni stranski produkt sprejemljivosti oziroma relevantnosti besedila, ampak udeleženčevih intuicij o koherentnosti kot posledici iskanja relevantnosti besedila glede na dani kontekst. Navedeno velja za govorjena in pisana besedila. Ubesediljeno je oblikovano in interpretirano v lokalnih okoliščinah drugih izrek, hkrati je posledica globalnih okoliščin, kot so identiteta udeležencev, tvorčeva namera, izbrana diskurzna strategija, tematski razvoji, zgradba komunikacijskega stika in družbeno-kulturna prepričanja ter delovanja.

\subsection{Informativnost in prepoznavanje osrednje nanašalnice ali teme besedila}

Pomembno $\mathrm{k}$ razumevanju besedila prispevata vrednost informacije $\mathrm{v}$ besedilu, kar imenujemo informativnost, in prepoznavanje osrednje nanašalnice besedila, ki je tema besedila.

3.2.1 Informativnost določa informacijsko vrednost besedila glede na delež novih informacij $\mathrm{v}$ primerjavi $\mathrm{z}$ znanimi/danimi informacijami. To razmerje oblikuje tvorec glede na predvidevanja o naslovnikovem védenju in glede na besedilno vrsto, npr.

${ }^{7}$ Mišljeni so tudi vsi okoliščinski tipi informacij, npr. slikovni, kinetični, zvočni. 
Letošnji popolni Lunin mrk je $\mathrm{v}$ javnosti vzbudil veliko pozornosti z glavnim poudarkom na rekordnem trajanju tega nebesnega pojava. Resnici na ljubo pa je bil ta mrk za javnost zanimiv predvsem zaradi tega, ker je bil viden $\mathrm{v}$ večernih urah in sredi poletja. Podoben mrk, ki bi nastopil v drugi polovici noči in sredi zime, bi pritegnil mnogo manj opazovalcev. Toda Lunini mrki so več kot le atrakcija. (Guštin 2018/2019: 19)

Za razumevanje zapisanega ni potrebno le poznati pomene rabljenih leksemov, npr. letošnji - tak, ki se nanaša na to leto; rekordno trajanje, zanimiv, atrakcija, ampak je treba najti informacijo npr. o tem, katero leto je bilo mišljeno kot to leto. Ta podatek ste najverjetneje takoj poskušali najti ali v sprotni opombi, seznamu virov in literature ali na koncu odlomka. Navedena mesta so zapisana $v$ zaporedju od najbolj pričakovanega do najmanj pričakovanega. To zaporedje pa je lahko tudi povsem napačno, saj so pričakovanja oblikovana na osnovi posameznikovih individualnih izkušenj. Nemara ste se spraševali tudi, zakaj je izbrana frazeološka enota resnici na ljubo, vsekakor pa je verjetnost, da je branje odlomka vzbudilo željo, da bi prebrali še kaj več, saj se zaključi na način, da dviguje naslovnikovo zanimanje.

Informativnost je torej povezana $\mathrm{z}$ naslovnikovimi pričakovanji in predvidevanji o besedilu, tvorec s stopnjo informativnosti dviguje naslovnikov interes. Naslovnik na osnovi znanih informacij oblikuje svoja pričakovanja in predvidevanja o besedilu, npr. slika 2. 


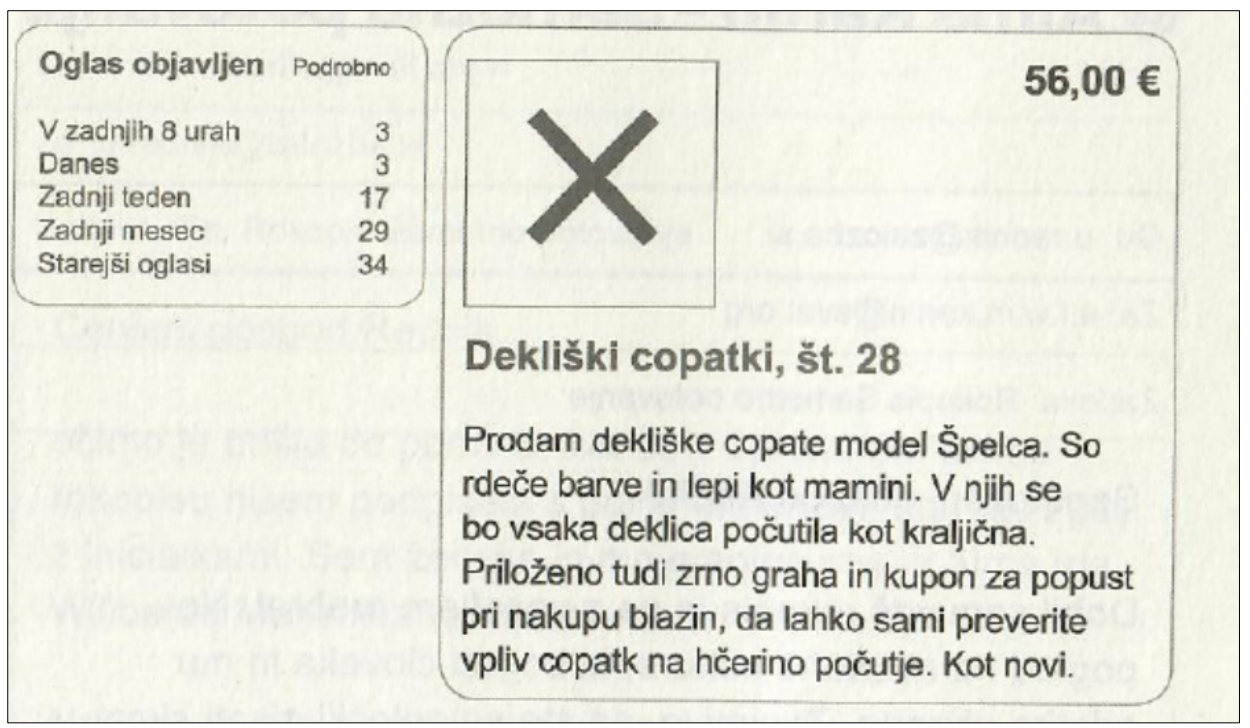

Slika 2: Informativnost malega oglasa

(vir: B. Gorenc - Pižama 2016: 109)

Izvori naslovnikovih pričakovanj so a) dejanskost (dejstva in prepričanja), b) jezik, ki omogoča poljubnosti pri povezovanju jezikovnih prvin, c) jezikovni in nejezikovni kontekst: besedilna vrsta, neposredni fizični svet, členitev po aktualnosti. V primeru na sliki 2 naslovnik glede na obliko zapisanega pričakuje, da je zapisano mali oglas. Oblika zapisanega predstavlja a) dejanskost. Sem sodi tudi mesto objave besedila. Nadalje naslovnik na osnovi b) jezikovnih prvin, kot so prodam, kot novi, svoja pričakovanja o malem oglasu potrdi in sledi rdeči niti interpretiranja zapisanega kot primer malega oglasa. Vendar c) jezikovni in nejezikovni kontekst, npr. priloženo žmo graha, objava zapisanega na nepričakovanem mestu, tj. v knjigi SLOLvenski klasiki 1 , ustvarita neskladje pri razumevanju zapisanega. Naslovnik ugotovi svojo zmoto in zapisano prepozna kot humorno namigovanje na pravljico Ele Peroci Muca Copatarica in ponorčevanje iz značilnosti še drugih pravljic, npr. Kraljična na żmu graha, ki lahko spodbujajo določena nerealna pričakovanja (vsaka deklica si želi postati kraljična).

Glede na razmerje med novimi in znanimi informacijami ima besedilo različno stopnjo informativnosti. Besedila prve stopnje imajo nizko informativnost, saj vsebujejo več znanih informacij kot novih. Skrajni primer tovrstnega besedila je besedilo stop na prometnem znaku (de Beaugrande, Dressler 1992: 103). Tako nizka 
stopnja informativnosti lahko vodi do zavrnitve besedila kot nezanimivega, dolgočasnega. V primeru prometnega znaka, kjer je pomembno, da naslovnik besedilo hitro in brez napora ustrezno interpretira, je nizka stopnja informativnosti potrebna. Vsako besedilo vsebuje dele s prvo stopnjo informativnosti, npr. a) kiti so red sesalcev $/ \ldots /$, b) veverica se brani z rastlinsko brano /.../. Enoti s prvo stopnjo informativnosti običajno sledi(jo) enota/-e, ki vsebuje(jo) nove informacije, npr. a) ... katerega predstavniki so prilagojeni na ̌̌vivljenje pod vodo. Telo je ribje oblike in golo, sprednje okončine so preobražene v plavuti, zadnje pa močno zakmele. Kljub temu so pravi sesalci, ki s pljuči dibajo zrak, mladiče pa branijo z mlekom; b) / .../ - sadje, semena, glive in zelišra. Hrani se tudi z jajci in mladimi ptici ter そ̌ǔ̌ellkami.

Običajno so besedila druge stopnje $z$ uravnoteženim razmerjem med znanimi in novimi informacijami. Besedila tretje stopnje vsebujejo večji delež novih informacij. Interpretacija takih besedil je lahko prezahtevna in posledično nezanimiva.

3.2.2 Prepoznavanje teme besedila. Besedilo za naslovnika ne more biti zanimivo, če ne prepozna osrednje nanašalnice oziroma teme besedila, saj ga lahko razume šele, če razume smisel besedilnega sporočila, ki se nanaša na določen del dejanskosti ( $\mathrm{v}$ nadaljevanju nanosnik). Smisel besedilnega sporočila tvori sporočanjsko osredotočenje na neko temo oziroma osrednjo nanašalnico, to je prva omemba nanosnika $v$ besedilu. Pogostost njenih/njegovih omemb kaže, ali gre za osrednjo temo ali za temo na nižjih ravneh oziroma delno temo. Nanašanje je tako vzpostavljanje razmerja do nanosnika in hkrati tudi njegovo določanje in prepoznavanje.

Nanašanje lahko razumemo tudi kot tvorčevo in naslovnikovo medsebojno sodelovanje, rezultat katerega je odvisen od skupnega védenja, prepričanj in predpostavk. Nanosnik mora biti v besedilo vpeljan tako, da njegova prva omemba ustvari pogoje za različne nadaljnje omembe in opravi prepoznavanje. Prepoznavanje nanosnika je predpogoj za razumevanje besedila, npr. odlomek pogovarjanja med vzgojiteljico $\mathrm{V}$ in malčkom $\mathrm{D}$. Izraz tam je razumljiv iz sobesedila, nanaša se na knjigo, ki je kasneje $\mathrm{v}$ pogovoru omenjena izrecno in določno ( $v$ tisti knjigici). D-jev odziv mamo doma vlake je razumljiv in smiseln, če oba, vzgojiteljica in malček, vesta, da se ubesediljeno nanaša na slikanico z vlaki, ki je malčkovo priljubljeno branje. Če bi malček uporabil izraz vlakci, bi se ubesediljeno lahko nanašalo na igračke vlakce. 


\section{$V$ : So tam kakšne slike, ko so ti všeré? Kdo pa ... Koga najdeš use v tisti knjigici? \\ D: Vlake najdem. Veš, mamo doma vlake. \\ $V$ : Vlake tudi mate? Pa bom jaz tudi prinesla takšnno knjügico v vrtec pa bova skupaj pogledala, ne?}

Glavni dejavnik pri razumevanju ubesediljenega je status informacije in njena dostopnost: ali jo imajo udeleženci še oziroma že v zavesti ali je še nimajo v zavesti. Kaj vpliva na to, da/ali imamo informacijo v zavesti? Vsaka posamezna beseda ali leksem ima svoj pomen ali leksikalni scenarij. Najmanjši možni leksikalni scenarij je slovarski sestavek k iztočnici v splošnem razlagalnem slovarju. Vsebine ali pojmi se aktivirajo ob ubesedenju nekega pojma ali ob zaznavanju (poslušanju/branju) neke izrazne podobe leksema. Npr. leksem ptica $\mathrm{v}$ aktivno spominsko shrambo prikliče pojme, kot so krila, letenje, peruti, jajca, žvrgolenje, svoboda idr., leksem pandemija najpogosteje prikliče katastrofa, ǐbruh, gripa, kuga, simptom, virus, aids, recesija. Slika 3 predstavlja oblak besed na temo rojstni dan. Na sliki velikost pisave nakazuje pogostost vzajemnega priklica med besedo rojstni dan in drugimi besedami: večji kot je zapis te besede, večja je pogostost vzajemnih priklicev. Priklici so odvisni od posameznikovih individualnih izkušenj, a tudi od družbe. Pogostost vzajemnih priklicev ustvarja osnovo za koherenco med pojmi, vključenimi v besedilo, in posledično omogoča razumevanje prebranega ali slišanega. Glede na potrebe jezikovnega in nejezikovnega konteksta se ti pojmi združujejo v stavke, povedi, izreke itd.

Presenečenje Babica Pesem Prvi Sin Mesec Ponos IgračaPrijatelji Obletnica Dedek Novoleten RezrezatiPraznovanje Torta Slavljenec Družina R otrok Družina Rojstni dan Darilovelik Češnjevabilo Zabava Veselje Rojstvo Čokoladna Pijača Žalost

Naslednji Priprava 
Za razumevanje je nadalje pomembno skupno védenje. To oblikuje skupine tistih, ki isto »mislijo« in isto »razumejo«, npr. nadaljevanje pogovarjanja med vzgojiteljico $\mathrm{V}$ in malčkom D:

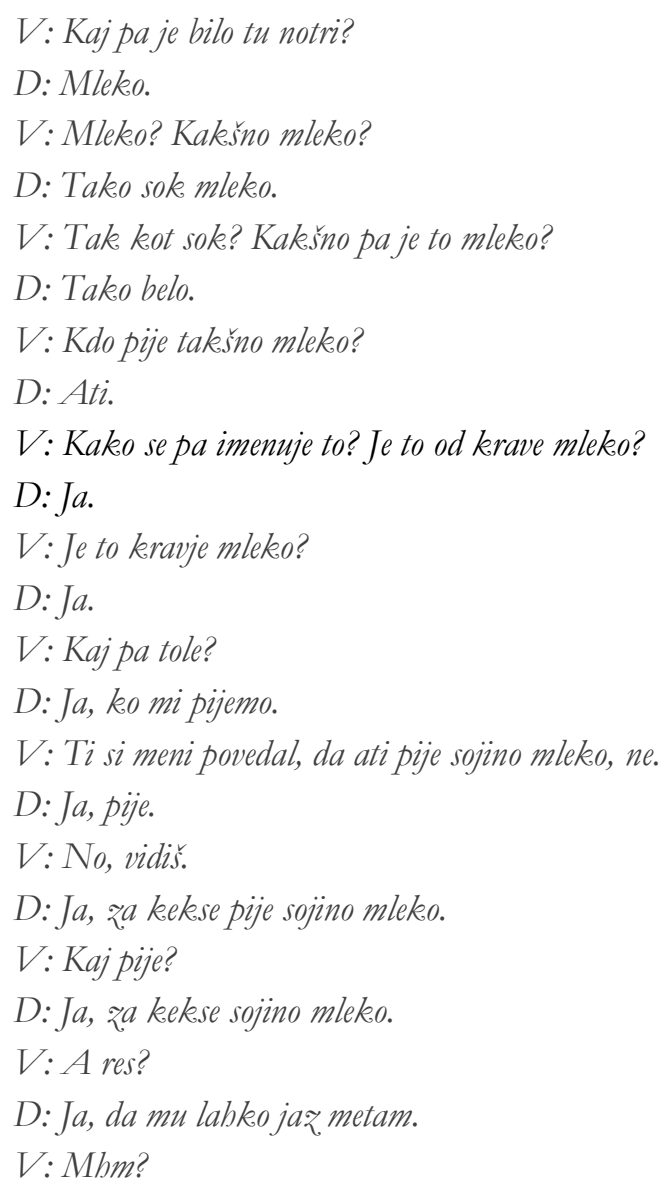

Ko sta po mnenju vzgojiteljice izčrpala temo o slikanicah, sta pozornost usmerila na kotiček v igralnici, opremljen tako, da je spominjal na trgovino, tako se zveza tu notri nanaša na embalažo. Malček po svoji presoji in sporazumevalni jezikovni zmožnosti ubeseduje informacije tako, kot je prepričan, da bo ubesedeno omogočilo razumevanje pri vzgojiteljici. Razvidno je, da ga vzgojiteljica ne razume, vendar ima o družinskih članih določene informacije, da malčka sooči z morda napačnim navajanjem. Malček neskladja ne opazi, nasprotno, doda novo informacijo za kekse pije sojino mleko. Ker vzgojiteljica iz ubesedenega ne more sklepati o delu dejanskosti, na katerega se ubesedeno nanaša, poskuša od malčka pridobiti več informacij. A 
malčku je vse razumljivo in izrečeno ponovi še enkrat, nato pa doda še novo informacijo da mu labko jaz metam. Tu je očitno, da je ubesedil premalo informacij, da bi ga vzgojiteljica lahko razumela.

Primer prikazuje, da je razumevanje jezikovnih prvin (od zloga prek besede, besedne zveze, izreka do besedila) rezultat aktivnega delovanja tvorca in naslovnika. To velja tudi za pisana besedila, saj se lahko zgodi, da bralec 1) prepozna besedo in njen pomen, a ne v konkretnem kontekstu, 2) besede niti ne prepozna, npr.:

Problem dveh jajc je zanimiv miselni problem, ki po urbani legendi slovi kot eno izmed vprašanj iz intervjuja za službo pri velikih računalniških podjetjih, kot sta npr. Microsoft ali Google. To vprašanje se na intervjujih najverjetneje ne pojavlja več, saj je zaradi svoje rešitve pritegnilo preveč pozornosti in $\mathrm{s}$ spraševanjem ne bi dosegli tega, čemur je bilo prvotno namenjeno. Oglejmo si ta problem pobliže tudi mi. /.../ Ilustracija problema je prikazana na sliki 1. Možne vrednosti za h so cela števila od 0 do 100 . Vrednost 0 pomeni, da se jajce razbije že pri spustu iz prvega nadstropja, vrednost 100 pa, da tudi pri spustu iz stotega nadstropja še vedno ne bomo imeli izgovora za omleto. (Slak 2018/2019: 23)

Kot družboslovka ali humanistka težko $\mathrm{v}$ popolnosti razumem prvo poved izbranega odlomka, čeprav vem, kaj pomenijo uporabljeni leksemi in strukture, kako so leksemi medsebojno povezani (dveh jajc, miselni problem, slavna urbana legenda, interyju za službo). Hkrati sem precej prepričana, da se kdo od vas ob izpostavljeni povedi ni niti za hip ustavil, ker mu/ji je vse popolnoma jasno. Ob koncu odlomka mora bralec narediti še en miselni preskok, saj mora povezati izgovor za omleto z (razbitimi) jajci.

Morebitne nejasnosti pri prepoznavanju nanašalnice so v pisanih besedilih opaznejše kot $\mathrm{v}$ govorjenih: $Z$ robčkom sem si obrisal nos in ga vrgel v koš, ko naslovnik brez razmišljanja nesmiselne, a slovnično mogoče nanašalnice (nos) izloči iz aktivnega spomina. 
Za prepoznavanje nanosnika je pomemben vir informacij tudi predhodno besedilo, glede na katerega so nanosniki v besedilni zgodbi relevantni. Tvorec se namreč nenehno odloča, kateri tip informacije (besedilni ali kontekstni) bo ubesedil do katere stopnje na lestvici med izraznima jasnostjo in ekonomičnostjo. Oblikovanje omemb nanosnika torej pomeni tudi (ne)upoštevanje maksim sodelovalnega načela, zlasti pomembni sta maksimi količine in relevantnosti. Prva vodi naslovnika, da išče količino informacij v besedilu, druga ga vodi, da uporabi informacijo na določen način, tj. najde njeno relevantnost glede na ostalo besedilo in kontekst. Vse to so informacije, ki jih naslovnik vrednoti in ki ga usmerjajo pri prepoznavanju in mu pomagajo prirazumljati tvorčevo namero, npr. na vprašanje Ali imaš uro? se naslovnik pogosto odzove kar z Ura je 13. Za tak odziv naslovnik predvideva, da je kar najbolj relevanten.

Pri prepoznavanju osrednje teme ali smisla besedilnega sporočila in $\mathrm{s}$ tem pri razumevanju besedila si naslovnik $\mathrm{v}$ enaki meri kot $\mathrm{z}$ jezikovnimi znaki pomaga tudi z nejezikovnimi, npr. vizualnimi, zvočnimi idr., saj je besedilo multimodalni kulturno-družbeni pojav. Govorjena besedila so primarna multimodalna ali večkodna besedila. Za ta besedila sta značilna a) vsaj dva vira pomenjenja: jezikovni in nejezikovni kod, npr. slikovni, kinetični, zvočni, b) dva principa kompozicije: princip prostorske kompozicije in princip časovne kompozicije.

Če se pisano besedilo začne desno od točke nič in zaradi zapovrstnosti oziroma linearnosti sledi stavčnim vzorcem, govorjeno besedilo in tudi druga pisana multimodalna besedila ali npr. kretanje zaradi nelinearnega nizanja ne sledijo stavčnim vzorcem. Pri tem sporočilna dinamika načeloma narašča linearno od leve proti desni, kot $\mathrm{v}$ zahodni kulturi zlasti poteka smer branja, $\mathrm{s}$ tem pa določa mesto znane informacije na levi in nove informacije na desni. V vsakem primeru smisel ubesediljenega zaokroži šele na koncu. Besedilo tako deluje oziroma mora delovati kot specifična celovita sporočanjska tvorba, ki ni vnaprej določena kot npr. stavek, ampak vedno znova deluje in učinkuje kot organska celota. Besedilo kot tako je jezikovni znak.

Kot vsak znak ima tudi besedilo svojo izrazno podobo in vsebino. Smisel besedila predstavlja vsebino znaka. Če nemotivirano besedo lahko izrazno primerjamo s preprostim jezikovnim znakom, katerega vsebina ostaja $\mathrm{v}$ posameznikovem spominu, potem lahko besedilo opredelimo kot zapleteni znak, saj je razmerje med izrazno podobo besedila in njegovo vsebino ustaljeno prek pravil vezanja preprostih 
jezikovnih znakov $\mathrm{v}$ besedilo in veljavnih družbenih ter kulturnih pravil za manifestacijo besedila $\mathrm{v}$ danem kontekstu. Vsebina besedila kot zapletenega znaka se namreč oblikuje v vsakokratnem komunikacijskem dogodku. Pri besedilu kot jezikovnem znaku pa lahko z vidika naslovnika opazujemo, kako besedilo učinkuje na naslovnikovo zavest in prihaja $\mathrm{v}$ stik $\mathrm{s}$ drugimi vrstami znakov; mišljeno je tudi medsebojno učinkovanje različnih znakovnih sistemov, npr. slika 4.

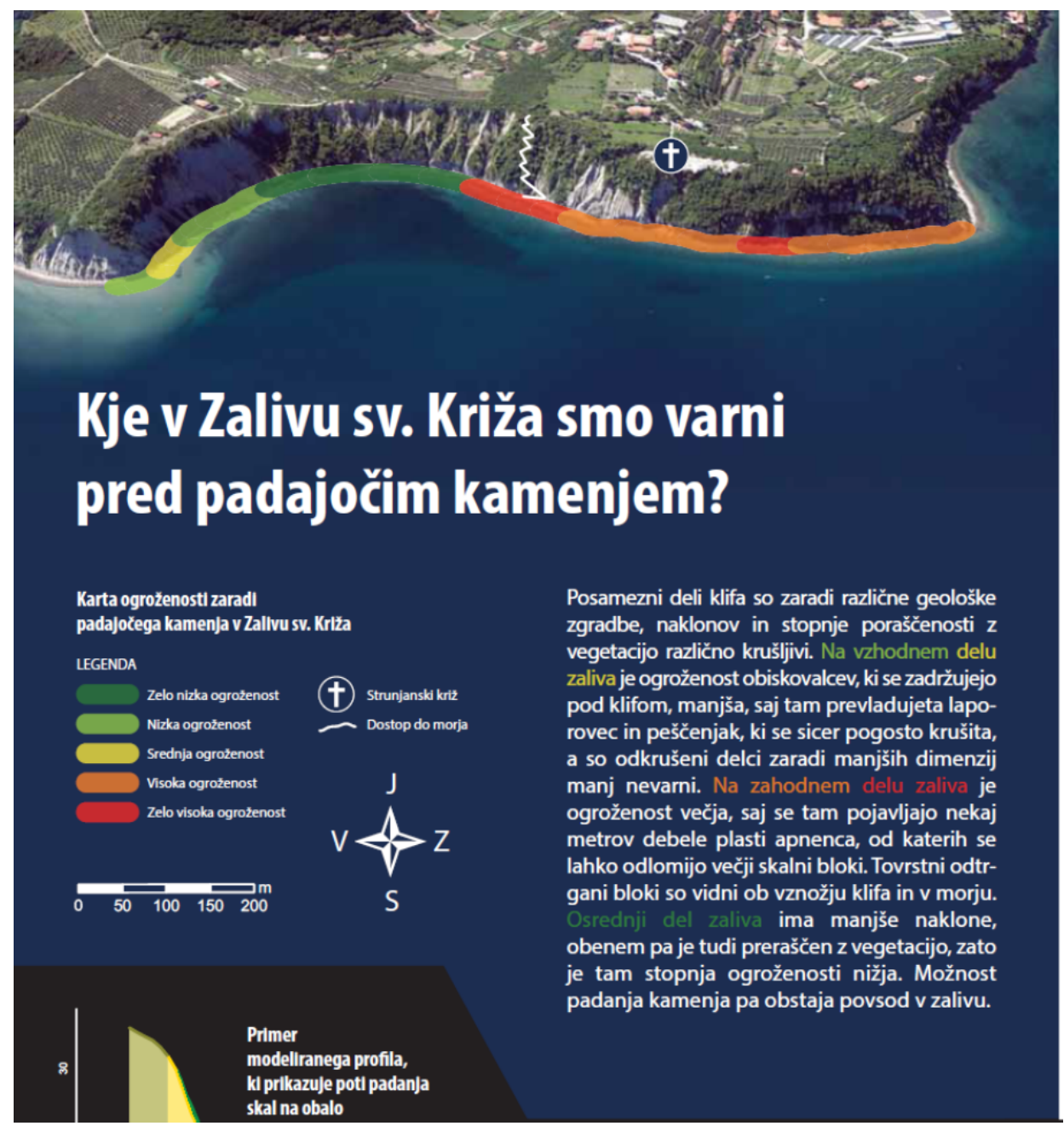

Slika 4: Prepoznavanje osrednje teme prek jezikovnega in nejezikovnega koda

(vir: Kje v Zalivu sv. Križa smo varni?; https://parkstrunjan.si/wpcontent/uploads/2018/11/Zgibanka_Previdno-klif-se-kru\%C5\%A1i.pdf) 
Slika 4 kot del turistične zgibanke prikazuje za obiskovalce varna območja Zaliva sv. Križa. Naslovnik iste vrste informacije dobi iz jezikovnega in nejezikovnega koda (slika, barve). Barvni tisk ga usmeri k informacijam, ki pojasnijo, zakaj je kateri del Zaliva (ne)varen. Pojasnilo vsebuje za povprečnega naslovnika primerno razmerje med znanimi in novimi informacijami. Te so $\mathrm{v}$ besedilo vpeljane tako, da jih naslovnik lahko uredi v smiselno sporočilo: večja ali manjša (ne)varnost je posledica večje ali manjše krušljivosti delcev, krušljivost delcev je posledica kombinacije treh dejavnikov, ti dejavniki so geološka zgradba, naklon in poraščenost območja z rastlinami, geološka zgradba je torej neke vrste nadpomenka za laporovec, peščenjak in apnenec.

\section{$4 \quad$ Cilji in dejavnosti, vezane na gradnik razumevanje besedil}

Učne cilje za slovenščino $\mathrm{v}$ osnovni šoli in na srednješolskih programih ter cilje za področje jezika iz Kurikuluma za vrtce (1999) lahko posplošeno združimo in predstavimo prek dejavnosti, ki jih učeči se opravljajo sami, v paru ali skupaj v skupini. Posplošeno navajanje ciljev in dejavnosti ni ločeno po stopnjah, temveč so navedeni od osnov razumevanja do njegove poglobitve.

Cilj in dejavnosti so:

- Berejo/poslušajo/gledajo besedilo.

- Določajo okoliščine: udeleženci, kraj in čas, družbeno razmerje, sporočevalni namen, tema, podteme, ključne besede, bistveni podatki, kanal itd.; razmerje med udeleženci.

- Obnavljajo besedilo.

- Povzamejo temo, ključno misel, idejo.

- Povzamejo besedilo.

- Prepoznajo in določijo jezikovno zvrstnost.

- Določijo značilnosti besedilne vrste: zgradbene /npr. izrek vabila/, leksikalne, slovnične, oblikovne /krepki tisk/ značilnosti besedilne vrste, vloga nebesednih prvin.

- Primerjajo prebrano besedilno vrsto z drugo besedilno vrsto, predstavijo ugotovitve.

- Iščejo dane podatke $\mathrm{v}$ besedilu.

- Razvrščajo podatke iz besedila. 
- Razvrščajo dele besedila v smiselno zaporedje.

- Razlikujejo med dejstvi in mnenji oziroma med dejstvi in stališči.

- Izraze $\mathrm{v}$ besedilu povezujejo $\mathrm{z}$ drugimi, ki so smiselni in pomensko primerljivi: sopomenke, nadpomenke, podpomenke idr.

- Prepoznajo in določijo slogovni postopek/način razvijanja teme: opisovanje, pripovedovanje, razlaganje, utemeljevanje.

- Poiščejo izraze, ki se nanašajo na isti del dejanskosti (nanašanjska zaporedja), členitev po aktualnosti in druga besedilotvorna sredstva.

Iz navedenih dejavnosti in ciljev je razvidno, da se razumevanje besedil povezuje z besediščem, izpustili pa smo cilje in dejavnosti, pri katerih se razumevanje besedil povezuje s tekočim branjem, kritičnim branjem, odzivom na besedilo in tvorjenjem besedil. Navedene aktivnosti učeči se lahko opravlja prek različnih didaktičnih tipov nalog, npr. nalog alternativnega tipa, nalog izbiranja, dopolnjevanja. Izbira didaktičnega tipa nalog je vezana na stopnjo izobraževanja in zmožnosti učečega se.

\section{$5 \quad$ Sklep}

Prispevek jasno prikazuje, da sta branje in poslušanje kot osnovi za razumevanje besedil aktivna procesa ali aktivni sestavini (kritične) sporazumevalne jezikovne zmožnosti in tako tudi bralne pismenosti. Gradnik razumevanje besedil skuša sistematično razvijati branje $z$ razumevanjem, in sicer tako, da učeči se a) išče, primerja, ureja, organizira podatke iz besedil, b) sklepa, razbira bistvo, c) povzema in $v$ manjši meri vrednoti besedila. Pri tem uporablja bralne učne strategije in uzavešča procesa branja ter razumevanja prebranega oziroma slišanega. Učeči se $\mathrm{s}$ tem prikazuje svoje razumevanje prebranega/slišanega ter tudi prepoznavanje in dojemanje jezikovnega in nejezikovnega posameznega konkretnega konteksta, $\mathrm{v}$ katerem je obravnavano besedilo nastalo. Pri razvijanju razumevanja besedil je nujno treba preseči delitve na področje jezik in področje književnost, saj so vse strategije razumevanja umetnostnega besedila potrebne tudi za razumevanje neumetnostnega besedila oziroma drži obratno: vse strategije in zmožnosti za razumevanje neumetnostnega besedila je mogoče prenesti na umetnostna besedila. Tako postanejo priložnost za razvijanje razumevanja besedil vse jezikovnokomunikacijske interakcije, $\mathrm{v}$ katerih učeči se sodeluje. 


\section{Opomba}

Avtorica Mira Krajnc Ivič je prispevek napisala v okviru projekta OBJEM - Bralna pismenost in razvoj slovenščine (Ozaveščanje, Branje, Jezik, Evalvacija, Modeli), šifra projekta OP20.01462, vodja dr. Sandra Mršnik, ki ga vodi Zavod RS za šolstvo. Naložbo sofinancirata Republika Slovenija in Evropska unija iz Evropskega socialnega sklada.

\section{Viri}

Boštjan GORENC - PIŽAMA, 2016: SLOLvenski klasiki 1. Ljubljana: Cankarjeva založba.

Andrej GUŠTIN, 2018/2019: Lunini mrki. Presek, list za mlade matematike, firiłke, astronome in računalničarje 46(2). 19-22.

Kiti, Wikipedija; https://sl.wikipedia.org/wiki/Kiti

Kje v Zalivu sv. Križa smo varni?; https://parkstrunjan.si/wpcontent/uploads/2018/11/Zgibanka_Previdno-klif-se-kru\%C5\%A1i.pdf

Navadna veverica, Wikipedija; https://sl.wikipedia.org/wiki/Navadna_veverica

Jure SLAK, 2018/2019: Problem dveh jajc. Presek, list za mlade matematike, firikee, astronome in računalničarje 46(2). 23-28.

Zbirka BERTA - zbirka besedil praktičnega sporazumevanja, oblikovanja za učno e-okolje projekta Slovenšina na dlani. Interno gradivo projekta Slovenščina na dlani. 2019.

\section{Literatura}

Salvatore ATTARDO, 2001: Humorous Texts: A Semantic and Pragmatic Analysis. Berlin, New York: Mouton de Gruyter.

Robert Alain DE BEAUGRANDE, Wolfgang Ulrich DRESSLER, 1992: Uvod v besediloslovje. Ljubljana: Park.

Marja BEŠTER, 2011: Sporazumevalna zmožnost - eden izmed temeljnih ciljev pouka slovenščine. Jezik in sloustvo 56(3-4). 122-127.

Karl BÜHLER, 1965: Sprachtheorie: Die Darstellungsfunktion der Sprache. (1. izdaja 1934). Stuttgart:

Gustav Fischer. 24-33.

https://pure.mpg.de/pubman/faces/ViewItemFullPage.jsp?itemId=item_2305592_5

Norman FAIRCLOUGH, 2004: Analysing Discourse. Textual Analysis for Social Research. London, New York: Routledge.

Paul GRICE, 1989: Logic and Conversation. Studies in the W ay of Words. Cambridge: Harvard University Press. 22-40.

Paul GRICE, 1989a: Further Notes on Logic and Conversation. Studies in the Way of Words. Cambridge: Harvard University Press. 41-57.

Wolfgang HEINEMANN in Dieter VIEHWEGER, 1991: Textlinguistik. Eine Einfübrung. Tübingen: Max Niemeyer Verlag.

Tomo KOROŠEC, 1998: Stilistika slovenskega poročevalstva. Ljubljana: Kmečki glas.

Mira KRAJNC IVIČ, 2020: Obravnava besedil: merila za razlikovanje med besedilno vrsto in besedilnim tipom. Slavisticna revija 68(1). 55-71.

Olga KUNST GNAMUŠ, 1994: Performativni glagoli v opisni slovnici slovenskega jezika. Jeriik in slovstvo 39(5). 189-198.

Kurikulum za vrtce, 1999. Ljubljana: Strokovni svet RS za splošno izobraževanje.

Stephen C. LEVINSON, 1995: Activity Types and Language. Talk at Work: Interaction in Institutional Settings. Ur. Paul Drew in John Heritage. Cambridge: Cambridge University Press. 66-101.

Jan NUYTS, 1992: Aspects of a Cognitive-Pragmatic Theory of Language. On Cognition, Functionalism, and Grammar. Amsterdam, Philadelphia: John Benjamins Publishing Company.

Charles Sandres PEIRCE, 2004: Izbrani spisi o teoriji znaka in pomena ter pragmaticizmu. Ljubljana: Krtina.

Ferdinand de SAUSSURE, 1997: Predavanja iz splošnega ję̧ikoslovja. Ljubljana: ISH Fakulteta za podiplomski humanistični študij. 
Skupni evropski jezileovni okvir: učenje, poučevanje, ocenjevanje (= SEJO). El. knjiga. Ljubljana: Ministrstvo RS za šolstvo in šport, Urad za razvoj šolstva, 2011. https://centerslo.si/wpcontent/uploads/2015/10/SEJO-komplet-za-splet.pdf

Sonja STARC, 2011: Stik disciplin v besedilu iz besednih in slikovnih semiotskih virov. Meddisciplinarnost v slovenistiki. Obdobja 30. Ljubljana: Znanstvena založba Filozofske fakultete. 433-440.

Michael STUBBS, 1983: Discourse Analysis. The Sociolinguistic Analysis of Natural Languarge. Chichago: University of Chichago.

Učni načrt. Slovenšina: gimnarija: splošna, klasična, strokovna gimnarija, 2008. Ljubljana: Ministrstvo za šolstvo in šport, Zavod RS za šolstvo.

http://eportal.mss.edus.si/msswww/programi2019/programi/media/pdf/un_gimnazija/un _slovenscina_gimn.pdf

Učni načrt. Program osnovna šola. Slovenščna, 2018. Ljubljana: Ministrstvo za izobraževanje, znanost in šport, Zavod RS za šolstvo.

https://www.gov.si/assets/ministrstva/MIZS/Dokumenti/Osnovna-sola/Ucninacrti/obvezni/UN_slovenscina.pdf

Andreja VEZOVNIK, 2009: Diskuræ. Fakulteta za družbene vede. Knjižna zbirka Psibologija vsakdanjega življenja. http://unilj.academia.edu/AndrejaVezovnik/Papers/820881/Diskurz._monograph

Jerca VOGEL, 2014: Jezikovna kulturna zavest pri pouku maternega/prvega jezika. Jezik in slovstvo 59(4). 3-14.

Andreja ŽELE, 2010: Elipsa med glagolsko intenco in besedilno koherenco (Izpustnost med glagolsko usmerjenostjo in besedilno soveznostjo). Slavistična revija 58(1). 117-131.

Andreja ŽELE in Mira KRAJNC IVIČ, 2020: Sodobna slovensk a skeladnja: diskurž in slovnični vidik. Maribor: Univerzitetna založba. Mednarodna knjižna zbirka Zora, Zora 134. V tisku. 


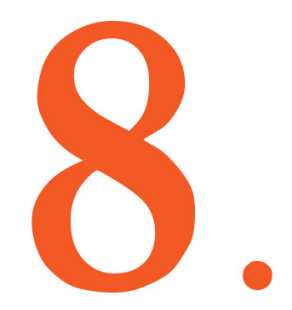

G R A D N I K

\section{ODZIV NA BESEDILO IN TVORJENJE BESEDIL}

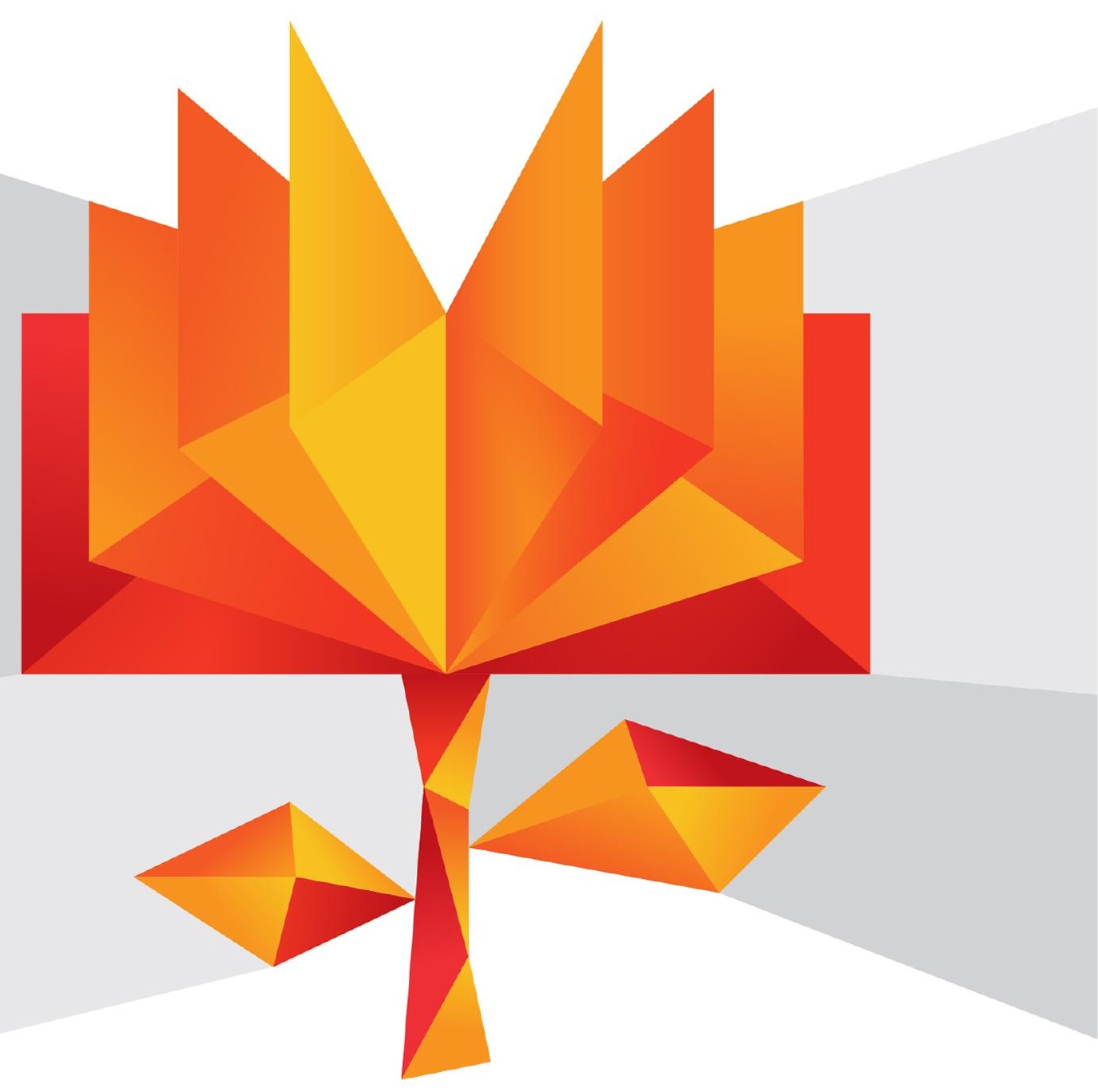


Elementi gradnika:

- tvorjenje ustreznih in smiselnih govorjenih in pisnih besedil o prebranem

- uporaba prebranega v novih situacijah

- razvijanje veščine pisanja ustreznih besedil 


\title{
8. GRADNIK:
}

\section{ODZIV NA BESEDILO IN TVORJENJE}

\section{BESEDIL}

\author{
Simona Pulko ${ }^{1}$ In Eva KRANJEC ${ }^{2}$ \\ ${ }^{1}$ Univerza v Mariboru, Filozofska fakulteta, Maribor, Slovenija. \\ E-pošta: simona.pulko@um.si \\ ${ }^{2}$ Univerza v Mariboru, Pedagoška fakulteta, Maribor, Slovenija. \\ E-pošta: eva.kranjec@um.si
}

Povzetek Prispevek obravnava gradnik odziv na besedilo in tvorjenje besedil za razvoj bralne pismenosti. Ob tem so upoštevani kurikulum za vrtce, učna načrta za slovenščino v osnovni šoli in gimnaziji, ki predstavljajo pomembno izhodišče za prenos obravnavanega gradnika na vsa predmetna področja. Gradnik se izkazuje skozi tvorjenje ustreznih in smiselnih govorjenih in pisnih besedil o prebranem, uporabo prebranega $v$ novih situacijah in razvijanje veščne pisanja ustreznih besedil.

Ključne besede: bralna pismenost, odziv na besedilo, tvorjenje besedila, učenci, razvoj. 


\title{
THE EIGHTH COMPONENT OF READING LITERACY: RESPONSE TO THE TEXT AND Creating TEXTS
}

\author{
Simona Pulko ${ }^{1} \&$ Eva KranjeC ${ }^{2}$ \\ ${ }^{1}$ University of Maribor, Faculty of Arts, Maribor, Slovenija. \\ E-mail: simona.pulko@um.si \\ 2 University of Maribor, Faculty of Education, Maribor, Slovenija. \\ E-mail: eva.kranjec@um.si
}

Keywords: reading literacy, text response, text production, students, development.

\begin{abstract}
The paper discusses the component of reading literacy of text response and text production for the development of reading literacy. It takes into account the curriculum for kindergartens, the curricula for Slovenian in primary and secondary schools, which are an important starting point for the transfer of the considered components of reading literacy to all subject areas. The component of reading literacy manifests itself through the creation of appropriate and meaningful spoken and written texts about what is read, the use of what is read in new situations and the development of the ability to write relevant texts.
\end{abstract}




\section{$1 \quad$ Uvod}

Namen sistematičnega opismenjevanja oziroma razvoja bralnih zmožnosti otrok v zgodnjih obdobjih je razvijanje sposobnosti samostojnega branja oziroma bralne pismenosti. Opredelitev bralne pismenosti, ki je nujna za potrebe razumevanja odziva na besedilo in tvorjenje besedil za razvoj bralne pismenosti, je podana $\mathrm{v}$ uvodnem delu pričujočega gradiva.

Različni raziskovalci (npr. Marjanovič Umek, Fekonja Peklaj in Pečjak 2012) opredeljujejo samostojno branje kot odraz otrokove sposobnosti identifikacije (dekodiranja) posameznih besed in razumevanje prebranega brez posebnega napora, ki ga učenec vlaga $\mathrm{v}$ samo aktivnost. Razumevanje prebrane vsebine nadalje omogoča tvorjenje ustreznih in smiselnih govorjenih in pisnih besedil o prebranem ter uporabo informacij/znanja $\mathrm{v}$ novih situacijah. Skupno branje in pogovor $\mathrm{z}$ otrokom na ravni referenčne komunikacije, znotraj katere so vprašanja in razlage, vezane na informacije, ki jih otrok ne more neposredno razbrati iz slik ali besedila, $\mathrm{v}$ predšolskem obdobju razvija metajezikovno zavedanje in kasnejšo pismenost (npr. Ko Vander Woude, van Kleeck in Vander Veen 2009). Učinki branja na pomenu dobijo predvsem $\mathrm{v}$ šolskem obdobju, saj se branje $\mathrm{z}$ razumevanjem pozitivno povezuje $z$ lažjim vstopom $v$ proces učenja, $z$ oceno branja, $z$ oceno maternega jezika in učenčevo učno uspešnostjo (Pečjak, Količ-Vehovec, Rončević Zubkovič in Ajdišek 2009; Pečjak 1995).

Otrok se z branjem in pisanjem seznani že $\mathrm{v}$ predšolskem obdobju, intenzivno in sistematično pa z njim nadaljuje v času šolanja (Pečjak in Potočnik 2011). Obravnava zgodnje pismenosti ne vključuje zgolj razumevanja razvojnih vidikov branja in pisanja, temveč tudi drugih sporazumevalnih dejavnosti, kot sta govorjenje in poslušanje. Na osnovi spoznanj o raznolikosti dejavnikov, ki pomembno prispevajo $\mathrm{k}$ individualnim razlikam $\mathrm{v}$ bralni pismenosti otrok (npr. otrokov govor in intelektualne sposobnosti, družinsko in vrtčevsko/šolsko okolje, skupno branje otroka in vzgojitelja, vzgojiteljice, učitelja, učiteljice), je razvojne mejnike bralne pismenosti težko enoznačno določiti. Tako v znanstvenem kot strokovnem prostoru prihaja v ospredje model avtoric D. Barone, M. Mallette in S. Xu (2005), ki začetni razvoj pismenosti vidijo kot posameznikov napredek na treh stopnjah: stopnji porajajoče se pismenosti, stopnji začetne pismenosti in stopnji prehodne pismenosti. 
$\mathrm{Na}$ stopnji porajajoče se pismenosti otroci spoznavajo pismenost zelo globalno. V tem obdobju otrok še nima razvite predstave besede, zato se pretvarja, da bere in piše. Otrok gleda knjigo in ilustracije, pogosto $z$ obmjeno postavitvijo in osredotočenostjo na začetni in končni del zgodbe. Z razvojem govora in širjenjem besednjaka postaja sposoben poimenovati predmete, ljudi ali živali (npr. muca, dojenček, hiša) in odgovarja na vprašanja o tem, kaj vidi v knjigi. Otrok prepozna naslovnice najljubših knjig, razliko med sliko in pisavo, za pisanje besed pa uporablja številke ali izbrane črke. Ko je otrok sposoben prepoznati slike na vsaki strani knjige, jih smiselno povezati skupaj in na njihovi osnovi pripovedovati zgodbo, pravimo, da ima razvit koncept knjige, branja in pravil o branju (Pečjak in Potočnik 2011).

$\mathrm{Na}$ stopnji začetne pismenosti ima otrok razvito predstavo besede, ki jo pri branju pogosto vokalizira na polglasen ali šepetajoč način. Zgodbo pogosto obnovi z istimi besedami. Na področju pisanja je sposoben povezati črke v besedo. V ospredje prihaja oblikovano abecedno načelo, ki narekuje, da ima vsaka črka svoj glas. S premikom na stopnjo prehodne pismenosti otrok usvoji sposobnost tihega in tekočega branja večje skupine besed, dobesedne obnove ali povzemanja, izražanje odnosa do prebranega, usmerjanja na pomen povedi in razlikovanja med zapisom ter izgovorjavo besed (Pečjak in Potočnik 2011). Pri tem je treba izpostaviti, da tekoče branje $\mathrm{z}$ razumevanjem, odzivanje na besedilo in tvorjenje besedil zahtevajo sočasno in usklajeno izvajanje raznolikih procesov. Tovrstna aktivnost presega zmožnost preprostega zapisovanja črk in vključuje procese, ki segajo od dekodiranja črk in prepoznavanja besed, do dejavnosti, povezanih z razumevanjem besed, fraz in stavkov (Snowling in Hulme 2005).

Pričujoče poglavje obravnava 8. gradnik bralne pismenosti - odziv na besedilo in tvorjenje besedil. Gradnik se izkazuje skozi tvorjenje ustreznih in smiselnih govorjenih in pisnih besedil o prebranem, uporabo prebranega $\mathrm{v}$ novih situacijah in razvijanje veščine pisanja ustreznih besedil. Na osnovi spoznanj o odsotnosti ostro začrtanih meja med posameznimi ravnmi pismenosti tako z vidika razvoja otrok na sploh kot z vidika dinamike razvoja posameznega otroka (npr. Pečjak in Potočnik 2011), poglavje obravnava značilnosti gradnika glede na posamezna razvojna oz. vzgojno-izobraževalna obdobja. Pri tem je v ospredju preverjanje skladnosti oz. doslednosti gradnika z vsebinami Kurikuluma za vrtce (1999) in posameznimi učnimi načrti obveznih in izbirnih osnovnošolskih ter srednješolskih predmetov. 


\section{Branje besedila, odziv na besedilo in tvorjenje besedil}

Gradnik, obravnavan v poglavju, obravnava odziv na besedilo in tvorjenje besedil, a gradnik težko obravnavamo brez predhodnega branja besedila, saj je tovrstna povezava nujna.

Iz vrste besedila izhaja pogosto uporabljeno razločevanje med branjem umetnostnih besedil ali literarnim branjem in branjem neumetnostnih besedil in tudi med bralno zmožnostjo za branje leposlovja - včasih ji pravijo kar literarna zmožnost - in bralno zmožnostjo za pridobivanje podatkov in učenje. /.../ Nenazadnje je umetnostno besedilo mogoče brati tudi kot neumetnostno, kadar v njem iščemo samo razne podatke ali slovnične strukture, mogoče pa je tudi domiselno sanjariti ob telefonskem imeniku in nekaterih drugih neumetnostnih besedilih (Grosman 2006: 87).

\subsection{Branje besedil $\mathrm{z}$ razumevanjem}

Branje besedil z razumevanjem pomeni, da bralec razume, kar bere, torej da zaznava besedilne informacije in jih je sposoben povezati $\mathrm{v}$ smiselno pomensko celoto. Bralec običajno pred branjem razmisli ali prikliče iz spomina informacije o tem, kaj o temi, o kateri bo bral, že ve, med samim branjem pa ugotavlja, da je to tako oziroma utrjuje ter shemo dopolnjuje in jo po potrebi popravlja. Bralna strategija zlasti neumetnostnega besedila predvideva, da si bo bralec prebrano zapomnil in pozneje po potrebi tudi uporabil (Kordigel in Saksida 2001: 12; Pečjak in Gradišar 2015).

Bralni pouk je naloga vseh predmetnih področij; bralec naj usvoji učinkovite bralne strategije za branje strokovnih besedil določenega predmetnega področja. Razvijanje spretnosti branja neumetnostnih besedil je usmerjeno tudi v odpravljanje regresije in v izkoriščanje preobilja (Kordigel in Saksida 2001: 12).

\subsubsection{Preverjanje razumevanja besedila}

$\mathrm{V}$ pedagoškem procesu na sploh je delo z neumetnostnimi besedili veliko bolj pogosto in pristno kot delo z umetnostnimi besedili, zlasti če upoštevamo vsa predmetna področja. Vedno moramo najprej oceniti stopnjo razumevanja prebranega besedila in temu prilagoditi strategije (Pečjak in Gradišar 2015). Dobro 
bralno razumevanje je osnova vseh bralnih učnih strategij, hkrati pa je tudi pomembno izhodišče za odziv na prebrano in tvorjenje besedila. Bralno razumevanje lahko preverjamo pred in med branjem ter po njem (Gradišar 2003: 33-39).

\subsubsection{Preverjanje razumevanja pred branjem}

Pred branjem besedila s pogovorom ugotovimo, kaj bralca zanima. Nato sledi pogovor o izbrani temi, kjer preverimo bralčevo predznanje, na osnovi katerega lažje izberemo primerno besedilo. Bralci skušajo na podlagi nebesednega gradiva, naslova, mednaslovov, podnaslovov in hitrega preleta besedila določiti cilje in vsebino besedila. Pogovor pred branjem ima močno motivacijsko moč (Gradišar 2003: $33-$ 39).

\subsubsection{Preverjanje razumevanja med branjem}

Pri preverjanju razumevanja med branjem je $\mathrm{v}$ ospredju bralčevo razumevanje prebranega in kako bralec med branjem to informacijo predeluje. Branje neumetnostnega besedila poteka počasi, saj moramo dele besedila večkrat ponovno prebrati. Pogovor je nujen, saj nas zanima, ali bralec obvladuje predbralna pričakovanja, ali pozna pojme, ali zna sklepati, ali zna povzemati vsebino in ali zna vsebino vizualizirati (Gradišar 2003: 33-39).

\subsubsection{Preverjanje razumevanja po branju in odziv na prebrano}

$\mathrm{Z}$ vprašanji preverjamo razumevanje celotnega besedila. Preverimo, ali bralec zna izluščiti bistvene informacije ter kako jih povezuje. Zanima nas, kako si bralec te informacije zapomni, kako jih presodi in kako to vsebino besedno ali grafično predstavi (Gradišar 2003: 33-39).

\section{Odziv na besedilo in tvorjenje besedil}

V poglavju so predstavljeni elementi gradnika odziv na besedilo in tvorjenje besedil glede na posamezna razvojna oz. vzgojno-izobraževalna obdobja, pri čemer so upoštevani temeljni elementi gradnika, tj. tvorjenje ustreznih in smiselnih govorjenih in pisnih besedil o prebranem, uporaba prebranega $\mathrm{v}$ novih situacijah in razvijanje veščine pisanja ustreznih besedil. Jezik predstavlja eno od temeljnih področij dejavnosti 
Kurikuluma za vrtce (1999), pri čemer je $\mathrm{v}$ ospredju povezava med aktivnostmi spoznavanja otroške literature, seznanjanjem s pisnim jezikom in učenjem tako besednega kot nebesednega izražanja izkušenj, čustev, misli in sporočil. Vloga in pomen odziva na besedilo ter tvorjenje besedila sta eksplicitno izpostavljena in kontinuirano zastopana $\mathrm{v}$ vseh vzgojno-izobraževalnih obdobjih $\mathrm{v}$ opredelitvi predmeta $\mathrm{v}$ učnem načrtu za slovenščino $\mathrm{v}$ osnovni šoli (UN 2018: 6):

V vseh vzgojno-izobraževalnih obdobjih se predmet s cilji, z vsebinami in dejavnostmi učencev in učenk tesno povezuje $z$ drugimi predmeti in pri njih kot učni jezik poleg pridobivanja stvarnega znanja pomembno prispeva k razvijanju sporazumevalne zmožnosti učencev in učenk. / . . / učenci in učenke $\mathrm{v}$ tem obdobju poleg vstopanja $\mathrm{v}$ svet branja in pisanja opravljajo tudi druge sporazumevalne dejavnosti, npr. se pogovarjajo, kritično sprejemajo oz. interpretirajo govorjena in zapisana besedila, se (po)ustvarjalno odzivajo nanje, govorno nastopajo, pišejo krajša besedila ter razvijajo svojo jezikovno (poimenovalno, skladenjsko, pravorečno, pravopisno), slogovno in metajezikovno zmožnost (podčrtala S. P.). $\mathrm{V}$ 2. in 3. vzgojno-izobraževalnem obdobju pa sprejemajo, interpretirajo, vrednotijo in razčlenjujejo svoji starosti, sporazumevalni, spoznavni in domišlijiski zmožnosti, izkušnjam in interesom ustrezna neumetnostna in umetnostna besedila, tvorijo govorjena in zapisana monološka besedila, se pogovarjajo in pišejo dopise raznih vrst; tako dejavno razvijajo svojo sporazumevalno, spoznavno in ustvarjalno zmožnost ter uzaveščajo temeljne podobnosti in razlike na ravni sprejemanja, razumevanja, doživljanja in vrednotenja neumetnostnih in umetnostnih besedil, na ravni tvorjenja neumetnostnih in poustvarjalnih besedil, na ravni enosmernega in dvosmernega sporazumevanja, na ravni tvorjenja tiskanih in elektronskih sporočil, na ravni sprejemanja, razumevanja, doživljanja in vrednotenja prikazovalnih in oglasnih besedil ipd. (podčrtala S. P.). Ob tem sistematično razvijajo vse sestavine sporazumevalne zmožnosti, torej tudi metajezikovno zmožnost, hkrati pa uzaveščajo znanje za uspešno tvorjenje, sprejemanje, razumevanje, doživljanje in vrednotenje besedil v novih, dolgoročno nepredvidliivih medijih in oblikah, ki jih prinaša elektronska doba (podčrtala S. P.). 
Tudi v splošnih ciljih (UN 2018: 8) sta poudarjena vloga in pomen obravnavanega gradnika, pri čemer je poseben poudarek namenjen razvijanju zmožnosti tvorjenja besedil ter usvajanju in utrjevanju strategij in načel za tvorjenje verodostojnih, razumljivih, ustreznih in učinkovitih besedil, skladnih z jezikovno in slogovno normo knjižne zvrsti.

Med splošnimi cilji velja izpostaviti tudi cilj, da učenci in učenke razvijajo pripravljenost za pogovarjanje in dopisovanje ter za govorno nastopanje in pisanje (UN 2018: 8):

Tako ubesedujejo svoje znanje, misli, stališča, hotenje, čustva in izkušnje, se pogajajo ter miroljubno rešujejo probleme v raznih življenjskih položajih. Zavedajo se raznih okoliščin, v katerih nastajajo besedila, raznih namenov, ki jih imajo tvorci besedil, ter raznih medijev, prek katerih so besedila lahko posredovana, zato so sposobni tvoriti ustrezna in učinkovita besedila raznih vrst. Ob tem razvijajo svojo empatično, socialno, kulturno in estetsko zmožnost. Razvijanje zmožnosti tvorjenja besedil ter usvajanje in utrjevanje strategij in načel za tvorjenje verodostojnih, razumljivih, ustreznih in učinkovitih besedil, skladnih z jezikovno in slogovno normo knjižne zvrsti, pa spodbuja tudi razvijanje zmožnosti učenja.

\subsection{Odziv na besedilo in tvorjenje besedil v obdobju zgodnje pismenosti}

Bralna pismenost je izjemno obsežen in kompleksen koncept, zaradi česar ga ni moč pojasniti z le enim samim modelom. V slovenskem prostoru je izraz zgodnja pismenost uveljavljen za ponazoritev otrokovega učenja branja in pisanja skozi predšolsko obdobje in del osnovnošolskega izobraževanja (predvsem 1. VIO ). Za razumevanje nadaljnje vsebine izhajamo iz modela zgodnje pismenosti, ki se deli na tri obdobja: porajajoča se pismenost, začetna pismenost in prehodna pismenost (Pečjak in Potočnik 2011: 62).

Porajajoča se pismenost ima svoje začetke $\mathrm{v}$ zgodnjih socialnih interakcijah med dojenčkom ali malčkom in njemu pomembno osebo, ki ga spodbuja na področju govornega razvoja (Marjanovič Umek 2010). Porajajoča se pismenost kot prva stopnja zgodnje pismenosti zajema predšolske otroke in prvošolce ter poudarja postopnost in dolgotrajnost procesa opismenjevanja, ki zajema večji del predšolske 
vzgoje (Pečjak 2003). Spodbujanju jezikovne dejavnosti v predšolskem obdobju namenja Kurikulum za vrtce (1999) precejšnjo mero pozornosti, predvsem na osnovi kritičnosti obdobja za razvoj govora. Jezikovne dejavnosti se v predšolskem obdobju tesno povezujejo s fonološko, morfološko, skladenjsko-pomensko in pragmatično ravnino, v obdobju zgodnjega otroštva (tj. obdobje, ki traja od otrokovega tretjega do šestega leta starosti) pa na pomenu začne pridobivati razvoj predpisalnih in predbralnih sposobnosti.

Pri pojasnjevanju otrokovega odziva na besedila različnih vrst (tj. pripovedovalna, razlagalna, utemeljevalna, opisovalna) in načinih tvorjenja besedil $\mathrm{v}$ najbolj zgodnjem obdobju ne gre prezreti spoznanj o značilnostih predjezikovne in jezikovne faze otrokovega govornega razvoja. Novorojenček in dojenček se prej naučita razumevanja kot uporabe govora. Pozornost usmerjata na ritem, intonacijo in vzorce glasov njemu pomembne osebe in se na slednje odzivata $z$ intenzivnim brcanjem, zvijanjem, gruljenjem in grgranjem. Dojenčki v petem ali šestem mesecu preidejo $\mathrm{v}$ fazo bebljanja, $\mathrm{v}$ kateri uporabljajo artikulirane povezave samoglasnikov in soglasnikov v različnih zaporedjih. Proti koncu prvega leta začnejo uporabljati geste in kretnje, s katerimi izražajo želje, vzbujajo pozornost nekoga drugega ali simbolizirajo predmete in dejavnosti. Pospešen razvoj govora na pomenski, skladenjski in besedoslovni ravnini sledi po drugem letu starosti. Otrok zelo hitro povečuje obseg besednjaka, prične povezovati besede $\mathrm{v}$ stavke, slovnična in pragmatična zmožnost govora se pričneta razvijati sočasno (pregled v Marjanovič Umek in Fekonja 2004a, 2004b).

Razvoj in učenje govora malčkov in otrok najpogosteje poteka v kontekstu otroške igre in izpostavljenosti otroka otroški literaturi. Preučevanje povezanosti otroške literature in otrokovega govornega razvoja je umeščeno v dve znanstveni disciplini - psihologijo in jezikoslovje - pri čemer pozitivne učinke otroške igre in literature za otrokov celostni razvoj potrjujejo številne raziskave (Marjanovič Umek, Fekonja, Lešnik Musek in Kranjc 2002). V kontekstu predšolskih aktivnosti otroci razvijajo govor in se učijo jezika ob "poslušanju vsakdanjih pogovorov, pripovedovanju literarnih besedil, ob poslušanju glasnega branja odraslih, s pripovedovanjem, opisovanjem, ob rabi jezika $\mathrm{v}$ domišlijijkih igrah, izmišljanju zgodbic in pesmic, ob učenju otrok od otrok, in sicer $\mathrm{v}$ različnih socialnih igrah, pravljicah, izštevankah, rimah, šaljivkah, ugankah, besednih igrah« (Kurikulum za vrtce 1999: 19). 
Mejniki bralne pismenosti otrok prvega starostnega obdobja (tj. otrok v starosti od enega do treh let) podpirajo predpostavko gradnika o otrokovih besednih in nebesednih odzivih na slišano in videno. $V$ tem obdobju se otroci naučijo, da imajo kretnje in zvoki pomen, se odzivajo, ko se jim odrasla oseba oglasi, svojo pozornost usmerjajo nanjo ali predmete $\mathrm{v}$ bližini, posegajo po knjigah in obračajo strani $\mathrm{s}$ pomočjo bolj kompetentnega vrstnika ali odrasle osebe. Med prvim in tretjim letom so otroci sposobni prepoznati in odgovoriti na vprašanja o objektih v otroški knjigi (npr. »Kje je krava? Kako se krava oglaša? ), uporabijo prste (najpogosteje kazalec) za označitev predmeta, po katerem sprašujemo, in se pretvarjajo, da berejo knjigo. Aktivnosti, ki jih v tem sklopu predpostavlja Kurikulum za vrtce (1999), se nanašajo na branje pravljic, zgodbic, ugank, pesmic in pripovedi o dogodku, sodelovanje $\mathrm{v}$ jezikovnih, prstnih, akcijskih in rajalnih igrah, doživljanju ritma besed, glasbe ter pesmi. S kritično uporabo otrokovi starosti primerne otroške literature in aktivnosti vzgojitelj otroku omogoča stik s knjižim jezikom (tako govorjenim kot zbornim), spodbuja njegovo izražanje s pomočjo verbalnih in neverbalnih sredstev ter mu nudi možnosti sodelovanja in odzivanja na dialog. Raznolikost (socialnih) situacij otroku omogoča razvijanje jezikovne zmožnosti, ki se povezuje s spretnostmi porajajoče se pismenosti ter poznejšim učenjem branja. Obenem raziskovalni izsledki kažejo pomembno napovedno vlogo govora otrok/mladostnikov za šolsko uspešnost (npr. Marjanovič Umek, Sočan in Bajc 2007).

V drugem starostnem obdobju (tj. od starosti treh do šestih let) lahko opazimo pomemben napredek otrok tako na področju govornega razvoja kot porajajoče se pismenosti. Na področju govornega razvoja otrok začne presegati dvobesedne stavke, samostalnikom začne dodajati glagole ter pridevnike in spreminjati zaporedja besed $\mathrm{z}$ namenom oblikovanja vprašalnih in nikalnih stavkov. Iz razvojnega vidika otrok najprej oblikuje vprašalne stavke z vprašalnicami kaj, kje in kedo, nato pa z vprašalnicami kako, kedaj, kateri in čigav (Brown 1968, v Marjanovič Umek in Fekonja 2004b). S tako oblikovanimi vprašalnimi stavki se otrok odziva na trenutno dogajanje oziroma videne dražljaje. Zmožnost oblikovanja slovnično pravilnih vprašalnih stavkov otroku omogoča, da se čim bolj aktivno vključuje v interakcije in deluje v svojem okolju. Pomembni napredki so opazni tudi na področju porajajoče se pismenosti. Okrog četrtega leta starosti otrok pozna pravilen način držanja in ravnanja s knjigo ter razume, da se besede berejo od leve proti desni, strani pa od zgoraj navzdol. Otrok opaža in se odziva na besede, ki se rimajo, prepozna približno polovico črk abecede in jih povezuje z njihovimi zvoki. V tem obdobju otrok začne prepoznavati svoje ime $\mathrm{v}$ tiskani besedi in je sposoben obnoviti pripovedovano 
zgodbo. Po petem letu starosti otrok prepoznava začetne, srednje in končne zvoke $\mathrm{v}$ govorjenih besedah ter vsako črko poveže z zvokom, ki ga predstavlja. Povezovanje besed, ki jih sliši, s tistimi, ki jih vidi v besedilnem gradivu, mu ne predstavlja večjih težav. Otrok v tem obdobju prepoznava nekatere besede tako, da si jih zgolj ogleda, pri čemer ni nujno, da jih tudi izgovori, sprašuje in odgovarja na kdo, kaj, kje, kdaj, zakaj in kako vprašanja o zgodbi ter jo obnovi po vrstnem redu z besedami ali slikami. Pojavi se sposobnost predvidevanja o nadaljnjem poteku zgodbe in uporaba jezika zgodbe med otroško igro ali pogovorom z vrstnikom oziroma odraslo osebo (npr. »Labko letim!«, je rekel zmaj. »Labko letim!«).

Aktivnosti, ki jih v drugem starostnem obdobju predpostavlja Kurikulum za vrtce (1999), predstavljajo nadgradnjo predhodnih, saj postanejo bolj dinamične, kompleksne in spodbujajoče za otrokov celostni razvoj. Preko smiselno načrtovanih aktivnosti se otroka izpostavlja poslušanju pravljic, zgodbic, ugank in pesmic. Otroka se vključuje v različne družabne in didaktične igre, ki razvijajo besedišče, obnavljanje in izmišljanje zgodb. Strokovni delavci vsebine posredujejo preko različnih medijev (npr. avdio in video) in v različnih kontekstih (npr. skozi obisk gledaliških in filmskih predstav ali knjižnice), spodbujajo otroka k odzivanju nanje, razvoju govora in porajajoče se pismenosti. Skozi omenjene aktivnosti otrok spoznava pisni jezik in njegovo vlogo, spoznava, da je mogoče izgovorjene besede zapisati in jih nato znova prebrati ter uporablja različne vrste simbolov za izražanje svojih misli (Kurikulum za vrtce 1999).

Pomembno vlogo pri porajajoči se pismenosti ima otroška igra, ki v predšolskem obdobju predstavlja otrokovo osrednjo dejavnost (Marjanovič Umek in Zupančič 2006). V drugem starostnem obdobju je izrazita predvsem simbolna igra in igra vlog, pri kateri otrok posnema ali igra osebe, živali in predmete. Preko povezovanja simbolne igre $z$ vsakdanjimi dogodki otrok razvija vedenje o pismenosti in odkriva njen pomen (npr. otrok prepoznava znake in napise knjig, pripravi si seznam za nakupovanje ...). Skozi tovrstne aktivnosti se otrok uči o pomenu in oblikah tiska ter razvija željo po napredovanju na področju pismenosti (Grginič 2005). Tako jezik kot simbolna igra predstavljata simbolna sistema različnih idej, občutij in izkušenj, pri čemer imajo pomembno vlogo posredni in neposredni vplivi vzgojitelja na igro otrok. Posredni vplivi se kažejo predvsem skozi izbiro okolja, igralnega materiala in soigralcev $\mathrm{v}$ igri, medtem ko se neposredni vplivi nanašajo na demonstracijo igre $\mathrm{z}$ določeno igračo in opisovanje dogajanja $\mathrm{v}$ igri. Slednje je pomembno predvsem $\mathrm{v}$ 
obdobju malčka in na prehodu v zgodnje otroštvo, $\mathrm{v}$ kasnejših letih pa se potreba po neposredni podpori otrokovi igri s strani odraslih zmanjšuje.

Kot že omenjeno, mejnikov in kazalcev pismenosti ne moremo enoznačno ter neposredno povezovati s starostjo otrok ali šolskimi razredi, saj na tem področju obstajajo velike individualne razlike. Zgodnja pismenost ob obdobju porajajoče se pismenosti vključuje še obdobje začetne in prehodne pismenosti, pri čemer stopnja začetne pismenosti zajema predšolske otroke, prvošolce in nekatere drugošolce, stopnja prehodne pismenosti pa učence od prvega do četrtega razreda. $\mathrm{Na}$ osnovi prekrivanja starostnih obdobij $\mathrm{s}$ stopnjami pismenosti bomo $\mathrm{v}$ tem poglavju predstavili značilnosti gradnika za obdobje srednjega otroštva (tj. obdobje od 6. do 8. leta starosti) oziroma 1. VIO (tj. obdobje od 1. do 3. razreda).

Z vstopom v šolo se razvoj govornih sposobnosti nadaljuje zelo pospešeno, zaznati je moč tako količinske kot kakovostne spremembe. Besednjak otrok vključuje vedno več besed, namenjenih opisovanju čustev, miselnih procesov (npr. reševanje problemov in napovedovanje), povečuje se tudi delež sestavljenih in celovitih stavkov. Zaradi sočasnega napredovanja na področju spoznavnega razvoja otrok razume, da imajo lahko iste besede več pomenov (npr. beseda list pomeni del rastline ali kos papirja), prav tako so jim razumljivi stavki $\mathrm{z}$ razmeroma zapleteno konstrukcijo in stavki, ki se začnejo z besedami čeravno, čeprav, potem ko (Chomsky 1986, Miller 1951, Owens 1996, v Marjanovič Umek in Svetina 2004). Pragmatičnost rabe govora $\mathrm{v}$ 1. VIO je močno povezana $\mathrm{s}$ konverzacijo in sposobnostjo pripovedovanja. Otroci med sedmim in enajstim letom starosti vključujejo v pripovedovanje zgodbe celovite elemente osebnih izkušenj, opise individualnih značilnosti drugih oseb, smiselno povezujejo vzroke in posledice ter spreminjajo potek ali vsebino zgodbe glede na trenutno situacijo (pregled v Marjanovič Umek in Svetina 2004).

Otroci se govorjenja in pisanja naučijo že pred vstopom v šolo, najpogosteje v najožjem družinskem okolju. $Z$ vstopom $v$ šolo napredujejo na področju branja. Otroci med šestim in sedmim letom starosti prebirajo njim znano otroško literaturo, dekodirajo neznane besede, $\mathrm{v}$ pisni obliki uporabijo nekaj ločil ali velikih začetnic, se popravijo pri napačnem prebiranju vsebine na glas in izkazujejo razumevanje zgodbe z risbami. Med sedmim in osmim letom samostojno prebirajo daljše knjige, vsebino berejo na glas z ustreznim poudarjanjem in izraznostjo, razumejo pojem odstavka in ga začnejo uporabljati $\mathrm{v}$ pisni obliki, pravilno črkujejo večje število besed in 
uporabljajo nove besede, besedne zveze ali elemente govora, ki so jih predhodno slišali. V tem starostnem obdobju so otroci sposobni ponovnega pregleda pisnih izdelkov $\mathrm{z}$ namenom ustvarjanja in ponazoritve zgodbe. Po devetem letu otrok postaja zmožen raziskovati in razumeti različne vrste besedila (npr. biografije, poezijo in leposlovje), pravilno prepoznava glavne elemente zgodbe (npr. čas, kraj, zaplet, težava in rešitev) in pomensko analizira dano besedilo.

Začetno opismenjevanje traja celotno 1. VIO, pri čemer sta prva dva razreda namenjena sistematičnemu usvajanju tehnike branja in pisanja, medtem ko se v 3 . razredu več pozornosti namenja utrjevanju in izboljševanju navedenih tehnik. Začetno opismenjevanje "poteka individualizirano, postopoma in sistematicno; učenci in učenke v tem obdobju poleg vstopanja v svet branja in pisanja opravljajo tudi druge sporazumevalne dejavnosti, npr. se pogovarjajo, kriticno sprejemajo oz: interpretirajo govorjena in zapisan a besedila, se (po)ustvarjalno odzivajo nanje, govorno nastopajo, pišejo krajša besedila ter razvijajo svojo jezikovno (poimenovalno, skladenjsko, pravorečno, pravopisno), slogovno in metajezikouno zmo:̌nostu (UN 2018: 6). Razvijanje branja in pisanja pa ni prepuščeno le predmetu slovenščina, ampak se tovrstna zmožnost naj in mora razvijati pri vseh predmetih (Krek 2016). Razvijanje bralne pismenosti je del izvedbe različnih predmetov, pri čemer učenci posamezne gradnike bralne pismenosti izkazujejo na osnovi ustrezno zastavljenih dejavnosti, s katerimi se dosegajo operativni in vsebinski cilji posamezne učne enote.

Gradnik bralne pismenosti odživ na besedilo in tvorjenje besedil se izkazuje skozi tvorjenje ustreznih in smiselnih govorjenih in pisnih besedil o prebranem, uporabo prebranega $\mathrm{v}$ novih situacijah in razvijanje veščine pisanja ustreznih besedil. Novi učni načrt za slovenščino (UN 2018) za 1. VIO z operativnimi cilji in vsebinami slednje predpostavlja tako za področje jezikovnega kot književnega pouka. Učenci in učenke se na besedila različnih vrst (npr. pripovedovalna, razlagalna, utemeljevalna, opisovalna) odzovejo z zmožnostjo določanja okoliščin nastanka besedila (sporočevalca, naslovnika, kraj, čas) in sporočevalčevega namena ter poročajo o besedilu, predstavijo njegove sestavne dele in njihovo vlogo ter poiščejo določene podatke, so zmožni pripovedovanja, povzemanja bistvenih podatkov in obnove besedila, vrednotijo zanimivost, verodostojnost, razumljivost in uporabnost besedila, poskušajo utemeljiti svoje mnenje, vrednotiti svojo zmožnost branja in na podlagi povratnih informacij načrtovati, kako bi jo izboljšali. $\mathrm{Na}$ področju književnosti izražajo in primerjajo svoje doživetje, čustva, predstave in misli, ki se jim vzbudijo pri poslušanju/branju, ob ponovnem branju/poslušanju zaznavajo 
sprva prezrte/preslišane sestavine ter izražajo mnenje o besedilu (predvsem govorno, tretješolci lahko tudi pisno). Učenci so ob koncu prvega triletja zmožni razlikovanja pomensko podobnih besed in pojasnjevanja pomena manj običajnih besed $\mathrm{v}$ pesmi. Učenci in učenke prav tako prepoznavajo za pravljico značilne književne osebe, čudeže in pravljično dogajanje, nedoločenost kraja in časa dogajanja ter ločujejo pravljico in pripoved.

Razvoj bralne pismenosti in izkazovanje obravnavanega gradnika se v 1. VIO razvija tudi skozi neslovenistične predmete, pri čemer načrtovanje dejavnosti za posamezni učni predmet najpogosteje vključuje učenje skozi poslušanje, izvajanje, branje in pisanje. Učni načrti za obvezne in izbirne osnovnošolske predmete tako predvidevajo, da so učenci zmožni branja znanih in neznanih besedil različnih vrst, uporabe bralnih strategij različnega tipa (npr. tabelarično spremljanje, večkratno branje istega besedila, branje po poslušanju, izmenično branje, branje $\mathrm{z}$ razumevanjem ob slikah, predstavah učencev), prepoznavanje sporočilnosti in odnosov ter na osnovi predstavljenega uporabe ustreznih pripomočkov za konkretno uporabo spoznanj v praksi. Poglavitne metode poučevanja v tem obdobju vključujejo didaktično igro, opazovanje in izkustveno učenje. $Z$ vpeljavo tovrstnih učnih praks je učencem in učenkam omogočeno zbiranje, urejanje in predstavitev podatkov na primerih iz vsakdanjega življenja. Poudarek 1. VIO je predvsem na razvoju poslušanja in govora, šele nato branja in pisanja. Skozi aktivnosti, ki učencu in učenki ponujajo veliko jezika (z opisovanjem, s pojasnjevanjem, z razlaganjem, branjem in s pripovedovanjem), učenci in učenke bolj učinkovito razvijajo zmožnosti vrednotenja, interpretiranja, povezovanja in organiziranja znanj. Slednje predstavlja temeljno osnovo za razvijanje kasnejših in bolj kompleksnih spretnosti ter znanj.

\subsection{Odziv na besedilo in tvorjenje besedil v 2 . VIO}

Tudi v 2. VIO se gradnik bralne pismenosti odziv na besedilo in tvorjenje besedil izkazuje skozi tvorjenje ustreznih in smiselnih govorjenih in pisnih besedil o prebranem, uporabo prebranega $\mathrm{v}$ novih situacijah in razvijanje veščine pisanja ustreznih besedil, in sicer tako pri književnem kakor tudi pri jezikovnem pouku. Tako pri Razvijanju zmožnosti dvosmernega sporazumevanja učenci in učenke tvorijo dialoško besedilo (pogovor oz. dopis) določene vrste, pri čemer se pred tvorjenjem dialoškega besedila pogovarjajo o strategijah in načelih ustreznega pogovarjanja oz. dopisovanja, po tvorjenju dialoškega besedila pa vrednotijo svoje in druge pogovore oz. dopise ter 
utemeliijo svoje mnenje in predlagajo izboljšave. Ob tem vrednotijo svojo zmožnost pogovarjanja oz. dopisovanja in na podlagi povratnih informacij načrtujejo, kako bi jo izboljšali (UN 2018: 20). Učenci in učenke pred tvorjenjem besedila razmišljajo o okoliščinah sporočanja in o značilnostih dane besedilne vrste, med tvorjenjem pa izberejo okoliščinam in besedilni vrsti ustrezne jezikovne prvine (UN 2018: 23).

Vrste besedil, ki jih učni načrt predvideva za tvorjenje, tj. za govorno nastopanje in pisanje, v 2. VIO, so:

- 4. razred: opis osebe, opis živali, opis poklica, opis življenja vrstnikov ali drugih oseb;

- 5. razred: obnova besedila, opis rastline, opis predmeta, definicija pojma;

- 6. razred: ocena besedila, opis kraja, opis naravnega pojava, navodilo za delo, opis igre, športa ali ljudskega običaja;

- pripoved o tem, kar so doživeli, videli ali slišali (za celotno 2. VIO).

Odzivu na prebrano je posebna pozornost pri obravnavi umetnostnih besedil namenjena pri govornem nastopanju. Tako velja pri obravnavi umetnostnih besedil izpostaviti, da pri govornem nastopanju učenci in učenke razvijajo zmožnost doživljanja, razumevanja in vrednotenja umetnostnih besedil tako, da se »strokovno« in/ali (po)ustvarjalno govorno odzivajo na umetnostna besedila (podčrtala S. P.). V vsakem razredu pripravijo en govorni nastop - izbirajo med ponujenimi možnostmi, se odločijo za povezavo z domačim branjem ali temo izberejo samostojno (UN 2018: 31).

V okviru Didaktičnih priporočil avtorji in avtorice učnega načrta izpostavljajo nekaj didaktičnih priporočil, ki so ključni za udejanjanje in razvijanje obravnavanega gradnika. Tako poudarjajo, da naj učenci in učenke razvijajo svojo zmožnost dvosmernega sporazumevanja (tij. pogovarjanja in dopisovanja) tako, da poslušajo (in gledajo) posnete ali odigrane pogovore oz. berejo dopise, ki jih nato razčlenjujejo, poročajo o njih in jih vrednotijo ter na koncu sami tvorijo dialoško besedilo dane vrste. Pred poslušanjem (in gledanjem) pogovora oz. pred branjem dopisa in pred tvorjenjem dialoškega besedila naj se pogovarjajo o svojih izkušnjah s pogovarjanjem oz. $z$ dopisovanjem in $z$ dano vrsto pogovora oz. dopisa pa tudi o tem, na kaj bodo pozorni med opazovanjem in med tvorjenjem pogovora oz. dopisa. Tako najprej obnovijo ali pridobijo, nato pa utrjujejo in dopolnjujejo svoje znanje o načelih 
ustreznega pogovarjanja oz. dopisovanja in o značilni zgradbi pogovora oz. dopisa dane vrste.

Učitelj oz. učiteljica naj pri razvijanju zmožnosti pogovarjanja ter tudi v vsakdanjih pogovorih $z$ učenci in učenkami upošteva načelo, da so odzivne replike večinoma skladenjsko nepopolne, tj. da vsebujejo samo novo informacijo, ne pa tudi že znane (zato je na vprašanje Kako ti je ime? ustreznejši odgovor Luka., ne pa Ime mi je Luka.). To načelo, ki ga učenci in učenke sicer instinktivno obvladajo, se namreč včasih ne ujema z »dolgimi odgovori«, ki jih zahteva zgodnje učenje tujih jezikov.

Učenci in učenke naj razvijajo svojo zmožnost enosmernega sporazumevanja tako, da poslušajo (in gledajo) oz. berejo monološka besedila raznih vrst, jih nato razčlenjujejo, povzemajo, primerjajo in vrednotijo ter na koncu tudi govorno nastopajo oz. pišejo raznovrstna monološka besedila. Poslušanje (z gledanjem) in branje naj bosta čim bolj enakovredno zastopana, prav tako govorno nastopanje in pisanje, vse to pa so raznovrstne oblike odziva na besedilo, in sicer tako pri slovenščini kakor tudi pri vseh drugih predmetih.

Zanimivo metodo dela zagotovo predstavlja tudi t. i. motivacijski in strateški pogovor. Metodo je zlasti smiselno vključiti pred poslušanjem oz. branjem monološkega besedila, s pomočjo te pa učenci in učenke lahko npr. pripovedujejo o svojih izkušnjah s poslušanjem oz. branjem, se odzovejo na napovedano temo, predstavijo svoje znanje o njej in izrazijo svoja pričakovanja do napovedanega besedila, kar je vsekakor prenosljivo tudi na druga predmetna področja. V strateškem pogovoru pa naj učenci in učenke povedo, kako se bodo pripravili na poslušanje oz. branje, kaj bodo delali med njim in kaj po njem (povezava s poglavjem 2). Pomembno je tudi, da se učenci in učenke pred govornim nastopanjem oz. pred pisanjem monološkega besedila pogovarjajo o tem, kako se bodo pripravili na govorni nastop oz. na pisanje, na kaj bodo pazili med njim in kaj bodo delali po njem - tako najprej pridobijo, nato pa utrjujejo in dopolnjujejo svoje znanje o strategijah govornega nastopanja oz. pisanja monoloških besedil in o načelih učinkovitega govornega nastopanja oz. pisanja.

Učenci in učenke naj po poslušanju oz. branju monološkega besedila izdelajo povzetek, pred govornim nastopom oz. pisanjem pa načrt. Povzetek in načrt naj bosta v strukturirani obliki (npr. v obliki miselnega vzorca, pojmovne mreže, preglednice, opornih točk). To svojo zmožnost naj razvijajo postopoma in 
individualizirano - na začetku naj jih pri tem vodi učitelj oz. učiteljica s sistematičnim frontalnim ponazarjanjem procesa izdelave miselnega vzorca, preglednice ipd.

Učenci in učenke naj svojo kritično sporazumevalno zmožnost razvijajo predvsem procesno, in sicer na razne načine, $\mathrm{z}$ raznimi dejavnostmi in $\mathrm{z}$ raznimi poudarki. Pomembno dejanje tega procesa je tudi učenčevo oz. učenkino vrednotenje zmožnosti in besedil in to ne le drugih besedil, temveč tudi lastnih, torej tudi svoje zmožnosti pogovarjanja, dopisovanja, poslušanja, branja, govornega nastopanja in pisanja ter svoje jezikovne in slogovne zmožnosti. K temu vrednotenju spada tudi odkrivanje lastnih napak ali pomanjkljivosti; temu pa morajo slediti predlaganje izboljšav, odpravljanje napak in tudi razmišljanje, zakaj delamo napake, $v$ katerih okoliščinah bi bilo to, kar zaznamujemo kot napačno, lahko tudi pravilno, v katerih okoliščinah nam je vseeno, ali so v besedilu napake ali ne, v katerih okoliščinah mora biti besedilo knjižno oz. čim bolj pravilno, kdaj popravljena beseda ali poved ni napačna, temveč je le manj ustrezna, ali je laže pisati knjižno pravilno (po normativnem dogovoru) ali brez vsakih pravil ipd. (UN 2018: 66-67). Vsekakor so to pomembni elementi obravnavanega gradnika, ki spodbujajo kritično odzivanje na besedilo oz. prebrano.

Pri tem je treba uzavestiti, da učenci in učenke (pa tudi učitelj oz. učiteljica) svojih in tujih napak in neustreznosti ne iščejo, odkrivajo, odpravljajo, vrednotijo, razlagajo ... zato, da bi se zavedali svojih pomanjkljivosti, svojega neznanja, svoje nemoči temveč zato, da bi izboljšali svojo sporazumevalno zmožnost. Pri tem je še kako pomembna vloga učitelja, učiteljice, ki naj učence in učenke spodbuja $\mathrm{k}$ iskanju odgovorov na pravopisna, oblikovna, tvorbna in druga vprašanja v raznih jezikovnih priročnikih (v knjižni in elektronski obliki) in jezikovnih svetovalnicah.

Učenci in učenke naj v 2. in 3. VIO ob primerih spoznavajo, da:

- so besedilne vrste, ki se jih učijo pri pouku, predvsem orientacija za čim bolj ustrezno tvorjenje besedil v vsakdanjem življenju;

- moramo biti v določenih okoliščinah pri tvorjenju bolj pozorni na značilnosti določene besedilne vrste, $\mathrm{v}$ drugih okoliščinah pa to ni potrebno; 
- se z elektronsko komunikacijo iz dneva $\mathrm{v}$ dan spreminjajo tudi nekatere značilnosti besedilnih vrst in da se moramo temu sproti prilagajati (UN 2018: 69).

Zapisano $\mathrm{v}$ učnem načrtu za predmet slovenščina izkazuje dosledno ujemanje razvijanja obravnavanega gradnika v 2. VIO, in sicer da učenec, učenka izkaže doseganje gradnika tako, da pove ali napiše povzetek prebranega, jezikovno ustrezno tvori govorna in pisna besedila različnih vrst, razlaga prebrano in razpravlja o prebranem, vrednoti besedilo in oblikuje odnos do njega, svoje stališče utemelji z dokazi, na podlagi prebranega tvori nova besedila različnih vrst, utemeljuje svoje odgovore oz. svoj odziv na prebrano, svoja besedila oblikuje rokopisno in $\mathrm{v}$ elektronski obliki, prav tako pa so skozi analizo nakazane možnosti prenosa na druga predmetna področja. Razvijanje odziva na prebrano in tvorjenje besedil torej ne more biti prepuščeno zgolj predmetu slovenščina, ampak se tovrstna dejavnost naj in mora razvijati pri vseh predmetih.

\subsection{Odziv na besedilo in tvorjenje besedil v 3 . VIO}

Tudi v 3. VIO se gradnik bralne pismenosti odziv na besedilo in tvorjenje besedil izkazuje skozi tvorjenje ustreznih in smiselnih govorjenih in pisnih besedil o prebranem, uporabo prebranega $\mathrm{v}$ novih situacijah in razvijanje veščine pisanja ustreznih besedil, in sicer tako pri književnem kakor tudi pri jezikovnem pouku. Tako pri Razvijanju żmožnosti dvosmernega sporazumevanja učenci in učenke tvorijo dialoško besedilo (pogovor oz. dopis) določene vrste po konceptu, predstavljenem v 2. VIO. Vrste besedil, ki jih učni načrt predvideva za tvorjenje, tj. za govorno nastopanje in pisanje, v 3. VIO, so:

- 7. razred: opis življenja osebe, opis države, definicija pojma, opis življenja ljudi v dani državi ali skupnosti;

- 8. razred: opis naprave, opis postopka, razlaga naravnega pojava, oglasno besedilo;

- 9. razred: opis in oznaka osebe, življenjepis, ocena besedila, opis poti;

- za celotno VIO pa še: pripoved o svojih doživetjih, obnova neumetnostnega ali umetnostnega besedila, predstavitev svojih poklicnih načrtov, poročilo o zanimivem ali aktualnem dogodku, predstavitev svojega doživljanja aktualnega dogodka in svojega mnenja o njem. 
Podobno kot v 2. VIO tudi v 3. VIO snovalci učnega načrta odzivu na prebrano namenjajo posebno pozornost $\mathrm{v}$ sklopu govornega nastopanja. Tako učenci in učenke razvijajo zmožnost doživljanja, razumevanja in vrednotenja umetnostnih besedil tudi tako, da se strokovno in (po)ustvarjalno odzivajo na umetnostna besedila (podčrtala S. P.) (UN 2018: 45). Slednje je upoštevano tudi v Standardih żnanja, kjer učenec, učenka svojo recepcijsko zmožnost pokaže tako, da najde bistvene prvine umetnostnega besedila in jih zna ustrezno uporabiti pri interpretativnih in (po)ustvarjalnih odzivih na to besedilo (7., 8., 9. razred) (UN 2018: 60). Pri književnem pouku učenci in učenke razvijajo recepcijsko zmožnost $z$ branjem ali poslušanjem umetnostnih besedil in $z$ govorjenjem/pisanjem o njih. V procesu šolske interpretacije opazujejo posamezne prvine besedila in si tako ustvarjajo odziv na celotno besedilo (UN 2018: 70).

Avtorji in avtorice učnega načrta izpostavljajo tudi nekaj didaktičnih priporočil, ki so ključni za udejanjanje in razvijanje obravnavanega gradnika, so pa isti kot za 2. VIO in so predstavljeni v poglavju 3.3.

V 3. VIO učenke in učenci razvijajo svojo sporazumevalno zmožnost tako, da poslušajo (in gledajo) oz. berejo dialoška in monološka besedila, ki jih nato razčlenjujejo, povzemajo, primerjajo, doživljajo in vrednotijo, ob tem pa svoje mnenje tudi utemeljijo. Pri tem spoznavajo, da njihove dejavnosti pred poslušanjem oz. branjem, med njim in po njem pomembno vplivajo na njihovo razumevanje in vrednotenje besedila, ob tem pa usvajajo temeljne strategije poslušanja oz. branja ter prepoznavajo zgradbene in jezikovne značilnosti tistih vrst besedil, ki jih bodo tudi tvorili.

Učenci in učenke se pogovarjajo, govorno nastopajo, pišejo dopise in monološka besedila. Pri tem se navajajo na to, da se je na tvorjenje besedila treba pripraviti in da je treba upoštevati naslovnika in druge okoliščine. Nujno je poznavanje teme, o kateri se sporoča, upoštevati pa je treba tudi poimenovalne možnosti in zakonitosti jezika, v katerem se sporoča, prezreti se ne more zgradbenih in jezikovnih značilnosti dane besedilne vrste. Predstavljene kriterije je nujno upoštevati pri tvorjenju različnih besedil tudi pri drugih predmetih (npr. govorni nastop, predstavitev znamenite osebe, potopis, reportažo pri zgodovini, zemljepisu, fiziki matematiki, glasbi ipd.). Pri tem učenci in učenke kritično opazujejo svoje sporazumevanje in sporazumevanje drugih, ga vrednotijo in utemeliijo svoje mnenje; če je potrebno, predlagajo izboljšave in utemeljijo svoje predloge. Z vsemi 
predstavljenimi dejavnostmi dejavno in problemsko razvijajo temeljne gradnike sporazumevalne zmožnosti, tj. jezikovno (poimenovalno, skladenjsko, pravorečno, pravopisno), slogovno in metajezikovno zmožnost, ter se zavedajo njihove vloge pri izboljšanju svojega sporazumevanja.

Pri tem je treba poudariti, da razvijanje sporazumevalne zmožnosti poteka $\mathrm{v}$ vseh treh vzgojno-izobraževalnih obdobjih, le da je prilagojeno starosti, spoznavni, sporazumevalni, spoznavni in domišljijski zmožnosti učencev in učenk ter njihovim sporazumevalnim izkušnjam, potrebam ipd.

Zapisano $\mathrm{v}$ učnem načrtu za predmet slovenščina izkazuje dosledno ujemanje razvijanja obravnavanega gradnika $v 3$. VIO, in sicer učenec, učenka izkaže doseganje gradnika tako, da sodeluje $v$ pogovoru o prebranem besedilu in utemeljuje svoja stališča z dokazi iz besedila, govorno in pisno ter jezikovno ustrezno glede na sobesedilo tvori besedila različnih vrst, besedilo razloži, razčleni, povzame, vrednoti ... s pomočjo različnih strategij, besedilo ali njegove dele zna pretvoriti v nebesedno sporočilo (npr. grafični prikaz, pojmovna mreža, primerjalna matrika, Vennov diagram), utemeljuje svoje odgovore oz. svoj odziv na prebrano ter svoja besedila oblikuje rokopisno in v elektronski obliki.

\subsection{Odziv na besedilo in tvorjenje besedil v srednješolskem izobraževanju}

Tudi v gimnazijskem učnem načrtu (kot je moč zasledovati v osnovnošolskem učnem načrtu) se gradnik bralne pismenosti odzৃiv na besedilo in tvorjenje besedil izkazuje skozi tvorjenje ustreznih in smiselnih govorjenih in pisnih besedil o prebranem, uporabo prebranega $\mathrm{v}$ novih situacijah in razvijanje veščine pisanja ustreznih besedil, in sicer tako pri književnem kakor tudi pri jezikovnem pouku.

Med splošnimi cilji v učnem načrtu za slovenščino v gimnazijah (UN 2008: 6-7) velja izpostaviti zlasti tri cilje, povezane $z$ gradnikom, obravnavanem v poglavju. To so:

- Dijaki in dijakinje besedila poslušajo in berejo razmišljujoče in kritično, razčlenjujejo in vrednotijo jih $\mathrm{z}$ različnih vidikov ter prepoznavajo morebitno manipulativnost. Umeščanje prebranih/poslušanih besedil $\mathrm{v}$ časovni in kulturni kontekst spodbuja razvijanje in poglabljanje kulturne in medkulturne zmožnosti. 
- Dijaki in dijakinje tvorijo učinkovita, razumljiva, ustrezna ter jezikovno pravilna ustna in pisna besedila. Razumevanje in vrednotenje procesov sprejemanja in tvorjenja besedil spodbuja učenje učenja. Razvijanje sporazumevalne zmožnosti se povezuje z uporabo IKT; tako se razvija posameznikova digitalna zmožnost.

- Dijaki/dijakinje razvijajo zmožnost literarnega branja kot specifično podvrsto sporazumevalne zmožnosti. Usposabljajo se za branje in interpretacijo literarnih besedil: doživljajo, razumevajo, aktualizirajo in s pomočjo svojih izkušenj, književnega znanja in splošne razgledanosti vrednotijo ter poimenujejo idejno-tematske in slogovno-kompozicijske plasti literarnih besedil iz domače in prevodne sodobne, novejše in starejše književnosti.

Po razčlenjenih vsebinah in ciljih so v UN strnjeno prikazani dosežki oz. rezultati, med katerimi so za obravnavani gradnik pomembne naslednje razvite zmožnosti: dijak/dijakinja ima razvito zmožnost (uradnega) pogovarjanja, razvito zmožnost (uradnega) dopisovanja, tvorjenja enogovornih besedil.

Posamezno zmožnost pokaže tako, da $\mathrm{v}$ vlogi pobudnega in odzivnega sogovorca/dopisovalca tvori učinkovite, ustrezne, smiselne, razumljive in pravilne replike/dopise ustreznih vrst; razčlenjuje tuje pogovore/dopise (in sicer okoliščinsko, naklonsko, pomensko, besedno-skladenjsko in tvarno) ter jih vrednoti; svoje mnenje utemelji s strokovnimi argumenti. Pri tvorjenju enogovornih besedil pridobljeno zmožnost dokaže tako, da piše besedila ali govorno nastopa - tvori učinkovita, ustrezna, razumljiva in pravilna besedila; vrednoti svoje besedilo, svoje mnenje pa utemelji s strokovnimi argumenti; poroča o svoji strategiji tvorjenja besedila, primerja jo $s$ t. i. fazami sporočanja ter predstavi svoje napake/pomanjkljivosti in razloge zanje.

Vsebine in cilji gimnazijskega učnega načrta predstavljajo nadgradnjo ter poglobitev ciljev in vsebin osnovnošolskega učnega načrta.

Predstavljeno v učnem načrtu za predmet slovenščina izkazuje dosledno ujemanje razvijanja obravnavanega gradnika $\mathrm{v}$ učnem načrtu za gimnazije, in sicer dijak, dijakinja izkaže doseganje gradnika tako, da sodeluje v pogovoru o prebranem besedilu in utemeljuje svoja stališča z dokazi iz besedila in konteksta; besedilo razloži, 
razčleni, povzame s pomočjo različnih strategij; tvori smiselna, slogovno dodelana in jezikovno pravilna besedila različnih vrst; tvorjena besedila poveže s svojim predstavnostnim svetom, učenjem in prihodnjim poklicem; besedilo prilagodi glede na okoliščine nastanka in naslovnika; pri tvorjenju upošteva značilnosti vrste besedila; razume in pravilno uporablja sklice, opombe, vire ... kot del besedila; svoja besedila oblikuje rokopisno in $\mathrm{v}$ elektronski obliki ter pri tvorjenju besedil izbira učinkovite strategije in pojasni rabo strategij.

\section{$4 \quad$ Sklep}

V poglavju so predstavljeni elementi gradnika odziv na besedilo in tvorjenje besedil glede na posamezna razvojna oz. vzgojno-izobraževalna obdobja, pri čemer so upoštevani temeljni elementi gradnika, tj. tvorjenje ustreznih in smiselnih govorjenih in pisnih besedil o prebranem, uporaba prebranega $\mathrm{v}$ novih situacijah in razvijanje veščine pisanja ustreznih besedil. Cilji Kurikuluma za vrtce (1999) s področja jezika omogočajo otrokom obeh starostnih obdobij odzivanje na besedilo in tvorjenje novih besedil. Temeljne aktivnosti poslušanja, pripovedovanja in igre razvijajo otrokovo zmožnost, rabe jezika v povezavi z mišljenjem, samostojnega pripovedovanja, domišljijske rabe jezika in ustvarjalnega izražanja. $Z$ načrtnim razvijanjem predbralnih in predpisalnih sposobnosti in spretnosti otrok pridobiva temelje za kasnejše tvorjenje bolj kompleksnih odzivov in uporabo prebranega v novih situacijah. Analiza je pokazala, da sta vloga in pomen odziva na besedilo ter tvorjenje besedila eksplicitno izpostavljena in kontinuirano zastopana $\mathrm{v}$ vseh vzgojno-izobraževalnih obdobjih osnovnošolskega učnega načrta za predmet slovenščina in $\mathrm{v}$ gimnazijskem učnem načrtu, hkrati pa so skozi analizo nakazane možnosti prenosa na druga predmetna področja. Zapisano $\mathrm{v}$ učnih načrtih za predmet slovenščina izkazuje dosledno ujemanje razvijanja obravnavanega gradnika, vendar pa je treba pri vzgojiteljih in vzgojiteljicah ter učiteljih in učiteljicah uzavestiti dejstvo, da razvijanje odziva na prebrano in tvorjenje besedil ne more in ne sme biti prepuščeno zgolj predmetu slovenščina, ampak se tovrstna dejavnost naj in mora razvijati pri vseh predmetih.

\section{Opomba}

Avtorica Simona Pulko je prispevek napisala v okviru projekta OBJEM - Bralna pismenost in razvoj slovenščine (Ozaveščanje, Branje, Jezik, Evalvacija, Modeli), šifra projekta OP20.01462, vodja dr. Sandra Mršnik, ki ga vodi Zavod RS za šolstvo: Naložbo sofinancirata Republika Slovenija in Evropska unija iz Evropskega socialnega sklada. 


\section{Literatura}

Diane M. BARONE, Marla H. MALLETTE in Shelley H. XU, 2005: Teaching early literacy: Development, assessment, and instruction. New York in London: The Guilford Press.

Bralna pismenost v Sloveniji in Evropi. https://www.zrss.si/bralnapismenost/files/ZBORNIK_BRALNA_PISMENOST_2011.pdf

Ana GRADIŠAR, 2000: Bralno razumevanje. Zbornik Bralnega društva Slovenije. Bralna sposobnost ima neomejene možnosti ražoja. Ljubljana: Zavod Republike Slovenije za šolstvo.

Ana GRADIŠAR, 2003: Pogovor ob učbeniškem besedilu: metoda preverjanja razumevanja in motivacija za učenje. Pogovor o prebranem besedilu: zbornik Bralnega društva Slovenije. Ur. M. Ivšek. Ljubljana: Zavod Republike Slovenije za šolstvo.

Marija GRGINIČ, 2005: Pomen porajajoče se pismenosti za začetno opismenjevanje. Sodobna pedagogika 56 (posebna izdaja). 68-79.

Meta GROSMAN, 2006: Razsę̌nosti branja: za boljš bralno pismenost. Ljubljana: Karantanija.

Livija KNAFLIČ, 2009: Branje za znanje in branje za zabavo: Priročnik za spodbujanje druð̌inske pismenosti [elektronski vir]. Ljubljana: Andragoški center Slovenije. http://arhiv.acs.si/publikacije/Branje_za_znaje_in_branje_za_zabavo-prirocnik.pdf

Metka KORDIGEL in Igor SAKSIDA, 2001: Ją,pa berem. Priročnik za učitelje. Ljubljana: Rokus.

Ivanka KOREZ, 2001: Funkcionalno branje - branje za učenje. Zbornik bralnega društva Slovenije, Rąlične vrste branja terjajo razvijanje različnih bralnih strategij. 4. strokovno posvetovanje Bralnega drustva Slovenije. Ljubljana: Zavod Republike Slovenije za šolstvo.

Janez KREK, 2016: Predgovor. Bralna pismenost kot izæiv in odgovornost. Ur. Tatjana Devjak in Igor Saksida. Ljubljana: Pedagoška fakulteta. 5-6.

Kurikulum za vrtce, 1999. Ljubljana: Ministrstvo za šolstvo in šport, Urad RS za šolstvo.

Ljubica MARJANOVIČ UMEK, 2010: Pojmovanje otroka v sociokulturni teoriji Vigotskega. Lev S. Vigotski: Mišljenje in govor. Ljubljana: Pedagoška fakulteta Univerze v Ljubljani. 373-400.

Ljubica MARJANOVIČ UMEK, Gregor SOČAN in Katja BAJC, 2007: Vpliv psiholoških dejavnikov in izobrazbe staršev na učno uspešnost mladostnikov. Psibološka obzorja 16(3). 27-48.

Ljubica MARJANOVIČ UMEK in Maja ZUPANČIČ, 2006: Psihologija otroške igre: od rojstva do ustopa v solo. Ljubljana: Znanstvenoraziskovalni inštitut Filozofske fakultete.

Ljubica MARJANOVIČ UMEK in Matija SVETINA, 2004: Spoznavni in govorni razvoj v srednjem in poznem otroštvu. Ražvojna psihologija. Ur. Ljubica Marjanovič Umek, Maja Zupančič. Ljubljana: Znanstvenoraziskovalni inštitut Filozofske fakultete. 408-428.

Ljubica MARJANOVIČ UMEK in Urška FEKONJA, 2004a: Govorni razvoj dojenčka in malčka. Ražojna psibologija. Ur. Ljubica Marjanovič Umek, Maja Zupančič. Ljubljana: Znanstvenoraziskovalni inštitut Filozofske fakultete. 215-232.

Ljubica MARJANOVIČ UMEK in Urška FEKONJA, 2004b: Razvoj govora v zgodnjem otroštvu. Ražvojna psibologija. Ur. Ljubica Marjanovič Umek, Maja Zupančič. Ljubljana: Znanstvenoraziskovalni inštitut Filozofske fakultete. 315-334.

Ljubica MARJANOVIČ UMEK, Urška FEKONJA PEKLAJ, Petra LEŠNIK MUSEK in Simona KRANJC, 2002: Otroška literatura kot kontekst za govorni razvoj predšolskega otroka. Psibološka obrorja 11(1). 51-64.

Ljubica MARJANOVIČ UMEK, Urška FEKONJA PEKLAJ in Sonja PEČJAK, 2012: Govor in branje otrok: ocenjevanje in spodbujanje. Ljubljana: Znanstvena založba Filozofske fakultete.

Margaret J. SNOWLING in Charles HULME, 2005: Learning to read with a language impairment. The science of reading: a handbook. Ur. Margaret J. Snowling, Charles Hulme. Oxford, UK: Blackwell.

Sonja PEČJAK in Ana GRADIŠAR, 2015: Bralne učne strategije. Ljubljana: Zavod Republike za šolstvo.

Sonja PEČJAK, 1995: Izhodišča za prenovo bralnega pouka pri predmetu slovenski jezik. Jęik in slovstvo 41(1-2). 75-88.

Sonja PEČJAK in Nataša POTOČNIK, 2011: Razvoj zgodnje pismenosti ter individualizacija in diferenciacija dela v prvem razredu osnovne šole. Bralna pismenost v Sloveniji in Evropi. Ur. Fani Nolimal. Ljubljana: Zavod RS za šolstvo in šport. 61-80. 
Sonja PEČJAK, Svjetlana KOLIĆ-VEHOVEC, Barbara RONČEVIĆ in Neža AJDIŠEK, 2009: (Meta)kognitivni i motivacijski prediktori razumijevanja teksta adolescenata u Hrvatskoj i Sloveniji. Suvremena psibologija 12. 257 270.

Ǔ̌ni načrt. Program osnovna šola. Slovenščina, 2018. Ljubljana. Ministrstvo za šolstvo in šport: Zavod Republike Slovenije za šolstvo.

Judith VANDER WOUDE, Anne VAN KLEECK in Elizabeth VANDER VEEN, 2009: Book sharing and the development of meaning. Emergent literacy and early language acquisition: Making the connection. Ur. Paula M. Rhyner. New York: Guilford Press. 


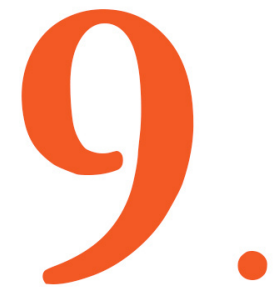

G R A D N I K

KRITIČNO BRANJE

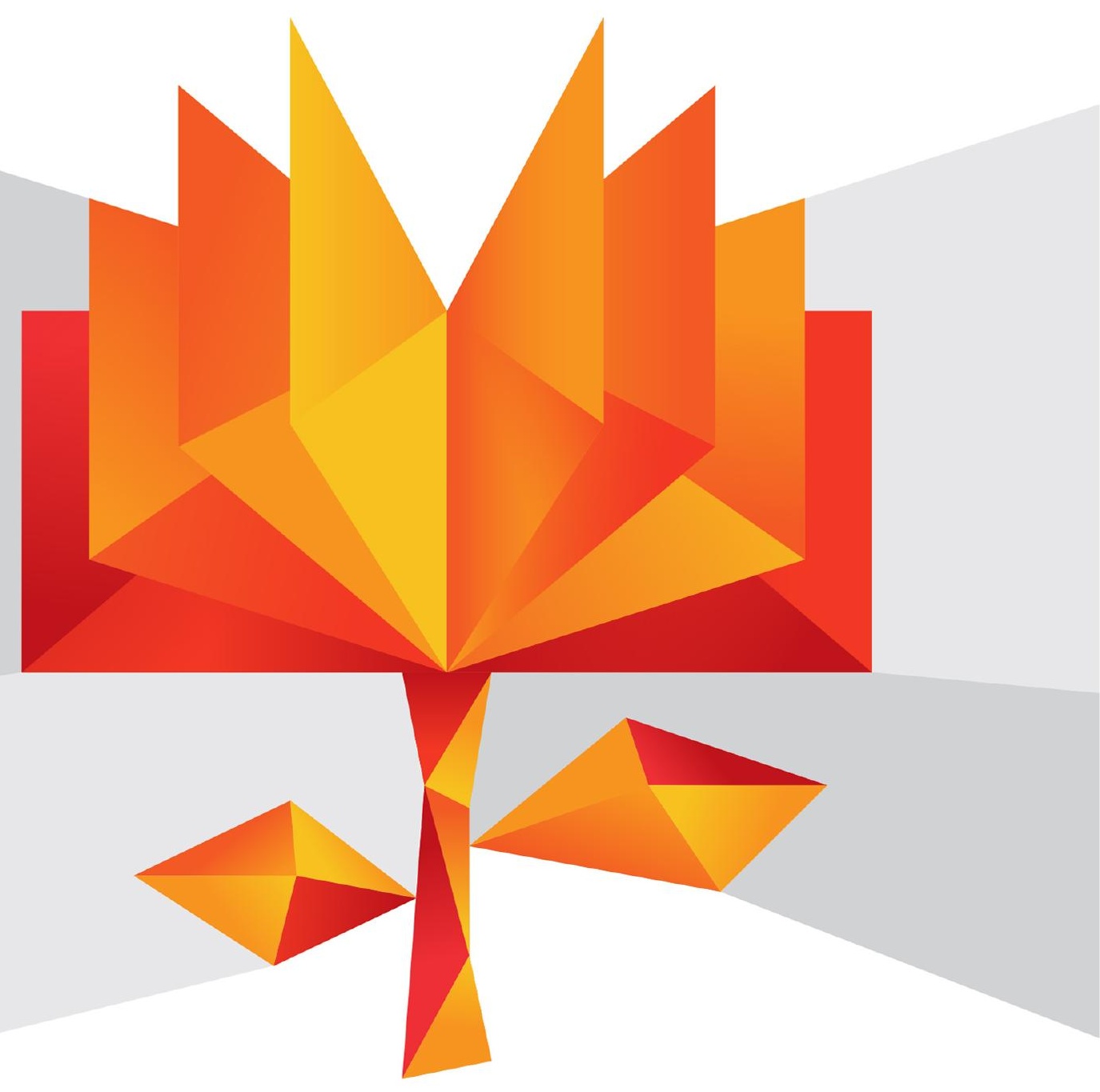




\section{Elementi gradnika:}

- prepoznavanje, presojanje, vrednotenje sporočilnosti, dejstev in stališč $v$ besedilu, avtorjevega načina pisanja

- oblikovanje lastnega mnenja $z$ utemeljevanjem

- presojanje glede na dane kriterije

- postavljanje kriterijev za kritično vrednotenje besedil 


\title{
9. GRADNIK: KRITIČNO BRANJE
}

\section{KRITIČNO BRANJE - RAZVIJAJOČA SE VEŠČINA BRALNE PISMENOSTI V VRTCU, OSNOVNI IN SREDNJI ŠOLI}

\author{
MARTA LICARDO ${ }^{1}$ IN MIRA KRAJNC IVIČ $\check{~}^{2}$ \\ ${ }^{1}$ Univerza v Mariboru, Pedagoška fakulteta, Maribor, Slovenija. \\ E-pošta: marta.licardo@um.si \\ 2 Univerza v Mariboru, Filozofska fakulteta, Maribor, Slovenija. \\ E-pošta: mira.krajnc@um.si
}

Povzetek V poglavju je predstavljeno kritično branje kot eden od gradnikov bralne pismenosti, ki smo ga predstavili za predšolsko obdobje, za 1., 2. in 3. VIO osnovne šole ter za srednjo šolo. Kritično branje razumemo kot veščino uporabe različnih strategij za odkrivanje informacij in idej $\mathrm{v}$ besedilu, kamor sodita vrednotenje in vzpostavljanje kritičnega odnosa do prebranega skozi kritično razmišljanje. Analiza ciljev učnih načrtov za slovenski jezik po celotni vertikali je pokazala, da se cilji, povezani s kritičnim branjem, pojavljajo $\mathrm{v}$ različnih sklopih, vendar je eksplicitna raba termina kritično branje zelo redka. Operativnih ciljev, ki vključujejo ta gradnik, je malo. Ugotavljamo, da bi v učnem načrtu za slovenščino v osnovni šoli bilo smiselno dati več poudarka na cilje, vezane na razvoj kritičnega branja in kritičnega razmišljanja v 1., 2. in 3. VIO, ter da bi večji poudarek na kritičnem branju moral biti razviden tudi pri standardih znanja. Poglavje je pomembno, saj omogoča pregled ciljev, povezanih s kritičnim branjem na področju slovenskega jezika za vsako posamezno vzgojno-izobraževalno obdobje.

Ključne besede:
gradniki bralne
pismenosti,
kritično
branje,
kritično
razmišljanje,
bralna
pismenost,
učni
načrti.




\title{
THE NINTH COMPONENT OF
}

READING LITERACY:

CRITICAL READING

\section{Critical READING - THE \\ EVOLVING SKILL OF THE READING \\ LITERACY IN KINDERGARTENS, ELEMENTARY AND UPPER SECONDARY SCHOOLS}

\author{
MARTA LICARDO $^{1} \&$ MIRA KRAJNC IVIČ ${ }^{2}$ \\ ${ }^{1}$ University of Maribor, Faculty of Education, Maribor, Slovenija. \\ E-mail: marta.licardo@um.si \\ 2 University of Maribor, Faculty of Arts, Maribor, Slovenija. \\ E-mail: mira.krajnc@um.si
}

Keywords: components of reading literacy, critical reading, critical thinking, reading literacy, curricula.

\begin{abstract}
This chapter presents critical reading, as one of the components of reading literacy, through early childhood education, first, second and third educational period in elementary school and in upper secondary school. Critical reading is understood as a skill for implementing various strategies to reveal information and ideas in the text, which includes evaluation and critical approach to the text by critical thinking. Analysis of goals in curricula for Slovenian language by the entire vertical indicates that goals related to critical thinking are written in different chapters in the curricula, however, explicit use of the term critical reading is very scarce. Concrete learning goals which includes this component are also rare. Conclusions are that the curricula for Slovenian language in elementary school should be more focused on goals related to development of critical reading and critical thinking in the first, second and third educational period of elementary education and more focus should be on critical reading in the educational standards. The chapter is important because it includes analysis of learning goals related to critical reading for Slovenian language for each educational period separately.
\end{abstract}

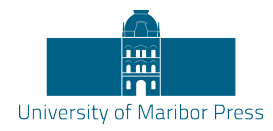




\section{$1 \quad$ Uvod}

Deveti gradnik bralne pismenosti je kritično branje, ki v delovnem gradivu projekta OBJEM (Gradniki bralne pismenosti 2018) zajema prepoznavanje, presojanje, vrednotenje sporočilnosti, dejstev in stališč v katerem koli besedilu. To pomeni, da lahko bralec (otrok, učenec, dijak) razvija zmožnost zgoraj navedenih veščin prek različnih kriterijev, ki si jih zastavi sam ali pa so postavljeni s strani učitelja. Primer takega kriterija je lahko kritično presojanje avtorjevega načina pisanja, raba besedišča, analiza retoričnih figur, analiza slovnice in skladnje, analiza povezav med besedilom in družbenimi problemi ipd. Nadalje je $\mathrm{v}$ gradnik vključeno oblikovanje lastnega mnenja z utemeljevanjem, presojanje glede na dane kriterije, postavljanje kriterijev za kritično vrednotenje besedil ter kritična uporaba virov. Vse to je zlasti pomembno pri t. i. mehkih znanostih (družboslovje in humanistika). Hkrati pa to predstavlja tudi osnovne elemente gradnika, ki jih $\mathrm{v}$ nadaljevanju opredelimo po posameznih stopnjah izobraževanja. Za osnovno analizo po stopnjah izobraževanja smo izbrali področje slovenskega jezika, kjer naj bi bilo že zaradi narave samega predmeta v ospredju kritično branje, ki je nujno za razvoj kritičnega mišljenja tudi na drugih področjih posameznikovega udejstvovanja.

\section{Definicija kritičnega branja}

Da bi učenec zmogel razvijati kritično branje, je potrebno, da zmore kritično razmišljati. $\mathrm{V}$ nadaljevanju bomo opredelili razliko med enim in drugim pojmom, oba sta sicer v samem gradniku kritično branje združena.

Kritično branje $\mathrm{v}$ najširšem smislu zajema različne strategije za odkrivanje informacij in idej $\mathrm{v}$ nekem besedilu. Ne gre zgolj za razumevanje besedila, temveč za vrednotenje in vzpostavljanje kritičnega odnosa do prebranega. Kritično branje pomeni aktivno, razmišljujoče, analitično branje. Kritično branje lahko predpostavlja uporabo strategij, s katerimi bralec vrednoti, kako avtor besedila pristopa $\mathrm{k}$ obravnavi teme in katere prikrite pomene morebiti sporoča. Kritično razmišljanje predpostavlja kognitivno procesiranje strategij za vrednotenje oziroma presojanje idej v besedilu. Pogosto kritično mišljenje oziroma razmišljanje vsebuje element sprejemanja informacije, torej ali bralec informacijo sprejme kot pomembno, relevantno in resnično. Prav tako gre za vprašanje veljavnosti, o kateri bralec presoja na podlagi lastnega predznanja, izkušenj in razumevanja sveta (Kurland 1994; 
Manarin, Carey, Rathburn in Ryland 2016: 4-8; Pečjak in Gradišar 2012). Pri tem je pomembno poudariti, da tovrstna opredelitev kritičnega branja predpostavlja, da kritično branje omogoča prepoznavanje logičnih in dejanskih napak v besedilu (Luke 2012: 6), ni pa nujno, da je to vedno namen kritičnega branja. Namen kritičnega branja torej ni vedno enoznačen. ${ }^{1}$

Da bi učenec zmogel kritično razmišljati, mora znati kritično brati. V nekaterih primerih je kritično branje pred kritičnim razmišljanjem, npr. ko učenec $\mathrm{v}$ polni meri razume besedilo (ga kritično prebere, pozna kriterije/strategije za kritično branje), lahko $\mathrm{v}$ polni meri presoja o sporočilu (o njem kritično razmišlja), $\mathrm{v}$ nekaterih primerih pa oba procesa potekata simultano. $V$ teh primerih nam kritično razmišljanje omogoča, da sproti, med branjem, razvijamo kritično razumevanje prebranega (Fisher 2011; Kompare in Rupnik Vec 2016). Na primer, če preberemo kaj smešnega ali na videz nesmiselnega, bomo morda nadaljevanje besedila brali bolj pozorno in sproti preverjali naše razumevanje.

Primeri uporabe kritičnega branja $\mathrm{v}$ šoli naj bi vključevali sistematično voden bralni dogodek, pri katerem učenci odkrivajo prezrte ali nejasne sestavine besedila ter jih pojasnjujejo, se na prebrano kritično odzivajo s svojim osebnim mnenjem, ki ga znajo utemeljiti. To je preskok iz »naivnega« branja v razmišljujoče branje, kjer učitelj izpostavi tiste elemente besedila, ki predstavljajo priložnost za razmislek, kritično presojo in izražanje stališč (Saksida 2014: 30).

$\mathrm{S}$ kritičnim branjem učenec odkriva mnogotere pomene $\mathrm{v}$ besedilu, morebitno pristranskost avtorja, povezuje brano s predhodnim znanjem, presoja in vrednoti besedilo po različnih kriterijih ipd. Ob tem ne smemo zanemariti dejstva, da tudi šolska bralna gradiva lahko vključujejo družbeno, zgodovinsko ali politično

\footnotetext{
1 K. Manarin in sodelavci (2016) ločijo kritično branje za izobraževalni namen in kritično branje z družbeno angažiranim namenom. Pri kritičnem branju za izobraževalni namen naj bi učenec ločil vzorce v prvinah besedila, razlikoval med glavnim in podrejenim sporočilom (idejo) besedila, ovrednotil veljavnost besedila, presodil, kako je besedilo smiselno vključeno $\mathrm{v}$ konkretni komunikacijski dogodek, in izpeljal sklepe, ki temeljijo na prebranem. Branje z družbeno angažiranim namenom pa razen zgoraj omenjenih kompetenc od učenca zahteva še povezovanje med prebranim in osebno izkušnjo, na višji ravni pa povezovanje med prebranim in družbenimi problemi, na katere se lahko opozarja in vpliva prek pisanja, branja in interpretiranja besedil. Pri tem pripominjamo dvoje: 1) da se smiselno vključevanje besedila $\mathrm{v}$ konkretni komunikacijski dogodek nanaša le na osnovno prepoznavanje prvin nejezikovnega konteksta, kot so kraj in čas nastanka besedila, družbeno razmerje med udeleženci, in 2) da je družbeno angažirano kritično branje veščina, ki jo učenec pridobiva na ravni poznega srednješolskega oziroma visokošolskega izobraževanja.
} 
pristranska besedila, ki služijo določenim interesom aktualne družbene ureditve (Luke 2012: 6).

Razlikovanje med kritičnim branjem in kritičnim razmišljanjem je pomembno predvsem zaradi pristopov $\mathrm{k}$ branju različnih besedil. Vsako besedilo ima svoje lastnosti in učence je treba naučiti, da se pri branju opazujejo, da so pozorni zlasti na to, kaj in kako razmišljajo ter kako berejo. Oziroma natančneje, kako kognitivno procesirajo besedilo. Zlasti besedila, ki implicitno izražajo vrednote, stališča, ideje naj bi brali objektivno in $z$ razumevanjem (prepoznavanjem in povezovanjem idej). Presojanje besedila je šele druga faza branja, sicer lahko na učenčevo razumevanje prehitro vplivajo predznanja, stereotipi, predsodki ipd. Bralec ima tako možnosti, da se nauči česa novega; v nasprotnem je lahko interpretiranje prebranih informacij prehitro podrejeno že ustaljenim predstavam in predznanju (Kurland 1995).

Motiv in nameni, ki vplivajo na naslovnika, da se odloči prebrati neko besedilo, so različni. Eden od namenov branja je lahko prepoznavanje in razumevanje različnih informacij ali idej. Večkrat pa beremo besedila iz drugih razlogov, npr. da rešimo svoj problem, ustvarimo kaj novega, izvedemo projekt ipd. V teh primerih je kritično razmišljanje ključnega pomena, saj prebrano (ali slišano) vedno vede ali nevede integriramo v predhodne kognitivne sheme (predznanje) (Nuyts 1992: 47-48) in se odločamo, ali je prebrano relevantno za trenutne potrebe. Presojanje glede na lastne izkušnje je pestrost in vrednota sama po sebi, saj kritično branje tako razvija tudi čuječnost in sočutje. Z vstopom v komunikacijski dogodek, npr. branje časopisne novice, objave na družabnem omrežju, e-sporočila, voznega reda, romana, črtice, šale v dnevnem časopisu, naslovnik pristane na »vesolje verjetij« tvorca (Žagar 2009: 72-75), torej tvorcu zaupa, da so informacije v besedilu resnične. Za informacije, za katere ve, da niso resnične, sklene s tvorcem dogovor oziroma bralec pristane na to, da so nekatere informacije v besedilu predstavljene, kot da so resnične, npr. volk, ki govori (Eco 1999). Dejstvo je, da bralec časopisne novice ali voznega reda v prvi vrsti tvorcu prebranega besedila zaupa, da so v besedilu navedeni podatki resnični. Torej se vsako branje ali poslušanje giblje na osi resnica - zaupanje. Ko umanjka resnice, se poveča zaupanje in obratno. Kritično branje je ozaveščanje tega procesa. Zlasti za neumetnostna besedila, ki imajo uporabno vrednost, ima navedeno posebno težo, saj pridobljene informacije uporabljamo za vrednotenje realnih 
problemov, ${ }^{2}$ npr. ali je bolezen COVID-19 resnična ali lažna novica. Pridobljene informacije namreč sprejmemo za zanesljive in veljavne in tako vplivajo tudi na posameznikovo védenje, vedênje in odločanje. Naloga kritičnega branja je presojanje resničnostne vrednosti informacije in ne ugotavljanje, kako se informacije skladajo s posameznikovimi prepričanji in verjetji. Le tako lahko posameznik besedilo vrednoti kot kompetenten, avtonomen individuum. Presojanje glede na lastne izkušnje je pestrost in vrednota sama po sebi. Subjektivnost je s tem poudarjena. Kar je dobro. H kritičnosti sodi tudi razvijanje sočutja.

Iz perspektive liberalnega humanizma je kritično branje eno izmed orodij za uspeh posameznika $v$ družbi, gre za temeljno veščino in nujen pogoj za aktivno sodelovanje $\mathrm{v}$ demokratični družbi. Kritično branje ima tudi potencial, da spreminja mišljenja in posledično tudi dejanja posameznika, s tem da predstavlja orodje za odkrivanje zmot, indoktrinacij, načinov vodenja, razkrivanje neenakosti, nepravičnosti v družbi ipd. (Manarin, Carey, Rathburn in Ryland 2016: 8, 9).

S tega vidika je kritično branje tudi del kritične sporazumevalne jezikovne zmožnosti. Ta zmožnost poudarja učenčevo občutljivost tudi za širši kontekst, večjo čustveno občutljivost (čuječnost) in potrebo po preseganju stereotipov, predsodkov, lastnih vzorcev komuniciranja in večjo etično in nasploh družbeno odgovornost (Vogel 2014: 108).

\section{Gradnik kritično branje po vzgojno-izobraževalnih obdobjih}

V poglavju bomo predstavili osnovne kompetence za kritično branje po posameznih vzgojno-izobraževalnih obdobjih (VIO); analizirali bomo primere ciljev iz Kurikuluma za vrtce (1999) - področje jezik, učnega načrta za slovenščino v osnovni šoli (UN 2018) in učnega načrta za slovenščino za splošno, klasično in strokovno gimnazijo (UN 2008) ter navedli nekaj praktičnih možnosti, kako spodbujati in poučevati kritično branje. Primeri ciljev so samo s področja slovenskega jezika, saj bi analiza ciljev iz drugih učnih načrtov presegla obseg tega prispevka, vendar so posamezni analizirani cilji prenosljivi na druga predmetna področja. Analizirali smo tiste cilje učnih načrtov, ki nakazujejo na kritično branje. Pri tem nismo vključevali

\footnotetext{
2 Vrednotenje branega besedila poteka skladno z vrednotami, npr. življenje, svoboda, družina, zdravje, ljubezen. Vrednote so lahko univerzalne, transkulturne, transsituacijske, kulturne, osebne, praviloma so hierarhično razporejene. Posameznik razvija lastne vrednote skozi osebnostni razvoj. Kritično branje lahko predstavlja orodje za razvoj vrednot.
} 
ciljev, ki se nanašajo na branje z razumevanjem, saj razumemo, da je branje z razumevanje ločen gradnik od gradnika kritično branje (Gradniki bralne pismenosti 2018). Pri analizi ciljev smo izpisali tiste, ki so vsebovali glagole in njihove tvorjenke, ki smiselno sodijo v gradnik kritično branje za posamezno VIO.

\subsection{Predšolska vzgoja}

Otrok kritično branje razvija postopoma od predšolskega obdobja dalje, kjer se v prvem starostnem obdobju (od 1. do 3. leta) uči prepoznavati temeljna sporočila preprostih zgodb ali informacij. Pri zgodbah so to lahko sporočila o tem, kaj je naredil osrednji lik $\mathrm{v}$ zgodbi, osnovno razlikovanje med dobrim in slabim ${ }^{3}$ ter preprost potek zgodbe. Otrok pri branju opazuje verbalne in neverbalne odzive odraslega, ki kažejo na kritično vrednotenje besedila in te odzive posnema. Učenje s posnemanjem je $\mathrm{v}$ obdobju do treh let eden osnovnih procesov učenja, zato je pomembno, kako odrasli zgodbo bere in se odziva na prebrano. Pri prepoznavanju sporočil, vezanih na informativne slikanice ali druga informativna multimodalna gradiva (videoposnetki, piktogrami, napisi $\mathrm{v}$ okolici ipd.), otrok prav tako prepoznava temeljna sporočila oziroma usvaja osnovne kognitivne koncepte (Boehm 2001). V tem obdobju gre predvsem za prepoznavanje smisla in pomena. V drugem starostnem obdobju predšolske vzgoje (od 3. do 6. leta) pa že lahko govorimo o prepoznavanju oziroma razlikovanju med realnim in domišljijskim besedilom, prepoznavanju in vrednotenju akterjev $\mathrm{v}$ zgodbah, prepoznavanju in razumevanju temeljnih sporočil, izražanju svojega mnenja o besedilu ipd., kar so tudi osnovne veščine za razvijajoče se kritično branje oziroma razvijajoče se predbralne veščine, ki jih $\mathrm{v}$ tem kontekstu uvrščamo $\mathrm{v}$ deveti gradnik bralne pismenosti (Gradniki bralne pismenosti 2018).

Skladno s tem lahko v Kurikulumu za vrtce (1999) zasledimo, da so jezikovne dejavnosti povezane z vsemi jezikovnimi ravninami: s fonološko, morfološko, skladenjsko, pomensko in pragmatično. Razvoj jezika in s tem tudi kritičnega branja pa je naravno vpleten $v$ vsa področja dejavnosti. Od tretjega leta naprej je zlasti pomemben razvoj predbralnih sposobnosti. Med globalnimi cilji za področje jezika je v Kurikulumu za vrtce (1999) naveden cilj razvijanje jezika z vidika moralno-etične dimenzije. Ta poudarja pomen kritičnega branja. Na področju družba pa zasledimo

\footnotetext{
${ }^{3}$ Dobro razumemo kot posameznikovo družbeno sprejemljivo in zaželeno ravnanje/mišljenje, slabo pa kot družbeno nesprejemljivo, nedopustno ravnanje/mišljenje.
} 
globalni cilj spodbujanje občutjivosti za etično dimenzijo različnosti. To sta edina zapisana globalna cilja, ki ju lahko povežemo z gradnikom kritično branje. Med primeri dejavnosti za prvo starostno in drugo starostno obdobje v Kurikulumu za vrtce (1999) za področje jezika ne zasledimo primera, ki bi se neposredno nanašal na razvoj kritičnega branja, kar lahko označimo kot možnost za izboljšavo zapisov, lahko pa takšne primere najdemo v drugih virih (IELG 2015; Haramija idr. 2017; Nottingham in Nottingham 2019; Licardo, Hmelak, Vršnik Perše in Košir 2017).

Smernice za delo pri razvijanju predbralnih veščin, ki vključujejo prvine kritičnega branja in kritičnega razmišljanja, so: 1) vzgojitelj izbira bralna gradiva, ki so otroku pomembna in ki vsebujejo ilustracije ali druge vizualne simbole; 2) pri branju otroka sprašuje, kaj se je zgodilo v zgodbi, zakaj se je kaj zgodilo, kaj bi se lahko zgodilo v nadaljevanju; 3) otroka spodbuja, da o prebranem postavlja vprašanja, tudi o vzrokih in posledicah. Tako razvija logično mišljenje in s tem spodbuja razvoj kritičnega mišljenja (Haramija idr. 2017; Notthingham in Nottingham 2019). Otroka spodbudi še, da uporablja znanje iz svojih preteklih izkušenj in ga nadgradi z novim znanjem (IELG 2015). Pri nadgradnji znanja naj otrok presoja o resničnostni vrednosti informacij, o njihovi relevantnosti in veljavi. To so veščine kritičnega razmišljanja, ki se neposredno povezujejo s kritičnim branjem. Kritično razmišljanje vključuje tudi iskanje drugih možnosti, predvidevanje morebitnih posledic, skupinjenje informacij, presojanje ipd.

Ker kritično branje pogosto zajema presojanje glede na lastne izkušnje in predhodno znanje, je dobro, da otroka spodbujamo, da se pri reševanju problemov odziva jezikovno. Teme, ki so zlasti pomembne za razvoj kritičnega branja, so teme o identiteti, individualnosti, o različnih vlogah otrok in odraslih, teme o odnosih do ljudi, pojavov in procesov v družbi, to je to: ohranjanje edinstvenosti posameznika ob razviti empatiji ali sočutju, do vsega živega in neživega. Pri branju gradiv smo pozorni na stereotipe, ${ }^{4}$ predsodke, ki so vezani na spolne, posledično socialne vloge, etično pripadnost in druge družbene probleme oziroma pogoste teme kritičnega branja. Prek bralnih gradiv pri otroku spodbujamo tudi razvoj vrednot, ki se dotikajo za ta namen primernih tem, kot so različnost in enakost, upoštevanje individualnosti drugih, spoštovanje lastnine, skupinska odgovornost, pravila $\mathrm{v}$ različnih socialnih situacijah ipd. Otroka spodbujamo, da razvija notranji dialog, da razvija občutek

\footnotetext{
${ }^{4}$ Stereotip je sestavni del obdelovanja vsake pridobljene informacije.
} 
odgovornosti do sebe in drugih (Licardo, Hmelak, Vršnik Perše in Košir 2017), kar oboje predstavlja osnovo za razvoj kritičnega razmišljanja in kritičnega branja, na ta način pa hkrati razvijamo tudi moralno-etično področje. Zgoraj navedene teme so ključne za kritično branje besedil v vseh VIO.

\subsection{Osnovna šola}

$\mathrm{V}$ osnovnošolskem izobraževanju se $\mathrm{v}$ 1. VIO kritično branje razvija a) $\mathrm{s}$ spodbujanjem in sistematičnim poučevanjem o razlikah med domišljijskim in nedomišljijskim besedilom, b) z iskanjem vodilnega sporočila ter razbiranjem podatkov, s katerimi lahko prepoznano sporočilo utemelji (Gradniki bralne pismenosti 2018). V tem obdobju naj bi učenec znal že podati lastno mnenje o prebranem skladno $z$ različnimi merili. Npr. prepoznavanje in vrednotenje sporočila in povezav z lastnimi izkušnjami in čustvi, vrednotenje $\mathrm{v}$ smislu etičnosti ali drugega preprostejšega dihotomnega razlikovanja, npr. varno/nevarno, prav/narobe, škodljivo/koristno v različnih kontekstih, kot so promet, zdrava prehrana, požarna varnost. Pomembna veščna je izpeljevanje preprostih sklepov na podlagi poznavanja različnih podatkov, ki jih učenec prebere ali prepozna v besedilu. Primer pri leposlovju je lahko, da smiselno nadaljuje zgodbo, sklepa o razlogih za dejanja osrednjih likov ali zmore napovedati, kaj se bo zgodilo. Primer pri neumetnostnih besedilih je lahko izpeljevanje sklepov na podlagi podatkov, ko se uči o posameznih pojavih ali procesih (npr. zakaj ne smemo požara, ki je nastal zaradi elektrike, gasiti $\mathrm{z}$ vodo ali kaj nastane, če pomešamo modro in rumeno barvo).

V učnem načrtu za slovenski jezik (UN 2018) pri zapisu splošnih ciljev lahko razberemo, da ti vsebujejo prvine kritičnega branja, saj je pri drugem splošnem cilju, ki se nanaša na razvijanje zmožnosti sprejemanja, razumevanja, doživljanja, vrednotenja in tvorjenja besedil $v$ slovenskem jeziku, na več mestih pojasnjeno, da se to nanaša na razmišljujoče in kritično sprejemanje raznovrstnih besedil ter na vrednotenje in utemeljevanje lastnega mnenja, prepoznavanje prvin, ki usmerjajo $\mathrm{k}$ prepoznavanju ter sprejemanju vodilne ideje besedila in oblikovanju kritičnih stališč do le-teh. Zanimivo je tudi, da se v tem učnem načrtu (UN 2018) med splošnimi cilji omenja metajezikovna zmožnost, ki predstavlja znanje o vlogah jezika. Vloga jezika je lahko eden od kriterijev kritičnega branja, kjer učenci analizirajo jezikovne prvine na vseh jezikovnih ravneh - raba leksike, novotvorjenke, retorične figure, skladenjske in oblikoslovne značilnosti besedila. Jezikovne prvine lahko služijo 
(manipulativnim, ideološkim) namenom, zato tovrstne analize nekateri avtorji uvrščajo na področje kritičnega jezikoslovja.

Za razliko od splošnih ciljev med operativnimi cilji učnega načrta za slovenščino za 1. VIO v sklopu Razvijanje zmožnosti branja in pisanja zasledimo le bežno omenjene cilje, ki se povezujejo s kritičnim branjem, in sicer: učenci vrednotijo zanimivost, verodostojnost in uporabnost besedila ter utemeljujejo svoje mnenje; ne zasledimo pa nobenega cilja, ki bi eksplicitno omenjal kritično branje. Ugotavljamo, da bi v učnem načrtu za slovenščino (UN 2018) bilo smiselno dati več poudarka na ciljih, vezanih na razvoj kritičnega branja in kritičnega razmišljanja $\mathrm{v} 1$. VIO.

$\mathrm{V}$ 2. VIO se kritično branje po gradniku bralne pismenosti povezuje s cilji in vsebinami pri vseh predmetih. Izkaže se tako, da učenec vodilno idejo vrednoti skladno s svojimi izkušnjami in čustvi, vrednoti besedilo tako, da zmore iz podatkov $\mathrm{v}$ besedilu razbrati verjetno ključno idejo, ${ }^{5}$ misel ali sporočilo ter da zmore iz besedila izpeljati različne sklepe (ZRSŠ 2017). ${ }^{6}$ Besedila v 2 . VIO so zahtevnejša od besedil iz 1. VIO glede na obseg, vsebino, abstraktnost, poglobljenost in jezikovno zahtevnost, predvidene veščine kritičnega branja pa so podobne.

Pri analizi operativnih ciljev učnega načrta za slovenščino (UN 2018) za 2. VIO smo ugotovili, da se elementi kritičnega branja odražajo skozi cilje na področju a) jezika in b) književnosti.

a) Področje jezika:

- učenci in učenke vrednotijo verodostojnost, razumljivost in uporabnost besedila ter utemeljujejo svoje mnenje ( $v$ sklopu razvijanje zmožnosti enosmernega sporazumevanja);

- učenci vrednotijo svojo zmožnost kritičnega poslušanja oziroma branja ( $\mathrm{v}$ sklopu razvijanje zmožnosti enosmernega sporazumevanja);

- spoznavajo merila za vrednotenje besedil ( $v$ sklopu metajezikovna zmožnost).

\footnotetext{
${ }^{5}$ Naloga bralca je, da se skuša približati tvorčevemu svetu. Tvorec pa besedilo oblikuje na način, da ima pred seboj idealnega aktivnega, razmišljajočega bralca.

${ }^{6}$ Navedeni so le tisti deli cilja, ki so neposredno vezani na kritično branje.
} 
b) Področje književnosti:

- učenci in učenke razvijajo recepcijsko zmožnost, tj. zmožnost doživljanja, razumevanja in vrednotenja umetnostnih besedil ( $\mathrm{v}$ sklopu razvijanje recepcijske zmožnosti z branjem/poslušanjem/gledanjem);

- izrekajo svoje mnenje o umetnostnem besedilu in ga utemeljijo $s$ sklicevanjem nanj ( $v$ sklopu razvijanje recepcijske zmožnosti $z$ branjem/poslušanjem/gledanjem);

- oblikujejo svoje stališče do ravnanja književnih oseb in ga utemeljijo (v sklopu razvijanje recepcijske zmožnosti z branjem/poslušanjem/gledanjem).

Od prek 200 operativnih ciljev, ki so navedeni za 2. VIO, je le 6 ciljev povezanih z razvojem kritičnega branja. To pomeni, da je le 3-odstotni delež ciljev namenjen temu gradniku (UN 2018). Kritično branje v tem delu učnega načrta je eksplicitno omenjeno le enkrat. Ugotavljamo, da bi v učnem načrtu za slovenščino bilo smiselno dati več poudarka na ciljih, vezanih na razvoj kritičnega branja in kritičnega razmišljanja v 2. VIO, kar bi se spremenilo že, če bi se cilji za področje književnosti uporabljali tudi pri vrednotenju neumetnostnih besedil.

V 3. VIO se pri poučevanju kritičnega branja preide na višje taksonomske ravni. Učenec kritično branje glede na gradnik izkaže tako, da analizira in argumentirano vrednoti vsebino besedila, razlikuje med dejstvi in stališči, oblikuje lastno mnenje, ki ga zmore podpreti $z$ argumenti in informacijami iz besedila, kritično presoja različne dele besedila in se jih uči vrednotiti (to so lahko vizualni elementi, uvod, jedro, sklep, dialogi ipd.). Razume pojem kriterij za presojo besedila, ki je lahko podan s strani učitelja ali si ga učenec postavi sam in na podlagi kriterija besedilo oziroma več besedil tudi presoja, jih med sabo primerja. Na podlagi podatkov iz besedila samostojno oblikuje domneve, lastne sklepe, predvidevanja. Zna uporabljati različne vire tako, da jih uporablja namensko, samostojno, kritično in odgovorno (Gradniki bralne pismenosti, 2018).

Pri analizi operativnih ciljev učnega načrta za slovenščino (UN 2018) za 3. VIO smo ugotovili, da se elementi kritičnega branja neposredno odražajo skozi cilje na področju a) jezika in b) književnosti: 
a) Področje jezika:

- učenci in učenke vrednotijo zanimivost, verodostojnost, razumljivost in uporabnost besedila ter utemeljujejo svoje mnenje (sklop razvijanje zmožnosti enosmernega sporazumevanja);

- $\quad \mathrm{v}$ besedilu prepoznajo dejstva in izraze, s katerimi sporočevalec razodeva svoje doživljanje in vrednotenje predmetnosti; razmišljajo o tem, s katerim namenom je sporočevalec uporabil čustvene in vrednotenjske izraze, ter vrednotijo to njegovo odločitev (sklop razvijanje zmožnosti enosmernega sporazumevanja);

- berejo kompleksna avtentična besedila /.../ ter razmišljajo o tem, čemu se je avtor odločil za posebnosti in kako le-te učinkujejo na poslušalca (in gledalca) oziroma bralca (sklop razvijanje zmožnosti enosmernega sporazumevanja);

- vrednotijo svojo zmožnost kritičnega poslušanja oziroma branja /.../ (sklop razvijanje zmožnosti enosmernega sporazumevanja);

- vrednotijo učinek pridobljenega procesnega in vsebinskega znanja na svojo zmožnost kritičnega poslušanja oziroma branja besedil (sklop razvijanje zmožnosti enosmernega sporazumevanja).

b) Področje književnosti:

- učenci in učenke razvijajo recepcijsko zmožnost, tj. zmožnost doživljanja, razumevanja in vrednotenja umetnostnih besedil (sklop razvijanje recepcijske zmožnosti z branjem /.../ v umetnostnih besedilih);

- besedila med seboj primerjajo in vrednotijo, svoje mnenje utemeljijo in se sklicujejo na besedila (sklop razvijanje recepcijske zmožnosti z branjem /.../ v umetnostnih besedilih);

- prepoznajo književno osebo, ki jim je blizu (po značaju, ravnanju, načinu razmišljanja, iz zunajliterarnih razlogov); do te osebe so tudi kritični (sklop razvijanje recepcijske zmožnosti z branjem /.../ v umetnostnih besedilih);

- vživijo se v književno osebo, ki je drugačna od njih, in so do nje kritični (sklop razvijanje recepcijske zmožnosti z branjem /.../ v umetnostnih besedilih); 
- opazujejo razvijanje teme $\mathrm{v}$ besedilu, npr. na dogajalni ravni (ali so predstavljeni vsi bistveni dogodki ali pa jih je treba ugotoviti/predvideti/»brati« med vrsticami), na jezikovni ravni (ali za neposredno/direktno izražanje ali za posredno/metaforično), na ravni časovne ureditve dogajanja (ali so dogodki razvrščeni kronološko ali retrospektivno), na ravni slogovnih postopkov (pripovedno, opisovalno, dialoško razvijanje teme); ${ }^{7}$ primerjajo in presojajo tematsko sorodna besedila glede na razvijanje teme (sklop razvijanje recepcijske zmožnosti z branjem /.../ v umetnostnih besedilih);

- prepoznavajo in navajajo motive za ravnanje književnih oseb (socialne, psihološke, etične) (sklop razvijanje recepcijske zmožnosti z branjem / .../ $\mathrm{v}$ umetnostnih besedilih).

Iz izpisanih ciljev je razvidno, da se isti cilj nanaša na dva gradnika bralne pismenosti: razumevanje besedila in kritično branje. Npr. cilj opazujejo raqvijanje teme v besedilu /... / se sam po sebi nanaša na gradnik razumevanje besedil, dela tega cilja, npr. »branje« med vrsticami in metaforično izražanje, pa lahko razumevanje presegata, kar je odvisno od vplivanjske funkcije besedila, konteksta idr. Npr. naslov novice Krvavi pokol v Parizu je ekspresiven in pritegne pozornost, a hkrati sporoča, da je v Parizu življenje na surov in krvav način izgubilo veliko ljudi; s temi ljudmi se je tik pred smrtjo ravnalo kot z živalmi. Za polno razumevanje besedil je torej potrebno tudi kritično branje, zato je gradnika razumevanje besedil in kritično branje težko ločiti. To se kaže tudi v vseh tistih ciljih, ki posredno razvijajo učenčeve kompetence kritičnega branja in ki jih tu ne navajamo. Izpisali smo 12 ciljev od več kot 240 operativnih ciljev za 3. VIO. Izpisani cilji se še najbolj skladajo z definicijo kritičnega branja po gradniku kritično branje (Gradniki bralne pismenosti, 2018). Njihov delež predstavlja približno $5 \%$ vseh ciljev. Iz analize izhaja, da bi tudi za 3 . VIO v učnem načrtu za slovenščino bilo smiselno dati več poudarka ciljem, vezanim na razvoj kritičnega branja in kritičnega razmišljanja.

$\mathrm{V}$ primerjavi s 1. in 2. VIO je v 3. VIO največ ciljev neposredno povezanih s kritičnim branjem. To je pričakovano, saj so učenci starejši in so njihove kognitivne sposobnosti višje. Vendarle pa bi opozorili, da se termin kritično branje pojavi $\mathrm{v}$ zapisu ciljev za 3. VIO le dvakrat in dvakrat se pojavi termin, da so učenci kritični

\footnotetext{
${ }^{7}$ Pri navajanju ciljev so opazne tudi strokovne nedoslednosti, npr. govorjeno ali pisano besedilo se razvija skladno z vsaj enim prevladujočim tematskim razvojem ali slogovnim postopkom, dialoškost pa ni slogovni postopek.
} 
do književne osebe (kar ni nujno identično kritičnemu branju v smislu diskurzne analize, temveč lahko gre samo za razumevanje vsebine oziroma vloge notranjih udeležencev besedila, saj bralno razumevanje in kritično branje nista identična procesa).

Tudi pri pregledu standardov znanja za vsa tri VIO smo ugotovili, da se kritično branje pojavlja zelo redko, predvsem $\mathrm{v}$ temeljnih standardih znanja, izraženih $\mathrm{s}$ termini, ki posredno nakazujejo na kritično vrednotenje, branje besedila.

\subsection{Srednja šola}

V srednješolskem izobraževanju je razvoj kritičnega branja odvisen od zahtevnosti srednješolskega izobraževalnega programa. Temeljne veščine, ki naj bi jih izkazoval dijak glede na gradnik kritično branje, so, da zmore povezovati različne informacije iz različnih besedil med sabo ter jih kritično vrednotiti. Svoje mnenje in sklepe utemeljuje ter ponazarja. Uporablja dano merilo ali oblikuje svojega ter skladno z njim vrednoti besedilo ali informacije. $\mathrm{V}$ besedilu $\mathrm{z}$ vidika relevantnosti in sprejemljivosti vrednoti kakovost trditev, oblikuje predvidevanja, hipoteze in prepoznava argumente za hipoteze. Pri argumentiranju prepoznava napake v argumentaciji ter zmore to znanje uporabiti pri lastni argumentaciji, torej argumentira smiselno, logično in utemeljeno ter se izogiba napakam. Kadar rešuje nove probleme zmore uporabljati informacije na kritičen način, presoja, ali so informacije relevantne ter ali podpirajo reševanje problema. Pomembno pa je tudi, da zna kritično uporabljati in presojati tradicionalne in nove bralno-pisne tehnologije in vire, npr. blogi, videodnevniki, spletni portali, aplikacije (Gradniki bralne pismenosti, 2018).

Pri analizi učnega načrta za slovenščino za splošne, klasične in strokovne gimnazije (UN 2008) smo ugotovili, da se elementi kritičnega branja neposredno odražajo skozi naslednje splošne cilje/kompetence:

- učenci in učenke besedila poslušajo in berejo razmišljujoče in kritično, razčlenjujejo in vrednotijo jih $\mathrm{z}$ različnih vidikov ter prepoznavajo morebitno manipulativnost /.../; 
- svoja in tuja besedila sistematično opazujejo in razčlenjujejo $\mathrm{z}$ različnih vidikov ter utrjujejo in nadgrajujejo svojo jezikovno, slogovno in metajezikovno zmožnost /.../;

- usposabljajo se za branje in interpretacijo literarnih besedil: doživljajo, razumevajo, aktualizirajo in s pomočjo svojih izkušenj, književnega znanja in splošne razgledanosti vrednotijo ter poimenujejo idejno-tematske in slogovno-kompozicijske plasti literarnih besedil /.../.

Med operativnimi cilji v učnem načrtu za gimnazije (UN 2008) smo izbrali naslednje cilje, ki se najbolj skladajo z vsebino gradnika bralne pismenosti kritično branje (Gradniki bralne pismenosti 2018) na področju a) jezikovnega in b) književnega pouka.

a) Področje jezikovnega pouka:

- dijaki in dijakinje uzaveščajo večplastnost/raznovrstnost slovenščine in jezikov nasploh (sklop oblikovanje in razvijanje zavesti o jeziku, narodu, državi);

- presojajo učinek pridobljenega vsebinskega in procesnega znanja na svojo zmožnost kritičnega branja in pisanja dopisov ter izdelajo načrt za izboljšanje teh svojih zmožnosti (sklop razvijanje zmožnosti (uradnega) dopisovanja);

- sodelujejo v vodenem pogovoru o strategijah poslušanja oziroma branja enogovornih neumetnostnih besedil (sklop razvijanje zmožnosti kritičnega sprejemanja enogovornih neumetnostnih besedil);

- sodelujejo $\mathrm{v}$ vodenem pogovoru o načelih učinkovitega poslušanja oziroma branja enogovornih neumetnostnih besedil (sklop razvijanje zmožnosti kritičnega sprejemanja enogovornih neumetnostnih besedil);

- razčlenjujejo besedilo (npr. okoliščinsko, naklonsko, pomensko, besedno, povedno, tvarno) (sklop razvijanje zmožnosti kritičnega sprejemanja enogovornih neumetnostnih besedil);

- vrednotijo učinkovitost, ustreznost, razumljivost in pravilnost besedil (sklop razvijanje zmožnosti kritičnega sprejemanja enogovornih neumetnostnih besedil); 
- vrednotijo svojo zmožnost kritičnega sprejemanja enogovornih besedil in izdelajo načrt za izboljšanje te svoje zmožnosti (sklop razvijanje zmožnosti kritičnega sprejemanja enogovornih neumetnostnih besedil);

- vrednotijo razumljivost, zanimivost, resničnost, aktualnost, živost, učinkovitost, ustreznost in jezikovno pravilnost svojega zapisanega besedila/govornega nastopa in zapisanih besedil/govornih nastopov sošolcev ter utemeljujejo svoje mnenje (sklop razvijanje zmožnosti tvorjenja enogovornih neumetnostnih besedil);

- presojajo učinek pridobljenega vsebinskega in procesnega znanja na svojo zmožnost kritičnega sprejemanja in pisanja enogovornih besedil oziroma govornega nastopanja ter izdelajo načrt za izboljšanje teh svojih zmožnosti (sklop razvijanje zmožnosti tvorjenja enogovornih neumetnostnih besedil);

- po sprejemanju besedila sklepajo o okoliščinah nastanka besedila in povedo, iz katerih prvin besedila so jih prepoznali (sklop razvijanje poimenovalne, skladenjske, pravorečne, pravopisne in slogovne zmožnosti ter zmožnosti nebesednega sporazumevanja);

- med sprejemanjem besedil opazujejo njihove nebesedne dele in nebesedne spremljevalce pisanja oziroma govorjenja, prepoznavajo njihovo vlogo ter vrednotijo njihovo učinkovitost in ustreznost (sklop razvijanje poimenovalne, skladenjske, pravorečne, pravopisne in slogovne zmožnosti ter zmožnosti nebesednega sporazumevanja);

- usvajajo merila za vrednotenje besedil in ta nato upoštevajo pri vrednotenju svojih in tujih besedil (sklop razvijanje metajezikovne zmožnosti);

- usvajajo merila za vrednotenje zmožnosti sprejemanja in tvorjenja besedil ter ta nato upoštevajo pri vrednotenju svoje in tuje zmožnosti sprejemanja in tvorjenja besedil (sklop razvijanje metajezikovne zmožnosti).

b) Področje književnega pouka:

- dijaki in dijakinje interpretirajo besedila tako, da izražajo svoje doživljanje, razumevanje, aktualizacijo in vrednotenje književnih besedil (sklop razvijanje zmožnosti branja in interpretiranja književnih besedil);

- književna besedila iz slovenske in prevodne književnosti časovno razvrščajo, spoznavajo in samostojno povzemajo značilnosti 
literarnozgodovinskih obdobij, smeri, poetik avtorjev in lastnosti prebranih del (sklop pridobivanje književnega znanja);

- pridobljeno znanje iz literarne zgodovine in teorije uporabljajo pri vrednotenju in aktualizaciji pomena posameznih in splošnih literarnih pojavov (sklop pridobivanje književnega znanja);

- vrednotijo pomen književnih obdobij, smeri, poetik in del za kulturni razvoj in jih aktualizirajo s stališča osebne in družbene izkušnje (sklop širjenje spoznanj o književnosti, kritična aktualizacija, njihovo uvrščanje v širši kulturnorazvojni kontekst).

Pri operativnih ciljih smo $\mathrm{v}$ analizi učnega načrta za slovenščino (UN 2008) prepoznali 18 ciljev, ki se povezujejo s kritičnim branjem, kar predstavlja $13 \%$ vseh operativnih ciljev, ki jih je več kot 140. Besedna zveza kritično branje se v celotnem učnem načrtu pojavi le enkrat, pojavljajo pa se sorodni pojmi, npr. kritično sprejemanje besedil (trikrat), kritična aktualizacija (enkrat), kritično opredeljevanje (enkrat), kritično mišljenje (enkrat). Zanimivo je dejstvo, da se v zadnjem sklopu za področje književnega pouka, ki vsebuje $\mathrm{v}$ naslovu besedno zvezo kritična aktualizacija, ne pojavita termina kritično branje in kritično razmišljanje. Videti je, da je poudarek na kritičnem branju opredeljen predvsem v sklopu splošnih ciljev, ki pa se potem v manjši meri odražajo $\mathrm{v}$ poglavjih, kjer so zapisani operativni cilji. Spodbudno pa je dejstvo, da je kritično branje posredno zastopano $\mathrm{v}$ zadostni meri skozi cilje, ki smo jih izpostavili zgoraj. Vendar tudi tu lahko opazimo povezovanje gradnika kritično branje $z$ gradnikom razumevanje besedila in gradnikom odziv na besedilo in tvorjenje besedila, npr. pri ciljih: sodelijejo v vodenem pogovoru ${ }^{8}$ strategijah poslušanja / .../ ali sodelujejo v vodenem pogovoru o načelih učinkovitega poslušanja.

\section{$4 \quad$ Sklep}

Rezultati analize učnih načrtov so pokazali, da se v učnih načrtih osnovne in srednje šole za slovenščino cilji, povezani s kritičnim branjem, pojavljajo v različnih sklopih. $\mathrm{V}$ vseh analiziranih učnih načrtih ni pogosta eksplicitna raba termina kritično branje ali kritično razmišljanje oziroma mišljenje. Še največ sorodnih pojmov, povezanih s kritičnim branjem, smo zasledili v učnem načrtu za slovenščino za splošne, klasične in strokovne gimnazije (UN 2008), kar je pričakovano.

\footnotetext{
${ }^{8} \mathrm{~V}$ tem primeru je ustrezen termin raggovor.
} 
Ugotavljamo, da bi bilo v učnem načrtu za slovenščino v osnovni šoli (UN 2018) smiselno dati več poudarka na ciljih, vezanih na razvoj kritičnega branja in kritičnega razmišljanja, in sicer v 1., 2. in 3. VIO. Prav tako smo pri pregledu slovenske literature ugotovili, da tema o kritičnem branju ni obravnavana pogosto, natančno in poglobljeno, kar je zagotovo priložnost za izboljšanje. Rezultati te analize nakazujejo potrebo po posodabljanju učnih načrtov za slovenski jezik tudi za gradnik kritično branje, kar ugotavlja že J. Vogel (2014).

Zaradi omejenega obsega prispevka nismo mogli narediti podobne analize še za druga predmetna področja, kar predstavlja priložnost za nadaljnje raziskovanje. Toda popis ciljev po posameznih vzgojno-izobraževalnih obdobjih omogoča njihov prenos na druga predmetna področja, npr. zgodovino, sociologijo, filozofijo, biologijo, in povezavo s temi področji. Ne nazadnje je osnova za zdravo in za posameznika spodbudno družbeno okolje zmožnost oblikovanja lastnega mnenja, ki ga je pomembno znati oblikovati na vseh življenjskih področjih. Želimo si, da bi v prispevek lahko vključili tudi nekaj praktičnih primerov za poučevanje kritičnega branja, a to ostaja naloga za prihodnjič. Vendar pa pripominjamo, da prispevek odraža subjektivno perspektivo avtoric, saj predstavlja analizo in rezultate s specifične, izbrane točke analiziranja, zato ga je treba brati kritično.

\section{Opombi}

Avtorica Marta Licardo je prispevek napisala v okviru projekta OBJEM - Bralna pismenost in razvoj slovenščine (Ozaveščanje, Branje, Jezik, Evalvacija, Modeli), šifra projekta OP20.01462, vodja dr. Sandra Mršnik, ki ga vodi Zavod RS za šolstvo. Naložbo sofinancirata Republika Slovenija in Evropska unija iz Evropskega socialnega sklada.

Avtorica Mira Krajnc Ivič je prispevek napisala v okviru projekta OBJEM - Bralna pismenost in razvoj slovenščine (Ozaveščanje, Branje, Jezik, Evalvacija, Modeli), šifra projekta OP20.01462, vodja dr. Sandra Mršnik, ki ga vodi Zavod RS za šolstvo. Naložbo sofinancirata Republika Slovenija in Evropska unija iz Evropskega socialnega sklada.

\section{Literatura}

Ann BOEHM, 2001: Boehm Test of Basic Concepts-3: Preschool. San Antonio: The Psychological Corporation.

Umberto ECO, 1999: Šest sprehodov skozi pripovedne gozdove. Ljubljana: Literarno-umetniško društvo Literatura (Zbirka Labirinti).

Dragica HARAMIJA, Jana AMBROŽIČ DOLINŠEK, Janja BATIČ, Katja KOŠIR, Mira KRAJNC IVIČ, Marta LICARDO, Alenka LIPOVEC, Simona PULKO, Marija ROPIČ, Polona VILAR, Tina VRŠNIK PERŠE, Melita ZEMLJAK JONTES, 2017: Razvijanje družinskee pismenosti: priročnik za starše. Maribor: Univerzitetna založba UM. 
IELG - Illinois Early Learning Guidelines For Children Birth to Age Three. Standards, age descriptors, indicators for children, and strategies for interaction, 2015. Illinois: University of Illinois at Urbana-Champaign.

Alenka KOMPARE in Tanja RUPNIK VEC, 2016: Kako spodbujati razvoj mišljenja: od temeljnib miselnih procesov do argumentiranja. Ljubljana: Zavod Republike Slovenije za šolstvo.

Kurikulum za vrtce, 1999. Ljubljana: Strokovni svet RS za splošno izobraževanje.

Mira KRAJNC IVIČ, 2020: Obravnava besedil: merila za razlikovanje med besedilno vrsto in besedilnim tipom. Slavisticna revija 68(1). 55-71.

Daniel J. KURLAND, 1995: I know what is says ... What does it mean? Critical skills for critical reading. Belmont ZDA: Wadsworth Publishing Company.

Marta LICARDO, Maja HMELAK, Tina VRŠNIK PERŠE, Katja KOŠIR, 2017: Družinska pismenost kot pomemben dejavnik za področja otrokovega razvoja. $V$ objemu besed: razvijanje družinskee pismenosti. Ur. Dragica Haramija. Maribor: Univerzitetna založba Univerze v Mariboru. 9-19.

Allan LUKE, 2012: Critical literacy: Foundational notes. Theory Into Practice 51(1). 4-11.

Karen MANARIN; Miriam CAREY; Melanie RATHBURN in Glen RYLAND, 2016: Critical reading in bigher education: Academic goals and social engagement. Bloomington Inidana: Indiana University Press.

James NOTTINGHAM in Jill NOTTINGHAM, 2019: Challenging early learning. Abingdon: Routledge. Jan NUYTS, 1992: Aspects of a Cognitive-Pragmatic Theory of Language. On Cognition, Functionalism, and Grammar. Amsterdam, Philadelphia: John Benjamins Publishing Company.

Gradniki bralne pismenosti: delovno gradivo, 2018. Ljubljana: Zavod Republike Slovenije za šolstvo.

Sonja PEČJAK in Ana GRADIŠAR, 2012: Bralne ǔ́ne strategije. Ljubljana: Zavod Republike Slovenije za šolstvo.

Igor SAKSIDA, 2014: Tabuji v mladinski književnosti, kritično branje in Cankarjevo tekmovanje. Otrok in knjiga 41(91). 25-35.

Ǔ̌ni načrt. Program osnovna šola. Slovenšcina, 2018. Ljubljana: Ministrstvo za izobraževanje, znanost in šport, Zavod RS za šolstvo.

https://www.gov.si/assets/ministrstva/MIZS/Dokumenti/Osnovna-sola/Ucninacrit/obvezni/UN_slovenscina

Ǔ̌ni načrt. Slovenšina: gimnazija: splošna, klasična, strokovna gimnarija, 2008. Ljubljana: Ministrstvo za šolstvo in šport, Zavod RS za šolstvo.

http://eportal.mss.edus.si/msswww/programi2019/programi/media/pdf/un_gimnazija/un _slovenscina_gimn.pdf

Andreja VEZOVNIK, 2009: Diskurz. Ljubljana. Založba FDV.

Jerica VOGEL, 2010: Zmožnost kritičnega sporazumevanja kot temeljni cilj jezikovnega izobraževanja v šoli. Pot k. jezikeorni politiki v iz̧obraževanju. Ljubljana: Zavod RS za šolstvo. 106-135.

Jerica VOGEL, 2014: Modeli jezikovnega pouka pri predmetu slovenščina od leta 1990 do danes. Jezile in slovstvo 60(3-4). 173-183.

Igor Ž. ŽAGAR, 2009: Odperformativa do govornib dejanj. Digitalna knjižnica. Diserrtationes 1. Ljubljana: Pedagoški inštitut. Digitalna knjižnica. https://www.dlib.si/stream/URN:NBN:SI:DOC-FKXXWIIP/7021df8f-525f-41f1-aee4fa544a51655b/PDF 


\section{GRADNIK: KRITIČNO BRANJE}

DIALOŠKI PRESKOKI KNJIŽEVNOSTI, INTERPRETACIJA IN DOŽIVETJE,

\section{KONTEKSTUALIZACIJA TER}

\section{MEDMEDIALNI PREHODI}

\section{MIRAN ŠTUHEC}

Univerza v Mariboru, Filozofska fakulteta, Maribor, Slovenija. E-pošta: miran.stuhec@um.si

Povzetek Besedilo je uvid v različne vidike književnosti, še posebej tistih plasti, ki so $\mathrm{v}$ neposredni povezavi s poukom književnosti. Pri tem se ne omejuje le na srednješolsko delo, marveč upošteva tudi univerzo in njene zahteve. Idejna podlaga je prepričanje, da med eno in drugo ravnijo ukvarjanja z izbranim literarnim korpusom zmeraj ni nujno velike razlike. Dostikrat namreč gre samo za drugačen obseg večperspektivnosti in stopnjo analitične izostrenosti ali temeljitejšo sintezo. Tolmačenje, kontekstualizacija literarnega diskurza, medialnost ter doživetje, kritičnost in spodbuda za vrednotenje, estetske opredelitve, poznavanje slovstvenih procesov, občutek za jezikovne in slogovne presežke, razumevanje specifičnega literarnega pomena $\mathrm{z}$ vidika slovenstva itn. so presečišča različnih ali celo zelo drugačnih pogledov in hkrati njihova sredotežna sila tudi, če mislimo na srednješolski pouk (slovenske) književnosti.

Ključne besede: književnost, pouk književnosti, interpretacija, medialnost, fiktivni model realnosti. 


\title{
THE NiNTH COMPONENT OF
}

READING LITERACY:

CRITICAL READING

DiALOGIC LEAPS OF LITERATURE:

INTERPRETATION AND

EXPERIENCE,

CONTEXTUALISATION AND

INTERMEDIAL CROSSINGS

\author{
MIRAN ŠTUHEC \\ University of Maribor, Faculty of Arts, Maribor, Slovenija. \\ E-mail:miran.stuhec@um.si
}

\begin{abstract}
The text offers an insight in different aspects of literature, especially its layers, which are in a direct connection with teaching literature. Here it is not limited to secondary school work, but also considers university and its requirements. The ideational foundation is a belief, that there is not necessary much difference between one and the other level of dealing with literature corpus. Often, namely, it is only about different extent of multiperspectivity and level of analytical sharpness or more in-depth synthesis. Interpretation, contextualisation of literary discourse, mediality and experience, criticism and encouragement for evaluation, aesthetic definitions, knowledge of literary meaning from the viewpoint of Slovenehood etc. are intersections of various or ever very different perspectives and at the same time its centripetal force, even if we have in mind the secondary education of (Slovenian) literature.
\end{abstract}

Keywords: literature, literature lessons, interpretation, mediality, fictional models of reality. 


\section{$1 \quad$ Uvod}

Pouk književnosti je del literarnega sistema, ${ }^{1}$ kamor spadajo zelo različne z literaturo povezane dejavnosti, od same slovstvene produkcije, socioloških in psiholoških ter literarnovednih znanstvenih vidikov, do prevajanja, prirejanja različnih literarnih dogodkov, literarne kritike, nagrad, književne esejistike, ustreznih TV-oddaj itn. Književni pouk bodisi univerzitetni bodisi osnovnošolski ali srednješolski je znotraj navedenega polja eden ključnih. Delo na univerzi razumem predvsem kot znanstveni in strokovni uvid v različne književnozgodovinske in literarnoteoretske dinamike, kjer, denimo, odlično pridejo do izraza kontekstualni procesi; ti zmeraj znova opozarjajo, da je literatura področje, kjer odlično pride do izraza stara de Mannova sintagma napačno branje. ${ }^{2}$ Pomembni so tudi medmedialni vidiki, ki $\mathrm{v}$ polju intermedijskih umetnosti književnost večkrat postavljajo $\mathrm{v}$ središčno pozicijo. Denimo takrat, kadar gre za prenos literarnoustvarjalnih postopkov na videoprodukcijo, računalniške igre, videoromane ipd. ${ }^{3}$ Ob srednješolskem pouku je treba poudariti nekaj drugega, in sicer njegovo dvojno naravo. Prvič, slediti mora svetovnemu in slovenskemu literarnemu kanonu, kar preprosto pomeni, da ne sme spregledati besedil, ki tja sodijo, in drugič, če upoštevamo njegovo hermenevtično vsebino, izpostavlja osebni odnos do izbranega slovstva - učiteljev in dijakov. Gre torej za sintezo odkrivanja zvez med splošnim in posameznim, subjektivnim ter objektivnim, aktualnim in historičnim. Do te točke je pravzaprav vseeno, ali gre za tuj korpus ali domač; od tu naprej pa je potrebno ločiti. Slovenska književnost je sicer nastajala v enkrat bolj drugič manj tesni povezavi s tujim svetom, ${ }^{4}$ vendar je ob tem prej ali slej reflektirala specifično kolektivno izkušnjo, utemeljeno $\mathrm{v}$ zgodovinskih prilikah. ${ }^{5}$ Pisci so svoje kulturno poslanstvo ali civilizacijsko nujo udejanjali s tem, da so se pravzaprav zmeraj ali na umetniški način ali politično oziroma družbenopolitično odzivali na aktualne dogodke, ki so zadevali v srž slovenske narodne biti. Naj k povedanemu dodam, da so že Brižinski spomeniki

\footnotetext{
${ }^{1} \mathrm{~V}$ branje priporočam knjigo Urške Perenič z naslovom Empirično-sistemsko raziskovanje literature: Konceptualne podlage, teoretski modeli in uporabni primeri (2010).

${ }^{2} \mathrm{~V}$ branje priporočam sicer že nekoliko staro, a vendarle zanimivo delo Paula de Man, Allegories of Reading: Figural Language in Rousseau, Nietzsche, Rilke and Proust.

${ }^{3} \mathrm{Naj}$ ob tem opozorim, da se v literarni teoriji, vsaj od slovstvenih modernizmov tipa francoskega novega romana naprej, govori o t. i. pogledu filmske kamere oz. o pripovedovalčevi posebni perspektivizaciji prostora in oseb; postopek ima izrazito idejno podlago.

${ }_{4}^{4}$ Težko si je zamisliti slovensko romantiko, ne da bi ob tem opozarjali na delo bratov Schlegel, Schillerja idr.

5 Tu seveda ne moremo spregledati pravzaprav preprostega dejstva, da je slovenska književnost v razmerah dolgo časa nedržavotvornega naroda imela specifično mesto vedno, kadar se je postavilo vprašanje narodne samobitnosti, slovenstva ali nacionalno-historične dimenzije.
} 
nastajali na ozadju treh zagonov - antičnega, krščanskega in staroslovenskega. Prav slednje je takrat na svoj način realiziralo Wittgensteinovo premiso Meje mojega jerilka so meje mojega sveta.

Pričakovanja obsega znanja, ki naj ga dijaki, $\mathrm{k}$ samostojnemu ter kritičnemu razmišljanju usmerjeni subjekti, pokažejo ob koncu književnozgodovinskega šolanja, seveda odvisno od vsebinskih in interesnih posebnosti posameznih srednjih šol, gotovo obsegajo naslednje:

- sposobnost analize in sinteze ter predvidevanja rešitve strokovnih problemov primerne težavnostne stopnje ter obsega,

- interdisciplinarno povezovanje vsebin,

- sposobnost uporabe znanja $\mathrm{v}$ praksi,

- poznavanje in razumevanje temeljnih književnih tem,

- zmožnost interpretacije slovstvenih besedil,

- poznavanje večplastnosti literarnega jezika,

- sposobnost za nadgrajevanje znanja o književnosti,

- sposobnost analitičnega pristopa, doživljanja, vrednotenja in čustvenega odzivanja do posameznih ključnih literarnih tokov ter del,

- uzaveščanje vloge in pomena slovenske književnosti kot pomembne sestavine narodnostnega diskurza,

- medmedialni vidiki.

Verjetno pa je ključna naloga tega pouka vabilo k permanentnemu branju.

Kot rečeno, univerzitetni pouk književnosti prej ali slej zadene ob vprašanje tako imenovane kontekstualnosti; mislim celo, da je ta stična točka učiteljevega in študentovega dela, denimo v seminarju. Saj razmeroma skrčen referenčni krog pisca na podlagi dialoškosti njegovega besedila omogoča temeljito širjenje pomenske plasti, pač odvisno od vsebine, v kateri poteka vsakokratna recepcija. Navedene teoretske predpostavke nas privedejo do koncepta interpretacijskega konteksta. Če ob tem upoštevamo še stališče o dveh različnih ustvarjalnih zagonih, od katerih prvi 
nastaja $\mathrm{v}$ polju osebnega in nacionalnega, drugi literarne izjave širi ter išče stike $\mathrm{z}$ nadnacionalnim prostorom, je potrebno pomisliti še na kontekst medkulturnosti. ${ }^{6}$

Pred nadaljevanjem je smiselno opozoriti vsaj na eno od definicij, kaj da je književnost. Je del umetnosti, ki prej ali slej aktivira različne kanale recepcije, recimo tistega, po katerem potekajo racionalni procesi, in onega, katerega namen je spodbuditi čustvene dinamike. Gre za spoj duhovnega in estetskega, za iskreno ter subtilno doživetje človeka in sveta ter ob tem za predstavljanje večnih zamisli in vrednot. Gotovo je slovstvo prav tako poseben ritem pesnikove subjektivizacije življenjske izkušnje, kakor bi poudarili skozi perspektivo romantične ali novoromantične idealizacije ustvarjalca. Seveda je književnost še plod racionalnih procesov, ti naj na primer na organsko vključen angažma in upoštevajoč sodobne izrazne tehnike nagovorijo bralca še zato, da bodo zmotili njegovo miselno lenobo ali razgibali letargijo družbe. Take vrste književnost poudarja aktivno razmerje do sveta. To je seveda že dolgo znano. Tudi Slovenci imamo na področju z intenco nabitega slovstva bogate izkušnje, vsaj od pridig Janeza Svetokriškega naprej, prek mohorjanke, besedil z močnim narodnostnim nabojem, nekoliko kasnejših bolj ali predvsem manj posrečenih realizacij didaktičnih estetik, podloženih z ortodoksnimi katoliškimi idejami Antona Mahniča, dalje z nekaterimi diskurzivno izjemno močnimi teksti Srečka Kosovela in socialnih realistov, do neoavantgard Šalamunovega časa, kasnejših feminističnih literarnih zagonov pa do tematizacije različnih spolnih praks, grobosti, patoloških stanj, posilstva, zločina, čemur smo priča danes. Če je angažma kot avtorjev glas ${ }^{7}$ naravno vključen v delo, spontan, nenasilen in nemoteč ter temelji $\mathrm{v}$ ustvarjalčevi notranjosti in njegovem iskrenem ter odgovornem odnosu do sveta, tudi literarna zgodovina tu ne more imeti pripomb. Drugače je, če gre za instrumentalizacijo umetniškega dela v pomenu propagiranja ideje, če, denimo, roman postane zgolj medij za plasiranje zamisli in je celotna njegova struktura podrejena ali bolje rečeno kontaminirana, kot to lahko brez velikih špekulacij potrdimo $\mathrm{v}$ nekaterih pravkar navedenih primerih. V Samorastnikih, recimo, ne najdemo le oživitve ideje Jurčičevega Sosedovega sina, delno tudi Desetega brata, ampak njeno izostritev do skrajnih meja. Če je pisec prvega slovenskega romana $\mathrm{v}$ obeh delih našel stik $\mathrm{z}$ razsvetljensko paradigmo, ta je prek idej Francoza Jeana Jacquesa Rousseauja propagirala svobodno izbiro in iskreno

\footnotetext{
${ }^{6} \mathrm{~V}$ premislek priporočam razpravo Kovača z naslovom Interpretacijski kao Zvonka interkulturni kontekst. / Jeqik književnosti, znanosti i medija. Kolar, Mario, Tkalec, Gordana, Kovač, Zvonko (ur.). Koprivnica: Sveučilište Sjever, 2018. 139-154.

${ }^{7}$ Avtorjev glas je signal avtorjevih nezavednih svetovnonazorskih, političnih, ideoloških, spolnih idr. struktur.
} 
čustvo, potem moramo ugotoviti, da je Voranc v smislu takratne socialistične misli temeljito prestopil njen etični horizont. Prav na tej točki se Samorastniki danes pokažejo tudi kot problem. Zato, ker je v noveli hiperbolizirana roussojevska vera $\mathrm{v}$ moč ljubezni medij, prek katerega avtor realizira misel o rodu, ki bo v pomenu socialno-socialistične preobrazbe zavladal in $\mathrm{v}$ družbi uresničil nove ter drugačne norme, vrednote in interese.

Prežihov Voranc je bil brez dvoma nadarjen pripovedovalec in je ob slogovni ter jezikovni pomoči Ferda Kozaka ustvaril imenitna dela slovenskega socialnega realizma, kljub temu pa ne morem spregledati, da so Meta in Ožbej ter z njima zgodba strukturirani s prepoznavnim ciljem. Ugotavljam namreč, da pisatelju vendarle ni uspelo zamisli o nujnosti političnih sprememb in zgodovinski perspektivi socialno najnižjih slojev prek plodne Hudabivnice organsko vključiti v celoto. Morda tega niti ni nameraval, saj bi lahko bil prikriti družbeno-prevratniški diskurz manj opazen. Če vemo, da je bila $\mathrm{v}$ preteklosti slovenska književnost večkrat kontaminirana s krščanskim poukom, nacionalno mitologijo, gospodarsko vzgojo, moraliziranjem, celo z anarhističnimi zamislimi, potem moramo tudi ob Vorančevih Samorastnikih ugotoviti ne le epsko sliko »legendarne zvestobe, čiste vdanosti in iskrenega plamena ljubezni«, ampak tudi pripoved s poudarjeno socialno in politično ostjo. Da se Vorančevo pisanje giblje na nevarnem robu tendencioznosti in ga mestoma tudi prestopa, je mogoče najpregledneje ugotoviti prek nekaterih povzemalnih in $\mathrm{v}$ smislu revolucionarnega diskurza zelo izrazitih odstavkov.

»Ali ni to dih in stok stoterih, tisočerih Hudabivnikov, molitev in kletev, prisega in bojna napoved vseh tistih, ki iščejo vsak svoje lastne Karnice? ... Da, to je bojni klic črnih kovačnic, prečnih jam, ožganih razgonov, stisnjenih zar, zapuščenih globač in kopišč ... to je bojni klic zavrženega, prekletega rodu ...« (Voranc 1964: 225)

Tudi pri velikem Cankarju bi se kaj našlo, recimo v povesti Hlapec Jernej in njegova pravica (1907) ter še kje.

Kontekstualni vidik književnega dela, recimo, zanimivo izpostavi literarizacijo nezaželene neveste Friderika II. Celjana Veronike Deseniške. Josipina Turnograjska je ob njej poudarila močno čustvo in globoko ljubezen, Josip Jurčič jo je vključil v socialne ter moralne dinamike 19. stoletja, Oton Župančič je prek nje evociral narodnopolitično dogajanje na začetku 20. stoletja, Bratka Krefta je zanimala v 
kontekstu marksistično razumljenega razrednega boja med fevdalci in meščanstvom itn. ${ }^{8}$ Zdaj bi seveda lahko razpravljal o tendenci v sodobni književnosti, a tega ne bom napravil, ker je moj namen pravzaprav le opozoriti na močno relevanten vidik, ki pride $\mathrm{v}$ poštev pri tolmačenju literature - branje slovstva na način izrazitega osebnega opredeljevanja, vrednotenja in etičnega premisleka tudi, če mislimo na srednješolsko lektiro. Tolmačenje ali interpretacijo razumem kot aplikacijo izbranega znanja na literarni korpus, pisca ali posamezno delo. Zelo pogosto gre seveda za prenos literarnozgodovinskega ali književnoteoretskega znanja, a ne nujno, saj poznamo zelo dobre filozofske (Dušan Pirjevec, Taras Kermauner, Tine Hribar), psihološke (Matjaž Lunaček), sociološke (Rastko Močnik, Dimitrij Rupel) in zgodovinske (Igor Grdina) literarne razprave.

Kakorkoli že, književnost je avtonomen proces nastajanja del z namenom na estetski način evocirati pomembna vprašanja posameznika in kolektiva tako, da bo avtentična individualna izkušnja dobila univerzalno obeležje. Področje lepega, do njega seveda pridemo zelo hitro, izpostavi svojo ambivalentno naravo, izmikajočo se strukturo. Že stari Josip Vidmar je ugotovil (čeprav tega nikoli zares ni tudi priznal), da se stvari ne da formalizirati, a v vsakem primeru drži, da se nobena literarna smer, literarni tok ali kar celo obdobje ni hotelo odreči niti lepoti niti resnici. $\mathrm{V}$ ta namen so nastajali zelo različni estetski koncepti, od tistih, ki so lepoto do skrajnosti idealizirali in njeno vsebino povezovali z božanskim početjem, do onih z vsaj na videz mnogo bolj prozaičnimi trditvami o tem, da je lepota $\mathrm{v}$ neposredni zvezi s količino informacij.

Veliki sufijski pesnik Omer Hajam je pred kakšnimi devetimi stoletji zapisal približno takole: Ves čas ugotavljamo, kaj je za veliko zaveso, ko stopimo za njo in ugotovimo, pa tega zanamcem ne moremo sporočiti. Tudi književnost tega ne more. Govori pa nam, kdo smo in za kaj smo. In to še zmeraj ter kljub temu, da popkultura s svojimi obskurnimi oblikami želi prek siromašnih estetik določiti merila kritični recepciji ter okus utemeljiti ob predvidljivosti in preračunljivosti, pomenski enostavnosti ter izpraznjenosti, shematičnosti in diktatu takojšnjega učinka. ${ }^{9}$

\footnotetext{
${ }^{8} \mathrm{O}$ tem je zanimiv esej že pred časom napisal Matjaž Kmecl, naslov je Esej o deseniški Veroniki.

${ }^{9}$ Drugače je, če te fiktivne modele sveta sprejemamo na simbolni ravni. Tako jih namreč pogosto lahko povsem brez težav vključimo v različne okoliščine, na primer prva predstava mariborskega profesionalnega gledališča je bil Jurčičev Tugomer, ta je upodobil klasičnega tragičnega junaka, ki je moral propasti, da je njegova ideja zmagala. Gledališki dogodek sam je po koncu 1. svetovne vojne seveda odlično poglobil triumf slovenstva kot takega.
} 


\section{$2 \quad$ Pouk književnosti}

Književni svetovi so seveda izmišljeni, a kljub temu ali ravno zato, ker slovstvo formira fiktivne modele sveta, je poučevanje literature izjemno pomembno. Vsaj trije kompleksni razlogi so za to: prvi opozarja, da recepcija izbranih del širi in poglablja vedenje o književnosti ter s tem ustvarja podlage za nastajanje specifične bralčeve izkušnje, drugi angažira bralčevo sposobnost avtonomnega doživljanja idejno, estetsko, slogovno-jezikovno in pomensko večplastne strukture, tretji aktivira samostojno racionalno ter kritično presojanje. Pravzaprav ne morem reči, kaj je pomembnejše, vse troje namreč pusti dalekosežne sledi v življenju posameznika zato, ker na poseben način oblikuje njegovo zavest.

V času, ki ga živimo, bolj kot kdaj prej prihaja do izraza, da je prodiranje kapitalistične logike $\mathrm{v}$ vse pore javne in zasebne sfere temeljito revidiralo, verjetno tudi kontaminiralo različne vidike življenja vseh generacij. Trivializacija vrednot, vera v zgolj horizontalno resničnost, grobi liberalizem, želja po instant užitkih, instrumentalizacija itd. opozarjajo, da je polje literature odličen prostor, na katerem se da realizirati več, in je književnost modeliranje sveta, $\mathrm{v}$ katerem pridejo do izraza etos, moralne vrednote, empatija, globoko čutenje, večdimenzionalnost, kreativnost, svobodna domišlijia, medmedialnost in dialog. In kar je vsaj toliko pomembno ter lahko temeljito spremeni podobo vsakdanje verbalne komunikacije, slovstveno delo opozori na specifično jezilkovno įkušnjo. Našteto gotovo argumentira izjemen pomen pouka književnosti in postavlja pred visokošolske ustanove, kjer poteka izobraževanje bodočih učiteljev, veliko odgovornost. Sicer ne razpolagam z zadnjimi podatki o branju leposlovja, a nekoliko starejše raziskave kažejo na izrazit upad na tem področju. Splošno znano je, da so včasih ljudje brali izvirno literaturo, kasneje članke o izvirni literaturi, danes le še vesti o njih. Usmerjenost vseh generacij $\mathrm{k}$ uporabi poenostavljenih oblik komuniciranja, jezikovna zloraba kratkih in še krajših besedil, pomenska enoznačnost in skoraj do neprepoznavnosti izmaličena slovnična in leksikalna podoba esemesov in spletnih klepetalnic po moje ultimativno usmerja $\mathrm{k}$ potrebi po branju polisemantičnih, slogovno izbrušenih in jezikovno korektnih književnih del. To sicer ne pomeni širjenja kurikuluma, ta je morebiti že zdaj s svojim obsegom odvračajoč, ampak cilja na premišljeno izbiranje gradiva, privabljanje, prepričevanje, spodbujanje, opozarjanje na možnosti, zahtevanje, verjetno tudi delo s starši. Le tako je mogoče pozornost mladih ponovno usmeriti k iskanju interesa za enigmatične prostore, poglobiti željo po imaginaciji, občutku za jezikovno bogastvo, 
vznemirljivem doživetju lepote literariziranega sveta. Tu srednješolski pouk zadene ob verjetno glavni problem učnega procesa, kako v celovitost združiti recepcijo, ki aktivira racionalne kanale na eni strani ter poti čustvenega, čutnega in doživljajskega sprejemanja na drugi. Zdaj si seveda na upam trditi, da znanstveni postopki ne vključujejo tudi spontanosti, intuitivnosti in odprtosti za vaporedna spoznanja. Moje trdno prepričanje je že dolgo časa, da, denimo, literarna esejistika odkriva zelo zanimivo dojemanje in je zato nadvse dobrodošel korektiv strogim, včasih tudi vase zagledanim literarnim raziskavam, ki jim je umetniški izdelek zgolj objekt za preizkus metodološke neoporečnosti in analitične bravuroznosti. ${ }^{10}$ Prav tak sproščujoč, esejistično neavtoritativen in dialoški odnos je ob upoštevanju kanoniziranih znanj eden od dveh presežkov srednješolskega pouka književnosti. Zato, ker opozarja na obstoj alternativnih svetov in dijake spodbuja, da se do njih opredeljujejo ter jih samostojno tvorijo.

Drugi presežek, ta je drugačne narave, je premišljeno, rekel bi, razsodno branje literarnega besedila. Mislim, da je ta vidik tesno povezan ne le z razvijanjem razumskih procesov zavesti, marveč je zelo pomemben tudi, če pomislimo na institut šolskega eseja. Z njim mora namreč dijak takrat, kadar gre za proces ocenjevanja, $\mathrm{v}$ veliki meri argumentirati obvladanje predpisanih vsebin: prepoznavanje slogovnih in jezikovnih značilnosti, motivne konfiguracije, literarnozgodovinske umeščenosti, dalje ugotavljanje literarnega sporočila, poudariti mora moralne ter etične razsežnosti, utemeljeno, skladno s svojimi sposobnostmi in tudi polemično mora oblikovati lastno mnenje, kritično vrednotiti, primerjati, smiselno interpretirati, pač odvisno od tega, kaj izbrani literarni korpus ponuja. ${ }^{11}$

Pouk književnosti torej razumem kot sintezo hermenevtičnega in literarnovednega (literarnozgodovinskega in literarnoteoretskega) procesa, pri čemer gre $\mathrm{v}$ prvem primeru za razlaganje književnosti, $v$ drugem za sistematično, metodološko ter terminološko pregledno poučevanje. Znanje obojega je podlaga kritičnemu branju. Zdaj se je najprej potrebno vprašati, kakšne so danes okoliščine za to. Moje mnenje seveda je, da je v času izrazite želje po miselnem udobju, konzumiranju popkulture,

\footnotetext{
${ }^{10}$ Pred časom je bilo v okviru literarnega strukturalizma, ta je med drugim prispeval tudi nekaj še danes uporabnih teoremov, mogoče najti smeri, ki so književni tekst reducirale na mehanizem za zagon pomenov, ki mu je potrebno ugotoviti algoritem delovanja. A, pozor, rezultat je bil lahko tudi zelo uspešen, a je vendarle pogosto šlo le za oris skeleta.

${ }^{11}$ Mislim, da bi se dijak v teku priprave na maturitetni esej moral prvič srečati s študijem literature, kar je v primerjavi z učenjem gotovo kakovostni preskok.
} 
v pogojih, kjer je očitna želja po popreproščanju na eni strani in plasiranju fiktivne samopodobe prek različnih medijskih kanalov na drugi, pravzaprav težko oblikovati kritično maso tistih, ki jih bo književnost zanimala do te mere, da bodo pripravljeni vložiti potreben trud za poglobljeno refleksijo. A brezupno ni in se je $\mathrm{v}$ razredu vredno potruditi za oblikovanje dialoškega odnosa literarno delo - dijak, za poudarjanje pomenske polifonosti izbranega literarnega teksta, spodbujanje $\mathrm{k}$ argumentiranim odzivom (dokazi in protidokazi), za primerjanje, osredotočenost na slogovne ali (funkcionalno-) jezikovne plasti, tematiko, motivno konfiguracijo, na vlogo upovedenih oseb, karakterje, na idejne poudarke. O didaktičnih konceptih si ne upam govoriti, ker o njih vem premalo, želim pa spomniti na nekatere vidike, ki jih obsega književni pouk. Še zmeraj se mi zdi uporabno staro stališče, da literarna umetnina vključuje estetsko, kognitivno in etično dimenzijo. Jasno je, da estetska komponenta lahko hitro preide $\mathrm{v}$ tako imenovani esteticizem, ta razgradi občutljivo notranje razmerje, prav tako ni nujno že na prvi pogled razumljiva trditev, da kvazirealnost zelo specifično spodbudi »realno« izkušnjo, prav tako ne moremo spregledati, da je etični diskurz v književnem besedilu lahko kompleksen in na videz celo paradoksalen, ${ }^{12}$ še zlasti $v$ primeru satire ali parodije. A kljub povedanemu mislim, da je treba biti na našteto pri pouku posebej pozoren zato, ker zadeva $\mathrm{v}$ srž slovstva, izbranega korpusa ali posameznega dela. Estetska komponenta opozarja, da je literarno delo še zmeraj predmet, $z$ več vidikov povezan s pojmom lepote, in torej na specifičen estetski način tematizira zelo različne vidike posameznika ter sveta. Spoznavna funkcija izpostavlja, da literarno delo ni zavezano resnici, kakor jo razumemo v smislu etabliranih dogovorov, temveč je književna resničnost posebna, rekel bi izmišljena. Posebej problem etosa ocenjujem za danes zelo pomemben. Dva razloga sta za to, prvič, ker v trivialni literaturi ta dimenzija gotovo umanjka, drugič zato, ker je današnji čas še kako potreben tovrstnega premisleka. Etično v književnosti daje možnost novih spoznanj na osnovi splošno sprejetega kodeksa. To pomeni, da literarno delo v svoj diskurz vpisuje informacije, ki bodo spodbujale avtonomno refleksijo, preverjanje lastnih opredelitev in nastanek samostojne nravstvene drže ter povzdigovale duha in plemenitile človeka.

\footnotetext{
${ }^{12}$ Tu je treba samo pomisliti na pesem Tomaža Šalamuna Zakaj sem fašist (Katalog 1970).
} 
Kritično branje književnih del prej ali slej pomeni apliciranje literarne aksiologije na izbrani korpus. ${ }^{13}$ Vendar je takšno delo rezervirano za literarno kritiko v ožjem pomenu besede in je mogoče pri srednješolskem kritičnem branju njene prakse upoštevati le $\mathrm{v}$ prilagojenem smislu. ${ }^{14} \mathrm{~V}$ vsakem primeru, pomisliti je potrebno samo na zahteve šolskega in maturitetnega eseja, je drugače $z$ dijakovim prepoznavanjem najbolj izpostavljenih oblikovnih in vsebinskih lastnosti, njihova formalizacija in sistematizacija. Tu namreč gre za dinamičen odnos, katerega namen je vabilo $\mathrm{k}$ sintezi objektivne in subjektivne recepcije, vrednotenju na ozadju lastnega referenčnega polja ter $\mathrm{h}$ kontekstualizaciji $\mathrm{v}$ širšem smislu. Zdaj se je potrebno vprašati, kaj sploh je tisto, kar naj učenec presoja. Oboje, tista sporočila, ki jih razumeva na podlagi osebne sodbe, in ona s širšim, tudi $\mathrm{v}$ historičnem smislu utemeljenim pomenom. Če se vrnem k že navedenim trem dimenzijam, te naj v medsebojnem miselno urejenem razmerju tvorijo književni tekst, potem kognitivna brez dvoma spodbuja različna spoznanja - moralna, socialna, seksualna, zgodovinska, politična itn. Etična razsežnost omogoča bralčevo sprejemanje in odklanjanje upovedenih značajev, aktivnosti literarnih oseb in dogodkov; estetska sporoča signale, ki spodbujajo estetske sodbe, recimo o jeziku Cankarjevih del, slogu Udovičevih nadrealističnih pesmi ali o miselnem kombiniranju Štihovih esejev in subtilnih pogledov Inkretovih gledaliških kritik. ${ }^{15}$ Ena od bistvenih sestavin ocenjevanja estetskega pomena je gotovo odsotnost tako imenovane dejstvenosti. Merilo resničnosti namreč tudi v primeru realistične proze ni bistveno, saj estetsko tudi v tem primeru prej ali slej pomeni pomensko polivalenčnost, kar tekst povsem loči od monosemantičnih besedil. Večpomenskost namreč opozarja na odsotnost popreproščenega tematiziranja izbrane snovi in hkrati možnost vpisovanja lastnega interpretacijskega koda/konteksta. ${ }^{16} \mathrm{Ob}$ povedanem je potrebno ponovno pomisliti

\footnotetext{
13 Opozarjam na zanimivo disertacijo Roberta Jereba z naslovom Struktura in funkecija literarne kritike: Na primeru sodobnega slovenskega romana (2009). V njej avtor najprej opozori na pomembnost količinskega razmerja med časopisnim in revijalnim tiskom ter kritiko, primerjalno povzame dogajanje v nemškem in angleškem prostoru ter pri Slovencih in prek Pierra Bourdieuja ter Sigfrieda J. Schmidta književno kritiko definira kot osrednjo dejavnost literarnega sistema. Nato formalizira metodološki okvir, strukturne prvine, se ustavlja ob pomenu vrednotenja s stališča avtorja in bralca ter ugotavlja, da je temeljno metakritiško opravilo določiti obseg posameznih tipov izjav (deskriptivnih, interpretativnih in vrednotenjskih), tabelarno prikaže kvantitativno pridobljene podatke o strukturnih sestavinah presojanja ter opozori na medbesedilne vidike in jezikovno-slogovne vzorce. Poučna je še njegova ugotovitev, da se bralci s kritikami v glavnem ne strinjajo.

14 Nujno pa je poudariti, da nekateri študenti že zelo kmalu pokažejo izrazit interes in sposobnost za književnokritično delo. Od tod sklepam, da so podobne ambicije imeli že v srednji šoli. Izbrane kritike Oddelek za slovanske jezike in književnosti po ustreznem teoretskem uvidu v okviru enega od obveznih predmetov objavlja na spletni strani https://www.Subskop.

${ }^{15}$ Namenoma izpostavljam zvrstno zelo različna besedila, ker menim, da se lepota lahko reprezentira na različne načine in $\mathrm{v}$ različnem okolju.

${ }^{16}$ Morda je zapisano na prvi pogled povsem jasno, a želim opozoriti, da marsikateri bralec v realistični pripovedi z jazovim (prvoosebnim) pripovedovalcem išče neposredno zvezo med literarno resničnostjo in dejanskim svetom.
} 
na kognitivno dimenzijo, na refleksijo različnih podatkov, prek katerih prihaja bralec do novih spoznanj. Tudi v tem primeru moram izpostaviti, da je umetniško slovstvo večpomenski pojav, rekel bi metaforična ali metonimična struktura. Slednje pa ne pomeni, da se bralec ob na primer Kersnikovem Agitatorju ali Ciklamnu kljub izmišljenim osebam in zelo poljubno literariziranim dogodkom ne more o čem "poučitik. Denimo o tem, kako je bil v drugi polovici 19. stoletja slovenski malomestni živelj oblečen, kakšne navade je imel, katere kulturne vrednote so mu bile blizu. ${ }^{17}$ Prav zaradi povedanega je mogoče pričakovati, da ima književnost vsaj pogojni vpliv na normativni in vrednostni sistem (mladega) bralca, prav tako prek prenašanja spleta emocionalnih učinkov na krepitev njegove senzibilnosti in poglabljanja ter širjenja njegove čustvene izkušnje.

\section{$3 \quad$ Sklep}

Prispevek zaključujem z mislijo na tako imenovani 9. gradnik kritično branje in na podlagi zapisanega potrjujem implicitno tezo tega prispevka, da književni pouk v največji meri omogoča, celo zahteva, kritično branje virov, torej v kurikulumu predpisanega literarnega korpusa in s tem poudarjanje različnih izjav, stališč, sporočil, ki jih umetniška reprezentacija izbrane teme ponuja v premislek, oceno, utemeljevanje, vrednotenje, zgledovanje, odklanjanje, individualiziranje, vpisovanje, kontekstualizacijo ali medmedialnost. Pouk književnosti je ob tem prav tako vaja $\mathrm{v}$ interpretaciji in sintetičnem mišljenju, $v$ izvirnosti, je jezikovni trening, možnost vključevanja različnih kontekstov, opozarja na drugačno branje lirskega in epskega besedila. Pomembno je, da se dijak nauči diskutirati, iskati pomenska ozadja, iskati morebitne medmedialne vsebine, posploševati, doumeti smisel sporočila, najti funkcionalne zveze med posameznimi plastmi problema. Skratka, ciljam na znanja in izkušnje, ki ne pridejo v poštev le pri ukvarjanju s slovstvenimi temami, ampak so pomembne tudi sicer pri razčlenjevanju in interpretiranju zelo različnih problemov.

\footnotetext{
Najmanj, kar naredi, je, da išče avtobiografske sestavine, čeprav so dogodki in osebe povsem izmišljeni. In pri tem ne "priznava«, da je literarizirani svet že v osnovi fikcija. Bitka pri Borodinu, denimo, ki jo je upovedil veliki ruski realist, je v prvi vrsti literarni dogodek ter Vojna in mir nikakor ni historična razprava, v kateri je avtor zavezan resnici ter jo tudi nenehno dokazuje s sklici, opombami itd., marveč književna umetnina. Ta ima do resnice (dejstvenosti) samosvoje in $z$ intenco podloženo razmerje.

17 Zgodovinopisje pozna pojem literarni vir.
} 
Če je maturitetni esej ocena vseh ocen srednješolskega pouka književnosti, v kar sicer dvomim tudi zato, ker se je $\mathrm{v}$ zadnjem času zmanjšal korpus maturitetnih besedil, ker med njimi tako rekoč ni v slovenskem prostoru iz več perspektiv zelo produktivne lirike, ker se je skrčil čas pisanja in je esej namesto primerjalnega problemskega premisleka prevečkrat postal povzemanje zgodb, ${ }^{18}$ potem je treba zapisati vsaj še naslednje. Ena od načelnih prednosti šolskega (maturitetnega) eseja in spodbuda siceršnjemu srednješolskemu pouku književnosti ni zgolj zahteva po tvorjenju celovitega besedila, korektnega na sinhroni in diahroni ravni jezika, prav tako ne samo sposobnost navajanja različnih faktografskih podatkov ob določenem tekstu, marveč predvsem izražanje specifǐnega individualiziranega odnosa. Slednje omogočajo možnosti selekcije in kombiniranja literarnozgodovinskega znanja, premišljeno branje del, samostojno oblikovanje hipoteze, postopek logične argumentacije, vzročno-posledično nizanje delnih zaključkov, smiselno upoštevanje danih meril, dalje sodbe o tipičnih avtorskih poetikah, upoštevanje zahtev, ki jih predpostavlja tema itd. Če tega ni ali če besedilo dosledno ne vpisuje osebne percepcije avtorja, potem je šolski esej dejansko zreduciran na »kontrolko« in maturitetni esej na »kontrolko kontrolk«. Tu pa se postavlja verjetno sploh temeljno vprašanje pouka nasploh. So okoliščine danes šolam sploh naklonjene, so spodbudne v tem smislu, da bi na njih lahko gradili učitelji in dijaki ter bi povprečen (tudi zrel) človek znanje sprejemal kot temeljno civilizacijsko poslanstvo in kulturno vrednoto, ali le samozadovoljno podpiramo mediokritete vseh vrst?

\section{Literatura}

Marijan DOVIĆ, 2003: Empirična literarna znanost in literarni sistem S. J. Schmidta. Slavistična revija, 51(3). 267-284.

Robert JEREB, 2009: Struktura in funkcija literarne kritike: Na primeru sodobnega slovenskega romana. Doktorska disertacija. FF UL.

Matjaž KMECL, 1974: Esej o deseniški Veroniki. S. Sitar: Z Desenic Veronika ₹ Desenic. Ljubljana: Partizanska knjiga.

Zvonko KOVAČ, 2018: Interpretacijski kao interkulturni kontekst. Jęike, knjižernosti, znanosti i medija. (ur. Kolar, Mario; Tkalec, Gordana; Kovač, Zvonko). Koprivnica: Sveučilište Sjever. 139-154.

Paula de MAN, 1979: Allegories of Reading: Figural Language in Rousseau, Nietzsche, Rilke and Proust. New Haven and London: Yale University Press.

Boris PATERNU, 2017: Pomen literature v mentalno iztirjenem svetu. Ljubljana: Delo 23. 5. 2017, 59/116. 9 .

Urška PERENIČ (ur.) 2017: Slavistična revija 65(1-2, tematski številki). Ljubljana: Slavistično društvo Slovenije.

\footnotetext{
${ }^{18}$ Moja kritičnost izhaja iz primerjave z esejem na mednarodni maturi in iz prepričanja, da bi si tudi povprečen, kaj šele odličen »domači« maturant zaslužil višje postavljene cilje.
} 
Urška PERENIČ, 2010: Empirično-sistemsko raziskovanje literature: Konceptualne podlage, teoretski modeli in uporabni primeri. Ljubljana: Zveza društev Slavistično društvo Slovenije.

Davor PISKAČ, 2009: Kako napisati esej na dř̌avnoj maturi. Zagreb: Alfa.

Denis PONIŽ, 1994: Šolski esej. Ljubljana: Sophia.

Voranc PREŽIHOV, 1964: Zbrano delo. Druga knjiga. Ljubljana: Državna založba Slovenije 


\section{ŠOLSKE KNJIŽNICE}

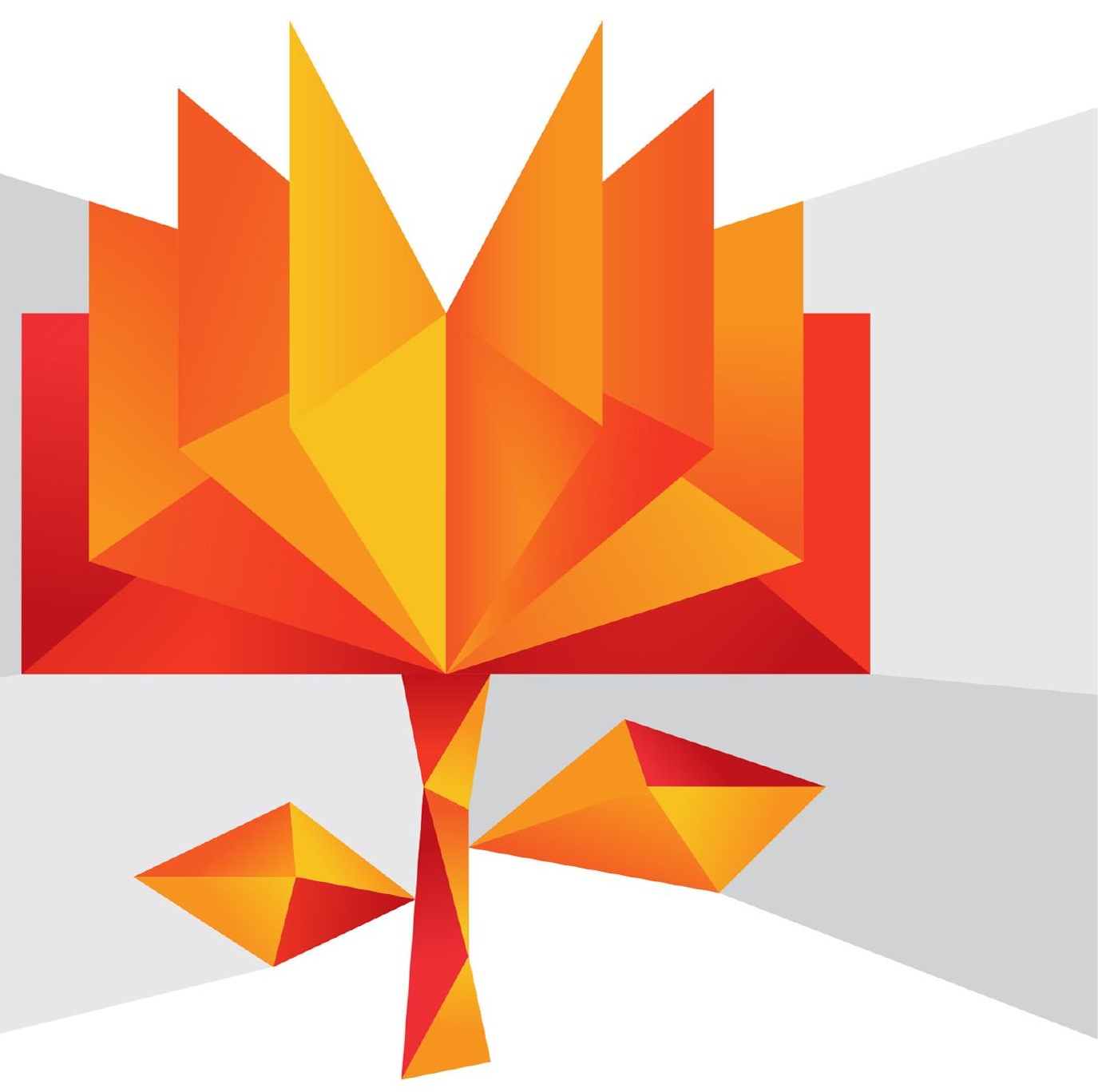





\title{
VLOGA ŠOLSKE KNJIŽNICE PRI RAZVOJU GRADNIKOV BRALNE PISMENOSTI
}

\author{
POLONA VILAR IN VLASTA ZabUKOVEC \\ Univerza v Ljubljani, Filozofska fakulteta, Ljubljana, Slovenija. \\ E-pošta: polona.vilar@ff.uni-lj.si,vlasta.zabukovec@ff.uni-lj.si
}

Povzetek V prispevku orišemo vlogo kakovostne šolske knjižnice v izobraževalnem procesu, zlasti pri razvoju gradnikov bralne pismenosti. Za vsak gradnik tudi predlagamo konkretne načine in področja, kjer se lahko vključuje kakovostna šolska knjižnica. $\mathrm{Na}$ to navezujemo tudi model kakovostne šolske knjižnice s sedmimi elementi, ki ga razumemo tudi kot usmeritve za razvoj slovenskih šolskih knjižnic: (1) dobri pogoji delovanja, (2) kompetenten knjižničar, (3) strategija razvoja, (4) prisotnost v zavesti deležnikov, pomembnost, nepogrešljivost, (5) aktivnost in dostopnost, (6) vključenost, integriranost, (6) nedvoumen in merljiv prispevek $\mathrm{k}$ znanju.

Ključne besede:
kakovostna
šolska
knjižnica,
izobraževalni
proces,
gradniki
bralne
pismenosti,
model
kakovostne
šolske
knjižnice,
elementi
modela.




\title{
SCHOOL LIBRARY ROLE IN THE DEVELOPMENT OF COMPONENTS OF READING LITERACY
}

\author{
POLONA VILAR \& VLASTA ZABUKOVEC \\ University of Ljubljana, Faculty of Arts, Ljubljana, Slovenia. \\ E-mail: polona.vilar@ff.uni-lj.si, vlasta.zabukovec@ff.uni-lj.si
}

Keywords:

quality

school

library,

educational

process,

components of

reading

literacy,

model of a

quality

school

library,

elements.

Abstract The paper describes the role of a quality school library in educational process, with emphasis on components of reading literacy. For each component we suggest in which ways and in which areas a quality school library can participate. We also include a model of a quality school library consisting of seven elements, which is also understood as a set of guidelines for further development of Slovenian school libraries: (1) good working conditions, (2) a competent librarian, (3) development strategy, (4) importance, indispensability, presence in the minds of stakeholders, (5) activity and approachability, (6) inclusiveness, integratedness, (7) visible and measurable contribution to

knowledge. 


\section{$1 \quad$ Uvod}

$\mathrm{V}$ prispevku smo orisali vlogo kakovostne šolske knjižnice $\mathrm{v}$ izobraževalnem procesu na predšolski in osnovnošolski stopnji, s poudarkom na njenem sodelovanju pri razvoju gradnikov bralne pismenosti. Osredotočili smo se na 2., 3., 7. in 9. gradnik, ki so najtesneje povezani s šolsko knjižnico, njenim delovanjem in gradivom, ter navedli konkretna področja in načine vključevanja šolske knjižnice. $\mathrm{Na}$ to smo navezali tudi osnutek modela kakovostne šolske knjižnice s sedmimi elementi in pogoji, ki morajo biti zagotovljeni za kakovostno delo: (1) dobri pogoji delovanja, (2) kompetenten knjižničar, (3) strategija razvoja, (4) prisotnost v zavesti deležnikov, pomembnost, nepogrešljivost, (5) aktivnost in dostopnost, (6) vključenost, integriranost, (6) nedvoumen in merljiv prispevek k znanju. Model kakovostne knjižnice in njegove elemente lahko razumemo tudi kot usmeritve za razvoj šolskih knjižnic v Sloveniji.

\section{Dinamična in kakovostna šolska knjižnica}

Dinamične in kakovostne šolske knjižnice imajo nepogrešljivo vlogo $\mathrm{v}$ procesu razvoja bralnih kompetenc, s svojim programom prispevajo k želenim učnim ciljem in boljšim učnim dosežkom, informacijske in bralne kompetence pa je potrebno razvijati od rane mladosti (Vilar in Zabukovec 2016, 2017, 2020, Knjižnica in medpredmetno povezovanje, 2010; Todd 2012). V tem prispevku osrednjo pozornost namenjamo pomenu in vlogi kakovostne šolske knjižnice pri razvoju gradnikov bralne pismenosti $\mathrm{v}$ kontekstu slovenskega izobraževalnega okolja. Naslanjamo se na spoznanja praktikov in teoretikov doma in v tujini (npr. Novljan, CISSL ...), glede vprašanj doprinosa kakovostne šolske knjižnice $\mathrm{k}$ učenju in poučevanju. Pri elementih kakovosti v šolski knjižnici so kot najpomembnejše prepoznali primerno usposobljenega in kompetentnega knjižničarja, kakovostno knjižnično zbirko in opremo knjižnice, ustrezno urejeno financiranje, promocijo knjižnice ter aktivno vključevanje knjižničarja ter knjižnice v pouk oziroma življenje in delo na šoli, za kar so potrebni ustrezno vzpostavljeni odnosi med knjižnico in strokovnimi delavci, vodstvom, starši itd. $\mathrm{V}$ pogosto citiranem Kurikulu za knjižnično informacijsko znanje (2008: 4) je šolska knjižnica opredeljena kot odprto informacijsko učno okolje, ki omogoča:

- učenje in poučevanje ter njuno fleksibilno prilagajanje potrebam posameznika in skupin; 
- razvijanje metod poučevanja in učenja (sodelovalno učenje, projektno in raziskovalno učenje, reševanje problemov, timsko poučevanje ...);

- medkulturnost $\mathrm{z}$ vsebino knjižnične zbirke in njeno dostopnostjo (dostopna je vsem učencem ne glede na starost, jezik, kulturo, vključno z učenci s posebnimi potrebami);

- skupno doseganje ciljev: ciljev posameznih predmetov in ciljev kroskurikularne teme;

- upravljanje $z$ informacijami;

- seznanjanje $z$ informacijsko komunikacijsko tehnologijo;

- razvijanje pismenosti, še posebej branja, pisanja in razvijanje bralne kulture;

- sodelovanje s starši, splošno knjižnico in drugimi dejavniki zunaj šolskega okolja.

Gre torej za prizorišče, kjer imajo uporabniki priložnost in možnost spoznavati ter uporabljati široko paleto virov informacij in navdiha ter se s tem učiti najti poti do rešitev problemov, novega znanja ali razvedrila, kar je še posebej pomembno $\mathrm{v}$ šolskem okolju. Seveda morajo biti pri tem vodeni in usmerjani s strani strokovnih delavcev, kar pomeni, da morajo biti tudi oni zelo dobro seznanjeni z vlogo in pomenom knjižnice ter ju pomagati uresničevati s svojim sodelovanjem s knjižnico in knjižničarjem ter vključevanjem obeh $\mathrm{v}$ pouk in ostalo delo in življenje na šoli. Novljanova je zapisala $(1996,2010)$, da kakovostna šolska knjižnica s kompetentnim šolskim knjižničarjem pomembno prispeva h kakovostnemu učenju in poučevanju. Knjižnica za ustvarjalno učenje prispeva informacije $\mathrm{v}$ treh dimenzijah (Novljan 2010: 15):

- kot stvari (predmet obdelave v informacijskih sistemih),

- kot proces (informiranje),

- kot znanje (osebno znanje, ki se spreminja).

$\mathrm{Na}$ te tri načine predstavljene informacije pomagajo graditi znanje o uporabi:

- informacijskih virov za namen pridobivanja ₹nanja (torej učenje),

- virov, ki razvijajo branje in druge sposobnosti s področja pismenosti,

- virov, ki razvijajo miselne sposobnosti in organizacijo dela. 
Novljanova (2010) tudi utemeljuje, da kakovostna šolska knjižnica pomaga tudi pri razvijanju mišljenja in ustvarjalnosti, saj so knjižnice pravzaprav najboljše učilnice za učenje z informacijskimi viri. V knjižnici in s knjižnico se razvija znanje o rabi virov, o učenju, o razvijanju bralne in drugih pismenosti, miselnih in socialnih sposobnosti. Tako knjižnica:

- spodbuja učenje in mu je v oporo s svojo zbirko knjižničnega gradiva in s storitvami, ki seznanjajo uporabnike tudi z informacijskimi viri zunaj knjižnice;

- daje možnosti za izbiro različnih poti (načinov, modelov) reševanja problemov in za trajno razvijanje sposobnosti in spretnosti, tudi z etičnim pogledom na posameznikovo in družbeno delovanje;

- je nepogrešljiva povezovalka ljudi, ved, vsebin, oblik, vsebin z obliko, spoznanja z etiko itd.

Kakovostna šolska knjižnica predstavlja pomembno partnerico v izobraževalnem procesu. Glede na to, da imamo v Sloveniji šolske knjižnice v izobraževalnem področju vzpostavljene na vseh ravneh, tudi v predšolski vzgoji, je nujen razmislek o podobi šolske knjižnice v očeh njenih uporabnikov, torej poleg učencev in dijakov, ki so sicer najštevilčnejši uporabniki, tudi (ali zlasti) strokovnih delavcev, vodstva, staršev, drugih informacijskih organizacij, družbe nasploh itd. S tem je namreč tesno povezana realizacija knjižničnega dela oziroma pogoji zanjo.

\section{$3 \quad$ Modela kakovostne šolske knjižnice}

Za predstavitev smo izbrali dva modela, ki sta vsak po svoje relevantna za prikazovanje pomembnih elementov in dejavnikov kakovosti šolske knjižnice. Prvi (Todd in Kuhlthau 2005) velja za enega pomembnejših in bolj celostnih modelov v svetovnem merilu (naslanja se tudi na temeljite empirične raziskave in poskuse implementacije $\mathrm{v}$ različnih delih sveta), pomemben je tudi zato, ker smo o njegovi uporabnosti v našem okolju že razmišljali in poročali (Vilar in Stričević 2014; Vilar in Zabukovec 2016, 2017; Zabukovec, Vilar in Fekonja 2020). Drugi izbrani model (Kovačević, Lasić-Lazić in Lovrinčević 2004) pa izhaja hrvaškega okolja, ki ga lahko neposredno primerjamo s slovenskim glede na mnoge dejavnike, kot sta ugotovili Vilar in Stričević (2014). 
1. Model kakovostne šolske knjižnice kot dinamičnega dejavnika učenja (Todd in Kuhlthau 2005: 6) (slika 1) povzemamo na kratko, podrobneje je predstavljen v Vilar in Zabukovec (2017). Govori o intelektualni in fizični infrastrukturi knjižnice in rezultatih njenega dela, kadar knjižnica deluje kot dinamični agent učenja. Tu nastopijo tri osnovne, medsebojno povezane in iterativne komponente:

2.

- informacijska (informational) - pri tem so $\mathrm{v}$ ospredju knjižnični in zunanji informacijski viri in informacijsko-komunikacijska tehnologija;

- učna (transformational) - to zlasti pomeni aktivnosti knjižnice glede učnih intervencij, iniciativ v zvezi z branjem in sorodnimi aktivnostmi ter druge spodbude za učence;

- oblikovalna (formational) - kar se navezuje na vpliv knjižnice na učenje in učne dosežke.

Model navaja tudi dva druga pomembna elementa: šolskega knjižničarja, ki deluje kot informacijski in učni strokovnjak ter partner-pobudnik v kurikulu, ter šolsko knjižñico, ki ni le informacijski, temveč tudi učni prostor.

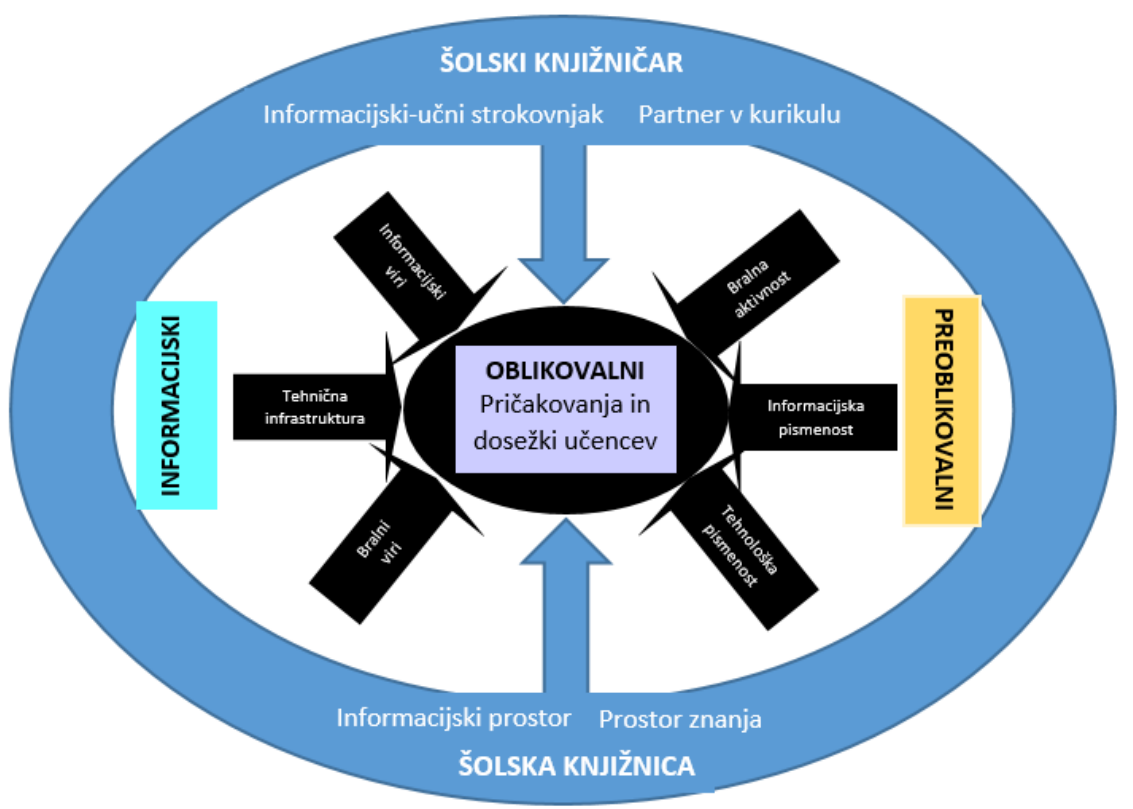

Slika 1: Prirejeni model šolske knjižnice kot dinamičnega dejavnika učenja (Vilar in Zabukovec 2017: 127) 
3. Model šolske knjižnice (Kovačević, Lasić-Lazić in Lovrinčević 2004) (slika 2) je še bolj ekspliciten, saj poskuša po eni strani prikazati, kam vse ter kako se lahko šolska knjižnica vključuje (desni del modela), po drugi strani pa, kaj vse je mogoče izvajati v šolski knjižnici (levi del modela), in je $\mathrm{v}$ tem delu pravzaprav zelo priročniški.

a) S šolsko knjižnico se povezujejo priprava pouka $\mathrm{v}$ smislu pedagoške priprave ter razmisleka o uporabi različnih informacijskih virov (učnih medijev), medpredmetno povezovanje, ki prinaša tudi razbremenitev učencev, ter sodelovanje in timsko delo z vsemi pomembnimi deležniki.

b) V šolski knjižnici (smiselno tudi $z$ viri, do katerih pomaga priti šolska knjižnica) je mogoče izvajati vse oblike usvajanja veščin informacijske pismenosti, pouka, dni dejavnosti, delavnic, projektov, pa tudi izdelovati didaktično gradivo.

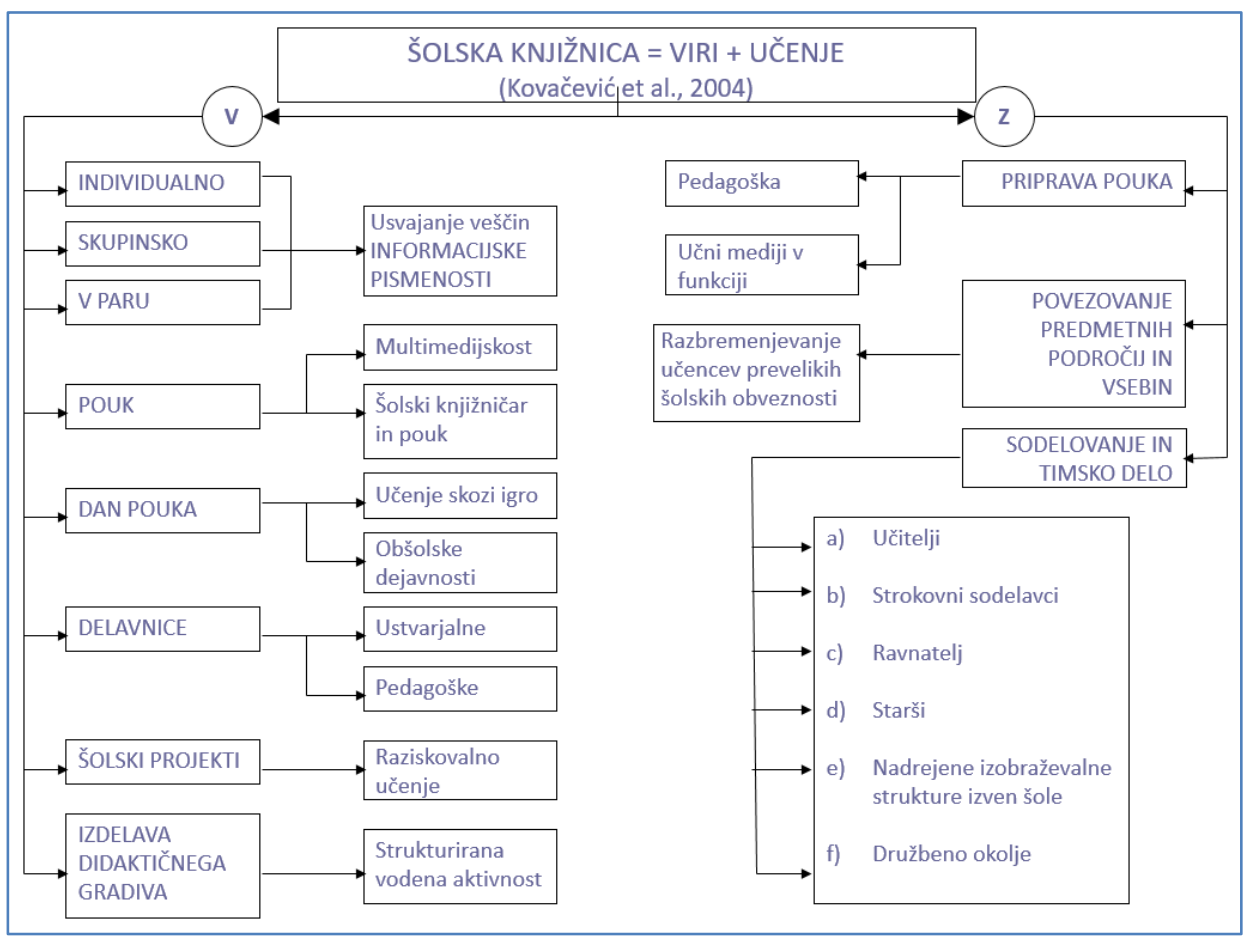

Slika 2: Model šolske knjižnice

(Kovačević, Lasić-Lazić in Lovrinčević 2004, priredila P. Vilar) 
V obeh primerih gre torej za modela, $\mathrm{v}$ katerih neposredno prepoznamo elemente, ki jih mora imeti zagotovljene šolska knjižnica, da lahko kakovostno izvaja svoje delo in naloge, pa tudi področja in načine dela, kamor se lahko vključuje s svojim delom.

\section{$4 \quad$ Kakovostna šolska knjižnica v vrtcu}

Vpliv kakovostne šolske knjižnice je zelo pomemben že $\mathrm{v}$ zgodnji dobi. V smislu razvijanja zgodnje pismenosti, ki je najpomembnejši temelj za razvoj bralne pismenosti, se tu lahko navežemo na tri najpomembnejše dejavnike njenega razvoja, kot jih definira IFLA (Jug in Vilar 2015; Haramija in Vilar 2017): spodbude za branje, bralni zgled ter obkroženost $\mathrm{z}$ bralnim gradivom. Pri spodbudah za branje gre za to, da odrasli otroku berejo in ga na različne načine spodbujajo k uporabi čim bolj raznolikega gradiva, skozi druženje pa tudi omogočajo pridobivanje pozitivnih izkušenj z branjem. Bralni zgled so otroku vsi odrasli, ki jih vidi, da sami berejo. Obkroženost $z$ bralnim gradivom pa pomeni ustvarjanje situacij in okolij, kjer je bralno gradivo stalno prisotno in samoumevno. Šolska knjižnica ima pri vseh lahko zelo pomembno vlogo: spodbude za branje izhajajo iz dobro založene in organizirane knjižnične zbirke ter knjižničnih aktivnosti, zlasti v sodelovanju s strokovnimi delavci, bralni zgled dobijo otroci, ko vidijo strokovne delavce, starše in druge pomembne odrasle, da berejo in uporabljajo prebrano, kakovostna, seveda tudi dobro urejena in prijetna knjižnica pa je najboljši način obkrožanja otrok z bralnim gradivom. $\mathrm{Na}$ ta način lahko knjižnica pomembno prispeva $\mathrm{k}$ doseganju učnih ciljev tudi $\mathrm{v}$ predšolskem obdobju, kar potrjujejo tudi študije (Kyung-Min 2015; Turbill 2001; Worthy, Moorman in Turner 1999).

Glede na strokovna in zakonska izhodišča $\mathrm{v}$ slovenskem šolskem knjižničarstvu (Pravilnik o pogojih za ižajanje knjižnične dejavnosti kot javne službe, 2003) šolske knjižnice delujejo tudi v vrtcu. Delovanje šolskih knjižnic v vrtcih sicer ni tako usmerjano in regulirano, kot je to v primeru osnovne in srednje šole, a vendarle deluje razmeroma dobro vsaj v tistih primerih, kjer je vrtec pridružen osnovni šoli in je torej knjižnica skupna obema. Zabukovec, Vilar in Fekonja (2020) opozarjajo na pomanjkljiv sistemski pristop in nezadostno prisotnost knjižnice $\mathrm{v}$ vrtcu zlasti tam, kjer vrtec ni skupaj z osnovno šolo. Njihove ugotovitve nakazujejo, da so knjižnice v vrtcu večinoma vodene s strani vzgojiteljic, ki za to delo seveda niso dovolj usposobljene. Knjižnice niso na voljo ves čas, ko je vrtec odprt, precej pogosto pa jih lahko uporabljajo le vzgojiteljice, kar pomeni, da otroci nimajo neposrednega stika s knjižnico. Glede knjižnične dejavnosti so ugotovile, da sta interna izposoja 
(najpogosteje vzgojiteljicam) in glasno branje otrokom pogosta, nekatere druge uporabniško usmerjene dejavnosti pa so redke (poučevanje o IT, ustvarjalne dejavnosti, izposoja na dom), zato tudi razvoj veščin multimodalne pismenosti ni dobro podprt. Vzgojiteljice sicer menijo, da je knjižnica dovolj vključena, je pa raziskava zaznala skoraj popolno odsotnost sodelovanja s šolskimi knjižničarji pobuda, načrtovanje, izvajanje in vrednotenje vzgojno-izobraževalnega dela, povezanega $\mathrm{z}$ branjem in knjižnico, je namreč $\mathrm{v}$ celoti področje vzgojiteljic.

V tem smislu in ob dejstvu, da je v vrtcih veliko bolj kot šolska knjižnica pogosta prisotnost bralnega gradiva $\mathrm{v}$ igralnicah oziroma njihovih knjižnih kotičkih, je zelo relevantno razmišljanje Haramije $(2017,2019,2020)$ o ogromnem pomenu dobro organiziranih in založenih knjižnih kotičkov v igralnicah. Utemeljuje, da knjižni kotički omogočajo intenzivno izpostavljenost otrok najrazličnejšemu bralnemu gradivu, pridobivanje izkušenj z bralnim gradivom in razvoj predbralnih in bralnih kompetenc (poslušanje, gledanje, branje, pripovedovanje), ob tem spoznavanje odraslega kot bralnega zgleda, pa tudi stik z gradivom in knjižničnimi dejavnostmi (izposoja). Namen knjižnih kotičkov je torej spodbujanje otrokovih dejavnosti, povezanih s knjigo, individualizacija in omogočanje dostopnosti kakovostne literature v vsakem trenutku (leposlovja, informativne (poučne) literature, otroške periodike). Knjižni kotiček je prostor, kjer otroci lahko sami segajo po gradivu in ga prosto izbirajo, vsebuje kakovostno gradivo, ki je smiselno povezano z drugimi dejavnostmi $\mathrm{v}$ vrtcu ter se tudi periodično in smiselno menjava. Izbor gradiv za bralni kotiček je izjemno pomemben, saj mora imeti otrok stik z raznolikim bralnim gradivom, torej z leposlovjem in informativno (poučno) literaturo, da bi razvil zavedanje o pomenu branja na vseh področjih dejavnosti (jezik, matematika, gibanje, umetnost, naravoslovje, družboslovje) in na vseh področjih otrokovega razvoja (kognitivnem, socialnem, čustvenem, estetskem, moralno-etičnem in motivacijskem področju). Haramija (2020) tudi predlaga kriterije izbora gradiva (kar je podrobneje predstavljeno v uvodnem poglavju Haramija in Ivanuš Grmek), gre za kakovostne in vsebinske kriterije izbora leposlovnih in informativnih gradiv. S knjižnimi kotički imajo, kot ugotovljeno, večinoma stik vzgojiteljice in žal ne knjižničarji, zato bi bilo dobro tudi v vrtcu vzpostaviti njihovo sodelovanje, ne le na ravni oblikovanja zbirke, temveč tudi pri dejavnostih vrtca. 


\section{$5 \quad$ Vloga šolske knjižnice pri razvoju gradnikov bralne pismenosti}

Med devetimi gradniki bralne pismenosti se zdijo nekateri bolj neposredno povezani s knjižnico, drugi morda vsaj na prvi pogled manj. $V$ tem poglavju izpostavljamo tiste, ki so najbolj neposredno povezani $z$ gradivom in viri ter delom $z$ informacijami, s tem pa s knjižnico in delom šolskega knjižničarja. Vendar je pomembno, da je šolska knjižnica in z njo šolski knjižničar venomer vpeta $\mathrm{v}$ življenje in delo šole ter da tudi strokovni delavci (med katerimi je šolski knjižničar) venomer aktivno iščejo možnosti za medsebojno sodelovanje in povezovanje ter skozenj razvijajo kakovostne pedagoške pristope. Ti so zlasti povezani s spoznavanjem različnih vrst bralnega gradiva in informacijskih virov glede na namen branja, formatov gradiva in virov (tiskani, digitalni, multimedijski itd.), bralnih in informacijskih lokacij in prizorišč vrednotenjem virov ter njihovo kritično, pa tudi etično uporabo, vse pa se povezuje tudi z različnimi spodbudami za branje. Gre za tim strokovnih delavcev, v katerem knjižničar igra vlogo povezovalca in koordinatorja (Kuhlthau, Maniotes in Caspari 2012). Pri kakovostnem pouku ter $\mathrm{v}$ kakovostnem sodelovanju med učiteljem in šolskim knjižničarjem je nedvomno mogoče najti povezave $z$ vsemi gradniki, saj vloga šolske knjižnice ni le v njeni neposredni povezavi z učenci, temveč tudi z drugimi udeleženci vzgojno-izobraževalnega procesa. Govorimo na primer tudi o oskrbi strokovnih delavcev in drugih uporabnikov knjižnice s kakovostnim in s kurikulom povezanim gradivom in viri, informiranju, pomoči pri pripravi na pouk, pripravi učnih gradiv ipd.

Vlogo šolske knjižnice pri razvoju posameznih gradnikov lahko torej prepoznamo na naslednje načine:

\section{1 Šolska knjižnica in 2. gradnik: Motiviranost za branje}

Pri tem gradniku sta $\mathrm{v}$ ospredju zbujanje interesa za branje in razvoj pozitivnega odnosa do različnih vrst besedil in informacijskih virov. Na to se navezujejo bralčeva samopodoba oziroma bralna samoučinkovitost, interes za izbiro besedil in virov glede na namen branja ter uporaba različnih lokacij bralnih virov. To pomeni spodbude v smislu spoznavanja branja kot prijetne in koristne aktivnosti, ki bralcu predstavlja užitek in razvedrilo, pomaga pa mu tudi priti do idej in rešitev za njegove šlske in osebne izzive in cilje. S tem je povezan tudi interes za izbiro primernih besedil in virov glede na bralčev namen, kar je povezano tudi z interesom za iskanje in lociranje. 
Če citiramo Novljanovo (2010), je ravno šolska knjižnica najboljša učilnica za spoznavanje različnih vrst gradiva in virov ter prizorišč branja in lokacij informacij za različne namene. Tu se šolska knjižnica vključuje v smislu seznanjanja z različnimi vrstami besedil in različnimi viri ter formati, omogočanja različnih informacijskih in bralnih situacij in izkušenj z besedili, nudenja različnih bralnih in informacijskih prizorišč. Pomembno je tudi upoštevanje različnih uporabnikov, njihovih značilnosti in interesov (npr. dečki, uporabniki z oviranostmi in primanjkljaji), od katerih vsak zahteva svojevrstne in prilagojene pristope in obravnavo.

\section{2 Šolska knjižnica in 3. gradnik: Razumevanje koncepta bralnega gradiva}

Elementi tega gradnika so seznanjanje $\mathrm{z}$ orientacijo $\mathrm{v}$ bralnem gradivu, povezovanje besednega in slikovnega dela $\mathrm{v}$ besedilu, poznavanje in obvladovanje smeri branja, spoznavanje in celostno branje multimodalnih besedil, pa tudi seznanjanje $\mathrm{z}$ različnimi formati (npr. spoznavanje tiskanih in digitalnih gradiv).

Šolska knjižnica ravno zaradi svoje kakovostne zbirke gradiva in informacij nudi najboljše možnosti tako otrokom kot tudi strokovnim delavcem, da lahko izbirajo med raznolikimi informacijskimi in bralnimi viri, v sodelovanju med strokovnimi delavci in knjižničarjem pridobivajo izkušnje $z$ njimi ter skoznje razvijajo različne pismenosti (bralno, informacijsko, vizualno, multimodalno itd.).

\section{3 Šolska knjižnica in 7. gradnik: Razumevanje besedil}

Gradnik ima morda celo nekoliko preozko poimenovanje, saj ne gre zgolj za razumevanje, temveč tudi uporabo prebranega. Njegovi elementi se dotikajo tvorjenja ustreznih in smiselnih govorjenih in pisnih besedil o prebranem gradivu, uporabe prebranega $\mathrm{v}$ novih situacijah ter razvijanja veščine pisanja ustreznih besedil glede na okoliščine in zahteve.

Šolska knjižnica se tu vključi z zagotavljanjem zgledov in primerov v svoji zbirki in širše tako za strokovne delavce kot tudi za učence, s pripravo ali pomočjo pri pripravi navodil za pripravo pisnih izdelkov in predstavitev, plakatov ipd. (struktura, dolžina oziroma obseg, elementi), s pomočjo pri poučevanju in učenju povzemanja, parafraziranja, ubesedenja, tvorjenja vprašanj, oblikovanja besedišča, nastopanja in predstavljanja. Gre za pomoč in sodelovanje knjižničarja s strokovnimi delavci pri 
pripravi na pouk, izboru in pripravi učnih gradiv, vrednotenju/ocenjevanju znanja, vrednotenju poučevanja itd., z učenci pa pri učenju, pripravi izdelkov, zadolžitev, domačih nalog, predstavitev itd. Šolska knjižnica nudi tudi raznolike možnosti za ustvarjanje različnih besedil. V sodelovanju s strokovnimi delavci gre za neposredno sodelovanje pri pouku, šolski knjižničar pa lahko v knjižnici tudi samostojno dela z učenci ob pouku in drugih obšolskih dejavnostih.

\section{4 Šolska knjižnica in 9. gradnik: Kritično branje}

Tudi deveti gradnik se tesno dotika šolske knjižnice in knjižničarja, saj prav skozi pridobivanje izkušenj z branjem in ustvarjanjem posameznik razvija zmožnosti za prepoznavanje, presojanje, vrednotenje sporočilnosti, dejstev in stališč v besedilu, avtorjevega načina pisanja, oblikovanje lastnega mnenja z utemeljevanjem, presojanje glede na dane kriterije, postavljanje kriterijev za kritično vrednotenje besedil in kritično uporaba virov.

Šolska knjižnica je zgled in priložnost za učenje razvrščanja in kategoriziranja virov in informacij. Skozi uporabo gradiva in informacij posameznik razvija kritičen odnos do prebranega oz. do pridobljenih informacij (npr. prepoznavanje lažnih novic). Kritičen odnos do prebranega, do poiskanih informacij, pa tudi temeljit razmislek glede njihove ponovne uporabe so med pomembnimi učnimi cilji pri informacijskem opismenjevanju, zelo pomembno vlogo ima tudi etičnost pri uporabi gradiva in informacij.

\section{Osnutek modela kakovostne šolske knjižnice v slovenskem prostoru}

Razmisleki o vključevanju šolske knjižnice pri razvoju gradnikov bralne pismenosti nam dajejo tudi osnovo za razmisleke o nadaljnjem razvoju šolskih knjižnic, zlasti seveda na Slovenskem. Ta razvoj seveda sooblikujejo dogajanja $\mathrm{v}$ šolskem knjižničarstvu po svetu, v izobraževanju nasploh, seveda tudi družbena, strokovna in zakonodajna situacija pri nas. Zgornji razmisleki, pa tudi nekateri empirični podatki o stanju šolskih knjižnic v Sloveniji, zbrani z naše strani ter s strani pristojnih institucij (prispevek o tem je v pripravi na objavo), in drugi zaključki, ki so nastali $\mathrm{v}$ projektu OBJEM, ${ }^{1}$ so vplivali na oblikovanje osnutka modela kakovostne šolske knjižnice v slovenskem okolju, ki ga navajamo v nadaljevanju.

${ }^{1}$ Dostopno na: https://www.zrss.si/objava/projekt-objem. 


\subsection{Izhodišča}

Ugotovitve v projektu OBJEM (Zabukovec in Vilar 2018) kažejo, da je za vzpostavitev kakovostne knjižnice potrebno:

1. Izboljšati sodelovanje med šolsko knjižnico/šolskim knjižničarjem in strokovnimi delavci v šoli in vrtcu, da vsako leto izpelje nove povezave s KIZ, da poišče možnosti za vzpostavljanje stikov na drugačni ravni kot običajno.

2. Okrepiti oz. posodobiti promocijo šolske knjižnice znotraj šole, njene dejavnosti in možnosti, ki jih nudi - predvsem promocija med strokovnimi delavci in vodstvom; npr. knjižničar naj pripravi akcijski načrt, vezan na konkretno šolo in situacijo, $\mathrm{v}$ katerem predvidi korake (npr. predstavitev knjižnice na pedagoški konferenci, osebni stiki knjižničarja z drugimi strokovnimi delavci, izdelava izjave o poslanstvu ŠK, načrt nove vloge ŠK na šoli ...).

3. Okrepiti oz. posodobiti zunanjo promocijo šolske knjižnice in s tem vplivati na spreminjanje zaznavanja šolske knjižnice s strani zunanjih deležnikov (starši, odločevalci, knjižničarska stroka in strokovna združenja, splošna javnost).

4. Okrepiti možnosti za ozaveščanje o pomenu in vlogi bibliotekarske stroke (vodstva, sodelavcev); npr. vzpostaviti redna srečanja knjižničarjev z ravnateljem, knjižničarjevo udeleževanje pedagoških konferenc (kjer to še ni praksa) in drugih sestankov.

5. Izboljšati/razjasniti zakonodajni okvir, $\mathrm{v}$ katerem delujejo šolski knjižničarji (norme, status, pogoji ...); to sicer ni domena posameznega knjižničarja, a se stvari že dogajajo na ravni MIZŠ/NUK (delovni skupini za spremembo pravilnika in za strategijo ŠKK).

6. Okrepiti možnosti za strokovno izpopolnjevanje šolskih knjižničarjev, npr. usposabljanja za knjižničarje in/ali strokovne delavce (vključno z izboljšanjem možnosti, da se jih res tudi lahko udeležijo); možne teme: kompleksnejši segmenti informacijske pismenosti, IKT in spletne teme, timsko (sodelovalno) poučevanje, medpredmetno poučevanje, učbenik kot vzvod za izgradnjo knjižnične zbirke, navezovanje odnosov s sodelavci, veščine nastopanja, usposabljanja za ureditev knjižničnega prostora, za nove vrste gradiva in storitev (v povezavi z IKT itd.).

7. Izboljšati prostorske in materialne možnosti knjižnic, več knjižničarjevega vpliva na finančna sredstva, npr. izvzetje sredstev za knjižnico iz materialnih sredstev šole in vzpostavitev samostojnega knjižničnega ,stroškovnega mesta $a$. 
8. Razmisliti o možnostih in načinih, kako knjižnico bolj in predvsem bolj redno vključiti $\mathrm{v}$ življenje in delo vrtca, kar med drugim vključuje tudi ozaveščanje, izobraževanje in usposabljanje vzgojiteljev, vodstev vrtcev, pa tudi šolskih knjižničarjev.

9. Razmisliti, kako izboljšati sodelovanje in povezovanje vzgojiteljev s knjižničarji, ki bi vključevalo skupno načrtovanje, izvajanje ter vrednotenje dejavnosti s ciljem stalnega napredka.

10. Razmisliti, kako bi izboljšali prostorske, materialne, kadrovske in druge razmere knjižnic $\mathrm{v}$ vrtcih, npr. glede gradiva, sistematičnega in načrtnega dela. Tudi za to je potrebna prilagoditev zakonodajnega okvirja in predpisov.

11. Za knjižnice $\mathrm{v}$ vrtcih bi morali biti zadolženi ter $\mathrm{v}$ njih delati kvalificirani šolski knjižničarji, ne pa vzgojitelji; a je potrebno, da se knjižničarjem to delo ustrezno prizna in ovrednoti, kar pomeni ustrezno prilagoditev zakonodajnega okvirja in predpisov.

12. Razmisliti o kakovostnejših, raznovrstnejših in pogostejših knjižničnih dejavnostih znotraj vzgojno-izobraževalnega dela, ki bi vključevale bolj raznovrstno gradivo, naslavljane različne pismenosti (predbralno, bralno, multimodalno, družinsko itd.) ter vključevale tudi druge otrokom pomembne osebe (npr. starše).

13. Razviti načrtno in sistematično zbiranje kvantitativnih in kvalitativnih podatkov o delu šolskih knjižnic, ki bi zagotavljalo neprestano spremljanje stanja in identifikacijo izzivov.

Pomembno je tudi, da v skladu z zakonom o knjižničarstvu res vsaka knjižnica oblikuje strategijo svojega razvoja in da je ta integralni del strategije razvoja zavoda, v katerega sodi. To je v skladu z zakonodajnimi in strokovnimi spremembami, med katere sodi tudi najnovejši slovenski prevod druge izdaje smernic IFLA za šolske knjižnice (2019).

\subsection{Osnutek modela kakovostne šolske knjižnice in njegovi elementi}

Vse te ugotovitve so vtkane $\mathrm{v}$ osnutek modela kakovostne šolske knjižnice, ki prispeva $\mathrm{k}$ učenju in znanju (slika 3). V njem je prisotnih sedem med seboj povezanih in prepletenih elementov, ki vplivajo drug na drugega in skupaj tvorijo celoto kakovostne šolske knjižnice $\mathrm{v}$ slovenskem okolju. Za nekatere lahko rečemo, da so že precej uveljavljeni v teoriji in praksi, drugi pa potrebujejo temeljite razmisleke, podporo $\mathrm{v}$ zakonskih, teoretičnih in praktičnih izhodiščih, vstop $\mathrm{v}$ zavest 
knjižničarske in izobraževalne stroke ter splošne javnosti in podobno. Seveda je za to potrebno razviti mnogo orodij in pristopov, bi se pa s tem pričele zmanjševati velike razlike med šolskimi knjižnicami, ki jih ugotavljajo zadnje raziskave (Škufca 2019). Kakovostna šolska knjižnica v slovenskem okolju ima torej naslednje povezane in soodvisne elemente.

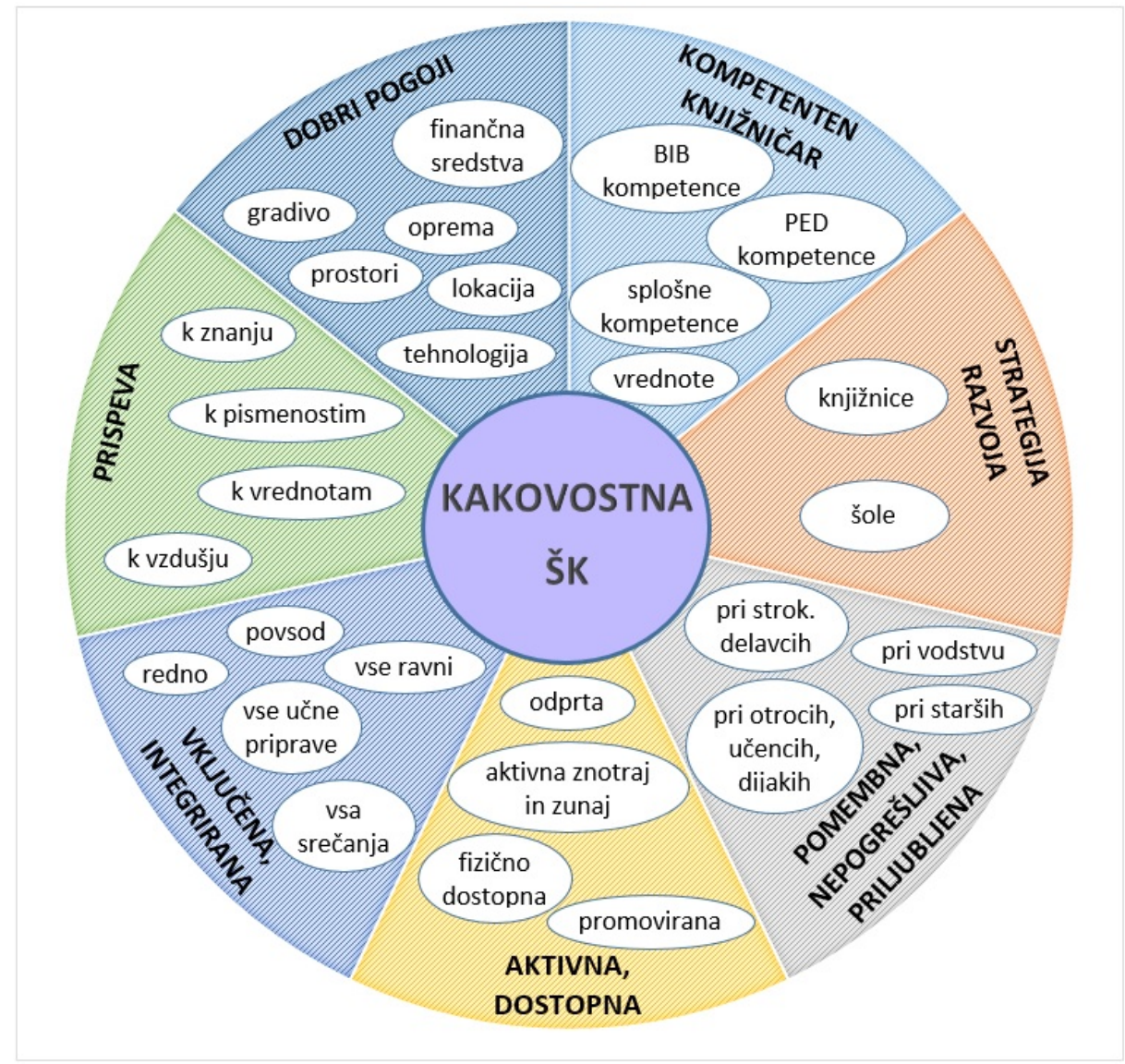

Slika 3: Model kakovostne šolske knjižnice v slovenskem okolju

\subsubsection{Dobri pogoji delovanja}

Knjižnica mora imeti za svoje kakovostno delovanje nujno izpolnjene osnovne pogoje delovanja, kot so urejeno, pregledno in zanesljivo financiranje, s čimer se zagotavlja kakovostno, ažurno, ustrezno knjižnično gradivo v ustreznem obsegu, ustrezno locirane, dostopne ter ustrezne prostore, sodobno opremo in tehnologijo. 
V slovenskem prostoru je glede na ugotovitve (Škufca 2019) pri mnogih knjižnicah to nujno potrebno urediti, kajti gre za nujno osnovo, brez katere kakovostno delo ni mogoče.

\subsubsection{Kompetenten knjižničar}

Kompetenten šolski knjižničar je naslednji pomemben element kakovostne šolske knjižnice - kompetence obravnavajo številni kompetenčni modeli (glej npr. Zabukovec in Steinbuch 2010; Zabukovec 2014), ki poudarjajo knjižničarjeve bibliotekarske, pedagoške in splošne kompetence ter vrednote. $\mathrm{V}$ zadnjih letih na tem področju opažamo nedvomen napredek, ki je posledica sprememb in prizadevanj $\mathrm{v}$ zakonskem ter strokovnem polju, in upati je, da se soglasje o kompetentnosti šolskega knjižničarja kmalu prenese tudi $\mathrm{v}$ zavest njegovih strokovnih sodelavcev, vodstva, učencev ter zunanjih uporabnikov. Je pa za vzpostavljanje svoje podobe $\mathrm{v}$ očeh uporabnikov odgovoren tudi sam knjižničar. Res je tudi, da na njegovo delo močno vpliva organizacija dela na šoli, odnos vodstva, seveda pa tudi normativi in določbe, ki določajo vsebino in obseg njegovega dela. Izzivi so zahtevni, zlasti ob dejstvu, da ima le peščica slovenskih šolskih knjižnic več kot enega strokovnega delavca, pogosto celo manj kot enega.

\subsubsection{Strategija razvoja}

Kakovostna šolska knjižnica naj ima pripravljen strateški načrt, ta pa mora biti vključen v strateški načrt šole oziroma zavoda. Strateški pogled v prihodnost je pomemben za razvoj vsake knjižnice, izhajati pa mora iz trenutnega stanja. Oboje po razpoložljivih podatkih spada med težavnejša področja šolskega knjižničarstva na Slovenskem, morda tudi širše. Potrebno je tudi poudariti, da zakon o knjižničarstvu zahteva od vsake knjižnice, da pripravi strateški načrt svojega razvoja in da se ta načrt umesti v strateški načrt razvoja šole. Zato je potrebno opremiti knjižničarje z znanji za ugotavljanje značilnosti svojega okolja ter uporabnikov, pa tudi za merjenje kakovosti in načrtovanje knjižničnega dela. Pri tem, pa tudi pri zagotavljanju kakovostnih podatkov imajo veliko vlogo tudi strokovne organizacije (npr. nacionalna knjižnica s svojimi nacionalnimi pregledi stanja, resorno ministrstvo $\mathrm{s}$ pripravo nacionalne strategije razvoja šolskih knjižnic ...). 


\subsubsection{Prisotnost v zavesti deležnikov, pomembnost, nepogrešljivost}

Šolska knjižnica je kakovostna, če se aktivno in dinamično vključuje v življenje in delo šole, če se vsi akterji zavedajo njenega pomena, če je pri njih priljubljena in jo zaznavajo kot nepogrešljivo. To so zlasti otroci, učenci oziroma dijaki ter strokovni delavci kot najpogostejši uporabniki in ciljne skupine, nujno tudi vodstvo zavoda, pomembni pa so tudi starši. To je med drugim pomembno tudi zato, ker ustvarja pozitivna pričakovanja uporabnikov do knjižnice. Vendar se je treba zavedati, da odgovornosti za ustvarjanje teh pričakovanj ne moremo v celoti prenašati zgolj na uporabnike - pri tem ima namreč pomembno vlogo tudi knjižničar.

\subsubsection{Aktivnost in dostopnost}

Šolska knjižnica je kakovostna, kadar je aktivna in dostopna. To se kaže v njeni odprtosti med poukom, pred poukom in po njem, v njeni fizični dostopnosti, kar vključuje tako lokacijo knjižnice na šoli kot tudi njen prostor, v njeni aktivnosti znotraj in izven knjižničnih prostorov (vključno z virtualnimi vrstami dostopnosti). $\mathrm{Na}$ vse to pa se navezuje tudi aktivna notranja in zunanja promocija knjižnice.

\subsubsection{Vključenost, integriranost}

Šolska knjižnica je kakovostna, kadar je tesno in redno vključena oziroma integrirana $\mathrm{v}$ vse življenje in delo šole (Vilar 2014). To se kaže z uporabo njenega gradiva in virov, prostora, tehnologije, knjižničarja v sleherno aktivnost, ki se dogaja na šoli oziroma v zavodu in to na vseh ravneh, v vseh oddelkih, razredih in letnikih. Kaže se $\mathrm{z}$ vključenostjo šolske knjižnice $\mathrm{v}$ učne priprave in načrtovanje vzgojnoizobraževalnega dela. Na tak način šolska knjižnica postane v zavesti vseh deležnikov nepogrešljiv del šolskega dela in življenja. Pomeni tudi, da je šolski knjižničar del strokovnega kolektiva in prisoten na strokovnih srečanjih, srečanjih aktivov, pedagoških konferencah in podobno.

\subsubsection{Nedvoumen in merljiv prispevek k znanju}

Šolska knjižnica je kakovostna, kadar je njen prispevek k učenju in znanju, pismenostim, vrednotam, vzdušju nedvoumno prepoznan ter merljiv. Za to morajo biti sicer vzpostavljeni jasni kriteriji in pristopi, ki pa se, podobno kot pri nastajanju strategije razvoja, zopet povezujejo z znanji in kompetencami knjižničarjev za 
ugotavljanje značilnosti uporabnikov, raziskovanje, merjenje kakovosti ipd., pa tudi aktivnostjo in prepoznavnostjo knjižnice. Jasna prepoznavnost in nedvoumen prispevek namreč omogočata uveljavljanje knjižnice kot pomembnega deležnika vzgojno-izobraževalnega dela. Gre seveda za mehka področja, kjer je ugotavljanje vpliva zgolj enega dejavnika nedvomno zelo zahtevno. Vendar se področje merjenja vpliva knjižnice na njeno okolje $\mathrm{v}$ zadnjem času intenzivno razvija, kar se lahko $\mathrm{s}$ pridom uporabi tudi na področju šolskega knjižničarstva.

\section{$7 \quad$ Sklep}

Kakovostna šolska knjižnica ima pomembno vlogo in pomen v izobraževalnem procesu na predšolski in osnovnošolski stopnji. $V$ prispevku prikažemo vključevanje kakovostne šolske knjižnice pri razvoju gradnikov bralne pismenosti, s poudarkom na gradnikih, ki so najtesneje povezani s šolsko knjižnico, njenim delovanjem in gradivom. V kontekstu vsakega gradnika so navedeni konkretni načini vključevanja in sodelovanja ter dela $\mathrm{z}$ gradivom in informacijami.

Skozi v poglavju 3 predstavljeni osnutek modela kakovostne šolske knjižnice identificiramo pomembne elemente in pogoje za njeno kakovostno delo: (1) dobri pogoji delovanja, (2) kompetenten knjižničar, (3) strategija razvoja, (4) prisotnost v zavesti deležnikov, pomembnost, nepogrešljivost, (5) aktivnost in dostopnost, (6) vključenost, integriranost, (6) nedvoumen in merljiv prispevek k znanju. Vsi so med seboj povezani in soodvisni.

Model kakovostne knjižnice in njegove elemente, ki se naslanja na obstoječe modele in strokovna izhodišča, lahko razumemo tudi kot usmeritve za razvoj šolskih knjižnic $\mathrm{v}$ Sloveniji. Razmislek, ki iz njih izhaja in je zelo aktualen $\mathrm{v}$ slovenskem izobraževalnem prostoru, je »Kako se šolska knjižnica $v$ slovenskem prostoru vključuje v pouk oziroma vzgojno-izobraževalno delo?«, možna podvprašanja pa so:

- Kakšno podobo ima knjižnica $v$ očeh strokovnih delavcev? Kakšna je ta podoba $\mathrm{v}$ očeh vodstva šole? Kaj o knjižnici menijo drugi deležniki (npr. starši, druge organizacije, odločevalci)?

- Koliko/kako strokovni delavci s knjižnico sodelujejo? Kakšni dejavniki vplivajo na to sodelovanje? 
- Koliko/kako strokovni delavci knjižnico uporabljajo? In $\mathrm{v}$ tem kontekstu zelo aktualen razmislek o tem, kakšen bralni zgled predstavljajo odrasli za mlade.

$\mathrm{V}$ prispevku seveda ne razrešujemo teh vprašanj, saj to presega njegov namen, ponujamo pa nekaj razmislekov, ki jih odslikava osnutek modela kakovostne šolske knjižnice. Tega je potrebno implementirati ter preizkusiti ter ga bomo nedvomno še preverjali in dopolnjevali.

Morda se zdi, kot da pri elementih kakovostne šolske knjižnice in njihovih značilnostih navajamo seznam želja. Vendar gre za mnogo elementov, ki so že danes prisotni pri mnogih kakovostnih šolskih knjižnicah v Sloveniji. Kakovost šolske knjižnice, ki prispeva $\mathrm{k}$ znanju, pismenostim in vrednotam, je povezana $\mathrm{s}$ financiranjem, izobraževanjem, kadrovanjem, ozaveščanjem, zagovorništvom in promocijo, družbenim ugledom in položajem knjižničarstva. Vse to pa je vzajemno povezano z možnostmi za njeno vključevanje in doprinos h kakovosti vzgoje in izobraževanja.

\section{Opombi}

Avtorica Polona Vilar je prispevek napisala v okviru projekta OBJEM - Bralna pismenost in razvoj slovenščine (Ozaveščanje, Branje, Jezik, Evalvacija, Modeli), šifra projekta OP20.01462, vodja dr. Sandra Mršnik, ki ga vodi Zavod RS za šolstvo: Naložbo sofinancirata Republika Slovenija in Evropska unija iz Evropskega socialnega sklada.

Avtorica Vlasta Zabukovec je prispevek napisala v okviru projekta OBJEM - Bralna pismenost in razvoj slovenščine (Ozaveščanje, Branje, Jezik, Evalvacija, Modeli), šifra projekta OP20.01462, vodja dr. Sandra Mršnik, ki ga vodi Zavod RS za šolstvo: Naložbo sofinancirata Republika Slovenija in Evropska unija iz Evropskega socialnega sklada.

\section{Literatura}

Dragica HARAMIJA, 2017: Uvod. Bralna pismenost v predšolski vaggoji in iæ̌obraževanju. Ur. Dragica Haramija Maribor: Univerzitetna založba Univerze. 1-5.

Dragica HARAMIJA, 2019: Spodbujanje družinskega branja v otrokovem predšolskem obdobju: Predšolska bralna značka. Slavia Centralis 12(2). 33-45.

Dragica HARAMIJA, 2020: Knjižni kotički v urtcih. PPT v okviru projekta OBJEM.

Dragica HARAMIJA in Polona VILAR, 2017: Bralna kultura kot pomemben dejavnik razvoja bralne pismenosti. Otrok in knjiga 44(98). 5-16.

IFLA Smernice za šolske knjižnice, 2015. 2. dopolnjena izdaja. The Hague, IFLA. https://www.ifla.org/files/assets/school-libraries-resource-centers/publications/iflaschool-library-guidelines-sl.pdf

Tjaša JUG in Polona VILAR, 2015: Focus group interview through storytelling : researching preschool children's attitudes towards books and reading. Journal of Documentation 71(6). 13001316. 
Dinka KOVAČEVIĆ, Jadranka LASIĆ-LAZIĆ, Jasmina LOVRINČEVIĆ, 2004: Školska knjižnica korak dalje. Zagreb: Filozofski fakultet, Zavod za informacijske studije, Odsjeka za informacijske znanosti.

Carol C. KUHLTHAU, Leslie K. MANIOTES in Ann K. CASPARI, 2012: Guided inquiry design: a framework for inquiry in your school. Santa Barbara: Libraries Unlimited.

Kurikul Knjižnično informacijsko znanje, 2008. Ljubljana, MIZŠ. http://portal.mss.edus.si/msswww/programi2016/programi/media/pdf/ucni_nacrti/K_K NJIZN_INF_ZNANJE_gimn.pdf

Lee KYUNG-MIN, 2015: The effects of book buddy program connecting kindergarten and elementary school on prosocial behavior and reading attitude of 2 nd graders. Journal of research in curriculum and instruction 19(1). 219-238.

Silva NOVLJAN, 2010: Knjižnica in medpredmetno povezovanje. Posodobitve pouka v gimnazijski praksi. Knjižnično informacijsko żnanje. Ur. Majda Steinbuch. Ljubljana: Zavod RS za šolstvo. 92 102.

Silva NOVLJAN, 1996: Sodobne dejavnosti šolske knjižnice s posebnim ozirom na njene bibliopedagoške naloge pri izvajanju izobraževalnega programa učenja branja v osnovni soli. Doktorsko delo. Ljubljana: Filozofska fakulteta.

Pravilnik o pogojih za izvajanje knjižnične dejavnosti kot javne službe, 2003. https:/ / www.uradni-list.si/glasilouradni-list-rs/vsebina/2003-01-3540?sop $=2003-01-3540$

Linda ŠKUFCA, 2019: Šolske knjǐ̌nice v šolskem letu 2017/18. Ljubljana: Narodna in univerzitetna knjižnica. (Center za razvoj knjižnic. Študije).https://cezar.nuk.unilj.si/common/files/studije/solske_knjiznice2017-18.pdf

Ross TODD in Carol C. KUHLTHAU, 2005: Student learning through Ohio school libraries, Part 1: How effective school libraries help students. School Libraries Worldwide 11(1). 89-110.

Jan TURBILL, 2001: A researcher goes to school: using technology in the kindergarten literacy curriculum. Journal of early cbildhood literacy 1(3). 255-279.

Polona VILAR, 2014: Medpredmetno povezovanje ter vloga šolske knjižnice in šolskega knjižničarja. Posodobitve pouka v osnovnošolski praksi. Knjižnično informacijsko znanje. Ur. Romana Fekonja. Ljubljana: Zavod RS za šolstvo. 164-174.

Polona VILAR in Ivanka STRIČEVIĆ, 2014: Quality school library - how do we find out?. Libraries in the digital age (LIDA): proceedings. Assesing libraries and library users and use: Zadar, Croatia, [16-20. 6.] 2014. Zadar: University of Zadar. http://ozk.unizd.hr/proceedings/index.php/lida/article/view/112

Polona VILAR in Vlasta ZABUKOVEC, 2016: Information literacy and reading literacy competences cannot develop without good school libraries. The fourth European conference on information literacy (ECIL): October 10th-13th, 2016, Prague, Czech Republic: abstracts. Ur. Sonja Špiranec idr. Prague: Association of Libraries of Czech Universities. 173. http://ecil2016.ilconf.org/wpcontent/uploads/sites/5/2016/11/ecil2016_abstracts.pdf

Polona VILAR in Vlasta ZABUKOVEC, 2017: Kakovostna šolska knjižnica - pomemben dejavnik pri razvoju veščin bralne in informacijske pismenosti. Bralna pismenost v predšlski vagoji in izobraževanju. Ur. Dragica Haramija Maribor: Univerzitetna založba Univerze. 123-133.

Jo WORTHY, Megan MOORMAN in Margo TURNER, 1999: What Johnny likes to read is hard to find in school. Reading research quarterly 34(1). 12-27. https://www.jstor.org/stable/748267

Vlasta ZABUKOVEC, 2014: Kompetence šolskih knjižničarjev. Posodobitve pouka v osnovnošolski praksi. Knjižnično informacijsko žnanje. Ur. Romana Fekonja. Ljubljana: Zavod RS za šolstvo. 126137.

Vlasta ZABUKOVEC in Majda STEINBUCH, 2010: Kompetence šolskega knjižničarja. Šolska knjižnica 20(3-4). 161-172.

Vlasta ZABUKOVEC in Polona VILAR, 2018: OBJEM: Kakovost solskih knjižnic: analiza stanja v okviru projekta (neobjavljeno).

Vlasta ZABUKOVEC, Polona VILAR in Romana Fekonja, 2019: Knjižnična dejavnost v vrtcih: primer Slovenje. Knjižnica 63(4). 27-43. 


\section{PREGLEDNICE}

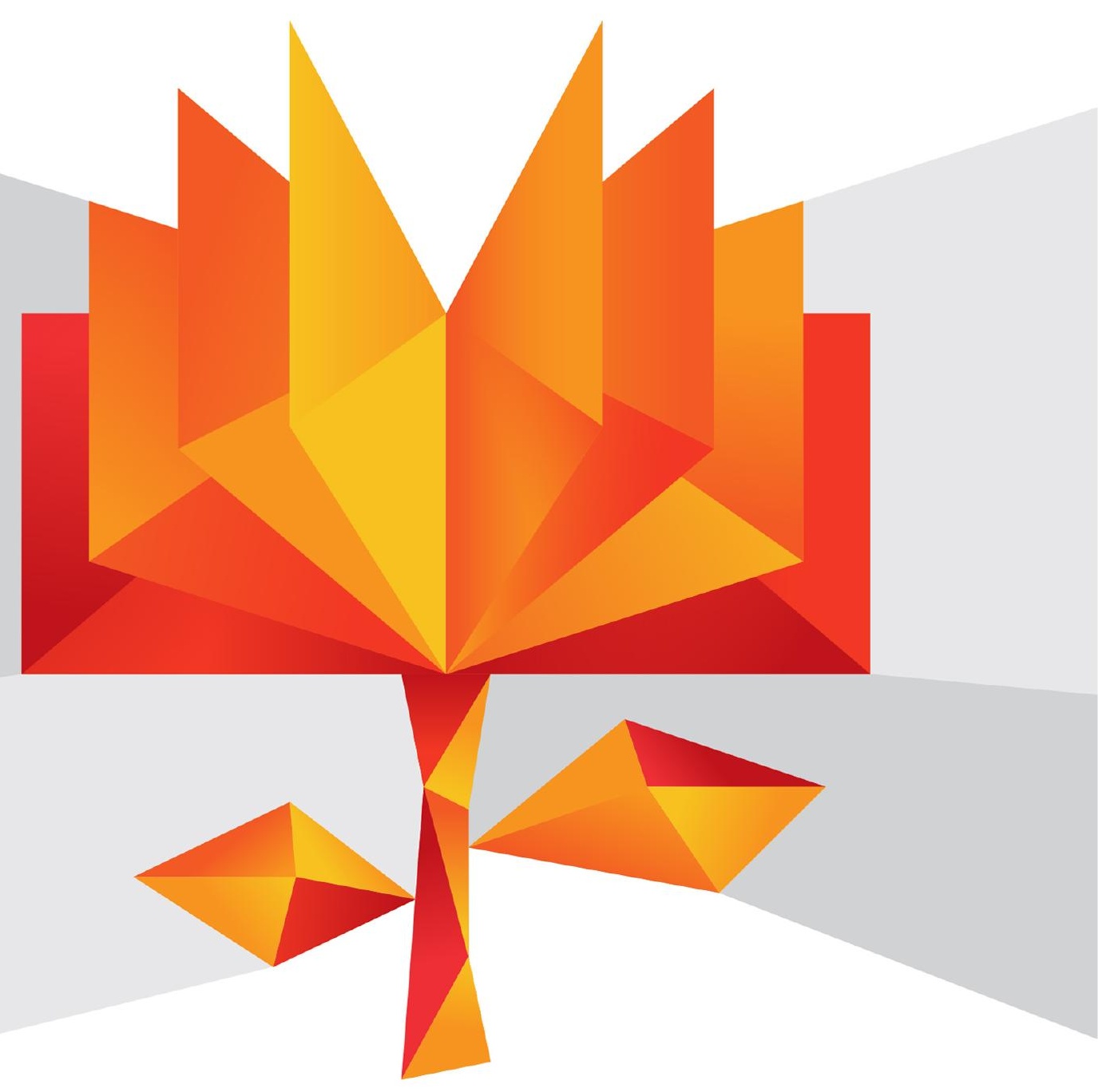





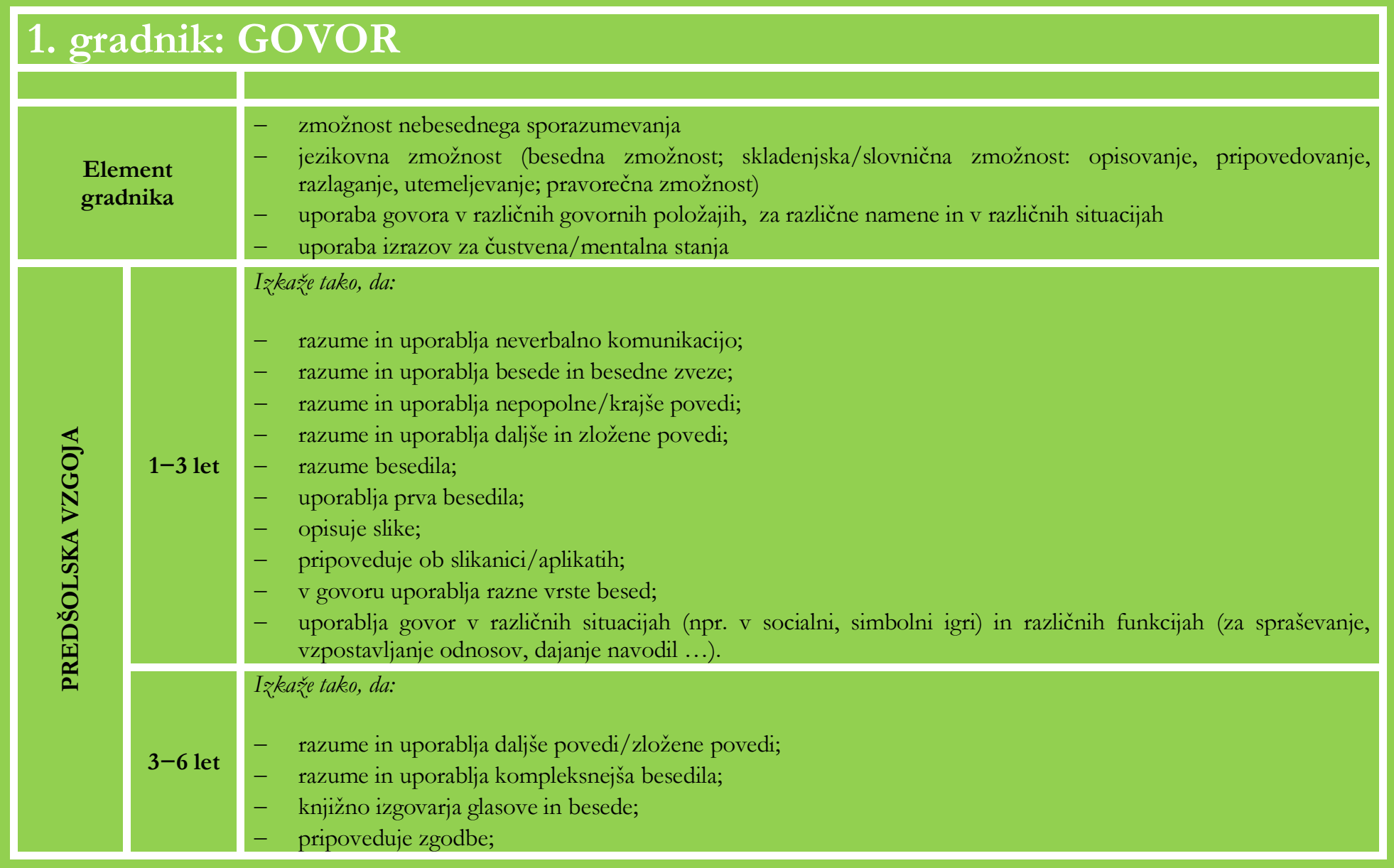




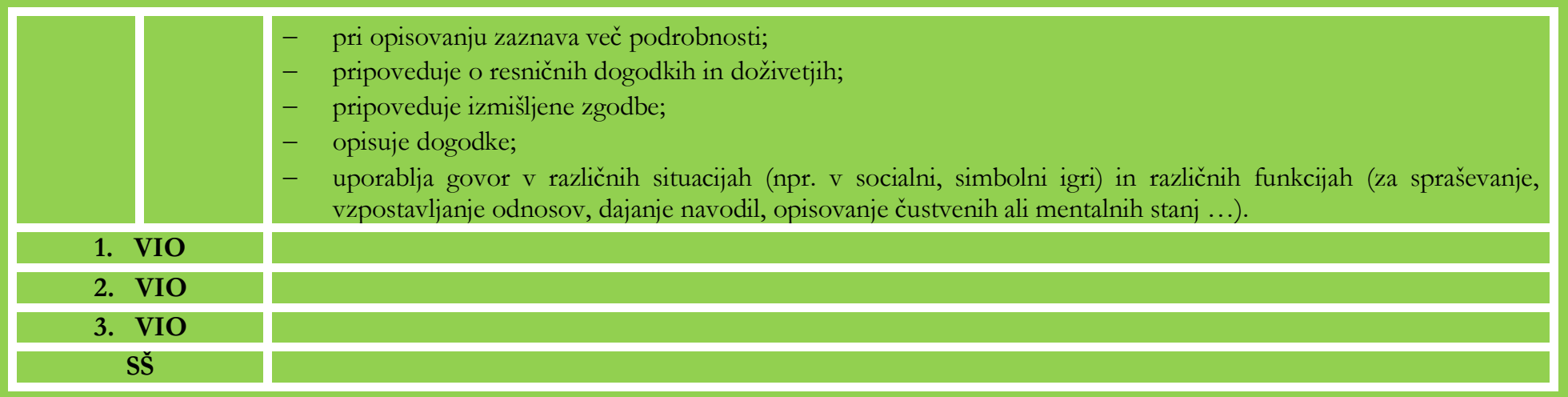




\section{2. gradnilk: MOTIVIRANOST ZA BRANJE}

\begin{tabular}{|c|c|c|}
\hline \multicolumn{2}{|c|}{$\begin{array}{l}\text { Element } \\
\text { gradnika }\end{array}$} & $\begin{array}{ll}\text { - } & \text { interes za branje } \\
\text { - } & \text { pozitiven odnos do branja }{ }^{1} \text { različnih vrst besedil }{ }^{2} \\
\text { - } & \text { bralna samoučinkovitost } \\
\text { - } & \text { izbira tiskanih in drugih informacijskih virov glede na namen branja } \\
\text { - } & \text { uporaba različnih lokacij bralnih virov }\end{array}$ \\
\hline 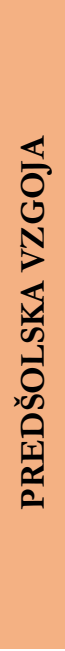 & 1-3 let & $\begin{array}{l}\text { Izkaže tako, da: } \\
\text { - } \quad \text { izraža pripravljenost po poslušanju in branju; } \\
\text { - } \quad \text { ohranja pozornost in se odziva ob skupnem branju; } \\
\text { - } \quad \text { lista bralno gradivo; } \\
\text { - } \quad \text { navidezno bere; } \\
\text { - } \quad \text { je zatopljen in vztraja pri samostojnem ali skupnem poslušanju in pripovedovanju zgodb; } \\
\text { - } \quad \text { izraža željo po pripovedovanju, branju in poslušanju; } \\
\text { - } \quad \text { skupaj z odraslim uporablja knjižno in neknjižno gradivo ter različne medije in obiskuje knjižnice. }\end{array}$ \\
\hline
\end{tabular}

\footnotetext{
${ }^{1}$ Pozitiven odnos do branja različnih vrst besedil za različne namene: branje za znanje, branje leposlovja (razvijanje bralne kulture).

${ }^{2}$ Različne vrste besedil: pripovedovalna, opisovalna in poustvarjalna besedila.

${ }^{3}$ Različno bralno gradivo: informativne in leposlovne slikanice in druga gradiva.
} 


\begin{tabular}{|c|c|}
\hline 1. VIO & $\begin{array}{l}\text { Izkeaže tako, da: } \\
\text { - } \quad \text { izbira različno bralno gradivo; } \\
\text { - } \quad \text { je zatopljen v branje; } \\
\text { - } \quad \text { vztraja pri branju; } \\
\text { - } \quad \text { spremlja svoj dosežek pri branju in načrtuje izboljšave; } \\
\text { - } \quad \text { pozna in uporablja lokacije bralnih virov (šolska knjižnica, medmrežje). }\end{array}$ \\
\hline
\end{tabular}




\begin{tabular}{|c|c|}
\hline & Į̇ą̌̌e tako, da: \\
\hline SŠ & $\begin{array}{l}\text { - } \quad \text { izbira bralno gradivo glede na interes, medbesedilno izkušenost, namen branja (spoznavni, etični ali estetski); } \\
\text { - } \quad \text { obvlada veščine strateškega bralca }{ }^{4} ; \\
\text { - } \quad \text { načrtuje, spremlja in vrednoti svojo bralno zmožnost in si prizadeva za njeno izboljšanje; } \\
\text { - } \quad \text { pozna in smiselno uporablja tiskane ter digitalne bralne vire; } \\
\text { - } \quad \text { glede na interes izbira bralno gradivo v drugih ter tujih jezikih. }\end{array}$ \\
\hline
\end{tabular}

${ }^{4}$ Strateški bralec: je samostojen, fleksibilen, učinkovit bralec, ki za različne namene in cilje branja zavestno izbira in uporablja različne bralne strategije. 


\begin{tabular}{|c|c|c|}
\hline \multicolumn{3}{|c|}{ 3. gradnik: RAZUMEVANJE KONCEP'TA BRALNEGA GRADIVA } \\
\hline \multicolumn{2}{|c|}{$\begin{array}{l}\text { Element } \\
\text { gradnika }\end{array}$} & $\begin{array}{ll}- & \text { orientacija } \mathrm{v} \text { bralnem gradivu } \\
- & \text { povezovanje besednega in slikovnega dela } \mathrm{v} \text { besedilu } \\
- & \text { poznavanje in obvladovanje smeri branja } \\
- & \text { celostno branje } \mathrm{e}^{5} \text { multimodalnih besedil } \\
- & \text { poznavanje tiskanih in digitalnih gradiv }\end{array}$ \\
\hline \multirow{2}{*}{ 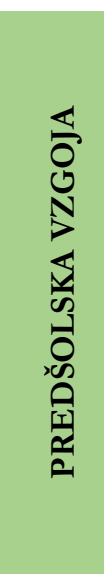 } & $1-3$ let & 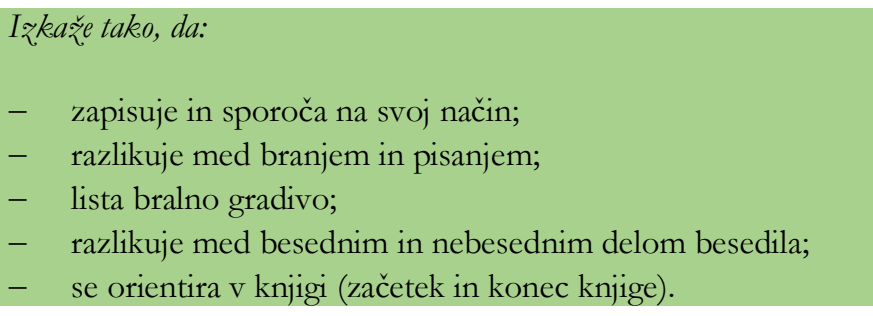 \\
\hline & $3-6$ let & $\begin{array}{l}\text { Izkaže tako, da: } \\
\text { - } \quad \text { pozna smer branja (od leve proti desni, od zgoraj navzdol); } \\
\text { - } \quad \text { razume, kaj sporoča nebesedni in kaj besedni del besedila; } \\
\text { - } \quad \text { ločuje med črko, števko in besedo; } \\
\text { - }\end{array}$ \\
\hline
\end{tabular}

${ }^{5}$ Celostno branje multimodalnih besedil: sestavljanje pomenov iz besedila in ilustracij, upoštevanje odnosa ali interakcije (zavedanje o pomenu multimodalnosti). ${ }^{6}$ Multimodalna besedila: vsebujejo besedilo in ilustracije, slike, fotografije, grafe, miselne vzorce, tabele, zemljevide, notne zapise ipd. 


\begin{tabular}{|c|c|c|}
\hline 1. VIO & \multirow{4}{*}{ 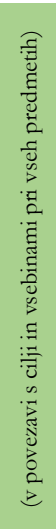 } & $\begin{array}{l}\text { Izkaže tako, da: } \\
\text { - } \quad \text { pozna in uporablja različne bralne vire (tiskane, zvočne, digitalne, interaktivne); } \\
\text { - } \quad \text { v bralnem gradivu poišče osnovne podatke o knjigi (naslov, avtorja, ilustratorja); } \\
\text { - } \quad \text { ločuje med povedjo in besedilom. }\end{array}$ \\
\hline 2. VIO & & $\begin{array}{l}\text { Izkaže tako, da: } \\
\text { - } \quad \text { razume razliko med bralnimi gradivi (tiskanimi, zvočnimi, digitalnimi/interaktivnimi) in to upošteva pri branju; } \\
\text { - } \quad \text { uporablja različne strategije linearnega in izbirnega branja; } \\
\text { - } \quad \text { celostno bere multimodalna besedila. }\end{array}$ \\
\hline \multicolumn{2}{|l|}{ 3. VIO } & \\
\hline SŠ & & \\
\hline
\end{tabular}




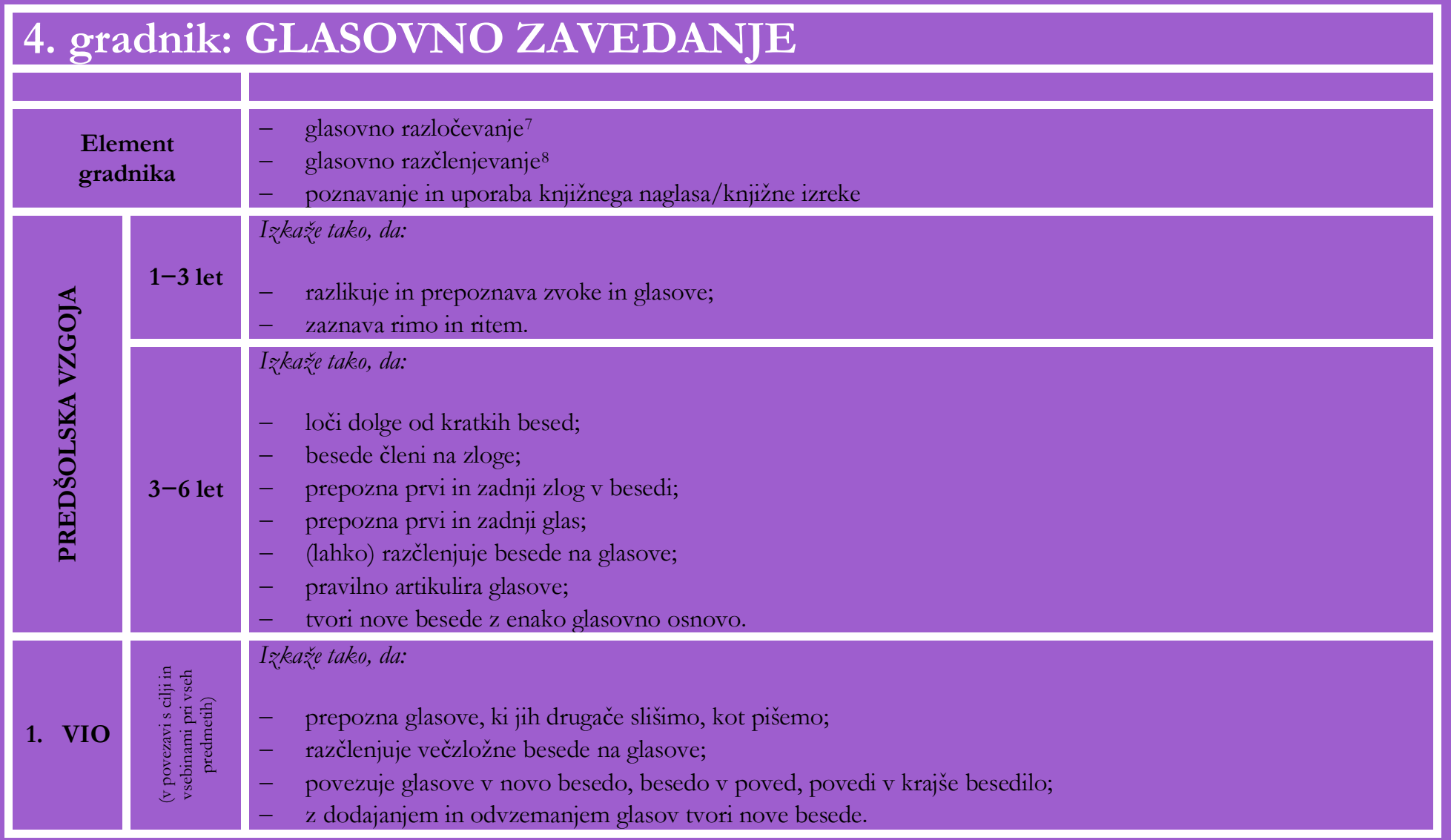

${ }^{7}$ Glasovno razločevanje: razločevanje dolžine besed in razločevanje glasov med seboj.

${ }^{8}$ Glasovno razčlenjevanje: členitve povedi na posamezne besede, na posamezne zloge, na posamezne glasove. 


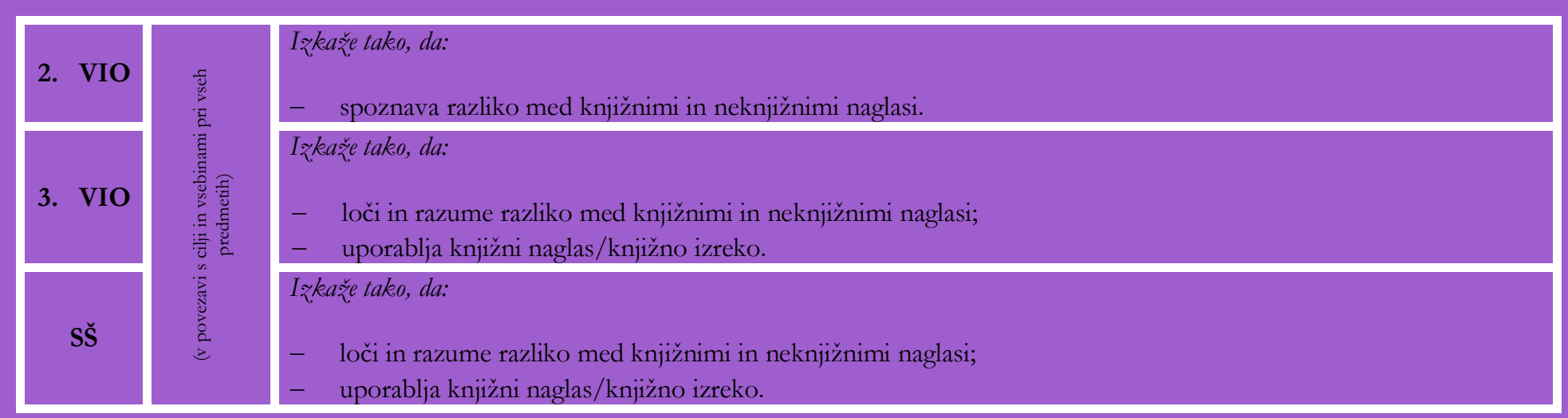




\section{5. gradnik: BESEDIŠČE}

\begin{tabular}{|c|c|c|}
\hline \multicolumn{2}{|c|}{$\begin{array}{l}\text { Element } \\
\text { gradnika }\end{array}$} & $\begin{array}{ll}\text { - } & \text { razumevanje pomena besed in njihova uporaba pri sprejemanju in tvorjenju besedil } \\
\text { - } & \text { širjenje in usvajanje besedišča za uspešno branje } z \text { razumevanjem, učenje in sporazumevanje } \\
\text { - } & \text { uporaba jezikovnih virov in priročnikov }\end{array}$ \\
\hline \multirow{2}{*}{ 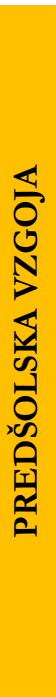 } & $1-3$ let & $\begin{array}{l}\text { Izkaže tako, da: } \\
\text { - } \quad \text { razume preprosta navodila; } \\
\text { - } \quad \text { poimenuje znane osebe in stvari iz svojega okolja ali na vizualnih gradivih; } \\
\text { - } \quad \text { tvori dvo- ali tribesedne izjave; } \\
\text { - } \quad \text { tvori enostavne prošnje; } \\
\text { - } \quad \text { se igra z besedami. }\end{array}$ \\
\hline & $3-6$ let & $\begin{array}{l}\text { Izkaže tako, da: } \\
\text { - } \quad \text { razume besede v daljših in zapletenejših povedih; } \\
\text { - } \quad \text { razume pomen besede v konkretnih situacijah in zgodbah; } \\
\text { - } \quad \text { razume in uporablja večino besed iz vsakdanjih situacij/okolja; } \\
\text { - } \quad \text { uporablja vprašalnice za namene sporazumevanja; } \\
\text { - } \quad \text { uporablja izraze za mentalna stanja (vedeti, spomniti, razumeti ...); } \\
-\quad \text { razume in uporablja vljudnostne izraze; } \\
\text { - } \quad \text { glede na interesno področje razume in uporablja strokovne izraze. }\end{array}$ \\
\hline
\end{tabular}




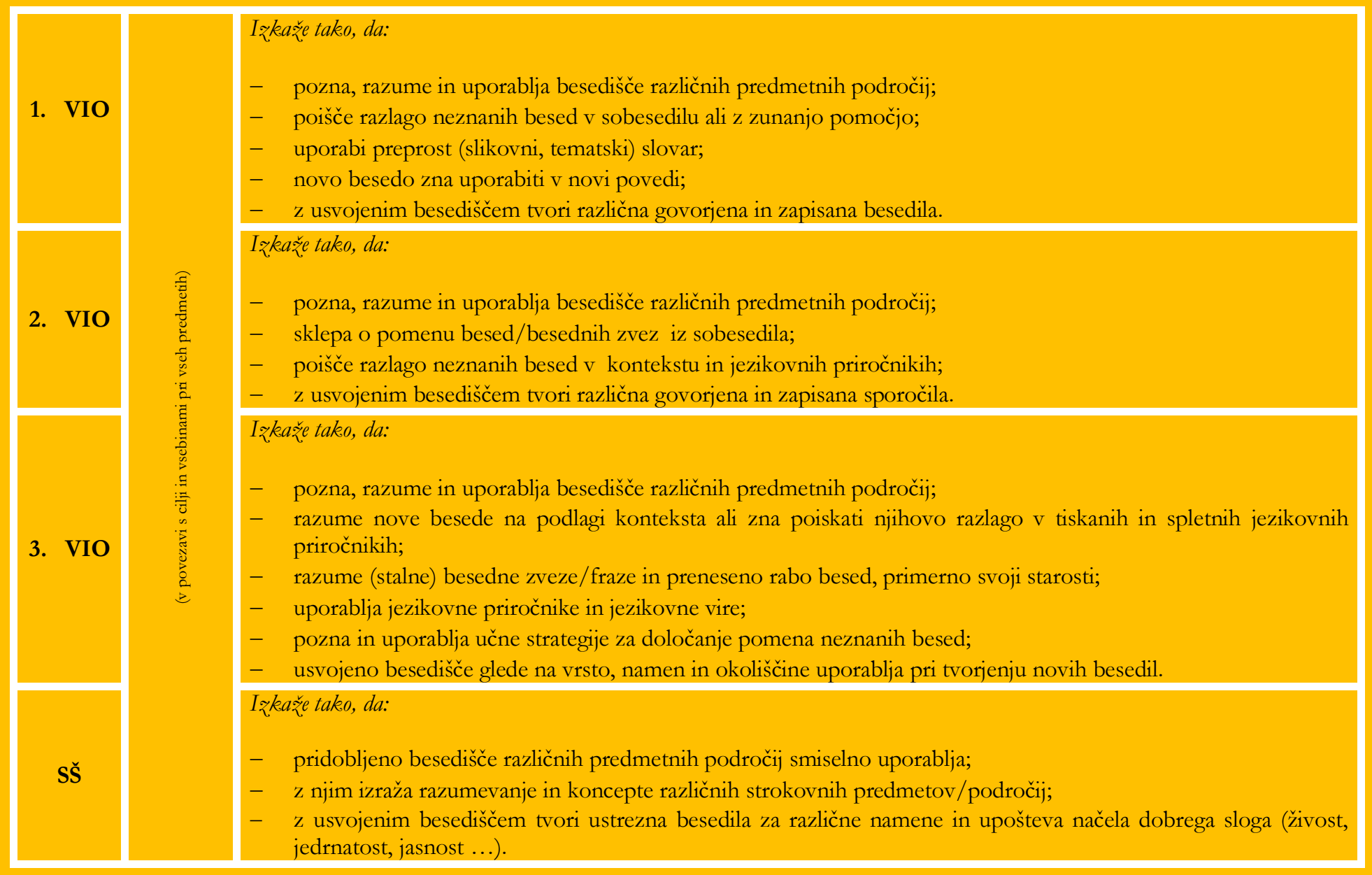




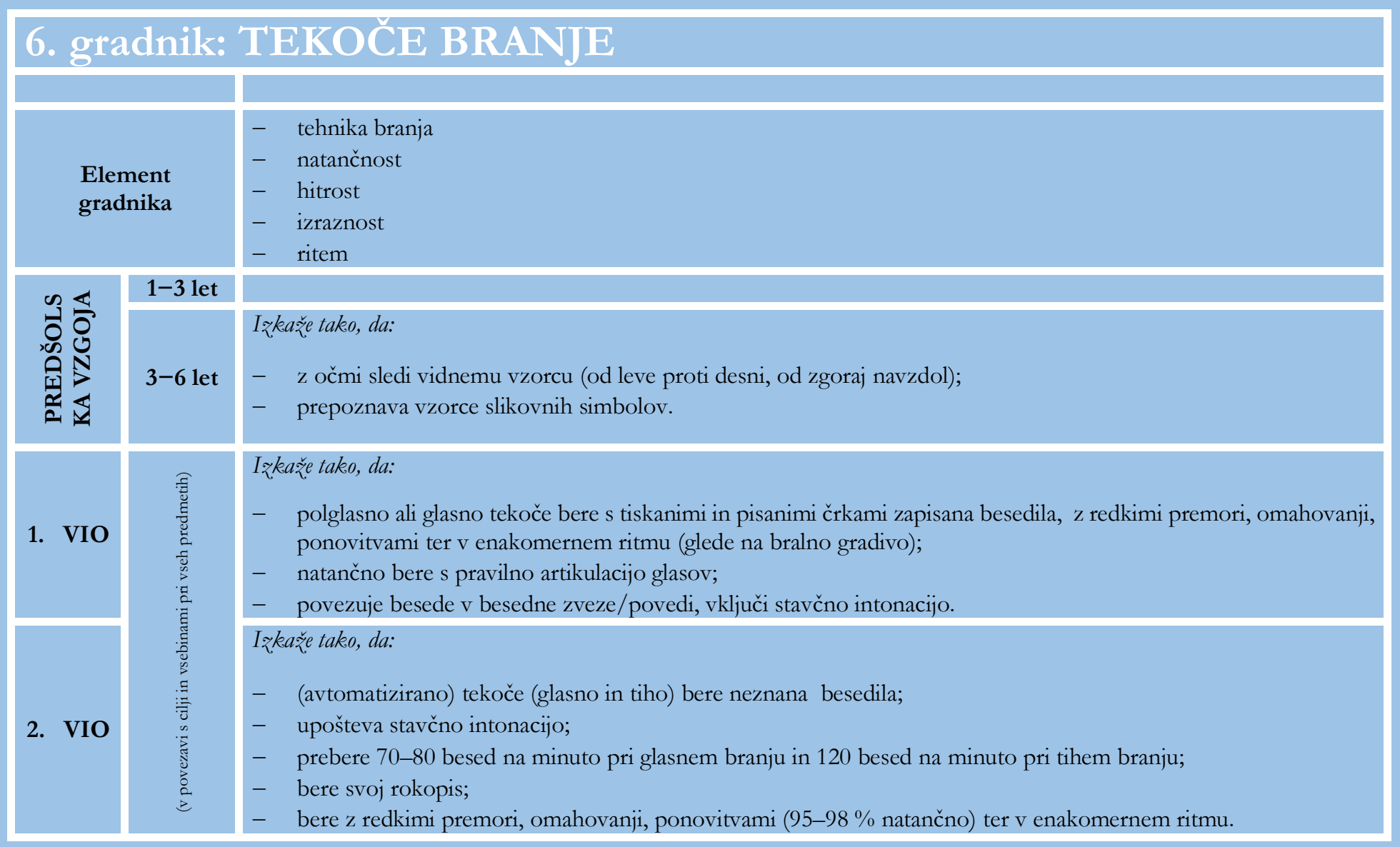




\begin{tabular}{|c|c|c|}
\hline 3. VIO & 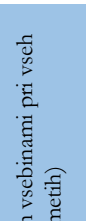 & $\begin{array}{l}\text { Iqkaže tako, da: } \\
\text { - } \quad \text { tekoče, smiselno in čim bolj zborno bere daljša in kompleksna (različna) besedila; } \\
\text { - } \quad \text { prilagaja hitrost branja zahtevam besedila; } \\
\text { - } \quad \text { pri glasnem branju upošteva zvočne prvine govora, predvsem intonacijo, barvo in hitrost. }\end{array}$ \\
\hline Sš & 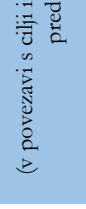 & $\begin{array}{l}\text { Iqkaže tako, da: } \\
\text { - } \quad \text { smiselno, razločno in tekoče ter pravorečno pravilno bere raznovrstna besedila; } \\
\text { - } \quad \text { upošteva vse zvočne prvine govora (intonacija, hitrost, barva, register, premori ....) in tudi vidne prvine govora } \\
\text { (branja). }\end{array}$ \\
\hline
\end{tabular}




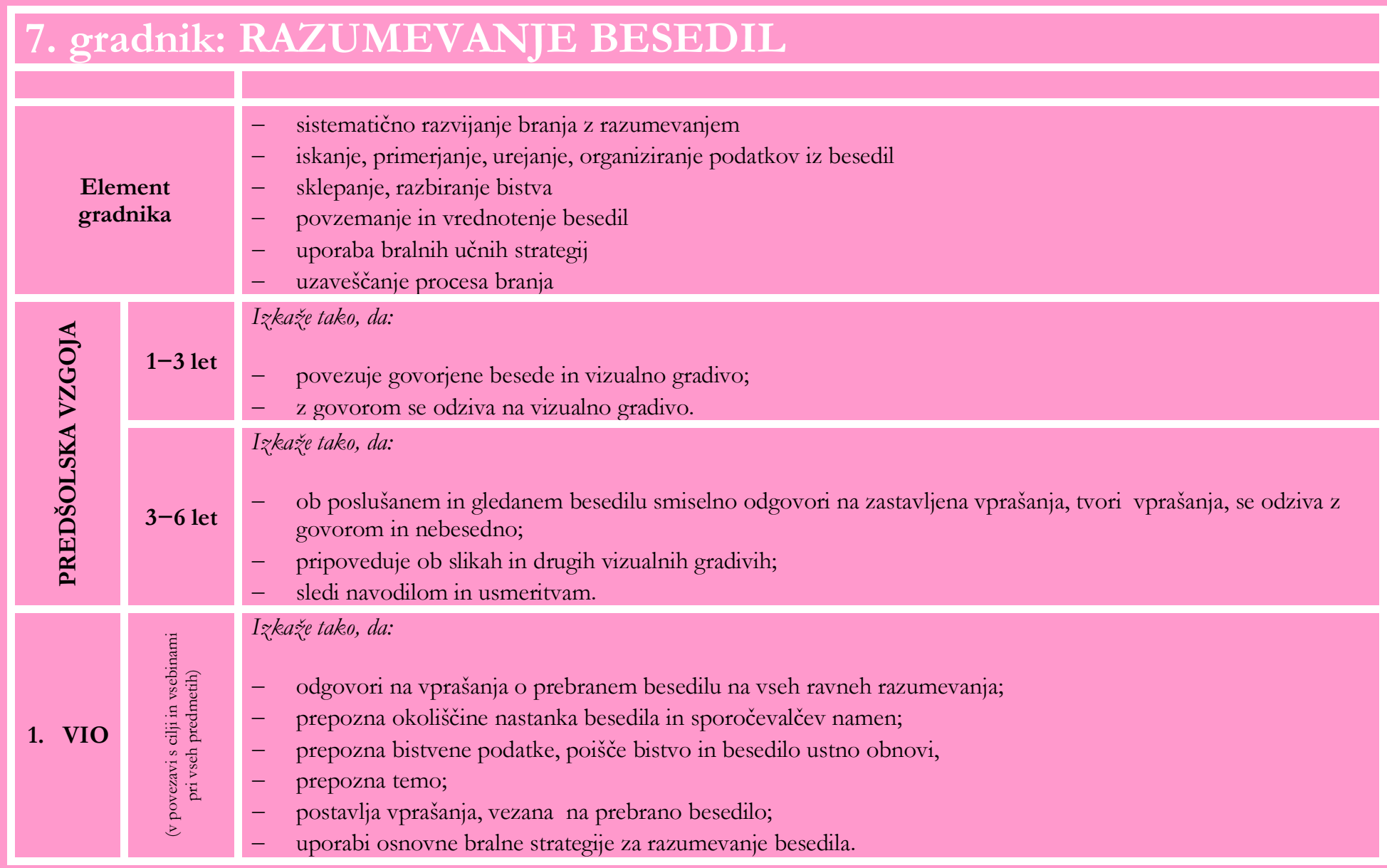




\begin{tabular}{|c|c|c|}
\hline 2. VIO & \multirow{3}{*}{ 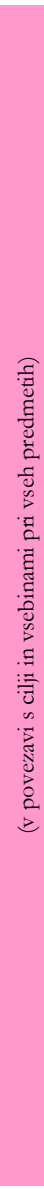 } & $\begin{array}{l}\text { Izkaže tako, da: } \\
\text { - } \quad \text { odgovarja na vprašanja na vseh ravneh razumevanja; } \\
\text { - } \quad \text { v besedilu poišče bistvene podatke in podrobnosti; } \\
\text { - } \quad \text { povzema besedilo s svojimi besedami; } \\
\text { - } \quad \text { predstavi podatke z različnimi prikazi; } \\
\text { - } \quad \text { razume od } 90 \text { do } 95 \% \text { besed v prebranem besedilu; } \\
\text { - } \quad \text { prebrano poveže z lastnimi izkušnjami; } \\
\text { - } \quad \text { pozna in uporablja osnovne (nekateri tudi kompleksne) bralne strategije za razumevanje vseh vrst besedil; } \\
\text { - } \quad \text { uzavešča lasten proces branja in učenja z branjem. }\end{array}$ \\
\hline 3. VIO & & $\begin{array}{l}\text { Izkaže tako, da: } \\
\text { - } \quad \text { prepozna namen in temo ter okoliščine nastanka besedila; } \\
\text { - } \quad \text { v besedilu poišče bistvene podatke in podrobnosti; } \\
\text { - } \quad \text { o besedilu oz. podatkih si postavlja vprašanja na vseh ravneh; } \\
\text { - } \quad \text { odgovarja na lastna in tuja vprašanja na vseh ravneh razumevanja; } \\
\text { - } \quad \text { prepozna odnose med različnimi informacijami besedila; } \\
\text { - } \quad \text { besedilo samostojno obnovi in povzame; } \\
\text { - } \quad \text { podatke pojasnjuje, utemeljuje, oblikuje hipoteze ...; } \\
\text { - } \quad \text { vztraja pri zahtevnejših bralnih nalogah; } \\
\text { - } \quad \text { izbira in uporablja ustrezne osnovne in kompleksne bralne strategije za razumevanje besedil; } \\
\text { - } \quad \text { uzavešča lasten proces branja in učenja z branjem. }\end{array}$ \\
\hline SŠ & & $\begin{array}{l}\text { Izkaže tako, da: } \\
\text { - } \quad \text { prepozna in poimenuje vrsto in strukturo besedila; } \\
\text { - } \quad \text { v besedilu poišče ključne besede/besedne zveze in povzame bistvene podatke; } \\
\text { - } \quad \text { ob besedilu si zastavlja in odgovarja na vprašanja vseh ravni razumevanja; }\end{array}$ \\
\hline
\end{tabular}




$\begin{array}{ll}- & \text { besedilo samostojno povzame in preoblikuje (parafrazira); } \\ - & \text { podatke iz besedila razvršča, primerja, interpretira, o njih sklepa, presoja, oblikuje hipoteze ... tudi iz več besedil } \\ & \text { hkrati; } \\ - & \text { vztraja pri zahtevnejših bralnih nalogah (naloge višjih taksonomskih ravni); } \\ - & \text { pozna in uporablja ustrezne strategije za razumevanje vseh vrst besedil; } \\ & -\quad \text { uporablja znanje o procesih/strategijah branja za dobro bralno razumevanje; } \\ & -\quad \text { uzavešča lasten proces branja in učenja z branjem; } \\ - & \text { na primerni zahtevnostni ravni razume besedila v različnih (maternih) jezikih ali v prvem tujem jeziku. }\end{array}$




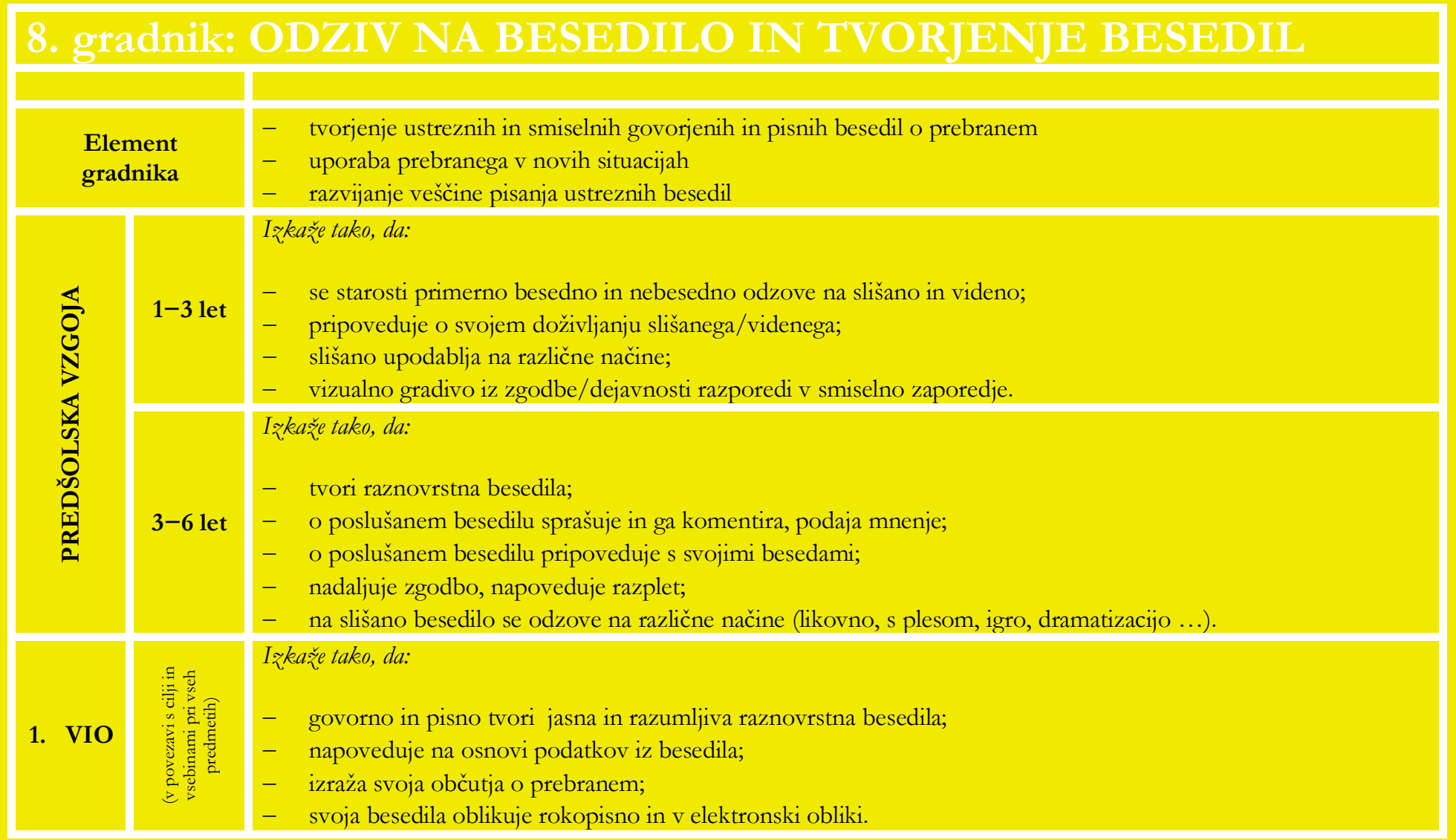




\begin{tabular}{|c|c|c|}
\hline 2. VIO & \multirow{2}{*}{ 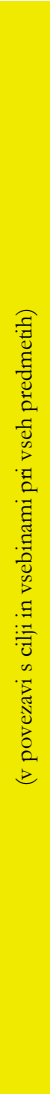 } & $\begin{array}{l}\text { Izkaže tako, da: } \\
\text { - } \quad \text { pove ali napiše povzetek prebranega; } \\
\text { - } \quad \text { jezikovno ustrezno tvori govorna in pisna besedila različnih vrst'; } \\
\text { - } \quad \text { razlaga prebrano in razpravlja o prebranem; } \\
\text { - } \quad \text { vrednoti besedilo in oblikuje odnos do njega, svoje stališče utemelji z dokazi; } \\
-\quad \text { na podlagi prebranega tvori nova besedila različnih vrst; } \\
-\quad \text { utemeljuje svoje odgovore oz. svoj odziv na prebrano; } \\
\text { - } \quad \text { svoja besedila oblikuje rokopisno in v elektronski obliki. }\end{array}$ \\
\hline 3. VIO & & $\begin{array}{l}\text { Izkaže tako, da: } \\
\text { - } \quad \text { sodeluje v pogovoru o prebranem besedilu in utemeljuje svoja stališča z dokazi iz besedila; } \\
\text { - } \quad \text { govorno in pisno ter jezikovno ustrezno glede na sobesedilo tvori besedila različnih vrst'; } \\
\text { - } \quad \text { besedilo razloži, razčleni, povzame vrednoti ... s pomočjo različnih strategij; } \\
\text { - } \quad \text { besedilo ali njegove dele zna pretvoriti v nebesedno sporočilo (npr. graf); } \\
-\quad \text { utemeljuje svoje odgovore oz. svoj odziv na prebrano; } \\
\text { - } \quad \text { svoja besedila oblikuje rokopisno in v elektronski obliki. }\end{array}$ \\
\hline
\end{tabular}

${ }^{9}$ Besedila različnih vrst: pripovedovalna, razlagalna, utemeljevalna, opisovalna. 


$-\quad$ razume in pravilno uporablja sklice, opombe, vire ... kot del besedila;
$-\quad$ svoja besedila oblikuje rokopisno in v elektronski obliki;
$-\quad$ pri tvorjenju besedil izbira učinkovite strategije in pojasni rabo strategij.




\section{9. gradnik: KRITIČNO BRANJE}

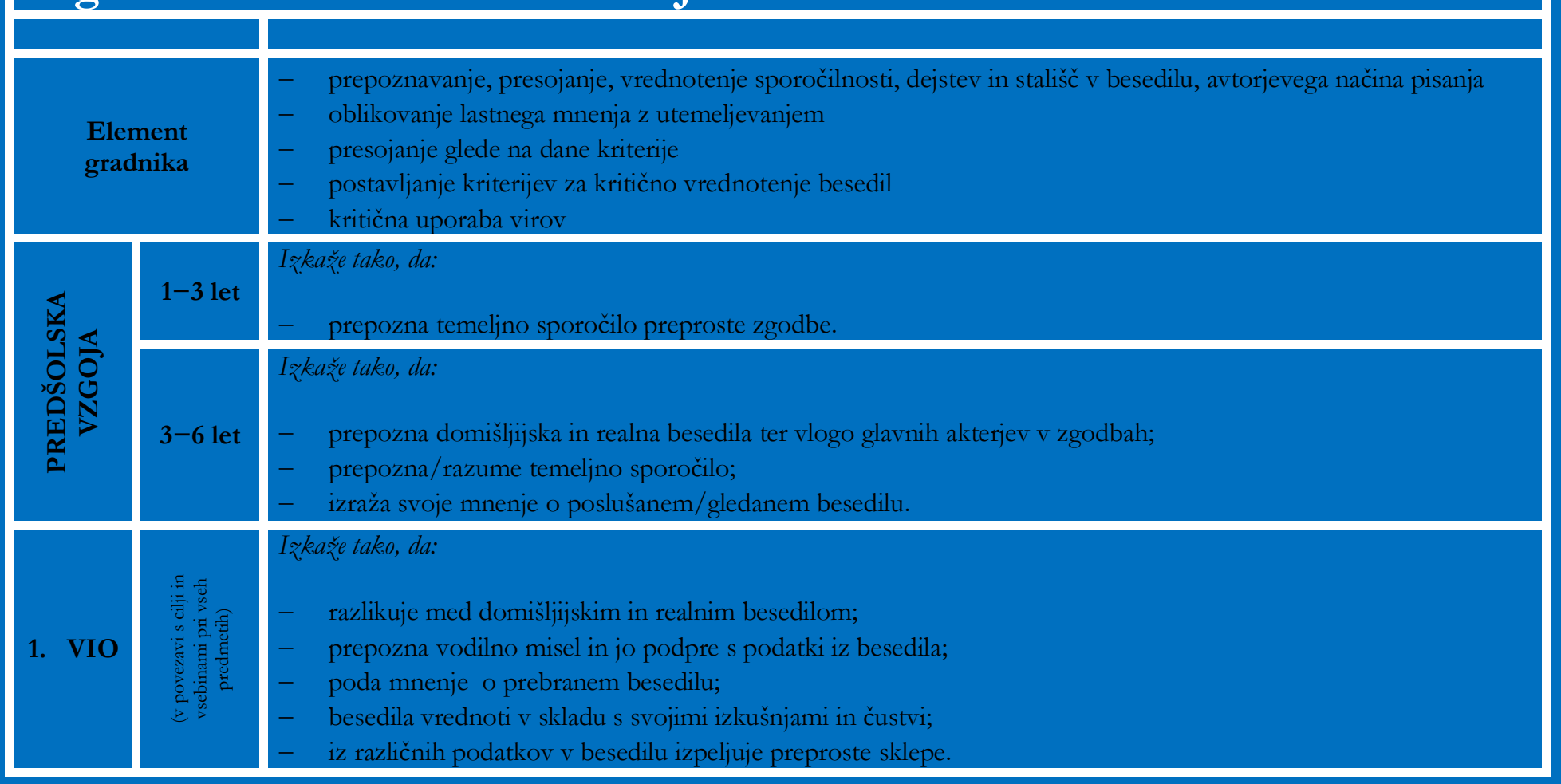




\begin{tabular}{|c|c|}
\hline 2. VIO & $\begin{array}{l}\text { Iৃkaže tako, da: } \\
\text { - } \quad \text { razlikuje med dejstvi in mnenji; } \\
\text { - } \quad \text { prepozna vodilno misel in jo vrednoti v skladu s svojimi izkušnjami in čustvi; } \\
-\quad \text { vrednotenje besedila podpre s podatki/dokazi iz besedila; } \\
\text { - } \quad \text { izpeljuje sklepe iz različnih podatkov v besedilu. }\end{array}$ \\
\hline 3. VIO & $\begin{array}{l}\text { Irkaže tako, da: } \\
\text { - } \quad \text { analizira in argumentirano vrednoti vsebino besedila; } \\
\text { - } \quad \text { razlikuje med dejstvi in stališči; } \\
\text { - } \quad \text { oblikuje lastno mnenje, ga zna utemeljiti oziroma podpreti s kakovostnimi dokazi iz besedila; } \\
\text { - } \quad \text { kritično presoja različne dele besedila (npr. vizualni del); } \\
\text { - } \quad \text { informacije v besedilu kritično presoja glede na dane kriterije ali glede na kriterije, ki jih sam postavi; } \\
\text { - }\end{array}$ \\
\hline SŠ & 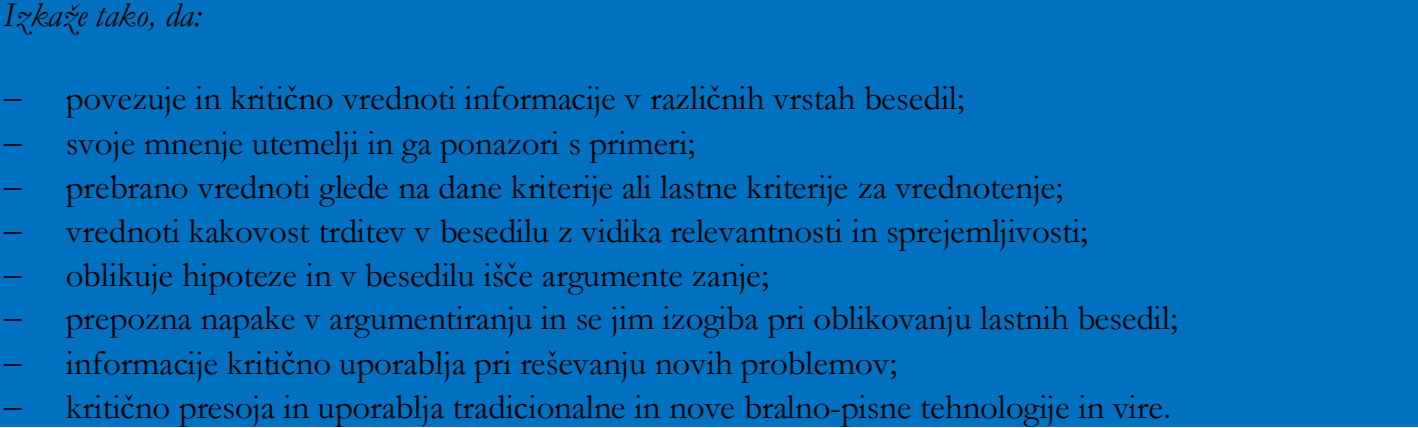 \\
\hline
\end{tabular}




\title{
GRADNIKI BRALNE PISMENOSTI
}

\author{
DRAGICA HARAMIJA (UR.)
}

Univerza v Mariboru, Filozofska fakulteta, Pedagoška fakulteta, Maribor, Slovenija.

E-pošta: dragica.haramija@um.si

Povzetek Znanstvena monografija o gradnikih bralne pismenosti vsebuje 11 poglavij, v katerih je poglobljeno zajeto izhodišče posameznega gradnika. Razvijanje gradnikov je sistematično, saj so namenjeni vsem stopnjam izobraževanja od vrtca do konca srednješolskega obdobja, hkrati pa je njihov temeljni namen, da se pozornost za razvoj bralne pismenosti usmerja na vsa področja dejavnosti v vrtcu in na vse predmete $\mathrm{v}$ osnovni in srednji šoli. Posamezni gradnik se razvija kot del celote, vsi gradniki so povezani s cilji vseh predmetov/področij, razvijajo se procesno. Pomembno je, da se gradniki razvijajo integrirano in $\mathrm{v}$ skladu z zmožnostjo otrok, učencev in dijakov glede na njihov razvoj, predznanje, potrebe in posebnosti. Izhodišča se navezujejo na vseh devet gradnikov bralne pismenosti: govor, motiviranost za branje, razumevanje koncepta bralnega gradiva, glasovno zavedanje, besedišče, tekoče branje, razumevanje besedil, odziv na prebrano, kritično branje.

Ključne besede: gradniki bralne pismenosti, pismenost, slovenski jezik, metode, medpredmetno povezovanje. 


\title{
COMPONENTS OF READING LITERACY
}

\author{
DRAGICA HARAMIJA (ED.) \\ Univetrsity of Maribor, Faculty of Arts, Faculty of Education, Maribor, Slovenia. \\ E-mail: dragica.haramija@um.si
}

\begin{abstract}
The academic monograph on the components of reading literacy includes eleven chapters that take an in-depth look at the basis for each individual block. Developing components of reading literacy is systematic as they are intended for all levels of education, from nursery school to secondary education, and at the same time their essential purpose is to direct the attention on the development of reading literacy into all areas of activities in nursey school and into all subjects in primary and secondary education. Each individual component of reading literacy develops as part of a w hole, a ll components are linked to the goals and objectives of all subjects/areas, and they develop procedurally. It is important that the components of reading literacy develop in an integrated way, in line with the abilities of children and students, depending on their development, prior knowledge, needs and particularities. Monograph includes nine components of reading literacy: speech, reading motivation, comprehending the concept of reading material, phonemic awareness, vocabulary, reading fluency, text understanding, response to the text and creating texts and critical reading.
\end{abstract}

Keywords: building blocks of reading literacy, literacy, Slovenian language, methods, interdisciplinary connections. 
